\title{
Water-Quality Trends for Selected Sampling Sites in the Upper Clark Fork Basin, Montana, Water Years 1996-2010
}

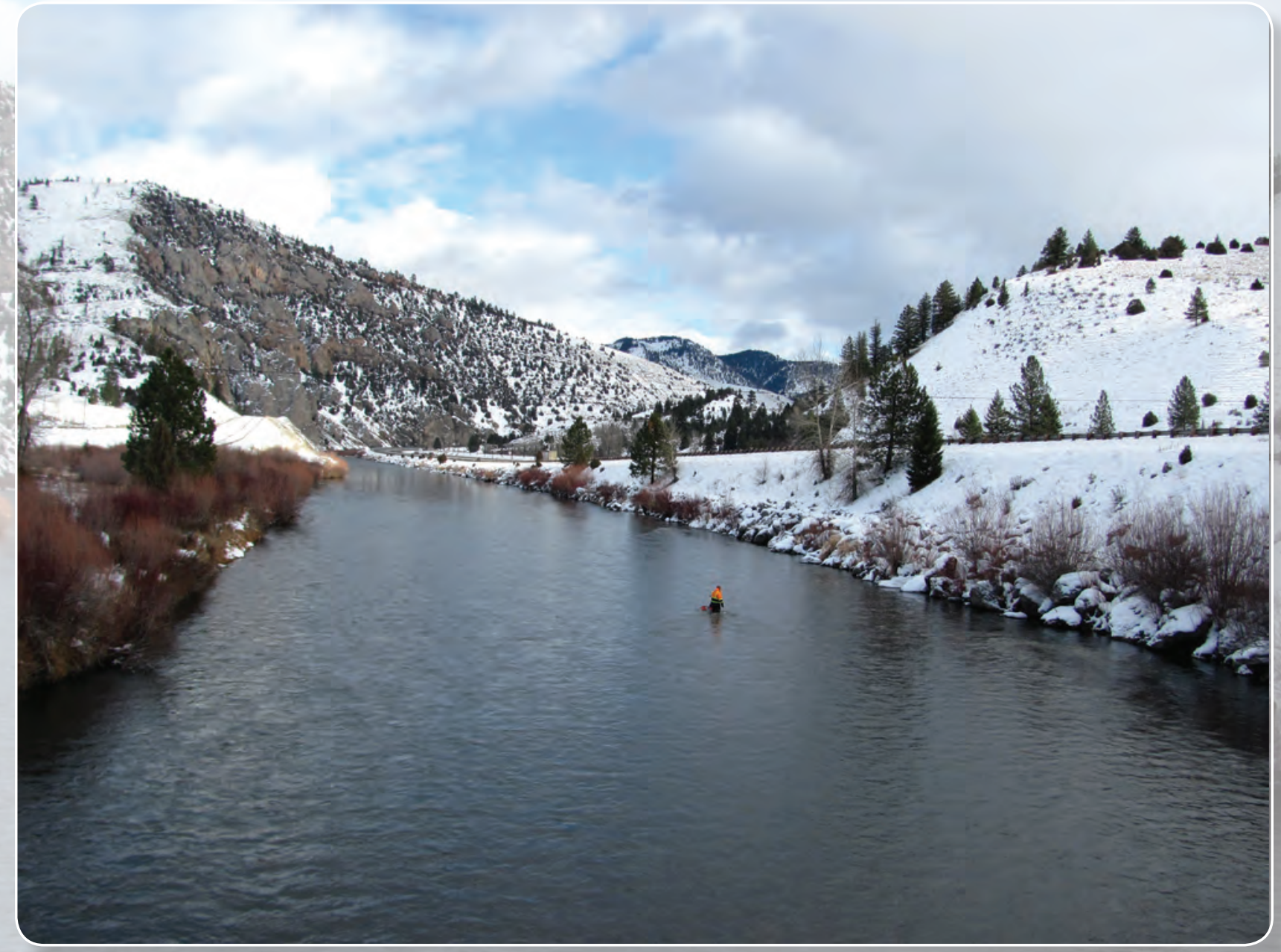

Scientific Investigations Report 2013-5217 
Cover photograph: Looking upstream from the Bear Gulch Road bridge on the Clark Fork near Drummond, Montana, on December 9, 2010. (Photograph by Donald A. Bischoff, U.S. Geological Survey.) 


\section{Water-Quality Trends for Selected Sampling Sites in the Upper Clark Fork Basin, Montana, Water Years 1996-2010}

By Steven K. Sando, Aldo V. Vecchia, David L. Lorenz, and Elliott P. Barnhart

Scientific Investigations Report 2013-5217 


\title{
U.S. Department of the Interior SALLY JEWELL, Secretary
}

\section{U.S. Geological Survey \\ Suzette M. Kimball, Acting Director}

\author{
U.S. Geological Survey, Reston, Virginia: 2014
}

For more information on the USGS - the Federal source for science about the Earth, its natural and living resources, natural hazards, and the environment, visit http://www.usgs.gov or call 1-888-ASK-USGS.

For an overview of USGS information products, including maps, imagery, and publications, visit http://www.usgs.gov/pubprod

To order this and other USGS information products, visit http://store.usgs.gov

Any use of trade, firm, or product names is for descriptive purposes only and does not imply endorsement by the U.S. Government.

Although this information product, for the most part, is in the public domain, it also may contain copyrighted materials as noted in the text. Permission to reproduce copyrighted items must be secured from the copyright owner.

Suggested citation:

Sando, S.K., Vecchia, A.V., Lorenz, D.L., and Barnhart, E.P., 2014, Water-quality trends for selected sampling sites in the upper Clark Fork Basin, Montana, water years 1996-2010: U.S. Geological Survey Scientific Investigations Report 2013-5217, 162 p., with appendixes, http://dx.doi.org/10.3133/sir20135217.

ISSN 2328-031X (print) ISSN 2328-0328 (online) ISBN 978-1-4113-3764-0 


\section{Acknowledgments}

The authors would like to recognize the valuable contributions to this report from the insightful technical reviews by David Anning (U.S. Geological Survey) and John Lambing (U.S. Geological Survey, retired). Also, the authors extend special thanks to individuals involved in the field data collection. Kent Dodge and Terry Heinert of the U.S. Geological Survey are noteworthy for their efforts.

Bill Bakeberg and Phil Sinerius (private contractors) also are noteworthy for their efforts. 



\section{Contents}

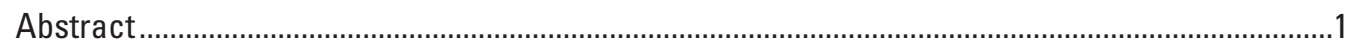

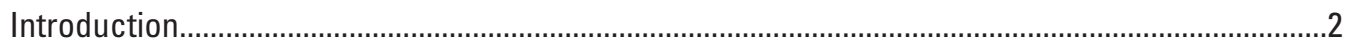

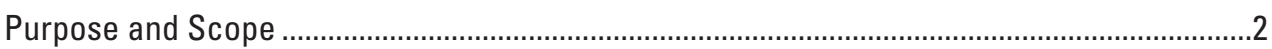

Description of Study Area ..................................................................................................

Hydrographic and Hydrologic Characteristics ...........................................................

Physiographic, Climatic, and Geologic Characteristics ...................................................

Overview of Mining and Remediation Activities .............................................................

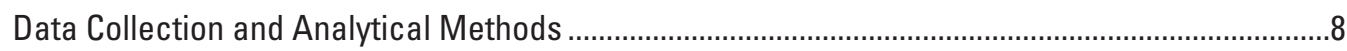

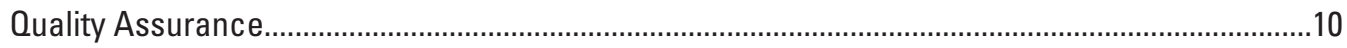

Overview of Water-Quality Characteristics for Sampling Sites in the Upper Clark Fork Basin .....11

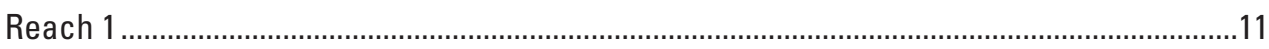

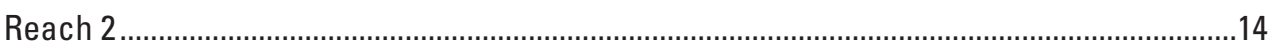

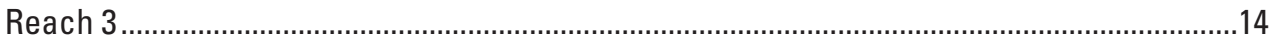

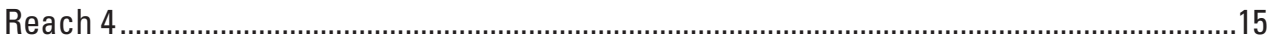

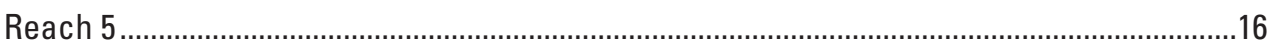

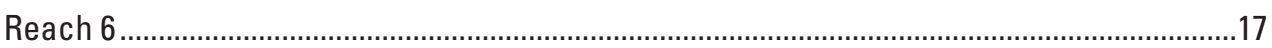

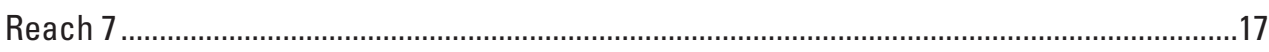

Reach 8

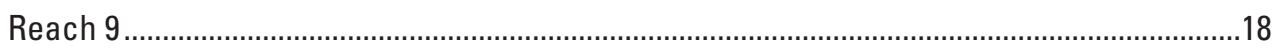

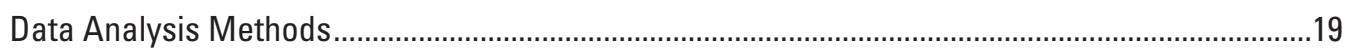

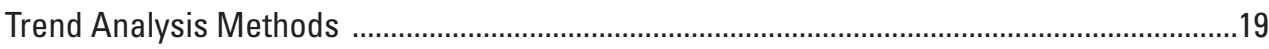

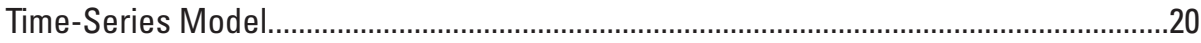

Multiple Linear Regression on Time, Streamflow, and Season .....................................21

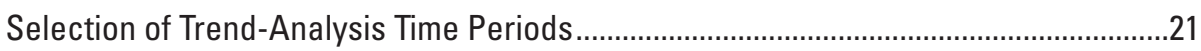

Estimation of Normalized Constituent Loads ........................................................................21

Streamflow Conditions and Various Data-Related Factors that Affect Trend Analysis and

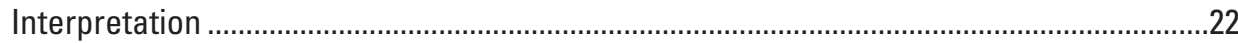

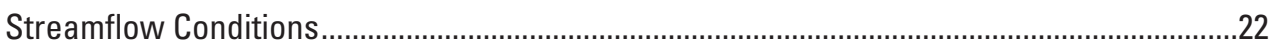

Various Data-Related Factors that Affect Trend Analysis and Interpretation.........................24

Water-Quality Trends for Selected Sampling Sites in the Upper Clark Fork Basin ..........................26

Trends in Flow-Adjusted Concentrations and Estimated Normalized Loads............................26

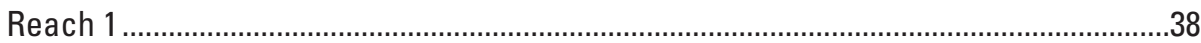

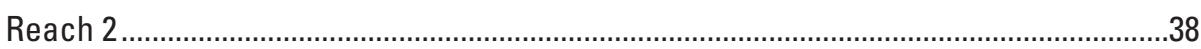

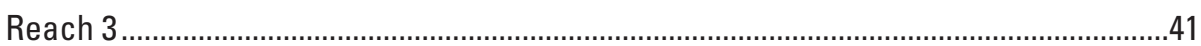

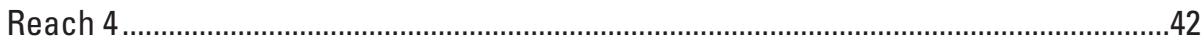

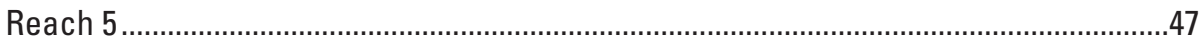

Reach 6

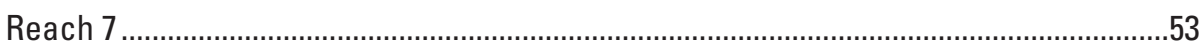

Reach 8

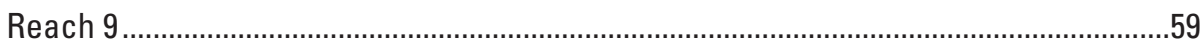


Overview of Water-Quality Trend Results for Data-Summary Reaches.

Summary of Estimated Normalized Loads and Within-Reach Contributions of Constituents and Streamflow.

Overview of Temporal Changes in Flow-Adjusted Concentrations and Estimated Normalized Constituent Loads

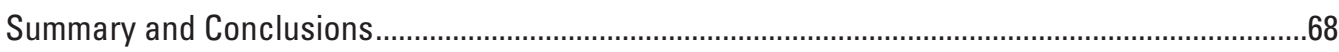

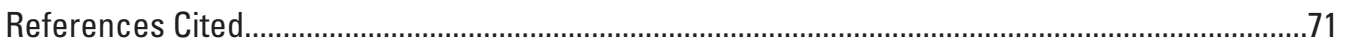

Appendix 1-Summary Information Relating to Quality-Control, Water-Quality, and

Continuous Streamflow Data ........................................................................................78

Appendix 2-Summary of the Time-Series Model as Applied in this Study.................................110

Appendix 3-Summary of Multiple Linear Regression of Water-Quality Constituents on

Time, Streamflow, and Season, as Applied in this Study..............................................113

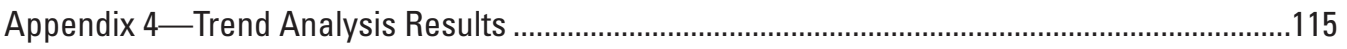

Appendix 5-Transport-Analysis Balance Calculations for Data-Summary Reaches ..................152

\section{Figures}

1. Map showing location of study area, sampling sites, and data-summary reaches in the upper Clark Fork Basin, Montana

2. Graphs showing statistical distributions of selected constituents for sites in the upper Clark Fork Basin, Montana, based on data collected during water years $2001-10$

3. Graphs showing daily mean streamflow for selected sites in the upper Clark Fork Basin, Montana, water years 1993-2010.

4. Graphs showing selected streamflow and constituent concentration information for Clark Fork near Galen, water years 1993-2010...

5. Graphs showing flow-adjusted fitted trends determined by using the time-series model for selected constituents for sites in reach 1, extending from Blacktail Creek to Silver Bow Creek at Butte, water years 1996-2010.

6. Pie diagrams showing drainage area, streamflow, and estimated normalized constituent loads contributed from reach inflow and within-reach sources for reach 1, extending from Blacktail Creek to Silver Bow Creek at Butte for selected periods

7. Graphs showing flow-adjusted fitted trends determined by using the time-series model for selected constituents for sites in reach 2, extending from Silver Bow Creek at Butte to Silver Bow Creek at Opportunity, water years 1996-2010.

8. Pie diagrams showing drainage area, streamflow, and estimated normalized constituent loads contributed from reach inflow and within-reach sources for reach 2, extending from Silver Bow Creek at Butte to Silver Bow Creek at Opportunity, for selected periods.

9. Graphs showing flow-adjusted fitted trends determined by using the time-series model for selected constituents for sites in reach 3, extending from Silver Bow Creek at Opportunity to Silver Bow Creek at Warm Springs, water years 1996-2010

10. Pie diagrams showing drainage area, streamflow, and estimated normalized constituent loads contributed from reach inflow and within-reach sources for reach 3, extending from Silver Bow Creek at Opportunity to Silver Bow Creek at Warm Springs for selected periods 
11. Graphs showing flow-adjusted fitted trends determined by using the time-series model for selected constituents for sites in reach 4, extending from Silver Bow Creek at Warm Springs to Clark Fork near Galen, based on data collected during water years 1985-2010.

12. Pie diagrams showing drainage area, streamflow, and estimated normalized constituent loads contributed from reach inflow and within-reach sources for each 4, extending from Silver Bow Creek at Warm Springs to Clark Fork near Galen for selected periods

13. Graphs showing flow-adjusted fitted trends determined by using the time-series model and multiple linear regression on time, streamflow, and season for selected constituents for selected sites in reach 5, extending from Clark Fork near Galen to Clark Fork at Deer Lodge, based on data collected during water years 1985-2010

14. Pie diagrams showing drainage area, streamflow, and estimated normalized constituent loads contributed from reach inflow and within-reach sources for reach 5, extending from Clark Fork near Galen to Clark Fork at Deer Lodge for selected periods

15. Graphs showing flow-adjusted fitted trends determined by using the time-series model for selected constituents for sites in reach 6, extending from Clark Fork at Deer Lodge to Clark Fork at Goldcreek, based on data collected during water years $1985-2010$.

16. Pie diagrams showing drainage area, streamflow, and estimated normalized constituent loads contributed from reach inflow and within-reach for reach 6 , extending from Clark Fork at Deer Lodge to Clark Fork at Goldcreek for selected periods.

17. Graphs showing flow-adjusted fitted trends determined by using the time-series model for selected constituents for sites in reach 7, extending from Clark Fork at Goldcreek to Clark Fork near Drummond, based on data collected during water years 1985-2010.

18. Pie diagrams showing drainage area, streamflow, and estimated normalized constituent loads contributed from reach inflow and within-reach for reach 7 , extending from Clark Fork at Goldcreek to Clark Fork near Drummond

19. Graphs showing flow-adjusted fitted trends determined by using the time-series model for selected constituents for sites in reach 8, extending from Clark Fork near Drummond to Clark Fork at Turah Bridge, based on data collected during water years 1985-2010

20. Pie diagrams showing drainage area, streamflow, and estimated normalized constituent loads contributed from reach inflow and within-reach sources for reach 8, extending from Clark Fork near Drummond to Clark Fork at Turah Bridge for selected periods

21. Graphs showing fitted trends determined by using the time-series model for selected constituents for sites in reach 9, extending from Clark Fork at Turah Bridge to Clark Fork above Missoula, based on data collected during water years 1985-2010.

22. Pie diagrams showing drainage area, streamflow, and estimated normalized constituent loads contributed from reach inflow and within-reach sources for reach 9, extending from Clark Fork at Turah Bridge to Clark Fork above Missoula for selected periods

23. Pie diagrams showing streamflow, and estimated normalized unfiltered-recoverable copper loads contributed from reach inflow and within-reach sources for datasummary reaches for selected periods. 
24. Pie diagrams showing streamflow, and estimated normalized unfiltered-recoverable arsenic loads contributed from reach inflow and within-reach sources for datasummary reaches for selected periods

25. Pie diagrams showing streamflow, and estimated normalized suspended-sediment loads contributed from reach inflow and within-reach sources for data-summary reaches for selected periods.

\section{Appendix Figures}

1-1. Graphs showing spike recoveries for laboratory-spiked deionized-water blank samples, based on data collected during water years 1993-2010.

1-2. Graphs showing spike recoveries for laboratory-spiked stream-water samples, based on data collected during water years 1993-2010.

4-1. Graphs showing flow-adjusted fitted trends determined by using the time-series model for selected water-quality constituents and properties for Blacktail Creek, water years 1996-2010.

4-2. Graphs showing flow-adjusted fitted trends determined by using the time-series model for selected water-quality constituents and properties for Silver Bow Creek at Butte, water years 1996-2010.

4-3. Graphs showing flow-adjusted fitted trends determined by using the time-series model for selected water-quality constituents and properties for Silver Bow Creek at Opportunity, water years 1996-2010

4-4. Graphs showing flow-adjusted fitted trends determined by using multiple linear regression on time, discharge, and season for selected water-quality constituents and properties for Mill Creek near Anaconda, water years 2006-2010

4-5. Graphs showing flow-adjusted fitted trends determined by using multiple linear regression on time, discharge, and season for selected water-quality constituents and properties for Mill Creek at Opportunity, water years 2006-10.

4-6. Graphs showing flow-adjusted fitted trends determined by using multiple linear regression on time, discharge, and season for selected water-quality constituents and properties for Willow Creek near Anaconda, water years 2006-10.

4-7. Graphs showing flow-adjusted fitted trends determined by using multiple linear regression on time, discharge, and season for selected water-quality constituents and properties for Willow Creek at Opportunity, water years 2006-10.

4-8. Graphs showing flow-adjusted fitted trends determined by using the time-series model for selected water-quality constituents and properties for Silver Bow Creek at Warm Springs, water years 1996-2010.

4-9. Graphs showing flow-adjusted fitted trends determined by using multiple linear regression on time, discharge, and season for selected water-quality constituents and properties for Warm Springs Creek near Anaconda, water years 2006-10

4-10. Flow-adjusted fitted trends determined by using the time-series model for selected water-quality constituents and properties for Warm Springs Creek at Warm Springs, water years 1996-10.

4-11. Graphs showing flow-adjusted fitted trends determined by using the time-series model for selected water-quality constituents and properties for Clark Fork near Galen, water years 1996-2010

4-12. Graphs showing flow-adjusted fitted trends determined by using multiple linear regression on time, discharge, and season for selected water-quality constituents and properties for Lost Creek near Anaconda, water years 2006-10. 
4-13. Graphs showing flow-adjusted fitted trends determined by using multiple linear regression on time, discharge, and season for selected water-quality constituents and properties for Lost Creek near Galen, water years 2006-10.

4-14. Graphs showing flow-adjusted fitted trends determined by using the time-series model for selected water-quality constituents and properties for Clark Fork at Deer Lodge, water years 1996-2010.

4-15. Graphs showing flow-adjusted fitted trends determined by using the time-series model for selected water-quality constituents and properties for Little Blackfoot River, water years 1996-2005...

4-16. Graphs showing flow-adjusted fitted trends determined by using the time-series model for selected water-quality constituents and properties for Clark Fork at Goldcreek, water years 1996-2010

4-17. Graphs showing flow-adjusted fitted trends determined by using the time-series model for selected water-quality constituents and properties for Flint Creek, water years 1996-2005

4-18. Graphs showing flow-adjusted fitted trends determined by using the time-series model for selected water-quality constituents and properties for Clark Fork near Drummond, water years 1996-2010.

4-19. Graphs showing flow-adjusted fitted trends determined by using the time-series model for selected water-quality constituents and properties for Rock Creek, water years 1996-2005

4-20. Graphs showing flow-adjusted fitted trends determined by using the time-series model for selected water-quality constituents and properties for Clark For at Turah Bridge, water years 1996-2010.

4-21. Graphs showing flow-adjusted fitted trends determined by using the time-series model for selected water-quality constituents and properties for Blackfoot River water years $1996-2010$...

4-22. Graphs showing flow-adjusted fitted trends determined by using the time-series model for selected water-quality constituents and properties for Clark Fork above Missoula, water years 1996-2010 


\section{Tables}

1. Information for study sampling sites and data-summary reaches in the upper Clark Fork Basin, Montana.

2. Property and constituents included in the trend analysis and information relating to laboratory and study reporting levels.

3. Percent of samples with unadjusted unfiltered-recoverable concentrations exceeding water-quality standards for sites in the upper Clark Fork Basin, water years 2001-10.

4. Summary of flow-adjusted trend results determined by using the time-series model for selected sites and constituents, water years 1996-2010.

5. Summary of flow-adjusted trend results determined by using the time-series model for Clark Fork above Missoula for selected constituents, water years 1996-2010

6. Summary of flow-adjusted trend results determined by using multiple linear regression on time, streamflow, and season for selected sites and constituents, water years $2006-10$

7. Drainage area and streamflow information relevant to the transport analysis for data-summary reaches in the upper Clark Fork Basin, Montana, water years 1996-2010

\section{Appendix Tables}

1-1. Summary information relating to quality-control samples collected at sites in the upper Clark Fork Basin, Montana, based on data collected during water years 1993-2010.

1-2. Summary information relating to quality-control samples collected at sites in the upper Clark Fork Basin, Montana, based on data collected during water years 1993-2010.

1-3. Summary information relating to quality-control samples collected at sites in the upper Clark Fork Basin, Montana, based on data collected during water years 1993-2010

1-4. Summary information relating to water-quality constituents and properties in samples collected at sites in the upper Clark Fork Basin, Montana, based on data collected during water years 2001-2010.

1-5. Aquatic life standards for selected sites in the upper Clark Fork Basin ...

1-6. Summary information relating to continuous streamflow data for sites in the upper Clark Fork Basin, Montana , based on data collected during water years 2001-2010

2-1. Statistical summaries of standard errors of estimates for the time-series model analyses

3-1. Statistical summaries of standard errors of estimates for multiple linear regression models of water-quality constituents on time, streamflow, and season.

4-1. Flow-adjusted trend results determined by using the time-series model for selected water-quality constituents and properties for selected sampling sites in the upper Clark Fork Basin, Montana, water years 1996-2010 
4-2. Flow-adjusted trend results determined by using the time-series model for selected water-quality constituents and properties for Clark Fork above Missoula, water years 1996-2010

4-3. Flow-adjusted trend results determined by using multiple linear regression on time, streamflow, and season for selected water-quality constituents and properties for selected sampling sites in the upper Clark Fork Basin, Montana, water years 2006-2010

5-1. Transport-analysis balance calculations for sites analyzed by using the time series model in reach 1, extending from Blacktail Creek to Silver Bow Creek at Butte for selected periods, water years 1996-2010.

5-2. Transport-analysis balance calculations for sites analyzed by using the time series model in reach 2, extending from Silver Bow Creek at Butte to Silver Bow Creek at Opportunity for selected periods, water years 1996-2010.

5-3. Transport-analysis balance calculations for sites analyzed by using the time series model in reach 3, extending from Silver Bow Creek at Opportunity to Silver Bow Creek at Warm Springs for selected periods, water years 1996-2010.

5-4. Transport-analysis balance calculations for sites analyzed by using the time series model in reach 4, extending from Silver Bow Creek at Warm Springs to Clark Fork near Galen for selected periods, water years 1996-2010

5-5. Transport-analysis balance calculations for sites analyzed by using the time series model in reach 5, extending from Clark Fork near Galen to Clark Fork at Deer Lodge for selected periods, water years 1996-2010

5-6. Transport-analysis balance calculations for sites analyzed by using the time series model in reach 6, extending from Clark Fork at Deer Lodge to Clark Fork at Goldcreek for selected periods, water years 1996-2010

5-7. Transport-analysis balance calculations for sites analyzed by using the time series model in reach 7, extending from Clark Fork at Goldcreek to Clark Fork near Drummond for selected periods, water years 1996-2010

5-8. Transport-analysis balance calculations for sites analyzed by using the time series model in reach 8, extending from Clark Fork near Drummond to Clark Fork at Turah Bridge for selected periods, water years 1996-2010.

5-9. Transport-analysis balance calculations for sites analyzed by using the time series model in reach 9, extending from Clark Fork at Turah Bridge to Clark Fork above Missoula for selected periods, water years 1996-2010 


\section{Conversion Factors}

\begin{tabular}{lcl}
\multicolumn{1}{c}{ Inch/pound to SI } & \multicolumn{1}{c}{ Multiply } & By obtain \\
\hline acre & 0.4047 & hectare $(\mathrm{ha})$ \\
acre-foot (acre-ft) & 1,233 & cubic meter $\left(\mathrm{m}^{3}\right)$ \\
cubic foot $\left(\mathrm{ft}^{3}\right)$ & 0.02832 & cubic meter $\left(\mathrm{m}^{3}\right)$ \\
cubic foot per second $\left(\mathrm{ft}^{3} / \mathrm{s}\right)$ & 0.02832 & cubic meter per second $\left(\mathrm{m}^{3} / \mathrm{s}\right)$ \\
foot (ft) & 0.3048 & meter $(\mathrm{m})$ \\
gallon (gal) & 3.785 & liter $(\mathrm{L})$ \\
inch (in.) & 2.54 & centimeter $(\mathrm{cm})$ \\
mile (mi) & 1.609 & kilometer $(\mathrm{km})$ \\
ounce, avoirdupois $(\mathrm{oz})$ & 28.35 & gram $(\mathrm{g})$ \\
square mile $\left(\mathrm{mi}^{2}\right)$ & 2.590 & square kilometer $\left(\mathrm{km}{ }^{2}\right)$ \\
tons per day $(\mathrm{t} / \mathrm{d})$ & 907.1 & kilograms per day $(\mathrm{kg} / \mathrm{d})$ \\
\hline
\end{tabular}

Temperature in degrees Celsius $\left({ }^{\circ} \mathrm{C}\right)$ may be converted to degrees Fahrenheit $\left({ }^{\circ} \mathrm{F}\right)$ as follows:

${ }^{\circ} \mathrm{F}=\left(1.8 \times^{\circ} \mathrm{C}\right)+32$

Vertical coordinate information is referenced to the National Geodetic Vertical Datum of 1988 (NGVD 88).

Horizontal coordinate information is referenced to North American Datum of 1983 (NAD 83).

Altitude, as used in this report, refers to distance above the vertical datum.

Specific conductance is given in microsiemens per centimeter at 25 degrees Celsius $(\mu \mathrm{S} / \mathrm{cm})$.

Concentrations of chemical constituents in water are given either in micrograms per liter $(\mu \mathrm{g} / \mathrm{L})$ or milligrams per liter $(\mathrm{mg} / \mathrm{L})$.

Water year is defined as the 12-month period from 0ctober 1 through September 30 of the following calendar year. The water year is designated by the calendar year in which it ends.

For example, water year 2010 is the period from October 1, 2009, through September 30, 2010. 


\section{Abbreviated Units and Symbols}

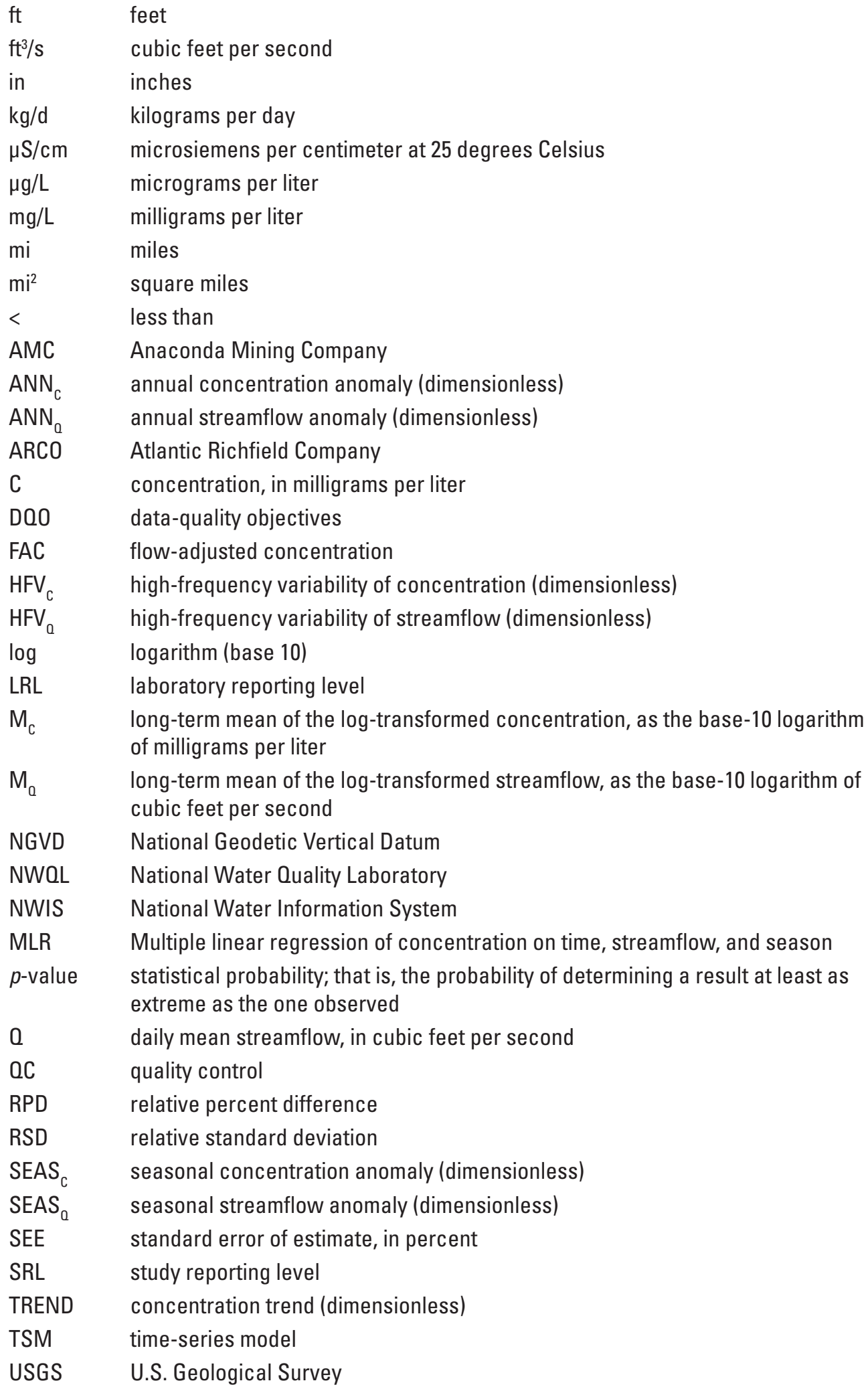





\title{
Water-Quality Trends for Selected Sampling Sites in the Upper Clark Fork Basin, Montana, Water Years 1996-2010
}

\author{
By Steven K. Sando, Aldo V. Vecchia, David L. Lorenz, and Elliott P. Barnhart
}

\section{Abstract}

The primary purposes of this report are to (1) characterize temporal trends in flow-adjusted concentrations (filtered and unfiltered) of mining-related contaminants and (2) assess those trends in the context of source areas and transport of those contaminants through the upper Clark Fork Basin. A large-scale trend analysis was done on specific conductance, selected trace elements (arsenic, cadmium, copper, iron, lead, manganese, and zinc), and suspended-sediment data for 22 sites for water years 1996-2010. Trend analysis was conducted by using two parametric methods: a time-series model (TSM) and multiple linear regression on time, streamflow, and season (MLR).

The main-stem Clark Fork begins at the confluence of Silver Bow and Warm Springs Creeks near Warm Springs, Montana and flows about 485 miles through Montana and Idaho. The study area encompasses the upper Clark Fork Basin in west-central Montana upstream from Clark Fork above Missoula (site 22) with a drainage area of 5,999 square miles $\left(\mathrm{mi}^{2}\right)$. Mining in the upper Clark Fork Basin began in 1864 when small-scale placer mining operations extracted gold from Silver Bow Creek and its tributaries in and near Butte. Large amounts of waste materials enriched with trace elements, including the metallic elements cadmium, copper, lead, and zinc, as well as the metalloid trace element arsenic, were generated from mining operations in the Butte area and the milling and smelting operations in the Anaconda area. Extensive deposition of mining wastes in the Silver Bow Creek and Clark Fork channels and floodplains had substantial effects on water quality. Federal Superfund remediation activities in the upper Clark Fork Basin began in 1983 and have included substantial remediation in the Butte area and removal of the former Milltown Dam near Missoula. The U.S. Geological Survey has been collecting streamflow and water-quality data in the upper Clark Fork Basin since 1983 to aid in identifying temporal changes in water quality.

For sites that were analyzed by using the TSM, normalized loads (hereinafter referred to as loads) were estimated to evaluate temporal changes in relative contributions of selected trace elements and suspended sediment from upstream source areas to reach outflows. Trend results are presented for all constituents investigated; however, in the discussion emphasis is placed on copper, arsenic, and suspended sediment.

Trend results for 1996-2010 indicate moderate to large decreases in flow-adjusted concentrations (FACs) and loads of copper (and other metallic elements) and suspended sediment in Silver Bow Creek upstream from Warm Springs. Deposition of metallic elements and suspended sediment within Warm Springs Ponds substantially reduces the downstream transport of those constituents. However, mobilization of copper and suspended sediment from floodplain tailings and stream banks in the Clark Fork reach from Galen to Deer Lodge is a large source of metallic elements and suspended sediment, which also affects downstream transport of those constituents. Copper and suspended-sediment loads mobilized from within this reach accounted for about 40 and 20 percent, respectively, of the loads for Clark Fork at Turah Bridge (site 20); whereas, streamflow contributed from within this reach only accounted for about 8 percent of the streamflow at Turah Bridge. Minor changes in FACs and loads of copper and suspended sediment are indicated for this reach during 1996-2010.

Clark Fork reaches downstream from Deer Lodge are relatively smaller sources of metallic elements than the reach from Galen to Deer Lodge. In general, small decreases in loads and FACs of copper and suspended sediment are indicated for Clark Fork sites downstream from Deer Lodge during 1996-2010. Thus, although large decreases in FACs and loads of copper and suspended sediment are indicated for Silver Bow Creek upstream from Warm Springs, those large decreases are not translated to the more downstream reaches largely because of temporal stationarity in constituent transport relations in the Clark Fork reach from Galen to Deer Lodge.

Unlike metallic elements, arsenic (a metalloid element) in streams in the upper Clark Fork Basin typically is mostly in dissolved phase, has less variability in concentrations, and has weaker direct relations with suspended-sediment concentrations and streamflow. Arsenic trend results for 1996-2010 indicate generally moderate decreases in FACs and loads in Silver Bow Creek upstream from Opportunity. In general, small temporal changes in loads and FACs of arsenic are indicated for Silver Bow Creek and Clark Fork reaches downstream from Opportunity during 1996-2010. Contribution of 
arsenic (from Warm Springs Ponds, the Mill-Willow bypass, and groundwater sources) in the Silver Bow Creek reach from Opportunity to Warm Springs is a relatively large source of arsenic. Arsenic loads originating from within this reach accounted for about 11 percent of the load for Clark Fork at Turah Bridge; whereas, streamflow contributed from within this reach only accounted for about 2 percent of the streamflow at Turah Bridge.

\section{Introduction}

Mining in the upper Clark Fork Basin (upstream from Missoula, Montana) began in 1864 when small-scale placer mining operations extracted gold from Silver Bow Creek and its tributaries in and near Butte (Freeman, 1900; U.S. Environmental Protection Agency, 2005). Large amounts of waste materials enriched with metallic contaminants (cadmium, copper, lead, and zinc) and the metalloid trace element arsenic were generated from mining operations in the Butte area and the milling and smelting operations in the Anaconda area (Andrews, 1987; Gammons and others, 2006). Extensive deposition of mining wastes in the Silver Bow Creek and Clark Fork channels and floodplains had substantial effects on water quality. Federal Superfund remediation activities in the upper Clark Fork Basin began in 1983 and have included substantial remediation in the Butte area and removal of the former Milltown Dam, near Missoula (CDM, 2005; U.S. Environmental Protection Agency, 2010; U.S. Environmental Protection Agency, 2004; Sando and Lambing, 2011).

Water-quality data collection by the U.S. Geological Survey (USGS) within the upper Clark Fork Basin began during 1985-88 with the establishment of a small long-term monitoring program that has expanded through time and continued through present (2013). A statistical evaluation of flow-adjusted water-quality trends for the monitoring data was needed to document changes in water quality that might have resulted from remediation activities. The USGS, in cooperation with the U.S. Environmental Protection Agency, conducted this study to test for flow-adjusted temporal trends in water quality at 22 sites (study sites are located at USGS streamflow gaging stations, fig. 1, table 1) using two parametric trends analysis methods: a joint time-series model (TSM; Vecchia, 2005) for concentration and streamflow and multiple linear regression of concentration on time, streamflow, and season (MLR; Helsel and Hirsch, 2002).

\section{Purpose and Scope}

The primary purposes of this report are to (1) characterize temporal trends in flow-adjusted concentrations (filtered and unfiltered) of mining-related contaminants and (2) assess those trends in the context of source areas and transport of those contaminants through the upper Clark Fork Basin. A large-scale trend analysis was done on 22 sites for water years
1996-2010. This report presents the trend results and also background information on mining and remediation activities in the upper Clark Fork Basin, trend-analysis methods, streamflow conditions, and various data-related factors that affect trend results. This information is presented to assist in evaluating trend results; however, it is beyond the scope of this report to provide detailed explanations for all observed temporal changes.

\section{Description of Study Area}

The Clark Fork drains an extensive region in western Montana and northern Idaho in the Columbia River Basin. The main-stem Clark Fork begins at the confluence of Silver Bow and Warm Springs Creeks near Warm Springs, Montana and flows about 485 miles through Montana and Idaho. The study area (fig. 1) encompasses the upper Clark Fork Basin in west-central Montana upstream from Clark Fork above Missoula (site 22, table 1), with a drainage area of 5,999 square miles $\left(\mathrm{mi}^{2}\right)$.

\section{Hydrographic and Hydrologic Characteristics}

Silver Bow Creek is one of two streams that join to form the Clark Fork. According to the National Hydrography Dataset (U.S. Geological Survey, 2012a), the Silver Bow Creek main-stem channel originates in mountains north of Butte, Montana, then is shown to flow south past the Berkeley Pit (not shown in fig. 1; historically, the largest single metal-ore mine in the upper Clark Fork Basin) and into Butte. However, streamflows in the upper reaches of Silver Bow Creek above the Berkeley Pit are diverted into a tailings pond. In the 1930's, the remnant section of Silver Bow Creek downgradient from the Berkeley Pit was channelized and replaced by a storm drain upstream from the confluence of Silver Bow Creek and Blacktail Creek (Don Booth, Atlantic Richfield Company, written commun., August 2013). The longest stream channel in the upper Silver Bow Creek Basin is Blacktail Creek, which originates in mountains south of Butte and then flows north to its confluence with Silver Bow Creek in Butte. Blacktail Creek (site 1, fig. 1, table 1) has a drainage area of $85 \mathrm{mi}^{2}$ and estimated mean annual streamflow (based on data from USGS streamflow-gaging station Blacktail Creek at Butte; station 12323240; water years 1989-2010) of 13 cubic feet per second ( $\mathrm{ft}^{3} / \mathrm{s}$; U.S. Geological Survey, 2012b). There have been numerous small mining operations in the upper reaches of the Blacktail Creek Basin, but at its mouth the effect of mining operations on water quality of Blacktail Creek is small to moderate. Silver Bow Creek at Butte (site 2, table 1) has a drainage area of $103 \mathrm{mi}^{2}$ and mean annual streamflow (water years 1984-2010) of $22 \mathrm{ft}^{3} / \mathrm{s}$ (U.S. Geological Survey, 2012b). The upper reaches of the Silver Bow Creek Basin in and near Butte contain numerous mine shafts, pits, mills, smelters, and tailings piles and ponds as a result of mining activities that began in the 1860's and generally ceased 


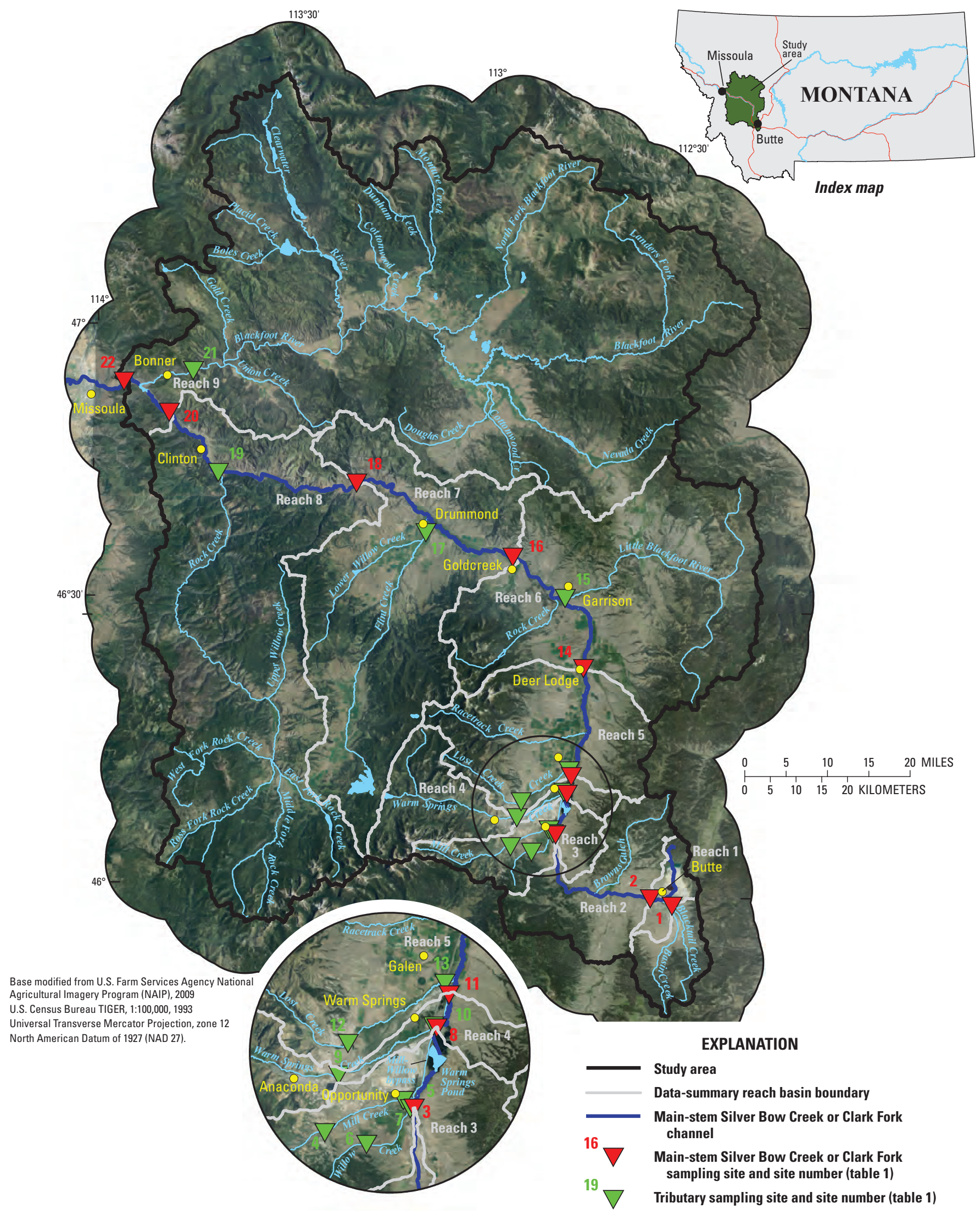

Figure 1. Location of study area, sampling sites, and data-summary reaches in the upper Clark Fork Basin, Montana. 
Table 1. Information for study sampling sites and data-summary reaches in the upper Clark Fork Basin, Montana.

[Water year is the 12-month period from October 1 through September 30 and is designated by the year in which it ends. USGS, U.S. Geological Survey; TSM, time-series model; MLR, multiple linear regression on time, streamflow and season]

\begin{tabular}{|c|c|c|c|c|c|c|c|c|c|}
\hline $\begin{array}{c}\text { Site } \\
\text { number } \\
\text { (fig. 1) }\end{array}$ & $\begin{array}{c}\text { USGS site } \\
\text { identification } \\
\text { number }\end{array}$ & USGS site name & Abbreviated site name & $\begin{array}{l}\text { Data- } \\
\text { summary } \\
\text { reach }^{1}\end{array}$ & $\begin{array}{l}\text { Drain- } \\
\text { age area, } \\
\text { square } \\
\text { miles }\end{array}$ & $\begin{array}{l}\text { Period of water- } \\
\text { quality data } \\
\text { collection }\end{array}$ & $\begin{array}{l}\text { Median an- } \\
\text { nual sampling } \\
\text { frequency, } \\
\text { samples per } \\
\text { year (range) }\end{array}$ & $\begin{array}{l}\text { Trend } \\
\text { analy- } \\
\text { sis } \\
\text { method }\end{array}$ & $\begin{array}{c}\text { Trend } \\
\text { analysis } \\
\text { periods }^{2}\end{array}$ \\
\hline 1 & 12323230 & $\begin{array}{l}\text { Blacktail Creek at Harrison } \\
\text { Avenue, at Butte, Montana }\end{array}$ & Blacktail Creek & 1 & 85 & $\begin{array}{c}3 / 1993-8 / 1995 \\
12 / 1996-8 / 2003 \\
12 / 2004-8 / 2010\end{array}$ & $8(7-10)$ & TSM & $1,2,3$ \\
\hline 2 & 12323250 & $\begin{array}{c}\text { Silver Bow Creek below Black- } \\
\text { tail Creek, at Butte, Montana }\end{array}$ & Silver Bow Creek at Butte & 1 and 2 & 103 & $\begin{array}{l}3 / 1993-8 / 1995 \\
12 / 1996-8 / 2010\end{array}$ & $8(7-10)$ & TSM & $1,2,3$ \\
\hline 3 & 12323600 & $\begin{array}{l}\text { Silver Bow Creek at Opportu- } \\
\text { nity, Montana }\end{array}$ & Silver Bow Creek at Opportunity & 2 and 3 & 363 & $\begin{array}{l}3 / 1993-8 / 1995 \\
12 / 1996-8 / 2010\end{array}$ & $8(8-11)$ & TSM & $1,2,3$ \\
\hline 4 & 12323670 & $\begin{array}{l}\text { Mill Creek near Anaconda, } \\
\text { Montana }\end{array}$ & Mill Creek near Anaconda & 3 & 34 & $12 / 2004-8 / 2010$ & $8(8-8)$ & MLR & 3 \\
\hline 5 & 12323700 & $\begin{array}{l}\text { Mill Creek at Opportunity, } \\
\text { Montana }\end{array}$ & Mill Creek at Opportunity & 3 & 43 & $3 / 2003-8 / 2010$ & $8(8-8)$ & MLR & 3 \\
\hline 6 & 12323710 & $\begin{array}{l}\text { Willow Creek near Anaconda, } \\
\text { Montana }\end{array}$ & Willow Creek near Anaconda & 3 & 14 & $12 / 2004-8 / 2010$ & $8(6-8)$ & MLR & 3 \\
\hline 7 & 12323720 & $\begin{array}{l}\text { Willow Creek at Opportunity, } \\
\text { Montana }\end{array}$ & Willow Creek at Opportunity & 3 & 31 & $3 / 2003-8 / 2010$ & $8(8-8)$ & MLR & 3 \\
\hline 8 & 12323750 & $\begin{array}{l}\text { Silver Bow Creek at Warm } \\
\text { Springs, Montana }\end{array}$ & Silver Bow Creek at Warm Springs & 3 and 4 & 473 & $3 / 1993-8 / 2010$ & $8(6-11)$ & TSM & $1,2,3$ \\
\hline 9 & 12323760 & $\begin{array}{l}\text { Warm Springs Creek near Ana- } \\
\text { conda, Montana }\end{array}$ & $\begin{array}{l}\text { Warm Springs Creek near Ana- } \\
\text { conda }\end{array}$ & 4 & 157 & $10 / 2005-8 / 2010$ & $6(6-6)$ & MLR & 3 \\
\hline 10 & 12323770 & $\begin{array}{l}\text { Warm Springs Creek at Warm } \\
\text { Springs, Montana }\end{array}$ & $\begin{array}{l}\text { Warm Springs Creek at Warm } \\
\text { Springs }\end{array}$ & 4 & 163 & $3 / 1993-8 / 2010$ & $6(4-8)$ & TSM & $1,2,3$ \\
\hline 11 & 12323800 & Clark Fork near Galen, Montana & Clark Fork near Galen & 4 and 5 & 651 & $7 / 1988-8 / 2010$ & $8(1-13)$ & TSM & $1,2,3$ \\
\hline 12 & 12323840 & $\begin{array}{l}\text { Lost Creek near Anaconda, } \\
\text { Montana }\end{array}$ & Lost Creek near Anaconda & 5 & 26 & $12 / 2004-8 / 2010$ & $8(7-8)$ & MLR & 3 \\
\hline 13 & 12323850 & Lost Creek near Galen, Montana & Lost Creek near Galen & 5 & 60 & $3 / 2003-8 / 2010$ & $8(8-8)$ & MLR & 3 \\
\hline 14 & 12324200 & $\begin{array}{l}\text { Clark Fork at Deer Lodge, } \\
\text { Montana }\end{array}$ & Clark Fork at Deer Lodge & 5 and 6 & 995 & $3 / 1985-8 / 2010$ & $8(4-20)$ & TSM & $1,2,3$ \\
\hline 15 & 12324590 & $\begin{array}{l}\text { Little Blackfoot River near Gar- } \\
\text { rison, Montana }\end{array}$ & Little Blackfoot River & 6 & 407 & $3 / 1985-8 / 2004$ & $6(2-10)$ & TSM & 1,2 \\
\hline 16 & 12324680 & $\begin{array}{l}\text { Clark Fork at Goldcreek, Mon- } \\
\text { tana }\end{array}$ & Clark Fork at Goldcreek & 6 and 7 & 1,704 & $3 / 1993-8 / 2010$ & $8(6-10)$ & TSM & $1,2,3$ \\
\hline
\end{tabular}


Table 1. Information for study sampling sites and data-summary reaches in the upper Clark Fork Basin, Montana.-Continued

[Water year is the 12-month period from October 1 through September 30 and is designated by the year in which it ends. USGS, U.S. Geological Survey; TSM, time-series model; MLR, multiple linear regression on time, streamflow and season]

\begin{tabular}{|c|c|c|c|c|c|c|c|c|c|}
\hline $\begin{array}{c}\text { Site } \\
\text { number } \\
\text { (fig. 1) }\end{array}$ & $\begin{array}{c}\text { USGS site } \\
\text { identification } \\
\text { number }\end{array}$ & USGS site name & Abbreviated site name & $\begin{array}{l}\text { Data- } \\
\text { summary } \\
\text { reach }^{1}\end{array}$ & $\begin{array}{l}\text { Drain- } \\
\text { age area, } \\
\text { square } \\
\text { miles }\end{array}$ & $\begin{array}{l}\text { Period of water- } \\
\text { quality data } \\
\text { collection }\end{array}$ & $\begin{array}{l}\text { Median an- } \\
\text { nual sampling } \\
\text { frequency, } \\
\text { samples per } \\
\text { year (range) }\end{array}$ & $\begin{array}{l}\text { Trend } \\
\text { analy- } \\
\text { sis } \\
\text { method }\end{array}$ & $\begin{array}{c}\text { Trend } \\
\text { analysis } \\
\text { periods }^{2}\end{array}$ \\
\hline 17 & 12331500 & $\begin{array}{l}\text { Flint Creek near Drummond, } \\
\text { Montana }\end{array}$ & Flint Creek & 7 & 490 & $3 / 1985-8 / 2004$ & $8(1-11)$ & TSM & 1,2 \\
\hline 18 & 12331800 & $\begin{array}{l}\text { Clark Fork near Drummond, } \\
\text { Montana }\end{array}$ & Clark Fork near Drummond & 7 and 8 & 2,501 & $3 / 1993-8 / 2010$ & $8(6-10)$ & TSM & $1,2,3$ \\
\hline 19 & 12334510 & $\begin{array}{l}\text { Rock Creek near Clinton, } \\
\text { Montana }\end{array}$ & Rock Creek & 8 & 885 & $3 / 1985-8 / 2004$ & $6(2-10)$ & TSM & 1,2 \\
\hline 20 & 12334550 & $\begin{array}{l}\text { Clark Fork at Turah Bridge, near } \\
\text { Bonner, Montana }\end{array}$ & Clark Fork at Turah Bridge & 8 and 9 & 3,641 & $3 / 1985-8 / 2010$ & $8(6-23)$ & TSM & $1,2,3$ \\
\hline 21 & 12340000 & $\begin{array}{l}\text { Blackfoot River near Bonner, } \\
\text { Montana }\end{array}$ & Blackfoot River & 9 & 2,290 & $3 / 1985-8 / 2010$ & $6(2-14)$ & TSM & $1,2,3$ \\
\hline 22 & 12340500 & $\begin{array}{l}\text { Clark Fork above Missoula, } \\
\text { Montana }\end{array}$ & Clark Fork above Missoula & 9 & 5,999 & $7 / 1986-8 / 2010$ & $8(2-18)$ & TSM & $\begin{array}{c}1,2,3 \mathrm{~A}, \\
3 \mathrm{~B}\end{array}$ \\
\hline
\end{tabular}

${ }^{1}$ Where two reach numbers are shown, the site is both an outflow from the upstream reach and an inflow to the downstream reach.

${ }^{2}$ The numerical designations of the trend analysis periods are defined as:

1: water years 1996-2000;

2: water years 2001-05; and

3: water years $2006-10$.

Because of the substantial effect of the breach and removal of Milltown Dam in 2008, for Clark Fork above Missoula (site 22), period 3 was subdivided into period 3A (October 1, 2005-March 27, 2008) and period 3B (March 28, 2008-September 30, 2010). Selection of trend analysis periods is discussed in the section of this report "Selection of Trend-Analysis Time Periods." 
in the early 1980's (Freeman, 1900; Gammons and others, 2006). During the many decades of mining activities, inadequate handling of waste rock, water, and smelter emissions, coupled with effects of large flood events, resulted in extensive deposition of mining wastes in the Silver Bow Creek channel and floodplain with substantial effects on Silver Bow Creek water quality (Smith and others, 1998). Downstream from Butte, Silver Bow Creek flows west about 10 miles then north about 10 miles to the confluence of Warm Springs Creek, marking the start of the Clark Fork. In the reach of Silver Bow Creek between Butte and the confluence with Warm Springs Creek, large areas of the intervening basin were affected by production and dispersion of waste materials (rock, water, and smelter emissions) primarily from milling and smelting activities of the Anaconda Mining Company (AMC) Smelter (Hooper and others, 2002).

About 5 miles upstream from the confluence of Silver Bow Creek and Warm Springs Creek, Silver Bow Creek enters the Warm Springs Ponds (fig. 1), which are a series of three large ponds (variously constructed during 1908-1959; CDM, 2005) to retain and treat contaminated sediment transported from the upper reaches of Silver Bow Creek. Upstream from the Warm Springs Ponds, Silver Bow Creek at Opportunity (site 3, fig. 1, table 1) represents the outflow of the Silver Bow Creek basin above substantial retention and diversion structures. Site 3 has a drainage area of $363 \mathrm{mi}^{2}$ and mean annual streamflow (water years 1988-2010) of $52 \mathrm{ft}^{3} / \mathrm{s}$ (U.S. Geological Survey, 2012b). Notable tributaries to Silver Bow Creek in the reach below site 3 include Mill and Willow Creeks. The natural stream channels of those tributaries originally entered Silver Bow Creek near Opportunity, Montana. However, in about 1969, the Mill-Willow bypass was constructed to capture flows of Mill and Willow Creeks near their mouths and divert the combined flows into Silver Bow Creek between the outlet from Warm Springs Ponds and the confluence with Warm Springs Creek (CDM, 2005). Silver Bow Creek at Warm Springs, Montana, (site 8, fig. 1, table 1), which includes the combined flow from the Warm Springs Ponds outlet and the Mill-Willow bypass, has a drainage area of $473 \mathrm{mi}^{2}$ and mean annual streamflow (water years 1994-2010) of $85 \mathrm{ft}^{3} / \mathrm{s}$ (U.S. Geological Survey, 2012b).

Warm Springs Creek joins Silver Bow Creek a short distance downstream from site 8 to form the Clark Fork. The Warm Springs Creek drainage basin also was affected by tailings, and water and smelter emissions primarily from milling and smelting activities of the AMC Smelter (Hooper and others, 2002). Warm Springs Creek at Warm Springs (site 10, fig. 1, table 1) has a drainage area of $163 \mathrm{mi}^{2}$ and mean annual streamflow (water years 1984-2010) of $54 \mathrm{ft}^{3} / \mathrm{s}$ (U.S. Geological Survey, 2012b).

From its start at the confluence of Silver Bow Creek and Warm Springs Creek, the Clark Fork flows for about 125 miles through the study area, draining forested mountains that flank the Clark Fork valley. In the reach of the Clark Fork between its start and Deer Lodge there are large quantities of floodplain tailings that originated from mining wastes generated near
Butte and Anaconda (Smith and others, 1998). In this reach, the Clark Fork valley is broad (about 5 miles wide and known locally as the Deer Lodge Valley) and the Clark Fork channel is highly meandering (Lambing, 1998). A notable minor tributary that enters the Clark Fork in this reach is Lost Creek. The Lost Creek drainage basin has an area of about $65 \mathrm{mi}^{2}$ and was affected by deposition of contaminants in emissions from smelting activities of the AMC Smelter (Hooper and others, 2002). Clark Fork at Deer Lodge (site 14, fig. 1, table 1) has a drainage area of $995 \mathrm{mi}^{2}$ and mean annual streamflow (water years 1985-2010) is $228 \mathrm{ft}^{3} / \mathrm{s}$ (U.S. Geological Survey, 2012b). Between Deer Lodge and Garrison, floodplain tailings along the Clark Fork are present to a similar extent as in the valley upstream from Deer Lodge (Smith and others, 1998). The Little Blackfoot River, a major tributary with a drainage area of $407 \mathrm{mi}^{2}$, enters the Clark Fork at the lower end of this reach near Garrison. Between Garrison and Drummond where the Clark Fork valley narrows, floodplain tailings are less extensive than in the Deer Lodge Valley and meandering of the Clark Fork channel decreases (Smith and others, 1998; Lambing, 1998). Flint Creek, a major tributary with a drainage area of $490 \mathrm{mi}^{2}$, enters the Clark Fork in the reach between Goldcreek and Drummond. Clark Fork near Drummond (site 18, fig. 1, table 1) has a drainage area of 2,501 $\mathrm{mi}^{2}$ and mean annual streamflow (water years 1994-2010) is $701 \mathrm{ft}^{3} / \mathrm{s}$ (U.S. Geological Survey, 2012b). Downstream from Drummond, the Clark Fork valley is narrow (generally less than 1 mile) and meandering of the Clark Fork decreases further in association with the narrow valley and presence of highway and railroad embankments (Lambing, 1998). Rock Creek, a major tributary with a drainage area of $885 \mathrm{mi}^{2}$, enters the Clark Fork between Drummond and Turah Bridge, near Bonner (fig. 1). Clark Fork at Turah Bridge (site 20, fig. 1, table 1) has a drainage area of $3,641 \mathrm{mi}^{2}$ and mean annual streamflow (water years 1986-2010) is $1,220 \mathrm{ft}^{3} / \mathrm{s}$ (U.S. Geological Survey, 2012b). Downstream from Turah Bridge, the Clark Fork flows through the area where the former Milltown Reservoir was located. Milltown Dam was completed in 1907 (U.S. Environmental Protection Agency, 2004) just downstream from the confluence of the Clark Fork and the Blackfoot River. During the decades following construction of Milltown Dam, substantial amounts of mining wastes (about 6.6 million cubic yards; U.S. Environmental Protection Agency, 2004) generated near Butte and Anaconda were transported downstream and deposited in Milltown Reservoir. Based on a management decision, Milltown Dam was breached and removed in 2008 (U.S. Environmental Protection Agency, 2013) and the Clark Fork was returned to a free-flowing river. The Clark Fork channel in the former Milltown Reservoir area was artificially reconstructed by using designs to approximate natural geomorphologic characteristics. The Clark Fork was diverted from a temporary bypass into the reconstructed channel in 2010. The Blackfoot River, with a drainage area of $2,290 \mathrm{mi}^{2}$, is a major tributary to the Clark Fork between Turah Bridge and Missoula (fig. 1). At the downstream end of the study area, the Clark Fork above 
Missoula (site 22, fig. 1, table 1) has a drainage area of $5,999 \mathrm{mi}^{2}$ and mean annual streamflow (water years 19852010) is $2,600 \mathrm{ft}^{3} / \mathrm{s}$.

The annual hydrographs of streams in the upper Clark Fork Basin are dominated by snowmelt runoff, typically during April through July although early low-altitude snowmelt can sometimes increase streamflow in late winter (FebruaryMarch). For example, mean streamflow volume during April through July (water years 1985-2010) for Clark Fork above Missoula (site 22, fig. 1, table 1) accounts for about 64 percent of mean annual streamflow volume (U.S. Geological Survey, 2012c).

\section{Physiographic, Climatic, and Geologic Characteristics}

The study area lies within the Middle Rockies Ecoregion (Woods and others, 2002), which is characterized by forested mountains and intermontane valleys. Altitudes in the study area range from about 3,200-10,650 feet (ft) above the National Geodetic Vertical Datum of 1988 (NGVD 88). Vegetation is predominantly Douglas fir and ponderosa pine conifer forests in the high-altitude mountainous areas, mixed conifers shrubs and grasses in the mid-altitude foothills, and grasses in the low-altitude valley (Woods and others, 2002). The predominant land uses are timber harvest in mountainous areas and livestock grazing and hay production in valleys.

Areally-weighted mean annual precipitation in the study area (1980-2010 30-year normal; PRISM Climate Group, 2012) is about 23.9 inches (with a range in annual precipitation of 10.2-73.0 inches across the study area). About one-half of annual precipitation falls during May through July while winter typically is the driest season (Nimick, 1993). Mean annual precipitation is highest in mountainous areas and generally ranges from about 11-13 inches in valleys.

Bedrock in mountainous areas of the study area generally consists of various types of consolidated Precambrian metasedimentary and Paleozoic and Metazoic sedimentary formations (Nimick, 1993; Woods and others, 2002). Dominant rock type of ore bodies targeted by the most extensive mining activities in the upper Clark Fork Basin near Butte is the Cretaceous Butte Quartz Monzonite of the Boulder Batholith of western Montana (Gammons and others, 2006). Valleys in the study area typically are underlain by unconsolidated Tertiary and Quaternary sedimentary deposits. Geology of the study is described in detail by Nimick (1993) and Gammons and others (2006).

\section{Overview of Mining and Remediation Activities}

Mining in the upper Clark Fork Basin began in 1864 when small-scale placer mining operations extracted gold from floodplain and channel deposits along Silver Bow Creek and its tributaries in and near Butte (Freeman, 1900; U.S. Environmental Protection Agency, 2005). The small gold mining operations generally ended about 1869 when larger scale underground silver and copper mining began in the Butte area. By about 1886, there were about 10 major ore-processing mill and smelter operations along Silver Bow Creek (Freeman 1900; U.S. Environmental Protection Agency, 2005). In 1884, the AMC constructed milling and smelting facilities in Anaconda and by about 1910 most of the ore from the Butte area was being processed at Anaconda (U.S. Environmental Protection Agency, 2005, 2010). By 1917, more than 150 mines were located in and near Butte (U.S. Environmental Protection Agency, 2005). From 1910 through the 1920's, AMC acquired nearly all of the mines in the Butte area and the AMC underground mining operations continued until the late 1970's (U.S. Environmental Protection Agency, 2005; Gammons and others, 2006). In 1955, the AMC mining operations began to transition from underground to open-pit mining with the opening of the Berkeley Pit north of Butte; by the late 1960 's the Berkeley Pit operations were the major focus of the AMC operations (Gammons and others, 2006). In 1977, AMC was purchased by the Atlantic Richfield Company (ARCO), which continued the Berkeley Pit mining operations until closure in the early 1980 's. ARCO became a subsidiary of British Petroleum in 2000. Mining operations in the Butte area by Montana Resources began in the mid 1980's and have continued to present (2013), with interruption of operations from 2001 through 2003 (Don Booth, Atlantic Richfield Company, written commun., August 2013). The mining operations of Montana Resources generally have been of similar scale to those before the closure of the Berkeley Pit; however, smelting is no longer done in the upper Clark Fork Basin.

Large amounts of waste materials enriched with metallic contaminants and arsenic were generated from mining operations in the Butte area. Andrews (1987) estimated that 100 million tons of tailings were disposed of in Silver Bow Creek and the upper Clark Fork between 1880 and 1982. Mining activities in the Butte area severely contaminated waters in pit lakes, flooded underground mines, and alluvial aquifers (Gammons and others, 2006). The milling and smelting operations in Anaconda produced about 230 million cubic yards of mill tailings, 30 million cubic yards of furnace slag, and 500,000 cubic yards of flue dust (U.S. Environmental Protection Agency, 2010). Pollution from the AMC Smelter was responsible for severely contaminating soil on about 20,000 acres by airborne emissions and also contaminating millions of gallons of groundwater from leaching of mining wastes and contaminated soils (U.S. Environmental Protection Agency, 2010). Several large floods, especially during the late 1800 's and early 1900's, resulted in floodplain deposition of substantial amounts of mining wastes as indicated by tailings deposits 3-4 ft thick along Silver Bow Creek and commonly 1 foot thick along the upper Clark Fork near Deer Lodge (Smith and others, 1998; Titan Environmental Corporation, 1995; Nimick and Moore, 1994). Also, diversion of water from the Clark Fork for irrigation of hay fields in the upper Clark Fork valley resulted in accumulation of trace elements in soils (Axtmann and Luoma, 1991). 
The need to control or remediate effects of mining wastes on stream environments became evident in the early 1900's. From 1908 to 1917, AMC constructed dikes near the mouth of Silver Bow Creek to form settling ponds (later known as the Warm Springs Ponds) to trap sediment enriched in trace elements (CDM, 2005). The Warm Springs Ponds system was expanded during the 1950's to provide greater sedimentcontainment capacity. In about 1967, AMC started introducing a lime and water suspension into Silver Bow Creek upstream from Warm Springs Ponds to raise $\mathrm{pH}$ and encourage precipitation and deposition of metals within Warm Springs Ponds (U.S. Environmental Protection Agency, 2000). In about 1969, the Mill-Willow bypass was constructed to capture flows of Mill and Willow Creeks near their mouths and divert the combined flows (believed to be "relatively clean water"; U.S. Environmental Protection Agency, 2000) around Warm Springs Ponds and into Silver Bow Creek between the outlet from the Warm Springs Ponds and the confluence with Warm Springs Creek (CDM, 2005). However, water from Silver Bow Creek, enriched in trace elements, overflowed into the Mill-Willow bypass on several occasions when channels in the Warm Springs Ponds became plugged with debris during runoff events (U.S. Environmental Protection Agency, 2000). By 1989 the channel banks of the bypass had accumulated mine tailings from Silver Bow Creek overflow, which contributed to several fish kills that resulted from exposure to contaminants along the lower bypass and upper Clark Fork (U.S. Environmental Protection Agency, 2000). The potential toxicity issues associated with Warm Springs Ponds and the Mill-Willow bypass were a primary focus of early Federal Superfund activities.

Early Federal Superfund activities in the upper Clark Fork Basin involved designation of three areas as Superfund sites in 1983: Silver Bow Creek Site; Anaconda Smelter Site; and Milltown Reservoir Site. Silver Bow Creek Site was redesignated as Silver Bow Creek/Butte Area Site in 1987 and includes remnants from mining operations in Butte and about 26 miles of Silver Bow Creek extending from near Butte to the outlet of Warm Springs Ponds (U.S. Environmental Protection Agency, 2000; CDM, 2005). Remediation activities in the Silver Bow Creek/Butte Area Site have targeted reducing environmental effects of (1) mining wastes deposited along upper Silver Bow Creek and its tributaries, (2) acidic water, with high concentrations of trace elements, from the Berkeley Pit and numerous underground mine workings, and (3) large amounts of sediments enriched in trace elements deposited in Warm Springs Ponds.

Anaconda Smelter Site includes about $300 \mathrm{mi}^{2}$, primarily in the Mill, Willow, Warm Springs, and Lost Creek drainage basins near Anaconda (U.S. Environmental Protection Agency, 2010). Remediation activities in the Anaconda Smelter Site have targeted reducing environmental effects of the extensive soil and water contamination caused by the operations, including airborne emissions, of the AMC Smelter.

Milltown Reservoir Site was redesignated as the Milltown Reservoir/Clark Fork River Site in 1992. Milltown
Reservoir/Clark Fork River Site includes two primary operable units: Milltown Reservoir Sediments Operable Unit and Clark Fork River Operable Unit. The Milltown Reservoir Sediments Operable Unit includes about 540 acres defined by the area inundated by maximum pool elevation of the former Milltown Reservoir (U.S. Environmental Protection Agency, 2004). Remediation activities in the Milltown Reservoir Sediments Operable Unit have targeted reducing environmental effects of large amounts of sediments enriched in trace elements that were deposited in the former Milltown Reservoir. Those activities have included removal of the Milltown Dam in 2008 and excavation of millions of cubic yards of contaminated sediment (U.S. Environmental Protection Agency, 2004). Clark Fork River Operable Unit includes streamside areas of the 115-mile reach of the Clark Fork extending from Warm Springs Ponds outlet to the start of Milltown Reservoir Sediments Operable Unit (U.S. Environmental Protection Agency, 2012). Remediation activities of Clark Fork River Operable Unit have targeted reducing environmental effects of mining wastes deposited along the Clark Fork and in its floodplain.

\section{Data Collection and Analytical Methods}

Concerns about effects of mining wastes in the upper Clark Fork Basin on stream environments and human health prompted extensive data-collection efforts by various State, Federal, university, and private entities that began in earnest in the late 1970's and early 1980's. Need for a long-term consistent monitoring effort was recognized to evaluate temporal changes in water quality. Water-quality data collection by USGS began during 1985 to 1988 at four main-stem Clark Fork sites (sites 11, 14, 20, and 22; fig. 1, table 1) and four sites on major tributaries to the Clark Fork (sites 15, 17, 19, and 21). In 1993, the monitoring program was expanded to include three sites on Silver Bow Creek (sites 2, 3, and 8), one site on Blacktail Creek (site 1), which is a tributary to Silver Bow Creek, one site on Warm Springs Creek (site 10), which is a tributary to the Clark Fork, and two additional main-stem Clark Fork sites (sites 16, and 18; fig.1, table 1). In 2003 to 2005 , the monitoring program was expanded again to include additional sites on tributaries to Silver Bow Creek and the Clark Fork that drain areas affected by milling and smelting activities near Anaconda. Those sites included sites 4 and 5 on Mill Creek, sites 6 and 7 on Willow Creek, site 9 on Warm Springs Creek, and sites 12 and 13 on Lost Creek. At the end of water year 2004, data collection was discontinued at three of the major tributary sites (sites 15, 17, and 19). Thus, there have been a total of 22 sites in the monitoring program with variable periods of record (fig. 1, table 1).

Sampling frequencies have been variable, especially during the early period of data collection. However, all main-stem Silver Bow Creek and Clark Fork sites and most tributary sites 
have median annual sampling frequencies of eight samples per year (table 1). Some tributary sites have a median annual sampling frequency of six samples per year. Two sites (sites 2 and 3) have single 1-year data gaps and one site (site 1) has two nonconsecutive 1-year gaps when no data were collected. Some other sites have a small number of years (no more than 3) when the sampling frequency was less than four samples per year. Since 1993, the sampling frequency of the monitoring program has been consistent, with most sites being sampled eight times per year, except for the tributary sites 9 , $10,15,19$, and 21 , which generally were sampled six times per year. In the monitoring program, the seasonal timing of sample collection placed greater emphasis on the snowmelt runoff period (typically April through July) when streamflow conditions are high and variable and constituent transport is large. About 75 percent of samples were collected during April through July. In general, throughout the period of data collection there is reasonable consistency in the frequency and timing of sample collection among the sites to provide reasonable consistency in trend analysis results.

Data collected in the monitoring program are published (typically on an annual basis) in data reports that present the methods of data collection, water-quality data, quality-assurance data, and statistical summaries of the data (Lambing, 1987 through 1991; Lambing and others, 1994, 1995; Dodge and others, 1996 through 2012). Those data reports provide detailed descriptions of the specific field-collection and laboratory-analytical methods (with associated literature references) used in each year of data collection. General information on field-collection and laboratory-analytical methods used during the study period is presented in the following paragraph. Specific issues related to changes in field and laboratory analytical methods during the study period that are relevant to longterm trend analysis are discussed in more detail in following paragraphs.

In the monitoring program, water samples were collected from vertical transits throughout the entire stream depth at multiple locations across the stream by using standard USGS depth- and width-integration methods (U.S. Geological Survey, variously dated). Those methods provide a vertically and laterally discharge-weighted composite sample that is intended to be representative of the entire flow passing through the cross section of a stream (Dodge and others, 2012). Specific conductance was measured on site in subsamples from the composite water samples. Subsamples of the composite water samples also were analyzed at the USGS National Water Quality Laboratory (NWQL) in Denver, Colorado for filtered (0.45-micrometer pore size) and unfiltered-recoverable concentrations of the trace element constituents included in the trend analysis (table 2). Water samples also were analyzed for suspended-sediment concentrations by the USGS sediment laboratory in Helena, Montana.

Table 2. Property and constituents included in the trend analysis and information relating to laboratory and study reporting levels.

[Water year is the 12-month period from October 1 through September 30 and is designated by the year in which it ends. NWQL, U.S. Geological Survey National Water Quality Laboratory; $\mu \mathrm{S} / \mathrm{cm}$, microsiemens per centimeter at 25 degrees Celsius; NA, not applicable; $\mu \mathrm{g} / \mathrm{L}$, micrograms per liter; mg/L, milligrams per liter]

\begin{tabular}{|c|c|c|c|c|}
\hline Property or constituent & Units of measurement & $\begin{array}{c}\text { Number of NWOL labo- } \\
\text { ratory reporting levels } \\
\text { during water years } \\
1993-2010\end{array}$ & $\begin{array}{c}\text { Range in NWOL } \\
\text { laboratory reporting } \\
\text { levels }\end{array}$ & $\begin{array}{l}\text { Study reporting level } \\
\text { used in application of } \\
\text { the time-series model }{ }^{1}\end{array}$ \\
\hline Cadmium, filtered & $\mu \mathrm{g} / \mathrm{L}$ & 7 & $0.02-1.4$ & 0.05 \\
\hline Cadmium, unfiltered-recoverable & $\mu \mathrm{g} / \mathrm{L}$ & 10 & $0.014-1.3$ & 0.09 \\
\hline Copper, unfiltered-recoverable & $\mu \mathrm{g} / \mathrm{L}$ & 5 & $0.6-4$ & 1 \\
\hline Iron, filtered & $\mu \mathrm{g} / \mathrm{L}$ & 7 & $3-10$ & 6 \\
\hline Iron, unfiltered-recoverable & $\mu \mathrm{g} / \mathrm{L}$ & 8 & $6-21$ & 20 \\
\hline Lead, filtered & $\mu \mathrm{g} / \mathrm{L}$ & 9 & $0.03-5$ & 0.5 \\
\hline Lead, unfiltered-recoverable & $\mu \mathrm{g} / \mathrm{L}$ & 5 & $0.06-5$ & 0.5 \\
\hline Zinc, unfiltered-recoverable & $\mu \mathrm{g} / \mathrm{L}$ & 7 & $1-40$ & 2 \\
\hline Arsenic, filtered & $\mu \mathrm{g} / \mathrm{L}$ & 5 & $0.044-2$ & 1 \\
\hline Arsenic, unfiltered-recoverable & $\mu \mathrm{g} / \mathrm{L}$ & 7 & $0.12-3$ & 1 \\
\hline Suspended sediment & $\mathrm{mg} / \mathrm{L}$ & NA & NA & 1 \\
\hline
\end{tabular}

${ }^{1}$ Procedures for determining and applying the study reporting level used in the application of the time-series model are discussed in the section of this report "Time-Series Model." 
Consistent field-collection and laboratory-analytical methods are important in trend analysis to be confident that observed trends represent real environmental changes and not methodology changes. Primary issues with respect to changes in field-collection and laboratory-analytical methods during the period of data collection include the following: (1) a change in April 1992 by NWQL from open-beaker to in-bottle digestion for analysis of unfiltered-recoverable concentrations of trace elements (Hoffman and others, 1996), (2) implementation by USGS in water year 1993 of ultra-clean field sample collection and processing methods (Lambing and others, 1994), and (3) a change in about water year 2000 by NWQL from analysis of most metallic elements by graphite furnace atomic absorption spectrophotometry (Fishman, 1993) to inductively coupled plasma-mass spectrometry (Garbarino and Struzeski, 1998; Garbarino and others, 2006). The most substantial changes in field and laboratory methods were before water year 1993. Also, many of the study sites were not sampled before water year 1993. Thus, to maintain consistency in trend analysis among sites, trend analysis was restricted to the period of water years 1996-2010 (as discussed in the section of this report "Selection of Trend-Analysis Time Periods"). However, potential effects of the change in about water year 2000 in analytical methods for most metallic elements warrant further discussion.

Before about water year 2000, NWQL analyzed for most metallic elements by using graphite-furnace atomic absorption spectrophotometry (Fishman, 1993). In about water year 2000, NWQL began analyzing for most metallic elements in water samples for the Clark Fork long-term monitoring program by using inductively coupled plasma-mass spectrometry (Garbarino and Struzeski, 1998; Garbarino and others, 2006). The change in analytical methods resulted in small changes in recoveries of metallic elements in laboratory-spiked deionized-water blank samples and laboratory-spiked stream-water samples. Because of importance of temporal consistency in analytical methods in trend analysis, potential effect of the change in analytical methods was evaluated and is discussed in detail in the section of this report "Appendix 1: Summary Information Relating to Quality-Control, Water-Quality, and Continuous Streamflow Data." It was determined that the change in analytical methods had minor effect on trend results.

\section{Quality Assurance}

Quality-assurance procedures (with associated literature references) and quality-assurance data for each year of data collection are presented in the data reports for the monitoring program (Lambing, 1987 through 1991; Lambing and others, 1994, 1995; Dodge and others, 1996 through 2012). General information on quality-assurance procedures used during the study period is provided in the following paragraph. An overview of quality-assurance results relevant to long-term trend analysis also is provided in this section of the report.
From its inception, the Clark Fork monitoring program used quality-assurance procedures that included chain-ofcustody procedures and collection of field blank and replicate samples at a frequency of about 15 percent of the total number of samples (Lambing, 1991). Coincident with the 1993 implementation of ultra-clean sampling methods, the following additional quality-assurance procedures were included in the monitoring program (Lambing and others, 1994): (1) establishment of data-quality objectives (DQOs) to ensure that the field-collection and laboratory-analytical methods are producing environmentally representative data in a consistent manner, (2) establishment of specific guidelines for evaluating analytical results for field blank samples and resolving persistent contamination issues, (3) collection of laboratory replicate samples used to evaluate data precision for meeting specific DQOs, (4) collection of laboratory spike samples used to evaluate recoveries of trace elements for meeting specific DQOs, and (5) systematic electronic storage of quality-assurance data in the USGS water-quality database [National Water Information System (NWIS); U.S. Geological Survey, 2012c]. DQOs established in 1993 identify analytical requirements of detectability, and serve as a guide for identifying questionable data by establishing limits for precision and bias of laboratory results (Lambing and others, 1994). In addition to analysis of analytical results for quality-assurance samples with respect to DQOs, analytical results for individual environmental samples were carefully reviewed based on the following: (1) comparisons with associated quality-assurance sample results, (2) comparisons with results for previously collected samples at the site, (3) relations between filtered and unfiltered-recoverable concentrations, (4) relations between unfiltered-recoverable concentrations and suspended-sediment concentrations, and (5) relations between concentrations and streamflow conditions. When one or more of those review criteria indicated problematic results for a given trace-element constituent, laboratory re-analysis was done. If the re-analysis did not resolve the problematic results, the analytical results were excluded from the trend analysis. For the entire study period, exclusion of analytical results that resulted from review of analytical results for field blank samples or review of analytical results for individual environmental samples affected a small proportion of the study database (about 0.4 percent of all trace-element analyses). Excluded sample results generally were sporadic or limited to short time periods and are considered to have negligible effects on trend analysis.

Analytical results for field quality-assurance samples (including field blank and replicate samples) that were collected during water years 1993-2010 were compiled and statistically summarized (table $1-1$ in appendix 1 at the back of the report). Those data provide information on the consistency and environmental representativeness of data collection. Representative sampling for trace elements in streams is particularly difficult because of low concentrations in stream waters and ubiquitous presence in the sampling environment that produce an associated large potential for contamination. Analysis of analytical results for field blank samples provides 
information on potential effects of contamination during the sampling process on trend analysis results. For field blank samples, the frequency of detection at concentrations greater than the laboratory reporting level (LRL) at the time of analysis was less than about 5 percent for all trace-element constituents except for filtered and unfiltered-recoverable zinc, which had detection frequencies of 14.7 and 6.6 percent, respectively (table 1-1). Precise statistical analysis of the analytical results of field blank samples is difficult because of the multiple LRLs used by NWQL during the study period (table 2). Also, it is difficult to precisely quantify the field blank sample results with respect to the study database because contamination indicated by field blank samples was monitored routinely in the Clark Fork monitoring program and stream-sample data judged to be affected by persistent contamination issues were deleted. However, it is important that trend-analysis procedures are structured to minimize potential effects of sampling contamination on low-concentration data included in the trend analysis. Specific procedures used in application of the two trend-analysis methods used in this report with respect to handling of lowconcentration and censored data (that is, analytical results reported as less than the LRL; Helsel, 2005) are discussed in the section of this report "Trend Analysis Methods." For the entire study period, relative standard deviations (RSDs; a measure of overall precision) for field replicate sample pairs (table 1-1) indicate that for all constituents the RSDs were within 20 percent (the DQO for laboratory replicate samples) indicating reasonable precision (Dodge and others, 2012).

\section{Overview of Water-Quality Characteristics for Sampling Sites in the Upper Clark Fork Basin}

Statistically summarizing water-quality characteristics of the sites is useful for generally describing water quality of the study sites and in providing comparative information relevant for interpretation of trend results. Statistical summaries of water-quality data (water years 2001-10) for sites in the upper Clark Fork Basin are presented in table 1-4 in appendix 1 (at the back of this report). Unadjusted (not flow adjusted) concentrations are presented in table 1-4; flow adjustment, discussed in the "Trend Analysis Methods" section of this report, is relevant when interpreting trends in concentrations of water-quality constituents that are strongly dependent on streamflow conditions. For trace elements, in addition to statistical summaries of unadjusted concentrations, ratios of median filtered to unfiltered-recoverable concentrations also are reported in table 1-4 to provide general information on the predominant phase (that is, dissolved or particulate) of transport. Aquatic life standards (Montana Department of Environmental Quality, 2012a; based on median hardness for each site for water years 2001-10) are presented in table 1-5. The arsenic human health standard is $10 \mu \mathrm{g} / \mathrm{L}$ (Montana Department of Environmental Quality, 2012a). Percents of samples (water years 2001-10) with unadjusted unfiltered-recoverable concentrations exceeding water-quality standards for each site are presented in table 3 . To aid in interpreting differences in water-quality characteristics between sites, statistical summaries of continuous streamflow data are presented in table 1-6. Data are summarized for water years 2001-10, which was selected as the summary period because all sites have available data for this time period, a large range in streamflow conditions is represented, and recent water-quality conditions are represented.

Water-quality characteristics of the study sites are illustrated by using boxplots of selected example constituents (specific conductance, and unadjusted concentrations of copper, arsenic, and suspended-sediment) presented in figure 2. Also shown in figure 2 are applicable water-quality standards. Specific conductance is presented as an example because it is an index of ionic strength and provides information on extent of water contact with geologic materials and types of geologic materials present in the site basins. Copper and arsenic are presented as examples of trace elements because they have much different geochemical characteristics, but are constituents of concern with respect to potential toxicity issues. Further, spatial and temporal variability in copper concentrations generally is similar to variability in other metallic contaminants, and is considered generally representative of those constituents. Suspended sediment is presented because it provides information on transport of particulate materials, which is a factor that can strongly affect transport of metallic contaminants.

To assist in the presentation of results, Silver Bow Creek and the Clark Fork were divided into nine data-summary reaches based on the location of sites along the mainstems of those streams. Water-quality characteristics within the reaches are affected by environmental characteristics within the delineated reach basin boundaries (fig. 1). Waterquality characteristics of the sites are discussed for each of the data-summary reaches. Emphasis is placed on describing spatial differences in water quality in the upper Clark Fork Basin.

\section{Reach 1}

Sites in reach 1 include the reach inflow [Blacktail Creek (site 1, fig. 1, table 1)] and the reach outflow [Silver Bow Creek at Butte (site 2, fig. 1, table 1)]. Reach 1 is 3.5-mi long and flows through an area substantially affected by large-scale mining activities in the Butte area, including the Berkeley Pit. In reach 1, mean annual streamflow of Silver Bow Creek increases from $13 \mathrm{ft}^{3} / \mathrm{s}$ (site 1) to $21 \mathrm{ft}^{3} / \mathrm{s}$ (site 2, table 1-6) because of base streamflow increases from groundwater inflow, discharges from the Butte wastewater treatment facility, and contributions from ephemeral sources (including stormwater runoff from Butte). 
Table 3. Percent of samples with unadjusted (not flow adjusted) unfiltered-recoverable concentrations exceeding water-quality standards for sites in the upper Clark Fork Basin, water years 2001-10.

\begin{tabular}{|c|c|c|c|c|c|c|c|c|c|c|}
\hline \multirow{4}{*}{$\begin{array}{c}\text { Site } \\
\text { number } \\
\text { (fig.1, } \\
\text { table 1) }\end{array}$} & \multirow{4}{*}{$\begin{array}{c}\text { Site name } \\
\text { (fig. 1, table 1) }\end{array}$} & \multicolumn{9}{|c|}{ Percent of samples exceeding indicated standard } \\
\hline & & \multirow{3}{*}{$\begin{array}{c}\text { Arsenic } \\
\text { human } \\
\text { health } \\
\text { standard }\end{array}$} & \multicolumn{8}{|c|}{ Aquatic life standards } \\
\hline & & & \multicolumn{2}{|c|}{ Cadmium } & \multicolumn{2}{|c|}{ Copper } & \multicolumn{2}{|c|}{ Lead } & \multicolumn{2}{|c|}{ Zinc } \\
\hline & & & Acute & Chronic & Acute & Chronic & Acute & Chronic & Acute & Chronic \\
\hline 1 & Blacktail Creek & 7 & 0 & 0 & 3 & 13 & 0 & 3 & 0 & 0 \\
\hline 2 & Silver Bow Creek at Butte & 13 & 0 & 29 & 48 & 91 & 0 & 9 & 25 & 25 \\
\hline 3 & $\begin{array}{l}\text { Silver Bow Creek at } \\
\text { Opportunity }\end{array}$ & 95 & 6 & 99 & 100 & 100 & 4 & 95 & 53 & 53 \\
\hline 4 & Mill Creek near Anaconda & 94 & 0 & 2 & 4 & 13 & 0 & 6 & 0 & 0 \\
\hline 5 & Mill Creek at Opportunity & 100 & 0 & 17 & 19 & 33 & 0 & 17 & 0 & 0 \\
\hline 6 & $\begin{array}{l}\text { Willow Creek near Ana- } \\
\text { conda }\end{array}$ & 98 & 0 & 5 & 9 & 21 & 0 & 25 & 0 & 0 \\
\hline 7 & $\begin{array}{l}\text { Willow Creek at Opportu- } \\
\text { nity }\end{array}$ & 100 & 0 & 3 & 16 & 39 & 0 & 9 & 0 & 0 \\
\hline 8 & $\begin{array}{l}\text { Silver Bow Creek at Warm } \\
\text { Springs }\end{array}$ & 100 & 0 & 3 & 4 & 8 & 0 & 3 & 0 & 0 \\
\hline 9 & $\begin{array}{l}\text { Warm Springs Creek near } \\
\text { Anaconda }\end{array}$ & 0 & 0 & 0 & 4 & 7 & 0 & 0 & 0 & 0 \\
\hline 10 & $\begin{array}{l}\text { Warm Springs Creek at } \\
\text { Warm Springs }\end{array}$ & 13 & 0 & 4 & 17 & 27 & 0 & 9 & 0 & 0 \\
\hline 11 & Clark Fork near Galen & 89 & 0 & 4 & 20 & 26 & 0 & 6 & 0 & 0 \\
\hline 12 & Lost Creek near Anaconda & 13 & 2 & 2 & 11 & 20 & 2 & 4 & 2 & 2 \\
\hline 13 & Lost Creek near Galen & 83 & 0 & 0 & 0 & 0 & 0 & 0 & 0 & 0 \\
\hline 14 & Clark Fork at Deer Lodge & 96 & 0 & 12 & 47 & 77 & 0 & 23 & 1 & 1 \\
\hline 15 & Little Blackfoot River & 0 & 0 & 0 & 0 & 0 & 0 & 0 & 0 & 0 \\
\hline 16 & Clark Fork at Goldcreek & 79 & 0 & 12 & 40 & 63 & 0 & 23 & 0 & 0 \\
\hline 17 & Flint Creek near Drummond & 83 & 0 & 0 & 0 & 0 & 0 & 24 & 0 & 0 \\
\hline 18 & Clark Fork near Drummond & 81 & 0 & 14 & 40 & 56 & 0 & 33 & 5 & 5 \\
\hline 19 & Rock Creek & 0 & 0 & 0 & 0 & 0 & 0 & 0 & 0 & 0 \\
\hline 20 & Clark Fork at Turah Bridge & 23 & 0 & 14 & 39 & 50 & 0 & 26 & 1 & 1 \\
\hline 21 & Blackfoot River & 0 & 0 & 0 & 0 & 0 & 0 & 2 & 0 & 0 \\
\hline 22 & Clark Fork above Missoula & 6 & 0 & 14 & 31 & 45 & 0 & 26 & 5 & 5 \\
\hline
\end{tabular}

Blacktail Creek (site 1) is on a tributary of Silver Bow Creek, but the Blacktail Creek channel is the longest stream channel in the upper Silver Bow Creek Basin, thus, site 1 is considered a main-stem Silver Bow Creek site for the purpose of discussion. There have been numerous small mining operations in the upper reaches of the Blacktail Creek Basin; however, at site 1 the effect of mining operations on water quality is small to moderate. Thus, site 1 is considered an "index site" and is used as a reference for comparing concentrations among sites. Median values of specific conductance, copper, arsenic, and suspended sediment for site 1 generally are lower than median values for most main-stem Silver Bow Creek and Clark Fork sites (fig. 2, table 1-4). Exceedances of water-quality standards for site 1 were relatively infrequent (that is, less than or equal to 25 percent of samples; table 3 ).

There are large spatial changes in water quality between site 1 and site 2 (the first study site downstream from the substantial mining activities in the Butte area). Median specific conductance increases from 265 to 484 microsiemens per centimeter at 25 degrees Celsius $(\mu \mathrm{S} / \mathrm{cm})$ and median concentrations of metallic contaminants increase substantially (fig. 2, table 1-4). For example, median unfiltered-recoverable copper concentration increases from 5.0 to $20 \mu \mathrm{g} / \mathrm{L}$. Increases in metallic contaminants in reach 1 are affected by groundwater inflow from contaminated alluvial aquifers (Gammons and others, 2006) and mobilization of contaminated sediments during storm and snowmelt runoff events (Gammons and others, 2005). 


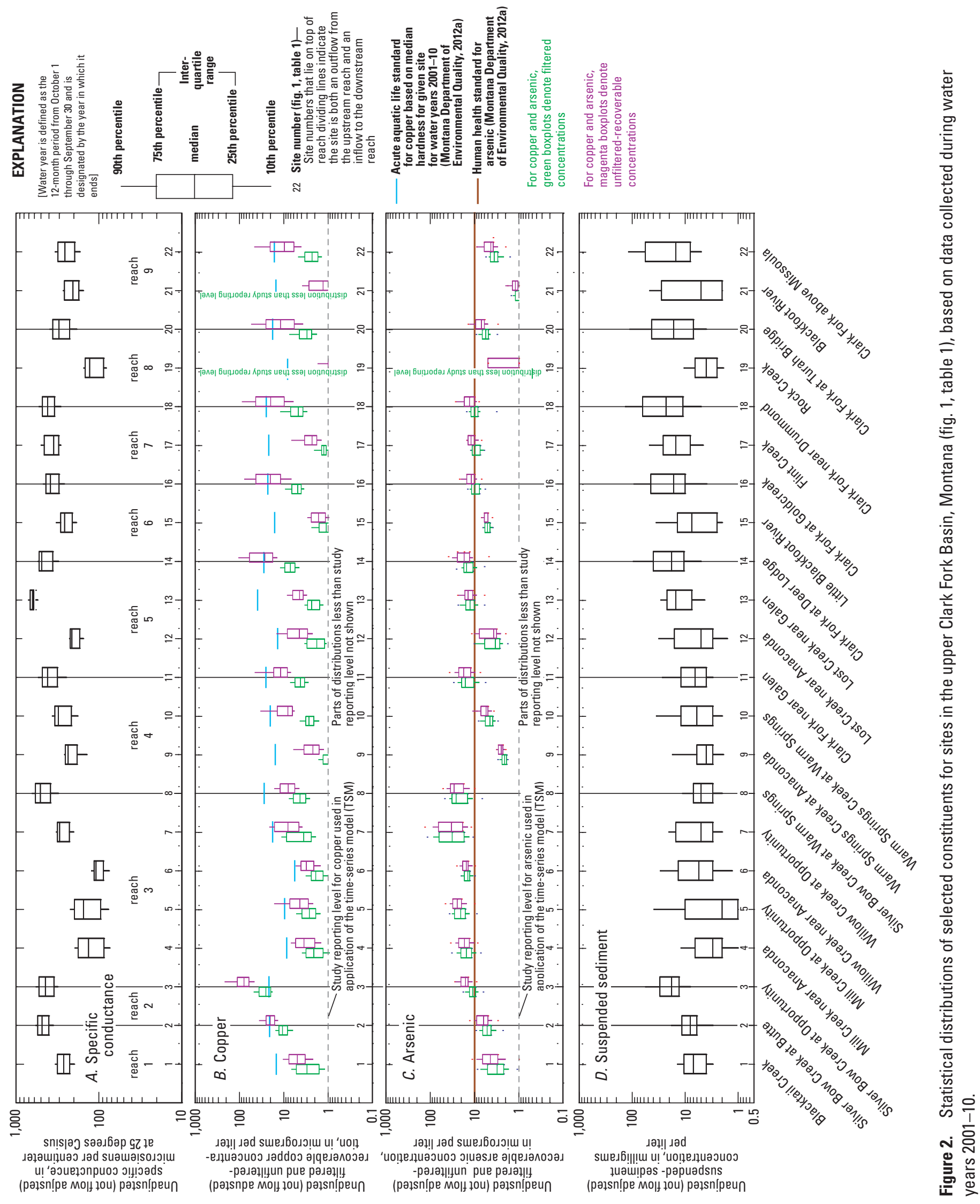


Cessation of most of the mining activities near Butte in the early 1980's and subsequent remediation efforts have substantially decreased mining effects on water quality at site 2 (as discussed in the section of this report "Water-Quality Trends for Selected Sampling Sites in the upper Clark Fork Basin"), but mining effects on water quality are still evident. Discharge of effluent from the Butte wastewater treatment facility just upstream from site 2 also affects water quality at site 2 . The effluent contributes elevated concentrations of nutrients, strongly affecting the biogeochemistry of Silver Bow Creek (Gammons and others, 2011). Also, filtered and unfiltered-recoverable copper concentrations in Silver Bow Creek substantially increase immediately downstream from the effluent discharge (Naughton, 2013), probably affected by direct contributions of copper in the effluent discharge. Contribution of complex organic compounds from the wastewater effluent to Silver Bow Creek also might affect metallic-element chemistry and transport at site 2 by complexation. Ratios of median filtered to unfiltered-recoverable concentrations of metallic elements for site 2 are higher than for most other main-stem Silver Bow Creek and Clark Fork sites (table 1-4). The ratio of median filtered to unfiltered-recoverable zinc for site 2 ( 80 percent) is higher than the zinc ratio for any other study site (except for site 19, which has low zinc concentrations). Relatively high ratios of median filtered to unfiltered-recoverable concentrations of metallic elements for site 2 might be affected by several factors, including inflow of groundwater with high filtered concentrations of metallic elements and effects of the Butte wastewater effluent. Exceedances of most water-quality standards were relatively infrequent for site 2 (table 3). However, exceedances of aquatic life standards for copper were relatively frequent for site 2 , with 48 and 91 percent of samples exceeding the acute and chronic standards, respectively. The chronic aquatic life standard for cadmium was exceeded in 29 percent of samples.

\section{Reach 2}

Sites in reach 2 include the reach inflow [Silver Bow Creek at Butte (site 2, fig. 1, table 1)] and the reach outflow [Silver Bow Creek at Opportunity (site 3, fig. 1, table 1)]. Reach 2 is about 15 -mi long and meanders through a floodplain with extensive deposits of mining wastes. In reach 2, mean annual streamflow of Silver Bow Creek increases from $21 \mathrm{ft}^{3} / \mathrm{s}$ (site 2) to $44 \mathrm{ft}^{3} / \mathrm{s}$ (site 3, table 1-6) largely because of contributions from Browns Gulch, other perennial tributaries, ephemeral gulches, and groundwater inflow.

There are large spatial changes in water quality between sites 2 and 3. Median suspended-sediment concentration increases from 8 to $18 \mathrm{mg} / \mathrm{L}$ (fig. 2 and table 1-4) and median $\mathrm{pH}$ increases from 7.6 to 8.4 (table 1-4). Concentrations of metallic contaminants and arsenic increase substantially between sites 2 and 3 (fig. 2, table 1-4). For example, median unfiltered-recoverable copper increases from 20 to $79 \mu \mathrm{g} / \mathrm{L}$, and unfiltered-recoverable arsenic increases from 6.3 to
$16 \mu \mathrm{g} / \mathrm{L}$. Median unfiltered-recoverable concentrations of cadmium, copper, and zinc for site $3(0.80,79$, and $197 \mu \mathrm{g} / \mathrm{L}$, respectively) are substantially higher than concentrations for any other study site. Ratios of filtered to unfiltered-recoverable concentrations of metallic elements are lower for site 3 than for site 2 , probably affected by increases in suspended sediment and $\mathrm{pH}$ between the sites. Exceedances of most waterquality standards were relatively frequent for site 3 (table 3 ). The arsenic human health standard and chronic aquatic life standards for cadmium, copper, and lead were exceeded in greater than or equal to 95 percent of samples. It is notable that the most extensive remediation activities in reach 2 began in 2004 and have included removal of tailings deposits and channel reconstruction (Montana Department of Environmental Quality, 2012b). Cessation of most of the mining activities near Butte in the early 1980's and subsequent remediation efforts have substantially decreased mining effects on water quality at site 3 (as discussed in the section of this report "Water-Quality Trends for Selected Sampling Sites in the upper Clark Fork Basin"), but mining effects on water quality are still evident.

\section{Reach 3}

Sites in reach 3 include the reach inflow [Silver Bow Creek at Opportunity (site 3, fig. 1, table 1)] and the reach outflow [Silver Bow Creek at Warm Springs (site 8, fig. 1, table 1)]. Also in reach 3 are the monitored tributary sites Mill Creek near Anaconda (site 4, fig. 1, table 1), Mill Creek at Opportunity (site 5, fig. 1, table 1), Willow Creek near Anaconda (site 6, fig. 1, table 1), and Willow Creek at Opportunity (site 7, fig. 1, table 1). Reach 3 is about 6-mi long, meanders through a floodplain with extensive deposits of mining wastes, and also passes through Warm Springs Ponds where deposition of particulate materials and treatment (liming) to remove metallic elements is conducted. Mill Creek and Willow Creek originate in mountains southwest from the former AMC Smelter and flow generally northeast to their confluence with the Mill-Willow bypass near Opportunity. The Mill and Willow Creek Basins are affected by pollution from milling and smelting operations of the former AMC Smelter, which primarily resulted in deposition of arsenic from flue dust and smelter emissions with resultant large-scale soil and groundwater contamination (U.S. Environmental Protection Agency, 2010). The Mill-Willow bypass diverts the combined flows of Mill Creek and Willow Creek into Silver Bow Creek between the outlet from Warm Springs Ponds and site 8. In reach 3, mean annual streamflow of Silver Bow Creek increases from $44 \mathrm{ft}^{3} / \mathrm{s}$ (site 3 ) to $70 \mathrm{ft}^{3} / \mathrm{s}$ (site 8 , table 1-6), primarily because of contributions from the Mill-Willow bypass and groundwater inflow.

There are large spatial changes in water quality between sites 3 and 8 that are strongly affected by Silver Bow Creek passing through Warm Springs Ponds. Warm Springs Ponds were designed to trap suspended sediment and metallic 
contaminants by physical deposition and treatment (liming). Warm Springs Ponds are eutrophic and have substantial growth of algae and rooted macrophytes that results from large inputs of nutrients (Chatham, 2012; Gammons and others, 2007). Highly complex biogeochemical processes in Warm Springs Ponds, relating to metals chemistry and nutrient processing, result in substantial chemical changes as Silver Bow Creek passes through Warm Springs Ponds (Chatham, 2012; Gammons and others, 2007). Also, contributions from the Mill-Willow bypass substantially affect water-quality in reach 3. Median suspended-sediment concentration decreases from 18 to $5 \mathrm{mg} / \mathrm{L}$ (fig. 2, table 1-4) and median $\mathrm{pH}$ increases from 8.4 to 8.8 (table $1-4$ ). The median $\mathrm{pH}$ for site 8 is higher than the median $\mathrm{pH}$ for any other study site. Similar to suspended sediment, concentrations of metallic elements decrease substantially between site 3 and site 8 . For example, median unfiltered-recoverable copper decreases from 79 to $8.0 \mu \mathrm{g} / \mathrm{L}$ (fig. 2, table 1-4). In contrast, median unfiltered-recoverable arsenic concentration increases substantially between site $3(16 \mu \mathrm{g} / \mathrm{L})$ and site $8(29 \mu \mathrm{g} / \mathrm{L}$; fig. 2 , table $1-4)$. The increase in arsenic concentration is affected by contributions of water with high arsenic concentrations from the Mill-Willow bypass. The increase in arsenic concentration in reach 3 also is affected by complex hydrologic and limnologic factors that affect arsenic biogeochemical processing in Warm Springs Ponds (Chatham, 2012). High pH in Warm Springs Ponds (a result of a combination factors, including liming and nutrient processing by aquatic vegetation; Chatham, 2012), promotes arsenic solubility and mobilization (Stumm and Morgan, 1970). Filtered and unfiltered-recoverable arsenic concentrations for site 8 (26 and $29 \mu \mathrm{g} / \mathrm{L}$, respectively) are higher than any other main-stem Silver Bow Creek or Clark Fork study site. Exceedances of aquatic life standards for metals were relatively infrequent for site 8 (table 3). However, the arsenic human health standard was exceeded in all samples.

For the two Mill Creek sites [Mill Creek near Anaconda (site 4, fig. 1, table 1) and Mill Creek at Opportunity (site 5, fig. 1, table 1)], specific conductance, and concentrations of metallic elements and suspended sediment are relatively low (fig. 2, table 1-4), with median values less than those for Blacktail Creek (site 1, fig.1, table 1; an index site representative of small to moderate mining effect). However, arsenic concentrations are high in Mill Creek (median unfiltered-recoverable arsenic concentrations of 17 and $25 \mu \mathrm{g} / \mathrm{L}$ for site 4 and site 5, respectively). Mill Creek mean annual streamflow decreases by about 50 percent from 33 to $15 \mathrm{ft}^{3} / \mathrm{s}$ (table 1-6) in the 6-mi reach between site 4 and site 5 primarily because of irrigation diversions, year-round diversions to ditches that flow into tailings ponds and ultimately discharge to the Mill-Willow bypass, and losing stream reaches. However, the factors affecting streamflow decreases between sites 4 and 5 do not result in substantial spatial changes in water quality between the sites. Exceedances of most aquatic life standards for metals were relatively infrequent for the Mill Creek sites (table 3). However, the arsenic human health standard was exceeded in 94 percent of samples for site 4 , and in all samples for site 5 .

In contrast to the two Mill Creek sites (site 4 and site 5), there are large spatial changes in water-quality between the two Willow Creek sites [Willow Creek near Anaconda (site 6) and Willow Creek at Opportunity (site 7)]. For site 6, specific conductance, and concentrations of metallic elements and suspended sediment are relatively low (fig. 2, table 1-4), with median values less than median values for Blacktail Creek (site 1) and similar to median values for the upstream Mill Creek site (site 4). Similar to site 4, arsenic concentrations are high for site 6 (median unfiltered-recoverable arsenic concentration of $15 \mu \mathrm{g} / \mathrm{L})$. Willow Creek mean annual streamflow increases from 7.0 to $10 \mathrm{ft}^{3} / \mathrm{s}$ (table 1-4) in the 5-mi reach between sites 6 and site 7. However, hydrologic characteristics of the reach are complex, with streamflow variably (spatially and seasonally) affected by irrigation diversions and return flows, contributions from tile drains, and losses to and gains from groundwater. In the reach, Willow Creek receives runoff from ephemeral gulches, irrigation return flows, and inflow from groundwater moving downgradient towards Silver Bow Creek. Specific conductance, $\mathrm{pH}$, and concentrations of unfiltered-recoverable copper and arsenic are substantially higher for site 7, than for site 6 (fig. 2, table 1-4). Median filtered and unfiltered-recoverable arsenic concentrations for site 7 ( 32 and $33 \mu \mathrm{g} / \mathrm{L}$, respectively) are moderately higher than concentrations for the downstream Mill Creek site (site 5) and also higher than concentrations for any other study site. Exceedances of most water-quality standards were relatively infrequent for the Willow Creek sites (table 3). However, the arsenic human health standard was exceeded in 98 percent of samples for site 6 , and in all samples for site 7. Also, the chronic aquatic life standard for copper was exceeded in 39 percent of samples for site 7 .

\section{Reach 4}

Sites in reach 4 include the reach inflow [Silver Bow Creek at Warm Springs (site 8, fig. 1, table 1)] and the reach outflow [Clark Fork near Galen (site 11, fig. 1, table 1)]. Also in reach 4 are the monitored tributary sites Warm Springs Creek near Anaconda (site 9, fig. 1, table 1) and Warm Springs Creek at Warm Springs (site 10, fig. 1, table 1). Reach 4 is short (about 2-mi long) but environmentally complex. Within the reach, water from Warm Springs Ponds, which is affected by treatment (liming), mixes with water contributed from the Mill-Willow bypass and Warm Springs Creek. Thick tailings deposits are extensive in the floodplain near Warm Springs (Smith and others, 1998) and provide a source of sediment enriched with metallic contaminants. Thus, there is potential for complex water-quality processes in the short reach. Warm Springs Creek originates in the mountains west of the former AMC Smelter, flows generally east through areas adjacent to the former AMC Smelter and various tailings piles and ponds, and joins Silver Bow Creek to form the Clark Fork near 
Warm Springs. The Warm Springs Creek Basin is affected by pollution from milling and smelting operations of the former AMC Smelter. In reach 4, mean annual streamflow increases from $70 \mathrm{ft}^{3} / \mathrm{s}$ (site 8 ) to $130 \mathrm{ft}^{3} / \mathrm{s}$ (site 11 , table $1-6$ ) primarily because of contributions from Warm Springs Creek (site 10 mean annual streamflow of $58 \mathrm{ft}^{3} / \mathrm{s}$ ), ephemeral gulches, and groundwater inflow. Near the end of reach 4, Warm Springs Creek and Silver Bow Creek join to form the Clark Fork.

Spatial changes in water quality between sites 8 and 11 generally are not large. However, unfiltered-recoverable arsenic decreases from 29 to $18 \mu \mathrm{g} / \mathrm{L}$. Site 11 is about $2 \mathrm{mi}$ downstream from site 8 and about $1 \mathrm{mi}$ downstream from the start of the Clark Fork at the confluence of Silver Bow Creek and Warm Springs Creek. There is little inflow between sites 8 and 11 other than the monitored contribution from Warm Springs Creek (site 10). On a median basis, water-quality characteristics for site 11 generally reflect proportional mixing of waters from site 8 and site 10 . However, median concentrations of unfiltered-recoverable copper and zinc and suspended sediment are somewhat higher for site 11 relative to proportional mixing of sites 8 and 10, which might provide evidence of mobilization of materials from floodplain tailings deposits near Warm Springs. Also, median concentration of unfilteredrecoverable arsenic is somewhat lower than proportional mixing of sites 8 and 10, which might provide evidence that arsenic can at times precipitate from solution in reach 4 . Ratios of filtered to unfiltered-recoverable concentrations of metallic elements are higher for site 11 than for other main-stem Clark Fork sites (table 1-4). Exceedances of most water-quality standards were relatively infrequent for site 11 (table 3 ). However, the arsenic human health standard was exceeded in 89 percent of samples. Also, the chronic aquatic life standard for copper was exceeded in 26 percent of samples.

There are large spatial changes in water-quality between the two Warm Springs Creek sites [Warm Springs Creek near Anaconda (site 9, fig. 1, table 1) and Warm Springs Creek at Warm Springs (site 10, fig. 1, table 1)]. For site 9, specific conductance, and concentrations of metallic elements, arsenic, and suspended sediment are relatively low (fig. 2, table 1-4), with median values less than median values for Blacktail Creek (site 1, fig.1, table 1; an index site representative of small to moderate mining effect). Warm Springs Creek mean annual streamflow decreases from 84 to $58 \mathrm{ft}^{3} / \mathrm{s}$ (table 1-6) in the 9-mi reach between sites 9 and 10, largely because of irrigation and various drainage-control diversions. Hydrologic characteristics of the reach are complex, with streamflow variably (spatially and seasonally) affected by instream-flow releases, irrigation diversions and return flows, drainagecontrol diversions, and groundwater inflow. In the reach, Warms Springs Creek receives runoff from ephemeral gulches, irrigation return flows, and inflow from groundwater. Median specific conductance, and concentrations of trace elements are higher for site 10 than medians for site 9 (fig. 2, table 1-4). For example, median unfiltered-recoverable copper increases from 2.1 to $8.1 \mu \mathrm{g} / \mathrm{L}$ between sites 9 and 10 . Exceedances of water-quality standards for the Warm Springs Creek sites were relatively infrequent (table 3 ). However, the chronic aquatic life standard for copper was exceeded in 27 percent of samples for site 10 .

\section{Reach 5}

Sites in reach 5 include the reach inflow [Clark Fork at Galen (site 11, fig. 1, table 1)] and the reach outflow [Clark Fork at Deer Lodge (site 14, fig. 1, table 1)]. Also in reach 5 are the monitored tributary sites Lost Creek near Anaconda (site 12, fig. 1, table 1) and Lost Creek near Galen (site 13, fig. 1, table 1). Reach 5 is about 21 -mi long and meanders through a broad valley with extensive floodplain tailings deposits. Lost Creek originates in the mountains northwest of the former AMC Smelter and flows generally east to its confluence with the Clark Fork near Galen. The Lost Creek Basin is affected by pollution from milling and smelting operations of the former AMC Smelter (U.S. Environmental Protection Agency, 2010). In reach 5, mean-annual streamflow of the Clark Fork increases from $130 \mathrm{ft}^{3} / \mathrm{s}$ (site 11) to $216 \mathrm{ft}^{3} / \mathrm{s}$ (site 14, table 1-6) partly because of contributions from Lost Creek (site 13 mean annual streamflow of $29 \mathrm{ft}^{3} / \mathrm{s}$ ), numerous ungaged tributaries, ephemeral gulches, and groundwater inflow.

There are large spatial increases in concentrations of suspended sediment and metallic contaminants between sites 11 and 14 that largely result from mobilization of mining wastes from floodplain tailings deposits and stream banks. Median suspended-sediment concentration increases from 7 to $18 \mathrm{mg} / \mathrm{L}$ and median unfiltered-recoverable copper concentration increases from 12 to $27 \mu \mathrm{g} / \mathrm{L}$ (fig. 2, table 1-4). Median concentrations of most metallic contaminants for site 14 are higher than concentrations for any other main-stem Clark Fork site. Median concentration of unfiltered-recoverable arsenic for site $14(17 \mu \mathrm{g} / \mathrm{L})$ is nearly equal to the concentration of site $11(18 \mu \mathrm{g} / \mathrm{L})$, but higher than concentrations for downstream main-stem Clark Fork sites. Exceedances of most water-quality standards were relatively infrequent for site 14 (table 3). However, exceedances of aquatic life standards for copper were relatively frequent, with 47 and 77 percent of samples exceeding the acute and chronic standards, respectively. Also, the arsenic human health standard was exceeded in 96 percent of samples.

There are some large spatial changes in water-quality between the two Lost Creek sites [Lost Creek near Anaconda (site 12, fig. 1, table 1) and Lost Creek near Galen (site 13, fig. 1, table 1)], but changes are variable among constituents. For site 12, specific conductance and concentrations of metallic elements, arsenic, and suspended sediment are relatively low (fig. 2, table 1-4), with median values less than median values for Blacktail Creek (site 1, fig.1, table 1; an index site representative of small to moderate mining effect). Lost Creek mean annual streamflow increases from 6.5 to $29 \mathrm{ft}^{3} / \mathrm{s}$ (table 1-6) in the 8-mi reach between sites 12 and 13. Hydrologic characteristics of the reach are complex, with streamflow 
variably (spatially and seasonally) affected by interbasin transfers, irrigation diversions and return flows, drainage-control diversions, and groundwater inflow. In the reach, Lost Creek receives runoff from ephemeral gulches, irrigation return flows, and groundwater inflow. Median specific conductance, and concentrations of arsenic and suspended sediment are higher for site 13 than medians for site 12 (fig. 2 , table 1-4). Between sites 12 and 13, median specific conductance increases from 211 to $631 \mu \mathrm{S} / \mathrm{cm}$, median concentration of unfiltered-recoverable arsenic increases from 3.7 to $14 \mu \mathrm{g} / \mathrm{L}$, and median concentration of suspended sediment increases from 5 to $15 \mathrm{mg} / \mathrm{L}$. Median concentrations of metallic contaminants are similar among sites 12 and 13. Exceedances of water-quality standards were relatively infrequent for site 12 (table 3). Exceedances of aquatic life standards for metals were relatively infrequent for site 13 (table 3). However, the arsenic human health standard was exceeded in 83 percent of samples for site 13 .

\section{Reach 6}

Sites in reach 6 include the reach inflow [Clark Fork at Deer Lodge (site 14, fig. 1, table 1)] and the reach outflow [Clark Fork at Goldcreek (site 16, fig. 1, table 1)]. Also in reach 6 is the monitored tributary site Little Blackfoot River (site 15, fig. 1, table 1). Reach 6 is about 26-mi long and meanders through a broad valley from Deer Lodge to Garrison. Between Deer Lodge and Garrison, floodplain tailings along the Clark Fork are present to a similar extent as in the valley upstream from Deer Lodge (Smith and others, 1998). The Little Blackfoot River, which drains a largely forested basin that historically has had numerous small-scale mining operations, discharges into reach 6 near Garrison where the Clark Fork valley begins to narrow. Downstream from Garrison, floodplain tailings are less extensive than in the valley upstream. In reach 6 , mean-annual streamflow of the Clark Fork increases from $216 \mathrm{ft}^{3} / \mathrm{s}$ (site 14) to $460 \mathrm{ft}^{3} / \mathrm{s}$ (site 16, table 1-6) partly because of contributions from the Little Blackfoot River (site 15 mean annual streamflow of $145 \mathrm{ft}^{3} / \mathrm{s}$ ), numerous ungaged tributaries, ephemeral gulches, and groundwater inflow.

There are moderate spatial decreases in median concentrations of suspended sediment, metallic contaminants, and arsenic between sites 14 and 16. Median concentration of unfiltered-recoverable copper decreases from 27 to $20 \mu \mathrm{g} / \mathrm{L}$, median concentration of unfiltered-recoverable arsenic decreases from 17 to $12 \mu \mathrm{g} / \mathrm{L}$, and median concentration of suspended sediment slightly decreases from 18 to $17 \mathrm{mg} / \mathrm{L}$ (fig.2, table 1-4). Exceedances of most water-quality standards were relatively infrequent for site 16 (table 3). However, exceedances of aquatic life standards for copper were relatively frequent, with 40 and 63 percent of samples exceeding the acute and chronic standards, respectively. Also, the arsenic human health standard was exceeded in 79 percent of samples. Water-quality changes in reach 6 are affected by transport of mining wastes from upstream source areas in combination with streamflow inputs from areas with less mining effects (including the Little Blackfoot River). Dispersion and dilution of mining wastes generally results in decreasing water-quality effects with distance downstream from primary source areas.

For Little Blackfoot River (site 15; fig. 1, table 1), specific conductance and concentrations of metallic elements, arsenic, and suspended sediment are relatively low (fig. 2, table 1-4), with median values less than or similar to median values for Blacktail Creek (site 1, fig. 1, table 1; an index site representative of small to moderate mining effect). Historical mining activities in the Little Blackfoot River have had relatively small effect on water quality of site 15 . There were no exceedances of water-quality standards for site 15 (table 3).

\section{Reach 7}

Sites in reach 7 include the reach inflow [Clark Fork at Goldcreek (site 16, fig. 1, table 1)] and the reach outflow [Clark Fork near Drummond (site 18, fig. 1, table 1)]. Also in reach 7 is the monitored tributary site Flint Creek (site 17, fig. 1, table 1). Reach 7 is about 31 -mi long; channel meandering and exposed floodplain tailings are less extensive in reach 7 than in upstream reaches (Smith and others, 1998; Lambing, 1998). Flint Creek, which drains a basin with substantial irrigation activities and also has had numerous smallscale mining operations, discharges into reach 7 near Drummond. Downstream from Drummond, the Clark Fork valley narrows further and meandering of the Clark Fork decreases further in association with the narrow valley and presence of highway and railroad embankments (Smith and others, 1998; Lambing, 1998). In reach 7, mean annual streamflow of the Clark Fork increases from $460 \mathrm{ft}^{3} / \mathrm{s}$ (site 16) to $648 \mathrm{ft}^{3} / \mathrm{s}$ (site 18, table 1-6) partly because of contributions from Flint Creek (site 17 mean annual streamflow of $123 \mathrm{ft}^{3} / \mathrm{s}$ ), numerous ungaged tributaries, ephemeral gulches, and groundwater inflow.

Spatial changes in water quality between sites 16 and 18 generally are not large. Median specific conductance and concentrations of most trace elements for site 18 are similar to the medians for site 16 . However, between sites 16 and 18, median concentration of unfiltered-recoverable lead increases from 2.4 to $3.2 \mu \mathrm{g} / \mathrm{L}$, unfiltered-recoverable zinc increases from 20 to $25 \mu \mathrm{g} / \mathrm{L}$, and suspended sediment increases from 17 to $23 \mathrm{mg} / \mathrm{L}$ (fig. 2, table 1-4). Although the increases in lead, zinc, and suspended-sediment concentrations are not large, they contrast with the pattern of decreasing water-quality effects with distance downstream from primary mining-waste source areas in the upper Clark Fork Basin. The spatial changes in water quality between sites 16 and 18 probably are affected by streamflow contributions from the Flint Creek Basin, which has a combination of relatively extensive historical mining operations (in comparison to other tributaries downstream from Deer Lodge) and irrigation activities. The Clark Fork floodplain and stream banks downstream 
from Flint Creek probably also contain mining-waste deposits sourced from the Flint Creek Basin. The median unfilteredrecoverable lead concentration for site $18(3.2 \mu \mathrm{g} / \mathrm{L})$ is higher than the median concentration for any other main-stem Clark Fork site. Exceedances of most water-quality standards were relatively infrequent for site 18 (table 3 ). However, exceedances of aquatic life standards for copper were relatively frequent, with 40 and 56 percent of samples exceeding the acute and chronic standards, respectively. The chronic aquatic life standard for lead was exceeded in 33 percent of samples. Also, the arsenic human health standard was exceeded in 81 percent of samples.

For Flint Creek (site 17, fig. 1, table 1), median specific conductance and concentrations of metallic contaminants, arsenic, and suspended sediment are higher than medians for Blacktail Creek (site 1, fig. 1, table 1; an index site representative of small to moderate mining effect) and also higher than medians for other major tributary sites downstream from Deer Lodge [Little Blackfoot River (site 15, fig. 1, table 1), Rock Creek (site 19, fig. 1, table 1), and Blackfoot River (site 21, fig. 1, table 1)]. Median unfiltered-recoverable lead concentration for site $17(3.1 \mu \mathrm{g} / \mathrm{L})$ exceeds the medians of all study sites except Silver Bow Creek at Opportunity (site 3, fig. 1, table 1) and Clark Fork near Drummond (site 18, fig. 1, table 1). Water-quality characteristics for site 17 probably are affected by the combination of relatively extensive historical mining operations (in comparison to other major tributaries downstream from Deer Lodge) and irrigation activities in the basin. Exceedances of most water-quality standards were relatively infrequent for site 17 (table 3). However the arsenic human health standard was exceeded in 83 percent of samples.

\section{Reach 8}

Sites in reach 8 include the reach inflow [Clark Fork near Drummond (site 18, fig. 1, table 1)] and the reach outflow [Clark Fork at Turah Bridge (site 20, fig. 1, table 1)]. Also in reach 8 is the monitored tributary site Rock Creek (site 19, fig. 1, table 1). Reach 8 is about 34-mi long and flows through a narrow floodplain with little or no visible mining tailings. In reach 8, the Clark Fork Valley is narrow (generally less than 1 mile). Rock Creek, which drains a heavily forested basin with few historical mining activities, discharges into reach 8 near Clinton. In reach 8, mean annual streamflow of the Clark Fork increases from $648 \mathrm{ft}^{3} / \mathrm{s}$ (site 18) to $1,200 \mathrm{ft}^{3} / \mathrm{s}$ (site 20, table 1-6) primarily because of contributions from Rock Creek (mean annual streamflow of $471 \mathrm{ft}^{3} / \mathrm{s}$ ), numerous ungaged tributaries, ephemeral gulches, and groundwater inflow.

There are large spatial decreases in median concentrations of suspended sediment, metallic contaminants, and arsenic between sites 18 and 20. Median concentration of unfiltered-recoverable copper decreases from 20 to $12 \mu \mathrm{g} / \mathrm{L}$, median concentration of unfiltered-recoverable arsenic decreases from 13 to $7.0 \mu \mathrm{g} / \mathrm{L}$, and median concentration of suspended sediment decreases from 23 to $17 \mathrm{mg} / \mathrm{L}$ (fig.2, table 1-4). Water-quality changes in reach 8 are affected by dilution from Rock Creek. Exceedances of most water-quality standards were relatively infrequent for site 20 (table 3 ). However, exceedances of aquatic life standards for copper were relatively frequent, with 39 and 50 percent of samples exceeding the acute and chronic standards, respectively. The chronic aquatic life standard for lead was exceeded in 26 percent of samples.

For Rock Creek (site 19), median specific conductance and concentrations of metallic elements, arsenic, and suspended sediment are low. Those medians are less than medians for Blacktail Creek (site 1, fig. 1, table 1; an index site representative of small to moderate mining effect), and also less than median values for other major tributary sites downstream from Deer Lodge [Little Blackfoot River (site 15, fig. 1, table 1), Flint Creek (site 17, fig. 1, table 1), and Blackfoot River (site 21, fig. 1, table 1)]. There were no exceedances of water-quality standards for site 19 (table 3 ).

\section{Reach 9}

Sites in reach 9 include the reach inflow [Clark Fork at Turah Bridge (site 20, fig. 1, table 1)] and the reach outflow [Clark Fork above Missoula (site 22, fig. 1, table 1)]. Also in reach 9 is the monitored tributary site Blackfoot River (site 21, fig. 1, table 1). Reach 9 is about 9-mi long and includes the former Milltown Reservoir where substantial amounts of mining wastes had been deposited. The former Milltown Dam was removed in 2008. The Blackfoot River, which drains a largely forested basin that historically has had numerous small-scale mining operations, discharges into reach 9 near Bonner. In reach 9, mean annual streamflow of the Clark Fork more than doubles from $1,200 \mathrm{ft}^{3} / \mathrm{s}$ (site 20) to $2,500 \mathrm{ft}^{3} / \mathrm{s}$ (site 22 , table 1-6) primarily because of contributions from the Blackfoot River (mean annual streamflow of 1,330 $\mathrm{ft}^{3} / \mathrm{s}$ ).

Assessment of spatial water-quality changes in reach 9 is complicated by effects of activities associated with the removal of the former Milltown Dam. The former Milltown Dam was breached in March 2008; however, activities in preparation for the dam removal (including construction of access roads and operational facilities, and preliminary reservoir drawdowns) began several years earlier (at least as early as water year 2004) and potentially affected water quality at site 22 . Thus the data-summary period (water years 2001-10) encompasses periods before, during, and after the removal of the former Milltown Dam. The variable conditions during the data-summary period do not represent typical conditions within the reach.

Spatial changes in water quality between sites 20 and 22 generally are not large. The most substantial change is a decrease in median unfiltered-recoverable arsenic from 7.0 to $4.3 \mu \mathrm{g} / \mathrm{L}$. Water-quality changes in reach 9 are affected by dilution from Blackfoot River and activities associated with the removal of the former Milltown Dam. Exceedances of most water-quality standards were relatively infrequent 
for site 22 (table 3). However, exceedances of aquatic life standards for copper were relatively frequent, with 31 and 45 percent of samples exceeding the acute and chronic standards, respectively. The chronic aquatic life standard for lead was exceeded in 26 percent of samples.

For Blackfoot River (site 21) median specific conductance and concentrations of metallic elements, arsenic, and suspended sediment are low. Those medians are less than medians for Blacktail Creek (site 1, fig. 1, table 1; an index site representative of small to moderate mining effect). Exceedances of water-quality standards were relatively infrequent for site 21 (table 3).

\section{Data Analysis Methods}

This section of the report describes methods used to analyze trends in flow-adjusted concentrations of water-quality constituents. For sites that were analyzed by using the TSM (Vecchia, 2005), normalized loads (as defined in the section of this report "Estimation of Normalized Constituent Loads") were estimated to evaluate temporal changes in relative contributions of selected trace elements and suspended sediment from upstream source areas to the outflows of each datasummary reach. Methods used for estimation of normalized constituent loads also are described.

\section{Trend Analysis Methods}

A variety of methods are available for analysis of waterquality trends, including nonparametric and parametric procedures (Hirsch and Slack, 1984; Helsel and Hirsch, 2002). Two parametric trend-analysis methods were used in this study: the TSM (Vecchia, 2005) and MLR (Helsel and Hirsch, 2002). Both of the trend-analysis methods analyze trends in flowadjusted concentrations (FACs); that is, the methods compute FACs, estimate best-fit trend lines that represent temporal changes in FACs, and determine statistical significance of changes. Flow adjustment is necessary because concentrations of many water-quality constituents are strongly dependent on streamflow conditions, which primarily are affected by climatic variability within the study area. The intent of flowadjustment is to identify and remove streamflow-related variability in concentration and thereby enhance the capability to detect trends independent from effects of climatic variability. Flow-adjustment procedures produce FACs that are estimates of constituent concentrations after removing effects of streamflow variability.

Flow-adjustment procedures differ between the TSM and MLR, which are discussed in more detail in appendixes 2 and 3 , respectively. In general, the primary difference between the two approaches is the TSM uses multiple flow-related variables computed from concurrent (same day as the concentration sample) and antecedent (days before the concentration sample) daily mean streamflow in the flow-adjustment process, whereas MLR uses only streamflow at the time of sampling. Thus, FACs determined by the TSM are analogous to FACs determined by MLR, in that FACs of both methods account for streamflow effects, but TSM FACs provide more detailed accounting by incorporating interannual, seasonal, and short-term streamflow variability (Vecchia, 2005).

The TSM was selected as the preferred trend-analysis method to MLR primarily because the TSM incorporates continuous streamflow data instead of just concurrently determined streamflow at the time of sampling. Detailed analysis of continuous streamflow data provides better definition of concentration and streamflow relations through time, better handling of temporal variability in sampling frequency, and interpolation of trend patterns to periods when water-quality data are sparse or absent. The TSM inherently accounts for effects of serial correlation. Further, the TSM incorporates interannual, seasonal, and short-term information in flowadjustment procedures. The MLR method used for selected sites in this study incorporates only streamflow at the time of sampling and fixed seasonal functions; thus, the concentration and streamflow relation at a given time of sampling is assumed to depend only on streamflow magnitude and season with no accounting for streamflow conditions before sampling. For example, if two water-quality samples were collected at similar streamflow magnitudes at the same time of year, the flow-adjustment applied using MLR to the samples would be identical regardless of differences in streamflow conditions before sampling. If one sample was collected during increasing streamflow (for example, on the rising limb of snowmelt runoff) in a dry year and the other sample was collected at a similar streamflow during decreasing streamflow (for example, on the receding limb of snowmelt runoff) in a wet year, the same flow-adjustment would be applied to concentrations of both samples; thus, there is no accounting for interannual or short-term hysteresis factors that affect concentration and streamflow relations (Vecchia, 2005; Colby, 1956; Chanat and others, 2002). The TSM, however, analyzes continuous streamflow data to determine the context of streamflow conditions associated with a given time of sampling and account for interannual, seasonal, and short-term streamflow variability in flow-adjustment procedures.

As applied in this study, the TSM required at least 15 years of continuous streamflow data and at least 11 years of water-quality data with at least 60 total samples and at least 10 samples (for all years) in each 3-month season. The TSM was used to analyze trends for 15 of the study sites that met these intensive data requirements (table 1). For those 15 sites, only the TSM results are presented to simplify and condense presentation of results. For seven sites, data requirements of the TSM were not met (table 1). In those cases, MLR was used to analyze trends. As applied in this study, MLR required at least 5 sequential years of water-quality data with six or more samples per year (temporally distributed consistently among years) and associated concurrent streamflow at times of sample collection. 
The TSM and MLR methods incorporate base-10 logarithm (hereinafter referred to as $\log$ ) transformation of the concentration and streamflow data. As such, the fitted trends in FACs quantify temporal changes in central tendency represented by the geometric mean of concentration in reference to log-transformed streamflow. The geometric mean is the mean of the logs transformed back into their original units. Overviews of the TSM and MLR methods are presented in the following sections of this report.

\section{Time-Series Model (TSM)}

A statistical time-series model for streamflow and constituent concentration (Vecchia, 2005) was used in this report to detect water-quality trends. Details on theory and parameter estimation for the model are presented in Vecchia (2005) and the model is summarized in appendix 2 (at the end of this report). Specific information concerning suitability of application of the TSM to the study datasets, and procedures for determination of statistical significance and magnitude of trends also is presented in appendix 2 .

Included in appendix 2 are definitions of anomaly terms that are used in the TSM and are important in contributing to the rigor of the TSM. In analysis of concentration and streamflow relations, the TSM partitions effects of streamflow variability into separate components for interannual, seasonal, and short-term (day-to-day) variability, and relative importance of each of those components is quantified. The annual concentration anomaly $\left(\mathrm{ANN}_{\mathrm{C}}\right.$; appendix 2, equation 2) quantifies interannual variability in concentration that is related to interannual variability in streamflow [as determined by the annual streamflow anomaly $\left(\mathrm{ANN}_{\mathrm{Q}}\right.$; appendix 2, equation 5)]. The seasonal concentration anomaly $\left(\mathrm{SEAS}_{\mathrm{C}}\right.$; appendix 2 , equation 2) quantifies seasonal variability in concentration that is related to seasonal variability in streamflow [as determined by the seasonal streamflow anomaly $\left(\mathrm{SEAS}_{\mathrm{Q}}\right.$; appendix 2 , equation 5)]. For unfiltered-recoverable constituent concentrations, $\mathrm{ANN}_{\mathrm{C}}$ and $\mathrm{SEAS}_{\mathrm{C}}$ typically are positive and indicate direct relations between concentration and streamflow. However, the strength of $\mathrm{ANN}_{\mathrm{C}}$ relative to SEAS $\mathrm{C}_{\mathrm{C}}$ might differ substantially among sites and constituents. For some site and constituent combinations, constituent concentration might be more sensitive to annual streamflow variability than seasonal streamflow variability and for other combinations, the reverse situation might hold. Short-term variability in concentration, also referred to as high-frequency variability $\left(\mathrm{HFV}_{\mathrm{C}}\right.$; appendix 2 , equation 2 ), is variability remaining after removing $\mathrm{ANN}_{\mathrm{C}}$ and $\mathrm{SEAS}_{\mathrm{C}}$. Similarly, high-frequency streamflow variability $\left(\mathrm{HFV}_{\mathrm{Q}}\right.$; appendix 2, equation 5$)$ is variability remaining after removing $\mathrm{ANN}_{\mathrm{Q}}$ and $\mathrm{SEAS}_{\mathrm{Q}}$. Relations between $\mathrm{HFV}_{\mathrm{C}}$ and $\mathrm{HFV}_{\mathrm{Q}}$ generally are more complex than relations for $\mathrm{ANN}_{\mathrm{C}}$ and $\mathrm{ANN}_{\mathrm{Q}}$ and for $\mathrm{SEAS}_{\mathrm{C}}$ and $\mathrm{SEAS}_{\mathrm{Q}}$. In accounting for relations between $\mathrm{HFV}_{\mathrm{C}}$ and $\mathrm{HFV}_{\mathrm{Q}}$, the TSM can account for effects of short-term streamflow variability (for example, hysteresis) and also potential serial correlation.
A limitation of the TSM is that it does not handle censored data in a rigorous manner. In the TSM, a single value is substituted for all censored data for a given constituent. Thus, criteria must be set to specify the allowable amount of censored data and a consistent substitution value for each constituent. Based on analysis of trial datasets with artificiallyimposed variable levels of censoring, the TSM generally can be applied to datasets with about 10 percent or less censored data without substantial effects on trend results (Vecchia, 2003). Multiple LRLs in the datasets of the Clark Fork monitoring program complicates the task of setting consistent substitution values. In applying the TSM to the study database, study reporting levels (SRLs; table 2) for setting consistent substitution values were established for each trace-element constituent based on investigation of the time frame during which various NWQL LRLs were used, the frequency of censoring that resulted from each LRL, and field blank sample data providing information on potential contamination bias of low concentrations. The SRLs were applied to the study database by (1) substituting one-half the SRL for all censored observations with LRLs equal or close to the SRL, (2) substituting one-half the SRL for all reported uncensored concentrations (analyzed during times when the LRL was less than the SRL) that were less than the SRL, and (3) excluding censored data with LRLs substantially larger than the SRL. Any analytical result that was revised by either substitution or exclusion was considered to be affected by the recensoring procedures used in applying the SRL. Application of the TSM generally was restricted to site and constituent combinations that had less than or equal to 6 percent of analytical results affected by the recensoring procedures. This conservative criterion was selected to minimize the potential effects of greater uncertainty (because of LRL and censoring issues, and potential contamination bias) in low-concentration data on trend results. The criterion was relaxed allowing as much as 10 percent of analytical results affected by the recensoring procedures for three site and constituent combinations (site 15, unfiltered-recoverable copper; site 17, unfiltered-recoverable lead and zinc) as discussed in the section of this report "WaterQuality Trends for Selected Sampling Sites in the Upper Clark Fork Basin." For many site and constituent combinations, the censored-data limitations of the TSM did not allow reporting of trend results. However, in this report, particular emphasis is placed on copper, arsenic, and suspended-sediment trend results. Copper and arsenic have much different geochemical characteristics and are constituents of concern with respect to potential toxicity issues. Further, trend patterns for copper generally are similar to other metallic contaminants. Suspendedsediment data provide information on transport of particulate materials, which is a factor that can strongly affect transport of metallic contaminants. For most sites with sufficient periods of data collection, copper, arsenic, and suspended-sediment data met all requirements for application of the TSM.

The TSM accounts for many hydrological factors that contribute to complexity in concentration and streamflow relations. In this study, the TSM was applied as consistently 
as possible among sites, and is considered to be a useful tool for simplifying the environmental complexity in the upper Clark Fork Basin to provide a large-scale evaluation of general temporal changes in FACs and constituent transport independent from streamflow variability. The TSM best-fit trend lines are considered to provide important information beyond the strict statistical characteristics of the trend results (in terms of $p$-values and levels of significance) because they aid in comparing and summarizing large-scale patterns among sites.

\section{Multiple Linear Regression on Time, Streamflow, and Season (MLR)}

MLR generally is regarded as a preferred alternative trend-analysis method relative to nonparametric methods when data distributions are approximately normal (Helsel and Hirsch, 2002). MLR for trend analysis was applied following guidelines presented in Helsel and Hirsch (2002) and specific information concerning application of MLR in this study is presented in appendix 3.

A consistent (in terms of dependent and explanatory variables) MLR model was used to provide general application for the numerous site and constituent combinations. Constituent concentrations were regressed on streamflow, decimal time, and periodic functions to represent seasonal variability in concentration and streamflow relations. MLR models were developed by using ordinary least squares if the concentration data contained no censored observations or by using adjusted maximum-likelihood estimation (Cohn, 1988, 2005) if censored observations were present. Specific information concerning suitability of application of MLR to the study datasets, and procedures for determination of the statistical significance and magnitude of trends is presented in appendix 3 .

\section{Selection of Trend-Analysis Time Periods}

Appropriate selection of trend analysis time periods is important because the results of trend analyses are dependent on how the time periods are structured. Factors considered in selection of trend analysis time periods included providing capability to (1) compare trend results among sites with different periods of data collection; (2) distinguish the short-term timing of changes in concentration and streamflow relations within the long study period; and (3) allow periodic future updates of trend analyses for evaluation of effects of remediation activities. Based primarily on those factors, trendanalysis periods were defined as sequential 5-year periods that extended from near the start of long-term data-collection activities for most sites in the upper Clark Fork Basin to the end of water year 2010. Thus, three trend-analysis time periods were defined: period 1 (water years 1996-2000); period 2 (water years 2001-05); and period 3 (water years 2006-10). Trend analysis periods that were applicable for each site are presented in table 1. For recently-established sites that did not satisfy data requirements for the TSM, trends for period 3 were analyzed by using MLR.

For the TSM, fitted trends in FACs during a defined trend-analysis period are monotonic trends that are smoothed to produce generally consistent slopes across the middle section of the trend-analysis period that become flatter near the ends. The flatter slopes near the ends provide gradual transition between adjacent trend-analysis periods. For MLR, fitted trends in FACs during a defined trend-analysis period are straight-line monotonic trends. In some cases, the fitted trends within a defined trend-analysis time period do not precisely follow the patterns in FACs and there are short-term (about 1-2 years) trend patterns in the FACs that are unresolved in the fitted trends. In those cases, better temporal resolution might have been attained by defining two or more additional trend-analysis periods within one of the defined 5-year trendanalysis periods. This approach generally was avoided because it would have required detailed site-by-site trend analysis for potentially inconsistent time periods among the 22 sites in this study. An important consideration in the design of the trend-analysis structure of this study was the capability to make general comparisons among the 22 sites with respect to evaluating potential effects of mining and remediation activities on a large-scale basis throughout consistent time periods. In general, when unresolved trending was apparent, more complicated trend models (with additional trend-analysis periods) were tested and the more complicated models did not change the general findings and conclusions of this report; that is, the overall fitted trends during the affected trend-analysis periods were consistent with overall patterns in FACs during the period. However, because of the substantial effect of the breach of Milltown Dam on March 28, 2008, an exception to consistent trend-analysis periods was made. For Clark Fork above Missoula (site 22), period 3 was subdivided into period $3 \mathrm{~A}$ (October 1, 2005-March 27, 2008) and period 3B (March 28, 2008-September 30, 2010).

\section{Estimation of Normalized Constituent Loads}

For sites that were analyzed by using the TSM, normalized constituent loads were estimated to assess the temporal trends in FACs of mining-related contaminants in the context of sources and transport. Sites analyzed by using MLR were not included in this transport analysis because of factors that complicate directly combining the TSM and MLR results within a single analysis, including: (1) MLR uses different flow-adjustment procedures than the TSM, and (2) the sites analyzed by using MLR had substantially shorter periods of data collection than the sites analyzed by using the TSM.

The fitted trends in concentration are best-fit lines through the FACs, which are independent of streamflow conditions. FAC trends at individual sites are important descriptors of water-quality changes in the upper Clark Fork Basin, but without consideration of differences in streamflow magnitudes between different sites, the FAC trends do not provide direct 
information on resultant changes in contaminant source-area contributions and transport characteristics. Combining the FAC trends with a stationary streamflow index (that maintains relative differences in streamflow magnitudes between sites but normalizes streamflow for a given site to a constant value through time) allows assessment of how the temporal changes in FACs translate into relative temporal changes in source and transport of mining-related contaminants in the upper Clark Fork Basin. Thus, normalized loads were estimated to conduct a transport analysis.

Normalized loads were estimated for each of the three 5 -year trend-analysis periods. The stationary streamflow index used in estimating normalized loads was the geometric mean streamflow for each site for water years 1996-2010. The geometric mean was selected as a measure of central tendency in streamflow to maintain consistency with the TSM analysis, which is conducted on log-transformed data.

For each site and constituent combination and each of the 5 -year periods, the normalized load was estimated by multiplying the mean annual fitted trend FAC during the period times the geometric mean streamflow for water years 19962010 and a units conversion factor, according to the following equation:

$$
L O A D=M A C * G M Q * K
$$

where

$\angle O A D \quad$ is the estimated normalized constituent load (in kilograms per day) for the indicated 5-year period;

$M A C \quad$ is the mean annual fitted trend FAC (in micrograms per liter for trace-elements or milligrams per liter for suspended sediment) for the indicated 5-year period;

$G M Q \quad$ is the geometric mean of daily mean streamflow for water years 1996-2010, in cubic feet per second; and

$K \quad$ is a units conversion constant $(0.00245$ for concentrations in micrograms per liter or 2.45 for concentrations in milligrams per liter) to convert instantaneous constituent discharge (in mass units per second) to an equivalent daily constituent load (in kilograms per day).

The MAC is calculated by temporally averaging (within each of the three 5-year periods) the fitted trend FACs that quantify temporal changes in central tendency based on the geometric mean. It is notable that the MAC is referred to as a mean annual value, and this terminology indicates temporal averaging of geometric mean concentrations. For data that are approximately log-normally distributed, the geometric mean generally is closely associated with the median of the original untransformed units. Thus, because of effects of analysis of log-transformed data the estimated normalized loads generally represent quantification with respect to near-median conditions. As such, the estimated normalized loads do not represent actual magnitudes of total mass transport. Rather, the estimated normalized loads provide information on relative temporal changes in constituent transport characteristics of the study sites quantified with respect to near-median conditions.

\section{Streamflow Conditions and Various Data-Related Factors that Affect Trend Analysis and Interpretation}

Several factors affect temporal trends in water quality. Climatic variability (interannual and seasonal) is indicated in variability in streamflow conditions, which strongly affect concentration and streamflow relations. Investigating streamflow conditions during the study period is relevant to interpreting trend results. Other factors relating to data assessment or treatment that also are relevant to understanding trend-analysis procedures and interpreting trend results include relations between unadjusted concentrations and FACs, and data transformation. The TSM is emphasized in this section because it is the method used for most sites in this study and it provides convenient access to relevant intermediate results to indicate trend-analysis concepts.

\section{Streamflow Conditions}

Daily mean streamflows for water years 1993-2010 for selected sites in the upper Clark Fork Basin are presented in figure 3. Locally weighted scatter plot smooth (LOWESS; Cleveland, 1985; Cleveland and McGill, 1984) lines through the daily mean streamflows also are presented in figure 3 to represent temporal variability in the moving central tendency of streamflow. The geometric mean streamflows for water years 1996-2010 are presented to represent overall central tendency of streamflow during the period of trend analysis. Silver Bow Creek at Opportunity (site 3, fig. 1, table 1), Clark Fork at Deer Lodge (site 14, fig. 1, table 1), and Clark Fork at Turah Bridge (site 20, fig. 1, table 1) were selected as examples for showing hydrologic patterns that generally apply to most other sites.

Temporal variability in streamflow conditions during the study period generally is similar among sites. In about water year 1993, streamflow conditions generally increased to above the geometric mean streamflows during a period of several years. Streamflows were high during water years 1996-97, near the start of period 1 (water years 1996-2000). During period 1, streamflow conditions above the geometric mean streamflows generally persisted through water year 1999, and then decreased substantially to below the geometric mean streamflows during water year 2000. High streamflow conditions prevalent through most of period 1 are evident in annual maximum streamflows being higher than maximums of most other years and also in annual minimum streamflows being higher than minimums of most other years. Streamflow during 


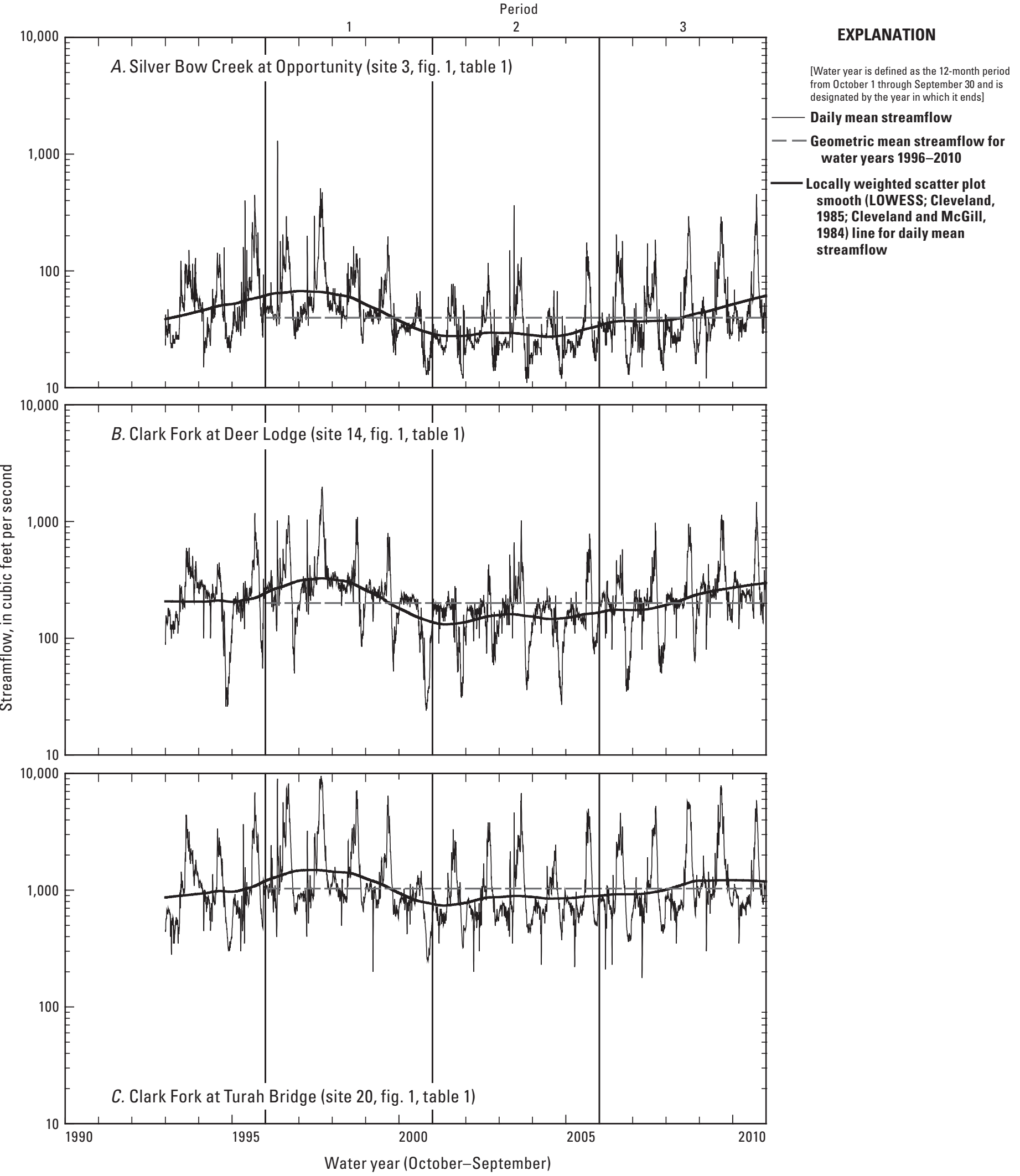

Figure 3. Daily mean streamflow for selected sites in the upper Clark Fork Basin, Montana, water years 1993-2010. 
water year 1997 was particularly unusual in that the receding limb of snowmelt runoff was less abrupt and less variable than most years, and post-runoff base streamflows generally were above or near the geometric mean streamflow. Further, the post-runoff base streamflows in water year 1997 at site 14 (fig. $3 B$ ) sometimes exceeded annual maximum streamflows during the low streamflow years 2000-02. During period 2 (water years 2001-05), streamflow conditions generally were below the geometric mean streamflows and represented a period of prolonged drought in the upper Clark Fork Basin. During period 3 (water years 2006-10), streamflow conditions generally were near the geometric mean streamflows during water years 2005-07, and increased to above the geometric mean streamflows during water years 2008-10.

\section{Various Data-Related Factors that Affect Trend Analysis and Interpretation}

Factors relating to data requirements, treatments, and assessment that affect trend analysis and interpretation of results include relations between unadjusted concentrations and FACs, and data transformation. Those factors are discussed in this section of the report.

FACs are estimates of constituent concentrations after removing effects of streamflow variability. Thus, FACs typically have less variability than unadjusted concentrations, although the strength of this pattern is variable among sites and constituents, and also can be variable through time for a given site. Data for Clark Fork near Galen (site 11) are presented in figure 4 to provide examples for discussion of relations between unadjusted and flow-adjusted concentrations.

For suspended sediment (fig. 4D), unadjusted concentrations tend to be higher during high streamflow conditions than during low-streamflow conditions. During high-streamflow conditions, with associated high hydraulic energy, particulate material is mobilized and transported in the stream. During low streamflow conditions, streams have less capacity for transporting particulate materials. Similarities among the LOWESS smooth line for unadjusted suspended-sediment concentrations (fig $4 D$ ) and streamflow (fig. $4 A$ ) illustrate the direct relations between streamflow and unadjusted suspended-sediment concentrations. Flow-adjustment procedures account for the response of suspended-sediment concentrations to variations in streamflow and produce FACs that represent temporal variability within consistent streamflow conditions. In the Clark Fork for high-streamflow conditions, FACs of suspended sediment are less variable and lower than unadjusted concentrations (for example, fig. $4 D$, water years 1996-99). For low-streamflow conditions, FACs of suspended sediment are less variable and generally are centered within unadjusted concentrations (for example, fig. $4 D$, water years 2000-01).

Unfiltered-recoverable copper (and other metallic elements) has concentration and streamflow relations that are similar to suspended sediment because of adsorption on inorganic and organic particulate materials. As a result, patterns in unadjusted concentrations and FACs for unfilteredrecoverable copper (fig. $4 B$ ) are similar to those of suspended sediment (fig. $4 D$ ).

Arsenic in streams in the upper Clark Fork Basin typically is mostly in dissolved phase, and has less variability and weaker direct relation with streamflow than is the case for metallic elements. Arsenic has been widely dispersed in the upper Clark Fork Basin as a result of deposition of flue dust and smelter emissions with resultant large-scale soil and groundwater contamination (U.S. Environmental Protection Agency, 2010). Further, arsenic generally is more soluble than metallic elements within the geochemical conditions that are prevalent in the upper Clark Fork Basin. These factors result in high arsenic concentrations in groundwater in some areas and also mobilization of arsenic to stream channels for a large range of streamflow conditions. Thus, patterns in unadjusted concentrations and FACs for unfiltered-recoverable arsenic (fig. 4C) generally are less variable than for unfiltered-recoverable copper (fig. $4 B$ ) and suspended sediment (fig. $4 D$ ). Also unadjusted concentrations of unfiltered-recoverable arsenic have less correspondence with streamflow than unfilteredrecoverable copper and suspended sediment.

For the period 2004-10, during transition from lowstreamflow to high-streamflow conditions, LOWESS smooth lines for unadjusted concentrations of unfiltered-recoverable copper and suspended sediment show substantial increases. However, the TSM flow-adjustment procedure accounts for the streamflow variability and fitted trends indicate consistent but small decreases in FACs of those constituents. Another period of substantial deviation between unadjusted concentrations and FACs is from 1994-2000. During both periods of deviation, the FACs are unaffected by large variations in streamflow. The dissimilar patterns between unadjusted concentrations and FACs indicate the importance of flow-adjusted trend analysis for identifying actual patterns in constituent concentrations independent from variability in streamflow conditions.

An important consideration in interpreting trend results relates to the trend-analysis methods incorporating log-transformation of constituent concentrations. Thus, the methods evaluate changes in geometric mean concentrations in reference to log-transformed streamflow. Log-transformation results in datasets that are approximately normally distributed and allow analysis using rigorous parametric procedures. However, log-transformation decreases variability in the data relative to the original untransformed units representative of actual environmental variability. In general, the statistical distributions of constituent concentrations and streamflow (in original untransformed units) for sites in the upper Clark Fork Basin are right skewed, indicating that the extent of data higher than the median is greater than the extent of data lower than the median. Log transformation results in expansion of the lower end of the distribution and compression of the higher end of the distribution. Compression of the higher end of the distribution has relatively larger effect than expansion of the 

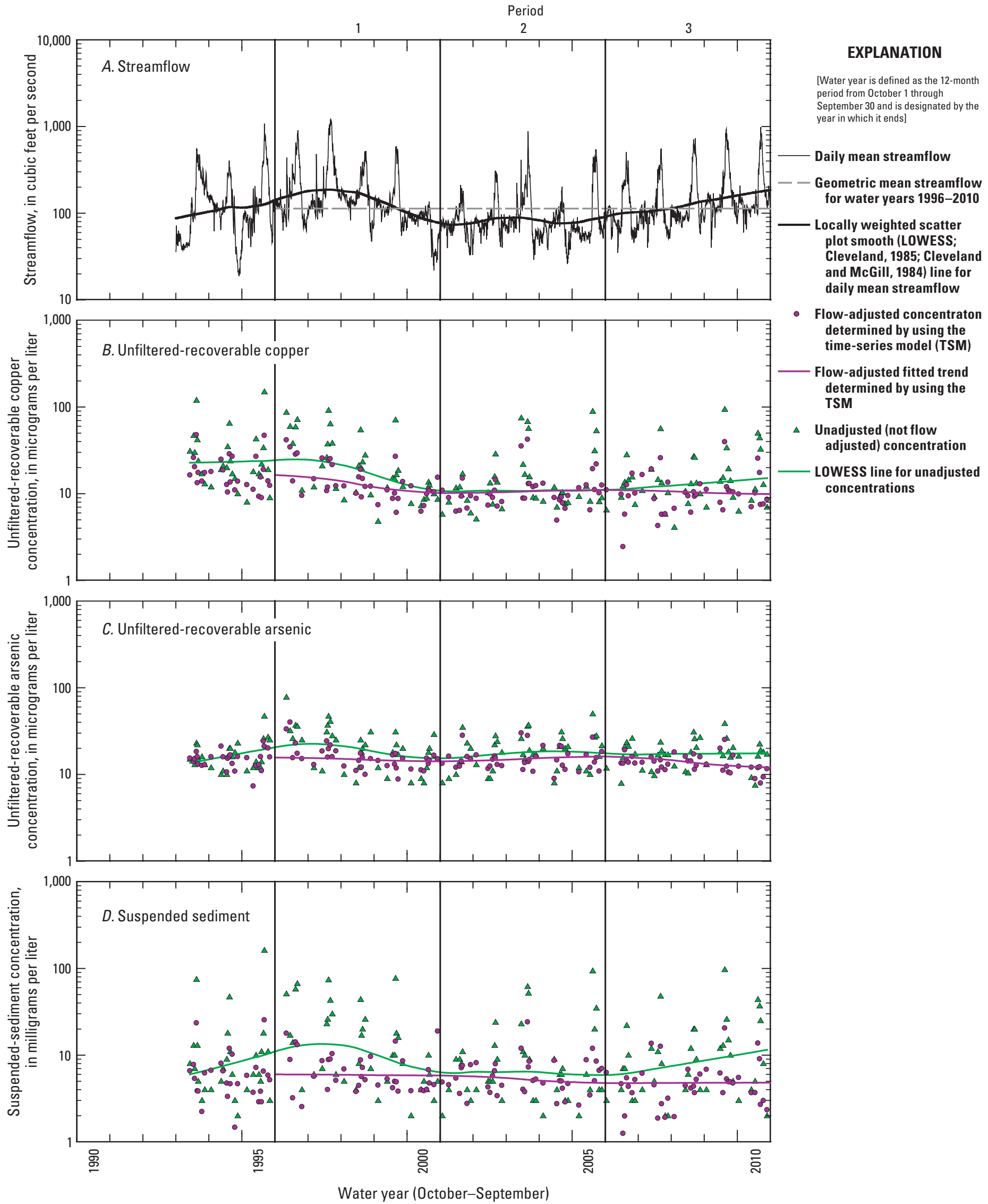

Figure 4. Selected streamflow and constituent concentration information for Clark Fork near Galen (site 11, fig. 1, table 1), water years 1993-2010. 
lower end of the distribution. This factor is important in interpreting trend results with respect to various regulatory issues, including compliance with drinking water standards or aquatic life criteria. Trends in FACs represent changes in central tendency quantified as changes in the geometric mean in reference to log-transformed streamflow. Thus, the trends in FACs provide general information on overall temporal changes (in terms of directions and relative magnitudes) in concentrations, but lack the specificity to indicate compliance or noncompliance with various regulatory standards. However, effects of data transformation do not negatively affect the primary purpose of this study in determining temporal water-quality trends through time and using the trend results to evaluate relative changes in constituent transport characteristics among sites. In the trend analyses, all data (high as well as low values) affect changes in the FAC geometric means. Thus, the fitted trends truly represent unbiased estimates of overall changes in central tendency.

\section{Water-Quality Trends for Selected Sampling Sites in the Upper Clark Fork Basin}

For all constituents investigated, detailed results for trend magnitudes, computed as the total percent changes in FAC geometric means from the beginning to the end of each 5-year period, are presented in table 4-1 (for most sites analyzed by using the TSM), table 4-2 [for Clark Fork above Missoula (site 22, fig. 1, table 1) analyzed by using the TSM], and table 4-3 (for sites analyzed by using MLR). Fitted trend values (that quantify the temporal changes in FAC geometric means in terms of concentration units) for selected constituents are summarized in tables 4-6 and graphically presented for all sites in figures 4-1 through 4-22. Although, trend magnitude results are presented for all constituents investigated, emphasis is placed on copper, arsenic, and suspended sediment.

In the discussion, qualitative observations on trend magnitude (percent change) are made. Trend magnitude was considered to be (1) large, if the deviation from zero was greater than about 60 percent; (2) moderate, if the deviation from zero was within the range of about 40-60 percent; (3) small, if the deviation from zero was within the range of about 20-40 percent; and (4) minor, if the deviation from zero was within the range of about $0-20$ percent. In some cases, when trending was within a small range at low concentrations, large trend magnitudes (on a percent basis) also were considered to be minor.

Trend-magnitude and fitted trend values are considered semiquantitative estimates determined by statistical analysis. Throughout this report, trend-magnitude and fitted trend values frequently are referred to (reported to two significant figures) in discussion of temporal and spatial changes in water quality. Reference to specific trend-magnitude and fitted trend values is intended to facilitate discussion of relative spatial and temporal differences between values, but is not intended to represent absolute accuracy at two significant figures. The discussion on trend results focuses on the trend-magnitude and fitted trend values. The $p$-values and levels of significance associated with the trend results are indicated in the tables and figures that present trend results, but not emphasized in the discussion. In this study, the TSM is considered to be a useful tool for simplifying the environmental complexity in the upper Clark Fork Basin to provide a large-scale evaluation of general temporal changes in FACs and constituent transport independent from streamflow variability. Thus, the TSM best-fit trend lines are considered to provide important information beyond the strict statistical characteristics of the trend results (in terms of $p$-values and levels of significance) because they aid in comparing and summarizing large-scale patterns among sites.

\section{Trends in Flow-Adjusted Concentrations (FACs) and Estimated Normalized Loads}

Fitted trends and estimated normalized loads of the study sites are presented and discussed for each of the data-summary reaches. Fitted trends for unfiltered-recoverable copper and arsenic, and suspended-sediment concentrations for sites in the reach are graphically presented (for example, fig. 5, which shows fitted trends for sites in reach 1). Estimated normalized loads are presented within the framework of a transport analysis to assess the temporal trends in FACs in the context of sources and transport. Drainage area and streamflow information relevant to the transport analysis is presented in table 7 . Balance calculations for the transport analysis (that is, differences between reach inflows, reach outflows, and monitored within-reach contributions) are presented in tables 5-1 through 5-9 for reaches 1-9, respectively. The transport balance calculations indicate within-reach changes in loads and allow assessment of relative contributions from upstream source areas to loads transported past each reach outflow.

Characteristics of the source areas (including drainage area and geometric mean streamflow; table 7) and balance results for the transport analysis are illustrated by using pie charts that show source-area information and load contributions to reach outflow. For example, in figure 6, pie charts illustrating drainage area and geometric streamflow characteristics of the upstream source areas that contribute to the reach 1 outflow are shown on the left-hand side. Pie charts illustrating balance results for estimated normalized constituent loads are shown on the right hand side. In figure 6 , the reach 1 inflow is the estimated normalized load for Blacktail Creek (site 1, fig. 1, table 1). The reach 1 outflow is the estimated normalized load for Silver Bow Creek at Butte (site 2, fig. 1, table 1). The difference between the reach outflow and the reach inflow indicates the within-reach change in load; that is, the incremental change in the load transported 
Table 4. Summary of flow-adjusted trend results determined by using the time-series model (TSM) for selected sites and constituents, water years $1996-2010$.

[Water year is the 12-month period from October 1 through September 30 and is designated by the year in which it ends. Bold values indicate statistically significant ( $p$-value less than 0.01 ) trend for trend period before the value presented in bold. $p$-value, statistical probability level; $\mu \mathrm{S} / \mathrm{cm}$, microsiemens per centimeter at 25 degrees Celsius; NR, not reported; $\mu \mathrm{g} / \mathrm{L}$, micrograms per liter; $\mathrm{mg} / \mathrm{L}$, milligrams per liter]

\begin{tabular}{|c|c|c|c|c|c|}
\hline \multirow[b]{2}{*}{$\begin{array}{l}\text { Constituent or property, } \\
\text { flow-adjusted units of } \\
\text { measurement }\end{array}$} & \multicolumn{4}{|c|}{ Fitted trend values } & \multirow{2}{*}{$\begin{array}{l}\text { Percent change } \\
\text { from start of } \\
\text { water year } 1996 \\
\text { to end of water } \\
\text { year } 2010\end{array}$} \\
\hline & $\begin{array}{l}\text { Start of water year } \\
1996 \text { (start of } \\
\text { period 1) }\end{array}$ & $\begin{array}{l}\text { Start of water year } \\
2001 \text { (start of } \\
\text { period 2) }\end{array}$ & $\begin{array}{l}\text { Start of water year } \\
2006 \text { (start of } \\
\text { period 3) }\end{array}$ & $\begin{array}{l}\text { End of water year } \\
2010 \text { (end of } \\
\text { period 3) }\end{array}$ & \\
\hline \multicolumn{6}{|c|}{ Blacktail Creek (site 1, fig. 1, table 1) } \\
\hline Specific conductance, $\mu \mathrm{S} / \mathrm{cm}$ & 279 & 297 & 295 & 289 & 4 \\
\hline Copper, filtered, $\mu \mathrm{g} / \mathrm{L}$ & 2.3 & 2.0 & 2.0 & 1.9 & -17 \\
\hline $\begin{array}{l}\text { Copper, unfiltered-recover- } \\
\text { able, } \mu \mathrm{g} / \mathrm{L}\end{array}$ & 5.2 & 4.3 & 4.3 & 3.8 & -27 \\
\hline Zinc, filtered, $\mu \mathrm{g} / \mathrm{L}$ & $\mathrm{NR}^{1}$ & $\mathrm{NR}^{1}$ & $\mathrm{NR}^{1}$ & $\mathrm{NR}^{1}$ & $\mathrm{NR}^{1}$ \\
\hline $\begin{array}{l}\text { Zinc, unfiltered-recoverable, } \\
\quad \mu \mathrm{g} / \mathrm{L}\end{array}$ & $\mathrm{NR}^{1}$ & $\mathrm{NR}^{1}$ & $\mathrm{NR}^{1}$ & $\mathrm{NR}^{1}$ & $\mathrm{NR}^{1}$ \\
\hline Arsenic, filtered, $\mu \mathrm{g} / \mathrm{L}$ & 2.9 & 2.1 & 2.5 & 2.6 & -10 \\
\hline $\begin{array}{l}\text { Arsenic, unfiltered-recover- } \\
\quad \text { able, } \mu \mathrm{g} / \mathrm{L}\end{array}$ & 3.8 & 2.8 & 3.1 & 3.3 & -13 \\
\hline Suspended sediment, $\mathrm{mg} / \mathrm{L}$ & 6.7 & 7.2 & 5.6 & 5.1 & -24 \\
\hline \multicolumn{6}{|c|}{ Silver Bow Creek at Butte (site 2, fig. 1, table 1) } \\
\hline Specific conductance, $\mu \mathrm{S} / \mathrm{cm}$ & 522 & 493 & 493 & 476 & -9 \\
\hline Copper, filtered, $\mu \mathrm{g} / \mathrm{L}$ & 60 & 13 & 13 & 6.0 & -90 \\
\hline $\begin{array}{l}\text { Copper, unfiltered-recover- } \\
\text { able, } \mu \mathrm{g} / \mathrm{L}\end{array}$ & 180 & 44 & 31 & 14 & -92 \\
\hline Zinc, filtered, $\mu \mathrm{g} / \mathrm{L}$ & 890 & 280 & 77 & 32 & -96 \\
\hline $\begin{array}{l}\text { Zinc, unfiltered-recoverable, } \\
\quad \mu \mathrm{g} / \mathrm{L}\end{array}$ & 1,100 & 350 & 98 & 43 & -96 \\
\hline Arsenic, filtered, $\mu \mathrm{g} / \mathrm{L}$ & 6.5 & 6.8 & 4.0 & 4.3 & -34 \\
\hline $\begin{array}{l}\text { Arsenic, unfiltered-recover- } \\
\quad \text { able, } \mu \mathrm{g} / \mathrm{L}\end{array}$ & 13 & 10 & 5.6 & 6.0 & -54 \\
\hline Suspended sediment, $\mathrm{mg} / \mathrm{L}$ & 15 & 14 & 7.5 & 7.3 & -51 \\
\hline \multicolumn{6}{|c|}{ Silver Bow Creek at Opportunity (site 3, fig. 1, table 1) } \\
\hline Specific conductance, $\mu \mathrm{S} / \mathrm{cm}$ & 424 & 463 & 470 & 440 & 4 \\
\hline Copper, filtered, $\mu \mathrm{g} / \mathrm{L}$ & 48 & 42 & 29 & 17 & -65 \\
\hline $\begin{array}{l}\text { Copper, unfiltered-recover- } \\
\text { able, } \mu \mathrm{g} / \mathrm{L}\end{array}$ & 130 & 120 & 94 & 44 & -66 \\
\hline Zinc, filtered, $\mu \mathrm{g} / \mathrm{L}$ & 290 & 220 & 130 & 53 & -82 \\
\hline $\begin{array}{l}\text { Zinc, unfiltered-recoverable, } \\
\quad \mu \mathrm{g} / \mathrm{L}\end{array}$ & 540 & 470 & 270 & 130 & -76 \\
\hline Arsenic, filtered, $\mu \mathrm{g} / \mathrm{L}$ & 9.0 & 11 & 12 & 7.4 & -18 \\
\hline $\begin{array}{l}\text { Arsenic, unfiltered-recover- } \\
\quad \text { able, } \mu \mathrm{g} / \mathrm{L}\end{array}$ & 16 & 17 & 18 & 8.8 & -45 \\
\hline Suspended sediment, $\mathrm{mg} / \mathrm{L}$ & 24 & 18 & 21 & 19 & -21 \\
\hline \multicolumn{6}{|c|}{ Silver Bow Creek at Warm Springs (site 8, fig. 1, table 1) } \\
\hline Specific conductance, $\mu \mathrm{S} / \mathrm{cm}$ & 527 & 526 & 506 & 530 & 0 \\
\hline Copper, filtered, $\mu \mathrm{g} / \mathrm{L}$ & 11 & 4.8 & 4.2 & 4.0 & -64 \\
\hline $\begin{array}{l}\text { Copper, unfiltered-recover- } \\
\text { able, } \mu \mathrm{g} / \mathrm{L}\end{array}$ & 18 & 8.8 & 8.0 & 7.0 & -61 \\
\hline
\end{tabular}


Table 4. Summary of flow-adjusted trend results determined by using the time-series model (TSM) for selected sites and constituents, water years 1996-2010.-Continued

[Water year is the 12-month period from October 1 through September 30 and is designated by the year in which it ends. Bold values indicate statistically significant ( $p$-value less than 0.01 ) trend for trend period before the value presented in bold. $p$-value, statistical probability level; $\mu \mathrm{S} / \mathrm{cm}$, microsiemens per centimeter at 25 degrees Celsius; NR, not reported; $\mu \mathrm{g} / \mathrm{L}$, micrograms per liter; $\mathrm{mg} / \mathrm{L}$, milligrams per liter]

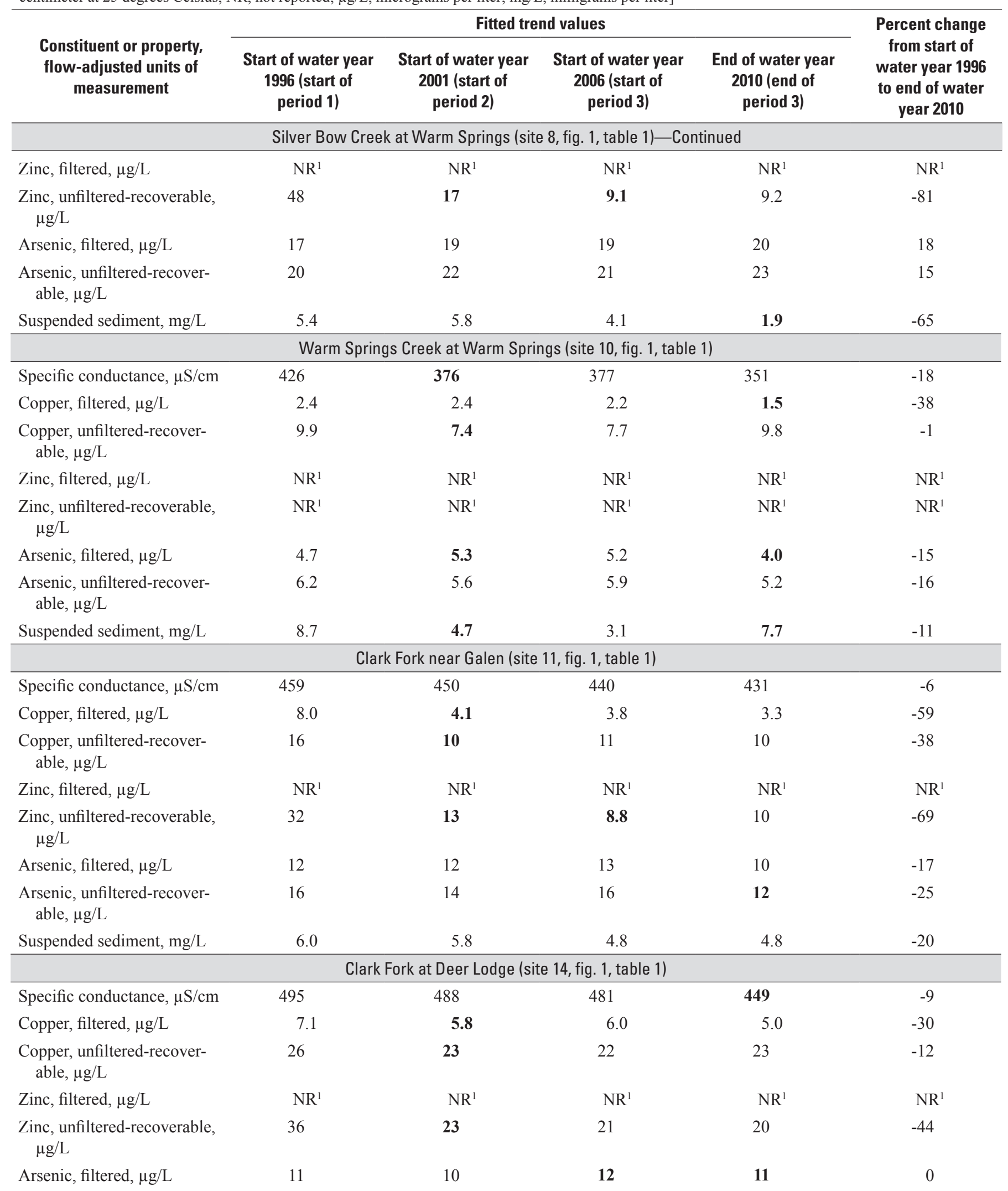


Table 4. Summary of flow-adjusted trend results determined by using the time-series model (TSM) for selected sites and constituents, water years 1996-2010.-Continued

[Water year is the 12-month period from October 1 through September 30 and is designated by the year in which it ends. Bold values indicate statistically significant ( $p$-value less than 0.01 ) trend for trend period before the value presented in bold. $p$-value, statistical probability level; $\mu \mathrm{S} / \mathrm{cm}$, microsiemens per centimeter at 25 degrees Celsius; NR, not reported; $\mu \mathrm{g} / \mathrm{L}$, micrograms per liter; $\mathrm{mg} / \mathrm{L}$, milligrams per liter]

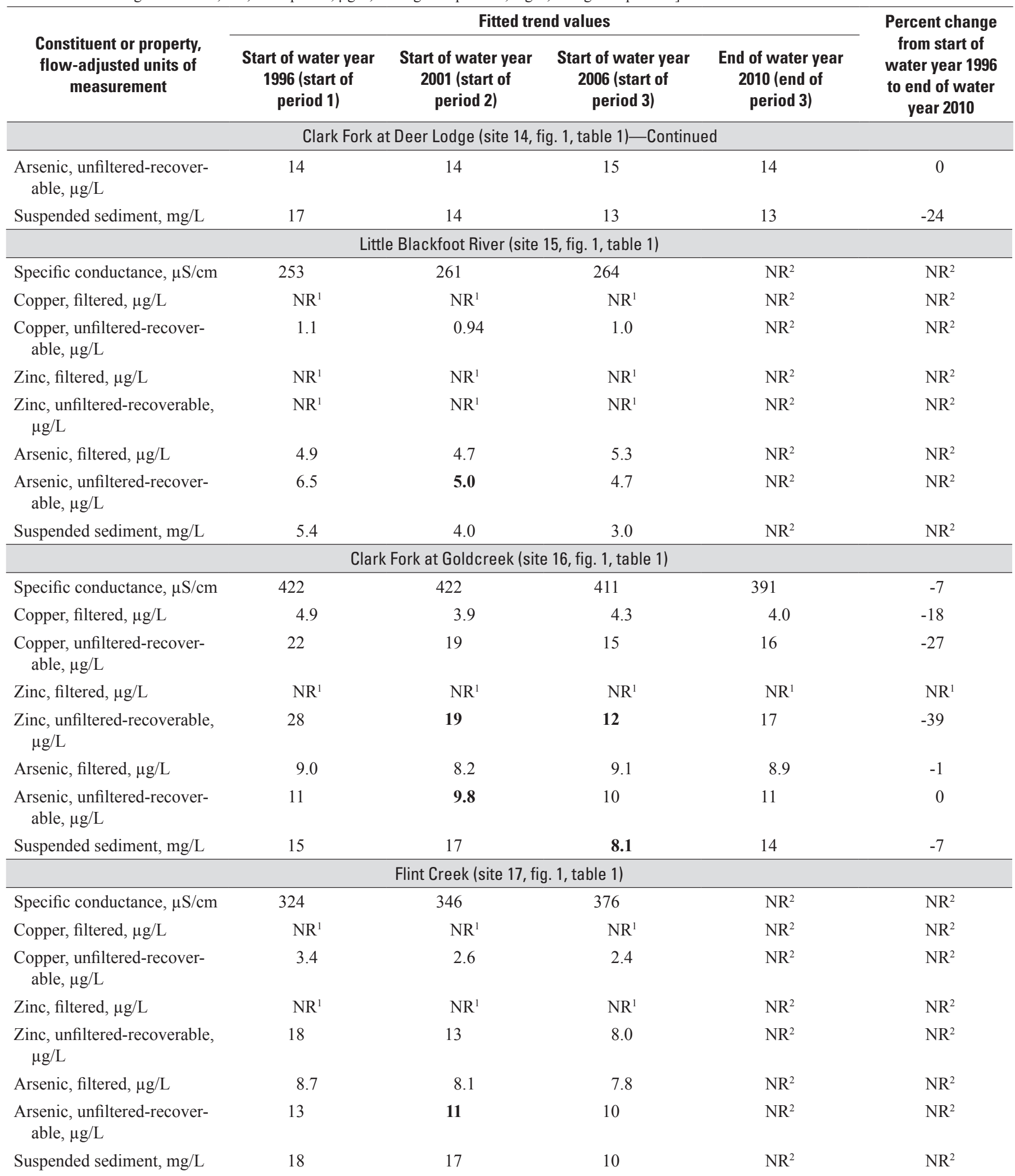


Table 4. Summary of flow-adjusted trend results determined by using the time-series model (TSM) for selected sites and constituents, water years 1996-2010.-Continued

[Water year is the 12-month period from October 1 through September 30 and is designated by the year in which it ends. Bold values indicate statistically significant ( $p$-value less than 0.01 ) trend for trend period before the value presented in bold. $p$-value, statistical probability level; $\mu \mathrm{S} / \mathrm{cm}$, microsiemens per centimeter at 25 degrees Celsius; NR, not reported; $\mu \mathrm{g} / \mathrm{L}$, micrograms per liter; $\mathrm{mg} / \mathrm{L}$, milligrams per liter]

\section{Constituent or property, flow-adjusted units of measurement}

Fitted trend values

\begin{tabular}{cccc}
\hline Start of water year & Start of water year & Start of water year & End of water year \\
1996 (start of & 2001 (start of & 2006 (start of & 2010 (end of \\
period 1) & period 2) & period 3) & period 3)
\end{tabular}

Percent change from start of water year 1996 to end of water year 2010

\begin{tabular}{|c|c|c|c|c|c|}
\hline \multicolumn{6}{|c|}{ Clark Fork near Drummond (site 18, fig. 1, table 1) } \\
\hline Specific conductance, $\mu \mathrm{S} / \mathrm{cm}$ & 486 & 472 & 458 & 445 & -8 \\
\hline Copper, filtered, $\mu \mathrm{g} / \mathrm{L}$ & 3.7 & 3.7 & 4.3 & 3.3 & -11 \\
\hline Zinc, filtered, $\mu \mathrm{g} / \mathrm{L}$ & $\mathrm{NR}^{1}$ & $\mathrm{NR}^{1}$ & $\mathrm{NR}^{1}$ & $\mathrm{NR}^{1}$ & $\mathrm{NR}^{1}$ \\
\hline Arsenic, filtered, $\mu \mathrm{g} / \mathrm{L}$ & 9.3 & 8.6 & 9.3 & 8.3 & -11 \\
\hline $\begin{array}{l}\text { Arsenic, unfiltered-recover- } \\
\quad \text { able, } \mu \mathrm{g} / \mathrm{L}\end{array}$ & 12 & 10 & 10 & 10 & -17 \\
\hline Suspended sediment, $\mathrm{mg} / \mathrm{L}$ & 21 & 13 & 11 & 12 & -43 \\
\hline $\begin{array}{l}\text { Copper, unfiltered-recover- } \\
\text { able, } \mu \mathrm{g} / \mathrm{L}\end{array}$ & $\mathrm{NR}^{1}$ & $\mathrm{NR}^{1}$ & $\mathrm{NR}^{1}$ & $\mathrm{NR}^{2}$ & $\mathrm{NR}^{2}$ \\
\hline Zinc, filtered, $\mu \mathrm{g} / \mathrm{L}$ & $\mathrm{NR}^{1}$ & $\mathrm{NR}^{1}$ & $\mathrm{NR}^{1}$ & $\mathrm{NR}^{2}$ & $\mathrm{NR}^{2}$ \\
\hline $\begin{array}{l}\text { Zinc, unfiltered-recoverable, } \\
\quad \mu \mathrm{g} / \mathrm{L}\end{array}$ & $\mathrm{NR}^{1}$ & $\mathrm{NR}^{1}$ & $\mathrm{NR}^{1}$ & $\mathrm{NR}^{2}$ & $\mathrm{NR}^{2}$ \\
\hline Arsenic, filtered, $\mu \mathrm{g} / \mathrm{L}$ & $\mathrm{NR}^{1}$ & $\mathrm{NR}^{1}$ & $\mathrm{NR}^{1}$ & $\mathrm{NR}^{2}$ & $\mathrm{NR}^{2}$ \\
\hline $\begin{array}{l}\text { Arsenic, unfiltered-recover- } \\
\quad \text { able, } \mu \mathrm{g} / \mathrm{L}\end{array}$ & $\mathrm{NR}^{1}$ & $\mathrm{NR}^{1}$ & $\mathrm{NR}^{1}$ & $\mathrm{NR}^{2}$ & $\mathrm{NR}^{2}$ \\
\hline Suspended sediment, $\mathrm{mg} / \mathrm{L}$ & 4.7 & 7.1 & 3.2 & $\mathrm{NR}^{2}$ & $\mathrm{NR}^{2}$ \\
\hline \multicolumn{6}{|c|}{ Clark Fork at Turah Bridge (site 20, fig. 1, table 1) } \\
\hline Arsenic, filtered, $\mu \mathrm{g} / \mathrm{L}$ & 5.3 & 5.1 & 5.4 & 5.5 & 4 \\
\hline $\begin{array}{l}\text { Arsenic, unfiltered-recover- } \\
\quad \text { able, } \mu \mathrm{g} / \mathrm{L}\end{array}$ & 6.8 & 6.3 & 5.9 & 7.2 & 6 \\
\hline Suspended sediment, $\mathrm{mg} / \mathrm{L}$ & 13 & 12 & 8.4 & 13 & 0 \\
\hline \multicolumn{6}{|c|}{ Blackfoot River (site 21, fig. 1, table 1) } \\
\hline Specific conductance, $\mu \mathrm{S} / \mathrm{cm}$ & 237 & 238 & 229 & 243 & 3 \\
\hline Copper, filtered, $\mu \mathrm{g} / \mathrm{L}$ & $\mathrm{NR}^{1}$ & $\mathrm{NR}^{1}$ & $\mathrm{NR}^{1}$ & $\mathrm{NR}^{1}$ & $\mathrm{NR}^{1}$ \\
\hline
\end{tabular}


Table 4. Summary of flow-adjusted trend results determined by using the time-series model (TSM) for selected sites and constituents, water years 1996-2010.-Continued

[Water year is the 12-month period from October 1 through September 30 and is designated by the year in which it ends. Bold values indicate statistically significant ( $p$-value less than 0.01 ) trend for trend period before the value presented in bold. $p$-value, statistical probability level; $\mu$ S/cm, microsiemens per centimeter at 25 degrees Celsius; NR, not reported; $\mu \mathrm{g} / \mathrm{L}$, micrograms per liter; mg/L, milligrams per liter]

\begin{tabular}{|c|c|c|c|c|c|}
\hline $\begin{array}{l}\text { Constituent or property, } \\
\text { flow-adjusted units of } \\
\text { measurement }\end{array}$ & \multicolumn{4}{|c|}{ Fitted trend values } & $\begin{array}{l}\text { Percent change } \\
\text { from start of } \\
\text { water year } 1996 \\
\text { to end of water } \\
\text { year } 2010\end{array}$ \\
\hline \multicolumn{6}{|c|}{ Blackfoot River (site 21, fig. 1, table 1)-Continued } \\
\hline $\begin{array}{l}\text { Copper, unfiltered-recover- } \\
\text { able, } \mu \mathrm{g} / \mathrm{L}\end{array}$ & $\mathrm{NR}^{1}$ & $\mathrm{NR}^{1}$ & $\mathrm{NR}^{1}$ & $\mathrm{NR}^{1}$ & $\mathrm{NR}^{1}$ \\
\hline Zinc, filtered, $\mu \mathrm{g} / \mathrm{L}$ & $\mathrm{NR}^{1}$ & $\mathrm{NR}^{1}$ & $\mathrm{NR}^{1}$ & $\mathrm{NR}^{1}$ & $\mathrm{NR}^{1}$ \\
\hline $\begin{array}{l}\text { Zinc, unfiltered-recoverable, } \\
\mu \mathrm{g} / \mathrm{L}\end{array}$ & $\mathrm{NR}^{1}$ & $\mathrm{NR}^{1}$ & $\mathrm{NR}^{1}$ & $\mathrm{NR}^{1}$ & $\mathrm{NR}^{1}$ \\
\hline Arsenic, filtered, $\mu \mathrm{g} / \mathrm{L}$ & $\mathrm{NR}^{1}$ & $\mathrm{NR}^{1}$ & $\mathrm{NR}^{1}$ & $\mathrm{NR}^{1}$ & $\mathrm{NR}^{1}$ \\
\hline $\begin{array}{l}\text { Arsenic, unfiltered-recover- } \\
\quad \text { able, } \mu \mathrm{g} / \mathrm{L}\end{array}$ & $\mathrm{NR}^{1}$ & $\mathrm{NR}^{1}$ & $\mathrm{NR}^{1}$ & $\mathrm{NR}^{1}$ & $\mathrm{NR}^{1}$ \\
\hline
\end{tabular}

${ }^{1}$ Results not reported because greater than 6 percent of values were affected by recensoring at study reporting level, as discussed in the section of this report "Time-Series Model."

${ }^{2}$ Results not reported because of no or insufficient data for application of the time-series model (TSM) during indicated trend-analysis period.

Table 5. Summary of flow-adjusted trend results determined by using the time-series model (TSM) for Clark Fork above Missoula (site 22, fig. 1, table 1) for selected constituents, water years 1996-2010.

[Water year is the 12-month period from October 1 through September 30 and is designated by the year in which it ends. Bold values indicate statistically significant ( $p$-value less than 0.01 ) trend for trend period before the value presented in bold. $p$-value, statistical probability level; $\mu \mathrm{S} / \mathrm{cm}$, microsiemens per centimeter at 25 degrees Celsius; NR, not reported; $\mu \mathrm{g} / \mathrm{L}$, micrograms per liter; $\mathrm{mg} / \mathrm{L}$, milligrams per liter]

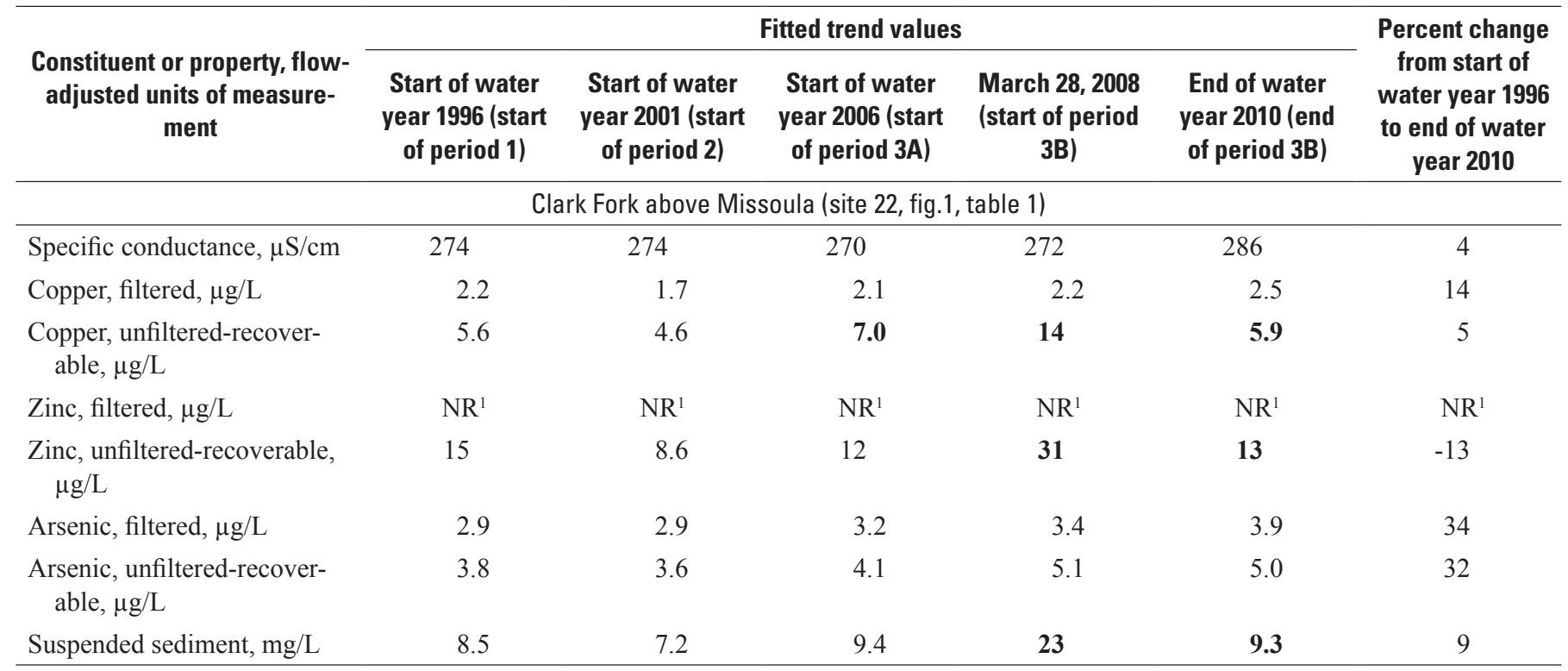

${ }^{1}$ Results not reported because greater than 6 percent of values were affected by recensoring at study reporting level, as discussed in the section of this report "Time-Series Model." 
Table 6. Summary of flow-adjusted trend results determined by using multiple linear regression on time, streamflow, and season (MLR) for selected sites and constituents, water years 2006-10.

[Water year is the 12-month period from October 1 through September 30 and is designated by the year in which it ends. Bold values indicate statistically significant ( $p$-value less than 0.01) trend for trend period 3. $p$-value, statistical probability level; $\mu \mathrm{S} / \mathrm{cm}$, microsiemens per centimeter at 25 degrees Celsius; $\mu \mathrm{g} / \mathrm{L}$, micrograms per liter; $\mathrm{mg} / \mathrm{L}$, milligrams per liter; NR, not reported]

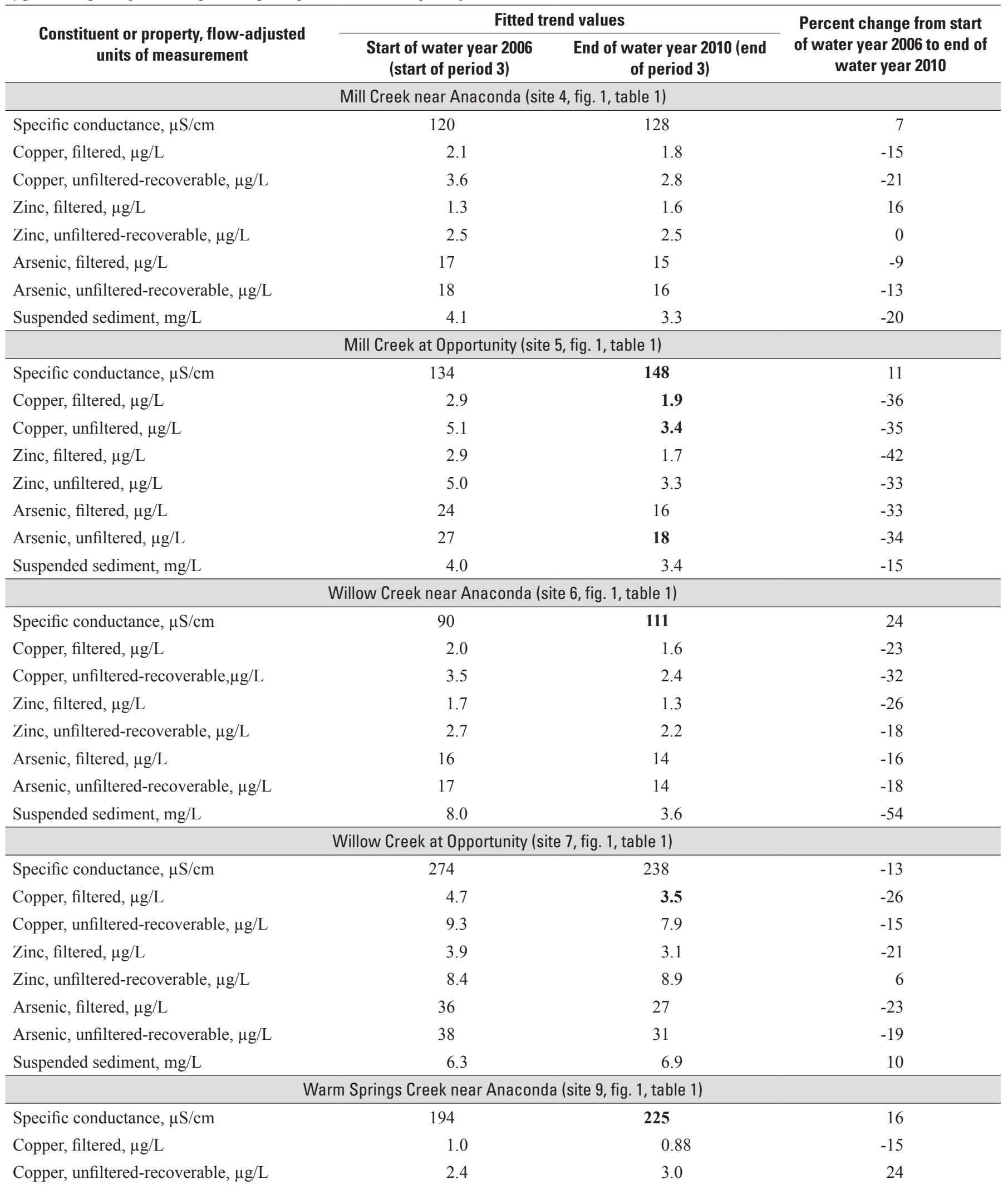


Table 6. Summary of flow-adjusted trend results determined by using multiple linear regression on time, streamflow, and season (MLR) for selected sites and constituents, water years 2006-10.-Continued

[Water year is the 12-month period from October 1 through September 30 and is designated by the year in which it ends. Bold values indicate statistically significant ( $p$-value less than 0.01 ) trend for trend period 3. $p$-value, statistical probability level; $\mu \mathrm{S} / \mathrm{cm}$, microsiemens per centimeter at 25 degrees Celsius; $\mu \mathrm{g} / \mathrm{L}$, micrograms per liter; $\mathrm{mg} / \mathrm{L}$, milligrams per liter; NR, not reported]

\begin{tabular}{|c|c|c|c|}
\hline \multirow{2}{*}{$\begin{array}{c}\text { Constituent or property, flow-adjusted } \\
\text { units of measurement }\end{array}$} & \multicolumn{2}{|c|}{ Fitted trend values } & \multirow{2}{*}{$\begin{array}{c}\text { Percent change from start } \\
\text { of water year } 2006 \text { to end of } \\
\text { water year } 2010\end{array}$} \\
\hline & $\begin{array}{l}\text { Start of water year } 2006 \\
\text { (start of period 3) }\end{array}$ & $\begin{array}{c}\text { End of water year } 2010 \text { (end } \\
\text { of period 3) }\end{array}$ & \\
\hline Zinc, filtered, $\mu \mathrm{g} / \mathrm{L}$ & $\mathrm{NR}^{1}$ & $\mathrm{NR}^{1}$ & $\mathrm{NR}^{1}$ \\
\hline Zinc, unfiltered-recoverable, $\mu \mathrm{g} / \mathrm{L}$ & 2.1 & 2.6 & 22 \\
\hline Suspended sediment, mg/L & 5.6 & 4.3 & -24 \\
\hline \multicolumn{4}{|c|}{ Lost Creek near Anaconda (site 12, fig. 1, table 1) } \\
\hline Specific conductance, $\mu \mathrm{S} / \mathrm{cm}$ & 200 & 192 & -4 \\
\hline Copper, filtered, $\mu \mathrm{g} / \mathrm{L}$ & 2.2 & 1.2 & -46 \\
\hline Arsenic, filtered, $\mu \mathrm{g} / \mathrm{L}$ & 4.9 & 2.4 & -51 \\
\hline Arsenic, unfiltered-recoverable, $\mu \mathrm{g} / \mathrm{L}$ & 5.4 & 3.1 & -44 \\
\hline Suspended sediment, mg/L & 7.4 & 3.3 & -56 \\
\hline \multicolumn{4}{|c|}{ Lost Creek near Galen (site 13, fig. 1, table 1) } \\
\hline Specific conductance, $\mu \mathrm{S} / \mathrm{cm}$ & 632 & 659 & 4 \\
\hline Copper, filtered, $\mu \mathrm{g} / \mathrm{L}$ & 2.3 & 1.1 & -52 \\
\hline Copper, unfiltered-recoverable, $\mu \mathrm{g} / \mathrm{L}$ & 5.1 & 2.6 & -49 \\
\hline Zinc, filtered, $\mu \mathrm{g} / \mathrm{L}$ & 1.3 & 1.5 & 13 \\
\hline Zinc, unfiltered-recoverable, $\mu \mathrm{g} / \mathrm{L}$ & 2.4 & 1.8 & -24 \\
\hline
\end{tabular}

${ }^{1}$ Results not reported because greater than 45 percent of values were censored (that is, concentrations reported as less than the laboratory reporting level).

in the main-stem stream between the reach inflow and the reach outflow. When the reach outflow is greater than the reach inflow, the within-reach change in load is positive and indicates net mobilization of the constituent from within-reach sources, including groundwater inflow, unmonitored tributaries, and the main-stem channel and floodplain. When the reach outflow is less than the reach inflow, the within-reach change in load is negative and indicates net accumulation of the constituent in the main-stem channel.

For the pie charts illustrating estimated normalized loads (hereinafter referred to as loads) in figure 6, the size (area) of each pie chart represents the total outflow from reach 1 , with colored areas indicating relative contributions from each of the two source areas [that is, (1) the reach 1 inflow and (2) the intervening drainage between the reach 1 inflow and outflow (or within-reach sources)]. For each constituent column on the right side of fig. 6 (that is, copper, arsenic, and suspended sediment), the size of the pie chart representing a given timeperiod load is sized proportionally to the largest load of all three time periods within the constituent group. For example, in the unfiltered-recoverable copper column, the largest load was 5.0 kilograms per day $(\mathrm{kg} / \mathrm{d})$ for period 1 ; thus, the size of the period 1 pie chart for unfiltered-recoverable copper is the largest and serves as the reference for scaling the other copper pie charts. The unfiltered-recoverable copper load for period 3 was $1.1 \mathrm{~kg} / \mathrm{d}$, which is 22 percent of the load for period 3 . Thus, the size of the period 3 pie chart for unfilteredrecoverable copper is 22 percent of the size of the period 1 pie chart for unfiltered-recoverable copper. Reach 1 is simple with respect to balance accounting because it consists only of 
Table 7. Drainage area and streamflow information relevant to the transport analysis for data-summary reaches in the upper Clark Fork Basin, Montana, water years 1996-2010.

[Water year is the 12-month period from October 1 through September 30 and is designated by the year in which it ends. $\mathrm{ft}^{3} / \mathrm{s}$, cubic feet per second]

\section{Site name and number or summation category}

Drainage area (square miles)
Geometric mean streamflow, water years 1996-2010

$\left(\mathrm{ft}^{3} / \mathbf{s}\right)$

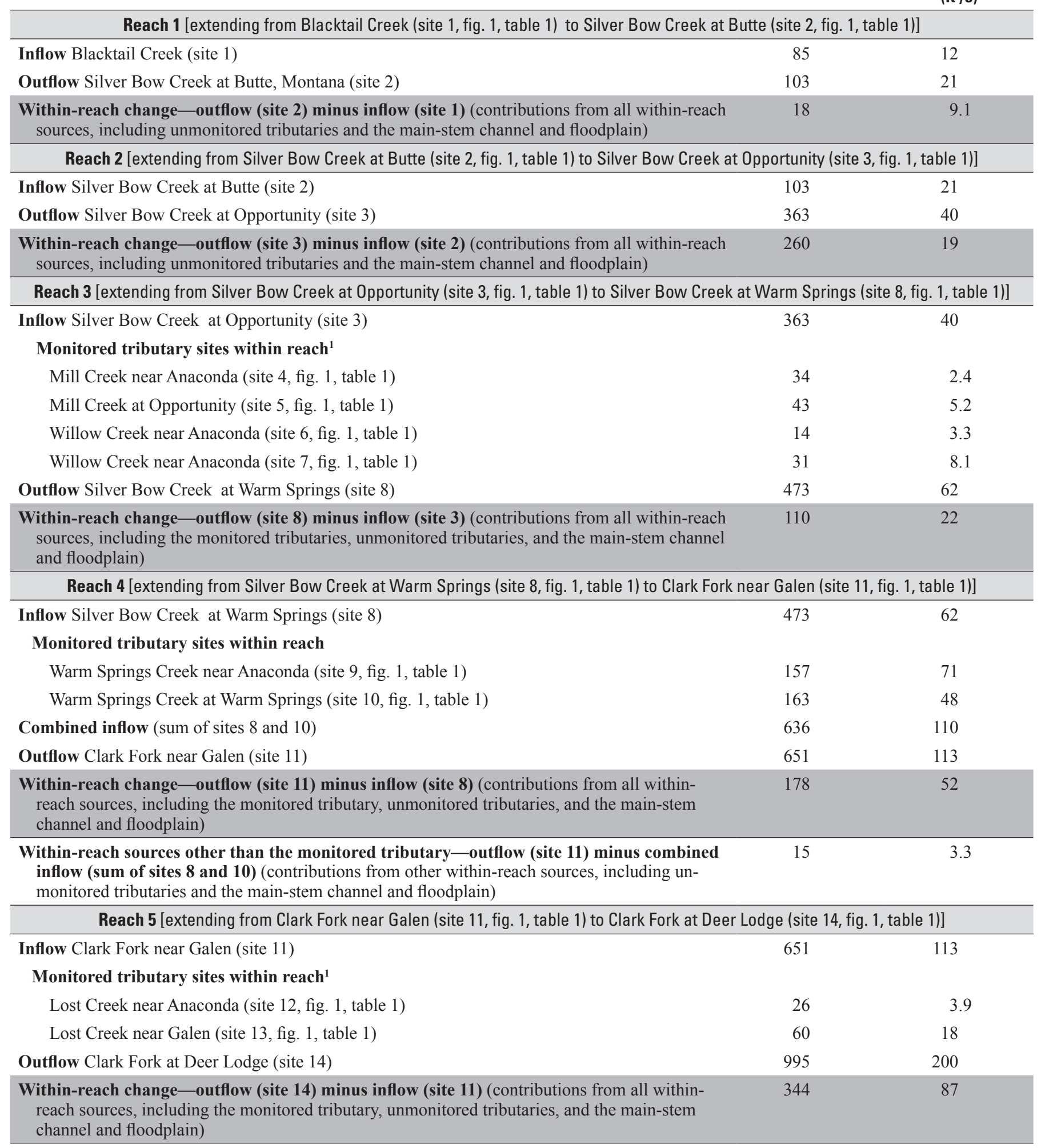


Table 7. Drainage area and streamflow information relevant to the transport analysis for data-summary reaches in the upper Clark Fork Basin, Montana, water years 1996-2010.-Continued

[Water year is the 12-month period from October 1 through September 30 and is designated by the year in which it ends. $\mathrm{ft}^{3} / \mathrm{s}$, cubic feet per second]

Site name and number or summation category

\section{(square miles) years 1996-2010}

$\left(\mathrm{ft}^{3} / \mathbf{s}\right)$

\begin{tabular}{|c|c|c|}
\hline \multicolumn{3}{|c|}{ Reach 6 [extending from Clark Fork at Deer Lodge (site 14, fig. 1, table 1) to Clark Fork at Goldcreek (site 16, fig. 1, table 1)] } \\
\hline Inflow Clark Fork at Deer Lodge (site 14) & 995 & 200 \\
\hline \multicolumn{3}{|l|}{ Monitored tributary site within reach } \\
\hline Combined inflow (sum of sites 14 and 15) & 1,402 & 296 \\
\hline Outflow Clark Fork at Goldcreek (site 16) & 1,704 & 394 \\
\hline $\begin{array}{l}\text { Within-reach change-outflow (site 16) minus inflow (site 14) (contributions from all within- } \\
\text { reach sources, including the monitored tributary, unmonitored tributaries, and the main-stem } \\
\text { channel and floodplain) }\end{array}$ & 709 & 194 \\
\hline $\begin{array}{l}\text { Within-reach sources other than the monitored tributary-outflow (site 16) minus combined } \\
\text { inflow (sum of sites } 14 \text { and 15) (contributions from other within-reach sources, including un- } \\
\text { monitored tributaries and the main-stem channel and floodplain) }\end{array}$ & 302 & 99 \\
\hline \multicolumn{3}{|c|}{ Reach 7 [extending from Clark Fork at Goldcreek (site 16, fig. 1, table 1) to Clark Fork near Drummond (site 18, fig. 1, table 1)] } \\
\hline Inflow Clark Fork at Goldcreek (site 16) & 1,704 & 394 \\
\hline $\begin{array}{l}\text { Within-reach change-outflow (site 18) minus inflow (site 16) (contributions from all within- } \\
\text { reach sources, including the monitored and unmonitored tributaries and the main-stem channel } \\
\text { and floodplain) }\end{array}$ & 797 & 182 \\
\hline $\begin{array}{l}\text { Within-reach sources other than the monitored tributary-outflow (site 18) minus combined } \\
\text { inflow (sum of sites } 16 \text { and 17) (contributions from other within-reach sources, including un- } \\
\text { monitored tributaries and the main-stem channel and floodplain) }\end{array}$ & 307 & 87 \\
\hline
\end{tabular}

Reach 8 [extending from Clark Fork near Drummond (site 18, fig. 1, table 1) to Clark Fork at Turah Bridge (site 20, fig. 1, table 1)]

Inflow Clark Fork near Drummond (site 18) $2,501 \quad 577$

Monitored tributary site within reach Rock Creek (site 19, fig. 1, table 1) 885

Combined inflow (sum of sites 18 and 19) $\quad 3,386 \quad 919$

$\begin{array}{lr}\text { Outflow Clark Fork at Turah Bridge (site 20) } & 3,641 \\ \end{array}$

Within-reach change_-outflow (site 20) minus inflow (site 18) (contributions from all within- $\quad 1,140 \quad 456$ reach sources, including the monitored and unmonitored tributaries and the main-stem channel and floodplain)

Within-reach sources other than the monitored tributary-outflow (site 20) minus combined 255 inflow (sum of sites 18 and 19) (contributions from other within-reach sources, including unmonitored tributaries and the main-stem channel and floodplain)

Reach 9 [extending from Clark Fork at Turah Bridge (site 20, fig. 1, table 1) to Clark Fork above Missoula (site 22, fig. 1, table 1)]

Inflow Clark Fork at Turah Bridge (site 20)

Monitored tributary site within reach Blackfoot River (site 21, fig. 1, table 1) $2,290 \quad 972$

Combined inflow (sum of sites 20 and 21) $\quad 5,931 \quad 2,000$

Outflow Clark Fork above Missoula (site 22) $\quad 5,999 \quad 2,030$

Within-reach change-outflow (site 22) minus inflow (site 20) (contributions from all within- $\quad 2,358 \quad 998$ reach sources, including the monitored and unmonitored tributaries and the main-stem channel and floodplain)

Within-reach sources other than the monitored tributary-outflow (site 22) minus combined inflow (sum of sites 20 and 21) (contributions from other within-reach sources, including unmonitored tributaries and the main-stem channel and floodplain)

${ }^{1}$ Trends for the monitored tributaries in reaches 3 and 5 were analyzed by using multiple linear regression on time, streamflow, and season (MLR). Trend results for the monitored tributaries were not included in the transport analysis because of factors that complicate directly combining the time-series model (TSM) results and MLR results within a single analysis. Thus, combined inflow calculations and the associated calculation of contributions from other within-reach sources are not presented for reaches 3 and 5. Drainage area and geometric mean streamflow for the monitored tributaries in reaches 3 and 5 are presented for informational purposes. 


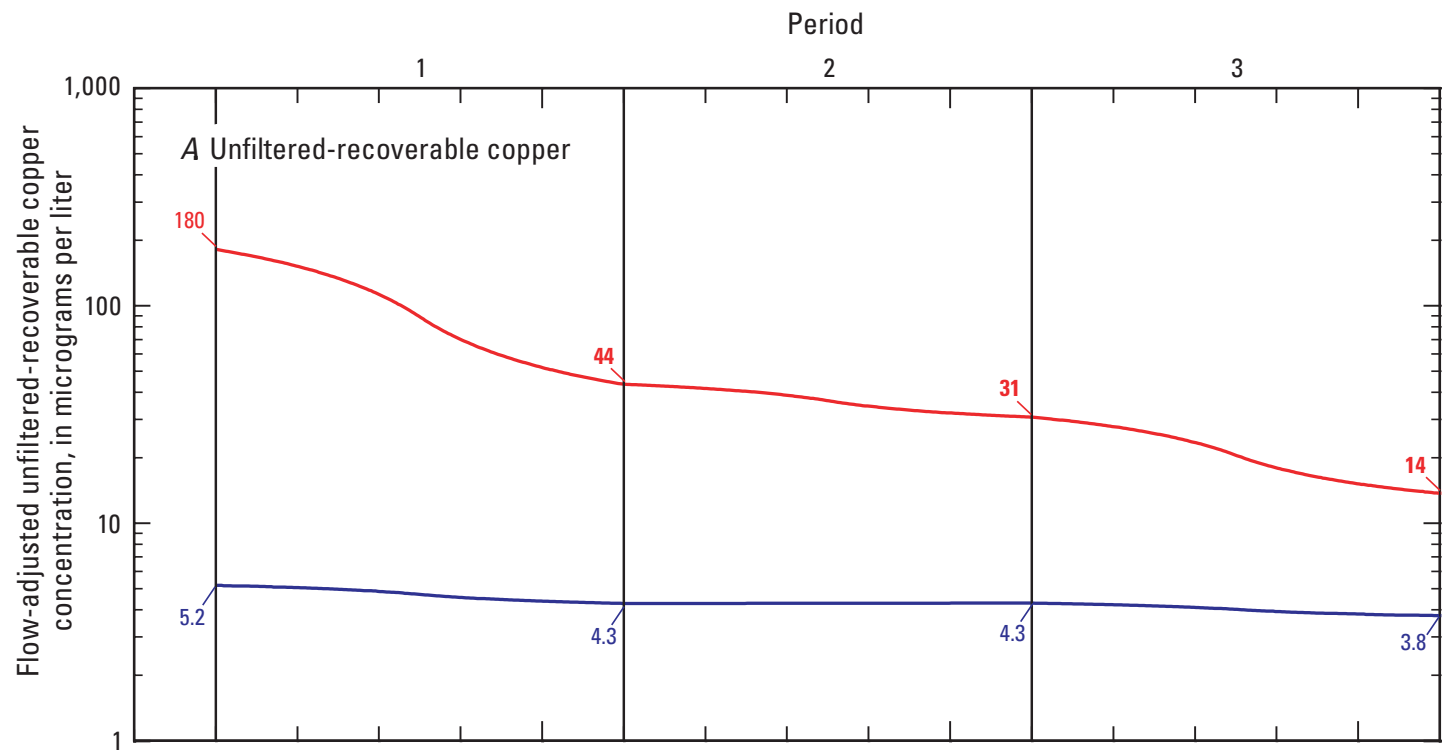

EXPLANATION

[Water year is defined as the 12-month period from October 1 through September 30 and is designated by the year in which it ends. $p$-value, statistical probability level]

Reach inflow-Blacktail Creek (site 1, fig. 1, table 1)

- Reach outflow-Silver Bow Creek at Butte (site 2, fig. 1, table 1)

3.8 Fitted trend value at start or end of period

31 Bold values indicate statistical significance ( $p$-value less than 0.01 ) for period before value presented in bold
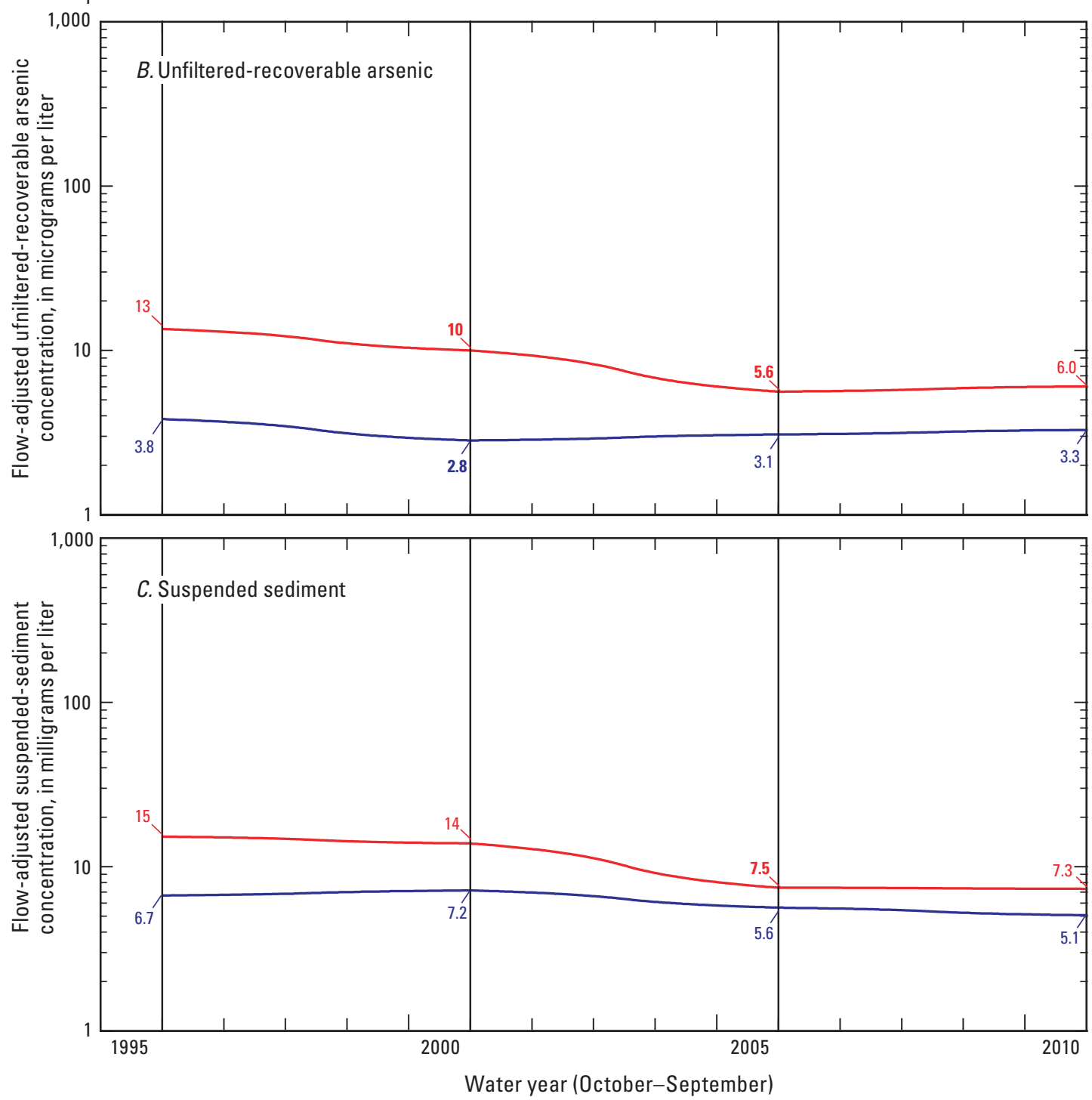

Figure 5. Flow-adjusted fitted trends determined by using the time-series model (TSM) for selected constituents for sites in reach 1, extending from Blacktail Creek (site 1, fig. 1, table 1) to Silver Bow Creek at Butte (site 2, fig. 1, table 1), water years $1996-2010$. 


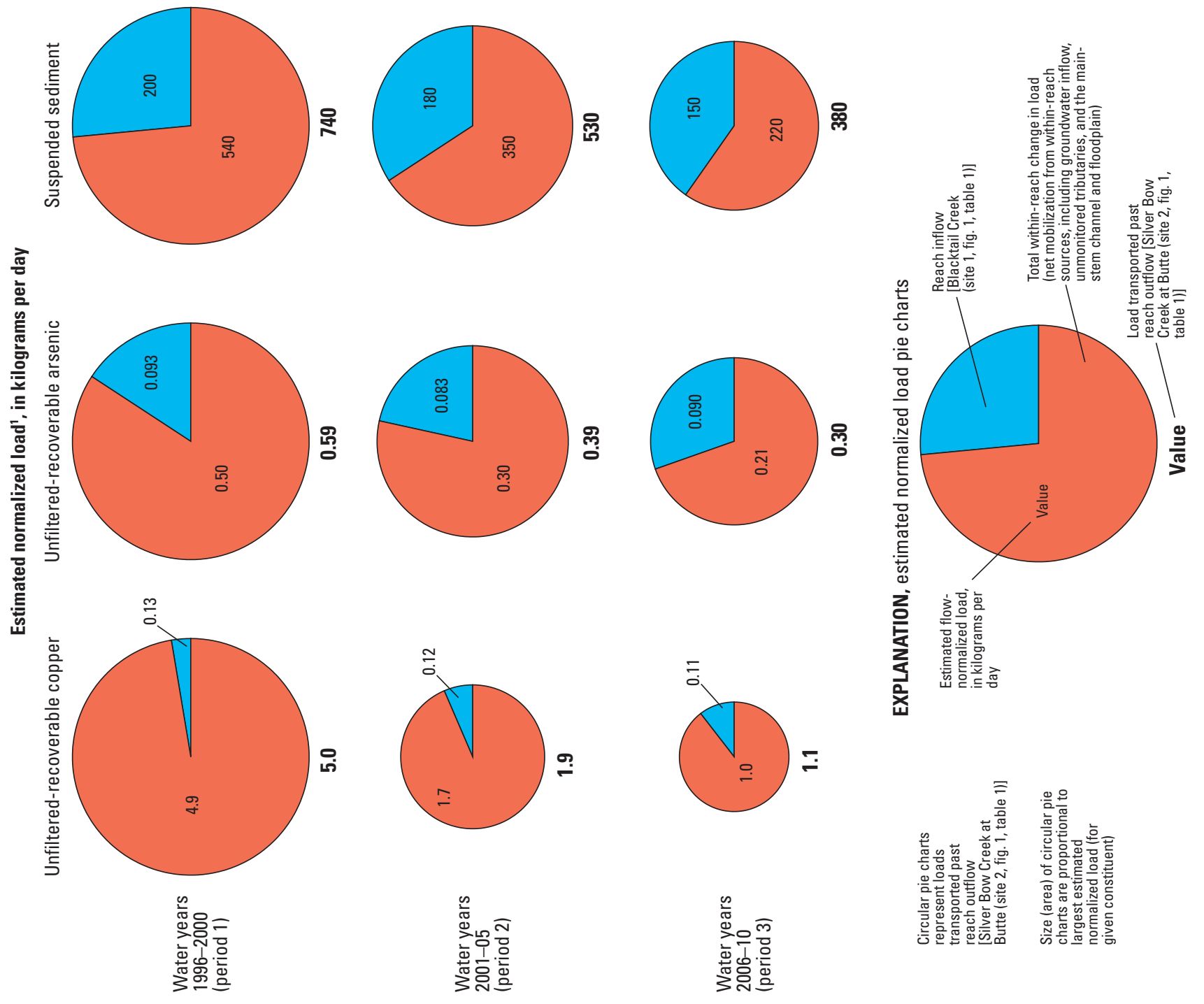

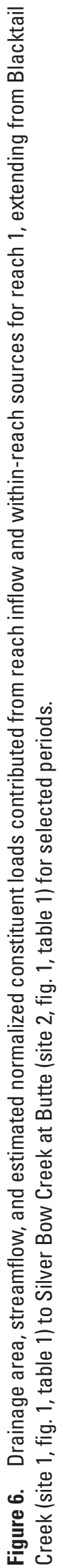
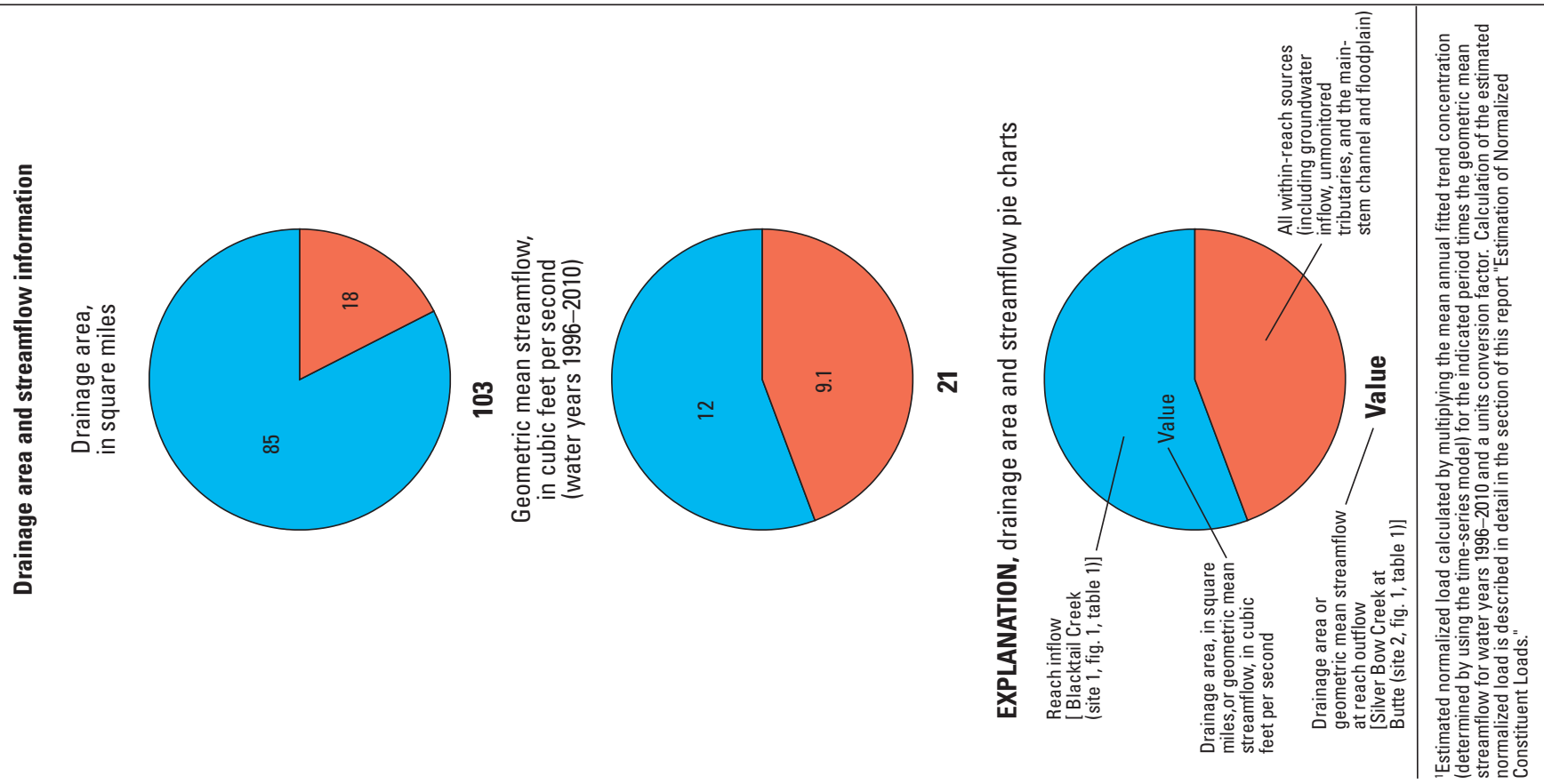
the reach inflow (site 1) and the reach outflow (site 2), with no monitored tributary inflows within the reach. Also, for all time periods and all constituents, reach 1 outflow loads are greater than reach 1 inflow loads, which indicates consistent net mobilization from within-reach sources. Other reaches are more complex than reach 1 . Some reaches have monitored tributary inflows within the reach. Also, for some reaches, the reach outflow load for some time periods is less than the combined reach inflow load (sum of reach inflow plus within-reach monitored tributary inflows), which indicates net accumulation within the reach channel. For reaches that are more complex than reach 1 , the formats of the pie charts illustrating estimated normalized loads are modified from figure 6 to represent the more complex characteristics. Modifications to the pie chart formats for reaches that are more complex than reach 1 are discussed on a case by case basis in following paragraphs.

In discussion of transport analysis results, observations are made comparing the relative proportions of within-reach contributions of constituent loads and within-reach contributions of streamflow. Those proportional comparisons indicate the importance of a given reach as a source of constituent loading to Silver Bow Creek or the Clark Fork. If the contribution of a constituent from within reach is proportionally larger than the contribution of streamflow from within reach, the given reach is indicated to be an important disproportionate source of constituent loading. Conversely, if the contribution of a constituent from within reach is proportionally smaller than the contribution of streamflow from within reach, the given reach is not indicated to be an important disproportionate source of constituent loading and acts either as an accumulation reach (sink) or flow-through reach.

Factors affecting temporal variability in water quality in the upper Clark Fork Basin are complex. Much information on observed changes in water quality is presented, but it is beyond the scope of this report to provide detailed explanations for all of the observed changes or to link specific trends with specific remediation activities. The primary focus is on describing flow-adjusted trends and patterns of constituent transport within each reach that will allow evaluation of temporal changes within the upper Clark Fork Basin as a whole.

\section{Reach 1}

Sites in reach 1 include the inflow [Blacktail Creek (site 1, fig. 1, table 1)], and the outflow [Silver Bow Creek at Butte (site 2, fig. 1, table 1)]. Trend results for both sites in reach 1 were determined by using the TSM and are presented in tables 4 and 4-1, figure 5, and also figures 4-1, and 4-2 for sites 1 and 2, respectively. Transport-analysis balance accounting for reach 1 (table 5-1) is simple and consists of calculation of the total within-reach change in load (outflow minus inflow). Transport analysis results for reach 1 are graphically presented in figure 6 .

Trend results for site 1 generally indicate minor changes in water quality during periods 1 through 3 (figs. 5 and $4-1$; tables 4 and 4-1). Decreases in arsenic, copper, and suspended sediment are within a small range at low concentrations. In contrast to site 1, trend results for site 2 indicate moderate to large decreases in FACs of metallic contaminants and suspended sediment (figs. 5 and 4-2; tables 4 and 4-1). The geometric mean FAC for unfiltered-recoverable copper for site 2 decreases by 92 percent from $180 \mu \mathrm{g} / \mathrm{L}$ at the start of period 1 to $14 \mu \mathrm{g} / \mathrm{L}$ at the end of period 3 (fig. 5 and table 4). Trend results for unfiltered-recoverable arsenic and suspended sediment for site 2 indicate moderate decreases of about 50 percent mostly during periods 1 and 2 (fig. 5, table 4).

Effects of moderate to large decreases in FACs of metallic contaminants, arsenic, and suspended sediment for site 2 are reflected in temporal changes in relative contributions from upstream source areas to reach 1 outflow loads (fig. 6, table 5-1). For unfiltered-recoverable copper, contributions (net mobilization) from within-reach sources decrease by about 80 percent from period $1(4.9 \mathrm{~kg} / \mathrm{d})$ to period 3 $(1.0 \mathrm{~kg} / \mathrm{d})$. For unfiltered-recoverable arsenic and suspended sediment, contributions from within-reach sources decrease by about 60 percent from period $1(0.50$ and $540 \mathrm{~kg} / \mathrm{d}$, respectively) to period $3(0.21$ and $220 \mathrm{~kg} / \mathrm{d}$, respectively). However, for all periods, contributions of metallic-contaminant, arsenic, and suspended-sediment loads from within-reach sources are proportionally much larger than streamflow contributed from within reach 1 , which indicates that reach 1 is a disproportionate source of constituent loading. For example, based on geometric mean streamflow for water years 1996-2010, the within-reach increase in streamflow $\left(9.1 \mathrm{ft}^{3} / \mathrm{s}\right.$, table 7$)$ accounts for about 43 percent of the streamflow at the reach 1 outflow $\left(21 \mathrm{ft}^{3} / \mathrm{s}\right.$, table 7). In contrast, even though FACs of metallic contaminants have declined sharply, in period 3 the withinreach increase in unfiltered-recoverable copper load $(1.0 \mathrm{~kg} / \mathrm{d}$, table 5-1) accounts for about 91 percent of the copper load at the reach 1 outflow $(1.1 \mathrm{~kg} / \mathrm{d}$, table $5-1)$.

\section{Reach 2}

Sites in reach 2 include the inflow [Silver Bow Creek at Butte (site 2, fig. 1, table 1)] and the outflow [Silver Bow Creek at Opportunity (site 3, fig. 1, table 1)]. Trend results for both sites in reach 2 were determined by using the TSM and are presented in tables 4 and 4-1, figure 7, and also figures 4-2, and 4-3 for sites 2 and 3, respectively. Transport-analysis balance accounting for reach 2 (table 5-2) is simple and consists of calculation of the total within-reach change in load (outflow minus inflow). Transport analysis results for reach 2 are graphically presented in figure 8 .

Similar to site 2, trend results for site 3 indicate moderate to large decreases in FACs of metallic contaminants and arsenic (figs. 7 and 4-3; tables 4 and 4-1); however, decreases are smaller for site 3 than for site 2 . The geometric mean FAC for unfiltered-recoverable copper for site 3 decreases by 66 percent from $130 \mu \mathrm{g} / \mathrm{L}$ at the start of period 1 to $44 \mu \mathrm{g} / \mathrm{L}$ at the end of period 3 . The geometric mean FAC for unfiltered-recoverable arsenic for site 3 decreases by 45 percent from $16 \mu \mathrm{g} / \mathrm{L}$ at the start of period 1 to $8.8 \mu \mathrm{g} / \mathrm{L}$ at the end 

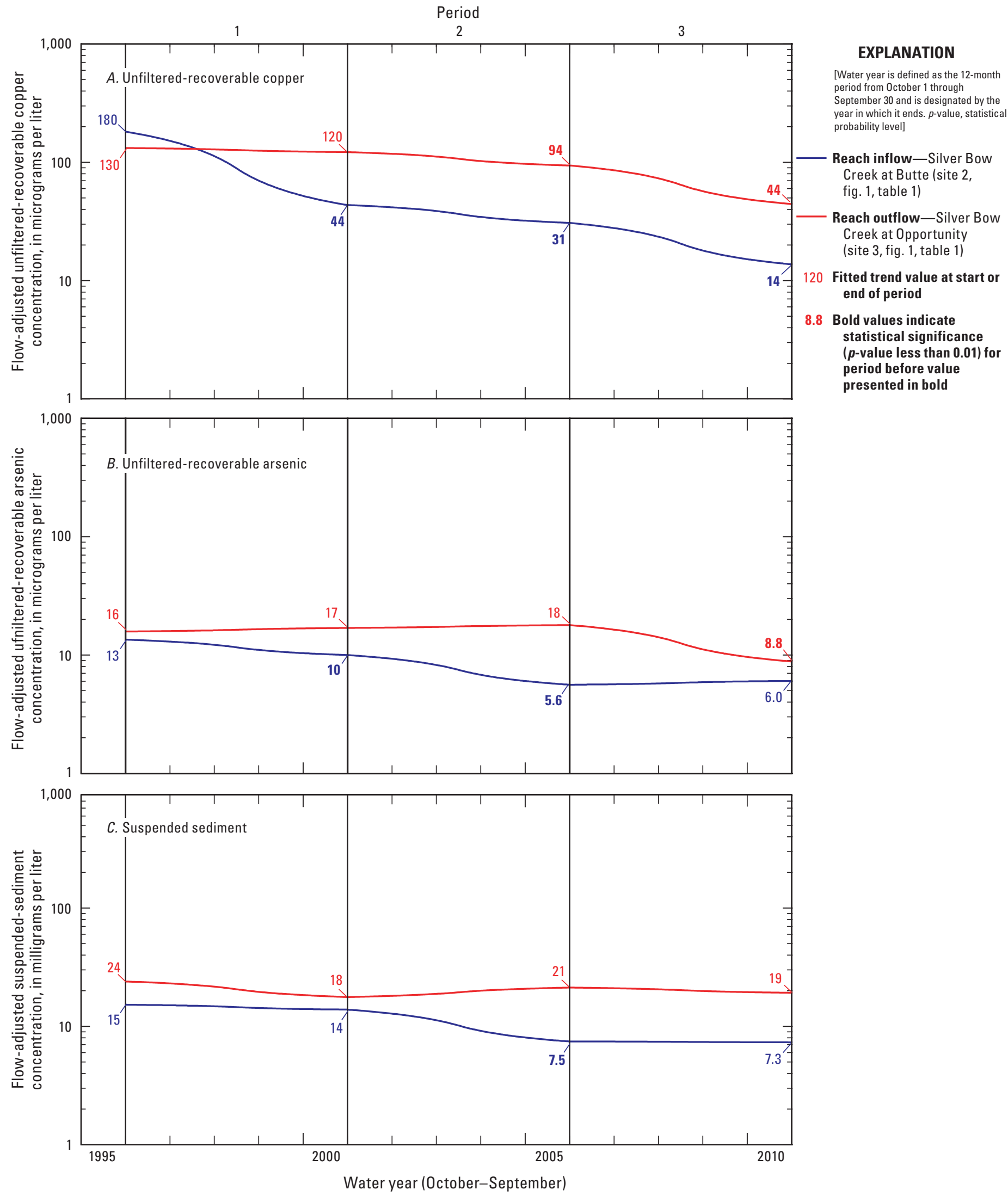

Figure 7. Flow-adjusted fitted trends determined by using the time-series model (TSM) for selected constituents for sites in reach 2, extending from Silver Bow Creek at Butte (site 2, fig. 1, table 1) to Silver Bow Creek at Opportunity, (site 3, fig. 1, table 1), water years 1996-2010. 

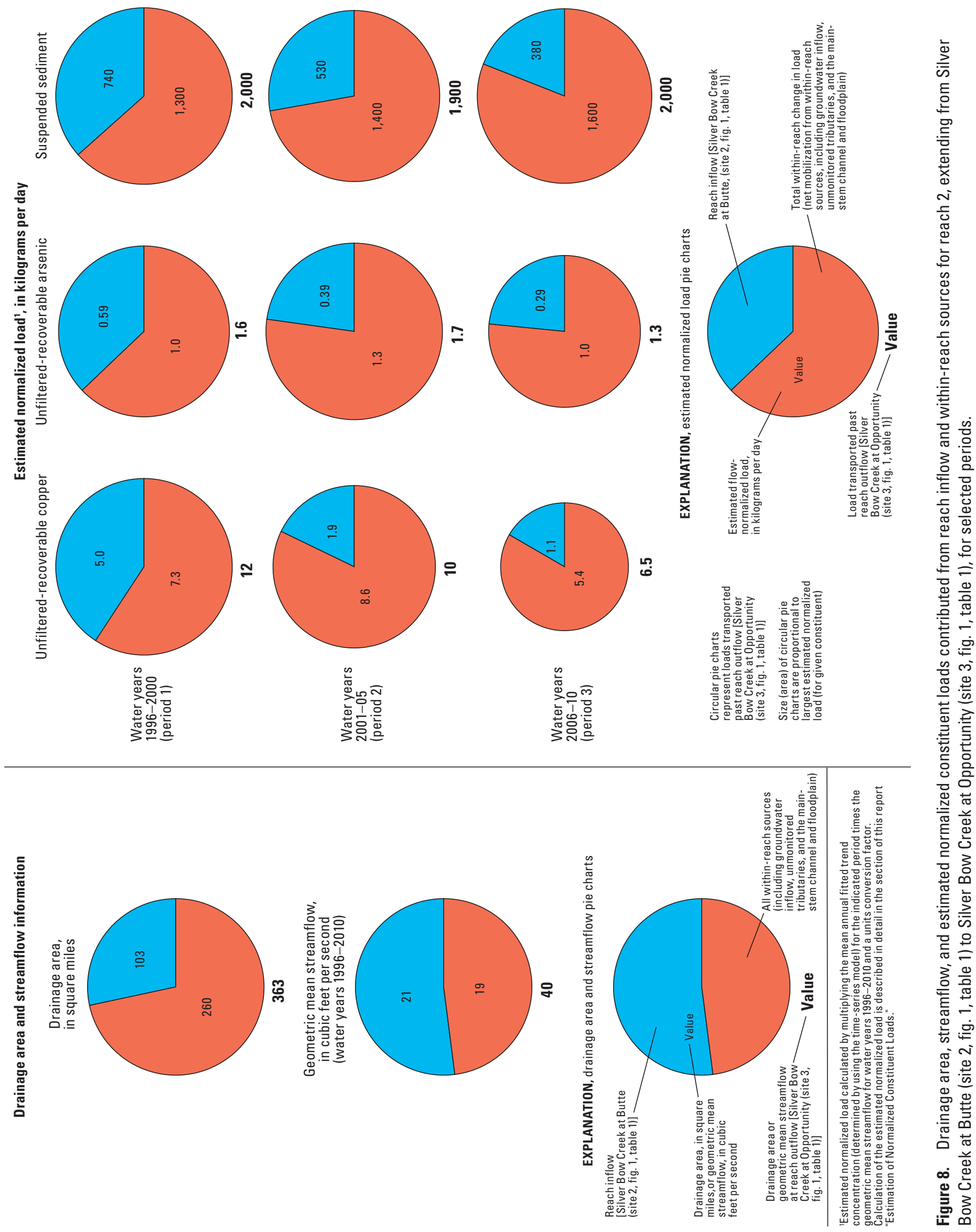
of period 3. Smaller decreases in FACs of metallic contaminant and arsenic for site 3 than for site 2 might reflect more intensive remediation efforts upstream from site 2 than in the reach between site 2 and site 3 . In contrast to site 2 , decreases in FACs of metallic contaminants and arsenic for site 3 were mostly during period 3. Also, a small decrease in FAC of suspended sediment is indicated for site 3 , whereas a moderate decrease is indicated for site 2 . The inconsistency between the large decrease in copper but the small decrease in suspended sediment for site 3 is difficult to interpret. A possible explanation for this pattern might relate to floodplain disturbance and placement of uncontaminated fill in the floodplain associated with remediation activities. As particulate materials derived from mining wastes are removed and transported from the reach through time, less-contaminated particulate materials might be proportionally increasing in suspended-sediment concentrations. The moderate decrease in suspended sediment for site 2 also might contribute to the capacity for the stream to transport the less-contaminated materials from reach 2. Because trend results for site 3 affect interpretation of trend results for Silver Bow Creek at Warm Springs (site 8), several TSM and MLR trend models for copper and suspended sediment were investigated, and all trend models produced similar results of large decreases in copper and minor to small changes in suspended sediment during water years 1996-2010. Further, the 95-percent confidence intervals about the trend magnitudes for unfiltered-recoverable copper and suspended sediment for period 3 (which had the largest decrease in copper) were examined and indicated no overlap. Thus, the TSM results for copper and suspended sediment for site 3 are considered to reasonably represent general trend patterns and there is strong indication that metallic contaminant FACs substantially decreased during water years 1996-2010 in the absence of substantial trending in suspended sediment.

Results of the transport analysis indicate how temporal changes in geometric mean FACs for sites 2 and 3 translate into temporal changes in relative contributions from upstream source areas to the reach 2 outflow loads (fig. 8, table 5-2). For unfiltered-recoverable copper, reach 2 outflow load decreases by about 50 percent from period $1(12 \mathrm{~kg} / \mathrm{d})$ to period $3(6.5 \mathrm{~kg} / \mathrm{d})$. Contributions (net mobilization) from sources within reach 2 decrease by about 25 percent from period $1(7.3 \mathrm{~kg} / \mathrm{d})$ to period $3(5.4 \mathrm{~kg} / \mathrm{d})$. However, because of a larger decrease in copper load for site 2 than for site 3 , contributions of copper from sources within reach 2 proportionally increase in relative contribution to the reach outflow between period 1 and period 3. Thus, most of the decrease in copper load at the reach 2 outflow is because of a decrease in load at site 2. For unfiltered-recoverable arsenic, there is a minor decrease in the reach 2 outflow load of about 20 percent from period $1(1.6 \mathrm{~kg} / \mathrm{d})$ to period $3(1.3 \mathrm{~kg} / \mathrm{d})$. Contributions from sources within reach 2 are near constant. For suspended sediment, there is no change in the reach 2 outflow load from period 1 to period 3, with both values equal to $2,000 \mathrm{~kg} / \mathrm{d}$. Contributions from sources within reach 2 increase by about 23 percent from period $1(1,300 \mathrm{~kg} / \mathrm{d})$ to period $3(1,600 \mathrm{~kg} / \mathrm{d})$.
For all periods, contributions of metallic-contaminant, arsenic, and suspended-sediment loads from within-reach sources are proportionally larger than streamflow contributed from within reach 2 , which indicates that reach 2 is a disproportionate source of constituent loading.

\section{Reach 3}

Sites in reach 3 include the inflow [Silver Bow Creek at Opportunity (site 3)], monitored tributary sites [Mill Creek near Anaconda (site 4), Mill Creek at Opportunity (site 5), Willow Creek near Anaconda (site 6), and Willow Creek at Opportunity (site 7)], and the outflow [Silver Bow Creek at Warm Springs (site 8)]. Trend results for the reach inflow and outflow sites (sites 3 and 8 ) were determined by using the TSM and are presented in tables 4 and 4-1, figure 9, and also in figures $4-3$, and $4-8$ for sites 3 and 8 , respectively. Trend results for monitored tributary sites [sites on Mill Creek (site 4 and site 5) and Willow Creek (site 6 and site 7), which had short periods of data collection] were determined by using MLR. Transport analysis results for reach 3 are graphically presented in figure 10 .

Detailed trend results for the monitored tributary sites on Mill Creek and Willow Creek are presented in table 4-3 and figures 4-4 through 4-7 for sites 4 through 7, respectively. Trend results are summarized in table 6 . Trend results for the downstream site on Mill Creek (site 5) and the downstream site on Willow Creek (site 7) also are shown in figure 9, in reference to trend results for the main-stem Silver Bow Creek inflow and outflow sites that bound the reach (site 3 and site 8). Because MLR and the TSM use different flow-adjustment procedures, caution should be used in directly comparing results of the two methods in terms of the estimated fitted trend values presented in figure 9. Magnitudes and directions of trends probably are reasonably comparable between the two methods within the short time frame of period 3. Trend results for both Mill Creek sites (sites 4 and 5) indicate decreases in geometric mean FACs of copper, arsenic, and suspended sediment for period 3 (figs. 4-4 and 4-5, tables 5 and 4-3). Decreases generally are minor for site 4, but small for site 5 . For example, unfiltered-recoverable copper results for period 3 for site 4 indicate a minor decrease of 21 percent (from 3.6 to $2.8 \mu \mathrm{g} / \mathrm{L}$ ) and for site 5 a small decrease of 35 percent (from 5.1 to $3.4 \mu \mathrm{g} / \mathrm{L}$; table 6). Unfiltered-recoverable arsenic results for period 3 for site 4 indicate a minor decrease of 13 percent (from 18 to $16 \mu \mathrm{g} / \mathrm{L}$ ) and for site 5 a small decrease of 34 percent (from 27 to $18 \mu \mathrm{g} / \mathrm{L}$; table 6). Trend results for both Willow Creek sites (site 6 and site 7) indicate minor to small decreases in FACs of copper and arsenic (figs. 4-6 and 4-7, tables 5 and 4-3) that generally were near or within the ranges of those for the Mill Creek sites.

Trend results for the reach 3 outflow [Silver Bow Creek at Warm Springs (site 8)] indicate large decreases in geometric mean FACs of metallic contaminants (figs. 9 and 4-8; tables 4 and 4-1) that are similar in magnitude to decreases in FACs for the reach 3 inflow [Silver Bow Creek at Opportunity (site 3)]. 
Unfiltered-recoverable copper for site 8 decreases by 61 percent from $18 \mu \mathrm{g} / \mathrm{L}$ at the start of period 1 to $7.0 \mu \mathrm{g} / \mathrm{L}$ at the end of period 3. Trend results for site 8 differ from results for site 3 with respect to arsenic and suspended sediment. Trend results for unfiltered-recoverable arsenic for site 8 indicate a minor increase of 15 percent from $20 \mu \mathrm{g} / \mathrm{L}$ at the start of period 1 to $23 \mu \mathrm{g} / \mathrm{L}$ at the end of period 3; whereas trend results for site 3 indicate a moderate decrease of 45 percent. Trend results for suspended sediment for site 8 indicate a large decrease of 65 percent from $5.4 \mathrm{mg} / \mathrm{L}$ at the start of period 1 to $1.9 \mathrm{mg} / \mathrm{L}$ at the end of period 3, with the largest decrease during period 3; whereas trend results for site 3 indicate a small decrease. These differences in trend results between site 8 and site 3 illustrate effects of particulate deposition and complex geochemical processes in the Warm Springs Ponds, coupled with mixing of tributary contributions from the Mill-Willow bypass.

The transport analysis for reach 3 is complicated by several factors including effects of Warm Springs Ponds on constituent transport and the inability to distinguish between the within-reach contributions from Warm Springs Ponds and the Mill-Willow bypass. Data for the monitored tributary sites on Mill Creek and Willow Creek were not included in transport analysis because of factors that complicate directly combining the TSM and MLR results within a single analysis. The combined unquantified contributions from Mill Creek and Willow Creek in the Mill-Willow bypass are part of the total undifferentiated contributions from within-reach sources.

Because of the complexity of reach 3 , the transport-analysis pie charts were modified to accommodate the characteristics of reach 3 (fig. 10). Most particulate material transported in Silver Bow Creek from site 3 is presumed to be deposited in Warm Springs Ponds. Thus, for suspended sediment and metallic elements, which entirely or predominantly are transported in particulate phase, the load at the reach 3 outflow (site 8) typically is less than the load at the reach 3 inflow (site 3). This consistently results in negative within-reach change in load and indicates net accumulation of sediment and metallic elements in Warm Springs Ponds. In figure 10, squares are used to represent net accumulation of copper and suspended sediment in Warm Springs Ponds. The squares represent the reach inflow load (site 3), all of which is presumed to be deposited in Warm Springs Ponds. Presumption that all of the reach inflow load (site 3) is deposited in Warm Springs Ponds results in the reach outflow load (site 8) entirely consisting of undifferentiated contributions (net mobilization) from within-reach sources including groundwater inflow, the Mill-Willow bypass, the Warm Springs Ponds outflow, and the main-stem channel and floodplain downstream from Warm Springs Ponds. Intuitively [and also based on similarities in statistical distributions of copper and suspended-sediment concentrations among sites 5, 7, and 8 (fig. 2)], contributions from the Mill-Willow bypass probably account for a large part of the reach 3 outflow loads of unfiltered-recoverable copper and suspended sediment at site 8 .
In contrast to copper, arsenic in the upper Clark Fork Basin typically is in dissolved phase (fig. 2, table 1-4) and a smaller fraction of the unfiltered-recoverable arsenic load is deposited in Warm Spring Ponds. As a result, the load at the reach 3 outflow (site 8) typically is greater than the load at the reach 3 inflow (site 3 ), indicating positive within-reach change in load and net mobilization from within-reach sources. Thus, pie charts for unfiltered-recoverable arsenic in figure 10 are similar in format to those of figures 6 and 8 .

For unfiltered-recoverable copper, reach 3 outflow load decreases by about 40 percent from period $1(2.0 \mathrm{~kg} / \mathrm{d})$ to period $3(1.1 \mathrm{~kg} / \mathrm{d}$; fig. 10, table 5-3). The estimated copper load deposited in Warm Springs Ponds decreases by about 45 percent from period $1(12 \mathrm{~kg} / \mathrm{d})$ to period $3(6.5 \mathrm{~kg} / \mathrm{d})$. For unfiltered-recoverable arsenic, a minor increase (from 3.1 to $3.4 \mathrm{~kg} / \mathrm{d}$ ) in reach 3 outflow load is indicated during periods 1 through 3 , but contributions (net mobilization) from within-reach sources increase by about 30 percent from period $1(1.6 \mathrm{~kg} / \mathrm{d})$ to period $3(2.1 \mathrm{~kg} / \mathrm{d})$. For suspended sediment, reach 3 outflow loads decrease by about 50 percent from period $1(850 \mathrm{~kg} / \mathrm{d})$ to period $3(430 \mathrm{~kg} / \mathrm{d})$. The estimated suspended-sediment load deposited in Warm Springs Ponds has no change from period 1 to period 3 , with both values equal to $2,000 \mathrm{~kg} / \mathrm{d}$.

\section{Reach 4}

Sites in reach 4 include the inflow [Silver Bow Creek at Warm Springs (site 8)], monitored tributary sites [Warm Springs near Anaconda (site 9) and Warm Springs Creek at Warm Springs (site 10)], and the outflow [Clark Fork near Galen (site 11)]. Trend results for the reach inflow and outflow sites (sites 8 and 11) and the downstream site on Warm Springs Creek (site 10) were determined by using the TSM and are presented in tables 4 and 4-1, figure 11, and figures $4-8,4-11$, and $4-10$, for sites 8,11 , and 10 , respectively. Trend results for the upstream site on Warm Springs Creek [site 9, which had a short period of data collection] were determined by using MLR and are presented in tables 5 and 4-3, and figure 4-9. Transport analysis results for reach 4 are graphically presented in figure 12 .

The MLR trend results for the upstream site on Warm Springs Creek (site 9) indicate minor to small increases in geometric mean FACs of unfiltered-recoverable copper and arsenic, and a small decrease in geometric mean FAC of suspended sediment for period 3 (fig. 4-9, tables 5 and 4-3). The TSM trend results for the downstream site on Warm Springs Creek (site 10) indicate small to moderate decreases in geometric mean FACs of unfiltered-recoverable copper and suspended sediment for period 1 , but small to large increases for period 3 (figs. 11 and 4-10; tables 4 and 4-1). The large increase in geometric mean FAC of suspended sediment from 3.1 to $7.7 \mathrm{mg} / \mathrm{L}$ for site 10 for period 3 is notable. Several TSM and MLR trend models for suspended sediment for site 10 were investigated, and all trend models produced similar results of large increases in suspended sediment FAC during 


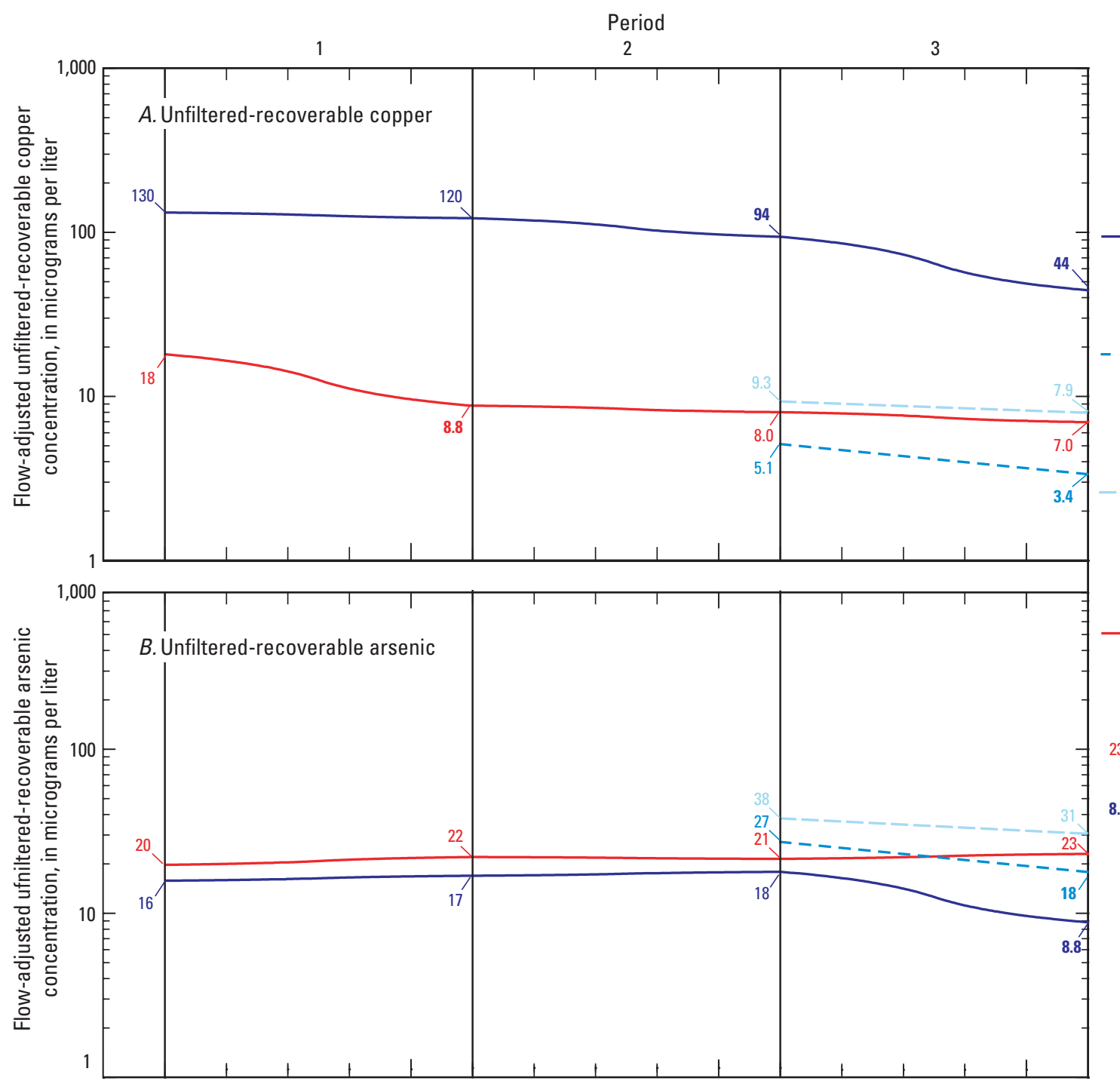

\section{EXPLANATION}

[Water year is defined as the 12-month period from October 1 through

September 30 and is designated by the year in which it ends. $p$-value, statistical probability level]

- Reach inflow-Silver Bow Creek at Opportunity (site 3,

fig. 1, table 1). Fitted trend determined by using the time-series mode

- - Monitored tributary inflow-Mill Creek at Opportunity (site 5, fig. 1, table 1). Fitted trend determined by using multiple linear regression

Monitored tributary inflow-Willow Creek at Opportunity (site 7, fig. 1, table 1). Fitted trend determined by using multiple linear regression

- Reach outflow-Silver Bow Creek at Warm Springs (site 8 , fig. 1, table 1). Fitted trend determined by using the time-series model.

23 Fitted trend value at start or end of period

8.8 Bold values indicate statistical significance ( $p$-value less than 0.01 ) for period before value presented in bold

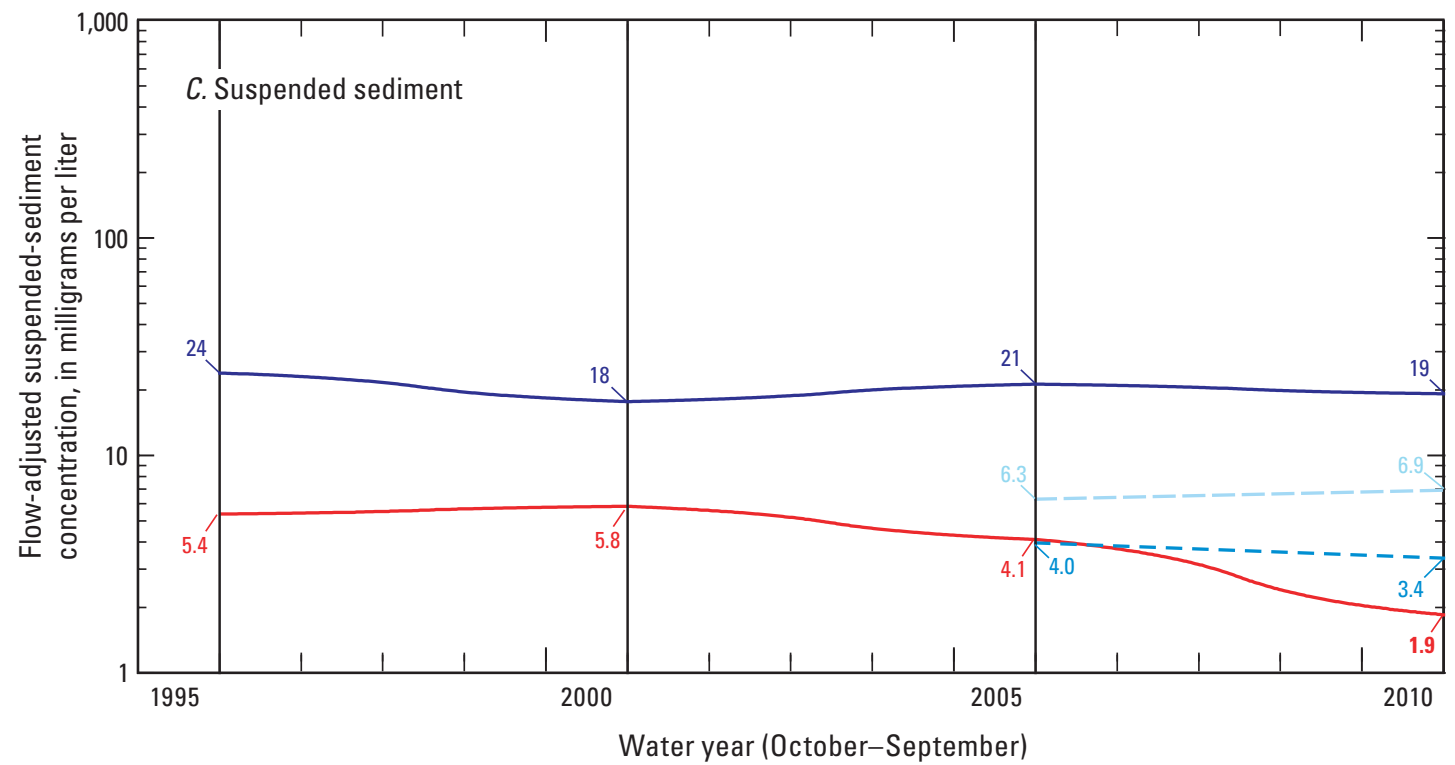

Figure 9. Flow-adjusted fitted trends determined by using the time-series model (TSM) for selected constituents for sites in reach 3 , extending from Silver Bow Creek at Opportunity (site 3, fig. 1, table 1) to Silver Bow Creek at Warm Springs, (site 8, fig. 1, table 1), water years 1996-2010. 

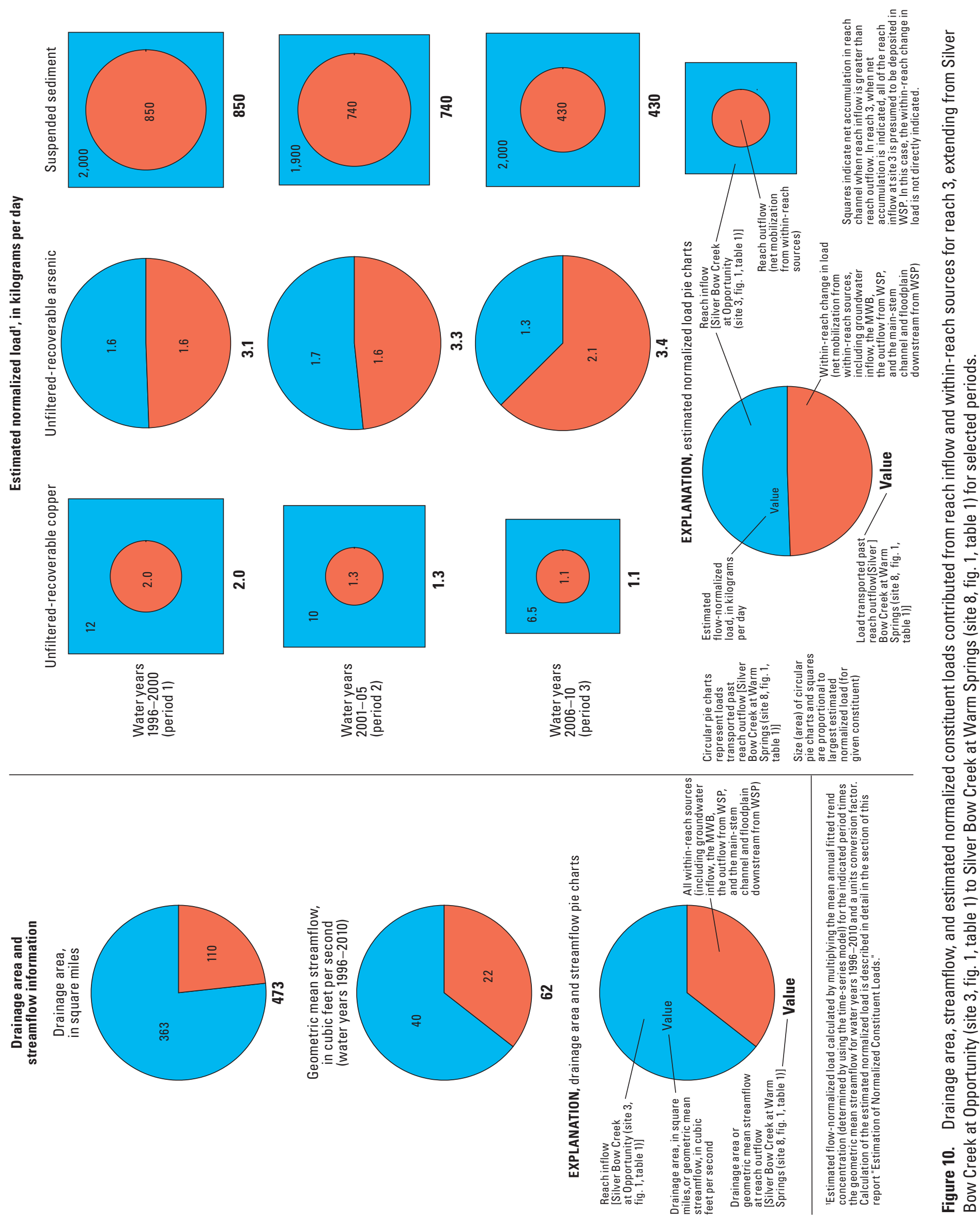

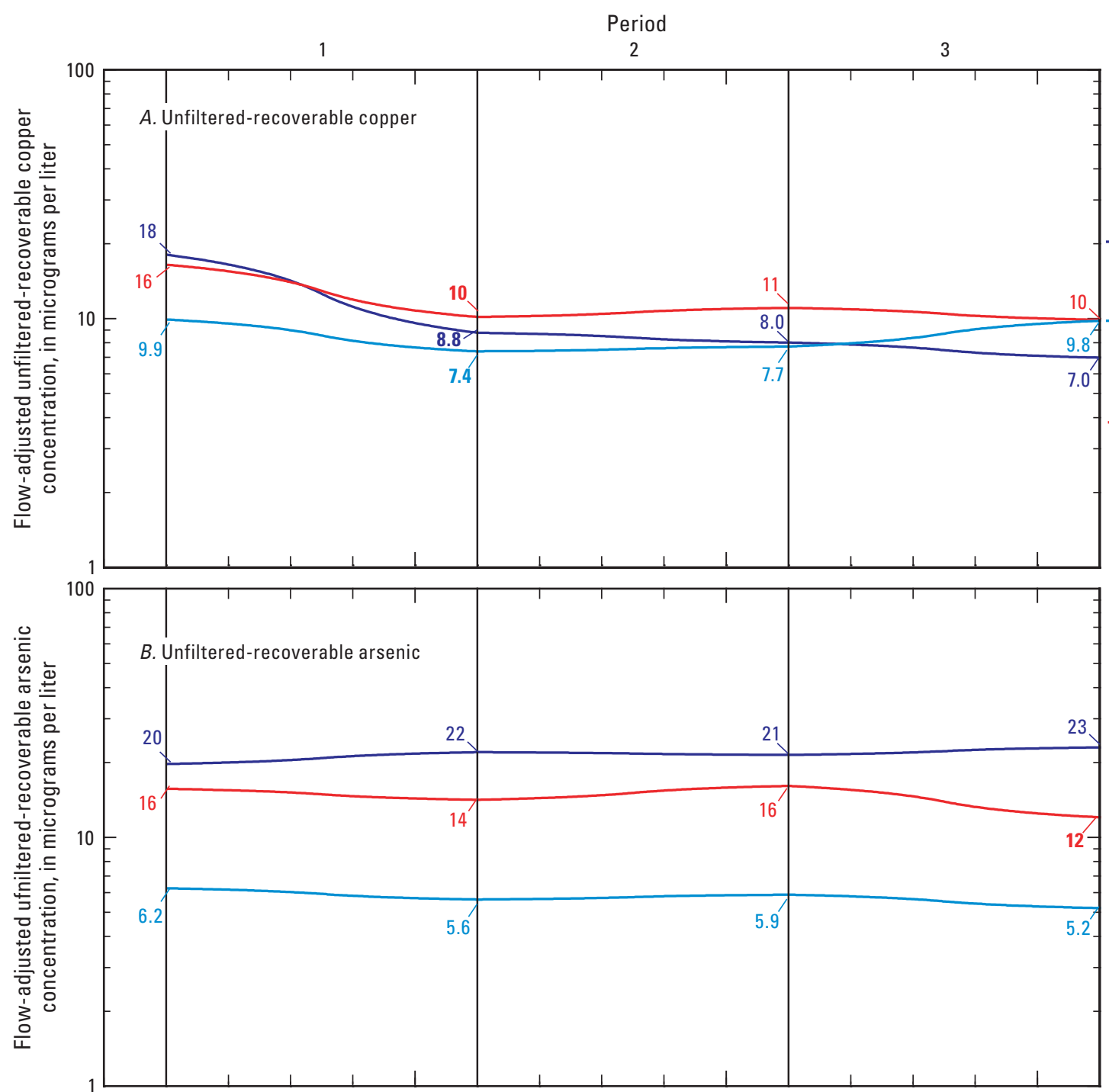

EXPLANATION

Water year is defined as the 12-month period from 0ctober 1 through

September 30 and is designated by the

year in which it ends. $p$-value, statistical probability level]

Reach inflow-Silver Bow

Creek at Warm Springs (site 8, fig. 1, table 1)

\section{Monitored tributary}

inflow-Warm Springs

Creek at Warm Springs

(site 10, fig. 1, table 1)

- Reach outflow-Reach outflow Clark Fork near Galen (site 11, fig. 1, table 1)

16 Fitted trend value at start or end of period

8.8 Bold values indicate statistical significance ( $p$-value less than 0.01 ) for period before value presented in bold

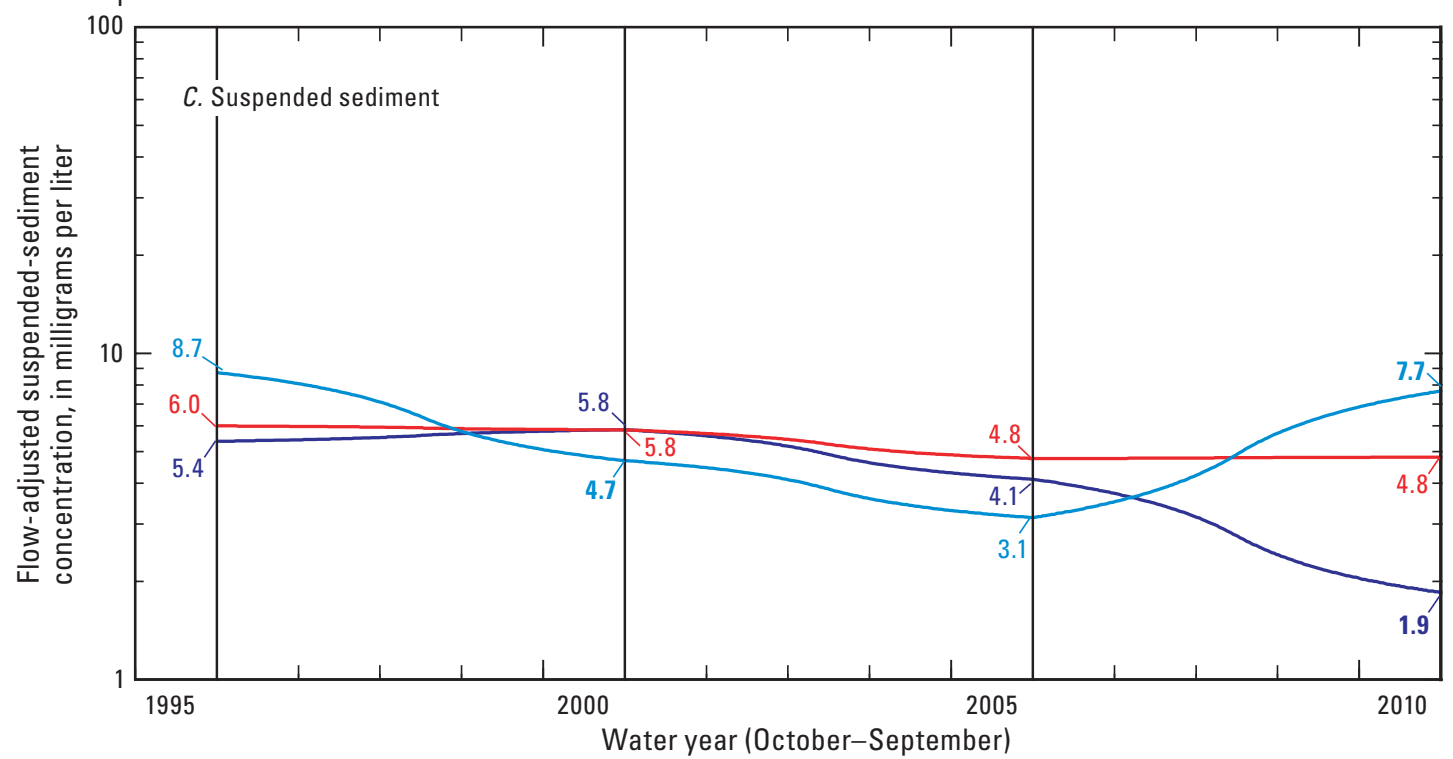

Figure 11. Flow-adjusted fitted trends determined by using the time-series model (TSM) for selected constituents for sites in reach 4 , extending from Silver Bow Creek at Warm Springs (site 8, fig. 1, table 1) to Clark Fork near Galen (site 11, fig. 1, table 1), based on data collected during water years 1985-2010. 


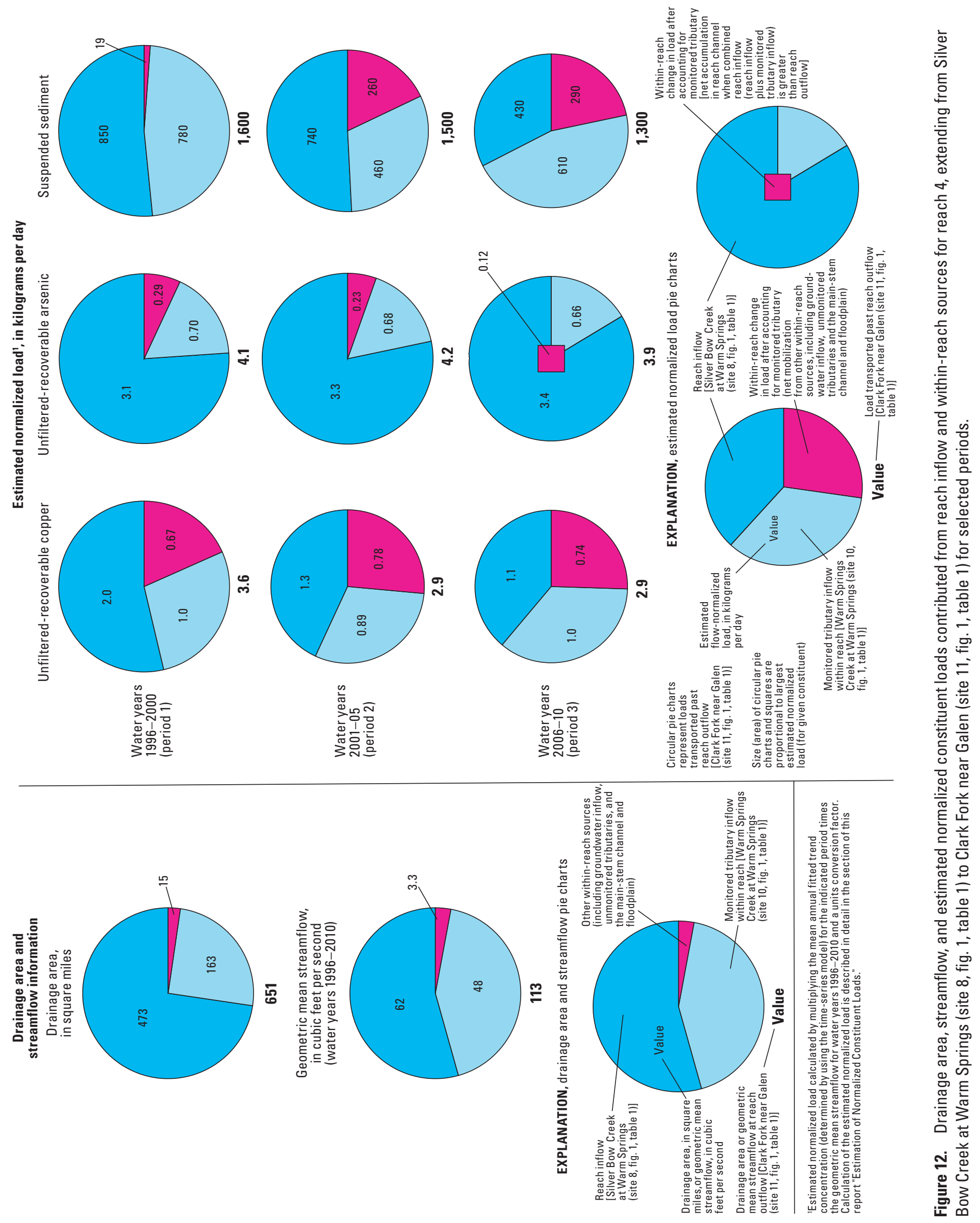


period 3. Overall, minor decreases are indicated for unfilteredrecoverable copper and arsenic, and suspended sediment from the start of period 1 to the end of period 3.

The TSM trend results for the reach 4 outflow (site 11) indicate minor to small decreases in geometric mean FACs of unfiltered-recoverable copper and arsenic, and suspended sediment from the start of period 1 to the end of period 3 (figs. 11 and 4-11; tables 4 and 4-1). The decreases in FACs of unfiltered-recoverable copper and suspended sediment for the reach 4 outflow (site 11) are of lower magnitude than decreases for the reach 4 inflow (site 8). Trend results for unfiltered-recoverable copper for site 11 indicate a small decrease of 38 percent from $16 \mu \mathrm{g} / \mathrm{L}$ at the start of period 1 to $10 \mu \mathrm{g} / \mathrm{L}$ at the end of period 3; whereas trend results for site 8 indicate a large decrease of 61 percent. Trend results for suspended sediment for site 11 indicate a minor decrease of 20 percent from $6.0 \mathrm{mg} / \mathrm{L}$ at the start of period 1 to $4.8 \mathrm{mg} / \mathrm{L}$ at the end of period 3; whereas trend results for site 8 indicate a large decrease of 65 percent. Trend results for unfilteredrecoverable arsenic for site 11 indicate a small decrease of 25 percent from $16 \mu \mathrm{g} / \mathrm{L}$ at the start of period 1 to $12 \mu \mathrm{g} / \mathrm{L}$ at the end of period 3; whereas trend results for site 8 indicate a minor increase of 15 percent.

Results of the transport analysis indicate how temporal changes in geometric mean FACs for sites 8, 10, and 11 translate into temporal changes in relative contributions from upstream source areas to the reach 4 outflow loads (fig. 12, table 5-4). For unfiltered-recoverable copper, the reach 4 outflow load (site 11) decreases by about 20 percent from period $1(3.6 \mathrm{~kg} / \mathrm{d})$ to period $3(2.9 \mathrm{~kg} / \mathrm{d})$, largely because of a decrease in the reach 4 inflow load (site 8). Contributions from Warm Springs Creek (site 10) and net mobilization from other sources within reach 4 have minor change during periods 1 through 3. For all periods, contributions of unfilteredrecoverable copper from Warm Springs Creek (site 10) are proportionally smaller than streamflow contributed from Warm Springs Creek. For all periods, contributions of unfiltered-recoverable copper from reach 4 sources other than Warm Springs Creek (site 10) are proportionally larger than streamflow contributed from the other within-reach sources. For unfiltered-recoverable arsenic, reach 4 outflow decreases by about 6 percent from period $1(4.1 \mathrm{~kg} / \mathrm{d})$ to period 3 $(3.9 \mathrm{~kg} / \mathrm{d})$. Net accumulation of arsenic in the reach 4 channel is indicated for period 3. Accumulation of arsenic in reach 4 at near-median conditions at times is plausible. In reach 4 , water from the Warm Springs Ponds (with high $\mathrm{pH}$ and arsenic concentration) mixes with water from the Mill-Willow bypass (with lower $\mathrm{pH}$ and higher arsenic concentrations) and also water from Warm Springs Creek (with lower $\mathrm{pH}$ ), which might result in precipitation of arsenic. However, reach 4 is short and nearly all inflows are accounted for (resulting in tight balance accounting) and small errors can result in uncertainty in distinguishing between net mobilization and net accumulation. Thus, indication of net accumulation of arsenic in reach 4 for period 3 is not confirmed, but cannot be discounted based on available data. Whether or not the indication of arsenic accumulation for period 3 is accurate, the transport analysis indicates that contributions of arsenic from reach 4 sources other than Warm Springs Creek (site 10) are not substantial and the reach 4 outflow largely is sourced from the reach 4 inflow (site 8) with much less contribution from Warm Springs Creek (site 10). For suspended sediment, reach 4 outflow load (site 11) decreases by about 19 percent from period $1(1,600 \mathrm{~kg} / \mathrm{d})$ to period $3(1,300 \mathrm{~kg} / \mathrm{d})$. Large variability in relative source-area contributions is indicated for suspended sediment. Overall, for periods 1 through 3, relative contributions of suspended-sediment from Warm Springs Creek (site 10) generally are proportionally similar to or larger than the relative contribution of streamflow from Warm Springs Creek. For periods 2 and 3, contributions of suspended sediment from reach 4 sources other than Warm Springs Creek (site 10) are proportionally larger than streamflow contributed from the other within-reach sources.

\section{Reach 5}

Sites in reach 5 include the inflow [Clark Fork near Galen (site 11)], monitored tributary sites [Lost Creek near Anaconda (site 12) and Lost Creek near Galen (site 13)], and the outflow [Clark Fork at Deer Lodge (site 14)]. Trend results for the reach inflow and outflow sites (sites 11 and 14) were determined by using the TSM and are presented in tables 4 and $4-1$, figure 13, and also figures 4-11 and 4-14, for sites 11 and 14, respectively. Trend results for the monitored tributary sites on Lost Creek [sites 12 and 13, which had short periods of data collection] were determined by using MLR. Transport analysis results for reach 5 are graphically presented in figure 14 .

Detailed trend results for the monitored tributary sites on Lost Creek are presented in tables 6 and 4-3, and also figures 4-12 and 4-13, for sites 12 and 13, respectively. Fitted trends for the downstream site on Lost Creek (site 13) also are shown in figure 13, in reference to fitted trends for the mainstem Silver Bow Creek inflow site and Clark Fork outflow site that bound the reach (site 11 and site 14, respectively). Because MLR and the TSM use different flow-adjustment procedures, caution should be used in directly comparing results of the two methods in terms of the estimated fitted trend values presented in figure 13 . However, magnitudes and directions of trends probably are reasonably comparable between the two methods within the short time frame of period 3. Trend results for the upstream Lost Creek site (site 12) indicate moderate to large decreases in geometric mean FACs of most trace-elements for period 3 (fig. 4-12, tables 6 and 4-3). Trend results for the downstream Lost Creek site (site 13) indicate decreases in some trace elements for period 3 (figs. 13 and 4-13, tables 6 and 4-3). For example, unfiltered-recoverable copper results for period 3 for site 13 indicate a moderate decrease of 49 percent (from 5.1 to $2.6 \mu \mathrm{g} / \mathrm{L}$ ). Minor increases are indicated for arsenic and suspended sediment for site 13 .

The TSM trend results for the reach 5 outflow (site 14) indicate minor decreases in geometric mean FACs of unfiltered-recoverable copper and suspended sediment from the 

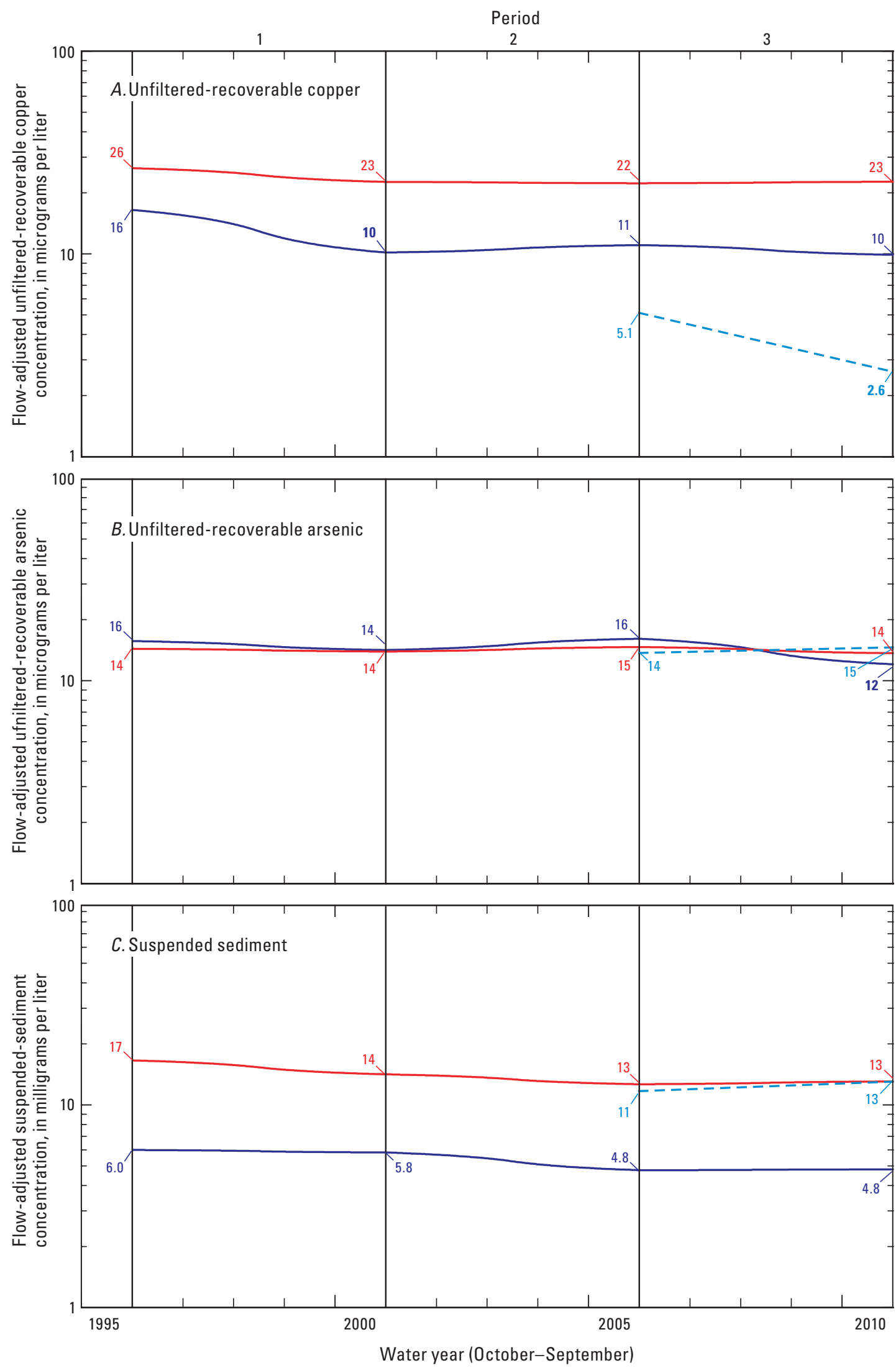

\section{EXPLANATION}

Water year is defined as the 12-month period from October 1 through

September 30 and is designated by the year in which it ends. $p$-value, statistical probability level]

- Reach inflow-Clark Fork near Galen (site 11, fig. 1

table 1). Fitted trend determined by using the time-series model

\section{- Monitored tributary} inflow-Lost Creek near Galen (site 13, fig. 1, table 1). Fitted trend determined by using multiple linear regression

— Reach outflow-Clark Fork at Deer Lodge (site 14, fig. 1, table 1). Fitted trend determined by using the time-series model

26 Fitted trend value at start or end of period

2.6 Bold values indicate statistical significance ( $p$-value less than 0.01 ) for period before value presented in bold

Figure 13. Flow-adjusted fitted trends determined by using the time-series model (TSM) and multiple linear regression on time, streamflow, and season (MLR) for selected constituents for selected sites in reach 5, extending from Clark Fork near Galen (site 11, fig. 1, table 1) to Clark Fork at Deer Lodge (site 14, fig. 1, table 1), based on data collected during water years 1985-2010. 

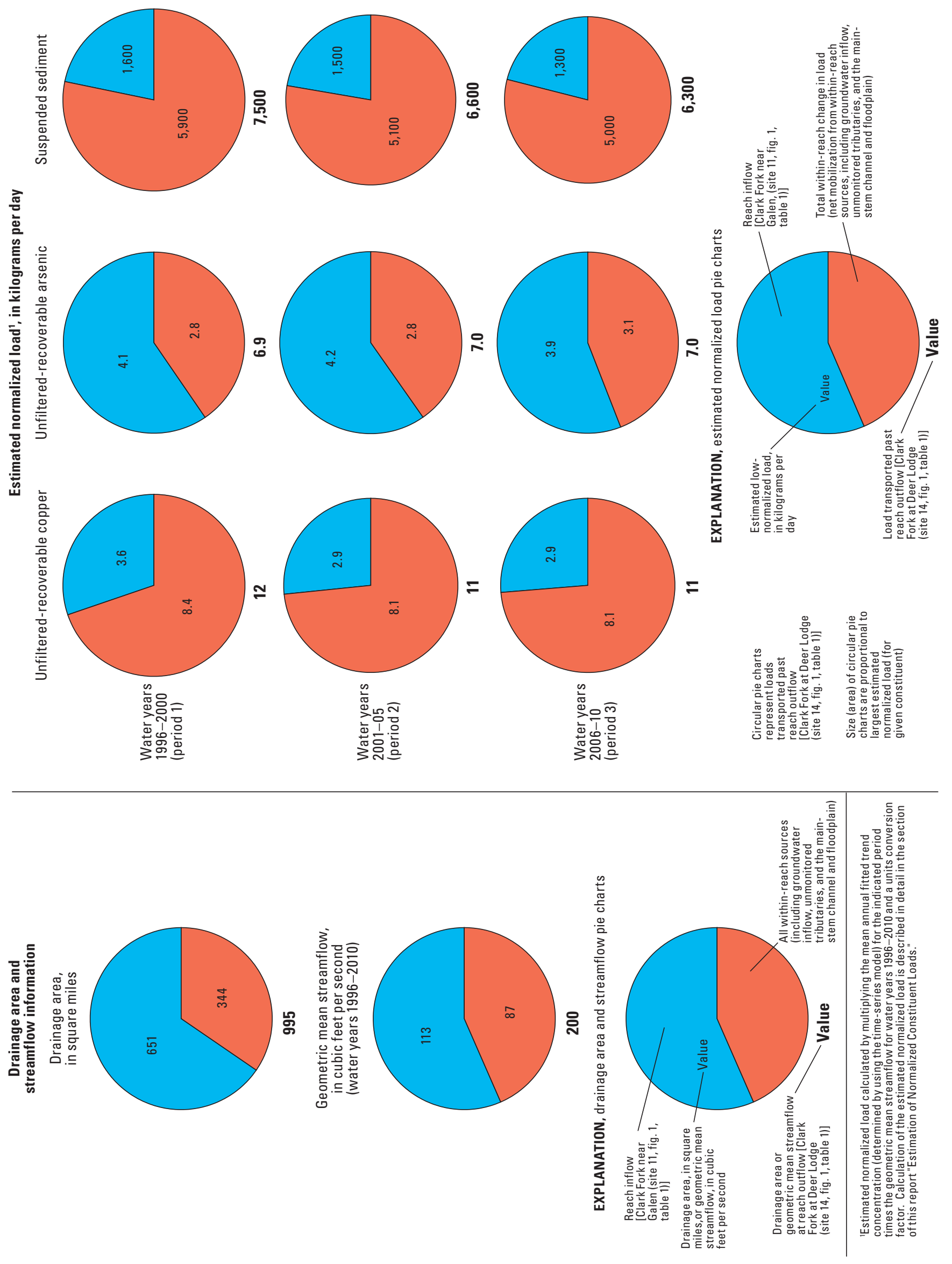
start of period 1 to the end of period 3 (figs. 11 and 4-11; tables 4 and 4-1) and no change in the FAC of unfilteredrecoverable arsenic from the start of period 1 to the end of period 3. Changes in FACs of unfiltered-recoverable copper and arsenic for the reach 5 outflow (site 14) are smaller than the decreases for the reach 5 inflow (site 11). Trend results for unfiltered-recoverable copper for site 14 indicate a minor decrease of about 12 percent from $26 \mu \mathrm{g} / \mathrm{L}$ at the start of period 1 to $23 \mu \mathrm{g} / \mathrm{L}$ at the end of period 3; whereas trend results for site 11 indicate a small decrease of 38 percent. Trend results for unfiltered-recoverable arsenic for site 14 indicate no change in FAC from the start of period 1 to the end of period 3, with both values equal to $14 \mu \mathrm{g} / \mathrm{L}$; whereas trend results for site 11 indicate a small decrease of about 25 percent. The decreases in FACs of suspended sediment for the reach 5 outflow (site 14) are of similar magnitude to the decreases for the reach 5 inflow (site 11). Trend results for suspended sediment for site 14 indicate a small decrease of 24 percent from $17 \mathrm{mg} / \mathrm{L}$ at the start of period 1 to $13 \mathrm{mg} / \mathrm{L}$ at the end of period 3 and trend results for site 11 indicate a similar decrease of about 20 percent.

Results of the transport analysis indicate how temporal changes in geometric mean FACs for sites 11 and 14 translate into temporal changes in relative contributions from upstream source areas to the reach 5 outflow loads (fig. 14, table 5-5). Data for the monitored tributary sites on Lost Creek were not included in the transport analysis because of factors that complicate directly combining the TSM and MLR results within a single analysis. The unquantified contributions from Lost Creek are part of the total undifferentiated contributions from within-reach sources. For unfiltered-recoverable copper, the reach 5 outflow load (site 14) decreases by about 8 percent from period $1(12 \mathrm{~kg} / \mathrm{d})$ to period $3(11 \mathrm{~kg} / \mathrm{d})$, largely because of a decrease in the reach 5 inflow load (site 11). Net mobilization from sources within reach 5 has minor change during periods 1 through 3 . For all periods, contributions of unfiltered-recoverable copper from sources within reach 5 are proportionally larger than streamflow contributed from the within-reach sources. For unfiltered-recoverable arsenic, reach 5 outflow increases slightly from period $1(6.9 \mathrm{~kg} / \mathrm{d})$ to period $3(7.0 \mathrm{~kg} / \mathrm{d})$. For all periods, contributions of unfilteredrecoverable arsenic from sources within reach 5 are proportionally similar to or slightly larger than streamflow contributed from the within-reach sources. For suspended sediment, reach 5 outflow load (site 14) decreases by about 16 percent from period $1(7,500 \mathrm{~kg} / \mathrm{d})$ to period $3(6,300 \mathrm{~kg} / \mathrm{d})$. For all periods, contributions of suspended sediment from sources within reach 5 are proportionally larger than streamflow contributed from the within-reach sources.

\section{Reach 6}

Sites in reach 6 include the inflow [Clark Fork at Deer Lodge (site 14)], the monitored tributary site [Little Blackfoot River (site 15)], and the outflow [Clark Fork at Goldcreek (site 16)]. Trend results for all sites in reach 6 were determined by using the TSM and are presented in tables 4 and $4-1$, figure 15 , and also figures $4-14,4-15$, and $4-16$, for sites 14,15 , and 16, respectively. Transport analysis results for reach 6 are graphically presented in figure 16.

Little Blackfoot River (site 15) had long-term waterquality data collection that was discontinued in water year 2005. Available data for site 15 were analyzed by using the TSM, but no results are presented for period 3. Trend results for periods 1 and 2 for site 15 indicate minor decreases (within a small range at low concentrations) in geometric mean FACs of unfiltered-recoverable copper and arsenic, and suspended sediment.

The TSM trend results for the reach 6 outflow (site 16) indicate minor to small decreases in geometric mean FACs of unfiltered-recoverable copper and suspended sediment from the start of period 1 to the end of period 3 (figs. 15 and 4-16; tables 4 and 4-1) and no change in the FAC of unfilteredrecoverable arsenic from the start of period 1 to the end of period 3. The decrease in FAC of unfiltered-recoverable copper for the reach 6 outflow (site 16) is slightly larger than the decrease for the reach 6 inflow (site 14). Trend results for unfiltered-recoverable copper for site 16 indicate a small decrease of about 27 percent from $22 \mu \mathrm{g} / \mathrm{L}$ at the start of period 1 to $16 \mu \mathrm{g} / \mathrm{L}$ at the end of period 3, and trend results for site 14 indicate a minor decrease of 12 percent. The absence of change in FAC of unfiltered-recoverable arsenic is consistent between the reach 6 outflow (site 16) and the reach 6 inflow (site 14). Trend results for unfiltered-recoverable arsenic for site 16 indicate no change in FAC from the start of period 1 to the end of period 3, with both values equal to $11 \mu \mathrm{g} / \mathrm{L}$. The decrease in FAC of suspended sediment for the reach 6 outflow (site 16) is smaller than the decrease for the reach 6 inflow (site 14). Trend results for suspended sediment for site 16 indicate a minor decrease of about 7 percent from $15 \mathrm{mg} / \mathrm{L}$ at the start of period 1 to $14 \mathrm{mg} / \mathrm{L}$ at the end of period 3, and trend results for site 14 indicate a small decrease of about 24 percent. Fitted trends for suspended sediment for site 16 show substantial variability between periods. Specific hydraulic and geomorphologic characteristics of reach 6 might contribute to complexity in suspended-sediment concentration and flow relations. Factors affecting the relations might include bedload and suspended-load relations, and sand-sized and fine-sized suspended-sediment transport relations. During extended wet or dry periods, variability in the suspendedsediment concentration and flow relations might happen over longer time scales than those accounted for in the TSM.

Results of the transport analysis indicate how temporal changes in geometric mean FACs for sites 14, 15, and 16 translate into temporal changes in relative contributions from upstream source areas to the reach 6 outflow loads (fig. 16, table 5-6). Data for Little Blackfoot River (site 15) were included in transport analysis, but no data were available for period 3. For period 3, the unquantified contributions from Little Blackfoot River (site 15) are part of the total undifferentiated contributions from within-reach sources. For unfiltered-recoverable copper, the reach 6 outflow load 


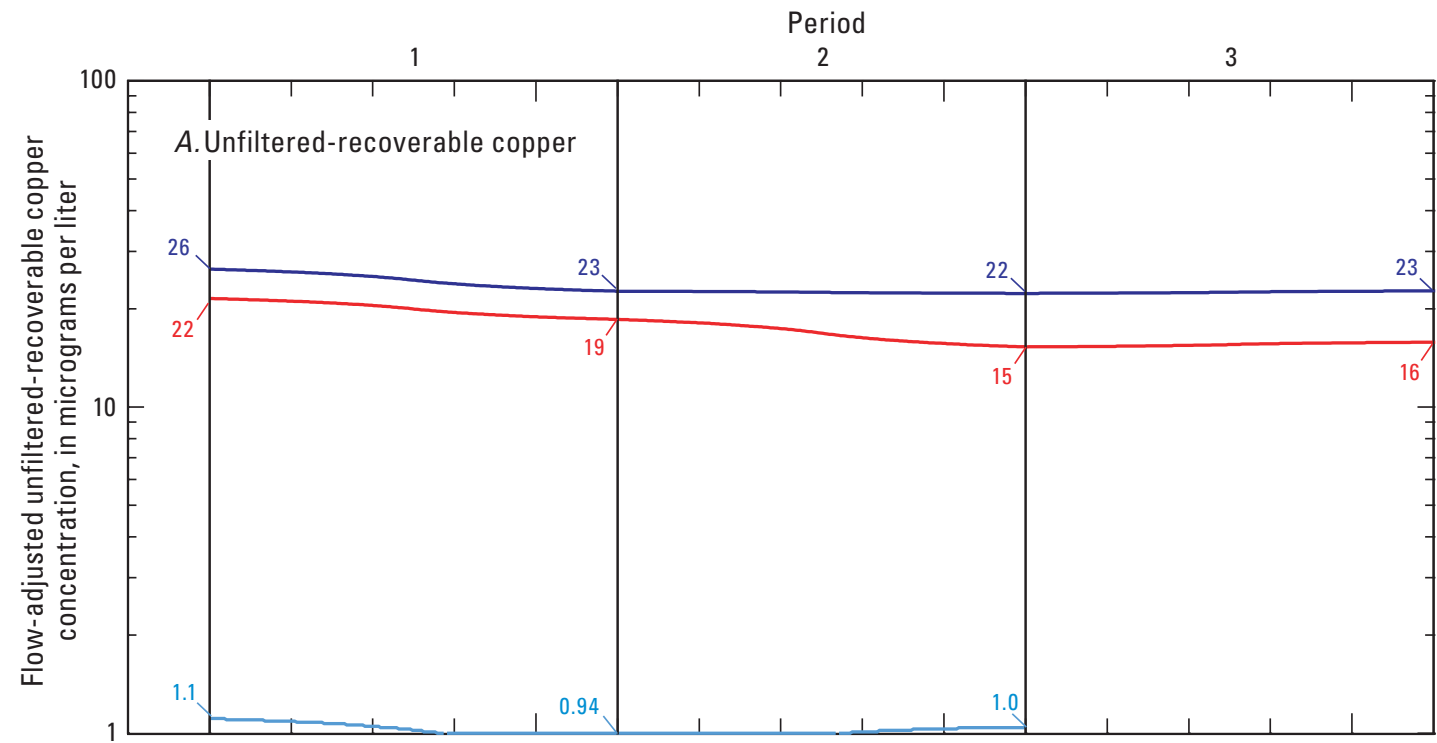

\section{EXPLANATION}

[Water year is defined as the 12-month period from October 1 through

September 30 and is designated by the year in which it ends. $p$-value, statistical probability level]

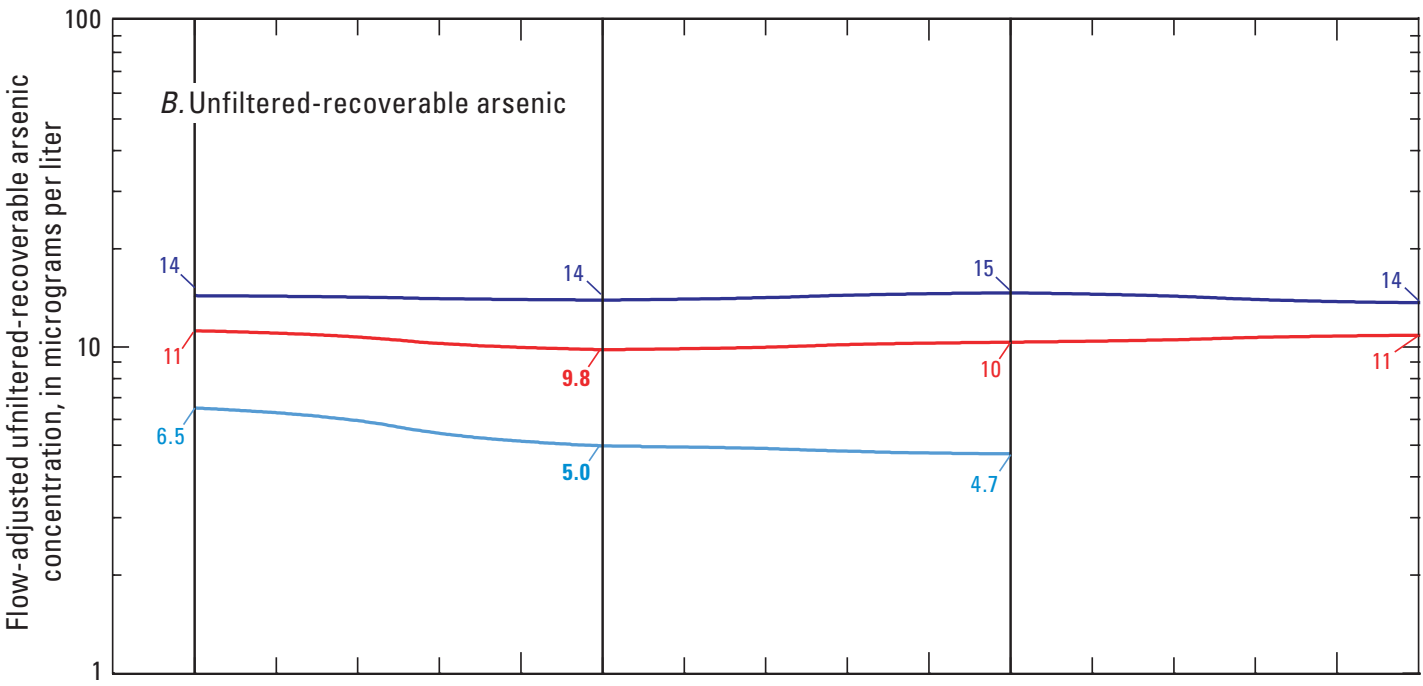

- Reach inflow-Clark Fork at Deer Lodge (site 14, fig. 1, table 1)

\section{Monitored tributary}

inflow-Little Blackfoot River (site 15, fig. 1, table 1)

- Reach outflow_Clark Fork at Goldcreek (site 16, fig. 1, table 1)

23 Fitted trend value at start or end of period

9.8 Bold values indicate statistical significance ( $p$-value less than 0.01 ) for period before value presented in bold

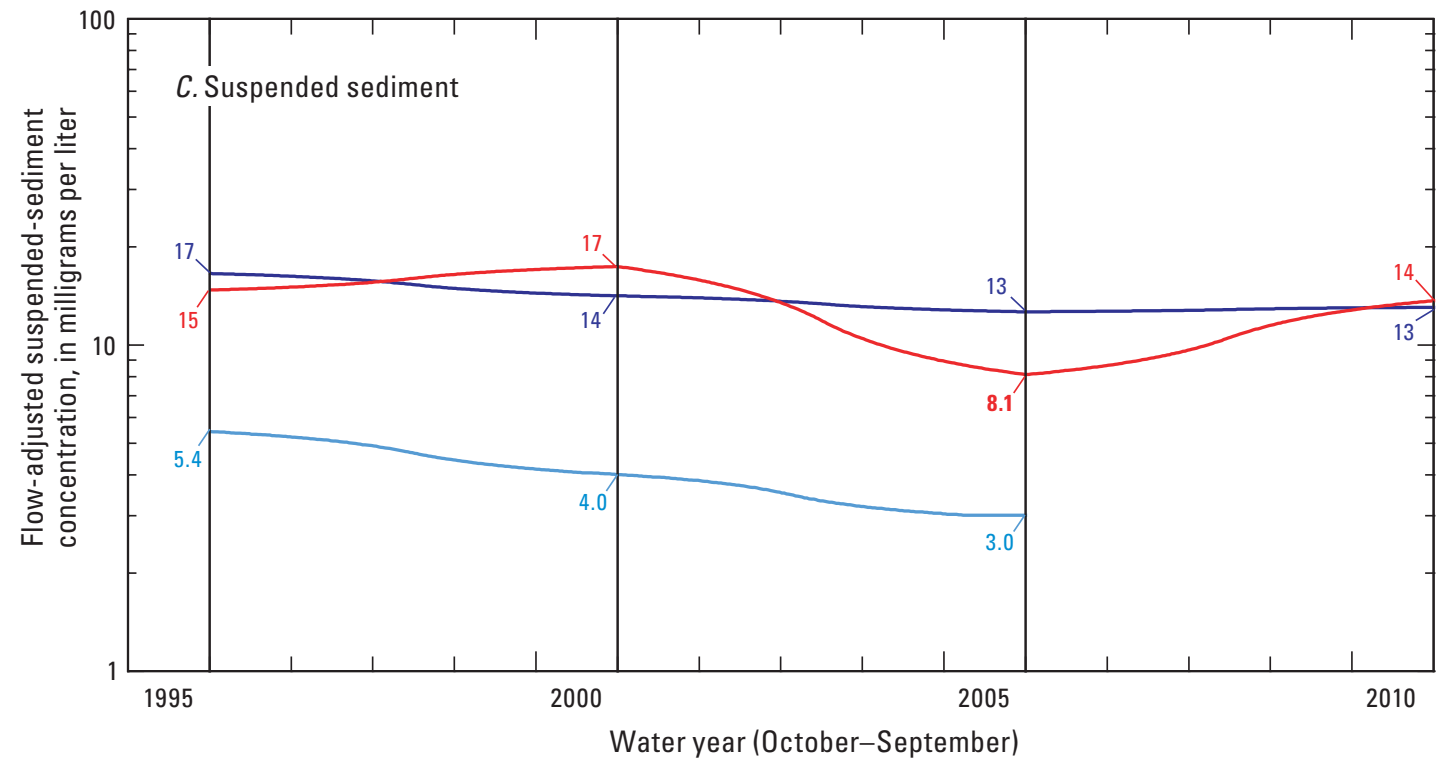

Figure 15. Flow-adjusted fitted trends determined by using the time-series model (TSM) for selected constituents for sites in reach 6 , extending from Clark Fork at Deer Lodge (site 14, fig. 1, table 1) to Clark Fork at Goldcreek (site 16, fig. 1, table 1), based on data collected during water years 1985-2010. 


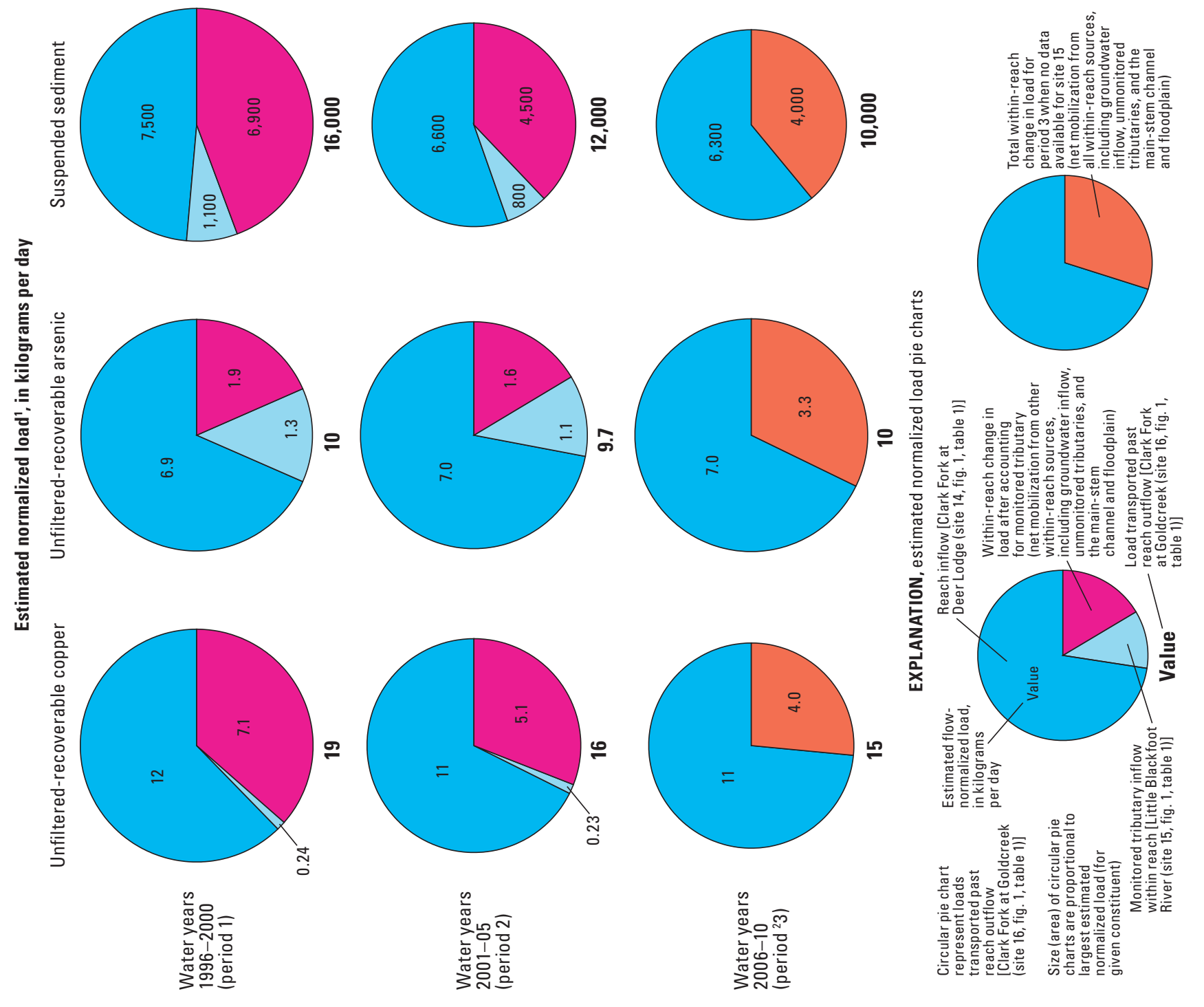

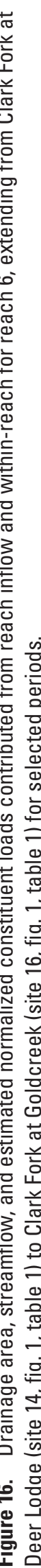
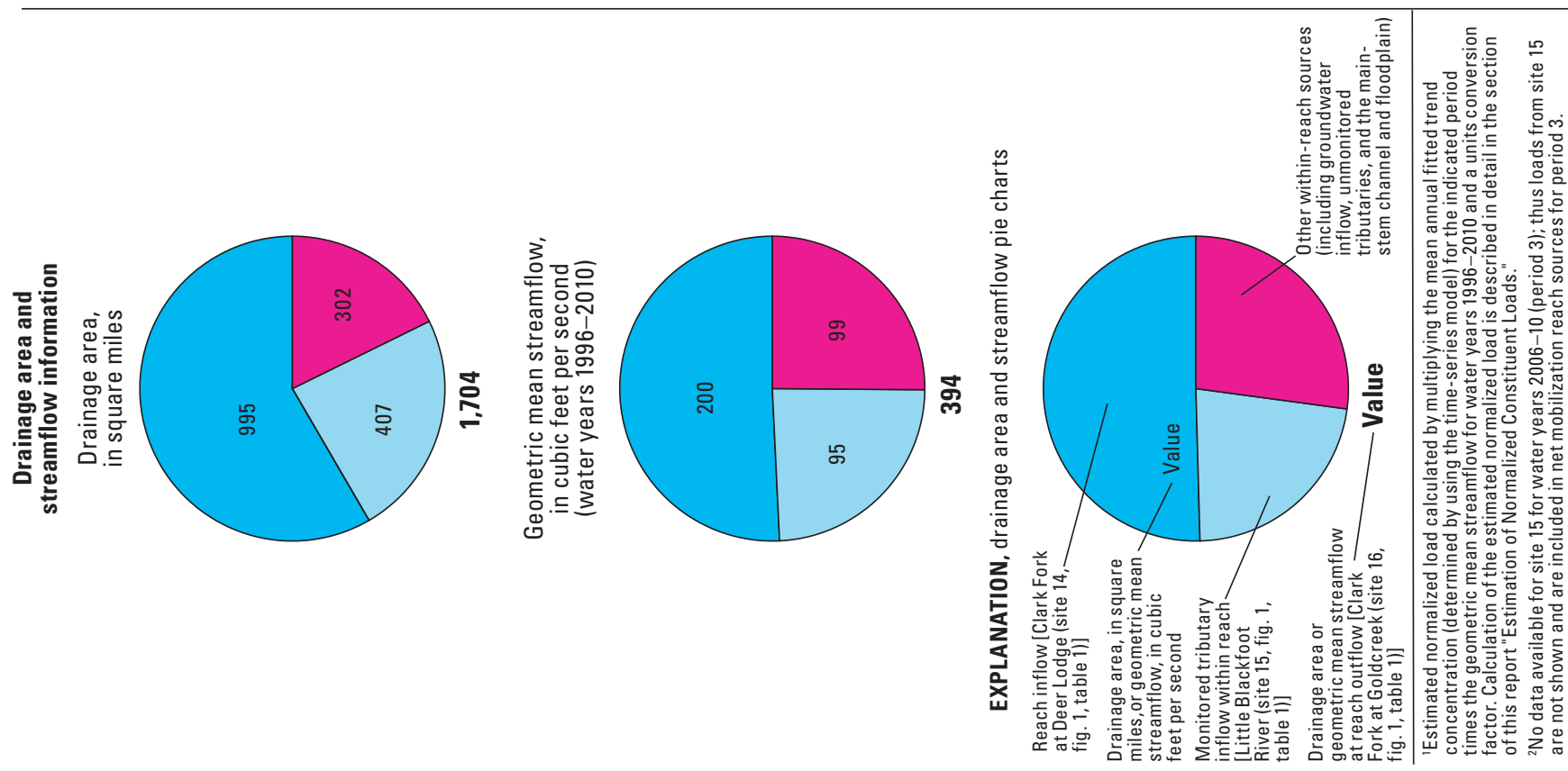

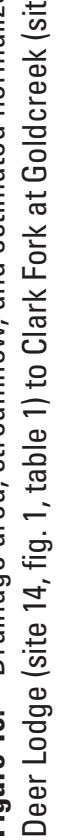


(site 16) decreases by about 21 percent from period 1 $(19 \mathrm{~kg} / \mathrm{d})$ to period $3(15 \mathrm{~kg} / \mathrm{d})$. Contributions of copper from Little Blackfoot River (site 15) have minor change during periods 1 and 2, and the contributions are proportionally much smaller than streamflow contributed from Little Blackfoot River (site 15). Net mobilization from all sources within reach 6 (including Little Blackfoot River) decreases by about 45 percent from period $1(7.3 \mathrm{~kg} / \mathrm{d})$ to period $3(4.0 \mathrm{~kg} / \mathrm{d})$. For all periods, contributions of copper from all sources within reach 6 (including Little Blackfoot River) are proportionally smaller than streamflow contributed from all of the withinreach sources. For unfiltered-recoverable arsenic, reach 6 outflow load (site 16) does not change from period 1 to period 3 , with outflow loads for both periods equal to $10 \mathrm{~kg} / \mathrm{d}$. Contributions of arsenic from Little Blackfoot River (site 15) have minor change during periods 1 and 2, and the contributions are proportionally much smaller than streamflow contributed from Little Blackfoot River (site 15). Net mobilization from all sources within reach 6 (including Little Blackfoot River) slightly increases by about 3 percent from period 1 $(3.2 \mathrm{~kg} / \mathrm{d})$ to period $3(3.3 \mathrm{~kg} / \mathrm{d})$. For all periods, contributions of unfiltered-recoverable arsenic from all sources within reach 6 (including Little Blackfoot River) are proportionally smaller than streamflow contributed from all of the withinreach sources. For suspended sediment, reach 6 outflow load (site 16) decreases by about 38 percent from period 1 $(16,000 \mathrm{~kg} / \mathrm{d})$ to period $3(10,000 \mathrm{~kg} / \mathrm{d})$. Contributions of suspended sediment from Little Blackfoot River (site 15) have small change during periods 1 and 2, and the contributions are proportionally much smaller than streamflow contributed from Little Blackfoot River (site 15). Net mobilization from all sources within reach 6 (including Little Blackfoot River) decreases by about 50 percent from period $1(8,000 \mathrm{~kg} / \mathrm{d})$ to period $3(4,000 \mathrm{~kg} / \mathrm{d})$. For all periods, contributions of suspended sediment from all sources within reach 6 (including Little Blackfoot River) are proportionally smaller than streamflow contributed from all of the within-reach sources.

\section{Reach 7}

Sites in reach 7 include the inflow [Clark Fork at Goldcreek (site 16)], the monitored tributary site [Flint Creek (site 17)], and the outflow [Clark Fork near Drummond (site 18)]. Trend results for all sites in reach 7 were determined by using the TSM and are presented in tables 4 and 4-1, figure 17, and also figures 4-16, 4-17, and 4-17, for sites 16, 17 , and 18, respectively. Transport analysis results for reach 7 are graphically presented in figure 18 .

Flint Creek (site 17) had long-term water-quality data collection that was discontinued in water year 2005. Available data for site 17 were analyzed by using the TSM, but no results are presented for period 3 . Trend results for periods 1 and 2 for site 17 indicate minor decreases (within a small range at low concentrations) in geometric mean FAC of unfiltered-recoverable copper. Trend results for periods 1 and
2 for site 17 indicate small to moderate decreases in FACs of unfiltered-recoverable arsenic and suspended sediment.

The TSM trend results for the reach 7 outflow (site 18) indicate minor to moderate decreases in geometric mean FACs of unfiltered-recoverable copper and arsenic, and suspended sediment from the start of period 1 to the end of period 3 (figs. 17 and 4-18; tables 4 and 4-1). The decrease in FAC of unfiltered-recoverable copper for the reach 7 outflow (site 18) is similar to the decrease for the reach 7 inflow (site 16). Trend results for unfiltered-recoverable copper for site 18 indicate a small decrease of about 32 percent from $19 \mu \mathrm{g} / \mathrm{L}$ at the start of period 1 to $13 \mu \mathrm{g} / \mathrm{L}$ at the end of period 3, and trend results for site 16 indicate a small decrease of 27 percent. The decrease in FAC of unfiltered-recoverable arsenic for the reach 7 outflow (site 18) differs slightly from trend results for the reach 7 inflow (site 16). Trend results for unfiltered-recoverable arsenic for site 18 indicate a minor decrease of about 17 percent from $12 \mu \mathrm{g} / \mathrm{L}$ at the start of period 1 to $10 \mu \mathrm{g} / \mathrm{L}$ at the end of period 3, and trend results for site 16 indicate no change. The decrease in FAC of suspended sediment for the reach 7 outflow (site 18) is larger than the decrease for the reach 7 inflow (site 16). Trend results for suspended sediment for site 18 indicate a moderate decrease of about 43 percent (mostly during period 1) from $21 \mathrm{mg} / \mathrm{L}$ at the start of period 1 to $12 \mathrm{mg} / \mathrm{L}$ at the end of period 3 , and trend results for site 16 indicate a small decrease of 7 percent.

Results of the transport analysis indicate how temporal changes in geometric mean FACs for sites 16, 17, and 18 translate into temporal changes in relative contributions from upstream source areas to the reach 7 outflow loads (fig. 18, table 5-7). Data for Flint Creek (site 17) were included in the transport analysis, but no data were available for period 3. For period 3, the unquantified contributions from Flint Creek (site 17) are part of the total undifferentiated contributions from within-reach sources. For unfiltered-recoverable copper, the reach 7 outflow load (site 18) decreases by about 21 percent from period $1(24 \mathrm{~kg} / \mathrm{d})$ to period $3(18 \mathrm{~kg} / \mathrm{d})$. Contributions of copper from Flint Creek (site 17) have minor change during periods 1 and 2, and the contributions are proportionally much smaller than streamflow contributed from Flint Creek (site 17). Net mobilization from sources within reach 7 decreases by about 20 percent from period 1 $(4.8 \mathrm{~kg} / \mathrm{d})$ to period $3(3.3 \mathrm{~kg} / \mathrm{d})$. For all periods, contributions of copper from sources within reach 7 are proportionally smaller than streamflow contributed from the within-reach sources. For unfiltered-recoverable arsenic, reach 7 outflow load (site 18) decreases by about 6 percent from period 1 $(16 \mathrm{~kg} / \mathrm{d})$ to period $3(15 \mathrm{~kg} / \mathrm{d})$. Contributions of arsenic from Flint Creek (site 17) have a minor decrease during periods 1 and 2, and the contributions are proportionally similar to streamflow contributed from Flint Creek (site 17). Net mobilization from sources within reach 7 decreases by about 18 percent from period $1(5.5 \mathrm{~kg} / \mathrm{d})$ to period $3(4.5 \mathrm{~kg} / \mathrm{d})$. For all periods, contributions of unfiltered-recoverable arsenic from sources within reach 7 are proportionally similar to streamflow contributed from the within-reach sources. For 


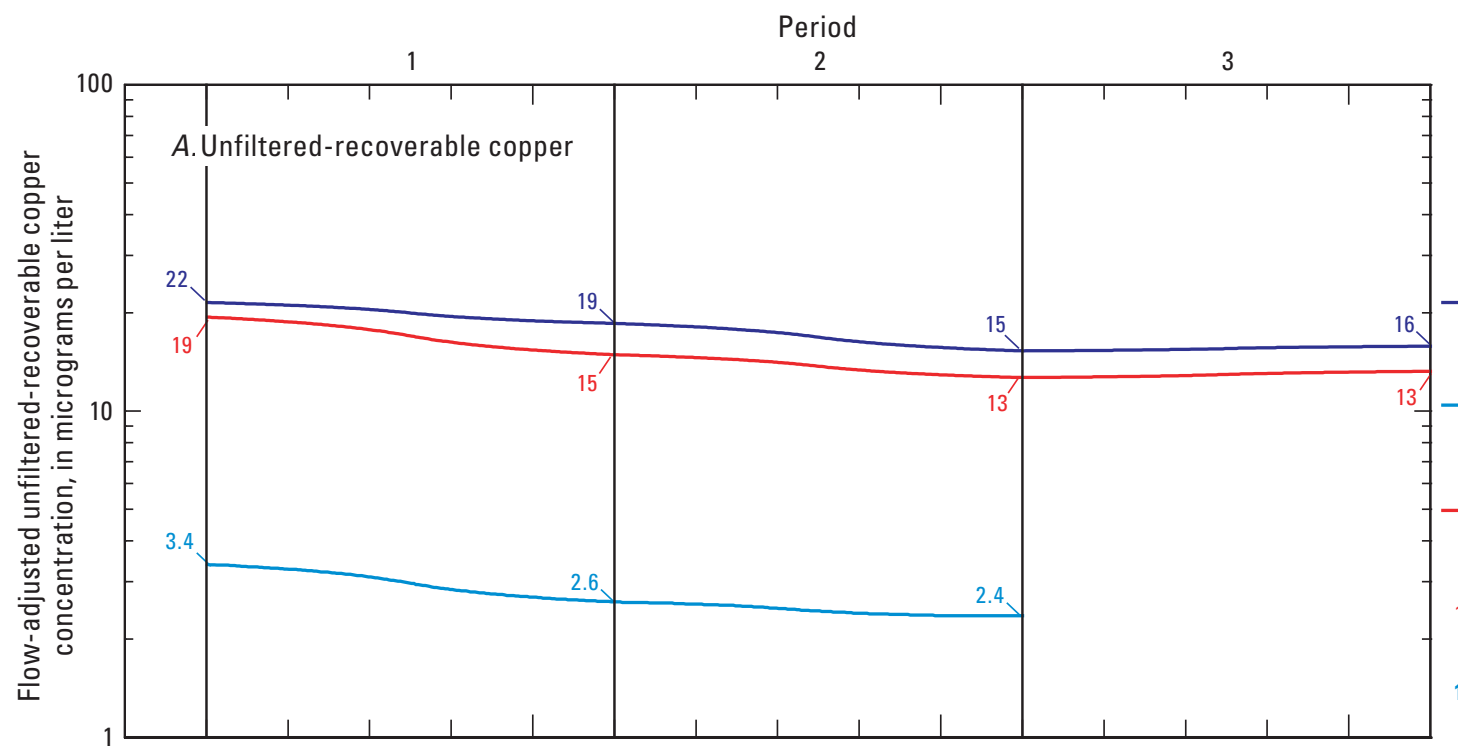

\section{EXPLANATION}

[Water year is defined as the 12-month period from October 1 through

September 30 and is designated by the

year in which it ends. $p$-value, statistical

probability level] Reach inflow-Clark Fork at
Goldcreek (site 16, fig. 1, table 1)

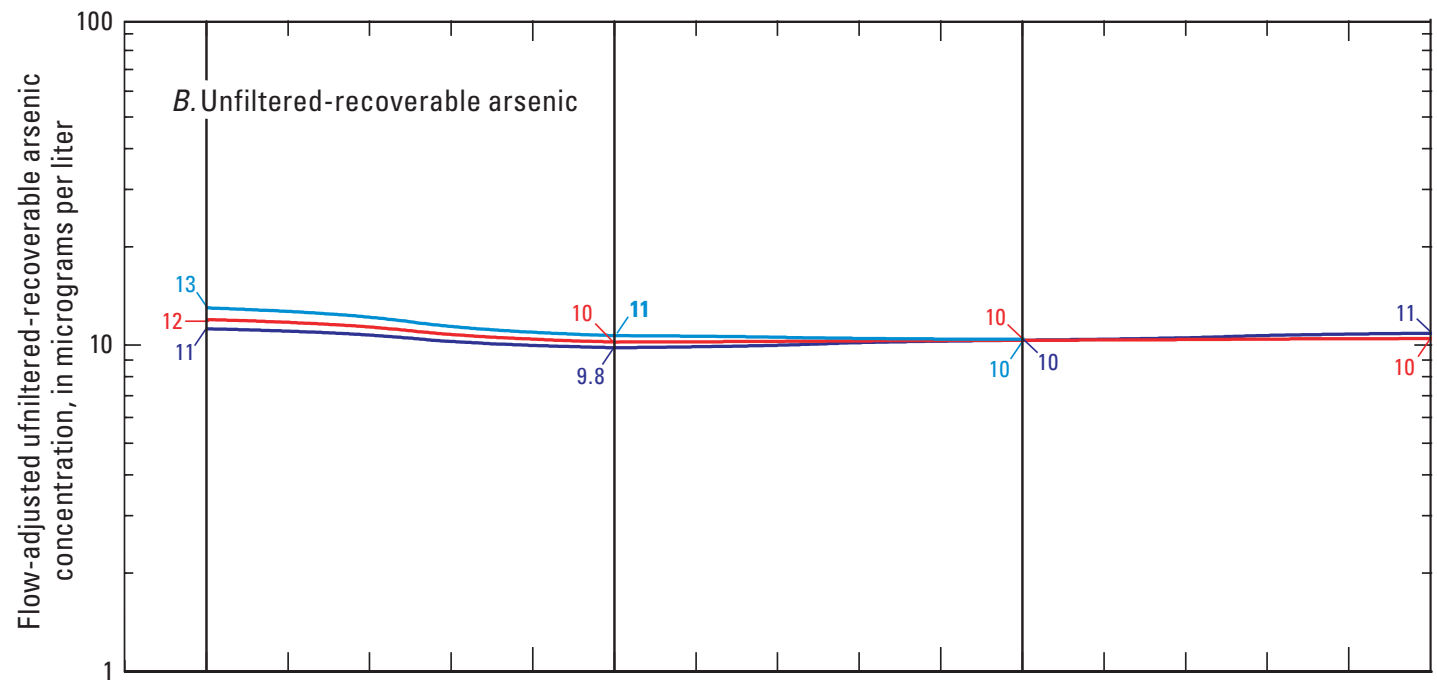

onitored tributary

inflow_Flint Creek (site 17,

fig. 1, table 1)

Reach outflow-Clark Fork

near Drummond (site 18,

fig. 1, table 1)

13 Fitted trend value at start or end of period

11 Bold values indicate statistical significance ( $p$-value less than 0.01$)$ for period before value presented in bold

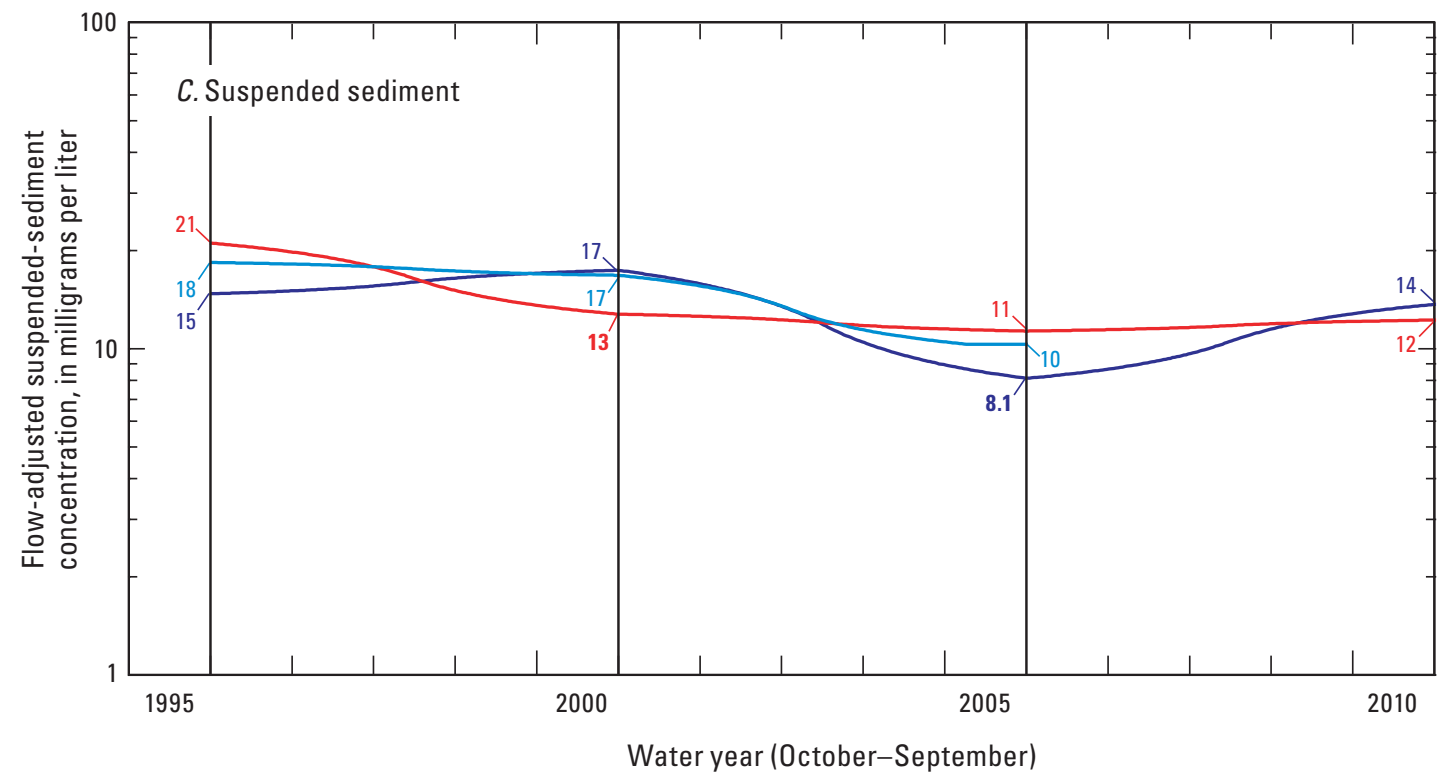

Figure 17. Flow-adjusted fitted trends determined by using the time-series model (TSM) for selected constituents for sites in reach 7, extending from Clark Fork at Goldcreek (site 16, fig. 1, table 1) to Clark Fork near Drummond (site 18, fig. 1, table 1), based on data collected during water years 1985-2010. 

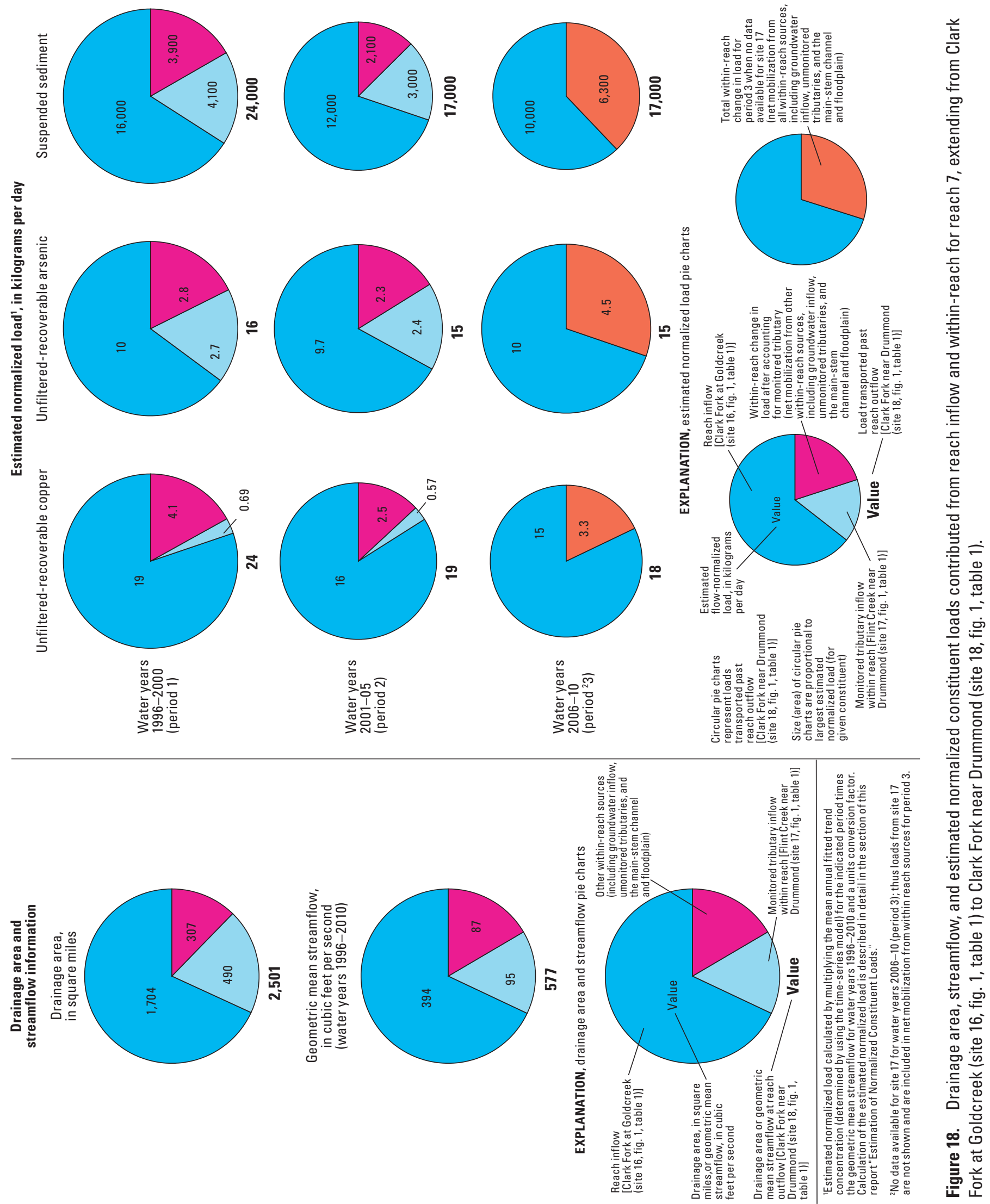

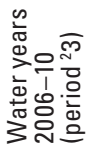

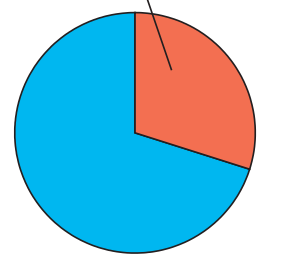

必

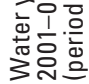

S. 
suspended sediment, reach 7 outflow load (site 18) decreases by about 29 percent from period $1(24,000 \mathrm{~kg} / \mathrm{d})$ to period 3 $(17,000 \mathrm{~kg} / \mathrm{d})$. Contributions of suspended sediment from Flint Creek (site 17) have a small decrease during periods 1 and 2, and the contributions are proportionally similar to streamflow contributed from Flint Creek (site 17). Net mobilization from sources within reach 7 decreases by about 21 percent from period $1(8,000 \mathrm{~kg} / \mathrm{d})$ to period $3(6,300 \mathrm{~kg} / \mathrm{d})$. For all periods, contributions of suspended sediment from sources within reach 7 are proportionally similar to streamflow contributed from the within-reach sources.

\section{Reach 8}

Sites in reach 8 include the inflow [Clark Fork near Drummond (site 18)], the monitored tributary site [Rock Creek (site 19)], and the outflow [Clark Fork at Turah Bridge (site 20)]. Trend results for all sites in reach 8 were determined by using the TSM and are presented in tables 4 and 4-1, figure 19 , and also figures 4-18, 4-19, and 4-20, for sites 18 , 19 , and 20, respectively. Transport analysis results for reach 8 are graphically presented in figure 20 .

Rock Creek (site 19) had long-term water-quality data collection that was discontinued in water year 2005. Available data for Rock Creek (site 19) were analyzed by using the TSM, but no results are presented for period 3. Further, because trace-element concentrations for site 19 are low and typically less than LRLs, no results for copper or arsenic are presented. Trend results for periods 1 and 2 for suspended sediment for site 19 indicate an overall small decrease. However, fitted trends for suspended sediment for site 19 show substantial variability between periods.

The TSM trend results for the reach 8 outflow (site 20 ) indicate minor increases in geometric mean FACs of unfiltered-recoverable copper and arsenic, and no change in FAC of suspended sediment from the start of period 1 to the end of period 3 (figs. 19 and 4-20; tables 4 and 4-1). The changes indicated for the reach 8 outflow (site 20) are somewhat in contrast to the changes indicated for the reach 8 inflow (site 18). Trend results for unfiltered-recoverable copper for site 20 indicate a minor increase of about 1 percent from $9.4 \mu \mathrm{g} / \mathrm{L}$ at the start of period 1 to $9.5 \mu \mathrm{g} / \mathrm{L}$ at the end of period 3 , and trend results for site 18 indicate a small decrease of 32 percent. Trend results for unfiltered-recoverable arsenic for site 20 indicate a minor increase of about 6 percent from $6.8 \mu \mathrm{g} / \mathrm{L}$ at the start of period 1 to $7.2 \mu \mathrm{g} / \mathrm{L}$ at the end of period 3 , and trend results for site 18 indicate a minor decrease of 17 percent. Trend results for suspended sediment for site 20 indicate no change in FAC from the start of period 1 to the end of period 3, with both values equal to $13 \mathrm{mg} / \mathrm{L}$; whereas trend results for site 18 indicate a moderate decrease of about 43 percent. Site 20 is the only main-stem Silver Bow Creek or Clark Fork site with increases of at least 20 percent indicated for unfiltered-recoverable copper and arsenic, and suspended sediment for period 3. A possible explanation for this pattern might relate to effects of the removal of the former Milltown
Dam during period 3. Before the removal of the former Milltown Dam, during high-flow conditions, backwater effects of the dam might have extended far enough upstream to affect the hydraulic gradient at site 20 and also affect the transport of particulate materials from reach 8 . After the removal of the former Milltown Dam, during high flow conditions, the hydraulic gradient at site 20 might have steepened and promoted transport of particulate materials from reach 8 .

Results of the transport analysis indicate how temporal changes in geometric mean FACs for sites 18, 19, and 20 translate into temporal changes in relative contributions from upstream source areas to the reach 8 outflow loads (fig. 20, table 5-8). Data for Rock Creek (site 19) were included in the transport analysis, but no data were available for period 3. Further, because trace-element concentrations for site 19 are low and typically less than LRLs, no results for copper or arsenic are presented. Thus, for copper and arsenic for all periods and for suspended sediment for period 3, the unquantified contributions from Rock Creek (site 19) are part of the total undifferentiated contributions from within-reach sources. For unfiltered-recoverable copper, the reach 8 outflow load (site 20) decreases by about 9 percent from period 1 $(23 \mathrm{~kg} / \mathrm{d})$ to period $3(21 \mathrm{~kg} / \mathrm{d})$. Net accumulation of copper in the reach 8 channel is indicated for period 1 , which is difficult to interpret. Concentration and streamflow relations within reach 8 are complex and affected by the mixing of dilute water from Rock Creek with main-stem Clark Fork and potential backwater effects of the former Milltown Dam, which was alternately present and absent during the period of trend analysis. Accurate definition of concentration and streamflow relations in reach 8 during period 1 also might have been affected by extremely high unfiltered-recoverable copper and suspended-sediment concentrations in water year 1996 (at the start of period 1) at site 20. Thus, indication of net accumulation of copper in reach 8 for period 1 is not confidently determined. Net mobilization of copper from sources within reach 8 is indicated for periods 2 and 3, increasing from $1.1 \mathrm{~kg} / \mathrm{d}$ in period 2 to $3.0 \mathrm{~kg} / \mathrm{d}$ in period 3 . The increase in net mobilization of copper from sources within reach 8 during period 3 might have been affected by an increased hydraulic gradient (during high streamflow conditions) following the removal of Milltown Dam. For all periods, contributions of copper from sources within reach 8 are proportionally much smaller than streamflow contributed from the within-reach sources. For unfiltered-recoverable arsenic, reach 8 outflow load (site 20) decreases by about 6 percent from period 1 $(17 \mathrm{~kg} / \mathrm{d})$ to period $3(16 \mathrm{~kg} / \mathrm{d})$. Net mobilization from sources within reach 8 increases by about 100 percent from period 1 $(0.89 \mathrm{~kg} / \mathrm{d})$ to period $3(1.8 \mathrm{~kg} / \mathrm{d})$. For all periods, contributions of unfiltered-recoverable arsenic from sources within reach 8 are proportionally much smaller than streamflow contributed from the within-reach sources. For suspended sediment, reach 8 outflow load (site 20) decreases by about 16 percent from period $1(32,000 \mathrm{~kg} / \mathrm{d})$ to period $3(27,000$ $\mathrm{kg} / \mathrm{d})$. Contributions of suspended sediment from Rock Creek (site 19) have a minor decrease during periods 1 and 2, and the 


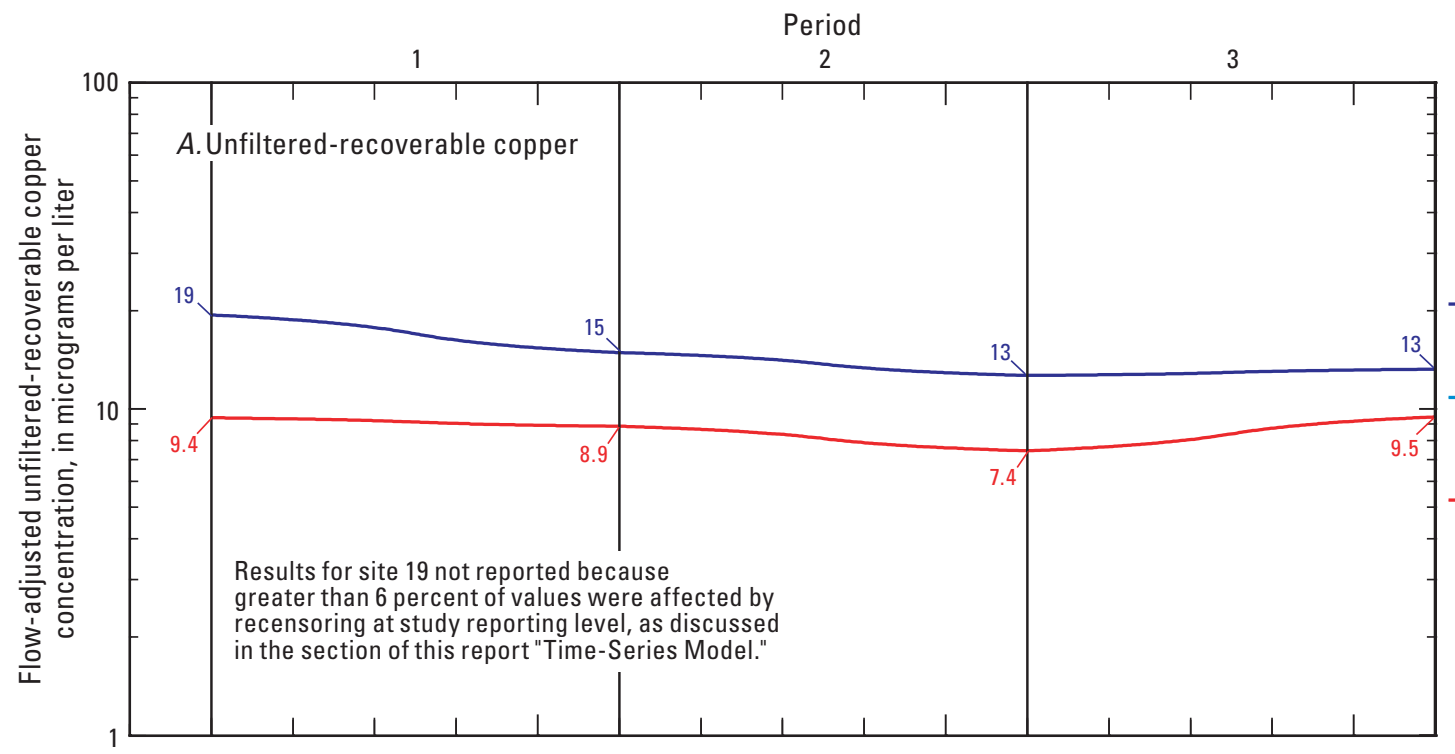

EXPLANATION

Water year is defined as the 12-month period from October 1 through

September 30 and is designated by the year in which it ends. $p$-value, statistical probability level]

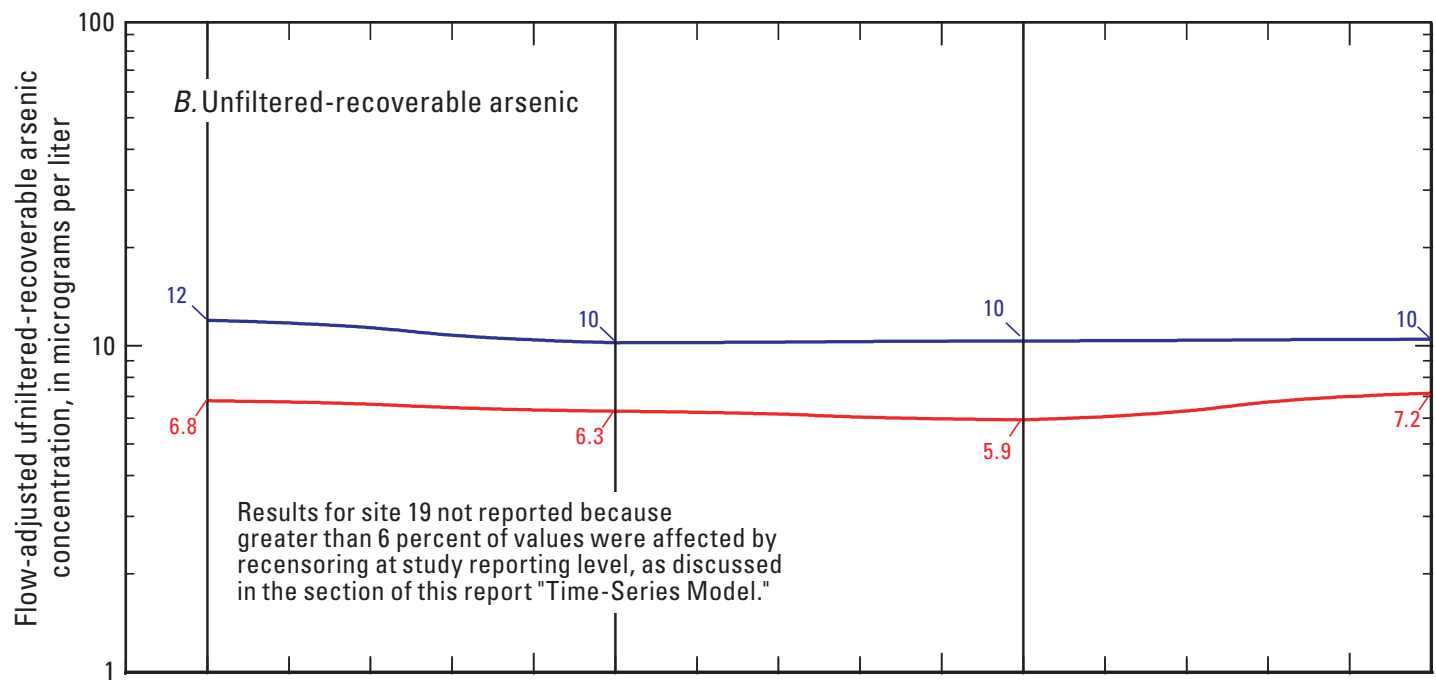

Reach inflow-Clark Fork near Drummond (site 18, fig. 1, table 1)

- Monitored tributary

inflow-Rock Creek (site 19, fig. 1, table 1)

- Reach outflow-Clark Fork at Turah Bridge (site 20, fig. 1, table 1)

9.5 Fitted trend value at start or end of period

13 Bold values indicate statistical significance ( $p$-value less than $\mathbf{0 . 0 1}$ ) for period before value presented in bold

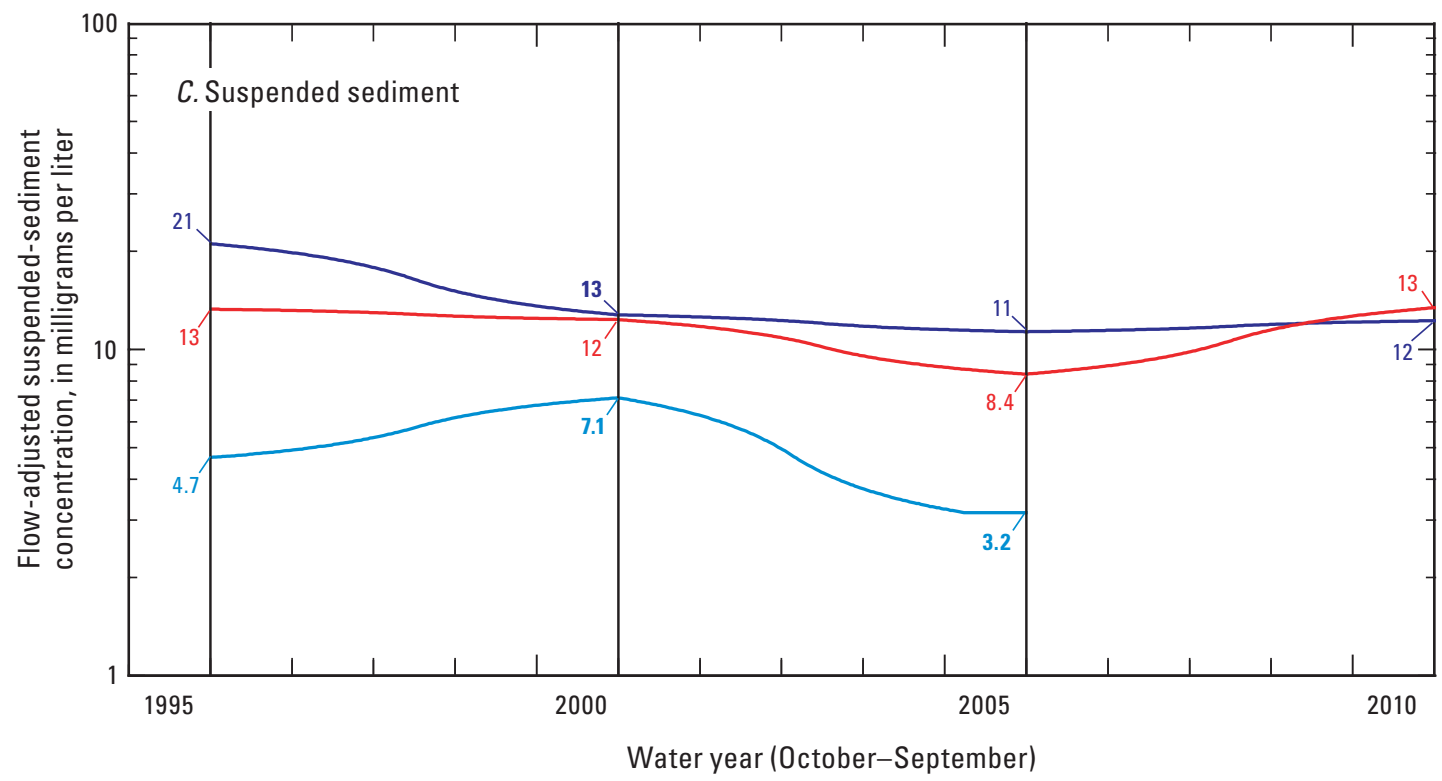

Figure 19. Flow-adjusted fitted trends determined by using the time-series model (TSM) for selected constituents for sites in reach 8 , extending from Clark Fork near Drummond (site 18, fig. 1, table 1) to Clark Fork at Turah Bridge (site 20, fig. 1, table 1), based on data collected during water years 1985-2010. 

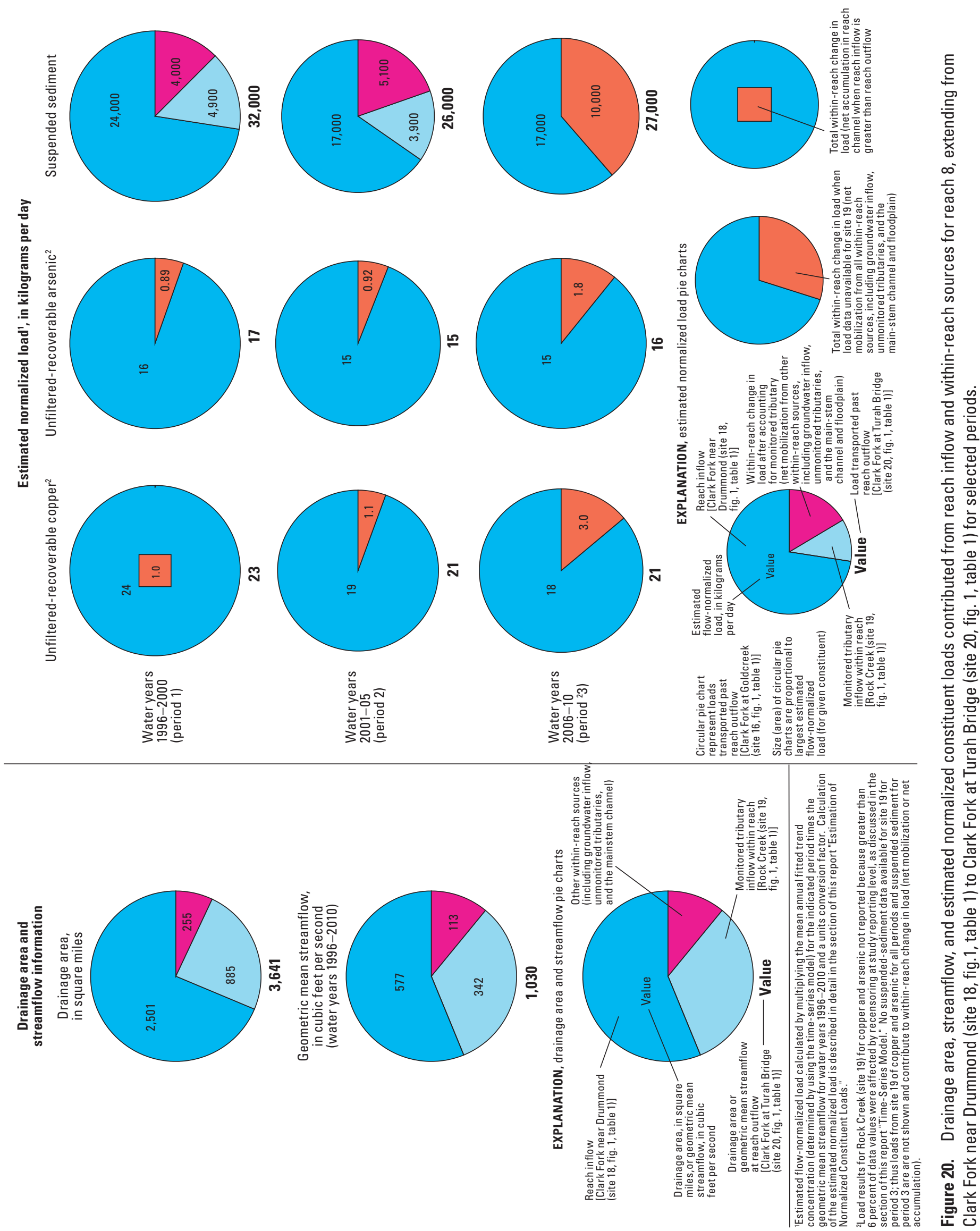
contributions are proportionally much smaller than streamflow contributed from Rock Creek (site 19). Net mobilization from sources within reach 8 increases by about 12 percent from period $1(8,900 \mathrm{~kg} / \mathrm{d})$ to period $3(10,000 \mathrm{~kg} / \mathrm{d})$. Contributions of suspended sediment from sources within reach 8 are proportionally smaller than or similar to streamflow contributed from the within-reach sources. The increases in net mobilization of copper, arsenic, and suspended sediment from sources within reach 8 between periods 2 and 3 are notable and might have been affected by an increased hydraulic gradient (during high streamflow conditions) following the removal of Milltown Dam.

\section{Reach 9}

Sites in reach 9 include the inflow [Clark Fork at Turah Bridge (site 20)], the monitored tributary site [Blackfoot River (site 21)], and the outflow [Clark Fork above Missoula (site 22)]. Trend results for all sites in reach 9 were determined by using the TSM and are presented in tables 4,5 , and $4-1$, figure 21, and also figures 4-20, 4-21, and 4-22, for sites 20 , 21 , and 22, respectively. Transport analysis results for reach 9 are graphically presented in figure 22 .

Trace-element concentrations for Blackfoot River (site 21) are low and typically less than LRLs; thus, no results for copper or arsenic are presented. Trend results for site 21 during periods 1 through 3 indicate a minor decrease (within a small range at low concentrations) in geometric mean FAC of suspended sediment.

The TSM trend results for the reach 9 outflow (site 22) indicate minor to small increases in geometric mean FACs of unfiltered-recoverable copper and arsenic, and suspended sediment from the start of period 1 to the end of period 3 (figs. 21 and 4-22; tables 5 and 4-2). Minor decreases in FACs of unfiltered-recoverable copper and arsenic, and suspended sediment are indicated for period 1 . Minor to moderate increases in FACs of unfiltered-recoverable copper and arsenic, and suspended sediment are indicated for period 2 . The increases in FACs during period 2 might be associated with preliminary remediation activities (including temporary reservoir drawdowns; Sando and Lambing, 2011) in preparation for breaching and subsequent removal of the former Milltown Dam. However, the period 2 increases in FACs also might be affected by smoothing procedures of the TSM that force connectivity of the fitted trend for period 2 with elevated FACs for water 2006 that probably were associated with preliminary drawdown for breaching of the former Milltown Dam. Because of the substantial effect of the breach of Milltown Dam on March 28, 2008, for site 22, period 3 was subdivided into period 3A (October 1, 2005-March 27, 2008) and period 3B (March 28, 2008-September 30, 2010). A large increase in FACs of unfiltered-recoverable copper is indicated for period 3A (associated with the breaching of the former Milltown Dam), from $7.0 \mu \mathrm{g} / \mathrm{L}$ at the start of water year 2006 to $14 \mu \mathrm{g} / \mathrm{L}$ at March 28, 2008. After the breach, a large decrease is indicated for period 3B from 14 to $5.9 \mu \mathrm{g} / \mathrm{L}$ at the end of water year 2010. For unfiltered-recoverable arsenic, a small increase is indicated for period $3 \mathrm{~A}$, from $4.1 \mu \mathrm{g} / \mathrm{L}$ at the start of water year 2006 to $5.1 \mu \mathrm{g} / \mathrm{L}$ at March 28, 2008. After the breach a minor decrease is indicated for period $3 \mathrm{~B}$ from 5.1 to $5.0 \mu \mathrm{g} / \mathrm{L}$ at the end of water year 2010 . For suspended sediment, a large increase is indicated for period $3 \mathrm{~A}$, from 9.4 $\mathrm{mg} / \mathrm{L}$ at the start of water year 2006 to $23 \mathrm{mg} / \mathrm{L}$ at March 28, 2008 , with a large decrease to $9.3 \mathrm{mg} / \mathrm{L}$ at the end of water year 2010. It is notable that for unfiltered-recoverable copper and suspended sediment, FACs at the end of water year 2010 have only a minor increase relative to FACs at the start of water year 1996, which indicates that the sediment and associated metallic contaminants that had accumulated in the former Milltown Reservoir were quickly flushed past the reach 9 outflow (site 22) following the breach of Milltown Dam on March 28, 2008. However, for unfiltered-recoverable arsenic, FAC at the end of water year $2010(5.0 \mu \mathrm{g} / \mathrm{L})$ has a small increase relative to FAC at the start of water year $1996(3.8 \mu \mathrm{g} / \mathrm{L})$. The small increase in FAC of unfiltered-recoverable arsenic might relate to increased contribution from groundwater inflow with elevated arsenic concentrations.

Results of the transport analysis indicate how temporal changes in geometric mean FACs for sites 20, 21, and 22 translate into temporal changes in relative contributions from upstream source areas to the reach 9 outflow loads (fig. 22, table 5-9). Because trace-element concentrations for site 21 are low and typically less than LRLs, no results for copper or arsenic are presented. Thus, for copper and arsenic for all periods, the unquantified contributions from Blackfoot River (site 21) are part of the total undifferentiated contributions from within-reach sources. For unfiltered-recoverable copper, the reach 9 outflow load (site 22) increases by about 100 percent from period $1(25 \mathrm{~kg} / \mathrm{d})$ to period $3(50 \mathrm{~kg} / \mathrm{d})$. Net mobilization of copper from sources with reach 9 is indicated for all periods, increasing from $2.4 \mathrm{~kg} / \mathrm{d}$ in period 1 to $28 \mathrm{~kg} / \mathrm{d}$ in period 3. The increase in net mobilization of copper (and also arsenic and suspended sediment) from sources within reach 9 during period 3 indicates effects of the removal of the former Milltown Dam. For periods 1 and 2, contributions of copper from all sources within reach 9 are proportionally smaller than streamflow contributed from the within-reach sources. For period 3, contributions of copper from all sources within reach 9 are proportionally larger than streamflow contributed from the within-reach sources. For unfiltered-recoverable arsenic, reach 9 outflow load (site 22) increases by about 33 percent from period $1(18 \mathrm{~kg} / \mathrm{d})$ to period $3(24 \mathrm{~kg} / \mathrm{d})$. Net mobilization of arsenic from sources within reach 9 is indicated for all periods, increasing from $1.9 \mathrm{~kg} / \mathrm{d}$ in period 1 to $7.4 \mathrm{~kg} / \mathrm{d}$ in period 3. For all periods, contributions of unfiltered-recoverable arsenic from all sources within reach 9 are proportionally smaller than streamflow contributed from the within-reach sources. For suspended sediment, reach 9 outflow load (site 22) increases by about 97 percent from period 1 $(39,000 \mathrm{~kg} / \mathrm{d})$ to period $3(77,000 \mathrm{~kg} / \mathrm{d})$. Contributions of suspended sediment from Blackfoot River (site 21) have a minor decrease during periods 1 through 3 , and the contributions are 


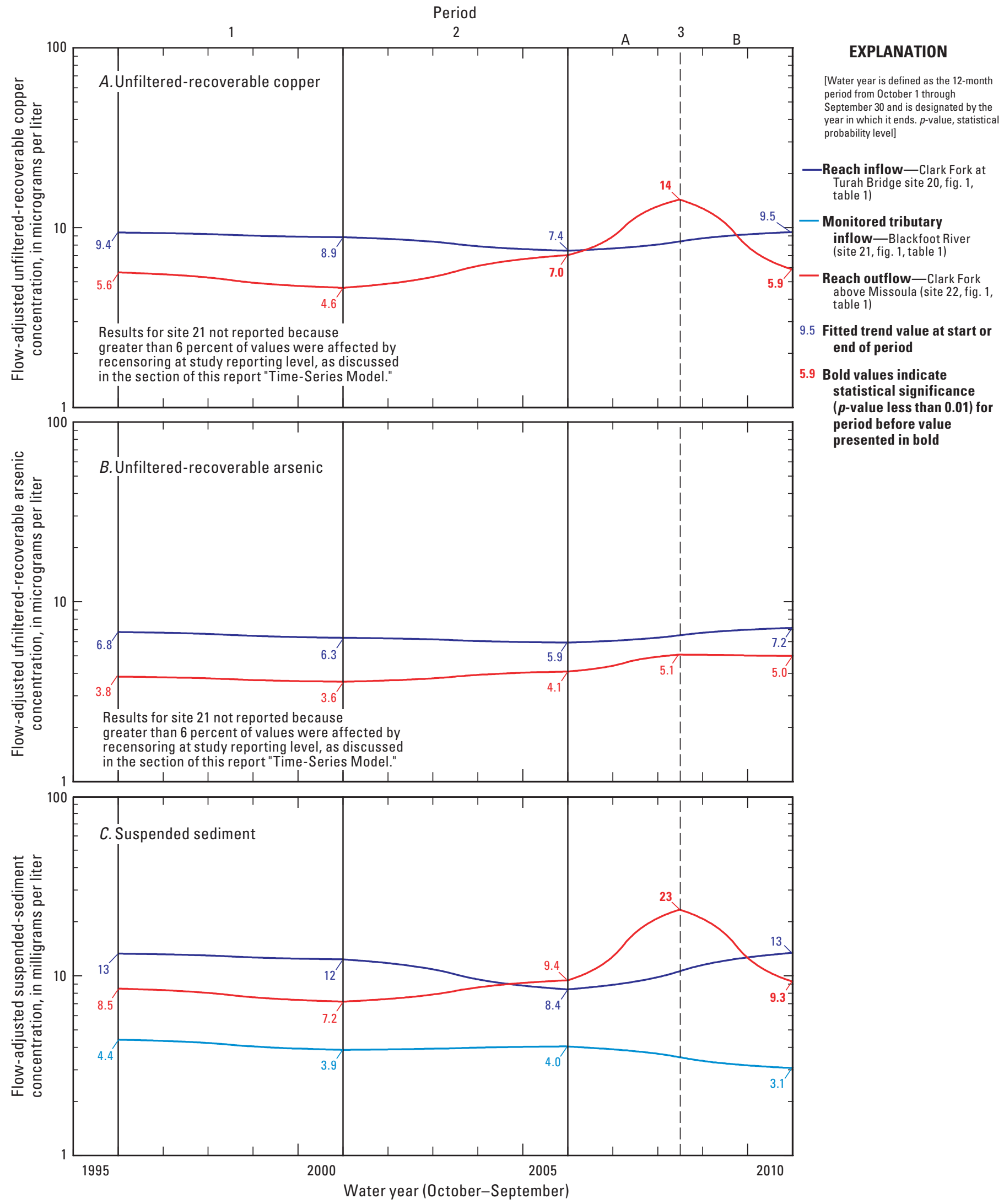

Figure 21. Fitted trends determined by using the time-series model (TSM) for selected constituents for sites in reach 9 , extending from Clark Fork at Turah Bridge (site 20, fig. 1, table 1) to Clark Fork above Missoula (site 22, fig. 1, table 1), based on data collected during water years 1985-2010. 

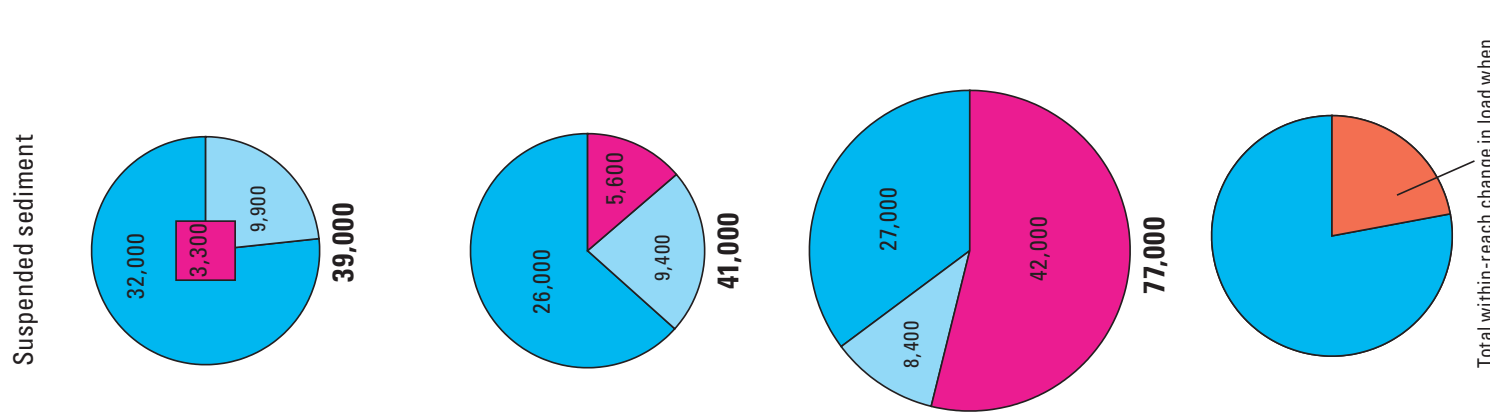

空离
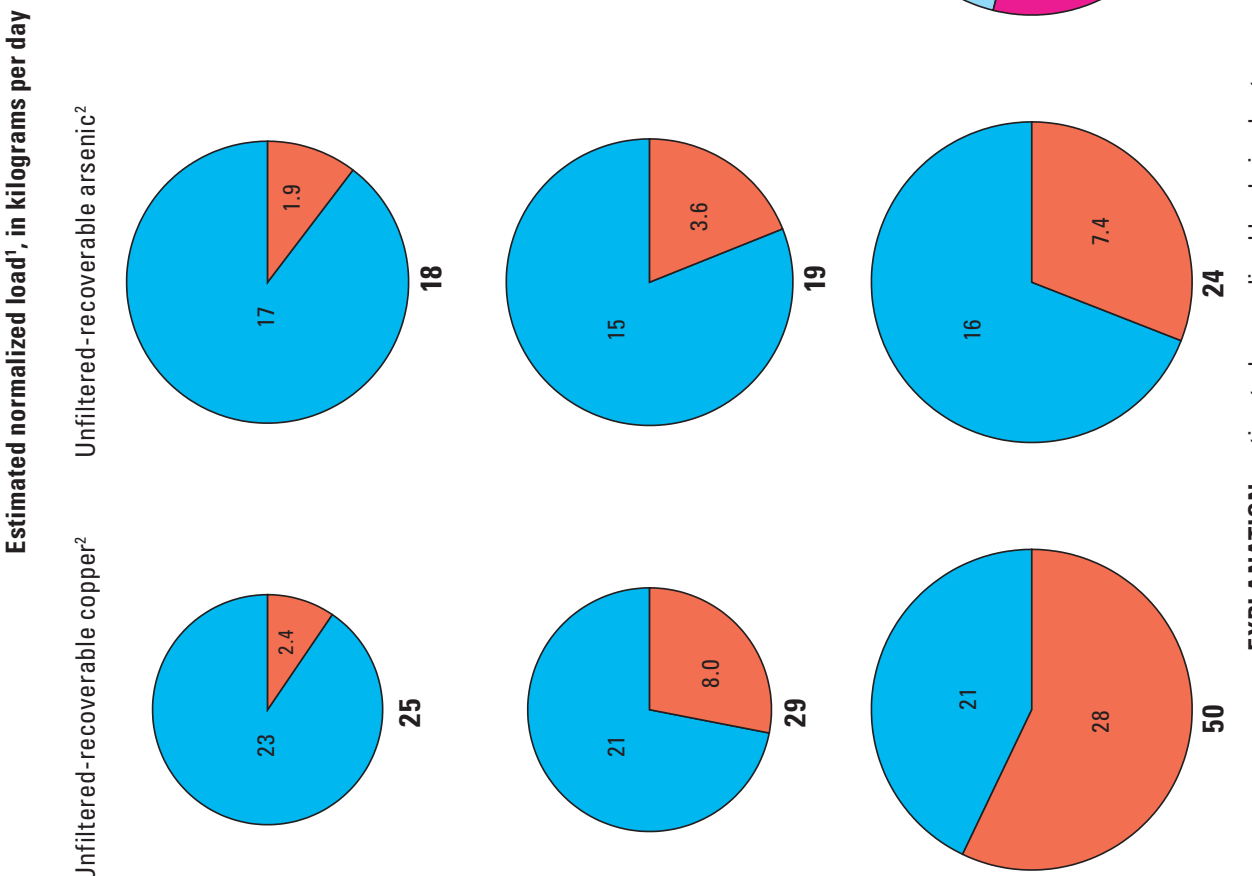

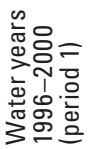
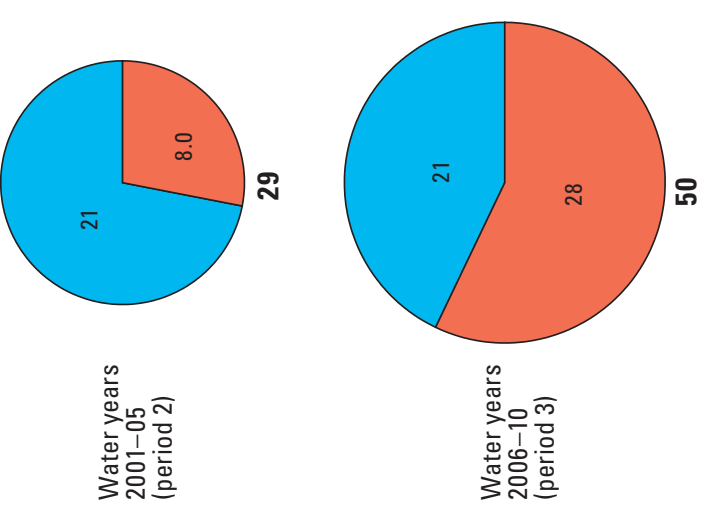

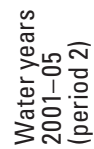
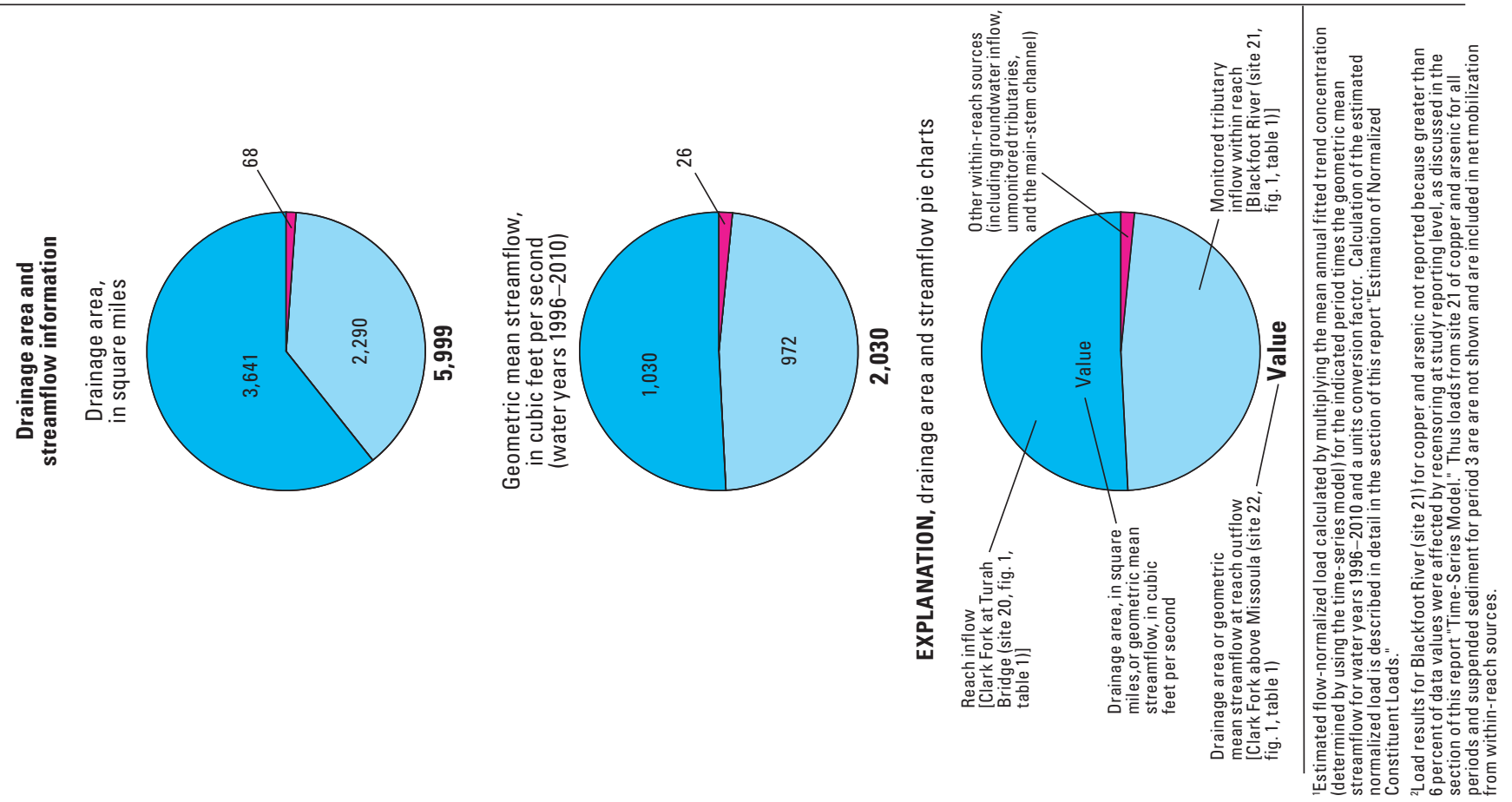
proportionally much smaller than streamflow contributed from Blackfoot River (site 21). Net accumulation of suspended sediment within reach 9 is indicated for period 1, during which the former Milltown Dam was in place. Indication of accumulation of suspended sediment within reach 9 for period 1 but net mobilization of copper from reach 9 for period 1 is difficult to interpret but might be plausible and affected by typical metals and suspended-sediment relations. Metals tend to have higher solid-phase concentrations in fine-grained suspended sediment than in coarse-grained suspended sediment (sand; Horowitz, 1991). In relation to the entire suspended-sediment load (that is, the combined fine-grained and coarse-grained fractions), during high streamflow conditions, fine-grained suspended sediment (with higher solid-phase metal concentrations) might be disproportionately transported through a reservoir, whereas coarse-grained suspended sediment (sand) might be disproportionately deposited in the reservoir. Thus, the transport analysis results for reach 9 for period 1 might be affected by the high-flow conditions during the period and especially by the unusually high-flow conditions of water years 1996-97 early in period 1. For periods 2 and 3, net mobilization of suspended sediment from sources within reach 9 increased from $5,600 \mathrm{~kg} / \mathrm{d}$ in period 2 to $42,000 \mathrm{~kg} / \mathrm{d}$ in period 3 . For periods 2 and 3 , contributions of suspended sediment from sources within reach 9 other than the Blackfoot River (site 21) are proportionally larger than streamflow contributed from the other within-reach sources.

\section{Overview of Water-Quality Trend Results for Data-Summary Reaches}

This section of the report summarizes trend and transport analysis results for the data-summary reaches. In the first part of the section, transport analysis results are concisely summarized with respect to evaluation of within-reach contributions of constituents relative to within-reach contributions of streamflow. In the second part of the section, an overview of temporal changes in FACs and estimated normalized loads is provided, with general discussion of processes and transport characteristics that might contribute to the observed changes.

\section{Summary of Estimated Normalized Loads and Within- Reach Contributions of Constituents and Streamflow}

Pie charts illustrating temporal patterns in estimated normalized loads for all data-summary reaches are presented in figures 23 through 25 for unfiltered-recoverable copper, unfiltered-recoverable arsenic, and suspended sediment, respectively. The estimated normalized loads do not represent actual magnitudes of total mass transport, but rather provide information on relative temporal changes in constituent transport characteristics in the upper Clark Fork Basin quantified with respect to near-median conditions. In figures 23 through 25 , geometric mean streamflow (water years 1996-2010) is shown at the top of each figure, with the size of each pie chart being proportional to the geometric mean streamflow for Clark
Fork above Missoula (site 22; the reach 9 outflow). Pie charts that illustrate transport analysis results for each data-summary reach for periods 1 through 3 are shown below the pie charts showing geometric mean streamflow. Unlike the pie charts presented in the previous sections of this report (figures 6,8 , $10,12,14,16,18,20$, and 22), the simplified constituent-load pie charts in figures 23 through 25 show only the contribution at reach inflow and the total within-reach change in load (reflecting either net accumulation in the main-stem channel or net mobilization from all within-reach sources). Thus, for reaches with monitored tributaries, the contributions from the monitored tributaries are considered part of the total undifferentiated contributions from within-reach sources. Sizes of pie charts illustrating estimated normalized constituent loads are sized proportionally to the period 1 reach 9 outflow. Results for reach 9 are not shown for periods 2 and 3 because of effects on constituent loads of remediation activities associated with the breach and subsequent removal of the former Milltown Dam and difficulties in presenting those results in conjunction with results for other reaches. The pie charts in figures 23 through 25 provide a side-by-side graphical summary for evaluation of spatial and temporal variability in constituent transport relative to streamflow contributions in the upper Clark Fork Basin.

For unfiltered-recoverable copper (fig. 23), contributions from sources within reach 1 are proportionally much larger than within-reach contributions of streamflow. A large decrease in reach 1 outflow is indicated for periods 1 through 3. Contributions of unfiltered-recoverable copper from sources within reach 2 are proportionally much larger than withinreach contributions of streamflow. A moderate decrease in reach 2 outflow is indicated for periods 1 through 3, because of combined effects of a large decrease in unfiltered-recoverable copper load transported from reach 1 and a small decrease in contributions from sources within reach 2 . Within reach 3, most of the unfiltered-recoverable copper load transported from reach 2 is deposited in Warm Springs Ponds. A moderate decrease in both the estimated load of unfilteredrecoverable copper deposited in Warm Springs Ponds and the reach 3 outflow copper load is indicated for periods 1 through 3. Contributions of unfiltered-recoverable copper from sources within reach 4 are proportionally larger than within-reach contributions of streamflow. A small decrease in reach 4 outflow is indicated for periods 1 through 3 , because of combined effects of a moderate decrease in load transported from reach 3 and a minor increase in contributions from sources within reach 4. Contributions of unfiltered-recoverable copper from sources within reach 5 are proportionally much larger than withinreach contributions of streamflow. Minor changes in reach 5 outflow or contributions from sources within reach 5 are indicated for periods 1 through 3 . Contributions of unfiltered-recoverable copper from sources within reach 6 are proportionally smaller than within-reach contributions of streamflow. A small decrease in reach 6 outflow is indicated for periods 1 through 3 , because of combined effects of a minor decrease in load transported from reach 5 and a moderate 


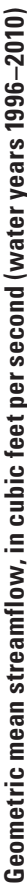
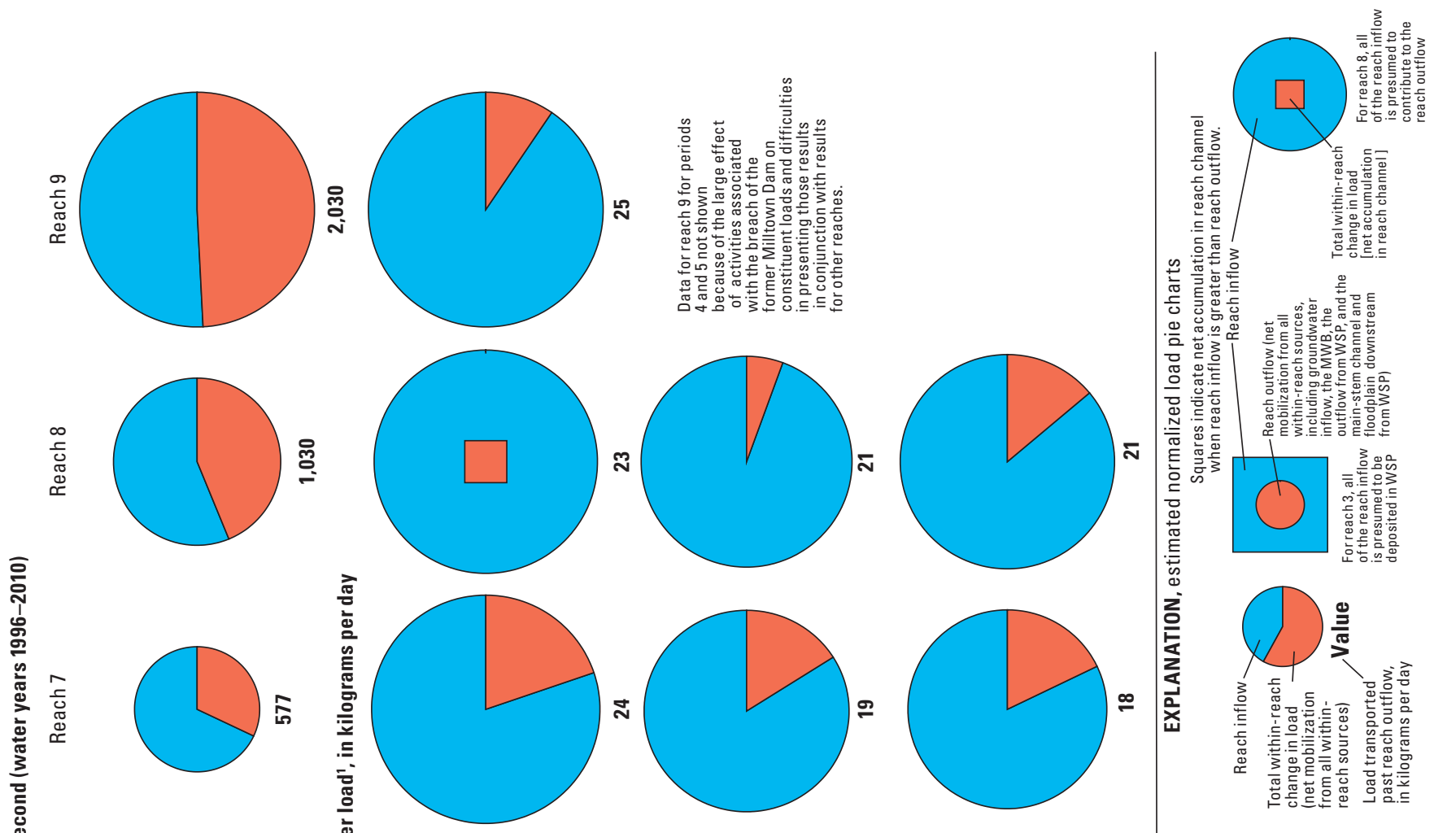

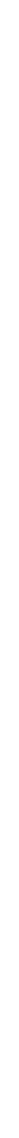

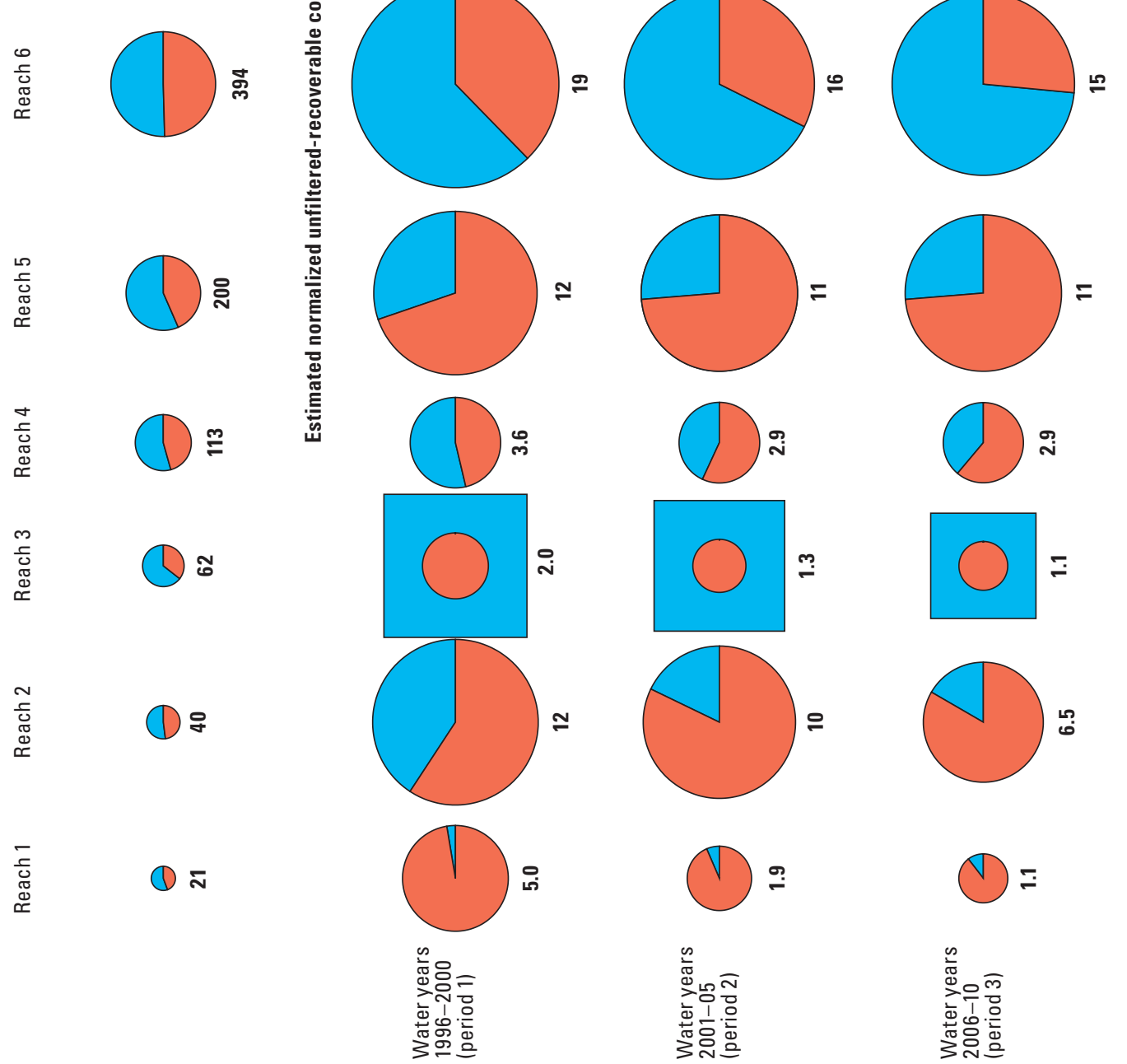

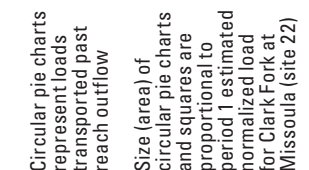

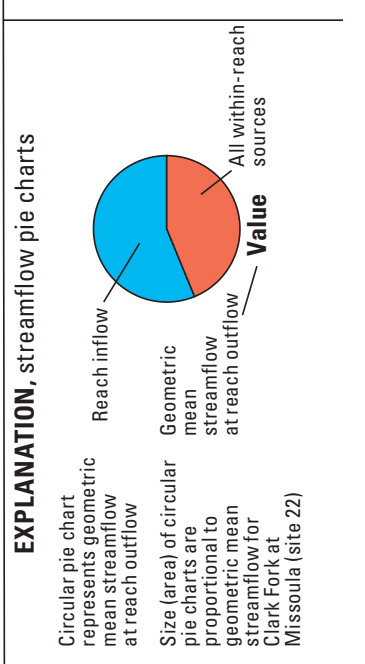

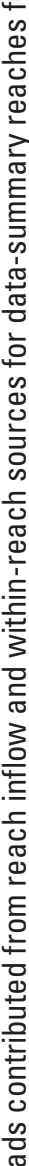

음

흥

음

$\frac{\pi}{\frac{\pi}{2}}$

¿

交

离

․ㅗㅇ

을

离

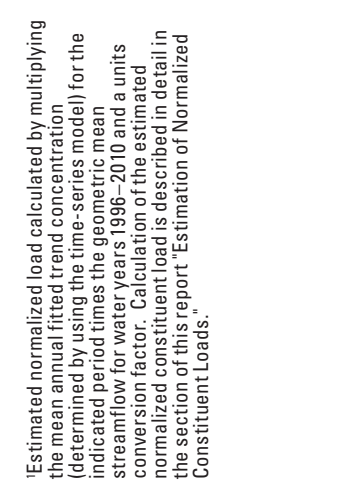




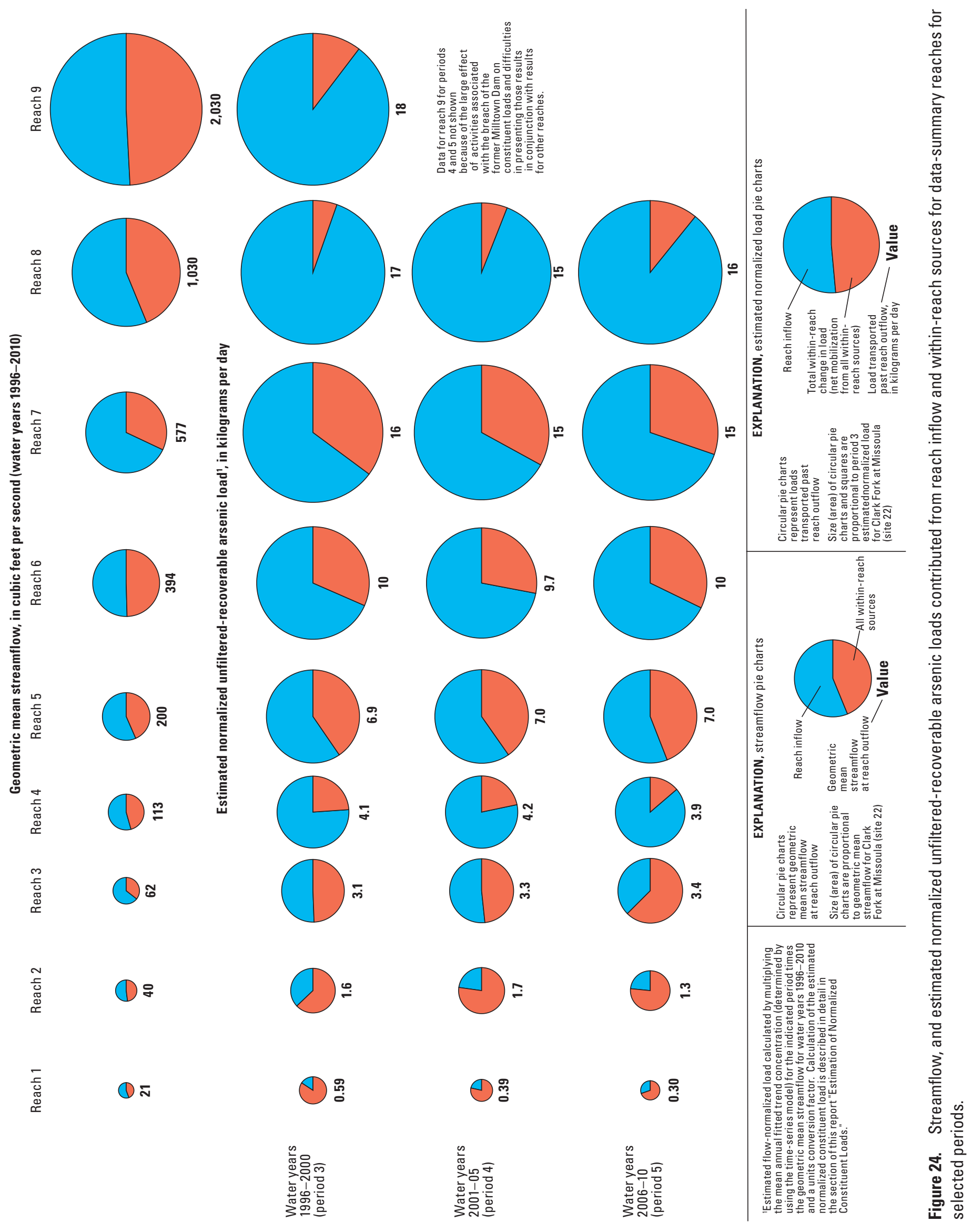




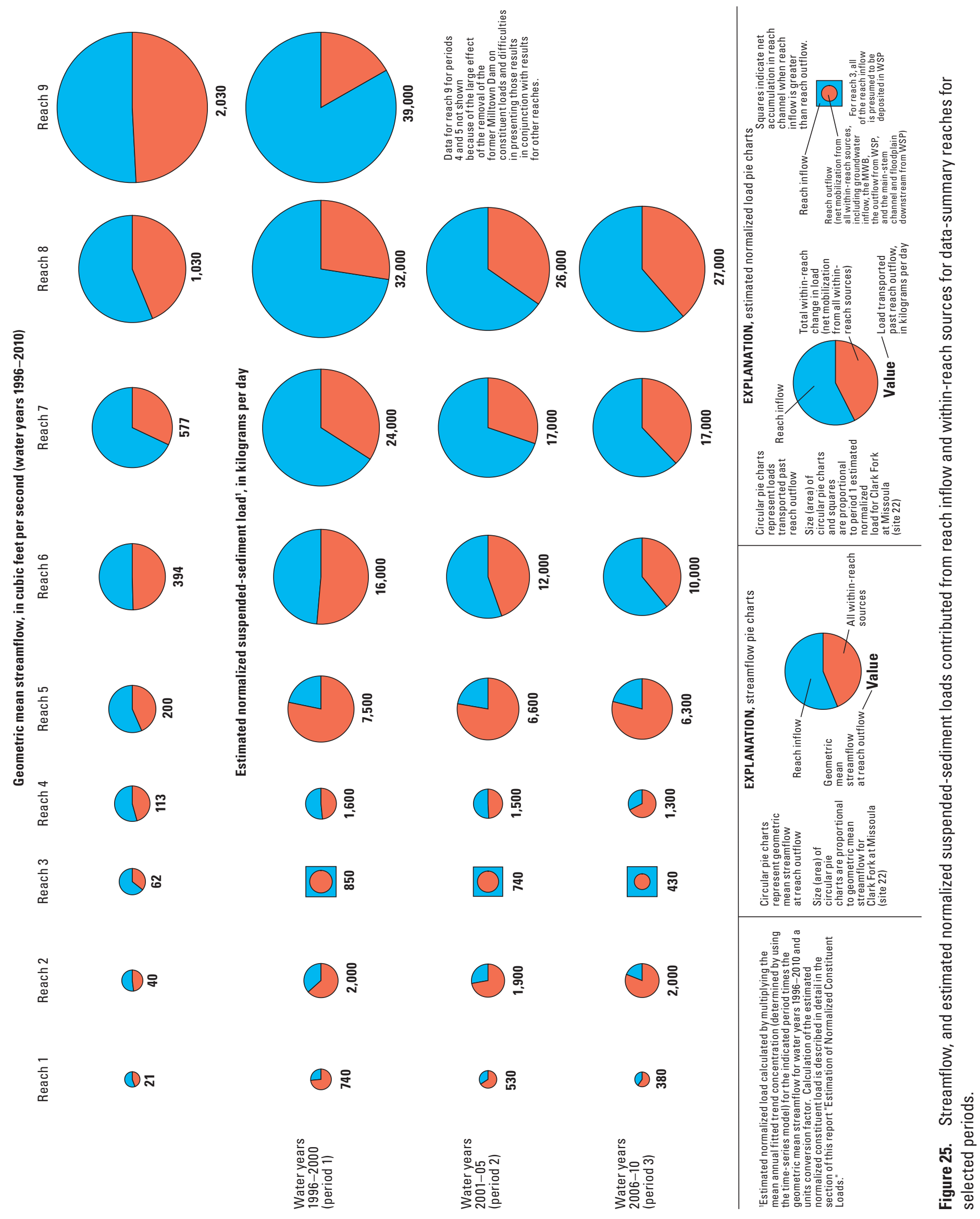


decrease in contributions from sources within reach 6 . Contributions of unfiltered-recoverable copper from sources within reach 7 are proportionally smaller than within-reach contributions of streamflow. A small decrease in reach 7 outflow is indicated for periods 1 through 3 , because of combined effects of a small decrease in load transported from reach 6 and a small decrease in contributions from sources within reach 7 . Contributions of unfiltered-recoverable copper from sources within reach 8 are proportionally smaller than within-reach contributions of streamflow. Accumulation of unfiltered-recoverable copper in the reach 8 main-stem channel for period 1 is difficult to interpret and is not confidently determined. A minor decrease in reach 8 outflow is indicated for periods 1 through 3 , because of combined effects of a small decrease in load transported from reach 7 and a large increase (primarily during period 3 ) in contributions from sources within reach 8 . Contributions of unfiltered-recoverable copper from sources within reach 9 for period 1 are proportionally smaller than within-reach contributions of streamflow. Results for periods 2 and 3 for reach 9 are not presented in figure 23 because of the large effect of the removal of the former Milltown Dam on constituent loads and difficulties in presenting those results in conjunction with results for other reaches.

For unfiltered-recoverable arsenic (fig. 24), contributions from sources within reach 1 are proportionally larger than within-reach contribution of geometric mean streamflow; however, this pattern is much weaker for unfiltered-recoverable arsenic than for unfiltered-recoverable copper. A moderate decrease in reach 1 outflow is indicated for periods 1 through 3 , because of a large decrease in contributions from sources within reach 1. Contributions of unfiltered-recoverable arsenic from sources within reach 2 also are proportionally larger than within-reach contributions of streamflow and, similar to reach 1 , the pattern is weaker for unfiltered-recoverable arsenic than for unfiltered-recoverable copper. A minor decrease in reach 2 outflow is indicated for periods 1 through 3 , because of combined effects of a small decrease in load transported from reach 1 and no change in contributions from sources within reach 2. Contributions of unfiltered-recoverable arsenic from sources within reach 3 are proportionally larger than within-reach contributions of streamflow. A minor increase in reach 3 outflow is indicated for periods 1 through 3, because of combined effects of a small decrease in load transported from reach 2 and a small increase in contributions from sources within reach 3 . Contributions of unfiltered-recoverable arsenic from sources within reach 4 are proportionally smaller than within-reach contributions of streamflow. A minor decrease in reach 4 outflow is indicated for periods 1 through 3 , because of combined effects of a minor increase in load transported from reach 3 and a moderate decrease in contributions from sources within reach 4 . Contributions of unfilteredrecoverable arsenic from sources within reach 5 are proportionally similar to within-reach contributions of streamflow. A minor increase in reach 5 outflow and contributions from sources within reach 5 is indicated for periods 1 through 3 . Contributions of unfiltered-recoverable arsenic from sources within reach 6 are proportionally smaller than within-reach contributions of streamflow. Minor changes in reach 6 outflow or contributions from sources within reach 6 are indicated for periods 1 through 3. Contributions of unfiltered-recoverable arsenic from sources within reach 7 are proportionally similar to within-reach contributions of streamflow. Minor changes in reach 7 outflow or contributions from sources within reach 7 is indicated for periods 1 through 3. Contributions of unfilteredrecoverable arsenic from sources within reach 8 are proportionally smaller than within-reach contributions of streamflow. A minor decrease in reach 8 outflow is indicated for periods 1 through 3 , because of combined effects of a minor decrease in load transported from reach 7 and a large increase (primarily during period 3) in contributions from sources within reach 8 . Contributions of unfiltered-recoverable arsenic from sources within reach 9 for period 1 are proportionally smaller than within-reach contributions of streamflow. Results for periods 2 and 3 for reach 9 are not presented in figure 24 because of the large effect of the removal of the former Milltown Dam on constituent loads and difficulties in presenting those results in conjunction with results for other reaches.

For suspended sediment (fig. 25), contributions from sources within reach 1 are proportionally larger than withinreach contributions of streamflow; however, this pattern is much weaker for suspended sediment than for unfilteredrecoverable copper. A moderate decrease in reach 1 outflow is indicated for periods 1 through 3. Contributions of suspended sediment from sources within reach 2 also are proportionally larger than within-reach contributions of streamflow and, similar to reach 1 , the pattern is weaker for suspended sediment than for unfiltered-recoverable copper. No change in reach 2 outflow is indicated for periods 1 through 3 , because of combined effects of a moderate decrease in load transported from reach 2 and a small increase in contributions from sources within reach 2. Similar to unfiltered-recoverable copper, within reach 3 most of the suspended-sediment load transported from reach 2 is deposited in Warm Springs Ponds. No change in the estimated load of suspended sediment deposited in Warm Springs Ponds is indicated for periods 1 through 3. A moderate decrease in reach 3 outflow is indicated for periods 1 through 3 . Overall for periods 1 through 3 , combined contributions from sources within reach 4 of suspended sediment generally are proportionally similar to or larger than within-reach contributions of streamflow. Large variability in relative source-area contributions is indicated for reach 4 for suspended sediment. A small decrease in reach 4 outflow is indicated for periods 1 through 3. Contributions of suspended sediment from sources within reach 5 are proportionally much larger than within-reach contributions of streamflow. Minor changes in reach 5 outflow or contributions from sources within reach 5 are indicated for periods 1 through 3 . Contributions of suspended sediment from sources within reach 6 are proportionally similar to (period 1) or smaller than (periods 2 and 3 ) within-reach contributions of streamflow. A small decrease in reach 6 outflow is indicated for periods 1 through 3 , because of combined effects of a minor decrease 
in load transported from reach 5 and a moderate decrease in contributions from sources within reach 6 . Contributions of suspended sediment from sources within reach 7 are proportionally similar to within-reach contributions of streamflow. A small decrease in reach 7 outflow is indicated for periods 1 through 3 , because of combined effects of a small decrease in load transported from reach 6 and a small decrease in contributions from sources within reach 7 . Overall for periods 1 through 3, combined contributions from sources within reach 8 of suspended sediment are proportionally smaller than or similar to within-reach contributions of streamflow. A minor decrease in reach 8 outflow is indicated for periods 1 through 3 , because of combined effects of a small decrease in load transported from reach 7 and a minor increase (primarily during period 3 ) in contributions from sources within reach 8 . Combined contributions from sources within reach 9 of suspended sediment for period 1 are proportionally much smaller than within-reach contributions of streamflow. Results for periods 2 and 3 for reach 9 are not presented in figure 25 because of the large effect of the removal of the former Milltown Dam on constituent loads and difficulties in presenting those results in conjunction with results for other reaches.

\section{Overview of Temporal Changes in Flow-Adjusted Concentrations (FACs) and Estimated Normalized Constituent Loads}

The following paragraphs discuss results of trend analysis of FACs in combination with results of the transport analysis to provide an overview of the most substantial findings. With respect to copper and suspended-sediment results for water years 1996-2010, in general most sites have decreases or minor changes in FACs, and increases were uncommon. The most substantial changes indicated in the upper Clark Fork Basin are moderate to large decreases in FACs and loads of copper and suspended sediment in reach 1 outflow (Silver Bow Creek at Butte, site 2). Also indicated are moderate to large decreases in FACs and loads of copper for reach 2 outflow (Silver Bow Creek at Opportunity, site 3), moderate to large decreases in FACs and loads of copper and suspended sediment for reach 3 outflow (Silver Bow Creek at Warm Springs, site 8), and a moderate decrease in the estimated load of copper deposited in Warm Springs Ponds. Accumulation of metallic contaminants and suspended sediment within the Warm Springs Ponds substantially reduces the transport of those constituents to downstream reaches. Generally minor to small decreases in FACs and loads of copper and suspended sediment are indicated for reach 4 outflow (Clark Fork near Galen, site 11).

Reach 5 is a large source of metallic contaminants and suspended sediment, which strongly affects downstream transport of those constituents. Mobilization of copper and suspended sediment from floodplain tailings and the streambed of the Clark Fork and its tributaries within reach 5 results in contribution of those constituents from within reach 5 that is proportionally much larger than the contribution of streamflow from within reach 5 . In reach 5, copper loads in the Clark Fork increase by a factor of about 4 and suspended-sediment loads increase by a factor of about 5 , whereas streamflow increases by a factor of slightly less than 2 . With respect to the effect of reach 5 on downstream constituent transport, copper and suspended-sediment loads sourced from within reach 5 account for about 40 and 20 percent, respectively, of the reach 8 outflow (Clark Fork at Turah Bridge, site 20); whereas, streamflow sourced from within reach 5 accounts for about 8 percent of the reach 8 outflow. During water years 19962010, minor changes in FACs and loads of copper and suspended sediment are indicated for reach 5 outflow (Clark Fork at Deer Lodge, site 14).

For the reaches downstream from reach 5, contributions of copper loads sourced from within the reaches are proportionally less than contributions of streamflow sourced from within the reaches. Thus, the lower reaches contribute proportionally much less than reach 5 to copper loading in the Clark Fork. In general, minor to small changes in loads and FACs of copper and suspended sediment are indicated for outflows of reaches 6, 7, and 8 during water years 1996-2010. Thus, although large decreases in FACs and loads of copper and suspended sediment are indicated upstream from reach 3 , those large decreases are not translated to the more downstream reaches. The effect of reach 5 as a large source of copper and suspended sediment, in combination with general temporal stationarity in those constituents for reach 5 outflow, contributes to this pattern. However, small to moderate decreases in within-reach contributions of copper and suspended-sediment loads are indicated for reaches 6 and 7.

In general, minor changes in FACs of copper and suspended sediment are indicated for reach 9 outflow from the start of water year 1996 to the end of water year 2010. Large magnitude trends are indicated for short periods before and after removal of the former Milltown Dam in March 2008. For the period of remediation activities leading up to the dam removal, copper and suspended-sediment FACs increase by a factor of about 2. For the period after the dam removal, FACs decrease by a similar magnitude, such that at the end of water year 2010 FACs are similar to pre-remediation levels.

With respect to arsenic trend results for water years 1996-2010, in general most sites have minor changes in FACs. The most substantial changes indicated in the upper Clark Fork Basin are small to moderate decreases in FACs and loads of arsenic in outflows of reaches 1 and 2. However, because of consistent loading of arsenic to the main-stem channels of Silver Bow Creek and the Clark Fork throughout the upper Clark Fork Basin, the decreases in FACs in reaches 1 and 2 do not substantially affect downstream transport relations. In general, for reaches downstream from reach 2, minor changes are indicated for FACs and loads of arsenic. Chemical characteristics of the metalloid element arsenic are substantially different from copper and other metallic contaminants. Unlike metallic contaminants, arsenic in streams in the upper Clark Fork Basin typically is mostly in dissolved phase, has less variability in concentrations, and has weaker direct relations 
with suspended-sediment concentrations and streamflow. Thus, arsenic transport characteristics in the upper Clark Fork Basin downstream from reach 2 differ from those of copper, and there is less variability in contributions of arsenic loads sourced from within the different reaches. Downstream from reach 2 , three reaches (reaches 3,5 , and 7) contribute arsenic loads sourced from within their reaches that are proportionally larger than contributions of streamflow sourced from within the reaches. Reach 3 is a relatively large source of arsenic, probably affected by geochemical processes in Warm Springs Ponds in combination with contributions of arsenic from the Mill-Willow bypass. In reach 3, arsenic loads in the Clark Fork increase by a factor of about 2 , whereas streamflow increases by a factor of about 1.5 . With respect to the effect of reach 3 on downstream constituent transport, arsenic loads sourced from within reach 3 account for about 11 percent of the reach 8 outflow; whereas, streamflow sourced from within reach 3 accounts for about 2 percent of the reach 8 outflow. During water years 1996-2010, minor increases in FACs and loads of arsenic are indicated for reach 3 outflow. Reaches 5 and 7 are relatively smaller arsenic source areas than reach 3 . With respect to the effect of reach 5 on downstream constituent transport, arsenic loads sourced from within reach 5 account for about 18 percent of the reach 8 outflow; whereas, streamflow sourced from within reach 5 accounts for about 8 percent of the reach 8 outflow. With respect to the effect of reach 7 on downstream constituent transport, arsenic loads sourced from within reach 7 account for about 30 percent of the reach 8 outflow; whereas, streamflow sourced from within reach 7 accounts for about 18 percent of the reach 8 outflow. During water years 1996-2010, minor changes in FACs and loads of arsenic are indicated for outflows of reaches 5 and 7 .

\section{Summary and Conclusions}

The primary purposes of this report are to (1) characterize temporal trends in flow-adjusted concentrations (filtered and unfiltered) of mining-related contaminants and (2) assess those trends in the context of source areas and transport of those contaminants through the upper Clark Fork Basin. A large-scale trend analysis was done on specific conductance, selected trace elements (arsenic, cadmium, copper, iron, lead, manganese and zinc), and suspended sediment for 22 sites for water years 1996-2010. Trend analysis was conducted by using two parametric methods: the time-series model (Vecchia, 2005) and multiple linear regression on time, streamflow, and season (Helsel and Hirsch, 2002). The report presents background information on mining and remediation activities in the upper Clark Fork Basin, trend-analysis methods, streamflow conditions, and various data-related factors that affect trend results. This information is presented to assist in evaluating trend results; however, it is beyond the scope of this report to provide detailed explanations for all observed temporal changes.
The main-stem Clark Fork begins at the confluence of Silver Bow and Warm Springs Creeks near Warm Springs, Montana and flows about 485 miles through Montana and Idaho. The study area encompasses the upper Clark Fork Basin in west-central Montana upstream from Clark Fork above Missoula (site 22) with a drainage area of 5,999 square miles $\left(\mathrm{mi}^{2}\right)$.

Mining in the upper Clark Fork Basin began in 1864 when small-scale placer mining operations extracted gold from Silver Bow Creek and its tributaries in and near Butte. Large amounts of waste materials enriched with trace elements, including the metallic elements cadmium, copper, lead, and zinc, as well as the metalloid trace element arsenic, were generated from mining operations in the Butte area and the milling and smelting operations in the Anaconda area. Extensive deposition of mining wastes in the Silver Bow Creek and Clark Fork channels and floodplains had substantial effects on water quality. Federal Superfund remediation activities in the upper Clark Fork Basin began in 1983 and have included substantial remediation in the Butte area and removal of the former Milltown Dam near Missoula.

Water-quality data collection by the U.S. Geological Survey began during 1985-88 with the establishment of a small long-term monitoring program that has expanded over time and continued through present (2013). Some substantial changes in field sampling and laboratory analytical methods in the monitoring program occurred before 1993. There have been a total of 22 sites in the monitoring program with variable periods of record. Many of the study sites were not sampled before 1993. To maintain consistency in trend analysis among sites, trend analysis was restricted to the period of water years 1996-2010. In general, during water years 1996-2010 there was reasonable consistency in the frequency and timing of sample collection among the sites to conduct trend analysis. Review of quality-assurance data collected in the monitoring program indicates the data are of suitable quality (with respect to precision, accuracy, and contamination issues) for analysis of long-term trends.

Two parametric trend-analysis methods were used in this study: the time-series model (TSM) and multiple linear regression on time, streamflow, and season (MLR). Both of the trend-analysis methods analyze trends in flow-adjusted concentrations (FACs); that is, the methods compute FACs, estimate best-fit trend lines that represent temporal changes in FACs, and determine statistical significance of changes. The TSM was selected as the preferred trend-analysis method to MLR because it incorporates multiple measures of antecedent and concurrent streamflow. The TSM was used to analyze trends for 15 of the 22 study sites. For seven sites, data requirements of the TSM were not met. In those cases, MLR was used to analyze trends.

To provide temporal resolution of changes in water quality, trend analysis was conducted on three sequential 5-year periods: period 1 (water years 1996-2000); period 2 (water years 2001-05); and period 3 (water years 2006-10). For recently established sites that did not satisfy data requirements 
for the TSM, MLR trend-analysis was conducted on period 3. Because of the substantial effect of the breach of Milltown Dam on March 28, 2008, for Clark Fork above Missoula (site 22), period 3 was subdivided into period 3A (October 1, 2005-March 27, 2008) and period 3B (March 28, 2008-September 30, 2010).

The TSM accounts for many hydrological factors that contribute to complexity in concentration and streamflow relations. In this study, the TSM, was applied as consistently as possible among sites, and is considered to be a useful tool for simplifying the environmental complexity in the upper Clark Fork Basin to provide a large-scale evaluation of general temporal changes in constituent transport independent from streamflow variability. The TSM best-fit trend lines are considered to provide important information beyond the strict statistical characteristics of the trend results (in terms of $p$-values and levels of significance) because they aid comparing and summarizing large-scale patterns among sites.

To assist in the presentation of results, Silver Bow Creek and the Clark Fork were divided into nine reaches based on the location of sites along the main-stems of those streams. The reaches include the following:

- Reach 1, which extends from Blacktail Creek (site 1) to Silver Bow Creek at Butte (site 2), is a 3.5-mile (mi) reach through an area affected by large-scale mining activities in the Butte Area, including the Berkeley Pit. Effluent from the Butte wastewater treatment plant discharges within this reach.

- Reach 2, which extends from Silver Bow Creek below Blacktail Creek (site 2) to Silver Bow Creek at Opportunity (site 3), is a 15-mi reach that meanders through a floodplain with extensive deposits of mining wastes.

- Reach 3, which extends from Silver Bow Creek at Opportunity (site 3) to Silver Bow Creek at Warm Springs (site 8), is a 6-mi reach that passes through Warm Springs Ponds where there is deposition of particulate materials, treatment (liming) to remove metallic elements, and complex biogeochemical processes. Tributary basins within this reach are affected by pollution from milling and smelting operations of the former Anaconda Mining Company (AMC) Smelter. The Mill-Willow bypass diverts the combined flows of Mill Creek and Willow Creek into Silver Bow Creek between the outlet from Warm Springs Ponds and the confluence with Warm Springs Creek.

- Reach 4, which extends from Silver Bow Creek at Warm Springs (site 8) to Clark Fork near Galen (site 11), is short (2-mi), but environmentally complex. In this reach, Warm Springs Creek joins with Silver Bow Creek to form the Clark Fork, and there also is mixing of waters contributed from the Warm Springs Ponds outlet, the Mill-Willow bypass, and Warm Springs Creek. The Warm Springs Creek Basin is affected by pollution from milling and smelting operations of the former AMC Smelter.

- Reach 5, which extends from Clark Fork near Galen (site 11) to Clark Fork at Deer Lodge (site 14), is a 21-mi reach that meanders through a broad valley with extensive floodplain tailings deposits. Lost Creek, which drains a basin affected by pollution from milling and smelting operations of the former AMC Smelter, discharges into this reach.

- Reach 6, which extends from Clark Fork at Deer Lodge (site 14) to Clark Fork at Goldcreek (site 16), is a 26-mi reach with a broad meandering valley from Deer Lodge to Garrison. The Little Blackfoot River discharges into this reach near Garrison and the Clark Fork valley narrows. Downstream from Garrison, floodplain tailings are less extensive than in the valley upstream.

- Reach 7, which extends from Clark Fork at Goldcreek (site 16) to Clark Fork near Drummond (site 18), is a 31-mi reach with less extensive floodplain tailings. Flint Creek discharges into this reach.

- Reach 8, which extends from Clark Fork near Drummond (site 18) to Clark Fork at Turah Bridge (site 20), is a 34-mi reach with little or no visible floodplain tailings. Rock Creek discharges into this reach.

- Reach 9, which extends from Clark Fork at Turah Bridge (site 20) to Clark Fork above Missoula (site 22), is a 9-mi reach that includes the former Milltown Reservoir where substantial amounts of mining wastes had been deposited. The former Milltown Dam was breached and removed in 2008. The Blackfoot River discharges into this reach.

For the reaches and their inclusive sites that were analyzed by using the TSM, normalized loads were estimated to evaluate temporal changes in relative contributions of selected trace elements and suspended sediment from upstream source areas to reach outflows.

Trend results are presented for all constituents investigated; however, in the discussion emphasis is placed on copper, arsenic, and suspended sediment. Copper and arsenic represent large differences in chemical characteristics and are constituents of concern with respect to potential toxicity issues. Also, trend patterns for copper generally are similar to other metallic contaminants. Suspended-sediment data provide information on transport of particulate materials, which is a factor that can strongly affect transport of metallic contaminants because of their tendency to adsorb to particulate materials. For most sites with sufficient periods of data collection, copper, arsenic, and suspended-sediment data met all requirements for application of the TSM.

With respect to copper and suspended-sediment results for water years 1996-2010, in general most sites have 
decreases or minor changes in FACs and increases were uncommon. The most substantial changes indicated in the upper Clark Fork Basin are moderate to large decreases in FACs and loads of copper and suspended sediment in reach 1 outflow (Silver Bow Creek at Butte, site 2). Also indicated are moderate to large decreases in FACs and loads of copper for reach 2 outflow (Silver Bow Creek at Opportunity, site 3), moderate to large decreases in FACs and loads of copper and suspended sediment for reach 3 outflow (Silver Bow Creek at Warm Springs, site 8), and a moderate decrease in the estimated load of copper deposited in Warm Springs Ponds. Accumulation of metallic contaminants and suspended sediment within the Warm Springs Ponds substantially reduces the transport of those constituents to downstream reaches. Generally minor to small decreases in FACs and loads of copper and suspended sediment are indicated for reach 4 outflow (Clark Fork near Galen, site 11).

Reach 5 is a large source of metallic contaminants and suspended sediment, which strongly affects downstream transport of those constituents. Mobilization of copper and suspended sediment from floodplain tailings and the streambed of the Clark Fork and its tributaries within reach 5 results in contribution of those constituents from within reach 5 that is proportionally much larger than the contribution of streamflow from within reach 5. In reach 5, copper loads in the Clark Fork increase by a factor of about 4 and suspended-sediment loads increase by a factor of about 5 , whereas streamflow increases by a factor of slightly less than 2 . With respect to the effect of reach 5 on downstream constituent transport, copper and suspendedsediment loads sourced from within reach 5 account for about 40 and 20 percent, respectively, of the reach 8 outflow (Clark Fork at Turah Bridge, site 20); whereas, streamflow sourced from within reach 5 accounts for about 8 percent of the reach 8 outflow. During water years 1996-2010, minor changes in FACs and loads of copper and suspended sediment are indicated for reach 5 outflow (Clark Fork at Deer Lodge, site 14).

For the reaches downstream from reach 5, contributions of copper loads sourced from within the reaches are proportionally less than contributions of streamflow sourced from within the reaches. Thus, the lower reaches contribute proportionally much less than reach 5 to copper loading in the Clark Fork. In general, minor to small changes in loads and FACs of copper and suspended sediment are indicated for outflows of reaches 6,7 , and 8 during water years 1996-2010. Thus, although large decreases in FACs and loads of copper and suspended sediment are indicated upstream from reach 3 , those large decreases are not translated to the more downstream reaches. The effect of reach 5 as a large source of copper and suspended sediment, in combination with general temporal stationarity in those constituents for reach 5 outflow, contributes to this pattern. However, small to moderate decreases in within-reach contributions of copper and suspended-sediment loads are indicated for reaches 6 and 7.

In general, minor changes in FACs of copper and suspended sediment are indicated for reach 9 outflow from the start of water year 1996 to the end of water year 2010. Large magnitude trends are indicated for short periods before and after removal of the former Milltown Dam in March 2008. For the period of remediation activities leading up to the dam removal, copper and suspended-sediment FACs increase by a factor of about 2. For the period after the dam removal, FACs decrease by a similar magnitude, such that at the end of water year 2010 FACs are similar to pre-remediation levels.

With respect to arsenic trend results for water years 1996-2010, in general, most sites have minor changes in FACs. The most substantial changes indicated in the upper Clark Fork Basin are small to moderate decreases in FACs and loads of arsenic in outflows of reaches 1 and 2. However, because of consistent loading of arsenic to the main-stem channels of Silver Bow Creek and the Clark Fork throughout the upper Clark Fork Basin, the decreases in FACs in reaches 1 and 2 do not substantially affect downstream transport relations. In general, for reaches downstream from reach 2, minor changes are indicated for FACs and loads of arsenic. Chemical characteristics of the metalloid element arsenic are substantially different from copper and other metallic contaminants. Unlike metallic contaminants, arsenic in streams in the upper Clark Fork Basin typically is mostly in dissolved phase, has less variability in concentrations, and has weaker direct relations with suspended-sediment concentrations and streamflow. Thus, arsenic transport characteristics in the upper Clark Fork Basin downstream from reach 2 differ from those of copper, and there is less variability in contributions of arsenic loads sourced from within the different reaches. Downstream from reach 2 , three reaches (reaches 3, 5, and 7) contribute arsenic loads sourced from within their reaches that are proportionally larger than or similar to contributions of streamflow sourced from within the reaches.

Reach 3 is a relatively large source of arsenic, probably affected by geochemical processes in Warm Springs Ponds in combination with contributions of arsenic from the Mill-Willow bypass. In reach 3 , arsenic loads in the Clark Fork increase by a factor of about 2 , whereas streamflow increases by a factor of about 1.5. With respect to the effect of reach 3 on downstream constituent transport, arsenic loads sourced from within reach 3 account for about 11 percent of the

reach 8 outflow; whereas, streamflow sourced from within reach 3 accounts for about 2 percent of the reach 8 outflow. During water years 1996-2010, minor increases in FACs and loads of arsenic are indicated for reach 3 outflow. Reaches 5 and 7 are relatively smaller arsenic source areas than reach 3 . With respect to the effect of reach 5 on downstream constituent transport, arsenic loads sourced from within reach 5 account for about 18 percent of the reach 8 outflow; whereas, streamflow sourced from within reach 5 accounts for about 8 percent of the reach 8 outflow. With respect to the effect of reach 7 on downstream constituent transport, arsenic loads sourced from within reach 7 account for about 30 percent of the reach 8 outflow; whereas, streamflow sourced from within reach 7 accounts for about 18 percent of the reach 8 outflow. During water years 1996-2010, minor changes in FACs and loads of arsenic are indicated for outflows of reaches 5 and 7 . 


\section{References Cited}

Andrews, E.D., 1987, Longitudinal dispersion of trace metals in the Clark Fork River, Montana. Pages 1-13 in R. C. Averett and D. M. McKnight, eds., The chemical quality of water and the hydrologic cycle: Chelsea, Michigan, USA, Lewis Publishers, Inc.

Axtmann, E.V., and Luoma, S.N., 1991, Large-scale distribution of metal contamination in the fine-grained sediments of the Clark Fork River, Montana, U.S.A: Applied Geochemistry, v. 6, p. $75-88$.

CDM, 2005, Second five year review report for Silver Bow Creek/Butte Area Superfund site: CDM, Helena, Montana, 217 p., accessed November 19, 2012, at http://www.epa. gov/superfund/sites/fiveyear/f05-08005.pdf.

Chanat, J.G., Rice, K.C., and Hornberger, G.M, 2002, Consistency of patterns in concentration-discharge plots: Water Resources Research, v. 38, 10 p.

Chatham, J. R., 2012, Chemical cycling and nutrient loading at Warm Springs Ponds (MT): LaPalma, California, Atlantic Richfield Company, 96 p.

Cleveland, W.S., 1985, The elements of graphing data: Monterey, Calif., Wadsworth Books, 323 p.

Cleveland, W.S., and McGill, R., 1984, The many faces of a scatterplot: Journal of the American Statistical Association, v. 79 , p. $807-822$.

Cohn, T.A., 1988, Adjusted maximum likelihood estimation of the moments of lognormal populations from type 1 censored samples: U.S. Geological Survey Open-File Report 88-350, $34 \mathrm{p}$.

Cohn, T. A., 2005, Estimating contaminant loads in riversAn application of adjusted maximum likelihood to type I censored data: Water Resources Research, v. 41, 13 p.

Colby, B.R., 1956, Relationship of sediment discharge to streamflow: U.S. Geological Survey Open-File Report 56-27, $170 \mathrm{p}$.

Dodge, K.A., Hornberger, M.I., and Axtmann, E.V., 1996, Water-quality, bed-sediment, and biological data (October 1994 through September 1995) and statistical summaries of data for streams in the upper Clark Fork Basin, Montana: U.S. Geological Survey Open-File Report 96-432, 109 p., accessed November 19, 2012, at http://pubs.er.usgs.gov/ publication/ofr 96432 .
Dodge, K.A., Hornberger, M.I., and Axtmann, E.V., 1997, Water-quality, bed-sediment, and biological data (October 1995 through September 1996) and statistical summaries of data for streams in the upper Clark Fork Basin, Montana: U.S. Geological Survey Open-File Report 97-552, 91 p., accessed November 19, 2012, at http://pubs.er.usgs.gov/ publication/ofr 97552 .

Dodge, K.A., Hornberger, M.I., and Axtmann, E.V., 1998, Water-quality, bed-sediment, and biological data (October 1996 through September 1997) and statistical summaries of data for streams in the upper Clark Fork Basin, Montana: U.S. Geological Survey Open-File Report 98-407, 102 p., accessed November 19, 2012, at http://pubs.er.usgs.gov/ publication/ofr 98407.

Dodge, K.A., Hornberger, M.I., and Bouse, R.M., 1999, Water-quality, bed-sediment, and biological data (October 1997 through September 1998) and statistical summaries of data for streams in the upper Clark Fork Basin, Montana: U.S. Geological Survey Open-File Report 99-251, 102 p., accessed November 19, 2012, at http://pubs.er.usgs.gov/ publication/ofr 99251 .

Dodge, K.A., Hornberger, M.I., and David, C.P.C., 2000, Water-quality, bed-sediment, and biological data (October 1998 through September 1999) and statistical summaries of data for streams in the upper Clark Fork Basin, Montana: U.S. Geological Survey Open-File Report 00-370, 102 p., accessed November 19, 2012, at http://pubs.er.usgs.gov/ publication/ofro0370.

Dodge, K.A., Hornberger, M.I., and David, C.P.C., 2001, Water-quality, bed-sediment, and biological data (October 1999 through September 2000) and statistical summaries of data for streams in the upper Clark Fork Basin, Montana: U.S. Geological Survey Open-File Report 01-379, 95 p., accessed November 19, 2012, at http://pubs.er.usgs.gov/ publication/ofro1379.

Dodge, K.A., Hornberger, M.I., and David, C.P.C., 2002, Water-quality, bed-sediment, and biological data (October 2000 through September 2001) and statistical summaries of data for streams in the upper Clark Fork Basin, Montana: U.S. Geological Survey Open-File Report 02-358, 94 p., accessed November 19, 2012, at http://pubs.er.usgs.gov/ publication/ofro2358.

Dodge, K.A., Hornberger, M.I., and Lavigne, I.R., 2003, Water-quality, bed-sediment, and biological data (October 2001 through September 2002) and statistical summaries of data for streams in the upper Clark Fork Basin, Montana: U.S. Geological Survey Open-File Report 03-356, 95 p., accessed November 19, 2012, at http://pubs.er.usgs.gov/ publication/ofro3356. 
Dodge, K.A., Hornberger, M.I., and Lavigne, I.R., 2004, Water-quality, bed-sediment, and biological data (October 2002 through September 2003) and statistical summaries of data for streams in the upper Clark Fork Basin, Montana: U.S. Geological Survey Open-File Report 2004-1340, 107 p., accessed November 19, 2012, at http://pubs.er.usgs. gov/publication/ofr20041340.

Dodge, K.A., Hornberger, M.I., and Dyke, J.L., 2005, Waterquality, bed-sediment, and biological data (October 2003 through September 2004) and statistical summaries of data for streams in the upper Clark Fork Basin, Montana: U.S. Geological Survey Open-File Report 2005-1356, 124 p., accessed November 19, 2012, at http://pubs.usgs. gov/of/2005/1356.

Dodge, K.A., Hornberger, M.I., and Dyke, J.L., 2006, Waterquality, bed-sediment, and biological data (October 2004 through September 2005) and statistical summaries of data for streams in the upper Clark Fork Basin, Montana: U.S. Geological Survey Open-File Report 2006-1266, 109 p., accessed November 19, 2012, at http://pubs.usgs. gov/of/2006/1266.

Dodge, K.A., Hornberger, M.I., and Dyke, J.L., 2007, Waterquality, bed-sediment, and biological data (October 2005 through September 2006) and statistical summaries of longterm data for streams in the Clark Fork Basin, Montana: U.S. Geological Survey Open-File Report 2007-1301, 124 p., accessed November 19, 2012, at http://pubs.usgs. gov/of/2007/1301.

Dodge, K.A., Hornberger, M.I., and Dyke, J.L., 2008, Waterquality, bed-sediment, and biological data (October 2006 through September 2007) and statistical summaries of longterm data for streams in the Clark Fork Basin, Montana: U.S. Geological Survey Open-File Report 2008-1318, 132 p., accessed November 19, 2012, at http://pubs.usgs. gov/of/2008/1318.

Dodge, K.A., Hornberger, M.I., and Dyke, J.L., 2009, Waterquality, bed-sediment, and biological data (October 2007 through September 2008) and statistical summaries of longterm data for streams in the Clark Fork Basin, Montana: U.S. Geological Survey Open-File Report 2009-1178, 139 p., accessed November 19, 2012, at http://pubs.usgs. gov/of/2009/1178.

Dodge, K.A., Hornberger, M.I., and Dyke, J.L., 2010, Waterquality, bed-sediment, and biological data (October 2008 through September 2009) and statistical summaries of longterm data for streams in the Clark Fork Basin, Montana: U.S. Geological Survey Open-File Report 2010-1267, 137 p., accessed November 19, 2012, at http://pubs.usgs. gov/of/2010/1267.
Dodge, K.A., Hornberger, M.I., and Dyke, J.L., 2012, Waterquality, bed-sediment, and biological data (October 2009 through September 2010) and statistical summaries of data for streams in the Clark Fork Basin, Montana: U.S. Geological Survey Open-File Report 2011-1314, 120 p., accessed November 19, 2012, at http://pubs.usgs.gov/of/2011/1314.

Fishman, M.J., 1993, Methods of analysis by the U.S. Geological Survey National Water Quality Laboratory-Determination of inorganic and organic constituents in water and fluvial sediments: U.S. Geological Survey Open-File Report 93-125, $217 \mathrm{p}$.

Freeman, H.C., 1900, A brief history of Butte, Montana-The world's greatest mining company: Henry O. Shepard Company, Chicago, Illinois, $128 \mathrm{p}$.

Gammons, C.H., Shope, C.L., and Duaime, T.E., 2005, A 24 $\mathrm{h}$ investigation of the hydrogeochemistry of baseflow and stormwater in an urban area impacted by mining-Butte, Montana: Hydrological Processes, v. 19, p. 2737-2753.

Gammons, C.H., Metesh, J.J., and Duaime, T.E., 2006, An overview of the mining history and geology of Butte, Montana: Mine Water and the Environment, v. 25, p. 70-75, accessed November 19, 2012, at http://www.springerlink. com/content/ml854q9059116586/.

Gammons, C.H., Grant, T.M., Nimick, D.A., Parker, S.R., and DeGrandpre, M.D., 2007, Diel changes in water chemistry in an arsenic-rich stream and treatment-pond system: Science of the Total Environment, v. 384, p. 434-451.

Gammons, C.H., Babcock, J.N., Parker, S.R., and Poulson, S.R., 2011, Diel cycling and stable isotopes of dissolved oxygen, dissolved inorganic carbon, and nitrogenous species in a stream receiving treated municipal sewage: Chemical Geology, v. 283, p. 44-55.

Garbarino, J.R., Struzeski, T.M., 1998, Methods of analysis by the U.S. Geological Survey National Water Quality Laboratory-Determination of elements in whole-water digests using inductively coupled plasma-optical emission spectrometry and inductively coupled plasma-mass spectrometry: U.S. Geological Survey Open-File Report 98-165, $101 \mathrm{p}$.

Garbarino, J.R., Kanagy, L.K., and Cree, M.E., 2006, Determination of elements in natural-water, biota, sediment, and soil samples using collision/reaction cell inductively coupled plasma-mass spectrometry: U.S. Geological Survey Techniques and Methods, book 5, chap. 1B, 88 p.

Helsel, D.R., 2005, Nondetects and data analysis-Statistics for censored environmental data: New York, John Wiley and Sons, $250 \mathrm{p}$. 
Helsel, D.R., and Hirsch, R.M., 2002, Statistical methods in water resources: Techniques of Water-Resources Investigations of the United States Geological Survey, book 4, chap. A3, 510 p.

Hirsch, R.M., and Slack, J.R., 1984, A nonparametric trend test for seasonal data with serial dependence: Water Resources Research, v. 20, p. 717-732.

Hoffman, G.L., Fishman, M.J., and Garbarino, J.R., 1996, Methods of analysis by the U.S. Geological Survey National Water Quality Laboratory - In-bottle digestion of wholewater samples: U.S. Geological Survey Open-File Report 96-225, $28 \mathrm{p}$.

Hooper, M.J., Cobb, G.P., and McMurry, S.T., 2002, Wildlife biomonitoring at the Anaconda Smelter site, Deer Lodge County, Montana: Final Report of the Institute of Environmental and Human Health, Texas Tech University, 380 p., accessed November 19, 2012, at http://www.fws. gov/montanafieldoffice/Environmental_Contaminants/ABR/ ABR_Final_Report.pdf.

Hornberger, M.I., Lambing, J.H., Luoma, J.H., and Axtmann, E.V., 1997, Spatial and temporal trends of trace metals in surface water, bed sediment, and biota of the upper Clark Fork Basin, Montana, 1985-95: U.S. Geological Survey Open-File Report 97-669, 127 p., accessed November 19, 2012, at http://pubs.er.usgs.gov/publication/ofr97669.

Horowitz, A.J., 1991, A primer on sediment-trace element chemistry (2nd ed.): Chelsea, Mich., Lewis Publishers, Inc., $136 \mathrm{p}$.

Lambing, J.H., 1987, Water-quality data for the Clark Fork and selected tributaries from Deer Lodge to Milltown, Montana, March 1985 through June 1986: U.S. Geological Survey Open-File Report 87-110, 48 p., accessed November 19, 2012, at http://pubs.er.usgs.gov/publication/ ofr 87110 .

Lambing, J.H., 1988, Water-quality data (July 1986 through September 1987) and statistical summaries (March 1985 through September 1987) for the Clark Fork and selected tributaries from Deer Lodge to Missoula, Montana: U.S. Geological Survey Open-File Report 88-308, 55 p., accessed November 19, 2012, at http://pubs.er.usgs.gov/ publication/ofr 88308 .

Lambing, J.H., 1989, Water-quality data (October 1987 through September 1988) and statistical summaries (March 1985 through September 1988) for the Clark Fork and selected tributaries from Galen to Missoula, Montana: U.S. Geological Survey Open-File Report 89-229, 51 p., accessed November 19, 2012, at http://pubs.er.usgs.gov/ publication/ofr89229.
Lambing, J.H., 1990, Water-quality data (October 1988 through September 1989) and statistical summaries (March 1985 through September 1989) for the Clark Fork and selected tributaries from Galen to Missoula, Montana: U.S. Geological Survey Open-File Report 90-168, 68 p., accessed November 19, 2012, at http://pubs.er.usgs.gov/ publication/ofr 90168 .

Lambing, J.H., 1991, Water-quality and transport characteristics of suspended sediment and trace elements in streamflow of the upper Clark Fork Basin from Galen to Missoula, Montana, 1985-90: U.S. Geological Survey WaterResources Investigations Report 91-4139, 73 p., accessed November 19, 2012, at http://pubs.er.usgs.gov/publication/ wri914139.

Lambing, J.H., Hornberger, M.I., Axtmann, E.V., and Pope, D.A., 1994, Water-quality, bed-sediment, and biological data (October 1992 through September 1993) and statistical summaries of water-quality data (March 1985 through September 1993) for streams in the upper Clark Fork Basin, Montana: U.S. Geological Survey Open-File Report 94-375, 85 p., accessed November 19, 2012, at http://pubs. er.usgs.gov/publication/ofr 94375 .

Lambing, J.H., Hornberger, M.I., Axtmann, E.V., and Dodge, K.A., 1995, Water-quality, bed-sediment, and biological data (October 1993 through September 1994) and statistical summaries of data for streams in the upper Clark Fork Basin, Montana: U.S. Geological Survey Open-File Report 95-429, 104 p., accessed November 19, 2012, at http:// pubs.er.usgs.gov/publication/ofr95429.

Lambing, J.H., 1998, Estimated 1996-97 and long-term average annual loads for suspended sediment and selected trace metals in streamflow of the upper Clark Fork Basin from Warm Springs to Missoula, Montana: U.S. Geological Survey Water-Resources Investigations Report 98-4137, 35 p., accessed November 19, 2012, at http://pubs.er.usgs. gov/publication/wri984137.

Lambing, J.H., and Sando, S.K., 2008, Estimated loads of suspended sediment and selected trace elements transported through Milltown Reservoir in the upper Clark Fork basin, Montana, water years 2004-07: U.S. Geological Survey Scientific Investigations Report 2008-5080, 24 p., accessed November 19, 2012, at http://pubs.usgs.gov/sir/2008/5080.

Lambing, J.H., and Sando, S.K., 2009, Estimated loads of suspended sediment and selected trace elements transported through Milltown Reservoir project area before and after the breaching of Milltown Dam in the upper Clark Fork basin, Montana, water year 2008: U.S. Geological Survey Scientific Investigations Report 2009-5095, 30 p., accessed November 19, 2012, at http://pubs.usgs.gov/sir/2009/5095. 
Montana Department of Environmental Quality, 2012a, DEQ - 7 Montana numeric water quality standards: Helena, Montana, Water Quality Planning Bureau, Water Quality Standards Section, $76 \mathrm{p}$.

Montana Department of Environmental Quality, 2012b, Silver Bow Creek Newsletter, Spring 2012 update: Helena, Montana, $8 \mathrm{p}$.

Naughton, J.P., 2013, Salmonid response to Superfund remediation in Silver Bow Creek, Montana: Bozeman, Montana State University, M.S. thesis, 166 p.

Nimick, D.A., 1993, Hydrology and water chemistry of shallow aquifers along the upper Clark Fork, western Montana: U.S. Geological Survey Water-Resources Investigations Report 93-4052, 63 p.

Nimick, D.A., and Moore, J.N., 1994, Stratigraphy and chemistry of sulfidic flood-plain sediments in the upper Clark Fork valley, Montana, in Alpers, C.N., and Blowes, D.W., eds., Environmental geochemistry of sulfide oxidation: Washington, D.C., American Chemical Society Symposium Series 550, p. 276-288.

PRISM Climate Group, 2012, PRISM Products Matrix: accessed January 23, 2012, at http://www.prism.oregonstate. edu/products $/$ matrix.phtml ? vartype $=$ ppt\&view $=$ data .

Sando, S.K., and Lambing, J.H., 2011, Estimated loads of suspended sediment and selected trace elements transported through the Clark Fork Basin, Montana, in selected periods before and after the breach of Milltown Dam (water years 1985-2009): U.S. Geological Survey Scientific Investigations Report 2011-5030, 64 p., accessed November 19, 2012, at $h t t p: / / p u b s . u s g s . g o v /$ sir/2011/5030.

Smith, J.D., Lambing, J.H., Nimick, D.A., Parrett, Charles, Ramey, Michael, Schafer, William, 1998, Geomorphology, flood-plain tailings, and metal transport in the upper Clark Fork Valley, Montana: U.S. Geological Survey WaterResources Investigations Report 98-4170, 56 p., accessed November 19, 2012, at http://pubs.er.usgs.gov/publication/ wri 984170 .

Stumm, Werner, and Morgan, J.J., 1970, Aquatic ChemistryAn introduction emphasizing chemical equilibria in natural water: John Wiley and Sons, New York, 583 p.

Tasker, G.D., 1978, Relation between standard errors in log units and standard errors in percent: U.S. Geological Survey Water Resources Division Bulletin, January-March 1978, p. $86-87$.

Titan Environmental Corporation, 1995, Silver Bow Creek/ Butte Area NPL Site-Streamside Tailings Operable Unit RI/ FS, Draft remedial investigation report: Bozeman, Montana, unpublished report prepared for ARCO, v. 1 of 2, 413 p.
U.S. Environmental Protection Agency, 2000, Five-Year Review Report, Silver Bow Creek/Butte Area Superfund Site with emphasis on the Warm Springs Ponds performance review: Helena, Montana, U.S. Environmental Protection Agency, Region 8, 266 p., accessed November 19, 2012, at http://www.epa.gov/superfund/sites/fiveyear/f00-08009.pdf.

U.S. Environmental Protection Agency, 2004, Milltown Reservoir Sediments Operable Unit of the Milltown Reservoir/ Clark Fork River Superfund Site-Record of Decision, Part 2: U.S. Environmental Protection Agency Decision Summary, 141 p., accessed November 19, 2012, at http:// www.epa.gov/region $8 /$ superfund/mt/milltown/mrsrod.html.

U.S. Environmental Protection Agency, 2005, Second FiveYear Review Report, Silver Bow Creek/Butte Area Superfund Site: Helena, Montana, U.S. Environmental Protection Agency, Region 8, 217 p., accessed November 19, 2012, at http://www.epa.gov/superfund/sites/fiveyear/f05-08005.pdf.

U.S. Environmental Protection Agency, 2010, Five-Year Review Report, Anaconda Smelter National Priority List Site, Deer Lodge County, Montana: Helena, Montana, U.S. Environmental Protection Agency, Region 8, 104 p., accessed November 19, 2012, at http://www.epa.gov/region8/superfund/mt/anaconda/ Anaconda_4th5YrRevReport2010_text.pdf.

U.S. Environmental Protection Agency, 2012, Clark Fork River Operable Unit: accessed November 19, 2012, at http://www.epa.gov/Region8/superfund/mt/milltowncfr/cfr/.

U.S. Environmental Protection Agency, 2013, Milltown reservoir sediments: accessed November 22, 2013, at http:// www2.epa.gov/region8/milltown-reservoir-sediments.

U.S. Geological Survey, 2012a, National Hydrography Dataset: accessed November 19, 2012, at http://nhd.usgs.gov/.

U.S. Geological Survey, 2012b, USGS surface-water data for Montana accessed November 19, 2012, at http://nwis. waterdata.usgs.gov/mt/nwis/sw.

U.S. Geological Survey, 2012c, National Water Information System (NWIS): accessed November 19, 2012, at http:// waterdata.usgs.gov/nwis.

U.S. Geological Survey, variously dated, National field manual for the collection of water-quality data: U.S. Geological Survey Techniques of Water-Resources Investigations, book 9, chaps. A1-A9, 2 v. [variously paged]. (Also available at http://pubs.water.usgs.gov/twri9A. Chapters originally were published from 1997-1999; updates and revisions are ongoing and are summarized at http://water.usgs.gov/owq/ FieldManual/mastererrata.html. 
Vecchia, A.V., 2003, Water-quality trend analysis and sampling design for streams in North Dakota: U.S. Geological Survey Water-Resources Investigations Report 03-4094, $79 \mathrm{p}$.

Vecchia, A.V., 2005, Water-quality trend analysis and sampling design for streams in the Red River of the North Basin, Minnesota, North Dakota, and South Dakota, 1970-2001: U.S. Geological Survey Scientific Investigations Report 2005-5224, 60 p.
Woods, A.J., Omernik, J.M., Nesser, J.A., Shelden, James, Comstock, J.A., Azevedo, S.H., 2002, Ecoregions of Montana, (2d ed.): U.S. Environmental Protection Agency, Western Ecology Division, accessed November 19, 2012, at http://www.epa.gov/wed/pages/ecoregions/mt_eco.htm. 

Appendixes 1-5 


\section{Appendix 1-Summary Information Relating to Quality-Control, Water- Quality, and Continuous Streamflow Data}

Summary information is presented relating to qualitycontrol, water-quality, and continuous streamflow data. Results for quality-control equipment blank and replicate samples collected during water years 1993-2010 are summarized in table 1-1. Spike recoveries for laboratory-spiked deionizedwater blank samples collected during water years 1993-2010 are presented in table 1-2. Spike recoveries for laboratoryspiked stream-water blank samples collected during water years 1993-2010 are presented in table 1-3. Statistical summaries of water-quality data collected during water years 2001-10 are presented in table 1-4. For reference, aquatic life standards (based on median hardness for water years 2001-10, Montana Department of Environmental Quality, 2012a) are presented in table 1-5. Statistical summaries of continuous streamflow data collected during water years 2001-10 are presented in table 1-6.

Evaluation of long-term spike-recovery data is of particular relevance to the long-term trend analysis. Spike-recoveries during water years 1993-2010 for laboratory-spiked deionized-water blank samples (table 1-2 and fig. 1-1) and laboratory-spiked stream-water samples (table 1-3 and fig. 1-2) indicate generally consistent recoveries over time, typically varying within plus or minus 10 percent of 100 percent recovery. However, before about water year 2000, spike recoveries for unfiltered-recoverable copper in spiked streamwater samples generally were near 100 percent (mean annual spike recovery for water years 1993-1999 of 99.1 percent), whereas after about water year 2000, spike recoveries were consistently less than 100 percent (mean annual spike recovery for water years 2000-2010 of 93.9 percent). Changes in spike recoveries in about water year 2000 probably were related to a change in about water year 2000 by the U.S. Geological Survey National Water Quality Laboratory from analysis of most metallic elements by graphite furnace atomic absorption spectrophotometry (Fishman, 1993) to inductively coupled plasma-mass spectrometry (Garbarino and Struzeski, 1998; Garbarino and others, 2006). Potential effects on trend results of differences in spike recoveries between pre-2000 and post2000 data relate only to sites with long-term data that were analyzed by using the TSM.

The potential effects of temporal differences in spike recoveries on trend results were evaluated by using two approaches: (1) exploratory TSM analysis with inclusion of a step trend in the trend model, and (2) exploratory TSM analysis on constituent concentrations adjusted based on annual mean spike recoveries. For the exploratory step-trend approach, for each site and constituent combination a step trend for the period water years 1996-1999 was included in the TSM model in addition to including applicable trends for periods 1 through 3 (depending on available data for the given site and constituent combination). Inclusion of a step trend allowed evaluation of whether there was a distinct change in data structure between pre- 2000 and post- 2000 data that might have affected trend results. Results of the exploratory steptrend analysis indicated that for all site and constituent combinations, the step trend was nonsignificant, and inclusion of the step trend had minor effects on trend results with respect to magnitude, direction, and significance on constituent concentration trends. For the exploratory spike-recovery adjustment approach, before TSM analysis constituent concentrations for each year were adjusted by multiplying the concentrations divided by the annual mean spike recovery for laboratoryspiked stream-water samples. Results of the exploratory spike-recovery adjustment analysis were more variable than results for the exploratory step-trend approach but resulted in the same general conclusion that temporal differences in spike recoveries had minor effects on trend results. 
Table 1-1. Summary information relating to quality-control samples (equipment blank and replicate samples) collected at sites in the upper Clark Fork Basin, Montana, based on data collected during water years 1993-2010.

[Water year is the 12-month period from October 1 through September 30 and is designated by the year in which it ends. LRL, laboratory reporting level; SRL, study reporting level; RSD, relative standard deviation; $\mu \mathrm{S} / \mathrm{cm}$, microsiemens per centimeter at 25 degrees Celsius; $\mathrm{NA}$, not applicable; $\mu \mathrm{g} / \mathrm{L}$, micrograms per liter; $\mathrm{mg} / \mathrm{L}$, milligrams per liter]

\begin{tabular}{|c|c|c|c|c|c|c|c|c|c|}
\hline \multirow[b]{2}{*}{$\begin{array}{l}\text { Constituent or property, units of } \\
\text { measurement }\end{array}$} & \multicolumn{7}{|c|}{ Summary information relating to field blank samples } & \multicolumn{2}{|c|}{$\begin{array}{l}\text { Summary informaiton } \\
\text { relating to field replicate } \\
\text { samples }\end{array}$} \\
\hline & 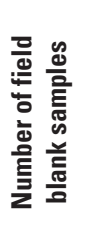 & 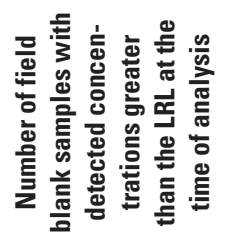 & 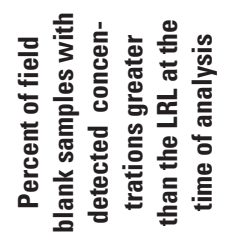 & 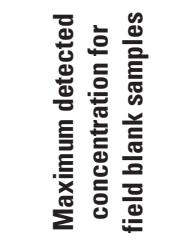 & 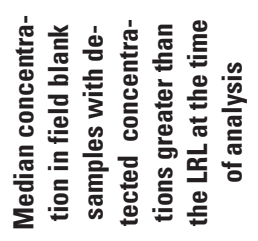 & 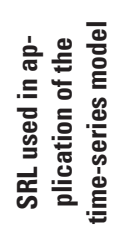 & 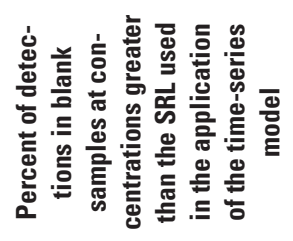 & 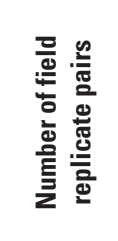 & 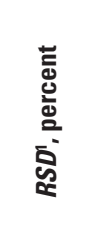 \\
\hline Specific conductance, $\mu \mathrm{S} / \mathrm{cm}$ & NA & NA & NA & NA & NA & 8 & NA & 121 & 0.1 \\
\hline Cadmium, filtered, $\mu \mathrm{g} / \mathrm{L}$ & 158 & 3 & 1.9 & 0.34 & 0.07 & 0.05 & 3.2 & 139 & 12.7 \\
\hline $\begin{array}{l}\text { Cadmium, unfiltered-recoverable, } \\
\mu \mu \mathrm{g} / \mathrm{L}\end{array}$ & 154 & 0 & 0 & no detections & no detections & 0.09 & 0 & 140 & 3.9 \\
\hline Copper, filtered, $\mu \mathrm{g} / \mathrm{L}$ & 157 & 8 & 5.1 & 3.6 & 0.52 & 1 & 1.3 & 141 & 12.4 \\
\hline $\begin{array}{l}\text { Copper, unfiltered-recoverable, } \\
\mu \mathrm{g} / \mathrm{L}\end{array}$ & 154 & 6 & 3.9 & 3.0 & 1.0 & 1 & 1.9 & 140 & 8.7 \\
\hline Iron, filtered, $\mu \mathrm{g} / \mathrm{L}$ & 154 & 0 & 0 & no detections & no detections & 6 & 0 & 130 & 9.8 \\
\hline Iron unfiltered-recoverable, $\mu \mathrm{g} / \mathrm{L}$ & 150 & 4 & 2.7 & 36 & 7 & 20 & 2.0 & 138 & 5.5 \\
\hline Lead, filtered, $\mu \mathrm{g} / \mathrm{L}$ & 158 & 4 & 2.5 & 0.60 & 0.23 & 0.5 & 0.6 & 137 & 11.0 \\
\hline Lead, unfiltered-recoverable, $\mu \mathrm{g} / \mathrm{L}$ & 154 & 3 & 1.9 & 0.16 & 0.06 & 0.5 & 0 & 140 & 16.2 \\
\hline Manganese, filtered, $\mu \mathrm{g} / \mathrm{L}$ & 153 & 0 & 0 & no detections & no detections & 1 & 0 & 142 & 5.5 \\
\hline $\begin{array}{l}\text { Manganese, unfiltered-recoverable, } \\
\mu \mathrm{g} / \mathrm{L}\end{array}$ & 150 & 2 & 1.3 & 0.30 & 0.15 & 1 & 0 & 140 & 5.6 \\
\hline Zinc, filtered, $\mu \mathrm{g} / \mathrm{L}$ & 156 & 23 & 14.7 & 6.20 & 0.90 & 5 & 0.6 & 141 & 8.6 \\
\hline Zinc, unfiltered-recoverable, $\mu \mathrm{g} / \mathrm{L}$ & 152 & 10 & 6.6 & 3.40 & 1.40 & 2 & 3.3 & 141 & 8.4 \\
\hline Arsenic, filtered, $\mu \mathrm{g} / \mathrm{L}$ & 158 & 0 & 0 & no detections & no detections & 1 & 0 & 142 & 6.1 \\
\hline $\begin{array}{l}\text { Arsenic, unfiltered-recoverable, } \\
\mu \mu \mathrm{g} / \mathrm{L}\end{array}$ & 154 & 0 & 0 & no detections & no detections & 1 & 0 & 141 & 7.5 \\
\hline Suspended sediment, $\mathrm{mg} / \mathrm{L}$ & NA & NA & NA & NA & NA & 1 & NA & 129 & 9.6 \\
\hline
\end{tabular}

${ }^{1}$ The $R S D$ is calculated according to the following equation (Taylor, 1987):

where

$$
R S D=\frac{S}{\bar{x}} \times 100,
$$

$R S D \quad$ is the relative standard deviation;

$S$ is the standard deviation; and

$\bar{x} \quad$ is the mean contentration for all replicates. 
Table 1-2. Summary information relating to quality-control samples (laboratory-spiked deionized-water blank samples) collected at sites in the upper Clark Fork Basin,

Montana, based on data collected during water years 1993-2010.

[Water year is the 12-month period from October 1 through September 30 and is designated by the year in which it ends. F, filtered; UFR, unfiltered-recoverable]

\begin{tabular}{|c|c|c|c|c|c|c|c|c|c|c|c|c|c|c|}
\hline \multirow{2}{*}{$\begin{array}{l}\text { Water } \\
\text { year }\end{array}$} & \multicolumn{14}{|c|}{ Mean spike recovery, percent (values in parentheses indicate 95-percent confidence intervals) } \\
\hline & $\begin{array}{c}\text { Cadmium, } \\
\text { F }\end{array}$ & $\begin{array}{l}\text { Cadmium, } \\
\text { UFR }\end{array}$ & $\begin{array}{c}\text { Copper, } \\
\text { F }\end{array}$ & $\begin{array}{l}\text { Copper, } \\
\text { UFR }\end{array}$ & $\begin{array}{l}\text { Iron, } \\
\text { F }\end{array}$ & $\begin{array}{l}\text { Iron, } \\
\text { UFR }\end{array}$ & $\begin{array}{l}\text { Lead, } \\
\text { F }\end{array}$ & $\begin{array}{l}\text { Lead, } \\
\text { UFR }\end{array}$ & $\begin{array}{c}\text { Manganese, } \\
\text { F }\end{array}$ & $\begin{array}{c}\text { Manganese, } \\
\text { UFR }\end{array}$ & $\begin{array}{l}\text { Zinc, } \\
\quad F\end{array}$ & $\begin{array}{l}\text { Zinc, } \\
\text { UFR }\end{array}$ & $\begin{array}{c}\text { Arsenic, } \\
\text { F }\end{array}$ & $\begin{array}{l}\text { Arsenic, } \\
\text { UFR }\end{array}$ \\
\hline 1993 & $\begin{array}{l}93.4(85.9 \\
101)\end{array}$ & $97(93.5,101)$ & $\begin{array}{l}99.5(95.9 \\
103)\end{array}$ & $\begin{array}{c}101.7 \\
(94.4 \\
109)\end{array}$ & $\begin{array}{c}94(90.0 \\
98.0)\end{array}$ & $\begin{array}{l}103.3 \\
\quad(92.4 \\
114)\end{array}$ & $\begin{array}{c}105.8 \\
\quad(99.5 \\
112)\end{array}$ & $\begin{array}{c}100.5 \\
(95.2 \\
106)\end{array}$ & $\begin{array}{c}96.9(96.3 \\
97.5)\end{array}$ & $\begin{array}{c}95.6(82.2 \\
109)\end{array}$ & $\begin{array}{c}106.5 \\
\quad(99.7 \\
113)\end{array}$ & $\begin{array}{c}96.3 \\
\quad(94.1 \\
98.5)\end{array}$ & $\begin{array}{c}94(89.6 \\
98.4)\end{array}$ & $\begin{array}{c}102.6(95.8, \\
109)\end{array}$ \\
\hline 1994 & $\begin{array}{c}97.5(89.1 \\
106)\end{array}$ & $\begin{array}{c}98.8(90.6 \\
107)\end{array}$ & $\begin{array}{c}101.1 \\
\quad(98.4 \\
104)\end{array}$ & $\begin{array}{c}99.7(94.3 \\
105)\end{array}$ & $\begin{array}{c}100 \\
(93.0 \\
107)\end{array}$ & $\begin{array}{l}94.6 \\
\quad(84.2 \\
105)\end{array}$ & $\begin{array}{c}100.5 \\
(98.5 \\
102)\end{array}$ & $\begin{array}{l}99.1 \\
\quad(94.3 \\
104)\end{array}$ & $\begin{array}{l}95.7(90.8 \\
100)\end{array}$ & $\begin{array}{c}101.5(96.2 \\
107)\end{array}$ & $\begin{array}{c}106.5 \\
(95.8 \\
117)\end{array}$ & $\begin{array}{c}102.6 \\
(91.5 \\
114)\end{array}$ & $\begin{array}{c}100.6 \\
(95.6 \\
106)\end{array}$ & $\begin{array}{c}109.3(104, \\
114)\end{array}$ \\
\hline 1995 & $\begin{array}{c}100(97.3 \\
103)\end{array}$ & $\begin{array}{c}101.3(97.5 \\
105)\end{array}$ & $\begin{array}{l}102.7(101 \\
105)\end{array}$ & $\begin{array}{c}97.6(92.3 \\
103)\end{array}$ & $\begin{array}{c}102.2 \\
(97.8 \\
107)\end{array}$ & $\begin{array}{c}93.8 \\
\quad(87.9 \\
99.7)\end{array}$ & $\begin{array}{c}1023 \\
(97.7 \\
107)\end{array}$ & $\begin{array}{l}100.8 \\
(96.6 \\
105)\end{array}$ & $\begin{array}{l}96.5(92.0 \\
101)\end{array}$ & $\begin{array}{l}98.5(93.1 \\
104)\end{array}$ & $\begin{array}{l}102.3 \\
\quad(97.1 \\
108)\end{array}$ & $\begin{array}{c}101.5 \\
(97.1 \\
106)\end{array}$ & $\begin{array}{c}103.9 \\
(99.1 \\
109)\end{array}$ & $\begin{array}{l}106.8(103, \\
110)\end{array}$ \\
\hline 1996 & $\begin{array}{l}95.3(92.2 \\
98.4)\end{array}$ & $\begin{array}{c}82.3(79.7 \\
84.9)\end{array}$ & $\begin{array}{l}99.2(91.4 \\
107)\end{array}$ & $\begin{array}{c}99.6(93.5 \\
106)\end{array}$ & $\begin{array}{l}89.8 \\
\quad(76.0 \\
104)\end{array}$ & $\begin{array}{l}90.8 \\
\quad(70.9 \\
111)\end{array}$ & $\begin{array}{c}100.5 \\
(93.3 \\
108)\end{array}$ & $\begin{array}{l}97.4 \\
\quad(80.2 \\
115)\end{array}$ & $\begin{array}{c}89.2(77.9 \\
100)\end{array}$ & $\begin{array}{l}96.5(91.6 \\
101)\end{array}$ & $\begin{array}{c}96.1(84.3, \\
108)\end{array}$ & $\begin{array}{c}87.8 \\
(82.8 \\
92.8)\end{array}$ & $\begin{array}{l}89.7 \\
\quad(77.1 \\
102)\end{array}$ & $\begin{array}{l}104.1(101, \\
107)\end{array}$ \\
\hline 1997 & $\begin{array}{l}98.5(92.1 \\
105)\end{array}$ & $\begin{array}{c}85.7(77.7 \\
93.7)\end{array}$ & $\begin{array}{c}101.1 \\
\quad(86.2 \\
116)\end{array}$ & $\begin{array}{c}106.4 \\
\quad(82.0 \\
131)\end{array}$ & $\begin{array}{l}94.7 \\
\quad(78.5 \\
111)\end{array}$ & $\begin{array}{l}96.1 \\
\quad(80.2 \\
112)\end{array}$ & $\begin{array}{c}101(93.4, \\
109)\end{array}$ & $\begin{array}{c}101.1 \\
\quad(88.9 \\
113)\end{array}$ & $\begin{array}{c}90.3(82.7 \\
97.9)\end{array}$ & $\begin{array}{c}99.3(95.8 \\
103)\end{array}$ & $\begin{array}{c}97.9(78.1 \\
118)\end{array}$ & $\begin{array}{c}92.7 \\
\quad(86.4 \\
99.0)\end{array}$ & $\begin{array}{l}93.9 \\
\quad(87.8 \\
100)\end{array}$ & $\begin{array}{l}106.1(104, \\
108)\end{array}$ \\
\hline 1998 & $\begin{array}{c}104(93.8 \\
114)\end{array}$ & $\begin{array}{c}97.4(87.0 \\
108)\end{array}$ & $\begin{array}{c}100.4 \\
\quad(93.4 \\
107)\end{array}$ & $\begin{array}{c}103.4 \\
(98.8 \\
108)\end{array}$ & $\begin{array}{l}101.8 \\
\quad(90.7 \\
113)\end{array}$ & $\begin{array}{l}95.7 \\
\quad(89.9 \\
102)\end{array}$ & $\begin{array}{c}100.2 \\
(91.8 \\
109)\end{array}$ & $\begin{array}{l}104.8 \\
\quad(88.8 \\
121)\end{array}$ & $\begin{array}{l}102.8(94.4, \\
111)\end{array}$ & $99(92.1,106)$ & $\begin{array}{l}95.2(85.9 \\
104)\end{array}$ & $\begin{array}{l}101.3 \\
\quad(86.9 \\
116)\end{array}$ & $\begin{array}{l}91.5 \\
\quad(87.3 \\
95.7)\end{array}$ & $\begin{array}{c}105.4(99.2, \\
112)\end{array}$ \\
\hline 1999 & $\begin{array}{c}100.9 \\
(92.6 \\
109)\end{array}$ & $\begin{array}{c}103.4(99.9 \\
107)\end{array}$ & $\begin{array}{c}107.5 \\
\quad(99.5 \\
116)\end{array}$ & $\begin{array}{c}105(102 \\
108)\end{array}$ & $\begin{array}{c}97.7 \\
(94.3 \\
101)\end{array}$ & $\begin{array}{l}96.5 \\
\quad(90.0 \\
103)\end{array}$ & $\begin{array}{c}97.4 \\
\quad(87.9 \\
107)\end{array}$ & $\begin{array}{l}96.2 \\
\quad(85.2 \\
107)\end{array}$ & $96(91.8,100)$ & $\begin{array}{l}95.9(86.3 \\
106)\end{array}$ & $\begin{array}{l}96.9(92.9, \\
101)\end{array}$ & $\begin{array}{c}93.3 \\
(88.9 \\
97.7)\end{array}$ & $\begin{array}{c}108.9 \\
\quad(95.4 \\
122)\end{array}$ & $\begin{array}{c}102.9(97.8, \\
108)\end{array}$ \\
\hline 2000 & $\begin{array}{c}103.8 \\
\quad(97.3 \\
110)\end{array}$ & $\begin{array}{c}105(96.0 \\
114)\end{array}$ & $\begin{array}{c}104(96.0 \\
112)\end{array}$ & $\begin{array}{c}100.3 \\
(92.4 \\
108)\end{array}$ & $\begin{array}{c}97.4 \\
(92.3 \\
102)\end{array}$ & $\begin{array}{l}100.6 \\
\quad(89.2 \\
112)\end{array}$ & $\begin{array}{l}98.3 \\
\quad(88.9 \\
108)\end{array}$ & $\begin{array}{c}102.6 \\
(97.3 \\
108)\end{array}$ & $\begin{array}{l}100.8(93.3 \\
108)\end{array}$ & $\begin{array}{l}103.2(96.8 \\
110)\end{array}$ & $\begin{array}{c}107.8 \\
(95.8 \\
120)\end{array}$ & $\begin{array}{c}102.6 \\
(90.0 \\
115)\end{array}$ & $\begin{array}{c}101.6 \\
(95.3 \\
108)\end{array}$ & $\begin{array}{c}101.4(95.1, \\
108)\end{array}$ \\
\hline 2001 & $\begin{array}{c}102.9 \\
(98.9 \\
107)\end{array}$ & $\begin{array}{l}107.9(101 \\
115)\end{array}$ & $\begin{array}{l}105.2 \\
\quad(98.6 \\
112)\end{array}$ & $\begin{array}{c}96.8(93.7, \\
99.9)\end{array}$ & $\begin{array}{c}101.3 \\
(95.5 \\
107)\end{array}$ & $\begin{array}{l}98.3 \\
\quad(86.7 \\
110)\end{array}$ & $\begin{array}{l}97.3 \\
\quad(91.9 \\
103)\end{array}$ & $\begin{array}{c}96.4 \\
\quad(93.7 \\
99.1)\end{array}$ & $\begin{array}{l}101.9(79.0 \\
125)\end{array}$ & $\begin{array}{l}103.7(89.9 \\
118)\end{array}$ & $\begin{array}{c}102(87.9 \\
116)\end{array}$ & $\begin{array}{l}99.1 \\
\quad(82.7 \\
116)\end{array}$ & $\begin{array}{c}99.2 \\
\quad(92.3 \\
106)\end{array}$ & $\begin{array}{l}97.7(86.6, \\
109)\end{array}$ \\
\hline 2002 & $\begin{array}{l}101.1 \\
\quad(98.8 \\
103)\end{array}$ & $\begin{array}{c}97.6(96.3 \\
98.9)\end{array}$ & $\begin{array}{l}99.4(95.0 \\
104)\end{array}$ & $\begin{array}{c}98.8(96.7 \\
101)\end{array}$ & $\begin{array}{c}95.1 \\
\quad(89.3 \\
101)\end{array}$ & $\begin{array}{l}102.3 \\
\quad(93.0 \\
112)\end{array}$ & $\begin{array}{c}98.5 \\
\quad(89.9 \\
107)\end{array}$ & $\begin{array}{l}96.9 \\
\quad(90.5 \\
103)\end{array}$ & $\begin{array}{c}98.5(95.4 \\
102)\end{array}$ & $\begin{array}{c}96.5(88.8 \\
104)\end{array}$ & $\begin{array}{l}103.9 \\
\quad(94.4 \\
113)\end{array}$ & $\begin{array}{c}98.3 \\
(91.8 \\
105)\end{array}$ & $\begin{array}{c}105.1 \\
\quad(95.8 \\
114)\end{array}$ & $\begin{array}{l}97.9(93.0 \\
103)\end{array}$ \\
\hline 2003 & $\begin{array}{l}98.6(92.6 \\
105)\end{array}$ & $\begin{array}{l}97.5(94.1 \\
101)\end{array}$ & $\begin{array}{l}100.4 \\
\quad(93.0 \\
108)\end{array}$ & $\begin{array}{c}97.6(93.2 \\
102)\end{array}$ & $\begin{array}{c}101.6 \\
(96.4 \\
107)\end{array}$ & $\begin{array}{l}93.1 \\
\quad(87.4 \\
8.8)\end{array}$ & $\begin{array}{l}97.2 \\
\quad(92.3 \\
102)\end{array}$ & $\begin{array}{c}96(93.9 \\
98.1)\end{array}$ & $\begin{array}{l}95.8(90.7 \\
101)\end{array}$ & $\begin{array}{c}96.6(79.7 \\
114)\end{array}$ & $\begin{array}{l}101.4 \\
\quad(89.8 \\
113)\end{array}$ & $\begin{array}{l}99.1 \\
\quad(93.2 \\
105)\end{array}$ & $\begin{array}{l}87.9 \\
\quad(71.3 \\
104)\end{array}$ & $\begin{array}{c}96.6(78.5 \\
115)\end{array}$ \\
\hline 2004 & $\begin{array}{c}97.4(95.6 \\
99.2)\end{array}$ & $\begin{array}{c}100(98.6 \\
101)\end{array}$ & $\begin{array}{c}98.9(92.7 \\
105)\end{array}$ & $\begin{array}{c}99.6(95.4 \\
104)\end{array}$ & $\begin{array}{l}101 \\
(96.3 \\
106)\end{array}$ & $\begin{array}{l}96.1 \\
\quad(88.8 \\
103)\end{array}$ & $\begin{array}{c}96(91.9 \\
100)\end{array}$ & $\begin{array}{l}98.9 \\
\quad(97.3 \\
100)\end{array}$ & $\begin{array}{c}99.1(92.3 \\
106)\end{array}$ & $\begin{array}{c}98.6(90.6 \\
107)\end{array}$ & $\begin{array}{c}102(91.7 \\
112)\end{array}$ & $\begin{array}{c}100 \\
(96.3 \\
104)\end{array}$ & $\begin{array}{c}101(75 \\
127)\end{array}$ & $\begin{array}{c}102(93.6 \\
110)\end{array}$ \\
\hline 2005 & $\begin{array}{c}102(97.3 \\
106)\end{array}$ & $\begin{array}{c}97.5(88.1 \\
107)\end{array}$ & $\begin{array}{c}102(97.4 \\
107)\end{array}$ & $\begin{array}{c}97.6(88.4 \\
107)\end{array}$ & $\begin{array}{l}97.6 \\
(90.5 \\
105)\end{array}$ & $\begin{array}{c}100(95.2 \\
105)\end{array}$ & $\begin{array}{c}101(95.5 \\
106)\end{array}$ & $\begin{array}{c}104(99.4 \\
108)\end{array}$ & $\begin{array}{c}93.8(82.2 \\
105)\end{array}$ & $\begin{array}{c}102(86.4 \\
117)\end{array}$ & $\begin{array}{c}102(88.3 \\
116)\end{array}$ & $\begin{array}{c}96.1 \\
(83.5 \\
109)\end{array}$ & $\begin{array}{l}97.4 \\
\quad(95.5 \\
99.3)\end{array}$ & $\begin{array}{c}101(90.7 \\
111)\end{array}$ \\
\hline
\end{tabular}


Table 1-2. Summary information relating to quality-control samples (laboratory-spiked deionized-water blank samples) collected at sites in the upper Clark Fork Basin, Montana, based on data collected during water years 1993-2010.-Continued

[Water year is the 12-month period from October 1 through September 30 and is designated by the year in which it ends. F, filtered; UFR, unfiltered-recoverable]

\begin{tabular}{|c|c|c|c|c|c|c|c|c|c|c|c|c|c|c|}
\hline \multirow{2}{*}{$\begin{array}{c}\text { Water } \\
\text { year }\end{array}$} & \multicolumn{14}{|c|}{ Mean spike recovery, percent (values in parentheses indicate 95-percent confidence intervals) } \\
\hline & $\begin{array}{c}\text { Cadmium, } \\
\text { F }\end{array}$ & $\begin{array}{l}\text { Cadmium, } \\
\text { UFR }\end{array}$ & $\begin{array}{c}\text { Copper, } \\
\text { F }\end{array}$ & $\begin{array}{l}\text { Copper, } \\
\text { UFR }\end{array}$ & $\begin{array}{l}\text { Iron, } \\
F\end{array}$ & $\begin{array}{l}\text { Iron, } \\
\text { UFR }\end{array}$ & $\begin{array}{l}\text { Lead, } \\
\text { F }\end{array}$ & $\begin{array}{l}\text { Lead, } \\
\text { UFR }\end{array}$ & $\begin{array}{c}\text { Manganese, } \\
\text { F }\end{array}$ & $\begin{array}{c}\text { Manganese, } \\
\text { UFR }\end{array}$ & $\begin{array}{l}\text { Zinc, } \\
\text { F }\end{array}$ & $\begin{array}{l}\text { Zinc, } \\
\text { UFR }\end{array}$ & $\begin{array}{c}\text { Arsenic, } \\
\text { F }\end{array}$ & $\begin{array}{c}\text { Arsenic, } \\
\text { UFR }\end{array}$ \\
\hline 2006 & $\begin{array}{c}100(92.6 \\
107)\end{array}$ & $\begin{array}{c}98.9(94.1 \\
104)\end{array}$ & $\begin{array}{c}102(97.7 \\
107)\end{array}$ & $\begin{array}{c}98.7(93.8, \\
104)\end{array}$ & $\begin{array}{l}106(101 \\
112)\end{array}$ & $\begin{array}{c}103(95.4 \\
111)\end{array}$ & $\begin{array}{c}99(89.3 \\
109)\end{array}$ & $\begin{array}{c}98(91.2 \\
105)\end{array}$ & $97(90.7,103)$ & $\begin{array}{c}105(95.3 \\
115)\end{array}$ & $\begin{array}{c}105(95.4 \\
115)\end{array}$ & $\begin{array}{l}94.9 \\
(90.1 \\
100)\end{array}$ & $\begin{array}{l}95.2 \\
\quad(89.2 \\
101)\end{array}$ & $\begin{array}{c}98.5(94.7, \\
102)\end{array}$ \\
\hline 2007 & $\begin{array}{c}107(103 \\
112)\end{array}$ & $\begin{array}{c}103(94.4 \\
111)\end{array}$ & $\begin{array}{c}105(99.2 \\
111)\end{array}$ & $\begin{array}{c}98.4(86.9 \\
110)\end{array}$ & $\begin{array}{l}99.9 \\
\quad(92.1 \\
108)\end{array}$ & $\begin{array}{c}104(98.5 \\
110)\end{array}$ & $\begin{array}{l}99.6 \\
\quad(93.9 \\
105)\end{array}$ & $\begin{array}{c}103(100 \\
106)\end{array}$ & $\begin{array}{c}107(99.9 \\
114)\end{array}$ & $\begin{array}{c}107(97.0 \\
116)\end{array}$ & $\begin{array}{c}107(102 \\
113)\end{array}$ & $\begin{array}{c}103 \\
(96.5 \\
110)\end{array}$ & $\begin{array}{c}105(96.6 \\
114)\end{array}$ & $\begin{array}{c}102(95.2 \\
109)\end{array}$ \\
\hline 2008 & $\begin{array}{c}102(88.2 \\
116)\end{array}$ & $\begin{array}{c}101(91.9 \\
110)\end{array}$ & $\begin{array}{c}105(88 \\
121)\end{array}$ & $\begin{array}{c}97.9(87.2, \\
109)\end{array}$ & $\begin{array}{c}103 \\
(95.9 \\
110)\end{array}$ & $\begin{array}{c}101(96.5 \\
106)\end{array}$ & $\begin{array}{c}101(89 \\
112)\end{array}$ & $\begin{array}{c}101(98, \\
105)\end{array}$ & $\begin{array}{c}102(92.9 \\
111)\end{array}$ & $\begin{array}{c}102(92.5 \\
112)\end{array}$ & $\begin{array}{c}99.8(87.9, \\
112)\end{array}$ & $\begin{array}{c}103(96 \\
111)\end{array}$ & $\begin{array}{c}103(89.2 \\
117)\end{array}$ & $\begin{array}{c}102(93.9 \\
110)\end{array}$ \\
\hline 2009 & $\begin{array}{c}102(97.4 \\
107)\end{array}$ & $\begin{array}{l}97.2(93.6 \\
101)\end{array}$ & $\begin{array}{c}102(92.0 \\
113)\end{array}$ & $\begin{array}{c}96(94.0 \\
97.0)\end{array}$ & $\begin{array}{l}102 \\
\quad(91.4 \\
112)\end{array}$ & $\begin{array}{c}104(78.8 \\
130)\end{array}$ & $\begin{array}{c}102(96.0 \\
107)\end{array}$ & $\begin{array}{l}98.4 \\
\quad(96.1 \\
101)\end{array}$ & $105(103,106)$ & $\begin{array}{l}99.7(94.6 \\
105)\end{array}$ & $\begin{array}{c}111(104 \\
118)\end{array}$ & $\begin{array}{c}93.3 \\
(88.5 \\
98.1)\end{array}$ & $\begin{array}{c}101(92.3 \\
110)\end{array}$ & $\begin{array}{c}97 \text { (94.9) } \\
99.1)\end{array}$ \\
\hline 2010 & $\begin{array}{c}106(94.9 \\
117)\end{array}$ & $\begin{array}{c}100(88.4 \\
112)\end{array}$ & $\begin{array}{c}97.2(84.9 \\
109)\end{array}$ & $\begin{array}{c}98.6(84.0, \\
113)\end{array}$ & $\begin{array}{l}108(101 \\
115)\end{array}$ & $\begin{array}{c}102(95.8 \\
108)\end{array}$ & $\begin{array}{c}102(91.5 \\
113)\end{array}$ & $\begin{array}{c}102(91.0, \\
113)\end{array}$ & $\begin{array}{c}103(95.2 \\
111)\end{array}$ & $\begin{array}{c}105(97.2 \\
112)\end{array}$ & $\begin{array}{c}113(94.7 \\
132)\end{array}$ & $\begin{array}{l}101 \\
\quad(89.6, \\
113)\end{array}$ & $\begin{array}{c}105(96.7 \\
113)\end{array}$ & $\begin{array}{c}102(89.7 \\
114)\end{array}$ \\
\hline
\end{tabular}


Table 1-3. Summary information relating to quality-control samples (laboratory-spiked stream-water samples) collected at sites in the upper Clark Fork Basin, Montana, based on data collected during water years 1993-2010.

[Water year is the 12-month period from October 1 through September 30 and is designated by the year in which it ends. F, filtered; UFR, unfiltered-recoverable]

\begin{tabular}{|c|c|c|c|c|c|c|c|c|c|c|c|c|c|c|}
\hline \multirow{2}{*}{$\begin{array}{l}\text { Water } \\
\text { year }\end{array}$} & \multicolumn{14}{|c|}{ Mean spike recovery, percent (values in parentheses indicate 95-percent confidence intervals) } \\
\hline & $\begin{array}{c}\text { Cadmium, } \\
\text { F }\end{array}$ & $\begin{array}{l}\text { Cadmium, } \\
\text { UFR }\end{array}$ & $\begin{array}{l}\text { Copper, } \\
\text { F }\end{array}$ & $\begin{array}{l}\text { Copper, } \\
\text { UFR }\end{array}$ & $\begin{array}{l}\text { Iron, } \\
\text { F }\end{array}$ & $\begin{array}{l}\text { Iron, } \\
\text { UFR }\end{array}$ & $\begin{array}{l}\text { Lead, } \\
\text { F }\end{array}$ & $\begin{array}{l}\text { Lead, } \\
\text { UFR }\end{array}$ & $\begin{array}{c}\text { Manganese, } \\
\text { F }\end{array}$ & $\begin{array}{c}\text { Manganese, } \\
\text { UFR }\end{array}$ & $\begin{array}{l}\text { Zinc, } \\
\text { F }\end{array}$ & $\begin{array}{l}\text { Zinc, } \\
\text { UFR }\end{array}$ & $\begin{array}{c}\text { Arsenic, } \\
\text { F }\end{array}$ & $\begin{array}{c}\text { Arsenic, } \\
\text { UFR }\end{array}$ \\
\hline 1993 & $\begin{array}{c}97.1(92.3 \\
102)\end{array}$ & $\begin{array}{l}98.1(95.2 \\
101)\end{array}$ & $\begin{array}{c}97.4(95.8 \\
99.0)\end{array}$ & $\begin{array}{c}97.2(92.3 \\
102)\end{array}$ & $\begin{array}{l}94.6 \\
\quad(86.7 \\
103)\end{array}$ & $\begin{array}{c}102.2 \\
\quad(94.4 \\
110)\end{array}$ & $\begin{array}{c}104.7 \\
\quad(98.5 \\
111)\end{array}$ & $\begin{array}{c}96(93.0 \\
99.0)\end{array}$ & $\begin{array}{c}95.7(92.1 \\
99.3)\end{array}$ & $\begin{array}{c}100.2(96.4 \\
104)\end{array}$ & $\begin{array}{c}105.7 \\
\quad(93.4 \\
118)\end{array}$ & $\begin{array}{c}95.7 \\
\quad(92.2 \\
99.2)\end{array}$ & $\begin{array}{c}95.2 \\
(92.0 \\
98.3)\end{array}$ & $\begin{array}{l}99.9(96.5 \\
103)\end{array}$ \\
\hline 1994 & $\begin{array}{c}101.3 \\
\quad(97.5 \\
105)\end{array}$ & $\begin{array}{l}97.9(94.4, \\
101)\end{array}$ & $\begin{array}{c}96.6(93.3 \\
99.8)\end{array}$ & $\begin{array}{c}98.4(91.1 \\
106)\end{array}$ & $\begin{array}{l}98.2 \\
\quad(94.8 \\
102)\end{array}$ & $\begin{array}{c}99.3 \\
(90.6 \\
108)\end{array}$ & $\begin{array}{c}103(101 \\
105)\end{array}$ & $\begin{array}{l}99.3 \\
\quad(95.6 \\
103)\end{array}$ & $\begin{array}{l}98.1(95.4 \\
101)\end{array}$ & $\begin{array}{l}100.4(95.4 \\
105)\end{array}$ & $\begin{array}{l}97.5(92.4 \\
102)\end{array}$ & $\begin{array}{l}106 \\
\quad(95.4 \\
117)\end{array}$ & $\begin{array}{l}97.3 \\
(90.4 \\
104)\end{array}$ & $\begin{array}{c}106.9(101, \\
113)\end{array}$ \\
\hline 1995 & $\begin{array}{c}101.3 \\
\quad(96.7 \\
106)\end{array}$ & $\begin{array}{l}102.9(98.0 \\
108)\end{array}$ & $\begin{array}{l}99.8(96.2 \\
103)\end{array}$ & $\begin{array}{c}98(92.7 \\
103)\end{array}$ & $\begin{array}{l}99.5 \\
\quad(96.1 \\
103)\end{array}$ & $\begin{array}{c}101.4 \\
\quad(96.2 \\
107)\end{array}$ & $\begin{array}{c}102.9 \\
\quad(98.6 \\
107)\end{array}$ & $\begin{array}{c}100(96.7 \\
103)\end{array}$ & $\begin{array}{c}97.4(92.9 \\
102)\end{array}$ & $\begin{array}{l}103.8(99.0 \\
109)\end{array}$ & $\begin{array}{c}104.7(101, \\
108)\end{array}$ & $\begin{array}{c}101.1 \\
\quad(99.1 \\
103)\end{array}$ & $\begin{array}{c}103.8 \\
\quad(94.6 \\
113)\end{array}$ & $\begin{array}{c}102.2(97.1, \\
107)\end{array}$ \\
\hline 1996 & $\begin{array}{c}100.2 \\
(91.5 \\
109)\end{array}$ & $\begin{array}{c}88.4(57.8 \\
119)\end{array}$ & $\begin{array}{c}101.1 \\
\quad(91.9 \\
110)\end{array}$ & $\begin{array}{c}100.3 \\
(92.3 \\
108)\end{array}$ & $\begin{array}{l}93.8 \\
\quad(73.3 \\
114)\end{array}$ & $\begin{array}{l}101.5 \\
\quad(88.5 \\
114)\end{array}$ & $\begin{array}{l}105.1 \\
\quad(90.4 \\
120)\end{array}$ & $\begin{array}{c}105.6 \\
\quad(98.4 \\
113)\end{array}$ & $\begin{array}{c}90.3(79.1 \\
102)\end{array}$ & $\begin{array}{c}99.5(92.9 \\
106)\end{array}$ & $\begin{array}{c}103.2 \\
\quad(90.2 \\
116)\end{array}$ & $\begin{array}{l}99.3 \\
\quad(74.8 \\
124)\end{array}$ & $\begin{array}{c}105.9 \\
(94.4 \\
117)\end{array}$ & $\begin{array}{c}102.8(96.0, \\
110)\end{array}$ \\
\hline 1997 & $\begin{array}{l}98.1(83.5 \\
113)\end{array}$ & $\begin{array}{l}84.3(75.0 \\
93.6)\end{array}$ & $\begin{array}{c}97.3(88.3 \\
106)\end{array}$ & $\begin{array}{l}100.5 \\
\quad(71.9 \\
129)\end{array}$ & $\begin{array}{l}99.3 \\
\quad(81.0 \\
118)\end{array}$ & $\begin{array}{l}97.5 \\
\quad(78.2 \\
117)\end{array}$ & $\begin{array}{l}100.8 \\
\quad(91.6 \\
110)\end{array}$ & $\begin{array}{l}102.1 \\
\quad(99.1 \\
105)\end{array}$ & $93(84.0,102)$ & $\begin{array}{c}99.8(94.5 \\
105)\end{array}$ & $\begin{array}{c}97(89.9 \\
104)\end{array}$ & $\begin{array}{l}92.7 \\
\quad(74.4 \\
111)\end{array}$ & $\begin{array}{l}93.3 \\
\quad(73.5 \\
113)\end{array}$ & $\begin{array}{c}107.1(99.9, \\
114)\end{array}$ \\
\hline 1998 & $\begin{array}{c}104.4 \\
\quad(97.3 \\
112)\end{array}$ & $\begin{array}{c}99.5(92.7 \\
106)\end{array}$ & $\begin{array}{l}97.2(90.6 \\
104)\end{array}$ & $\begin{array}{l}99.1(88.4 \\
110)\end{array}$ & $\begin{array}{l}97.5 \\
\quad(82.8 \\
112)\end{array}$ & $\begin{array}{c}101.8 \\
\quad(90.2 \\
113)\end{array}$ & $\begin{array}{c}102.2 \\
(94.3 \\
110)\end{array}$ & $\begin{array}{c}105(92.9 \\
117)\end{array}$ & $\begin{array}{c}99.5(85.8 \\
113)\end{array}$ & $\begin{array}{l}101.5(98.0 \\
105)\end{array}$ & $\begin{array}{l}99.5(89.1 \\
110)\end{array}$ & $\begin{array}{l}98.8 \\
\quad(85.6 \\
112)\end{array}$ & $\begin{array}{l}90.1 \\
\quad(85.5 \\
94.7)\end{array}$ & $\begin{array}{c}104(95.8 \\
112)\end{array}$ \\
\hline 1999 & $\begin{array}{l}102.6 \\
\quad(92.4 \\
113)\end{array}$ & $103(100,106)$ & $\begin{array}{l}102.7 \\
\quad(89.1 \\
116)\end{array}$ & $\begin{array}{c}100.5 \\
\quad(97.5 \\
104)\end{array}$ & $\begin{array}{l}97.2 \\
\quad(93.5 \\
101)\end{array}$ & $\begin{array}{c}99.9 \\
(90.6 \\
109)\end{array}$ & $\begin{array}{l}100.2 \\
(94.0 \\
106)\end{array}$ & $\begin{array}{l}101.1 \\
\quad(93.7 \\
108)\end{array}$ & $\begin{array}{c}99.8(92.8 \\
107)\end{array}$ & $\begin{array}{c}98.8(89.3, \\
108)\end{array}$ & $\begin{array}{l}98.6(95.7 \\
102)\end{array}$ & $\begin{array}{l}96.2 \\
\quad(91.1 \\
101)\end{array}$ & $\begin{array}{c}105.2 \\
\quad(97.5 \\
113)\end{array}$ & $\begin{array}{c}103.6(96.4, \\
111)\end{array}$ \\
\hline 2000 & $\begin{array}{l}104.2(100 \\
108)\end{array}$ & $\begin{array}{c}98.1(88.9 \\
107)\end{array}$ & $\begin{array}{c}101.6 \\
(97.3 \\
106)\end{array}$ & $\begin{array}{c}94.6(87.7 \\
102)\end{array}$ & $\begin{array}{l}96.5 \\
\quad(88.0 \\
105)\end{array}$ & $\begin{array}{c}98(88.3 \\
108)\end{array}$ & $\begin{array}{c}101.4 \\
(97.3 \\
106)\end{array}$ & $\begin{array}{l}105.3 \\
\quad(103, \\
108)\end{array}$ & $\begin{array}{c}97.3(83.3 \\
111)\end{array}$ & $\begin{array}{c}101.7(91.4, \\
112)\end{array}$ & $\begin{array}{c}101.5 \\
\quad(90.9 \\
112)\end{array}$ & $\begin{array}{l}97.8 \\
\quad(91.1 \\
104)\end{array}$ & $\begin{array}{c}102.5 \\
(97.5 \\
108)\end{array}$ & $\begin{array}{c}98.9(87.8 \\
110)\end{array}$ \\
\hline 2001 & $\begin{array}{l}103.2(100 \\
106)\end{array}$ & $\begin{array}{l}105.8(95.9 \\
116)\end{array}$ & $\begin{array}{l}106.8(104, \\
110)\end{array}$ & $\begin{array}{c}91.8(87.7 \\
95.9)\end{array}$ & $\begin{array}{l}95.8 \\
\quad(91.4 \\
100)\end{array}$ & $\begin{array}{c}101.6 \\
\quad(92.1 \\
111)\end{array}$ & $\begin{array}{l}99.7 \\
\quad(95.2 \\
104)\end{array}$ & $\begin{array}{c}97.3 \\
(95.3 \\
99.3)\end{array}$ & $\begin{array}{c}100(84.4 \\
116)\end{array}$ & $\begin{array}{c}100.9(90.3 \\
112)\end{array}$ & $\begin{array}{c}100.8 \\
\quad(85.7 \\
116)\end{array}$ & $\begin{array}{c}96.9 \\
\quad(75.9 \\
118)\end{array}$ & $\begin{array}{l}102.8 \\
\quad(95.1 \\
110)\end{array}$ & $\begin{array}{c}100.1(96.7, \\
104)\end{array}$ \\
\hline 2002 & $\begin{array}{c}106(97.5 \\
114)\end{array}$ & $\begin{array}{c}102(98.6 \\
101)\end{array}$ & $\begin{array}{c}97.3(91.2 \\
103)\end{array}$ & $\begin{array}{c}96.9(92.9 \\
101)\end{array}$ & $\begin{array}{l}92.6 \\
\quad(83.3 \\
102)\end{array}$ & $\begin{array}{c}107.1 \\
(103 \\
111)\end{array}$ & $\begin{array}{c}101.4 \\
\quad(91.9 \\
111)\end{array}$ & $\begin{array}{l}98.9 \\
\quad(92.2 \\
106)\end{array}$ & $\begin{array}{c}98.3(92.5 \\
104)\end{array}$ & $\begin{array}{c}94.3(88.4 \\
100)\end{array}$ & $\begin{array}{l}101.3 \\
\quad(92.6 \\
110)\end{array}$ & $\begin{array}{l}95.8 \\
\quad(89.9 \\
102)\end{array}$ & $\begin{array}{c}105.8 \\
\quad(97.1 \\
114)\end{array}$ & $\begin{array}{l}99.9(86.0 \\
114)\end{array}$ \\
\hline 2003 & $\begin{array}{l}100.5 \\
\quad(91.4 \\
110)\end{array}$ & $99(94.4,104)$ & $\begin{array}{c}95.8(88.9 \\
103)\end{array}$ & $\begin{array}{c}91.6(89.7 \\
93.5)\end{array}$ & $\begin{array}{c}106.4 \\
(100 \\
113)\end{array}$ & $\begin{array}{l}96.7 \\
\quad(91.6 \\
102)\end{array}$ & $\begin{array}{c}96(90.2 \\
102)\end{array}$ & $\begin{array}{l}96.8 \\
\quad(93.7 \\
99.9)\end{array}$ & $\begin{array}{c}93.9(78.8 \\
109)\end{array}$ & $\begin{array}{c}99.3(86.2 \\
112)\end{array}$ & $\begin{array}{c}98.4(93.6 \\
103)\end{array}$ & $\begin{array}{c}93(87.5 \\
98.5)\end{array}$ & $\begin{array}{l}94.6 \\
\quad(80.2 \\
109)\end{array}$ & $\begin{array}{c}108.6(100 \\
117)\end{array}$ \\
\hline 2004 & $\begin{array}{c}101(94.2 \\
108)\end{array}$ & $101(100,103)$ & $\begin{array}{c}95.4(93.8 \\
97)\end{array}$ & $\begin{array}{c}93.8(89.5 \\
98.1)\end{array}$ & $\begin{array}{l}104 \\
\quad(99.5 \\
108)\end{array}$ & $\begin{array}{c}111(91.2 \\
130)\end{array}$ & $\begin{array}{c}98.7(93 \\
104)\end{array}$ & $\begin{array}{c}100(98.6 \\
102)\end{array}$ & $\begin{array}{c}103(89.8 \\
117)\end{array}$ & $96(91.8,100)$ & $\begin{array}{c}100(95.3 \\
105)\end{array}$ & $\begin{array}{c}94.4(91, \\
97.8)\end{array}$ & $\begin{array}{l}97.3 \\
\quad(86.9 \\
108)\end{array}$ & $\begin{array}{c}112(106 \\
118)\end{array}$ \\
\hline 2005 & $\begin{array}{c}97.8(62.7 \\
133)\end{array}$ & $\begin{array}{c}98.2(88.5 \\
108)\end{array}$ & $\begin{array}{c}93.6(57.9 \\
129)\end{array}$ & $\begin{array}{c}93(84.8 \\
101)\end{array}$ & $\begin{array}{l}102 \\
\quad(95.9 \\
108)\end{array}$ & $\begin{array}{l}99.3 \\
\quad(95.6 \\
103)\end{array}$ & $\begin{array}{c}102(96.1 \\
109)\end{array}$ & $\begin{array}{c}103(99.7 \\
106)\end{array}$ & $\begin{array}{c}88.3(78.3 \\
98.3)\end{array}$ & $\begin{array}{c}97.5(87.3 \\
108)\end{array}$ & $\begin{array}{c}94.3(60.8 \\
128)\end{array}$ & $\begin{array}{l}91.6 \\
\quad(80.8 \\
102)\end{array}$ & $\begin{array}{c}103(98.3 \\
107)\end{array}$ & $\begin{array}{c}104(101 \\
108)\end{array}$ \\
\hline
\end{tabular}


Table 1-3. Summary information relating to quality-control samples (laboratory-spiked deionized-water blank samples) collected at sites in the upper Clark Fork Basin, Montana, based on data collected during water years 1993-2010.-Continued

[Water year is the 12-month period from October 1 through September 30 and is designated by the year in which it ends. F, filtered; UFR, unfiltered-recoverable]

\begin{tabular}{|c|c|c|c|c|c|c|c|c|c|c|c|c|c|c|}
\hline \multirow{2}{*}{$\begin{array}{c}\text { Water } \\
\text { year }\end{array}$} & \multicolumn{14}{|c|}{ Mean spike recovery, percent (values in parentheses indicate 95-percent confidence intervals) } \\
\hline & $\begin{array}{c}\text { Cadmium, } \\
\text { F }\end{array}$ & $\begin{array}{l}\text { Cadmium, } \\
\text { UFR }\end{array}$ & $\begin{array}{l}\text { Copper, } \\
\text { F }\end{array}$ & $\begin{array}{l}\text { Copper, } \\
\text { UFR }\end{array}$ & $\begin{array}{l}\text { Iron, } \\
\text { F }\end{array}$ & $\begin{array}{l}\text { Iron, } \\
\text { UFR }\end{array}$ & $\begin{array}{l}\text { Lead, } \\
\text { F }\end{array}$ & $\begin{array}{l}\text { Lead, } \\
\text { UFR }\end{array}$ & $\begin{array}{c}\text { Manganese, } \\
\text { F }\end{array}$ & $\begin{array}{c}\text { Manganese, } \\
\text { UFR }\end{array}$ & $\begin{array}{c}\text { Zinc, } \\
\text { F }\end{array}$ & $\begin{array}{l}\text { Zinc, } \\
\text { UFR }\end{array}$ & $\begin{array}{c}\text { Arsenic, } \\
\text { F }\end{array}$ & $\begin{array}{c}\text { Arsenic, } \\
\text { UFR }\end{array}$ \\
\hline 2006 & $\begin{array}{c}104(99.0 \\
108)\end{array}$ & $\begin{array}{c}99.6(94.7 \\
104)\end{array}$ & $\begin{array}{c}101(96.7 \\
104)\end{array}$ & $\begin{array}{l}94.8(91.0 \\
98.6)\end{array}$ & $\begin{array}{c}105(102 \\
109)\end{array}$ & $\begin{array}{c}102(93.6 \\
110)\end{array}$ & $\begin{array}{c}102(94.2 \\
111)\end{array}$ & $\begin{array}{c}100(92.9 \\
106)\end{array}$ & $\begin{array}{c}94.9(88.2 \\
102)\end{array}$ & $\begin{array}{c}106(97.9 \\
113)\end{array}$ & $\begin{array}{c}108(93.3, \\
123)\end{array}$ & $\begin{array}{c}91.2 \\
\quad(87.8 \\
94.6)\end{array}$ & $\begin{array}{l}96.5 \\
\quad(89.0 \\
104)\end{array}$ & $\begin{array}{c}99.1(94.9, \\
103)\end{array}$ \\
\hline 2007 & $\begin{array}{c}108(102 \\
114)\end{array}$ & $98(92.2,104)$ & $\begin{array}{c}100(89.8 \\
110)\end{array}$ & $\begin{array}{c}96.3(91.8 \\
101)\end{array}$ & $\begin{array}{c}107(103, \\
111)\end{array}$ & $\begin{array}{c}103(94.7 \\
112)\end{array}$ & $\begin{array}{c}109(103 \\
115)\end{array}$ & $\begin{array}{c}104(102 \\
107)\end{array}$ & $106(100,113)$ & $\begin{array}{c}101(96.1 \\
106)\end{array}$ & $\begin{array}{c}104(95.7 \\
113)\end{array}$ & $\begin{array}{c}98(89.2 \\
107)\end{array}$ & $\begin{array}{c}106(100 \\
113)\end{array}$ & $\begin{array}{c}102(98.2 \\
106)\end{array}$ \\
\hline 2008 & $\begin{array}{c}101(91 \\
112)\end{array}$ & $97(93.6,100)$ & $\begin{array}{c}98.9(92 \\
106)\end{array}$ & $\begin{array}{l}92.8(86.4 \\
99.1)\end{array}$ & $\begin{array}{l}105 \\
\quad(94.1 \\
117)\end{array}$ & $\begin{array}{c}99.4(92 \\
107)\end{array}$ & $\begin{array}{c}100(91.3, \\
109)\end{array}$ & $\begin{array}{c}103(99.5 \\
106)\end{array}$ & $\begin{array}{c}98.9(90.3 \\
108)\end{array}$ & $\begin{array}{c}98.4(92.5 \\
104)\end{array}$ & $\begin{array}{c}106(88.1, \\
124)\end{array}$ & $\begin{array}{c}95.7 \\
\quad(93.1 \\
98.2)\end{array}$ & $\begin{array}{c}100(90.2 \\
110)\end{array}$ & $\begin{array}{c}101(98.5 \\
104)\end{array}$ \\
\hline 2009 & $\begin{array}{l}106(101 \\
112)\end{array}$ & $\begin{array}{c}94.7(89.5 \\
99.8)\end{array}$ & $\begin{array}{c}96.2(91.2 \\
101)\end{array}$ & $\begin{array}{c}91.4(87.8 \\
95.0)\end{array}$ & $\begin{array}{l}107 \\
\quad(89.7 \\
124)\end{array}$ & $\begin{array}{c}102(86.9 \\
118)\end{array}$ & $\begin{array}{c}100(97.0 \\
103)\end{array}$ & $\begin{array}{c}100(98.8 \\
101)\end{array}$ & $97(88.0,106)$ & $\begin{array}{c}92.8(81.7 \\
104)\end{array}$ & $\begin{array}{c}114(104, \\
124)\end{array}$ & $\begin{array}{c}89.8 \\
\quad(80.4 \\
99.2)\end{array}$ & $\begin{array}{c}106(97.7 \\
114)\end{array}$ & $\begin{array}{c}100(89.6 \\
111)\end{array}$ \\
\hline 2010 & $\begin{array}{c}110(87.6 \\
132)\end{array}$ & $\begin{array}{l}98.2(87.1 \\
109)\end{array}$ & $\begin{array}{c}93.8(83.6 \\
104)\end{array}$ & $\begin{array}{l}96.5(84.4 \\
108)\end{array}$ & $\begin{array}{l}105 \\
\quad(91.7 \\
119)\end{array}$ & $\begin{array}{c}111(103 \\
118)\end{array}$ & $\begin{array}{c}101(87.7 \\
115)\end{array}$ & $\begin{array}{c}104(91.5 \\
116)\end{array}$ & $\begin{array}{c}104(93.3, \\
114)\end{array}$ & $\begin{array}{l}98.7(86.4 \\
111)\end{array}$ & $\begin{array}{l}109(101 \\
118)\end{array}$ & $\begin{array}{c}94(81.3, \\
107)\end{array}$ & $\begin{array}{c}106(96.0 \\
116)\end{array}$ & $\begin{array}{c}102(90.1 \\
113)\end{array}$ \\
\hline
\end{tabular}



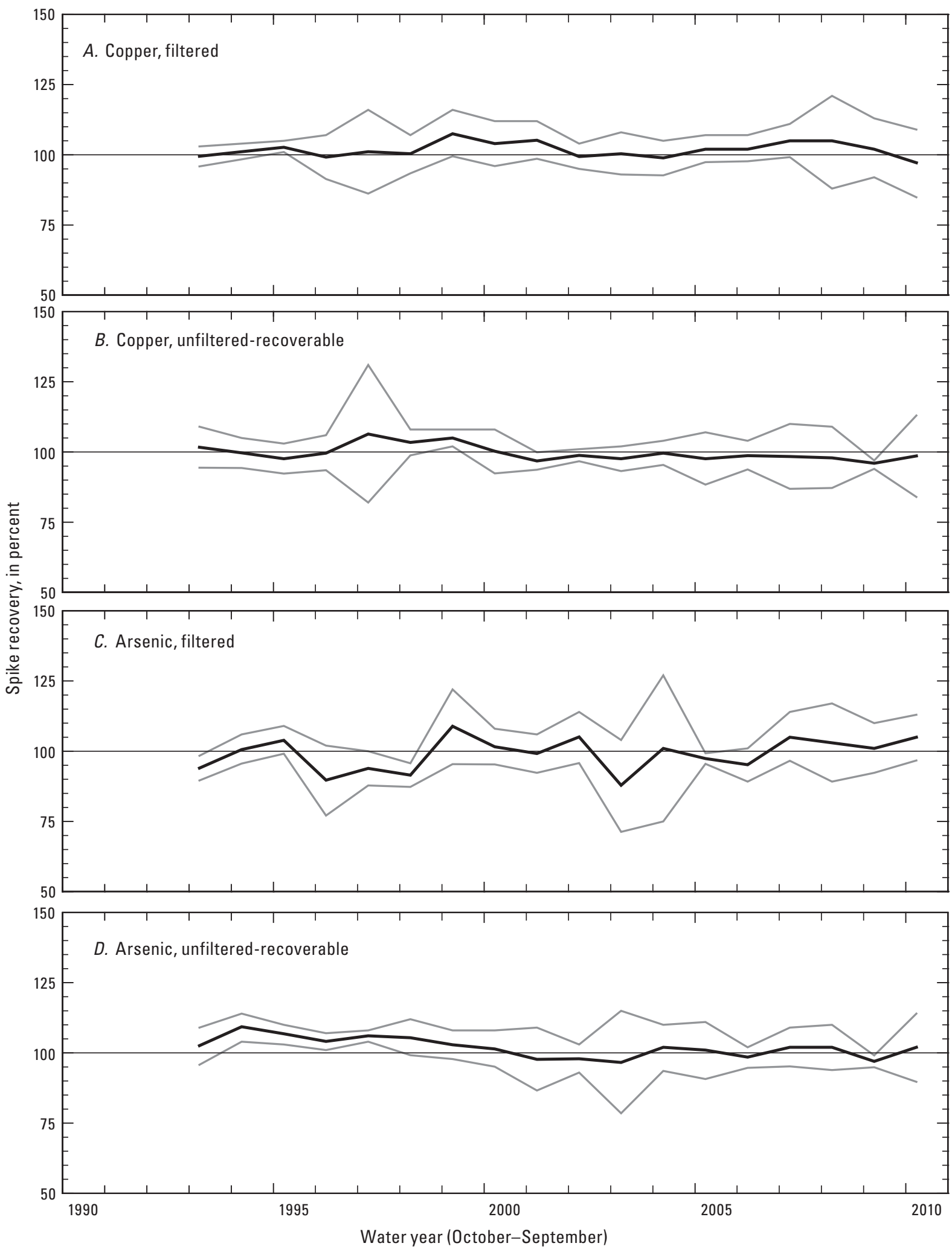

EXPLANATION

95-percent confidence interval about the mean spike recovery Mean spike recovery

Figure 1-1. Spike recoveries for laboratory-spiked deionized-water blank samples, based on data collected during water years 1993-2010. $A$, Copper, filtered; $B$, Copper, unfiltered-recoverable; $C$, Arsenic, filtered; $D$, Arsenic, unfiltered-recoverable. 

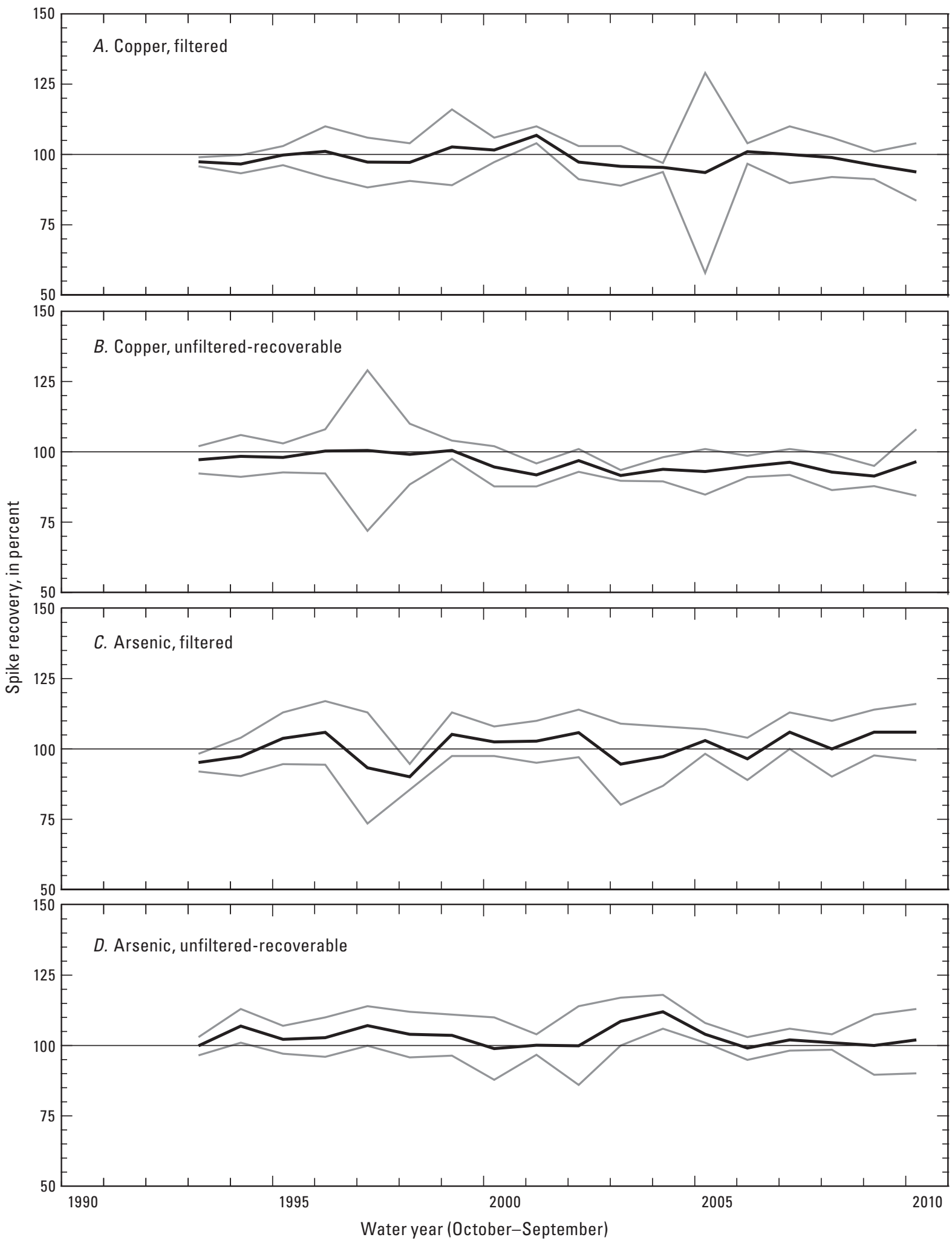

EXPLANATION

95-percent confidence interval about the mean spike recovery

Mean spike recovery

Figure 1-2. Spike recoveries for laboratory-spiked stream-water samples, based on data collected during water years 1993-2010. A, Copper, filtered; B, Copper, unfiltered-recoverable; $C$, Arsenic, filtered; $D$, Arsenic, unfiltered-recoverable. 
Table 1-4. Summary information relating to water-quality constituents and properties in samples collected at sites in the upper Clark Fork Basin, Montana, based on data collected during water years 2001-2010.

[Water year is the 12-month period from October 1 through September 30 and is designated by the year in which it ends. $\mathrm{ft}^{3} / \mathrm{s}$, cubic feet per second; NA, not applicable; $\mu \mathrm{S} / \mathrm{cm}$, microsiemens per centimeter at 25 degrees Celsius; $\mathrm{CaCO}_{3}$, calcium carbonate; $\mu \mathrm{g} / \mathrm{L}$, micrograms per liter; $\mathrm{mg} / \mathrm{L}$, milligrams per liter; $\mathrm{ND}$, distributional parameter not determined because of excessive number of censored values; $<$, less than]

\begin{tabular}{|c|c|c|c|c|c|c|c|c|c|}
\hline \multirow[b]{2}{*}{$\begin{array}{l}\text { Period of } \\
\text { water- } \\
\text { quality } \\
\text { sampling } \\
\text { during } \\
\text { water years } \\
2001-10\end{array}$} & \multirow[b]{2}{*}{$\begin{array}{l}\text { Constituent or property, } \\
\text { unadjusted (not flow adjusted) } \\
\text { units of measurement }\end{array}$} & \multicolumn{7}{|c|}{ Statistical summaries of water-quality data ${ }^{1}$} & \multirow[b]{2}{*}{$\begin{array}{l}\text { Ratios of median } \\
\text { filtered to median } \\
\text { unfiltered-recov- } \\
\text { erable concentra- } \\
\text { tions for trace } \\
\text { elements, percent }\end{array}$} \\
\hline & & $\begin{array}{c}\text { Number of } \\
\text { samples (values } \\
\text { in parentheses } \\
\text { indicate number } \\
\text { of censored } \\
\text { values) }\end{array}$ & $\begin{array}{l}\text { Minimum } \\
\text { uncensored } \\
\text { value }^{2}\end{array}$ & $\begin{array}{c}\text { 25th } \\
\text { percentile }\end{array}$ & Median & Mean & $\begin{array}{c}\text { 75th } \\
\text { percentile }\end{array}$ & Maximum & \\
\hline \multicolumn{10}{|c|}{ Blacktail Creek (site 1, fig. 1, table 1) } \\
\hline \multirow{22}{*}{$\begin{array}{r}10 / 2000- \\
8 / 2010\end{array}$} & Streamflow, instantaneous, $\mathrm{ft}^{3} / \mathrm{s}$ & 72 & 1.9 & 4.6 & 8.8 & 12 & 17 & 54 & NA \\
\hline & Specific conductance, $\mu \mathrm{S} / \mathrm{cm}$ & 72 & 161 & 226 & 265 & 267 & 316 & 364 & NA \\
\hline & $\mathrm{pH}$, standard units & 72 & 7.3 & 7.6 & 7.7 & 7.7 & 7.8 & 8.4 & NA \\
\hline & Hardness, filtered, $\mathrm{mg} / \mathrm{L}$ as $\mathrm{CaCO}_{3}$ & 72 & 65 & 87 & 106 & 105 & 122 & 146 & NA \\
\hline & Calcium, filtered, mg/L & 72 & 19.2 & 25.0 & 30.5 & 30.1 & 35.0 & 41.8 & NA \\
\hline & Magnesium, filtered, mg/L & 72 & 4.09 & 6.00 & 7.23 & 7.24 & 8.68 & 10.2 & NA \\
\hline & Cadmium, filtered, $\mu \mathrm{g} / \mathrm{L}$ & $70(12)$ & 0.02 & 0.03 & 0.04 & 0.04 & 0.05 & 0.10 & ${ }^{3} 133$ \\
\hline & Cadmium, unfiltered-recoverable, $\mu \mathrm{g} / \mathrm{L}$ & $72(18)$ & 0.02 & 0.02 & 0.03 & 0.04 & 0.05 & 0.11 & \\
\hline & Copper, filtered, $\mu \mathrm{g} / \mathrm{L}$ & $71(1)$ & 0.80 & 1.6 & 3.0 & 3.6 & 5.2 & 9.3 & 60 \\
\hline & Copper, unfiltered-recoverable, $\mu \mathrm{g} / \mathrm{L}$ & 72 & 1.7 & 3.4 & 5.0 & 5.8 & 7.6 & 17 & \\
\hline & Iron, filtered, $\mu \mathrm{g} / \mathrm{L}$ & 72 & 15 & 68 & 163 & 180 & 277 & 640 & 30 \\
\hline & Iron unfiltered-recoverable, $\mu \mathrm{g} / \mathrm{L}$ & 72 & 150 & 334 & 544 & 561 & 693 & 1,640 & \\
\hline & Lead, filtered, $\mu \mathrm{g} / \mathrm{L}$ & $72(20)$ & 0.04 & 0.06 & 0.11 & 0.17 & 0.21 & 2.8 & 19 \\
\hline & Lead, unfiltered-recoverable, $\mu \mathrm{g} / \mathrm{L}$ & $72(9)$ & 0.10 & 0.35 & 0.59 & 0.79 & 0.92 & 4.9 & \\
\hline & Manganese, filtered, $\mu \mathrm{g} / \mathrm{L}$ & 72 & 14 & 29 & 34 & 41 & 44 & 144 & 72 \\
\hline & Manganese, unfiltered-recoverable, $\mu \mathrm{g} / \mathrm{L}$ & 72 & 24 & 42 & 48 & 55 & 60 & 173 & \\
\hline & Zinc, filtered, $\mu \mathrm{g} / \mathrm{L}$ & $70(2)$ & 0.82 & 2.2 & 2.9 & 3.2 & 3.9 & 8.0 & 67 \\
\hline & Zinc, unfiltered-recoverable, $\mu \mathrm{g} / \mathrm{L}$ & 72 & 2.0 & 3.0 & 4.3 & 6.0 & 6.3 & 35 & \\
\hline & Arsenic, filtered, $\mu \mathrm{g} / \mathrm{L}$ & 71 & 1.1 & 2.2 & 3.1 & 3.9 & 5.1 & 8.7 & 74 \\
\hline & Arsenic, unfiltered-recoverable, $\mu \mathrm{g} / \mathrm{L}$ & $72(1)$ & 1.0 & 3.0 & 4.2 & 4.9 & 6.5 & 11 & \\
\hline & Suspended sediment, mg/L & 72 & 1 & 4 & 7 & 8 & 10 & 31 & NA \\
\hline & Suspended sediment, percent fines ${ }^{4}$ & 72 & 54 & 77 & 82 & 81 & 87 & 96 & NA \\
\hline
\end{tabular}


Table 1-4. Summary information relating to water-quality constituents and properties in samples collected at sites in the upper Clark Fork Basin, Montana , based on data collected during water years 2001-2010.-Continued

[Water year is the 12-month period from October 1 through September 30 and is designated by the year in which it ends. $\mathrm{ft}^{3} / \mathrm{s}$, cubic feet per second; NA, not applicable; $\mu \mathrm{S} / \mathrm{cm}$, microsiemens per centimeter at 25 degrees Celsius; $\mathrm{CaCO}$, calcium carbonate; $\mu \mathrm{g} / \mathrm{L}$, micrograms per liter; $\mathrm{mg} / \mathrm{L}$, milligrams per liter; $\mathrm{ND}$, distributional parameter not determined because of excessive number of censored values; <, less than]

\begin{tabular}{|c|c|c|c|c|c|c|c|c|c|}
\hline \multirow{2}{*}{$\begin{array}{l}\text { Period of } \\
\text { water- } \\
\text { quality } \\
\text { sampling } \\
\text { during } \\
\text { water years } \\
\text { 2001-10 }\end{array}$} & \multirow[b]{2}{*}{$\begin{array}{l}\text { Constituent or property, } \\
\text { unadjusted (not flow adjusted) } \\
\text { units of measurement }\end{array}$} & \multicolumn{7}{|c|}{ Statistical summaries of water-quality data ${ }^{1}$} & \multirow{2}{*}{$\begin{array}{l}\text { Ratios of median } \\
\text { filtered to median } \\
\text { unfiltered-recov- } \\
\text { erable concentra- } \\
\text { tions for trace } \\
\text { elements, percent }\end{array}$} \\
\hline & & $\begin{array}{l}\text { samples (values } \\
\text { in parentheses } \\
\text { indicate number } \\
\text { of censored } \\
\text { values) }\end{array}$ & $\begin{array}{l}\text { Minimum } \\
\text { uncensored } \\
\text { value }^{2}\end{array}$ & $\begin{array}{c}\text { 25th } \\
\text { percentile }\end{array}$ & Median & Mean & $\begin{array}{c}\text { 75th } \\
\text { percentile }\end{array}$ & Maximum & \\
\hline \multicolumn{10}{|c|}{ Silver Bow Creek at Butte (site 2, fig. 1, table 1) } \\
\hline \multirow{22}{*}{$\begin{array}{r}10 / 2000- \\
8 / 2010\end{array}$} & Streamflow, instantaneous, $\mathrm{ft}^{3} / \mathrm{s}$ & 80 & 13 & 17 & 22 & 27 & 33 & 76 & NA \\
\hline & Specific conductance, $\mu \mathrm{S} / \mathrm{cm}$ & 80 & 238 & 402 & 484 & 468 & 546 & 614 & NA \\
\hline & $\mathrm{pH}$, standard units & 80 & 7.4 & 7.6 & 7.6 & 7.6 & 7.7 & 8.0 & NA \\
\hline & Hardness, filtered, $\mathrm{mg} / \mathrm{L}$ as $\mathrm{CaCO}_{3}$ & 80 & 79 & 126 & 154 & 149 & 170 & 217 & NA \\
\hline & Calcium, filtered, $\mathrm{mg} / \mathrm{L}$ & 80 & 23.4 & 36.7 & 43.9 & 42.5 & 48.1 & 62.7 & NA \\
\hline & Magnesium, filtered, mg/L & 80 & 5.02 & 8.86 & 10.6 & 10.4 & 12.0 & 14.6 & NA \\
\hline & Cadmium, filtered, $\mu \mathrm{g} / \mathrm{L}$ & 80 & 0.05 & 0.10 & 0.13 & 0.33 & 0.24 & 2.0 & 58 \\
\hline & Cadmium, unfiltered-recoverable, $\mu \mathrm{g} / \mathrm{L}$ & 80 & 0.09 & 0.15 & 0.22 & 0.46 & 0.57 & 1.9 & \\
\hline & Copper, filtered, $\mu \mathrm{g} / \mathrm{L}$ & 80 & 3.20 & 8.3 & 11 & 11 & 13 & 24 & 53 \\
\hline & Copper, unfiltered-recoverable, $\mu \mathrm{g} / \mathrm{L}$ & 80 & 9.5 & 16 & 20 & 24 & 25 & 111 & \\
\hline & Iron, filtered, $\mu \mathrm{g} / \mathrm{L}$ & 80 & 10.0 & 28 & 51 & 85 & 143 & 268 & 12 \\
\hline & Iron unfiltered-recoverable, $\mu \mathrm{g} / \mathrm{L}$ & 80 & 85 & 278 & 414 & 480 & 571 & 2,970 & \\
\hline & Lead, filtered, $\mu \mathrm{g} / \mathrm{L}$ & $79(8)$ & 0.12 & 0.20 & 0.25 & 0.27 & 0.33 & 0.79 & 13 \\
\hline & Lead, unfiltered-recoverable, $\mu \mathrm{g} / \mathrm{L}$ & $80(1)$ & 0.64 & 1.4 & 2.0 & 2.8 & 2.8 & 31 & \\
\hline & Manganese, filtered, $\mu \mathrm{g} / \mathrm{L}$ & 80 & 21 & 71 & 109 & 150 & 177 & 505 & 84 \\
\hline & Manganese, unfiltered-recoverable, $\mu \mathrm{g} / \mathrm{L}$ & 80 & 26 & 98 & 129 & 180 & 200 & 555 & \\
\hline & Zinc, filtered, $\mu \mathrm{g} / \mathrm{L}$ & 80 & 16 & 34 & 47 & 100 & 104 & 478 & 80 \\
\hline & Zinc, unfiltered-recoverable, $\mu \mathrm{g} / \mathrm{L}$ & 80 & 29 & 44 & 59 & 120 & 173 & 473 & \\
\hline & Arsenic, filtered, $\mu \mathrm{g} / \mathrm{L}$ & 80 & 2.3 & 4.3 & 5.2 & 5.4 & 6.5 & 9.3 & 83 \\
\hline & Arsenic, unfiltered-recoverable, $\mu \mathrm{g} / \mathrm{L}$ & 80 & 3.0 & 5.0 & 6.3 & 7.0 & 8.9 & 19 & \\
\hline & Suspended sediment, $\mathrm{mg} / \mathrm{L}$ & 80 & 2 & 6 & 8 & 11 & 11 & 97 & NA \\
\hline & Suspended sediment, percent fines ${ }^{4}$ & 80 & 70 & 81 & 86 & 85 & 89 & 94 & NA \\
\hline
\end{tabular}


Table 1-4. Summary information relating to water-quality constituents and properties in samples collected at sites in the upper Clark Fork Basin, Montana , based on data

collected during water years 2001-2010.-Continued

[Water year is the 12-month period from October 1 through September 30 and is designated by the year in which it ends. $\mathrm{ft}^{3} / \mathrm{s}$, cubic feet per second; NA, not applicable; $\mu \mathrm{S} / \mathrm{cm}$, microsiemens per centimeter at 25 degrees Celsius; $\mathrm{CaCO}_{3}$, calcium carbonate; $\mu \mathrm{g} / \mathrm{L}$, micrograms per liter; $\mathrm{mg} / \mathrm{L}$, milligrams per liter; $\mathrm{ND}$, distributional parameter not determined because of excessive number of censored values; <, less than]

\begin{tabular}{|c|c|c|c|c|c|c|c|c|c|}
\hline \multirow{2}{*}{$\begin{array}{l}\text { Period of } \\
\text { water- } \\
\text { quality } \\
\text { sampling } \\
\text { during } \\
\text { water years } \\
\text { 2001-10 }\end{array}$} & \multirow[b]{2}{*}{$\begin{array}{l}\text { Constituent or property, } \\
\text { unadjusted (not flow adjusted) } \\
\text { units of measurement }\end{array}$} & \multicolumn{7}{|c|}{ Statistical summaries of water-quality data ${ }^{1}$} & \multirow[b]{2}{*}{$\begin{array}{l}\text { Ratios of median } \\
\text { filtered to median } \\
\text { unfiltered-recov- } \\
\text { erable concentra- } \\
\text { tions for trace } \\
\text { elements, percent }\end{array}$} \\
\hline & & $\begin{array}{c}\text { Number of } \\
\text { samples (values } \\
\text { in parentheses } \\
\text { indicate number } \\
\text { of censored } \\
\text { values) }\end{array}$ & $\begin{array}{l}\text { Minimum } \\
\text { uncensored } \\
\text { value }^{2}\end{array}$ & $\begin{array}{c}\text { 25th } \\
\text { percentile }\end{array}$ & Median & Mean & $\begin{array}{c}\text { 75th } \\
\text { percentile }\end{array}$ & Maximum & \\
\hline \multicolumn{10}{|c|}{ Silver Bow Creek at Opportunity (site 3, fig. 1, table 1) } \\
\hline \multirow{22}{*}{$\begin{array}{r}10 / 2000- \\
8 / 2010\end{array}$} & Streamflow, instantaneous, $\mathrm{ft}^{3} / \mathrm{s}$ & 80 & 13 & 29 & 44 & 65 & 88 & 222 & NA \\
\hline & Specific conductance, $\mu \mathrm{S} / \mathrm{cm}$ & 80 & 248 & 348 & 441 & 437 & 527 & 633 & NA \\
\hline & $\mathrm{pH}$, standard units & 80 & 7.8 & 8.2 & 8.4 & 8.4 & 8.8 & 9.5 & NA \\
\hline & Hardness, filtered, $\mathrm{mg} / \mathrm{L}$ as $\mathrm{CaCO}_{3}$ & 80 & 81 & 129 & 159 & 157 & 184 & 240 & NA \\
\hline & Calcium, filtered, mg/L & 80 & 24.2 & 38.9 & 47.3 & 46.5 & 54.3 & 71.6 & NA \\
\hline & Magnesium, filtered, mg/L & 80 & 4.96 & 7.30 & 9.89 & 9.87 & 12.0 & 15.0 & NA \\
\hline & Cadmium, filtered, $\mu \mathrm{g} / \mathrm{L}$ & 79 & 0.17 & 0.26 & 0.40 & 0.55 & 0.70 & 2.7 & 50 \\
\hline & Cadmium, unfiltered-recoverable, $\mu \mathrm{g} / \mathrm{L}$ & 80 & 0.38 & 0.67 & 0.80 & 1.2 & 1.3 & 5.2 & \\
\hline & Copper, filtered, $\mu \mathrm{g} / \mathrm{L}$ & 78 & 12 & 20 & 25 & 31 & 36 & 142 & 32 \\
\hline & Copper, unfiltered-recoverable, $\mu \mathrm{g} / \mathrm{L}$ & 80 & 31 & 61 & 79 & 120 & 110 & 860 & \\
\hline & Iron, filtered, $\mu \mathrm{g} / \mathrm{L}$ & $80(1)$ & 7.0 & 14 & 23 & 42 & 67 & 248 & 4 \\
\hline & Iron unfiltered-recoverable, $\mu \mathrm{g} / \mathrm{L}$ & 79 & 240 & 463 & 621 & 1,136 & 889 & 9,190 & \\
\hline & Lead, filtered, $\mu \mathrm{g} / \mathrm{L}$ & $80(8)$ & 0.20 & 0.29 & 0.44 & 0.54 & 0.60 & 3.2 & 3 \\
\hline & Lead, unfiltered-recoverable, $\mu \mathrm{g} / \mathrm{L}$ & 80 & 5.0 & 10 & 13 & 25 & 20 & 269 & \\
\hline & Manganese, filtered, $\mu \mathrm{g} / \mathrm{L}$ & 80 & 30 & 120 & 223 & 254 & 342 & 934 & 77 \\
\hline & Manganese, unfiltered-recoverable, $\mu \mathrm{g} / \mathrm{L}$ & 80 & 85 & 200 & 290 & 361 & 437 & 1,520 & \\
\hline & Zinc, filtered, $\mu \mathrm{g} / \mathrm{L}$ & 79 & 11 & 48 & 80 & 129 & 175 & 611 & 41 \\
\hline & Zinc, unfiltered-recoverable, $\mu \mathrm{g} / \mathrm{L}$ & 80 & 70 & 139 & 197 & 273 & 284 & 1,230 & \\
\hline & Arsenic, filtered, $\mu \mathrm{g} / \mathrm{L}$ & 80 & 6.4 & 9.5 & 11 & 12 & 13 & 22 & 69 \\
\hline & Arsenic, unfiltered-recoverable, $\mu \mathrm{g} / \mathrm{L}$ & 80 & 9.1 & 14 & 16 & 20 & 20 & 91 & \\
\hline & Suspended sediment, $\mathrm{mg} / \mathrm{L}$ & 80 & 5 & 13 & 18 & 33 & 30 & 286 & NA \\
\hline & Suspended sediment, percent fines ${ }^{4}$ & 80 & 45 & 78 & 84 & 81 & 86 & 92 & NA \\
\hline
\end{tabular}


Table 1-4. Summary information relating to water-quality constituents and properties in samples collected at sites in the upper Clark Fork Basin, Montana , based on data collected during water years 2001-2010.-Continued

[Water year is the 12-month period from October 1 through September 30 and is designated by the year in which it ends. $\mathrm{ft}^{3} / \mathrm{s}$, cubic feet per second; NA, not applicable; $\mu \mathrm{S} / \mathrm{cm}$, microsiemens per centimeter at 25 degrees Celsius; $\mathrm{CaCO}_{3}$, calcium carbonate; $\mu \mathrm{g} / \mathrm{L}$, micrograms per liter; $\mathrm{mg} / \mathrm{L}$, milligrams per liter; $\mathrm{ND}$, distributional parameter not determined because of excessive number of censored values; $<$, les than]

\begin{tabular}{|c|c|c|c|c|c|c|c|c|c|}
\hline \multirow{2}{*}{$\begin{array}{l}\text { Period of } \\
\text { water- } \\
\text { quality } \\
\text { sampling } \\
\text { during } \\
\text { water years } \\
\text { 2001-10 }\end{array}$} & \multirow[b]{2}{*}{$\begin{array}{l}\text { Constituent or property, } \\
\text { unadjusted (not flow adjusted) } \\
\text { units of measurement }\end{array}$} & \multicolumn{7}{|c|}{ Statistical summaries of water-quality data ${ }^{1}$} & \multirow{2}{*}{$\begin{array}{l}\text { Ratios of median } \\
\text { filtered to median } \\
\text { unfiltered-recov- } \\
\text { erable concentra- } \\
\text { tions for trace } \\
\text { elements, percent }\end{array}$} \\
\hline & & $\begin{array}{c}\text { samples (values } \\
\text { in parentheses } \\
\text { indicate number } \\
\text { of censored } \\
\text { values) }\end{array}$ & $\begin{array}{l}\text { Minimum } \\
\text { uncensored } \\
\text { value }^{2}\end{array}$ & $\begin{array}{c}\text { 25th } \\
\text { percentile }\end{array}$ & Median & Mean & $\begin{array}{c}\text { 75th } \\
\text { percentile }\end{array}$ & Maximum & \\
\hline \multicolumn{10}{|c|}{ Mill Creek near Anaconda (site 4, fig. 1, table 1) } \\
\hline \multirow{22}{*}{$\begin{array}{r}12 / 2004- \\
8 / 2010\end{array}$} & Streamflow, instantaneous, $\mathrm{ft}^{3} / \mathrm{s}$ & 48 & 7.4 & 13 & 26 & 58 & 102 & 213 & NA \\
\hline & Specific conductance, $\mu \mathrm{S} / \mathrm{cm}$ & 48 & 56 & 87 & 133 & 132 & 177 & 213 & NA \\
\hline & $\mathrm{pH}$, standard units & 48 & 7.6 & 7.9 & 8.1 & 8.1 & 8.2 & 8.6 & NA \\
\hline & Hardness, filtered, $\mathrm{mg} / \mathrm{L}$ as $\mathrm{CaCO}_{3}$ & 48 & 24 & 36 & 60 & 57 & 79 & 98 & NA \\
\hline & Calcium, filtered, mg/L & 48 & 7.00 & 10.5 & 16.9 & 15.8 & 21.7 & 25.9 & NA \\
\hline & Magnesium, filtered, mg/L & 48 & 1.45 & 2.39 & 4.22 & 4.28 & 5.96 & 8.01 & NA \\
\hline & Cadmium, filtered, $\mu \mathrm{g} / \mathrm{L}$ & $47(2)$ & 0.02 & 0.03 & 0.04 & 0.04 & 0.05 & 0.11 & 57 \\
\hline & Cadmium, unfiltered-recoverable, $\mu \mathrm{g} / \mathrm{L}$ & 48 & 0.03 & 0.05 & 0.07 & 0.08 & 0.09 & 0.19 & \\
\hline & Copper, filtered, $\mu \mathrm{g} / \mathrm{L}$ & 48 & 0.72 & 1.3 & 2.1 & 2.3 & 3.1 & 5.1 & 61 \\
\hline & Copper, unfiltered-recoverable, $\mu \mathrm{g} / \mathrm{L}$ & $48(1)$ & 1.3 & 2.1 & 3.5 & 3.9 & 5.4 & 11 & \\
\hline & Iron, filtered, $\mu \mathrm{g} / \mathrm{L}$ & 48 & 21.0 & 30 & 41 & 47 & 63 & 125 & 25 \\
\hline & Iron unfiltered-recoverable, $\mu \mathrm{g} / \mathrm{L}$ & 48 & 78 & 123 & 163 & 192 & 203 & 619 & \\
\hline & Lead, filtered, $\mu \mathrm{g} / \mathrm{L}$ & $48(3)$ & 0.02 & 0.08 & 0.11 & 0.12 & 0.16 & 0.24 & 19 \\
\hline & Lead, unfiltered-recoverable, $\mu \mathrm{g} / \mathrm{L}$ & 48 & 0.15 & 0.42 & 0.59 & 0.76 & 0.88 & 3 & \\
\hline & Manganese, filtered, $\mu \mathrm{g} / \mathrm{L}$ & 48 & 3.2 & 4.2 & 5.9 & 5.9 & 6.9 & 12 & 46 \\
\hline & Manganese, unfiltered-recoverable, $\mu \mathrm{g} / \mathrm{L}$ & 48 & 7.4 & 11 & 13 & 14 & 15 & 37 & \\
\hline & Zinc, filtered, $\mu \mathrm{g} / \mathrm{L}$ & $48(5)$ & 0.73 & 1.1 & 1.4 & 1.5 & 1.9 & 4.0 & 53 \\
\hline & Zinc, unfiltered-recoverable, $\mu \mathrm{g} / \mathrm{L}$ & 48 & 1.0 & 1.8 & 2.6 & 3.0 & 3.9 & 9.2 & \\
\hline & Arsenic, filtered, $\mu \mathrm{g} / \mathrm{L}$ & 48 & 7.3 & 12 & 15 & 16 & 20 & 33 & 91 \\
\hline & Arsenic, unfiltered-recoverable, $\mu \mathrm{g} / \mathrm{L}$ & 48 & 8.6 & 13 & 17 & 18 & 23 & 35 & \\
\hline & Suspended sediment, mg/L & 48 & 1 & 2 & 3 & 6 & 6 & 29 & NA \\
\hline & Suspended sediment, percent fines ${ }^{4}$ & 48 & 28 & 57 & 67 & 64 & 75 & 81 & NA \\
\hline
\end{tabular}


Table 1-4. Summary information relating to water-quality constituents and properties in samples collected at sites in the upper Clark Fork Basin, Montana, based on data

collected during water years 2001-2010.-Continued

[Water year is the 12-month period from October 1 through September 30 and is designated by the year in which it ends. $\mathrm{ft}^{3} / \mathrm{s}$, cubic feet per second; NA, not applicable; $\mu \mathrm{S} / \mathrm{cm}$, microsiemens per centimeter at 25 degrees Celsius; $\mathrm{CaCO}_{3}$, calcium carbonate; $\mu \mathrm{g} / \mathrm{L}$, micrograms per liter; $\mathrm{mg} / \mathrm{L}$, milligrams per liter; $\mathrm{ND}$, distributional parameter not determined because of excessive number of censored values; $<$, less than]

\begin{tabular}{|c|c|c|c|c|c|c|c|c|c|}
\hline \multirow[b]{2}{*}{$\begin{array}{l}\text { Period of } \\
\text { water- } \\
\text { quality } \\
\text { sampling } \\
\text { during } \\
\text { water years } \\
\text { 2001-10 }\end{array}$} & \multirow[b]{2}{*}{$\begin{array}{l}\text { Constituent or property, } \\
\text { unadjusted (not flow adjusted) } \\
\text { units of measurement }\end{array}$} & \multicolumn{7}{|c|}{ Statistical summaries of water-quality data ${ }^{1}$} & \multirow[b]{2}{*}{$\begin{array}{l}\text { Ratios of median } \\
\text { filtered to median } \\
\text { unfiltered-recov- } \\
\text { erable concentra- } \\
\text { tions for trace } \\
\text { elements, percent }\end{array}$} \\
\hline & & $\begin{array}{c}\text { Number of } \\
\text { samples (values } \\
\text { in parentheses } \\
\text { indicate number } \\
\text { of censored } \\
\text { values) }\end{array}$ & $\begin{array}{l}\text { Minimum } \\
\text { uncensored } \\
\text { value }^{2}\end{array}$ & $\begin{array}{c}\text { 25th } \\
\text { percentile }\end{array}$ & Median & Mean & $\begin{array}{c}\text { 75th } \\
\text { percentile }\end{array}$ & Maximum & \\
\hline \multicolumn{10}{|c|}{ Mill Creek at Opportunity (site 5, fig. 1, table 1) } \\
\hline \multirow{22}{*}{$\begin{array}{r}3 / 2003- \\
8 / 2010\end{array}$} & Streamflow, instantaneous, $\mathrm{ft}^{3} / \mathrm{s}$ & 64 & 0.43 & 3.6 & 9.7 & 35 & 48 & 261 & NA \\
\hline & Specific conductance, $\mu \mathrm{S} / \mathrm{cm}$ & 64 & 59 & 95 & 153 & 148 & 196 & 230 & NA \\
\hline & $\mathrm{pH}$, standard units & 64 & 7.7 & 7.9 & 8.0 & 8.0 & 8.1 & 8.2 & NA \\
\hline & Hardness, filtered, $\mathrm{mg} / \mathrm{L}$ as $\mathrm{CaCO}_{3}$ & 64 & 24 & 39 & 67 & 63 & 85 & 102 & NA \\
\hline & Calcium, filtered, mg/L & 64 & 7.01 & 11.5 & 18.8 & 17.6 & 23.5 & 28.0 & NA \\
\hline & Magnesium, filtered, mg/L & 64 & 1.56 & 2.64 & 4.67 & 4.56 & 6.30 & 7.83 & NA \\
\hline & Cadmium, filtered, $\mu \mathrm{g} / \mathrm{L}$ & 64 & 0.02 & 0.05 & 0.06 & 0.06 & 0.07 & 0.13 & 60 \\
\hline & Cadmium, unfiltered-recoverable, $\mu \mathrm{g} / \mathrm{L}$ & 64 & 0.04 & 0.07 & 0.10 & 0.15 & 0.13 & 0.85 & \\
\hline & Copper, filtered, $\mu \mathrm{g} / \mathrm{L}$ & 64 & 1.0 & 1.9 & 2.7 & 3.0 & 3.9 & 6.1 & 61 \\
\hline & Copper, unfiltered-recoverable, $\mu \mathrm{g} / \mathrm{L}$ & 64 & 1.5 & 2.8 & 4.4 & 6.8 & 7.2 & 39 & \\
\hline & Iron, filtered, $\mu \mathrm{g} / \mathrm{L}$ & 64 & 16 & 36 & 43 & 48 & 60 & 94 & 30 \\
\hline & Iron unfiltered-recoverable, $\mu \mathrm{g} / \mathrm{L}$ & 64 & 44 & 113 & 145 & 299 & 264 & 1,960 & \\
\hline & Lead, filtered, $\mu \mathrm{g} / \mathrm{L}$ & $64(6)$ & 0.02 & 0.09 & 0.13 & 0.14 & 0.17 & 0.32 & 29 \\
\hline & Lead, unfiltered-recoverable, $\mu \mathrm{g} / \mathrm{L}$ & 64 & 0.07 & 0.23 & 0.45 & 1.5 & 1.6 & 13 & \\
\hline & Manganese, filtered, $\mu \mathrm{g} / \mathrm{L}$ & 64 & 2.2 & 4.5 & 5.6 & 7.7 & 9.2 & 33 & 43 \\
\hline & Manganese, unfiltered-recoverable, $\mu \mathrm{g} / \mathrm{L}$ & 64 & 3.3 & 10 & 13 & 20 & 18 & 113 & \\
\hline & Zinc, filtered, $\mu \mathrm{g} / \mathrm{L}$ & $63(1)$ & 1.3 & 2.1 & 2.8 & 3.0 & 3.8 & 7.7 & 58 \\
\hline & Zinc, unfiltered-recoverable, $\mu \mathrm{g} / \mathrm{L}$ & 64 & 1.7 & 3.0 & 4.9 & 6.7 & 7.0 & 41 & \\
\hline & Arsenic, filtered, $\mu \mathrm{g} / \mathrm{L}$ & 64 & 9.0 & 16 & 21 & 22 & 28 & 55 & 84 \\
\hline & Arsenic, unfiltered-recoverable, $\mu \mathrm{g} / \mathrm{L}$ & 64 & 10 & 20 & 25 & 26 & 31 & 54 & \\
\hline & Suspended sediment, $\mathrm{mg} / \mathrm{L}$ & 64 & 1 & 1 & 2 & 12 & 10 & 107 & NA \\
\hline & Suspended sediment, percent fines ${ }^{4}$ & 64 & 26 & 57 & 74 & 69 & 82 & 90 & NA \\
\hline
\end{tabular}


Table 1-4. Summary information relating to water-quality constituents and properties in samples collected at sites in the upper Clark Fork Basin, Montana , based on data collected during water years 2001-2010.-Continued

[Water year is the 12-month period from October 1 through September 30 and is designated by the year in which it ends. $\mathrm{ft}^{3} / \mathrm{s}$, cubic feet per second; NA, not applicable; $\mu \mathrm{S} / \mathrm{cm}$, microsiemens per centimeter at 25 degrees Celsius; $\mathrm{CaCO}_{3}$, calcium carbonate; $\mu \mathrm{g} / \mathrm{L}$, micrograms per liter; $\mathrm{mg} / \mathrm{L}$, milligrams per liter; $\mathrm{ND}$, distributional parameter not determined because of excessive number of censored values; $<$, less than

\begin{tabular}{|c|c|c|c|c|c|c|c|c|c|}
\hline \multirow{2}{*}{$\begin{array}{l}\text { Period of } \\
\text { water- } \\
\text { quality } \\
\text { sampling } \\
\text { during } \\
\text { water years } \\
2001-10\end{array}$} & \multirow[b]{2}{*}{$\begin{array}{l}\text { Constituent or property, } \\
\text { unadjusted (not flow adjusted) } \\
\text { units of measurement }\end{array}$} & \multicolumn{7}{|c|}{ Statistical summaries of water-quality data ${ }^{1}$} & \multirow[b]{2}{*}{$\begin{array}{l}\text { Ratios of median } \\
\text { filtered to median } \\
\text { unfiltered-recov- } \\
\text { erable concentra- } \\
\text { tions for trace } \\
\text { elements, percen }\end{array}$} \\
\hline & & $\begin{array}{l}\text { samples (values } \\
\text { in parentheses } \\
\text { indicate number } \\
\text { of censored } \\
\text { values) }\end{array}$ & $\begin{array}{l}\text { Minimum } \\
\text { uncensored } \\
\text { value }^{2}\end{array}$ & $\begin{array}{c}\text { 25th } \\
\text { percentile }\end{array}$ & Median & Mean & $\begin{array}{c}\text { 75th } \\
\text { percentile }\end{array}$ & Maximum & \\
\hline \multicolumn{10}{|c|}{ Willow Creek near Anaconda (site 6, fig. 1, table 1) } \\
\hline \multirow{22}{*}{$\begin{array}{r}12 / 2004 \\
8 / 2010\end{array}$} & Streamflow, instantaneous, $\mathrm{ft}^{3} / \mathrm{s}$ & 44 & 1.0 & 2.5 & 7.6 & 14 & 16 & 75 & NA \\
\hline & Specific conductance, $\mu \mathrm{S} / \mathrm{cm}$ & 44 & 66 & 88 & 108 & 102 & 114 & 145 & NA \\
\hline & $\mathrm{pH}$, standard units & 44 & 7.5 & 7.6 & 7.7 & 7.7 & 7.8 & 8.2 & NA \\
\hline & Hardness, filtered, $\mathrm{mg} / \mathrm{L}$ as $\mathrm{CaCO}_{3}$ & 44 & 22 & 32 & 38 & 37 & 41 & 52 & NA \\
\hline & Calcium, filtered, mg/L & 44 & 7.56 & 10.8 & 13.0 & 12.4 & 13.8 & 16.5 & NA \\
\hline & Magnesium, filtered, mg/L & 44 & 0.78 & 1.18 & 1.43 & 1.44 & 1.64 & 2.49 & NA \\
\hline & Cadmium, filtered, $\mu \mathrm{g} / \mathrm{L}$ & $42(5)$ & 0.02 & 0.02 & 0.03 & 0.03 & 0.04 & 0.05 & 60 \\
\hline & Cadmium, unfiltered-recoverable, $\mu \mathrm{g} / \mathrm{L}$ & $44(3)$ & 0.02 & 0.04 & 0.05 & 0.06 & 0.07 & 0.33 & \\
\hline & Copper, filtered, $\mu \mathrm{g} / \mathrm{L}$ & 44 & 0.90 & 1.3 & 1.9 & 2.0 & 2.4 & 4.2 & 61 \\
\hline & Copper, unfiltered-recoverable, $\mu \mathrm{g} / \mathrm{L}$ & $44(1)$ & 1.0 & 2.1 & 3.1 & 3.7 & 4.1 & 17 & \\
\hline & Iron, filtered, $\mu \mathrm{g} / \mathrm{L}$ & 44 & 28 & 51 & 65 & 80 & 85 & 277 & 30 \\
\hline & Iron unfiltered-recoverable, $\mu \mathrm{g} / \mathrm{L}$ & 44 & 86 & 134 & 216 & 342 & 405 & 2,380 & \\
\hline & Lead, filtered, $\mu \mathrm{g} / \mathrm{L}$ & 44 & 0.03 & 0.07 & 0.13 & 0.14 & 0.16 & 0.37 & 26 \\
\hline & Lead, unfiltered-recoverable, $\mu \mathrm{g} / \mathrm{L}$ & 44 & 0.10 & 0.24 & 0.49 & 0.87 & 0.94 & 8.0 & \\
\hline & Manganese, filtered, $\mu \mathrm{g} / \mathrm{L}$ & 44 & 6.0 & 11 & 13 & 14 & 18 & 35 & 57 \\
\hline & Manganese, unfiltered-recoverable, $\mu \mathrm{g} / \mathrm{L}$ & 44 & 14 & 19 & 23 & 26 & 28 & 100 & \\
\hline & Zinc, filtered, $\mu \mathrm{g} / \mathrm{L}$ & $44(4)$ & 0.65 & 1.2 & 1.6 & 1.7 & 2.0 & 3.3 & 76 \\
\hline & Zinc, unfiltered-recoverable, $\mu \mathrm{g} / \mathrm{L}$ & $44(4)$ & 1.0 & 1.5 & 2.1 & 3.1 & 3.9 & 18 & \\
\hline & Arsenic, filtered, $\mu \mathrm{g} / \mathrm{L}$ & 44 & 9.9 & 13 & 14 & 15 & 17 & 25 & 93 \\
\hline & Arsenic, unfiltered-recoverable, $\mu \mathrm{g} / \mathrm{L}$ & 44 & 10 & 14 & 15 & 16 & 18 & 27 & \\
\hline & Suspended sediment, mg/L & 44 & 1 & 3 & 6 & 17 & 13 & 195 & NA \\
\hline & Suspended sediment, percent fines ${ }^{4}$ & 44 & 25 & 62 & 78 & 73 & 88 & 94 & NA \\
\hline
\end{tabular}


Table 1-4. Summary information relating to water-quality constituents and properties in samples collected at sites in the upper Clark Fork Basin, Montana, based on data

collected during water years 2001-2010.-Continued

[Water year is the 12-month period from October 1 through September 30 and is designated by the year in which it ends. $\mathrm{ft}^{3} / \mathrm{s}$, cubic feet per second; NA, not applicable; $\mu \mathrm{S} / \mathrm{cm}$, microsiemens per centimeter at 25 degrees Celsius; $\mathrm{CaCO}_{3}$, calcium carbonate; $\mu \mathrm{g} / \mathrm{L}$, micrograms per liter; $\mathrm{mg} / \mathrm{L}$, milligrams per liter; $\mathrm{ND}$, distributional parameter not determined because of excessive number of censored values; $<$, less than]

\begin{tabular}{|c|c|c|c|c|c|c|c|c|c|}
\hline \multirow[b]{2}{*}{$\begin{array}{l}\text { Period of } \\
\text { water- } \\
\text { quality } \\
\text { sampling } \\
\text { during } \\
\text { water years } \\
2001-10\end{array}$} & \multirow[b]{2}{*}{$\begin{array}{l}\text { Constituent or property, } \\
\text { unadjusted (not flow adjusted) } \\
\text { units of measurement }\end{array}$} & \multicolumn{7}{|c|}{ Statistical summaries of water-quality data ${ }^{1}$} & \multirow[b]{2}{*}{$\begin{array}{l}\text { Ratios of median } \\
\text { filtered to median } \\
\text { unfiltered-recov- } \\
\text { erable concentra- } \\
\text { tions for trace } \\
\text { elements, percent }\end{array}$} \\
\hline & & $\begin{array}{c}\text { Number of } \\
\text { samples (values } \\
\text { in parentheses } \\
\text { indicate number } \\
\text { of censored } \\
\text { values) }\end{array}$ & $\begin{array}{l}\text { Minimum } \\
\text { uncensored } \\
\text { value }^{2}\end{array}$ & $\begin{array}{c}\text { 25th } \\
\text { percentile }\end{array}$ & Median & Mean & $\begin{array}{c}\text { 75th } \\
\text { percentile }\end{array}$ & Maximum & \\
\hline \multicolumn{10}{|c|}{ Willow Creek at Opportunity (site 7, fig. 1, table 1) } \\
\hline \multirow{22}{*}{$\begin{array}{r}3 / 2003- \\
8 / 2010\end{array}$} & Streamflow, instantaneous, $\mathrm{ft}^{3} / \mathrm{s}$ & 64 & 4.5 & 6.2 & 9.1 & 17 & 20 & 70 & NA \\
\hline & Specific conductance, $\mu \mathrm{S} / \mathrm{cm}$ & 64 & 116 & 227 & 297 & 276 & 315 & 371 & NA \\
\hline & $\mathrm{pH}$, standard units & 64 & 7.7 & 8.0 & 8.1 & 8.1 & 8.3 & 9.0 & NA \\
\hline & Hardness, filtered, $\mathrm{mg} / \mathrm{L}$ as $\mathrm{CaCO}_{3}$ & 64 & 65 & 98 & 130 & 120 & 137 & 169 & NA \\
\hline & Calcium, filtered, mg/L & 64 & 20.10 & 28.8 & 36.9 & 34.8 & 39.8 & 47.4 & NA \\
\hline & Magnesium, filtered, mg/L & 64 & 3.52 & 6.27 & 8.56 & 7.98 & 9.40 & 12.30 & NA \\
\hline & Cadmium, filtered, $\mu \mathrm{g} / \mathrm{L}$ & $64(5)$ & 0.02 & 0.03 & 0.04 & 0.04 & 0.06 & 0.12 & 57 \\
\hline & Cadmium, unfiltered-recoverable, $\mu \mathrm{g} / \mathrm{L}$ & $64(1)$ & 0.02 & 0.05 & 0.07 & 0.10 & 0.14 & 0.52 & \\
\hline & Copper, filtered, $\mu \mathrm{g} / \mathrm{L}$ & 64 & 1.1 & 2.4 & 3.6 & 5.6 & 8.6 & 21 & 44 \\
\hline & Copper, unfiltered-recoverable, $\mu \mathrm{g} / \mathrm{L}$ & 64 & 2.8 & 4.6 & 8.1 & 12 & 16 & 49 & \\
\hline & Iron, filtered, $\mu \mathrm{g} / \mathrm{L}$ & 64 & 7.0 & 14 & 36 & 44 & 68 & 179 & 18 \\
\hline & Iron unfiltered-recoverable, $\mu \mathrm{g} / \mathrm{L}$ & 64 & 27 & 108 & 205 & 272 & 332 & 1,420 & \\
\hline & Lead, filtered, $\mu \mathrm{g} / \mathrm{L}$ & $64(1)$ & 0.04 & 0.10 & 0.19 & 0.22 & 0.30 & 0.58 & 12 \\
\hline & Lead, unfiltered-recoverable, $\mu \mathrm{g} / \mathrm{L}$ & 64 & 0.27 & 0.85 & 1.5 & 2.3 & 2.6 & 14 & \\
\hline & Manganese, filtered, $\mu \mathrm{g} / \mathrm{L}$ & 64 & 3.3 & 15 & 24 & 32 & 45 & 200 & 68 \\
\hline & Manganese, unfiltered-recoverable, $\mu \mathrm{g} / \mathrm{L}$ & 64 & 4.7 & 19 & 35 & 45 & 58 & 228 & \\
\hline & Zinc, filtered, $\mu \mathrm{g} / \mathrm{L}$ & $64(3)$ & 0.84 & 2.3 & 3.9 & 5.3 & 7.0 & 20 & 41 \\
\hline & Zinc, unfiltered-recoverable, $\mu \mathrm{g} / \mathrm{L}$ & 64 & 1.1 & 4.8 & 9.5 & 13 & 17 & 68 & \\
\hline & Arsenic, filtered, $\mu \mathrm{g} / \mathrm{L}$ & 64 & 11 & 17 & 32 & 42 & 63 & 164 & 96 \\
\hline & Arsenic, unfiltered-recoverable, $\mu \mathrm{g} / \mathrm{L}$ & 64 & 12 & 19 & 33 & 45 & 65 & 164 & \\
\hline & Suspended sediment, $\mathrm{mg} / \mathrm{L}$ & 64 & 1 & 3 & 5 & 11 & 15 & 84 & NA \\
\hline & Suspended sediment, percent fines ${ }^{4}$ & 64 & 55 & 80 & 88 & 85 & 92 & 96 & NA \\
\hline
\end{tabular}


Table 1-4. Summary information relating to water-quality constituents and properties in samples collected at sites in the upper Clark Fork Basin, Montana , based on data collected during water years 2001-2010.-Continued

[Water year is the 12-month period from October 1 through September 30 and is designated by the year in which it ends. $\mathrm{ft}^{3} / \mathrm{s}$, cubic feet per second; NA, not applicable; $\mu \mathrm{S} / \mathrm{cm}$, microsiemens per centimeter at 25 degrees Celsius; $\mathrm{CaCO}$, calcium carbonate; $\mu \mathrm{g} / \mathrm{L}$, micrograms per liter; $\mathrm{mg} / \mathrm{L}$, milligrams per liter; $\mathrm{ND}$, distributional parameter not determined because of excessive number of censored values; $<$, les than]

\begin{tabular}{|c|c|c|c|c|c|c|c|c|c|}
\hline \multirow{2}{*}{$\begin{array}{l}\text { Period of } \\
\text { water- } \\
\text { quality } \\
\text { sampling } \\
\text { during } \\
\text { water years } \\
2001-10\end{array}$} & \multirow[b]{2}{*}{$\begin{array}{l}\text { Constituent or property, } \\
\text { unadjusted (not flow adjusted) } \\
\text { units of measurement }\end{array}$} & \multicolumn{7}{|c|}{ Statistical summaries of water-quality data ${ }^{1}$} & \multirow{2}{*}{$\begin{array}{l}\text { Ratios of median } \\
\text { filtered to median } \\
\text { unfiltered-recov- } \\
\text { erable concentra- } \\
\text { tions for trace } \\
\text { elements, percent }\end{array}$} \\
\hline & & $\begin{array}{l}\text { samples (values } \\
\text { in parentheses } \\
\text { indicate number } \\
\text { of censored } \\
\text { values) }\end{array}$ & $\begin{array}{l}\text { Minimum } \\
\text { uncensored } \\
\text { value }^{2}\end{array}$ & $\begin{array}{c}\text { 25th } \\
\text { percentile }\end{array}$ & Median & Mean & $\begin{array}{c}\text { 75th } \\
\text { percentile }\end{array}$ & Maximum & \\
\hline \multicolumn{10}{|c|}{ Silver Bow Creek at Warm Springs (site 8, fig. 1, table 1) } \\
\hline \multirow{22}{*}{$\begin{array}{r}10 / 2000- \\
8 / 2010\end{array}$} & Streamflow, instantaneous, $\mathrm{ft}^{3} / \mathrm{s}$ & 80 & 21 & 41 & 65 & 112 & 146 & 481 & NA \\
\hline & Specific conductance, $\mu \mathrm{S} / \mathrm{cm}$ & 80 & 253 & 386 & 507 & 488 & 582 & 783 & NA \\
\hline & $\mathrm{pH}$, standard units & 80 & 8.1 & 8.5 & 8.8 & 8.8 & 9.0 & 9.6 & NA \\
\hline & Hardness, filtered, $\mathrm{mg} / \mathrm{L}$ as $\mathrm{CaCO}_{3}$ & 80 & 104 & 154 & 207 & 203 & 242 & 314 & NA \\
\hline & Calcium, filtered, mg/L & 80 & 29.1 & 45.4 & 60.7 & 58.8 & 69.6 & 90.4 & NA \\
\hline & Magnesium, filtered, mg/L & 80 & 6.04 & 10.5 & 13.7 & 13.5 & 16.5 & 21.4 & NA \\
\hline & Cadmium, filtered, $\mu \mathrm{g} / \mathrm{L}$ & $80(14)$ & 0.02 & 0.03 & 0.04 & 0.05 & 0.06 & 0.31 & 41 \\
\hline & Cadmium, unfiltered-recoverable, $\mu \mathrm{g} / \mathrm{L}$ & $80(4)$ & 0.03 & 0.07 & 0.10 & 0.12 & 0.14 & 0.56 & \\
\hline & Copper, filtered, $\mu \mathrm{g} / \mathrm{L}$ & 80 & 1.7 & 3.3 & 4.3 & 5.0 & 6.0 & 28 & 54 \\
\hline & Copper, unfiltered-recoverable, $\mu \mathrm{g} / \mathrm{L}$ & 80 & 2.4 & 5.7 & 8.0 & 11 & 12 & 97 & \\
\hline & Iron, filtered, $\mu \mathrm{g} / \mathrm{L}$ & $80(7)$ & 4.0 & 8.0 & 15 & 18 & 24 & 72 & 7 \\
\hline & Iron unfiltered-recoverable, $\mu \mathrm{g} / \mathrm{L}$ & 80 & 36 & 143 & 218 & 258 & 272 & 1,420 & \\
\hline & Lead, filtered, $\mu \mathrm{g} / \mathrm{L}$ & $80(23)$ & 0.03 & 0.05 & 0.08 & 0.10 & 0.13 & 0.57 & 7 \\
\hline & Lead, unfiltered-recoverable, $\mu \mathrm{g} / \mathrm{L}$ & $80(7)$ & 0.15 & 0.58 & 1.2 & 1.6 & 1.8 & 42 & \\
\hline & Manganese, filtered, $\mu \mathrm{g} / \mathrm{L}$ & 80 & 13 & 50 & 78 & 122 & 167 & 875 & 57 \\
\hline & Manganese, unfiltered-recoverable, $\mu \mathrm{g} / \mathrm{L}$ & 80 & 24 & 95 & 138 & 175 & 221 & 899 & \\
\hline & Zinc, filtered, $\mu \mathrm{g} / \mathrm{L}$ & $80(2)$ & 0.59 & 2.1 & 3.5 & 4.5 & 5.2 & 37 & 32 \\
\hline & Zinc, unfiltered-recoverable, $\mu \mathrm{g} / \mathrm{L}$ & 80 & 2.0 & 6.5 & 11 & 15 & 17 & 158 & \\
\hline & Arsenic, filtered, $\mu \mathrm{g} / \mathrm{L}$ & 80 & 6.8 & 15 & 26 & 24 & 32 & 47 & 90 \\
\hline & Arsenic, unfiltered-recoverable, $\mu \mathrm{g} / \mathrm{L}$ & 80 & 10.0 & 18 & 29 & 28 & 35 & 52 & \\
\hline & Suspended sediment, $\mathrm{mg} / \mathrm{L}$ & 80 & 1 & 3 & 5 & 7 & 7 & 47 & NA \\
\hline & Suspended sediment, percent fines ${ }^{4}$ & 80 & 47 & 79 & 84 & 82 & 88 & 97 & NA \\
\hline
\end{tabular}


Table 1-4. Summary information relating to water-quality constituents and properties in samples collected at sites in the upper Clark Fork Basin, Montana , based on data

collected during water years 2001-2010.-Continued

[Water year is the 12-month period from October 1 through September 30 and is designated by the year in which it ends. $\mathrm{ft}^{3} / \mathrm{s}$, cubic feet per second; NA, not applicable; $\mu \mathrm{S} / \mathrm{cm}$, microsiemens per centimeter at 25 degrees Celsius; $\mathrm{CaCO}_{3}$, calcium carbonate; $\mu \mathrm{g} / \mathrm{L}$, micrograms per liter; $\mathrm{mg} / \mathrm{L}$, milligrams per liter; $\mathrm{ND}$, distributional parameter not determined because of excessive number of censored values; <, less than]

\begin{tabular}{|c|c|c|c|c|c|c|c|c|c|}
\hline \multirow[b]{2}{*}{$\begin{array}{l}\text { Period of } \\
\text { water- } \\
\text { quality } \\
\text { sampling } \\
\text { during } \\
\text { water years } \\
\text { 2001-10 }\end{array}$} & \multirow[b]{2}{*}{$\begin{array}{l}\text { Constituent or property, } \\
\text { unadjusted (not flow adjusted) } \\
\text { units of measurement }\end{array}$} & \multicolumn{7}{|c|}{ Statistical summaries of water-quality data ${ }^{1}$} & \multirow[b]{2}{*}{$\begin{array}{l}\text { Ratios of median } \\
\text { filtered to median } \\
\text { unfiltered-recov- } \\
\text { erable concentra- } \\
\text { tions for trace } \\
\text { elements, percent }\end{array}$} \\
\hline & & $\begin{array}{c}\text { Number of } \\
\text { samples (values } \\
\text { in parentheses } \\
\text { indicate number } \\
\text { of censored } \\
\text { values) }\end{array}$ & $\begin{array}{l}\text { Minimum } \\
\text { uncensored } \\
\text { value }^{2}\end{array}$ & $\begin{array}{c}\text { 25th } \\
\text { percentile }\end{array}$ & Median & Mean & $\begin{array}{c}\text { 75th } \\
\text { percentile }\end{array}$ & Maximum & \\
\hline \multicolumn{10}{|c|}{ Warm Springs Creek near Anaconda (site 9, fig. 1, table 1) } \\
\hline \multirow{22}{*}{$\begin{array}{r}10 / 2005- \\
8 / 2010\end{array}$} & Streamflow, instantaneous, $\mathrm{ft}^{3} / \mathrm{s}$ & 30 & 41 & 61 & 84 & 137 & 170 & 573 & NA \\
\hline & Specific conductance, $\mu \mathrm{S} / \mathrm{cm}$ & 30 & 125 & 184 & 235 & 217 & 253 & 271 & NA \\
\hline & $\mathrm{pH}$, standard units & 30 & 8.0 & 8.4 & 8.5 & 8.5 & 8.6 & 8.8 & NA \\
\hline & Hardness, filtered, $\mathrm{mg} / \mathrm{L}$ as $\mathrm{CaCO}_{3}$ & 30 & 58 & 89 & 112 & 105 & 124 & 132 & NA \\
\hline & Calcium, filtered, mg/L & 30 & 18.5 & 27.5 & 33.8 & 31.6 & 36.5 & 39.2 & NA \\
\hline & Magnesium, filtered, mg/L & 30 & 2.96 & 4.90 & 6.90 & 6.36 & 7.85 & 8.57 & NA \\
\hline & Cadmium, filtered, $\mu \mathrm{g} / \mathrm{L}$ & $30(9)$ & 0.02 & 0.02 & 0.02 & 0.02 & 0.02 & 0.04 & 67 \\
\hline & Cadmium, unfiltered-recoverable, $\mu \mathrm{g} / \mathrm{L}$ & $30(3)$ & 0.01 & 0.02 & 0.03 & 0.04 & 0.04 & 0.14 & \\
\hline & Copper, filtered, $\mu \mathrm{g} / \mathrm{L}$ & $30(2)$ & 0.57 & 0.68 & 0.91 & 1.1 & 1.3 & 2.2 & 43 \\
\hline & Copper, unfiltered-recoverable, $\mu \mathrm{g} / \mathrm{L}$ & $30(3)$ & 1.1 & 1.5 & 2.1 & 3.2 & 3.3 & 28 & \\
\hline & Iron, filtered, $\mu \mathrm{g} / \mathrm{L}$ & $30(3)$ & 2.0 & 5.0 & 6.0 & 7.1 & 10 & 15 & 8 \\
\hline & Iron unfiltered-recoverable, $\mu \mathrm{g} / \mathrm{L}$ & 30 & 28 & 64 & 75 & 144 & 123 & 1,000 & \\
\hline & Lead, filtered, $\mu \mathrm{g} / \mathrm{L}$ & $30(21)$ & 0.02 & 0.01 & 0.02 & 0.03 & 0.03 & 0.11 & 8 \\
\hline & Lead, unfiltered-recoverable, $\mu \mathrm{g} / \mathrm{L}$ & 30 & 0.08 & 0.20 & 0.26 & 0.52 & 0.43 & 3.5 & \\
\hline & Manganese, filtered, $\mu \mathrm{g} / \mathrm{L}$ & $30(1)$ & 0.50 & 0.70 & 0.95 & 1.2 & 1.5 & 2.9 & 22 \\
\hline & Manganese, unfiltered-recoverable, $\mu \mathrm{g} / \mathrm{L}$ & 30 & 1.20 & 2.8 & 4.3 & 6.9 & 6.9 & 45 & \\
\hline & Zinc, filtered, $\mu \mathrm{g} / \mathrm{L}$ & $30(14)$ & 0.30 & 0.50 & 0.74 & 0.89 & 1.1 & 2.8 & 37 \\
\hline & Zinc, unfiltered-recoverable, $\mu \mathrm{g} / \mathrm{L}$ & $30(4)$ & 1.0 & 1.0 & 2.0 & 3.2 & 3.6 & 20 & \\
\hline & Arsenic, filtered, $\mu \mathrm{g} / \mathrm{L}$ & 30 & 1.8 & 2 & 2 & 2 & 2 & 4 & 84 \\
\hline & Arsenic, unfiltered-recoverable, $\mu \mathrm{g} / \mathrm{L}$ & 30 & 2 & 2 & 3 & 3 & 3 & 6 & \\
\hline & Suspended sediment, mg/L & 30 & 1 & 3 & 4 & 9 & 6 & 65 & NA \\
\hline & Suspended sediment, percent fines ${ }^{4}$ & 30 & 32 & 61 & 66 & 64 & 70 & 83 & NA \\
\hline
\end{tabular}


Table 1-4. Summary information relating to water-quality constituents and properties in samples collected at sites in the upper Clark Fork Basin, Montana , based on data collected during water years 2001-2010.-Continued

[Water year is the 12-month period from October 1 through September 30 and is designated by the year in which it ends. $\mathrm{ft}^{3} / \mathrm{s}$, cubic feet per second; NA, not applicable; $\mu \mathrm{S} / \mathrm{cm}$, microsiemens per centimeter at 25 degrees Celsius; $\mathrm{CaCO}$, calcium carbonate; $\mu \mathrm{g} / \mathrm{L}$, micrograms per liter; $\mathrm{mg} / \mathrm{L}$, milligrams per liter; $\mathrm{ND}$, distributional parameter not determined because of excessive number of censored values; $<$, less than]

\begin{tabular}{|c|c|c|c|c|c|c|c|c|c|}
\hline \multirow{2}{*}{$\begin{array}{l}\text { Period of } \\
\text { water- } \\
\text { quality } \\
\text { sampling } \\
\text { during } \\
\text { water years } \\
\text { 2001-10 }\end{array}$} & \multirow[b]{2}{*}{$\begin{array}{l}\text { Constituent or property, } \\
\text { unadjusted (not flow adjusted) } \\
\text { units of measurement }\end{array}$} & \multicolumn{7}{|c|}{ Statistical summaries of water-quality data ${ }^{1}$} & \multirow{2}{*}{$\begin{array}{l}\text { Ratios of median } \\
\text { filtered to median } \\
\text { unfiltered-recov- } \\
\text { erable concentra- } \\
\text { tions for trace } \\
\text { elements, percent }\end{array}$} \\
\hline & & $\begin{array}{l}\text { samples (values } \\
\text { in parentheses } \\
\text { indicate number } \\
\text { of censored } \\
\text { values) }\end{array}$ & $\begin{array}{l}\text { Minimum } \\
\text { uncensored } \\
\text { value }^{2}\end{array}$ & $\begin{array}{c}\text { 25th } \\
\text { percentile }\end{array}$ & Median & Mean & $\begin{array}{c}\text { 75th } \\
\text { percentile }\end{array}$ & Maximum & \\
\hline \multicolumn{10}{|c|}{ Warm Springs Creek at Warm Springs (site 10, fig. 1, table 1) } \\
\hline \multirow{22}{*}{$\begin{array}{r}10 / 2000- \\
8 / 2010\end{array}$} & Streamflow, instantaneous, $\mathrm{ft}^{3} / \mathrm{s}$ & 63 & 14 & 37 & 48 & 83 & 102 & 389 & NA \\
\hline & Specific conductance, $\mu \mathrm{S} / \mathrm{cm}$ & 63 & 155 & 219 & 308 & 287 & 339 & 431 & NA \\
\hline & $\mathrm{pH}$, standard units & 63 & 7.8 & 8.1 & 8.2 & 8.3 & 8.4 & 8.7 & NA \\
\hline & Hardness, filtered, $\mathrm{mg} / \mathrm{L}$ as $\mathrm{CaCO}_{3}$ & 63 & 40 & 106 & 148 & 138 & 167 & 222 & NA \\
\hline & Calcium, filtered, mg/L & 63 & 10.5 & 32.5 & 45.4 & 42.2 & 50.8 & 67.9 & NA \\
\hline & Magnesium, filtered, mg/L & 63 & 3.29 & 5.84 & 8.49 & 7.93 & 9.48 & 12.8 & NA \\
\hline & Cadmium, filtered, $\mu \mathrm{g} / \mathrm{L}$ & $63(14)$ & 0.02 & 0.02 & 0.03 & 0.03 & 0.04 & 0.10 & 62 \\
\hline & Cadmium, unfiltered-recoverable, $\mu \mathrm{g} / \mathrm{L}$ & $63(9)$ & 0.03 & 0.04 & 0.05 & 0.08 & 0.08 & 0.41 & \\
\hline & Copper, filtered, $\mu \mathrm{g} / \mathrm{L}$ & $63(1)$ & 1.1 & 2.0 & 2.7 & 2.9 & 3.2 & 11 & 33 \\
\hline & Copper, unfiltered-recoverable, $\mu \mathrm{g} / \mathrm{L}$ & 63 & 3.9 & 6.4 & 8.1 & 18 & 14 & 147 & \\
\hline & Iron, filtered, $\mu \mathrm{g} / \mathrm{L}$ & $63(4)$ & 5.0 & 8.0 & 10 & 11 & 14 & 28 & 10 \\
\hline & Iron unfiltered-recoverable, $\mu \mathrm{g} / \mathrm{L}$ & 63 & 39 & 76 & 102 & 272 & 219 & 2,110 & \\
\hline & Lead, filtered, $\mu \mathrm{g} / \mathrm{L}$ & $63(31)$ & 0.03 & 0.03 & 0.04 & 0.05 & 0.06 & 0.32 & 7 \\
\hline & Lead, unfiltered-recoverable, $\mu \mathrm{g} / \mathrm{L}$ & $63(10)$ & 0.21 & 0.34 & 0.60 & 1.3 & 1.2 & 14 & \\
\hline & Manganese, filtered, $\mu \mathrm{g} / \mathrm{L}$ & 63 & 19 & 48 & 78 & 98 & 135 & 394 & 55 \\
\hline & Manganese, unfiltered-recoverable, $\mu \mathrm{g} / \mathrm{L}$ & 63 & 37 & 95 & 142 & 180 & 203 & 1,270 & \\
\hline & Zinc, filtered, $\mu \mathrm{g} / \mathrm{L}$ & $62(7)$ & 0.60 & 0.92 & 1.5 & 1.6 & 1.9 & 7.6 & 50 \\
\hline & Zinc, unfiltered-recoverable, $\mu \mathrm{g} / \mathrm{L}$ & 63 & 1.0 & 2.7 & 3.0 & 7.1 & 6.0 & 48 & \\
\hline & Arsenic, filtered, $\mu \mathrm{g} / \mathrm{L}$ & 63 & 3.0 & 3.9 & 4.5 & 5.0 & 5.7 & 12 & 82 \\
\hline & Arsenic, unfiltered-recoverable, $\mu \mathrm{g} / \mathrm{L}$ & 63 & 3.7 & 5.0 & 5.5 & 6.9 & 7.1 & 22 & \\
\hline & Suspended sediment, $\mathrm{mg} / \mathrm{L}$ & 63 & 1 & 3 & 6 & 15 & 12 & 127 & NA \\
\hline & Suspended sediment, percent fines ${ }^{4}$ & 63 & 43 & 65 & 68 & 68 & 73 & 81 & NA \\
\hline
\end{tabular}


Table 1-4. Summary information relating to water-quality constituents and properties in samples collected at sites in the upper Clark Fork Basin, Montana , based on data collected during water years 2001-2010.-Continued

[Water year is the 12-month period from October 1 through September 30 and is designated by the year in which it ends. $\mathrm{ft}^{3} / \mathrm{s}$, cubic feet per second; NA, not applicable; $\mu \mathrm{S} / \mathrm{cm}$, microsiemens per centimeter at 25 degrees Celsius; $\mathrm{CaCO}_{3}$, calcium carbonate; $\mu \mathrm{g} / \mathrm{L}$, micrograms per liter; $\mathrm{mg} / \mathrm{L}$, milligrams per liter; $\mathrm{ND}$, distributional parameter not determined because of excessive number of censored values; <, less than]

\begin{tabular}{|c|c|c|c|c|c|c|c|c|c|}
\hline \multirow[b]{2}{*}{$\begin{array}{l}\text { Period of } \\
\text { water- } \\
\text { quality } \\
\text { sampling } \\
\text { during } \\
\text { water years } \\
2001-10\end{array}$} & \multirow[b]{2}{*}{$\begin{array}{l}\text { Constituent or property, } \\
\text { unadjusted (not flow adjusted) } \\
\text { units of measurement }\end{array}$} & \multicolumn{7}{|c|}{ Statistical summaries of water-quality data ${ }^{1}$} & \multirow[b]{2}{*}{$\begin{array}{l}\text { Ratios of median } \\
\text { filtered to median } \\
\text { unfiltered-recov- } \\
\text { erable concentra- } \\
\text { tions for trace } \\
\text { elements, percent }\end{array}$} \\
\hline & & $\begin{array}{c}\text { Number of } \\
\text { samples (values } \\
\text { in parentheses } \\
\text { indicate number } \\
\text { of censored } \\
\text { values) }\end{array}$ & $\begin{array}{l}\text { Minimum } \\
\text { uncensored } \\
\text { value }^{2}\end{array}$ & $\begin{array}{c}\text { 25th } \\
\text { percentile }\end{array}$ & Median & Mean & $\begin{array}{c}\text { 75th } \\
\text { percentile }\end{array}$ & Maximum & \\
\hline \multicolumn{10}{|c|}{ Clark Fork near Galen (site 11, fig. 1, table 1) } \\
\hline \multirow{22}{*}{$\begin{array}{r}10 / 2000- \\
8 / 2010\end{array}$} & Streamflow, instantaneous, $\mathrm{ft}^{3} / \mathrm{s}$ & 80 & 33 & 79 & 127 & 203 & 258 & 905 & NA \\
\hline & Specific conductance, $\mu \mathrm{S} / \mathrm{cm}$ & 80 & 216 & 320 & 416 & 405 & 480 & 607 & NA \\
\hline & $\mathrm{pH}$, standard units & 80 & 8.1 & 8.4 & 8.6 & 8.6 & 8.8 & 9.2 & NA \\
\hline & Hardness, filtered, $\mathrm{mg} / \mathrm{L}$ as $\mathrm{CaCO}_{3}$ & 80 & 91 & 135 & 188 & 176 & 211 & 280 & NA \\
\hline & Calcium, filtered, mg/L & 80 & 27.5 & 41.0 & 55.5 & 52.2 & 62.0 & 82.3 & NA \\
\hline & Magnesium, filtered, mg/L & 80 & 5.11 & 8.30 & 11.8 & 11.2 & 13.8 & 18.1 & NA \\
\hline & Cadmium, filtered, $\mu \mathrm{g} / \mathrm{L}$ & $80(13)$ & 0.02 & 0.03 & 0.04 & 0.05 & 0.05 & 0.25 & 40 \\
\hline & Cadmium, unfiltered-recoverable, $\mu \mathrm{g} / \mathrm{L}$ & $80(5)$ & 0.04 & 0.07 & 0.10 & 0.12 & 0.15 & 0.64 & \\
\hline & Copper, filtered, $\mu \mathrm{g} / \mathrm{L}$ & 80 & 1.7 & 3.4 & 4.2 & 4.8 & 5.6 & 21 & 36 \\
\hline & Copper, unfiltered-recoverable, $\mu \mathrm{g} / \mathrm{L}$ & 80 & 4.1 & 8.4 & 12 & 19 & 17 & 94 & \\
\hline & Iron, filtered, $\mu \mathrm{g} / \mathrm{L}$ & $80(5)$ & 4.0 & 7.0 & 11 & 14 & 19 & 63 & 5 \\
\hline & Iron unfiltered-recoverable, $\mu \mathrm{g} / \mathrm{L}$ & 80 & 56 & 135 & 224 & 332 & 324 & 2,030 & \\
\hline & Lead, filtered, $\mu \mathrm{g} / \mathrm{L}$ & $80(26)$ & 0.04 & 0.04 & 0.06 & 0.08 & 0.10 & 1.0 & 5 \\
\hline & Lead, unfiltered-recoverable, $\mu \mathrm{g} / \mathrm{L}$ & $80(8)$ & 0.36 & 0.69 & 1.3 & 2.3 & 2.1 & 31 & \\
\hline & Manganese, filtered, $\mu \mathrm{g} / \mathrm{L}$ & 80 & 24 & 42 & 67 & 94 & 120 & 460 & 45 \\
\hline & Manganese, unfiltered-recoverable, $\mu \mathrm{g} / \mathrm{L}$ & 80 & 47 & 104 & 149 & 177 & 227 & 785 & \\
\hline & Zinc, filtered, $\mu \mathrm{g} / \mathrm{L}$ & $80(3)$ & 0.90 & 1.7 & 2.7 & 3.5 & 4.7 & 31 & 24 \\
\hline & Zinc, unfiltered-recoverable, $\mu \mathrm{g} / \mathrm{L}$ & 80 & 2.7 & 7.5 & 11 & 16 & 18 & 116 & \\
\hline & Arsenic, filtered, $\mu \mathrm{g} / \mathrm{L}$ & 80 & 5.7 & 10 & 16 & 16 & 20 & 30 & 92 \\
\hline & Arsenic, unfiltered-recoverable, $\mu \mathrm{g} / \mathrm{L}$ & 80 & 7.5 & 12 & 18 & 19 & 23 & 50 & \\
\hline & Suspended sediment, $\mathrm{mg} / \mathrm{L}$ & 80 & 1 & 4 & 7 & 13 & 12 & 97 & NA \\
\hline & Suspended sediment, percent fines ${ }^{4}$ & 80 & 40 & 70 & 76 & 75 & 80 & 96 & NA \\
\hline
\end{tabular}


Table 1-4. Summary information relating to water-quality constituents and properties in samples collected at sites in the upper Clark Fork Basin, Montana , based on data collected during water years 2001-2010.-Continued

[Water year is the 12-month period from October 1 through September 30 and is designated by the year in which it ends. $\mathrm{ft}^{3} / \mathrm{s}$, cubic feet per second; NA, not applicable; $\mu \mathrm{S} / \mathrm{cm}$, microsiemens per centimeter at 25 degrees Celsius; $\mathrm{CaCO}$, calcium carbonate; $\mu \mathrm{g} / \mathrm{L}$, micrograms per liter; $\mathrm{mg} / \mathrm{L}$, milligrams per liter; $\mathrm{ND}$, distributional parameter not determined because of excessive number of censored values; $<$, les than]

\begin{tabular}{|c|c|c|c|c|c|c|c|c|c|}
\hline \multirow{2}{*}{$\begin{array}{l}\text { Period of } \\
\text { water- } \\
\text { quality } \\
\text { sampling } \\
\text { during } \\
\text { water years } \\
2001-10\end{array}$} & \multirow[b]{2}{*}{$\begin{array}{l}\text { Constituent or property, } \\
\text { unadjusted (not flow adjusted) } \\
\text { units of measurement }\end{array}$} & \multicolumn{7}{|c|}{ Statistical summaries of water-quality data ${ }^{1}$} & \multirow{2}{*}{$\begin{array}{l}\text { Ratios of median } \\
\text { filtered to median } \\
\text { unfiltered-recov- } \\
\text { erable concentra- } \\
\text { tions for trace } \\
\text { elements, percent }\end{array}$} \\
\hline & & $\begin{array}{l}\text { samples (values } \\
\text { in parentheses } \\
\text { indicate number } \\
\text { of censored } \\
\text { values) }\end{array}$ & $\begin{array}{l}\text { Minimum } \\
\text { uncensored } \\
\text { value }^{2}\end{array}$ & $\begin{array}{c}\text { 25th } \\
\text { percentile }\end{array}$ & Median & Mean & $\begin{array}{c}\text { 75th } \\
\text { percentile }\end{array}$ & Maximum & \\
\hline \multicolumn{10}{|c|}{ Lost Creek near Anaconda (site 12, fig. 1, table 1) } \\
\hline \multirow{22}{*}{$\begin{array}{r}12 / 2004- \\
8 / 2010\end{array}$} & Streamflow, instantaneous, $\mathrm{ft}^{3} / \mathrm{s}$ & 47 & 0.37 & 4.3 & 8.0 & 10 & 13 & 54 & NA \\
\hline & Specific conductance, $\mu \mathrm{S} / \mathrm{cm}$ & 47 & 121 & 173 & 211 & 198 & 221 & 253 & NA \\
\hline & $\mathrm{pH}$, standard units & 47 & 7.4 & 8.2 & 8.2 & 8.2 & 8.3 & 8.6 & NA \\
\hline & Hardness, filtered, $\mathrm{mg} / \mathrm{L}$ as $\mathrm{CaCO}_{3}$ & 47 & 50 & 85 & 99 & 94 & 106 & 122 & NA \\
\hline & Calcium, filtered, mg/L & 47 & 15.7 & 26.3 & 30.0 & 28.5 & 32.2 & 37.1 & NA \\
\hline & Magnesium, filtered, mg/L & 47 & 2.71 & 4.54 & 5.78 & 5.50 & 6.45 & 7.2 & NA \\
\hline & Cadmium, filtered, $\mu \mathrm{g} / \mathrm{L}$ & $46(5)$ & 0.01 & 0.02 & 0.03 & 0.03 & 0.03 & 0.90 & 75 \\
\hline & Cadmium, unfiltered-recoverable, $\mu \mathrm{g} / \mathrm{L}$ & $47(5)$ & 0.01 & 0.03 & 0.04 & 0.12 & 0.07 & 147 & \\
\hline & Copper, filtered, $\mu \mathrm{g} / \mathrm{L}$ & 47 & 0.86 & 1.3 & 1.8 & 3.9 & 2.9 & 91 & 41 \\
\hline & Copper, unfiltered-recoverable, $\mu \mathrm{g} / \mathrm{L}$ & $47(1)$ & 1.7 & 2.8 & 4.4 & 16.3 & 8.3 & 29,100 & \\
\hline & Iron, filtered, $\mu \mathrm{g} / \mathrm{L}$ & $47(4)$ & 4.0 & 6.0 & 9.0 & 10 & 12 & 25 & 9 \\
\hline & Iron unfiltered-recoverable, $\mu \mathrm{g} / \mathrm{L}$ & 47 & 22 & 61 & 98 & 2,300 & 217 & 99,700 & \\
\hline & Lead, filtered, $\mu \mathrm{g} / \mathrm{L}$ & $47(26)$ & 0.02 & 0.02 & 0.03 & 0.04 & 0.05 & 0.18 & 7 \\
\hline & Lead, unfiltered-recoverable, $\mu \mathrm{g} / \mathrm{L}$ & 47 & 0.10 & 0.28 & 0.42 & 28 & 1.0 & 1,290 & \\
\hline & Manganese, filtered, $\mu \mathrm{g} / \mathrm{L}$ & $47(1)$ & 0.40 & 0.80 & 1.1 & 1.6 & 1.5 & 42 & 24 \\
\hline & Manganese, unfiltered-recoverable, $\mu \mathrm{g} / \mathrm{L}$ & 47 & 1.2 & 2.8 & 4.6 & 194 & 7.6 & 8,830 & \\
\hline & Zinc, filtered, $\mu \mathrm{g} / \mathrm{L}$ & $47(14)$ & 0.62 & 0.71 & 1.1 & 1.3 & 1.5 & 30 & 46 \\
\hline & Zinc, unfiltered-recoverable, $\mu \mathrm{g} / \mathrm{L}$ & $47(2)$ & 1.0 & 2.0 & 2.4 & 7.7 & 4.0 & 7,780 & \\
\hline & Arsenic, filtered, $\mu \mathrm{g} / \mathrm{L}$ & 47 & 1.8 & 2.7 & 3.4 & 7.8 & 5.8 & 156 & 92 \\
\hline & Arsenic, unfiltered-recoverable, $\mu \mathrm{g} / \mathrm{L}$ & 47 & 2.0 & 3.2 & 3.7 & 87 & 7.7 & 3,860 & \\
\hline & Suspended sediment, mg/L & 47 & 1 & 3 & 5 & 1,270 & 15 & 58,900 & NA \\
\hline & Suspended sediment, percent fines ${ }^{4}$ & 47 & 22 & 49 & 61 & 58 & 67 & 97 & NA \\
\hline
\end{tabular}


Table 1-4. Summary information relating to water-quality constituents and properties in samples collected at sites in the upper Clark Fork Basin, Montana, based on data collected during water years 2001-2010.-Continued

[Water year is the 12-month period from October 1 through September 30 and is designated by the year in which it ends. $\mathrm{ft}^{3} / \mathrm{s}$, cubic feet per second; NA, not applicable; $\mu \mathrm{S} / \mathrm{cm}$, microsiemens per centimeter at 25 degrees Celsius; $\mathrm{CaCO}_{3}$, calcium carbonate; $\mu \mathrm{g} / \mathrm{L}$, micrograms per liter; $\mathrm{mg} / \mathrm{L}$, milligrams per liter; $\mathrm{ND}$, distributional parameter not determined because of excessive number of censored values; <, less than]

\begin{tabular}{|c|c|c|c|c|c|c|c|c|c|}
\hline \multirow[b]{2}{*}{$\begin{array}{l}\text { Period of } \\
\text { water- } \\
\text { quality } \\
\text { sampling } \\
\text { during } \\
\text { water years } \\
\text { 2001-10 }\end{array}$} & \multirow[b]{2}{*}{$\begin{array}{l}\text { Constituent or property, } \\
\text { unadjusted (not flow adjusted) } \\
\text { units of measurement }\end{array}$} & \multicolumn{7}{|c|}{ Statistical summaries of water-quality data ${ }^{1}$} & \multirow[b]{2}{*}{$\begin{array}{l}\text { Ratios of median } \\
\text { filtered to median } \\
\text { unfiltered-recov- } \\
\text { erable concentra- } \\
\text { tions for trace } \\
\text { elements, percent }\end{array}$} \\
\hline & & $\begin{array}{c}\text { Number of } \\
\text { samples (values } \\
\text { in parentheses } \\
\text { indicate number } \\
\text { of censored } \\
\text { values) }\end{array}$ & $\begin{array}{l}\text { Minimum } \\
\text { uncensored } \\
\text { value }^{2}\end{array}$ & $\begin{array}{c}\text { 25th } \\
\text { percentile }\end{array}$ & Median & Mean & $\begin{array}{c}\text { 75th } \\
\text { percentile }\end{array}$ & Maximum & \\
\hline \multicolumn{10}{|c|}{ Lost Creek near Galen (site 13, fig. 1, table 1) } \\
\hline \multirow{22}{*}{$\begin{array}{r}3 / 2003- \\
8 / 2010\end{array}$} & Streamflow, instantaneous, $\mathrm{ft}^{3} / \mathrm{s}$ & 64 & 1.3 & 3.5 & 13 & 21 & 41 & 71 & NA \\
\hline & Specific conductance, $\mu \mathrm{S} / \mathrm{cm}$ & 64 & 540 & 611 & 631 & 648 & 672 & 934 & NA \\
\hline & $\mathrm{pH}$, standard units & 64 & 8.0 & 8.2 & 8.3 & 8.3 & 8.5 & 8.7 & NA \\
\hline & Hardness, filtered, $\mathrm{mg} / \mathrm{L}$ as $\mathrm{CaCO}_{3}$ & 64 & 203 & 281 & 298 & 301 & 316 & 451 & NA \\
\hline & Calcium, filtered, mg/L & 64 & 48.5 & 78.5 & 85.2 & 84.7 & 92.2 & 122 & NA \\
\hline & Magnesium, filtered, mg/L & 64 & 17.3 & 19.9 & 21.0 & 21.7 & 23.2 & 35.7 & NA \\
\hline & Cadmium, filtered, $\mu \mathrm{g} / \mathrm{L}$ & $63(10)$ & 0.01 & 0.02 & 0.02 & 0.03 & 0.03 & 0.05 & 50 \\
\hline & Cadmium, unfiltered-recoverable, $\mu \mathrm{g} / \mathrm{L}$ & $64(5)$ & 0.01 & 0.03 & 0.04 & 0.04 & 0.05 & 0.11 & \\
\hline & Copper, filtered, $\mu \mathrm{g} / \mathrm{L}$ & 64 & 0.99 & 1.6 & 2.4 & 2.4 & 2.9 & 7 & 53 \\
\hline & Copper, unfiltered-recoverable, $\mu \mathrm{g} / \mathrm{L}$ & 64 & 1.6 & 3.7 & 4.4 & 5.5 & 6.3 & 23 & \\
\hline & Iron, filtered, $\mu \mathrm{g} / \mathrm{L}$ & $64(3)$ & 4.0 & 7.0 & 10 & 13 & 16 & 61 & 13 \\
\hline & Iron unfiltered-recoverable, $\mu \mathrm{g} / \mathrm{L}$ & 64 & 14 & 47 & 77 & 99 & 128 & 293 & \\
\hline & Lead, filtered, $\mu \mathrm{g} / \mathrm{L}$ & $63(35)$ & 0.02 & 0.02 & 0.03 & 0.04 & 0.05 & 0.33 & 12 \\
\hline & Lead, unfiltered-recoverable, $\mu \mathrm{g} / \mathrm{L}$ & 64 & 0.04 & 0.14 & 0.24 & 0.35 & 0.44 & 1.3 & \\
\hline & Manganese, filtered, $\mu \mathrm{g} / \mathrm{L}$ & 64 & 1.9 & 6.9 & 14 & 15 & 20 & 54 & 75 \\
\hline & Manganese, unfiltered-recoverable, $\mu \mathrm{g} / \mathrm{L}$ & 64 & 2.2 & 9.6 & 18 & 20 & 29 & 57 & \\
\hline & Zinc, filtered, $\mu \mathrm{g} / \mathrm{L}$ & $63(9)$ & 0.40 & 0.87 & 1.3 & 1.5 & 1.8 & 3.8 & 63 \\
\hline & Zinc, unfiltered-recoverable, $\mu \mathrm{g} / \mathrm{L}$ & $64(6)$ & 1.0 & 1.3 & 2.0 & 2.8 & 3.9 & 9.0 & \\
\hline & Arsenic, filtered, $\mu \mathrm{g} / \mathrm{L}$ & 64 & 6.0 & 10 & 13 & 14 & 16 & 42 & 90 \\
\hline & Arsenic, unfiltered-recoverable, $\mu \mathrm{g} / \mathrm{L}$ & 64 & 6.0 & 11 & 14 & 15 & 16 & 43 & \\
\hline & Suspended sediment, mg/L & 64 & 2 & 8 & 15 & 16 & 22 & 79 & NA \\
\hline & Suspended sediment, percent fines ${ }^{4}$ & 64 & 18 & 46 & 60 & 57 & 68 & 86 & NA \\
\hline
\end{tabular}


Table 1-4. Summary information relating to water-quality constituents and properties in samples collected at sites in the upper Clark Fork Basin, Montana , based on data collected during water years 2001-2010.-Continued

[Water year is the 12-month period from October 1 through September 30 and is designated by the year in which it ends. $\mathrm{ft}^{3} / \mathrm{s}$, cubic feet per second; NA, not applicable; $\mu \mathrm{S} / \mathrm{cm}$, microsiemens per centimeter at 25 degrees Celsius; $\mathrm{CaCO}$, calcium carbonate; $\mu \mathrm{g} / \mathrm{L}$, micrograms per liter; $\mathrm{mg} / \mathrm{L}$, milligrams per liter; $\mathrm{ND}$, distributional parameter not determined because of excessive number of censored values; $<$, les than]

\begin{tabular}{|c|c|c|c|c|c|c|c|c|c|}
\hline \multirow{2}{*}{$\begin{array}{l}\text { Period of } \\
\text { water- } \\
\text { quality } \\
\text { sampling } \\
\text { during } \\
\text { water years } \\
\text { 2001-10 }\end{array}$} & \multirow[b]{2}{*}{$\begin{array}{l}\text { Constituent or property, } \\
\text { unadjusted (not flow adjusted) } \\
\text { units of measurement }\end{array}$} & \multicolumn{7}{|c|}{ Statistical summaries of water-quality data ${ }^{1}$} & \multirow{2}{*}{$\begin{array}{l}\text { Ratios of median } \\
\text { filtered to median } \\
\text { unfiltered-recov- } \\
\text { erable concentra- } \\
\text { tions for trace } \\
\text { elements, percent }\end{array}$} \\
\hline & & $\begin{array}{c}\text { samples (values } \\
\text { in parentheses } \\
\text { indicate number } \\
\text { of censored } \\
\text { values) }\end{array}$ & $\begin{array}{l}\text { Minimum } \\
\text { uncensored } \\
\text { value }^{2}\end{array}$ & $\begin{array}{c}\text { 25th } \\
\text { percentile }\end{array}$ & Median & Mean & $\begin{array}{c}\text { 75th } \\
\text { percentile }\end{array}$ & Maximum & \\
\hline \multicolumn{10}{|c|}{ Clark Fork at Deer Lodge (site 14 , fig. 1, table 1) } \\
\hline \multirow{22}{*}{$\begin{array}{r}10 / 2000- \\
8 / 2010\end{array}$} & Streamflow, instantaneous, $\mathrm{ft}^{3} / \mathrm{s}$ & 80 & 38 & 151 & 215 & 282 & 343 & 1,130 & NA \\
\hline & Specific conductance, $\mu \mathrm{S} / \mathrm{cm}$ & 80 & 245 & 360 & 489 & 452 & 524 & 605 & NA \\
\hline & $\mathrm{pH}$, standard units & 80 & 8.0 & 8.2 & 8.3 & 8.3 & 8.5 & 8.9 & NA \\
\hline & Hardness, filtered, mg/L as $\mathrm{CaCO}_{3}$ & 80 & 102 & 152 & 210 & 196 & 230 & 282 & NA \\
\hline & Calcium, filtered, mg/L & 80 & 31.8 & 45.3 & 62.3 & 58.1 & 67.5 & 82.0 & NA \\
\hline & Magnesium, filtered, mg/L & 80 & 5.53 & 10.1 & 13.2 & 12.5 & 14.7 & 18.7 & NA \\
\hline & Cadmium, filtered, $\mu \mathrm{g} / \mathrm{L}$ & $79(9)$ & 0.02 & 0.04 & 0.06 & 0.06 & 0.07 & 0.12 & 40 \\
\hline & Cadmium, unfiltered-recoverable, $\mu \mathrm{g} / \mathrm{L}$ & $79(1)$ & 0.02 & 0.10 & 0.15 & 0.22 & 0.24 & 2.06 & \\
\hline & Copper, filtered, $\mu \mathrm{g} / \mathrm{L}$ & 80 & 3.2 & 5.6 & 7.1 & 7.9 & 9.5 & 19 & 27 \\
\hline & Copper, unfiltered-recoverable, $\mu \mathrm{g} / \mathrm{L}$ & 79 & 8.2 & 18 & 27 & 49 & 57 & 468 & \\
\hline & Iron, filtered, $\mu \mathrm{g} / \mathrm{L}$ & $80(9)$ & 3.0 & 6.0 & 8.0 & 12 & 17 & 44 & 2 \\
\hline & Iron unfiltered-recoverable, $\mu \mathrm{g} / \mathrm{L}$ & 80 & 27 & 218 & 393 & 711 & 823 & 6,960 & \\
\hline & Lead, filtered, $\mu \mathrm{g} / \mathrm{L}$ & $79(19)$ & 0.04 & 0.05 & 0.08 & 0.10 & 0.13 & 0.54 & 3 \\
\hline & Lead, unfiltered-recoverable, $\mu \mathrm{g} / \mathrm{L}$ & $80(2)$ & 0.33 & 1.8 & 3.0 & 6.7 & 7.0 & 62 & \\
\hline & Manganese, filtered, $\mu \mathrm{g} / \mathrm{L}$ & 80 & 4.0 & 24 & 34 & 38 & 49 & 98 & 30 \\
\hline & Manganese, unfiltered-recoverable, $\mu \mathrm{g} / \mathrm{L}$ & 80 & 12 & 76 & 112 & 143 & 164 & 1,010 & \\
\hline & Zinc, filtered, $\mu \mathrm{g} / \mathrm{L}$ & 80 & 0.90 & 4.5 & 5.9 & 6.5 & 8.1 & 19 & 23 \\
\hline & Zinc, unfiltered-recoverable, $\mu \mathrm{g} / \mathrm{L}$ & 78 & 4.0 & 16 & 26 & 40 & 44 & 359 & \\
\hline & Arsenic, filtered, $\mu \mathrm{g} / \mathrm{L}$ & 80 & 6.0 & 11 & 15 & 15 & 17 & 26 & 88 \\
\hline & Arsenic, unfiltered-recoverable, $\mu \mathrm{g} / \mathrm{L}$ & 79 & 4.8 & 13 & 17 & 20 & 24 & 78 & \\
\hline & Suspended sediment, $\mathrm{mg} / \mathrm{L}$ & 80 & 1 & 11 & 18 & 37 & 40 & 387 & NA \\
\hline & Suspended sediment, percent fines ${ }^{4}$ & 80 & 31 & 67 & 73 & 71 & 79 & 92 & NA \\
\hline
\end{tabular}


Table 1-4. Summary information relating to water-quality constituents and properties in samples collected at sites in the upper Clark Fork Basin, Montana, based on data

collected during water years 2001-2010.-Continued

[Water year is the 12-month period from October 1 through September 30 and is designated by the year in which it ends. $\mathrm{ft}^{3} / \mathrm{s}$, cubic feet per second; NA, not applicable; $\mu \mathrm{S} / \mathrm{cm}$, microsiemens per centimeter at 25 degrees Celsius; $\mathrm{CaCO}_{3}$, calcium carbonate; $\mu \mathrm{g} / \mathrm{L}$, micrograms per liter; $\mathrm{mg} / \mathrm{L}$, milligrams per liter; $\mathrm{ND}$, distributional parameter not determined because of excessive number of censored values; $<$, less than]

\begin{tabular}{|c|c|c|c|c|c|c|c|c|c|}
\hline \multirow[b]{2}{*}{$\begin{array}{c}\text { Period of } \\
\text { water- } \\
\text { quality } \\
\text { sampling } \\
\text { during } \\
\text { water years } \\
2001-10\end{array}$} & \multirow[b]{2}{*}{$\begin{array}{l}\text { Constituent or property, } \\
\text { unadjusted (not flow adjusted) } \\
\text { units of measurement }\end{array}$} & \multicolumn{7}{|c|}{ Statistical summaries of water-quality data ${ }^{1}$} & \multirow[b]{2}{*}{$\begin{array}{l}\text { Ratios of median } \\
\text { filtered to median } \\
\text { unfiltered-recov- } \\
\text { erable concentra- } \\
\text { tions for trace } \\
\text { elements, percent }\end{array}$} \\
\hline & & $\begin{array}{c}\text { Number of } \\
\text { samples (values } \\
\text { in parentheses } \\
\text { indicate number } \\
\text { of censored } \\
\text { values) }\end{array}$ & $\begin{array}{l}\text { Minimum } \\
\text { uncensored } \\
\text { value }^{2}\end{array}$ & $\begin{array}{c}\text { 25th } \\
\text { percentile }\end{array}$ & Median & Mean & $\begin{array}{c}\text { 75th } \\
\text { percentile }\end{array}$ & Maximum & \\
\hline \multicolumn{10}{|c|}{ Little Blackfoot River (site 15, fig. 1, table 1) } \\
\hline \multirow{22}{*}{$\begin{array}{r}11 / 2000- \\
8 / 2004\end{array}$} & Streamflow, instantaneous, $\mathrm{ft}^{3} / \mathrm{s}$ & 20 & 19.0 & 56.3 & 135 & 176 & 297 & 455 & NA \\
\hline & Specific conductance, $\mu \mathrm{S} / \mathrm{cm}$ & 20 & 174 & 211 & 259 & 255 & 287 & 347 & NA \\
\hline & $\mathrm{pH}$, standard units & 20 & 8.0 & 8.1 & 8.2 & 8.3 & 8.4 & 8.7 & NA \\
\hline & Hardness, filtered, $\mathrm{mg} / \mathrm{L}$ as $\mathrm{CaCO}_{3}$ & 20 & 79 & 94 & 116 & 117 & 136 & 172 & NA \\
\hline & Calcium, filtered, mg/L & 20 & 22.9 & 27.6 & 34.0 & 34.1 & 39.9 & 49.3 & NA \\
\hline & Magnesium, filtered, mg/L & 20 & 5.33 & 6.03 & 7.56 & 7.69 & 8.83 & 11.9 & NA \\
\hline & Cadmium, filtered, $\mu \mathrm{g} / \mathrm{L}$ & $20(18)$ & 0.02 & ND & ND & ND & ND & 0.04 & ND \\
\hline & Cadmium, unfiltered-recoverable, $\mu \mathrm{g} / \mathrm{L}$ & $20(14)$ & 0.02 & 0.01 & 0.02 & 0.02 & 0.03 & 0.10 & \\
\hline & Copper, filtered, $\mu \mathrm{g} / \mathrm{L}$ & $20(3)$ & 0.60 & 0.75 & 1.1 & 1.3 & 1.5 & 3.9 & 67 \\
\hline & Copper, unfiltered-recoverable, $\mu \mathrm{g} / \mathrm{L}$ & 20 & 0.80 & 1.2 & 1.7 & 1.9 & 2.4 & 4.2 & \\
\hline & Iron, filtered, $\mu \mathrm{g} / \mathrm{L}$ & $20(3)$ & 5.0 & 5.5 & 16 & 27 & 33 & 117 & 9 \\
\hline & Iron unfiltered-recoverable, $\mu \mathrm{g} / \mathrm{L}$ & 20 & 38 & 63 & 178 & 236 & 305 & 701 & \\
\hline & Lead, filtered, $\mu \mathrm{g} / \mathrm{L}$ & $19(13)$ & 0.05 & 0.03 & 0.04 & 0.05 & 0.06 & 0.13 & 16 \\
\hline & Lead, unfiltered-recoverable, $\mu \mathrm{g} / \mathrm{L}$ & $20(8)$ & 0.06 & 0.11 & 0.24 & 0.45 & 0.51 & 1.8 & \\
\hline & Manganese, filtered, $\mu \mathrm{g} / \mathrm{L}$ & 20 & 2.5 & 7.9 & 8.5 & 11 & 11 & 45 & 37 \\
\hline & Manganese, unfiltered-recoverable, $\mu \mathrm{g} / \mathrm{L}$ & 20 & 6.8 & 18 & 23 & 28 & 32 & 90 & \\
\hline & Zinc, filtered, $\mu \mathrm{g} / \mathrm{L}$ & $20(4)$ & 0.50 & 0.50 & 1.2 & 1.1 & 1.4 & 2.9 & 58 \\
\hline & Zinc, unfiltered-recoverable, $\mu \mathrm{g} / \mathrm{L}$ & $20(5)$ & 1.0 & 0.89 & 2.0 & 2.8 & 3.5 & 8.0 & \\
\hline & Arsenic, filtered, $\mu \mathrm{g} / \mathrm{L}$ & 20 & 3.9 & 4.6 & 5.1 & 5.2 & 5.8 & 6.5 & 85 \\
\hline & Arsenic, unfiltered-recoverable, $\mu \mathrm{g} / \mathrm{L}$ & 20 & 4.0 & 5.0 & 6.0 & 5.7 & 6.0 & 8.0 & \\
\hline & Suspended sediment, $\mathrm{mg} / \mathrm{L}$ & 20 & 2 & 3 & 8 & 13 & 14 & 47 & NA \\
\hline & Suspended sediment, percent fines ${ }^{4}$ & 20 & 54 & 73 & 83 & 80 & 85 & 95 & NA \\
\hline
\end{tabular}


Table 1-4. Summary information relating to water-quality constituents and properties in samples collected at sites in the upper Clark Fork Basin, Montana , based on data collected during water years 2001-2010.-Continued

[Water year is the 12-month period from October 1 through September 30 and is designated by the year in which it ends. $\mathrm{ft}^{3} / \mathrm{s}$, cubic feet per second; NA, not applicable; $\mu \mathrm{S} / \mathrm{cm}$, microsiemens per centimeter at 25 degrees Celsius; $\mathrm{CaCO}$, calcium carbonate; $\mu \mathrm{g} / \mathrm{L}$, micrograms per liter; $\mathrm{mg} / \mathrm{L}$, milligrams per liter; $\mathrm{ND}$, distributional parameter not determined because of excessive number of censored values; $<$, less than]

\begin{tabular}{|c|c|c|c|c|c|c|c|c|c|}
\hline \multirow{2}{*}{$\begin{array}{l}\text { Period of } \\
\text { water- } \\
\text { quality } \\
\text { sampling } \\
\text { during } \\
\text { water years } \\
\text { 2001-10 }\end{array}$} & \multirow[b]{2}{*}{$\begin{array}{l}\text { Constituent or property, } \\
\text { unadjusted (not flow adjusted) } \\
\text { units of measurement }\end{array}$} & \multicolumn{7}{|c|}{ Statistical summaries of water-quality data ${ }^{1}$} & \multirow{2}{*}{$\begin{array}{l}\text { Ratios of median } \\
\text { filtered to median } \\
\text { unfiltered-recov- } \\
\text { erable concentra- } \\
\text { tions for trace } \\
\text { elements, percent }\end{array}$} \\
\hline & & $\begin{array}{l}\text { samples (values } \\
\text { in parentheses } \\
\text { indicate number } \\
\text { of censored } \\
\text { values) }\end{array}$ & $\begin{array}{l}\text { Minimum } \\
\text { uncensored } \\
\text { value }^{2}\end{array}$ & $\begin{array}{c}\text { 25th } \\
\text { percentile }\end{array}$ & Median & Mean & $\begin{array}{c}\text { 75th } \\
\text { percentile }\end{array}$ & Maximum & \\
\hline \multicolumn{10}{|c|}{ Clark Fork at Goldcreek (site 16, fig. 1, table 1) } \\
\hline \multirow{22}{*}{$\begin{array}{r}10 / 2000- \\
8 / 2010\end{array}$} & Streamflow, instantaneous, $\mathrm{ft}^{3} / \mathrm{s}$ & 80 & 100 & 310 & 495 & 690 & 876 & 2,300 & NA \\
\hline & Specific conductance, $\mu \mathrm{S} / \mathrm{cm}$ & 80 & 206 & 304 & 384 & 370 & 435 & 498 & NA \\
\hline & $\mathrm{pH}$, standard units & 80 & 8.0 & 8.3 & 8.4 & 8.4 & 8.6 & 8.9 & NA \\
\hline & Hardness, filtered, $\mathrm{mg} / \mathrm{L}$ as $\mathrm{CaCO}_{3}$ & 80 & 90 & 132 & 169 & 163 & 196 & 220 & NA \\
\hline & Calcium, filtered, mg/L & 80 & 27.0 & 39.4 & 50.3 & 48.2 & 57.9 & 65.3 & NA \\
\hline & Magnesium, filtered, mg/L & 80 & 5.40 & 8.17 & 10.6 & 10.3 & 12.8 & 14.2 & NA \\
\hline & Cadmium, filtered, $\mu \mathrm{g} / \mathrm{L}$ & $80(18)$ & 0.02 & 0.03 & 0.04 & 0.04 & 0.05 & 0.14 & 31 \\
\hline & Cadmium, unfiltered-recoverable, $\mu \mathrm{g} / \mathrm{L}$ & $80(3)$ & 0.03 & 0.08 & 0.12 & 0.17 & 0.21 & 0.60 & \\
\hline & Copper, filtered, $\mu \mathrm{g} / \mathrm{L}$ & 80 & 2.1 & 4.1 & 4.9 & 5.6 & 6.6 & 14 & 24 \\
\hline & Copper, unfiltered-recoverable, $\mu \mathrm{g} / \mathrm{L}$ & 80 & 5.2 & 12 & 20 & 31 & 43 & 122 & \\
\hline & Iron, filtered, $\mu \mathrm{g} / \mathrm{L}$ & $80(10)$ & 3.0 & 5.1 & 11 & 18 & 25 & 71 & 3 \\
\hline & Iron unfiltered-recoverable, $\mu \mathrm{g} / \mathrm{L}$ & 80 & 27 & 198 & 371 & 640 & 870 & 3,020 & \\
\hline & Lead, filtered, $\mu \mathrm{g} / \mathrm{L}$ & $79(30)$ & 0.04 & 0.04 & 0.07 & 0.10 & 0.12 & 0.35 & 3 \\
\hline & Lead, unfiltered-recoverable, $\mu \mathrm{g} / \mathrm{L}$ & $80(2)$ & 0.14 & 1.3 & 2.4 & 4.8 & 5.8 & 20 & \\
\hline & Manganese, filtered, $\mu \mathrm{g} / \mathrm{L}$ & 80 & 4.0 & 11 & 15 & 17 & 21 & 57 & 20 \\
\hline & Manganese, unfiltered-recoverable, $\mu \mathrm{g} / \mathrm{L}$ & 80 & 11 & 56 & 76 & 99 & 117 & 348 & \\
\hline & Zinc, filtered, $\mu \mathrm{g} / \mathrm{L}$ & $80(1)$ & 0.70 & 2.2 & 3.1 & 4.0 & 5.2 & 11 & 15 \\
\hline & Zinc, unfiltered-recoverable, $\mu \mathrm{g} / \mathrm{L}$ & 80 & 2.0 & 12 & 20 & 30 & 42 & 122 & \\
\hline & Arsenic, filtered, $\mu \mathrm{g} / \mathrm{L}$ & 80 & 5.8 & 7.8 & 10 & 10 & 12 & 14 & 84 \\
\hline & Arsenic, unfiltered-recoverable, $\mu \mathrm{g} / \mathrm{L}$ & 80 & 7.0 & 10 & 12 & 13 & 15 & 26 & \\
\hline & Suspended sediment, mg/L & 80 & 1 & 10 & 17 & 35 & 44 & 196 & NA \\
\hline & Suspended sediment, percent fines ${ }^{4}$ & 80 & 44 & 66 & 77 & 74 & 82 & 94 & NA \\
\hline
\end{tabular}


Table 1-4. Summary information relating to water-quality constituents and properties in samples collected at sites in the upper Clark Fork Basin, Montana, based on data

collected during water years 2001-2010.-Continued

[Water year is the 12-month period from October 1 through September 30 and is designated by the year in which it ends. $\mathrm{ft}^{3} / \mathrm{s}$, cubic feet per second; NA, not applicable; $\mu \mathrm{S} / \mathrm{cm}$, microsiemens per centimeter at 25 degrees Celsius; $\mathrm{CaCO}_{3}$, calcium carbonate; $\mu \mathrm{g} / \mathrm{L}$, micrograms per liter; $\mathrm{mg} / \mathrm{L}$, milligrams per liter; $\mathrm{ND}$, distributional parameter not determined because of excessive number of censored values; $<$, less than]

\begin{tabular}{|c|c|c|c|c|c|c|c|c|c|}
\hline \multirow{2}{*}{$\begin{array}{l}\text { Period of } \\
\text { water- } \\
\text { quality } \\
\text { sampling } \\
\text { during } \\
\text { water years } \\
\text { 2001-10 }\end{array}$} & \multirow[b]{2}{*}{$\begin{array}{l}\text { Constituent or property, } \\
\text { unadjusted (not flow adjusted) } \\
\text { units of measurement }\end{array}$} & \multicolumn{7}{|c|}{ Statistical summaries of water-quality data ${ }^{1}$} & \multirow{2}{*}{$\begin{array}{l}\text { Ratios of median } \\
\text { filtered to median } \\
\text { unfiltered-recov- } \\
\text { erable concentra- } \\
\text { tions for trace } \\
\text { elements, percent }\end{array}$} \\
\hline & & $\begin{array}{l}\text { samples (values } \\
\text { in parentheses } \\
\text { indicate number } \\
\text { of censored } \\
\text { values) }\end{array}$ & $\begin{array}{l}\text { Minimum } \\
\text { uncensored } \\
\text { value }^{2}\end{array}$ & $\begin{array}{c}\text { 25th } \\
\text { percentile }\end{array}$ & Median & Mean & $\begin{array}{c}\text { 75th } \\
\text { percentile }\end{array}$ & Maximum & \\
\hline \multicolumn{10}{|c|}{ Flint Creek (site 17, fig. 1, table 1) } \\
\hline \multirow{22}{*}{$\begin{array}{r}11 / 2000- \\
8 / 2004\end{array}$} & Streamflow, instantaneous, $\mathrm{ft}^{3} / \mathrm{s}$ & 23 & 5.4 & 29 & 76 & 84 & 113 & 331 & NA \\
\hline & Specific conductance, $\mu \mathrm{S} / \mathrm{cm}$ & 23 & 276 & 305 & 350 & 373 & 430 & 529 & NA \\
\hline & $\mathrm{pH}$, standard units & 23 & 8.1 & 8.3 & 8.4 & 8.4 & 8.5 & 8.8 & NA \\
\hline & Hardness, filtered, $\mathrm{mg} / \mathrm{L}$ as $\mathrm{CaCO}_{3}$ & 23 & 115 & 140 & 161 & 172 & 204 & 253 & NA \\
\hline & Calcium, filtered, $\mathrm{mg} / \mathrm{L}$ & 23 & 30.5 & 38.5 & 43.8 & 46.8 & 56.6 & 70.0 & NA \\
\hline & Magnesium, filtered, mg/L & 23 & 9.51 & 10.9 & 12.5 & 13.3 & 15.4 & 19.0 & NA \\
\hline & Cadmium, filtered, $\mu \mathrm{g} / \mathrm{L}$ & $23(20)$ & 0.02 & ND & ND & ND & ND & 0.02 & ND \\
\hline & Cadmium, unfiltered-recoverable, $\mu \mathrm{g} / \mathrm{L}$ & $23(9)$ & 0.02 & 0.02 & 0.04 & 0.06 & 0.07 & 0.30 & \\
\hline & Copper, filtered, $\mu \mathrm{g} / \mathrm{L}$ & $23(2)$ & 0.70 & 1.0 & 1.2 & 1.4 & 1.4 & 4.4 & 52 \\
\hline & Copper, unfiltered-recoverable, $\mu \mathrm{g} / \mathrm{L}$ & 23 & 1.4 & 1.8 & 2.3 & 3.3 & 3.3 & 11 & \\
\hline & Iron, filtered, $\mu \mathrm{g} / \mathrm{L}$ & $23(2)$ & 5.0 & 8.0 & 15 & 23 & 21 & 113 & 6 \\
\hline & Iron unfiltered-recoverable, $\mu \mathrm{g} / \mathrm{L}$ & 23 & 56 & 127 & 245 & 374 & 432 & 2,050 & \\
\hline & Lead, filtered, $\mu \mathrm{g} / \mathrm{L}$ & $21(6)$ & 0.05 & 0.08 & 0.13 & 0.16 & 0.19 & 0.67 & 4 \\
\hline & Lead, unfiltered-recoverable, $\mu \mathrm{g} / \mathrm{L}$ & $23(2)$ & 0.65 & 1.5 & 3.1 & 5.3 & 5.6 & 34 & \\
\hline & Manganese, filtered, $\mu \mathrm{g} / \mathrm{L}$ & 23 & 22 & 38 & 51 & 56 & 59 & 139 & 50 \\
\hline & Manganese, unfiltered-recoverable, $\mu \mathrm{g} / \mathrm{L}$ & 23 & 53 & 78 & 101 & 143 & 142 & 595 & \\
\hline & Zinc, filtered, $\mu \mathrm{g} / \mathrm{L}$ & $23(1)$ & 1.1 & 1.2 & 1.6 & 2.0 & 1.9 & 8.7 & 16 \\
\hline & Zinc, unfiltered-recoverable, $\mu \mathrm{g} / \mathrm{L}$ & 23 & 2.0 & 5.0 & 10 & 15 & 15 & 87 & \\
\hline & Arsenic, filtered, $\mu \mathrm{g} / \mathrm{L}$ & 23 & 6.1 & 7.8 & 10 & 9.5 & 11 & 12 & 81 \\
\hline & Arsenic, unfiltered-recoverable, $\mu \mathrm{g} / \mathrm{L}$ & 23 & 7.0 & 11 & 12 & 13 & 14 & 35 & \\
\hline & Suspended sediment, $\mathrm{mg} / \mathrm{L}$ & 23 & 3 & 8 & 15 & 30 & 26 & 195 & NA \\
\hline & Suspended sediment, percent fines ${ }^{4}$ & 23 & 30 & 84 & 88 & 83 & 90 & 94 & NA \\
\hline
\end{tabular}


Table 1-4. Summary information relating to water-quality constituents and properties in samples collected at sites in the upper Clark Fork Basin, Montana , based on data collected during water years 2001-2010.-Continued

[Water year is the 12-month period from October 1 through September 30 and is designated by the year in which it ends. $\mathrm{ft}^{3} / \mathrm{s}$, cubic feet per second; NA, not applicable; $\mu \mathrm{S} / \mathrm{cm}$, microsiemens per centimeter at 25 degrees Celsius; $\mathrm{CaCO}_{2}$, calcium carbonate; $\mu \mathrm{g} / \mathrm{L}$, micrograms per liter; $\mathrm{mg} / \mathrm{L}$, milligrams per liter; $\mathrm{ND}$, distributional parameter not determined because of excessive number of censored values; $<$, les than]

\begin{tabular}{|c|c|c|c|c|c|c|c|c|c|}
\hline \multirow{2}{*}{$\begin{array}{l}\text { Period of } \\
\text { water- } \\
\text { quality } \\
\text { sampling } \\
\text { during } \\
\text { water years } \\
2001-10\end{array}$} & \multirow[b]{2}{*}{$\begin{array}{l}\text { Constituent or property, } \\
\text { unadjusted (not flow adjusted) } \\
\text { units of measurement }\end{array}$} & \multicolumn{7}{|c|}{ Statistical summaries of water-quality data ${ }^{1}$} & \multirow{2}{*}{$\begin{array}{l}\text { Ratios of median } \\
\text { filtered to median } \\
\text { unfiltered-recov- } \\
\text { erable concentra- } \\
\text { tions for trace } \\
\text { elements, percent }\end{array}$} \\
\hline & & $\begin{array}{c}\text { samples (values } \\
\text { in parentheses } \\
\text { indicate number } \\
\text { of censored } \\
\text { values) }\end{array}$ & $\begin{array}{l}\text { Minimum } \\
\text { uncensored } \\
\text { value }^{2}\end{array}$ & $\begin{array}{c}\text { 25th } \\
\text { percentile }\end{array}$ & Median & Mean & $\begin{array}{c}\text { 75th } \\
\text { percentile }\end{array}$ & Maximum & \\
\hline \multicolumn{10}{|c|}{ Clark Fork near Drummond (site 18, fig. 1, table 1) } \\
\hline \multirow{22}{*}{$\begin{array}{r}10 / 2000- \\
8 / 2010\end{array}$} & Streamflow, instantaneous, $\mathrm{ft}^{3} / \mathrm{s}$ & 80 & 157 & 464 & 709 & 964 & 1,158 & 3,350 & NA \\
\hline & Specific conductance, $\mu \mathrm{S} / \mathrm{cm}$ & 80 & 236 & 346 & 415 & 414 & 480 & 601 & NA \\
\hline & $\mathrm{pH}$, standard units & 80 & 7.9 & 8.2 & 8.3 & 8.3 & 8.4 & 8.7 & NA \\
\hline & Hardness, filtered, $\mathrm{mg} / \mathrm{L}$ as $\mathrm{CaCO}_{3}$ & 80 & 102 & 154 & 184 & 186 & 221 & 283 & NA \\
\hline & Calcium, filtered, $\mathrm{mg} / \mathrm{L}$ & 80 & 30.6 & 44.5 & 53.4 & 53.4 & 63.4 & 81.1 & NA \\
\hline & Magnesium, filtered, mg/L & 80 & 6.07 & 10.1 & 12.6 & 12.8 & 15.3 & 20.9 & NA \\
\hline & Cadmium, filtered, $\mu \mathrm{g} / \mathrm{L}$ & $79(14)$ & 0.02 & 0.03 & 0.04 & 0.05 & 0.05 & 0.30 & 29 \\
\hline & Cadmium, unfiltered-recoverable, $\mu \mathrm{g} / \mathrm{L}$ & $80(2)$ & 0.02 & 0.08 & 0.14 & 0.22 & 0.27 & 1.3 & \\
\hline & Copper, filtered, $\mu \mathrm{g} / \mathrm{L}$ & 79 & 2.0 & 3.8 & 4.7 & 5.9 & 7.0 & 20 & 24 \\
\hline & Copper, unfiltered-recoverable, $\mu \mathrm{g} / \mathrm{L}$ & 80 & 4.6 & 10 & 20 & 37 & 43 & 215 & \\
\hline & Iron, filtered, $\mu \mathrm{g} / \mathrm{L}$ & $80(18)$ & 3.0 & 4.0 & 8.0 & 16 & 23 & 88 & 2 \\
\hline & Iron unfiltered-recoverable, $\mu \mathrm{g} / \mathrm{L}$ & 79 & 20 & 179 & 379 & 822 & 1,140 & 5,770 & \\
\hline & Lead, filtered, $\mu \mathrm{g} / \mathrm{L}$ & $79(23)$ & 0.04 & 0.04 & 0.09 & 0.14 & 0.17 & 0.66 & 3 \\
\hline & Lead, unfiltered-recoverable, $\mu \mathrm{g} / \mathrm{L}$ & $80(2)$ & 0.18 & 1.3 & 3.2 & 7.4 & 8.3 & 44 & \\
\hline & Manganese, filtered, $\mu \mathrm{g} / \mathrm{L}$ & 79 & 3.3 & 10 & 12 & 16 & 18 & 61 & 14 \\
\hline & Manganese, unfiltered-recoverable, $\mu \mathrm{g} / \mathrm{L}$ & 80 & 8.0 & 53 & 84 & 129 & 157 & 691 & \\
\hline & Zinc, filtered, $\mu \mathrm{g} / \mathrm{L}$ & $80(1)$ & 0.95 & 2.9 & 4.1 & 4.7 & 5.8 & 13 & 17 \\
\hline & Zinc, unfiltered-recoverable, $\mu \mathrm{g} / \mathrm{L}$ & 80 & 2.9 & 12 & 25 & 46 & 57 & 276 & \\
\hline & Arsenic, filtered, $\mu \mathrm{g} / \mathrm{L}$ & 80 & 3.2 & 8.4 & 10 & 10 & 12 & 18 & 77 \\
\hline & Arsenic, unfiltered-recoverable, $\mu \mathrm{g} / \mathrm{L}$ & 80 & 8.0 & 10 & 13 & 15 & 17 & 41 & \\
\hline & Suspended sediment, mg/L & 80 & 2 & 11 & 23 & 52 & 63 & 315 & NA \\
\hline & Suspended sediment, percent fines ${ }^{4}$ & 80 & 50 & 66 & 74 & 74 & 81 & 91 & NA \\
\hline
\end{tabular}


Table 1-4. Summary information relating to water-quality constituents and properties in samples collected at sites in the upper Clark Fork Basin, Montana, based on data

collected during water years 2001-2010.-Continued

[Water year is the 12-month period from October 1 through September 30 and is designated by the year in which it ends. $\mathrm{ft}^{3} / \mathrm{s}$, cubic feet per second; NA, not applicable; $\mu \mathrm{S} / \mathrm{cm}$, microsiemens per centimeter at 25 degrees Celsius; $\mathrm{CaCO}_{3}$, calcium carbonate; $\mu \mathrm{g} / \mathrm{L}$, micrograms per liter; $\mathrm{mg} / \mathrm{L}$, milligrams per liter; $\mathrm{ND}$, distributional parameter not determined because of excessive number of censored values; $<$, less than]

\begin{tabular}{|c|c|c|c|c|c|c|c|c|c|}
\hline \multirow{2}{*}{$\begin{array}{l}\text { Period of } \\
\text { water- } \\
\text { quality } \\
\text { sampling } \\
\text { during } \\
\text { water years } \\
2001-10\end{array}$} & \multirow[b]{2}{*}{$\begin{array}{l}\text { Constituent or property, } \\
\text { unadjusted (not flow adjusted) } \\
\text { units of measurement }\end{array}$} & \multicolumn{7}{|c|}{ Statistical summaries of water-quality data ${ }^{1}$} & \multirow{2}{*}{$\begin{array}{l}\text { Ratios of median } \\
\text { filtered to median } \\
\text { unfiltered-recov- } \\
\text { erable concentra- } \\
\text { tions for trace } \\
\text { elements, percent }\end{array}$} \\
\hline & & $\begin{array}{l}\text { samples (values } \\
\text { in parentheses } \\
\text { indicate number } \\
\text { of censored } \\
\text { values) }\end{array}$ & $\begin{array}{l}\text { Minimum } \\
\text { uncensored } \\
\text { value }^{2}\end{array}$ & $\begin{array}{c}\text { 25th } \\
\text { percentile }\end{array}$ & Median & Mean & $\begin{array}{c}\text { 75th } \\
\text { percentile }\end{array}$ & Maximum & \\
\hline \multicolumn{10}{|c|}{ Rock Creek (site 19, fig. 1, table 1) } \\
\hline \multirow{22}{*}{$\begin{array}{r}11 / 2000- \\
8 / 2004\end{array}$} & Streamflow, instantaneous, $\mathrm{ft}^{3} / \mathrm{s}$ & 20 & 149 & 209 & 356 & 608 & 915 & 2,080 & NA \\
\hline & Specific conductance, $\mu \mathrm{S} / \mathrm{cm}$ & 20 & 68 & 88 & 129 & 118 & 145 & 160 & NA \\
\hline & $\mathrm{pH}$, standard units & 20 & 7.7 & 8.0 & 8.2 & 8.1 & 8.3 & 8.6 & NA \\
\hline & Hardness, filtered, $\mathrm{mg} / \mathrm{L}$ as $\mathrm{CaCO}_{3}$ & 20 & 28 & 38 & 57 & 53 & 67 & 74 & NA \\
\hline & Calcium, filtered, mg/L & 20 & 7.23 & 9.90 & 14.5 & 13.7 & 17.2 & 19.0 & NA \\
\hline & Magnesium, filtered, mg/L & 20 & 2.46 & 3.32 & 4.78 & 4.51 & 5.77 & 6.58 & NA \\
\hline & Cadmium, filtered, $\mu \mathrm{g} / \mathrm{L}$ & $20(17)$ & 0.02 & ND & ND & ND & ND & 0.04 & ND \\
\hline & Cadmium, unfiltered-recoverable, $\mu \mathrm{g} / \mathrm{L}$ & $20(18)$ & 0.02 & ND & ND & ND & ND & 0.06 & \\
\hline & Copper, filtered, $\mu \mathrm{g} / \mathrm{L}$ & $20(6)$ & 0.20 & 0.34 & 0.46 & 0.52 & 0.70 & 1.3 & 77 \\
\hline & Copper, unfiltered-recoverable, $\mu \mathrm{g} / \mathrm{L}$ & $20(3)$ & 0.30 & 0.45 & 0.60 & 0.80 & 1.2 & 1.8 & \\
\hline & Iron, filtered, $\mu \mathrm{g} / \mathrm{L}$ & $20(1)$ & 6.0 & 8.0 & 15 & 19 & 25 & 57 & 21 \\
\hline & Iron unfiltered-recoverable, $\mu \mathrm{g} / \mathrm{L}$ & 20 & 23 & 41 & 72 & 88 & 114 & 264 & \\
\hline & Lead, filtered, $\mu \mathrm{g} / \mathrm{L}$ & $20(19)$ & 0.05 & ND & ND & ND & ND & 0.05 & ND \\
\hline & Lead, unfiltered-recoverable, $\mu \mathrm{g} / \mathrm{L}$ & $20(15)$ & 0.03 & 0.02 & 0.04 & 0.05 & 0.06 & 0.14 & \\
\hline & Manganese, filtered, $\mu \mathrm{g} / \mathrm{L}$ & 20 & 0.60 & 1.0 & 1.6 & 1.5 & 1.8 & 2.9 & 31 \\
\hline & Manganese, unfiltered-recoverable, $\mu \mathrm{g} / \mathrm{L}$ & 20 & 1.5 & 3.5 & 5.2 & 5.6 & 7.2 & 13 & \\
\hline & Zinc, filtered, $\mu \mathrm{g} / \mathrm{L}$ & $20(15)$ & 0.40 & 0.15 & 0.25 & 0.32 & 0.41 & 1.6 & 91 \\
\hline & Zinc, unfiltered-recoverable, $\mu \mathrm{g} / \mathrm{L}$ & $20(15)$ & 1.0 & 0.11 & 0.27 & 0.66 & 0.80 & 3.0 & \\
\hline & Arsenic, filtered, $\mu \mathrm{g} / \mathrm{L}$ & 20 & 0.50 & 0.50 & 0.60 & 0.61 & 0.63 & 0.80 & ND \\
\hline & Arsenic, unfiltered-recoverable, $\mu \mathrm{g} / \mathrm{L}$ & $18(15)$ & 1.0 & ND & ND & ND & ND & 5.0 & \\
\hline & Suspended sediment, mg/L & 20 & 1 & 3 & 4 & 5 & 6 & 17 & NA \\
\hline & Suspended sediment, percent fines ${ }^{4}$ & 20 & 57 & 73 & 76 & 75 & 80 & 84 & NA \\
\hline
\end{tabular}


Table 1-4. Summary information relating to water-quality constituents and properties in samples collected at sites in the upper Clark Fork Basin, Montana , based on data collected during water years 2001-2010.-Continued

[Water year is the 12-month period from October 1 through September 30 and is designated by the year in which it ends. $\mathrm{ft}^{3} / \mathrm{s}$, cubic feet per second; NA, not applicable; $\mu \mathrm{S} / \mathrm{cm}$, microsiemens per centimeter at 25 degrees Celsius; $\mathrm{CaCO}_{2}$, calcium carbonate; $\mu \mathrm{g} / \mathrm{L}$, micrograms per liter; $\mathrm{mg} / \mathrm{L}$, milligrams per liter; $\mathrm{ND}$, distributional parameter not determined because of excessive number of censored values; $<$, les than]

\begin{tabular}{|c|c|c|c|c|c|c|c|c|c|}
\hline \multirow{2}{*}{$\begin{array}{l}\text { Period of } \\
\text { water- } \\
\text { quality } \\
\text { sampling } \\
\text { during } \\
\text { water years } \\
2001-10\end{array}$} & \multirow[b]{2}{*}{$\begin{array}{l}\text { Constituent or property, } \\
\text { unadjusted (not flow adjusted) } \\
\text { units of measurement }\end{array}$} & \multicolumn{7}{|c|}{ Statistical summaries of water-quality data ${ }^{1}$} & \multirow{2}{*}{$\begin{array}{l}\text { Ratios of median } \\
\text { filtered to median } \\
\text { unfiltered-recov- } \\
\text { erable concentra- } \\
\text { tions for trace } \\
\text { elements, percent }\end{array}$} \\
\hline & & $\begin{array}{l}\text { samples (values } \\
\text { in parentheses } \\
\text { indicate number } \\
\text { of censored } \\
\text { values) }\end{array}$ & $\begin{array}{l}\text { Minimum } \\
\text { uncensored } \\
\text { value }^{2}\end{array}$ & $\begin{array}{c}\text { 25th } \\
\text { percentile }\end{array}$ & Median & Mean & $\begin{array}{c}\text { 75th } \\
\text { percentile }\end{array}$ & Maximum & \\
\hline \multicolumn{10}{|c|}{ Clark Fork at Turah Bridge (site 20, fig. 1, table 1) } \\
\hline \multirow{22}{*}{$\begin{array}{r}10 / 2000- \\
8 / 2010\end{array}$} & Streamflow, instantaneous, $\mathrm{ft}^{3} / \mathrm{s}$ & 80 & 331 & 744 & 1,200 & 1,940 & 2,550 & 7,560 & NA \\
\hline & Specific conductance, $\mu \mathrm{S} / \mathrm{cm}$ & 80 & 139 & 226 & 303 & 290 & 359 & 416 & NA \\
\hline & $\mathrm{pH}$, standard units & 80 & 7.9 & 8.1 & 8.3 & 8.3 & 8.5 & 8.8 & NA \\
\hline & Hardness, filtered, $\mathrm{mg} / \mathrm{L}$ as $\mathrm{CaCO}_{3}$ & 80 & 54 & 98 & 130 & 128 & 159 & 191 & NA \\
\hline & Calcium, filtered, mg/L & 80 & 14.9 & 28.1 & 36.9 & 36.1 & 44.0 & 53.8 & NA \\
\hline & Magnesium, filtered, mg/L & 80 & 3.97 & 6.82 & 9.19 & 9.29 & 11.9 & 13.7 & NA \\
\hline & Cadmium, filtered, $\mu \mathrm{g} / \mathrm{L}$ & $79(29)$ & 0.02 & 0.02 & 0.03 & 0.03 & 0.04 & 0.10 & 27 \\
\hline & Cadmium, unfiltered-recoverable, $\mu \mathrm{g} / \mathrm{L}$ & $80(7)$ & 0.03 & 0.05 & 0.10 & 0.14 & 0.16 & 1.0 & \\
\hline & Copper, filtered, $\mu \mathrm{g} / \mathrm{L}$ & 80 & 1.1 & 2.4 & 3.0 & 3.8 & 4.4 & 13 & 25 \\
\hline & Copper, unfiltered-recoverable, $\mu \mathrm{g} / \mathrm{L}$ & 80 & 2.7 & 5.8 & 12 & 21 & 25 & 117 & \\
\hline & Iron, filtered, $\mu \mathrm{g} / \mathrm{L}$ & $80(16)$ & 3.0 & 4.3 & 11.0 & 22 & 30 & 93 & 4 \\
\hline & Iron unfiltered-recoverable, $\mu \mathrm{g} / \mathrm{L}$ & 80 & 33 & 117 & 289 & 590 & 711 & 4,250 & \\
\hline & Lead, filtered, $\mu \mathrm{g} / \mathrm{L}$ & $80(30)$ & 0.03 & 0.04 & 0.07 & 0.10 & 0.13 & 0.37 & 3 \\
\hline & Lead, unfiltered-recoverable, $\mu \mathrm{g} / \mathrm{L}$ & $80(6)$ & 0.17 & 0.58 & 2.0 & 4.2 & 4.3 & 30 & \\
\hline & Manganese, filtered, $\mu \mathrm{g} / \mathrm{L}$ & 80 & 2.9 & 4.8 & 7.3 & 8.1 & 10 & 30 & 14 \\
\hline & Manganese, unfiltered-recoverable, $\mu \mathrm{g} / \mathrm{L}$ & 80 & 8.9 & 24 & 53 & 80 & 92 & 622 & \\
\hline & Zinc, filtered, $\mu \mathrm{g} / \mathrm{L}$ & 78 & 0.94 & 2.1 & 3.1 & 3.6 & 4.6 & 12 & 18 \\
\hline & Zinc, unfiltered-recoverable, $\mu \mathrm{g} / \mathrm{L}$ & 80 & 2.9 & 9.0 & 18 & 31 & 35 & 236 & \\
\hline & Arsenic, filtered, $\mu \mathrm{g} / \mathrm{L}$ & 80 & 3.1 & 4.9 & 5.6 & 5.9 & 6.7 & 10 & 80 \\
\hline & Arsenic, unfiltered-recoverable, $\mu \mathrm{g} / \mathrm{L}$ & 80 & 3.0 & 6.0 & 7.0 & 8.3 & 9.3 & 28 & \\
\hline & Suspended sediment, mg/L & 80 & 2 & 7 & 17 & 39 & 43 & 302 & NA \\
\hline & Suspended sediment, percent fines ${ }^{4}$ & 80 & 54 & 69 & 77 & 76 & 83 & 90 & NA \\
\hline
\end{tabular}


Table 1-4. Summary information relating to water-quality constituents and properties in samples collected at sites in the upper Clark Fork Basin, Montana , based on data collected during water years 2001-2010.-Continued

[Water year is the 12-month period from October 1 through September 30 and is designated by the year in which it ends. $\mathrm{ft}^{3} / \mathrm{s}$, cubic feet per second; NA, not applicable; $\mu \mathrm{S} / \mathrm{cm}$, microsiemens per centimeter at 25 degrees Celsius; $\mathrm{CaCO}_{3}$, calcium carbonate; $\mu \mathrm{g} / \mathrm{L}$, micrograms per liter; $\mathrm{mg} / \mathrm{L}$, milligrams per liter; $\mathrm{ND}$, distributional parameter not determined because of excessive number of censored values; <, less than]

\begin{tabular}{|c|c|c|c|c|c|c|c|c|c|}
\hline \multirow{2}{*}{$\begin{array}{l}\text { Period of } \\
\text { water- } \\
\text { quality } \\
\text { sampling } \\
\text { during } \\
\text { water years } \\
\text { 2001-10 }\end{array}$} & \multirow[b]{2}{*}{$\begin{array}{l}\text { Constituent or property, } \\
\text { unadjusted (not flow adjusted) } \\
\text { units of measurement }\end{array}$} & \multicolumn{7}{|c|}{ Statistical summaries of water-quality data ${ }^{1}$} & \multirow[b]{2}{*}{$\begin{array}{l}\text { Ratios of median } \\
\text { filtered to median } \\
\text { unfiltered-recov- } \\
\text { erable concentra- } \\
\text { tions for trace } \\
\text { elements, percent }\end{array}$} \\
\hline & & $\begin{array}{c}\text { Number of } \\
\text { samples (values } \\
\text { in parentheses } \\
\text { indicate number } \\
\text { of censored } \\
\text { values) }\end{array}$ & $\begin{array}{l}\text { Minimum } \\
\text { uncensored } \\
\text { value }^{2}\end{array}$ & $\begin{array}{c}\text { 25th } \\
\text { percentile }\end{array}$ & Median & Mean & $\begin{array}{c}\text { 75th } \\
\text { percentile }\end{array}$ & Maximum & \\
\hline \multicolumn{10}{|c|}{ Blackfoot River (site 21, fig. 1, table 1) } \\
\hline \multirow{22}{*}{$\begin{array}{r}10 / 2000- \\
8 / 2010\end{array}$} & Streamflow, instantaneous, $\mathrm{ft}^{3} / \mathrm{s}$ & 57 & 450 & 634 & 1,310 & 2,430 & 3,980 & 9,320 & NA \\
\hline & Specific conductance, $\mu \mathrm{S} / \mathrm{cm}$ & 57 & 140 & 174 & 205 & 215 & 260 & 282 & NA \\
\hline & $\mathrm{pH}$, standard units & 57 & 8.0 & 8.2 & 8.4 & 8.4 & 8.5 & 8.7 & NA \\
\hline & Hardness, filtered, $\mathrm{mg} / \mathrm{L}$ as $\mathrm{CaCO}_{3}$ & 56 & 68 & 86 & 108 & 107 & 130 & 146 & NA \\
\hline & Calcium, filtered, mg/L & 56 & 18.6 & 22.5 & 27.9 & 27.3 & 32.0 & 37.7 & NA \\
\hline & Magnesium, filtered, mg/L & 56 & 5.37 & 7.14 & 9.46 & 9.48 & 11.9 & 13.2 & NA \\
\hline & Cadmium, filtered, $\mu \mathrm{g} / \mathrm{L}$ & $55(48)$ & 0.01 & ND & ND & ND & ND & 0.02 & ND \\
\hline & Cadmium, unfiltered-recoverable, $\mu \mathrm{g} / \mathrm{L}$ & $57(44)$ & 0.01 & $<0.01$ & $<0.01$ & 0.01 & 0.01 & 0.10 & \\
\hline & Copper, filtered, $\mu \mathrm{g} / \mathrm{L}$ & $55(10)$ & 0.23 & 0.44 & 0.63 & 0.72 & 0.93 & 1.8 & 50 \\
\hline & Copper, unfiltered-recoverable, $\mu \mathrm{g} / \mathrm{L}$ & $57(8)$ & 0.30 & 0.72 & 1.3 & 1.8 & 2.2 & 8.5 & \\
\hline & Iron, filtered, $\mu \mathrm{g} / \mathrm{L}$ & $56(13)$ & 3.0 & 3.6 & 7.0 & 13 & 17 & 100 & 8 \\
\hline & Iron unfiltered-recoverable, $\mu \mathrm{g} / \mathrm{L}$ & 57 & 14 & 30 & 86 & 232 & 387 & 2,200 & \\
\hline & Lead, filtered, $\mu \mathrm{g} / \mathrm{L}$ & $55(45)$ & 0.02 & ND & ND & ND & ND & 0.03 & ND \\
\hline & Lead, unfiltered-recoverable, $\mu \mathrm{g} / \mathrm{L}$ & $57(18)$ & 0.04 & 0.05 & 0.12 & 0.33 & 0.31 & 3.6 & \\
\hline & Manganese, filtered, $\mu \mathrm{g} / \mathrm{L}$ & 56 & 0.50 & 1.2 & 1.7 & 2.0 & 2.5 & 5.2 & 20 \\
\hline & Manganese, unfiltered-recoverable, $\mu \mathrm{g} / \mathrm{L}$ & 57 & 2.0 & 5.0 & 8.6 & 19 & 28 & 150 & \\
\hline & Zinc, filtered, $\mu \mathrm{g} / \mathrm{L}$ & $55(24)$ & 0.30 & 0.36 & 0.57 & 0.70 & 0.88 & 2.8 & 57 \\
\hline & Zinc, unfiltered-recoverable, $\mu \mathrm{g} / \mathrm{L}$ & $57(26)$ & 1.0 & 0.49 & 1.0 & 2.0 & 2.7 & 12 & \\
\hline & Arsenic, filtered, $\mu \mathrm{g} / \mathrm{L}$ & 56 & 0.41 & 0.80 & 0.97 & 1.0 & 1.2 & 1.5 & 88 \\
\hline & Arsenic, unfiltered-recoverable, $\mu \mathrm{g} / \mathrm{L}$ & $54(10)$ & 0.93 & 1.0 & 1.1 & 1.2 & 1.3 & 2.6 & \\
\hline & Suspended sediment, $\mathrm{mg} / \mathrm{L}$ & 57 & 1 & 2 & 5 & 19 & 28 & 228 & NA \\
\hline & Suspended sediment, percent fines ${ }^{4}$ & 57 & 69 & 79 & 82 & 82 & 85 & 95 & NA \\
\hline
\end{tabular}


Table 1-4. Summary information relating to water-quality constituents and properties in samples collected at sites in the upper Clark Fork Basin, Montana, based on data collected during water years 2001-2010.-Continued

[Water year is the 12-month period from October 1 through September 30 and is designated by the year in which it ends. $\mathrm{ft}^{3} / \mathrm{s}$, cubic feet per second; NA, not applicable; $\mu \mathrm{S} / \mathrm{cm}$, microsiemens per centimeter at 25 degrees Celsius; $\mathrm{CaCO}_{3}$, calcium carbonate; $\mu \mathrm{g} / \mathrm{L}$, micrograms per liter; $\mathrm{mg} / \mathrm{L}$, milligrams per liter; $\mathrm{ND}$, distributional parameter not determined because of excessive number of censored values; <, less than]

\begin{tabular}{|c|c|c|c|c|c|c|c|c|c|}
\hline \multirow{2}{*}{$\begin{array}{l}\text { Period of } \\
\text { water- } \\
\text { quality } \\
\text { sampling } \\
\text { during } \\
\text { water years } \\
\text { 2001-10 }\end{array}$} & \multirow[b]{2}{*}{$\begin{array}{l}\text { Constituent or property, } \\
\text { unadjusted (not flow adjusted) } \\
\text { units of measurement }\end{array}$} & \multicolumn{7}{|c|}{ Statistical summaries of water-quality data ${ }^{1}$} & \multirow[b]{2}{*}{$\begin{array}{l}\text { Ratios of median } \\
\text { filtered to median } \\
\text { unfiltered-recov- } \\
\text { erable concentra- } \\
\text { tions for trace } \\
\text { elements, percen }\end{array}$} \\
\hline & & $\begin{array}{l}\text { Number of } \\
\text { samples (values } \\
\text { in parentheses } \\
\text { indicate number } \\
\text { of censored } \\
\text { values) }\end{array}$ & $\begin{array}{l}\text { Minimum } \\
\text { uncensored } \\
\text { value }^{2}\end{array}$ & $\begin{array}{c}\text { 25th } \\
\text { percentile }\end{array}$ & Median & Mean & $\begin{array}{c}\text { 75th } \\
\text { percentile }\end{array}$ & Maximum & \\
\hline \multicolumn{10}{|c|}{ Clark Fork above Missoula (site 22, fig. 1, table 1) } \\
\hline \multirow{22}{*}{$\begin{array}{r}10 / 2000- \\
8 / 2010\end{array}$} & Streamflow, instantaneous, $\mathrm{ft}^{3} / \mathrm{s}$ & 80 & 772 & 1,320 & 3,300 & 4,280 & 6,510 & 15,400 & NA \\
\hline & Specific conductance, $\mu \mathrm{S} / \mathrm{cm}$ & 80 & 148 & 196 & 256 & 252 & 311 & 351 & NA \\
\hline & $\mathrm{pH}$, standard units & 80 & 7.9 & 8.2 & 8.3 & 8.3 & 8.4 & 8.8 & NA \\
\hline & Hardness, filtered, $\mathrm{mg} / \mathrm{L}$ as $\mathrm{CaCO}_{3}$ & 80 & 70 & 91 & 118 & 117 & 142 & 166 & NA \\
\hline & Calcium, filtered, mg/L & 80 & 19.3 & 24.7 & 31.5 & 31.5 & 38.3 & 44.8 & NA \\
\hline & Magnesium, filtered, mg/L & 80 & 5.34 & 7.08 & 9.08 & 9.22 & 11.6 & 13.4 & NA \\
\hline & Cadmium, filtered, $\mu \mathrm{g} / \mathrm{L}$ & $79(40)$ & 0.01 & 0.01 & 0.02 & 0.02 & 0.03 & 0.20 & 25 \\
\hline & Cadmium, unfiltered-recoverable, $\mu \mathrm{g} / \mathrm{L}$ & $80(8)$ & 0.02 & 0.05 & 0.08 & 0.14 & 0.15 & 1.9 & \\
\hline & Copper, filtered, mg/L & 80 & 0.90 & 1.7 & 2.3 & 2.7 & 3.3 & 13 & 24 \\
\hline & Copper, unfiltered-recoverable, $\mu \mathrm{g} / \mathrm{L}$ & 80 & 2.5 & 6.0 & 10 & 23 & 20 & 386 & \\
\hline & Iron, filtered, $\mu \mathrm{g} / \mathrm{L}$ & $80(9)$ & 3.0 & 7.0 & 13.5 & 20 & 25 & 106 & 5 \\
\hline & Iron unfiltered-recoverable, $\mu \mathrm{g} / \mathrm{L}$ & 80 & 43 & 141 & 246 & 603 & 724 & 5,980 & \\
\hline & Lead, filtered, $\mu \mathrm{g} / \mathrm{L}$ & $78(20)$ & 0.04 & 0.05 & 0.07 & 0.10 & 0.12 & 0.34 & 4 \\
\hline & Lead, unfiltered-recoverable, $\mu \mathrm{g} / \mathrm{L}$ & $80(7)$ & 0.18 & 0.77 & 1.7 & 3.4 & 3.8 & 54 & \\
\hline & Manganese, filtered, $\mu \mathrm{g} / \mathrm{L}$ & 80 & 5.9 & 9.5 & 13 & 14 & 17 & 38 & 30 \\
\hline & Manganese, unfiltered-recoverable, $\mu \mathrm{g} / \mathrm{L}$ & 80 & 11.7 & 28 & 45 & 64 & 72 & 314 & \\
\hline & Zinc, filtered, $\mu \mathrm{g} / \mathrm{L}$ & $79(2)$ & 0.80 & 1.5 & 2.4 & 2.7 & 3.4 & 8.0 & 16 \\
\hline & Zinc, unfiltered-recoverable, $\mu \mathrm{g} / \mathrm{L}$ & 80 & 3.3 & 8.5 & 15 & 35 & 33 & 495 & \\
\hline & Arsenic, filtered, $\mu \mathrm{g} / \mathrm{L}$ & 80 & 1.6 & 3.0 & 3.6 & 3.7 & 4.4 & 9.0 & 84 \\
\hline & Arsenic, unfiltered-recoverable, $\mu \mathrm{g} / \mathrm{L}$ & 80 & 2.0 & 3.8 & 4.3 & 5.6 & 6.0 & 27 & \\
\hline & Suspended sediment, $\mathrm{mg} / \mathrm{L}$ & 80 & 2 & 9 & 15 & 52 & 56 & 950 & NA \\
\hline & Suspended sediment, percent fines ${ }^{4}$ & 80 & 14 & 69 & 83 & 77 & 90 & 99 & NA \\
\hline
\end{tabular}

${ }^{1}$ Distributional parameters affected by censored observations (that is, concentrations reported as less than the laboratory reporting level) were estimated by using adjusted maximum likelihood estimation (Cohn, 1988).

${ }^{2}$ Minimum uncensored value refers to the smallest concentration reported as detected above any of the various laboratory reporting levels applicable for a given constituent.

${ }^{3}$ Ratio of median filtered to unfiltered-recoverable concentration greater than 100 percent affected by low median concentrations near minimum laboratory reporting levels (table 2 ) and small bias in filtered concentrations.

${ }^{4}$ Percent fines refers to the percentage of suspended sediment smaller than 0.062 -millimeter diameter. 
Table 1-5. Aquatic life standards (based on median hardness for water years 2001-10) for selected sites in the upper Clark Fork Basin, Montana.

[Water year is the 12-month period from October 1 through September 30 and is designated by the year in which it ends. $\mathrm{CaCO}_{3}$, calcium carbonate]

\begin{tabular}{|c|c|c|c|c|c|c|c|c|c|c|}
\hline \multirow{3}{*}{$\begin{array}{c}\text { Site } \\
\text { number } \\
\text { (fig. 1, } \\
\text { table 1) }\end{array}$} & \multirow{3}{*}{$\begin{array}{c}\text { Site name } \\
\text { (fig. 1, table 1) }\end{array}$} & \multirow{3}{*}{$\begin{array}{l}\text { Median hard- } \\
\text { ness for water } \\
\text { years 2001-10, } \\
\text { in milligrams } \\
\text { per liter as } \\
\mathrm{CaCO}_{3}\end{array}$} & \multicolumn{8}{|c|}{$\begin{array}{c}\text { Aquatic life standards (Montana Department of Environmental Quality, 2012a), in micrograms per liter } \\
\text { (adjusted for hardness) }\end{array}$} \\
\hline & & & \multicolumn{2}{|c|}{ Cadmium } & \multicolumn{2}{|c|}{ Copper } & \multicolumn{2}{|c|}{ Lead } & \multicolumn{2}{|c|}{ Zinc } \\
\hline & & & Acute & Chronic & Acute & Chronic & Acute & Chronic & Acute & Chronic \\
\hline 1 & Blacktail Creek & 106 & 2.26 & 0.283 & 14.8 & 9.81 & 87.9 & 3.43 & 126 & 126 \\
\hline 2 & Silver Bow Creek at Butte & 154 & 3.31 & 0.373 & 21.0 & 13.5 & 141 & 5.51 & 173 & 173 \\
\hline 3 & $\begin{array}{l}\text { Silver Bow Creek at Op- } \\
\text { portunity }\end{array}$ & 159 & 3.42 & 0.382 & 21.7 & 13.9 & 147 & 5.74 & 177 & 177 \\
\hline 4 & Mill Creek near Anaconda & 59.8 & 1.26 & 0.185 & 8.62 & 6.01 & 42.4 & 1.65 & 77.5 & 77.5 \\
\hline 5 & Mill Creek at Opportunity & 67.0 & 1.42 & 0.201 & 9.60 & 6.63 & 49.0 & 1.91 & 85.3 & 85.3 \\
\hline 6 & $\begin{array}{l}\text { Willow Creek near Ana- } \\
\text { conda }\end{array}$ & 38.4 & 0.806 & 0.133 & 5.68 & 4.12 & 24.1 & 0.941 & 53.3 & 53.3 \\
\hline 7 & $\begin{array}{l}\text { Willow Creek at Oppor- } \\
\text { tunity }\end{array}$ & 130 & 2.79 & 0.329 & 17.9 & 11.7 & 114 & 4.44 & 150 & 150 \\
\hline 8 & $\begin{array}{l}\text { Silver Bow Creek at Warm } \\
\text { Springs }\end{array}$ & 207 & 4.47 & 0.464 & 27.8 & 17.4 & 206 & 8.03 & 222 & 222 \\
\hline 9 & $\begin{array}{l}\text { Warm Springs Creek near } \\
\text { Anaconda }\end{array}$ & 112 & 2.39 & 0.294 & 15.6 & 10.3 & 94.3 & 3.68 & 132 & 132 \\
\hline 10 & $\begin{array}{l}\text { Warm Springs Creek at } \\
\text { Warm Springs }\end{array}$ & 148 & 3.18 & 0.362 & 20.3 & 13.0 & 134 & 5.24 & 167 & 167 \\
\hline 11 & Clark Fork near Galen & 188 & 4.05 & 0.432 & 25.4 & 16.0 & 182 & 7.11 & 205 & 205 \\
\hline 12 & Lost Creek near Anaconda & 98.8 & 2.11 & 0.268 & 13.8 & 9.23 & 80.4 & 3.13 & 119 & 119 \\
\hline 13 & Lost Creek near Galen & 298 & 6.47 & 0.608 & 39.2 & 23.7 & 328 & 12.8 & 302 & 302 \\
\hline 14 & Clark Fork at Deer Lodge & 210 & 4.54 & 0.469 & 28.2 & 17.6 & 210 & 8.18 & 225 & 225 \\
\hline 15 & Little Blackfoot River & 116 & 2.48 & 0.302 & 16.1 & 10.6 & 98.6 & 3.84 & 136 & 136 \\
\hline 16 & Clark Fork at Goldcreek & 169 & 3.64 & 0.399 & 23.0 & 14.6 & 159 & 6.21 & 187 & 187 \\
\hline 17 & $\begin{array}{l}\text { Flint Creek near Drum- } \\
\text { mond }\end{array}$ & 161 & 3.46 & 0.385 & 21.9 & 14.0 & 150 & 5.83 & 179 & 179 \\
\hline 18 & $\begin{array}{l}\text { Clark Fork near Drum- } \\
\text { mond }\end{array}$ & 184 & 3.96 & 0.425 & 24.9 & 15.7 & 177 & 6.91 & 201 & 201 \\
\hline 19 & Rock Creek & 56.9 & 1.20 & 0.178 & 8.23 & 5.76 & 39.8 & 1.55 & 74.3 & 74.3 \\
\hline 20 & Clark Fork at Turah Bridge & 130 & 2.79 & 0.329 & 17.9 & 11.7 & 114 & 4.44 & 150 & 150 \\
\hline 21 & Blackfoot River & 108 & 2.31 & 0.287 & 15.1 & 9.96 & 90.0 & 3.51 & 128 & 128 \\
\hline 22 & Clark Fork above Missoula & 118 & 2.52 & 0.306 & 16.4 & 10.7 & 101 & 3.93 & 138 & 138 \\
\hline
\end{tabular}


Table 1-6. Summary information relating to continuous streamflow data for sites in the upper Clark Fork Basin, Montana , based on data collected during water years 2001-2010.

[Water year is the 12-month period from October 1 through September 30 and is designated by the year in which it ends]

\begin{tabular}{|c|c|c|c|c|c|c|c|c|c|}
\hline \multirow{2}{*}{$\begin{array}{c}\text { Site } \\
\text { number } \\
\text { (fig. 1, } \\
\text { table 1) }\end{array}$} & \multirow{2}{*}{$\begin{array}{c}\text { Site name } \\
\text { (fig. 1, table 1) }\end{array}$} & \multirow{2}{*}{$\begin{array}{c}\text { Drainage } \\
\text { area, } \\
\text { square } \\
\text { miles }\end{array}$} & \multirow{2}{*}{$\begin{array}{c}\text { Water years } \\
\text { summarized } \\
\text { based on avail- } \\
\text { able data during } \\
\text { water years } \\
2001-10\end{array}$} & \multicolumn{6}{|c|}{ Daily mean streamflow, cubic feet per second } \\
\hline & & & & Minimum & $\begin{array}{c}\text { 25th } \\
\text { percentile }\end{array}$ & Median & Mean & $\begin{array}{c}\text { 75th } \\
\text { percentile }\end{array}$ & Maximum \\
\hline 1 & $\begin{array}{l}\text { Blacktail Creek at Harrison Avenue, at } \\
\text { Butte, Mont. }\end{array}$ & 85 & $2001-10$ & 4.4 & 7.2 & 8.9 & 13 & 13 & 131 \\
\hline 2 & $\begin{array}{l}\text { Silver Bow Creek below Blacktail } \\
\text { Creek, at Butte, Mont. }\end{array}$ & 103 & $2001-10$ & 11 & 15 & 17 & 21 & 22 & 156 \\
\hline 3 & Silver Bow Creek at Opportunity, Mont. & 363 & $2001-10$ & 11 & 24 & 30 & 44 & 45 & 454 \\
\hline 4 & Mill Creek near Anaconda, Mont. & 34 & $2005-10$ & 5.5 & 10 & 14 & 33 & 30 & 252 \\
\hline 5 & Mill Creek at Opportunity, Mont. & 43 & $2004-10$ & 0.20 & 1.7 & 4.3 & 15 & 10 & 195 \\
\hline 6 & Willow Creek near Anaconda, Mont. & 14 & $2005-10$ & 0.50 & 1.5 & 2.2 & 7.0 & 5.9 & 95 \\
\hline 7 & Willow Creek at Opportunity, Mont. & 31 & $2004-10$ & 2.5 & 5.1 & 6.6 & 10 & 9.2 & 114 \\
\hline 8 & $\begin{array}{l}\text { Silver Bow Creek at Warm Springs, } \\
\text { Mont. }\end{array}$ & 473 & $2001-10$ & 15 & 35 & 47 & 70 & 67 & 615 \\
\hline 9 & $\begin{array}{l}\text { Warm Springs Creek near Anaconda, } \\
\text { Mont. }\end{array}$ & 157 & $2001-10$ & 13 & 46 & 61 & 84 & 87 & 601 \\
\hline 10 & $\begin{array}{l}\text { Warm Springs Creek at Warm Springs, } \\
\text { Mont. }\end{array}$ & 163 & $2001-10$ & 5.0 & 30 & 40 & 58 & 59 & 387 \\
\hline 11 & Clark Fork near Galen, Mont. & 651 & $2001-10$ & 26 & 68 & 89 & 130 & 130 & 988 \\
\hline 12 & Lost Creek near Anaconda, Mont. & 26 & $2005-10$ & 0.00 & 3.1 & 4.7 & 6.5 & 7.1 & 56 \\
\hline 13 & Lost Creek near Galen, Mont. & 61 & $2004-10$ & 1.4 & 8.5 & 36 & 29 & 43 & 100 \\
\hline 14 & Clark Fork at Deer Lodge, Mont. & 995 & $2001-10$ & 27 & 147 & 187 & 216 & 236 & 1,470 \\
\hline 15 & $\begin{array}{l}\text { Little Blackfoot River near Garrison, } \\
\text { Mont. }\end{array}$ & 407 & $2001-10$ & 16 & 52 & 72 & 145 & 147 & 1,440 \\
\hline 16 & Clark Fork at Goldcreek, Mont. & 1,704 & $2001-10$ & 73 & 271 & 332 & 460 & 474 & 3,990 \\
\hline 17 & Flint Creek near Drummond, Mont. & 490 & $2001-10$ & 2.1 & 66 & 98 & 123 & 142 & 869 \\
\hline 18 & Clark Fork near Drummond, Mont. & 2,501 & $2001-10$ & 100 & 401 & 503 & 648 & 684 & 4,130 \\
\hline 19 & Rock Creek near Clinton, Mont. & 885 & $2001-10$ & 40 & 180 & 240 & 471 & 468 & 5,020 \\
\hline 20 & $\begin{array}{l}\text { Clark Fork at Turah Bridge, near Bon- } \\
\text { ner, Mont. }\end{array}$ & 3,641 & $2001-10$ & 177 & 654 & 816 & 1,200 & 1,160 & 7,900 \\
\hline 21 & Blackfoot River near Bonner, Mont. & 2,290 & $2001-10$ & 180 & 490 & 624 & 1,330 & 1,460 & 10,100 \\
\hline 22 & Clark Fork above Missoula, Mont. & 5,999 & $2001-10$ & 450 & 1,130 & 1,420 & 2,500 & 2,640 & 17,300 \\
\hline
\end{tabular}




\section{Appendix 2-Summary of the Time- Series Model (TSM) as Applied in this Study}

The theory and parameter estimation for the model are described in detail in Vecchia (2005). In the time-series model, log-transformed concentration data were partitioned into several components according to equation 2:

$$
\log (C)=M_{C}+A N N_{C}+S E A S_{C}+T R E N D+H F V_{C}
$$

where

$$
\begin{aligned}
& \log \text { is the base-10 logarithm; } \\
& C \text { is the concentration, in milligrams per liter; } \\
& M_{C} \text { is the long-term mean of the log-transformed } \\
& \text { concentration, as the base-10 logarithm of } \text { milligrams per liter; } \\
& A N N_{C} \text { is the annual concentration anomaly } \\
& \text { (dimensionless); }
\end{aligned}
$$

In equation 2, the annual concentration anomaly $\left(A N N_{C}\right)$, seasonal concentration anomaly $\left(S E A S_{C}\right)$, and high-frequency variability $\left(H F V_{C}\right)$ terms represent natural variability in concentration for different time scales. $A N N_{C}$ is an estimate of the interannual variability in concentration that can be attributed to long-term variability in streamflow. $A N N_{C}$ is quantified by relating annual means (for the 365-day period immediately before a given sample) of log concentration and log streamflow to long-term means (for the entire period of record). Extended droughts and wet periods can change the chemical and suspended-material composition of streamflow by changing the degree of contact between surface runoff and soil particles, availability of particulate material in stream channels and near-stream areas, and changing the relative composition of runoff among groundwater, overland flow, and subsurface flow (Vecchia, 2005).

$S E A S_{C}$ is an estimate of the seasonal variability in concentration that can be attributed to seasonal variability in streamflow or to factors other than variability in streamflow. $S E A S_{C}$ is quantified by relating seasonal means (for the 90-day period immediately before a given sample was collected) of $\log$ concentration and $\log$ streamflow to annual means (for the 365-day period immediately before a given sample was collected). For example, the seasonal snow-accumulation and snowmelt cycle causes seasonal fluctuations in streamflow and water quality. Seasonal differences in the relative amount of streamflow that comes from natural sources compared to anthropogenic contributions (such as wastewater inputs) also might cause seasonal fluctuations in concentration that are more complicated than a simple relation between concentration and streamflow could produce.

$H F V_{C}$ is an estimate of the variability in concentration for time scales that are smaller than the seasonal time scale (time scales of several days to several weeks). Thus, high-frequency variability is the variability that remains after the removal of seasonal and annual anomalies and trends. $H F V_{C}$ is quantified by relating $\log$ concentration and $\log$ streamflow for the day of sampling to $\log$ concentration and $\log$ streamflow for each of the two 10-day periods immediately before a given sample. Short-term changes in meteorological conditions might cause high-frequency variability in concentration and streamflow. The high-frequency variability depends on a timeseries model, called a periodic autoregressive moving average model, that accounts for the presence of serial correlation among concentrations (for example, the tendency for high or low values to persist for several days to several weeks before returning to normal levels; Vecchia, 2005).

TREND is an estimate of the long-term systematic changes in concentration during the study period that are unrelated to long-term variability in streamflow. For this report, a significant trend might indicate changes in the extent to which mining wastes affect chemical composition of surface water or changes in other activities, such as agricultural practices, that can change the amount of suspended sediment or trace elements that reach the stream. TREND consists of piecewise monotonic trends during specified trend-analysis periods. The overall significance of TREND (determined by using the generalized likelihood ratio principle; Vecchia, 2005, appendix 1) specifies whether there were any significant changes during any of the specified trend-analysis periods. For a given site and constituent combination, if TREND was determined to be nonsignificant, the trends for all of the specified trend-analysis periods were considered nonsignificant and $p$-values were not reported. Infrequently, overall significance of TREND could not be determined (and thus TREND was assumed to be nonsignificant), but the individual trend coefficient for a specified trend-analysis period was highly significant and of large magnitude. In those cases, with TREND included in the model, the numerical procedure for minimizing the likelihood function apparently converged to a local, rather than global, minimum and produced unrealistic results relative to the model without TREND included. However, trend directions and magnitudes for those infrequent cases generally were consistent with trends for other constituents that would be expected to behave in a similar manner, and with trends for upstream or downstream sites. Therefore, the TSM was presumed to provide reasonably accurate trend magnitudes for the specified trend-analysis period and overall trend patterns were not strongly affected. For a given site and constituent combination, if TREND was determined to be significant, the slope coefficient ( $\gamma$; Vecchia, 2005, appendix 1) for the trend for each specified trend-analysis period was used to determine the significance and magnitude of the trend for the specified trend-analysis period. The null hypothesis in the test for trend significance in a given trend analysis period is that there is 
no trend (that is, $\gamma=0$ ). If the two-tailed $p$-value for $\gamma$ was less than the selected alpha level ( 0.01 in this report), the null hypothesis was rejected and the trend was determined to be significant. Determination of a nonsignificant trend (that is, a $p$-value greater than 0.01) does not imply that the null hypothesis is accepted (that is, that there is no trend). It indicates that within the statistical framework of the analysis, a significant trend was not detected. The magnitude of the trend for a specified trend-analysis period is expressed as the percent difference between the geometric mean concentration at the end of the period and the geometric mean concentration at the start of the period and is determined by the equation:

$$
\% \triangle F A C=100\left(10^{\gamma}-1\right)
$$

where

$$
\begin{gathered}
\% \triangle F A C \quad \begin{array}{l}
\text { is the percent change in the geometric mean } \\
\text { of the flow-adjusted concentration, and }
\end{array} \\
\gamma \quad \begin{array}{r}
\text { is the slope coefficient of the trend for the } \\
\text { specified trend-analysis period in log- } \\
\text { transformed units. }
\end{array}
\end{gathered}
$$

Log-transformed concentrations that have $A N N_{C}$ and $S E A S_{C}$ removed are referred to in this report as flow-adjusted concentrations. Using equation 2 , the flow-adjusted concentration is defined as:

$$
F A C=\log (C)-A N N_{C}-S E A S_{C}=M_{C}+T R E N D+H F V_{C}
$$

where

$$
\begin{gathered}
\text { FAC is the flow-adjusted value, as the base- } \\
10 \text { logarithm of the original units of } \\
\text { measurement. }
\end{gathered}
$$

The FACs defined by equation 4 are analogous to FACs defined in previous publications as the residuals from a regression model that relates concentration to concurrent daily streamflow (Helsel and Hirsch, 2002); however, the TSM approach generally is more effective than a regression-based approach for removing streamflow-related variability (Vecchia, 2005). Time-series plots showing the FACs along with the fitted trend $\left(M_{C}+T R E N D\right)$ illustrate long-term changes in geometric mean concentration that might indicate changes in effects of mining wastes on water-quality in the selected watersheds.

The key to making TSM a powerful trend analysis tool is that the entire time series of daily streamflow data are used in the model, not just streamflow for the days when concentration samples are available. The model uses a three-per-month, or approximately 10-day, sampling frequency. Each month is divided into three intervals - days 1 through 10, days 11 through 20, and day 21 through the end of the month. If a water-quality sample is available for a particular interval, it is paired with daily streamflow for the same day of the waterquality sample. If no water-quality sample is available, the concentration value for the interval is missing and streamflow for the middle of the interval (day 5, 15, or 25) is used. If more than one concentration sample is available for the interval, the value nearest to the midpoint of the interval is used. The log-transformed streamflow time series (consisting of three values per month) is divided into an annual anomaly, seasonal anomaly, and high-frequency variability according to the following equation,

$$
\log (Q)=M_{Q}+A N N_{Q}+S E A S_{Q}+H F V_{Q}
$$

where

$$
\begin{aligned}
& Q \quad \text { is daily mean streamflow, in cubic feet per } \\
& H F V_{Q} \text { is } \log (Q)-M_{Q}-A N N_{Q}-S E A S_{Q} \text { is the high- }
\end{aligned}
$$

The water-quality time-series model (equation 2) is directly tied to the streamflow time-series model because the streamflow anomalies $\left(A N N_{Q}\right.$ and $S E A S_{Q}$ from equation 5) are used as predictor variables for concentration (equation 2). For example, $A N N_{C}$ is assumed to equal a constant coefficient (estimated from the time-series model) times $A N N_{Q}$. The different scales of streamflow variability often affect concentration in different ways. The relation between $H F V_{C}$ and $H F V_{Q}$ can be particularly complicated, changing depending on the time-of-year and the degree of serial correlation in the concentration data and cross-correlation between concentration and streamflow.

The TSM residuals for each site and constituent combination were examined graphically to verify the model assumptions that the residuals had constant variance, were serially uncorrelated, and were approximately normally distributed. Because of the application of the TSM to the large number of site and constituent combinations, and practical considerations to keep the trend periods comparable among sites and constituents, some minor deviations of the residuals from model assumptions were tolerated. Such deviations included small changes in residual variance through time and shortterm (about 1 to 2 years) unresolved trending in the residuals. In cases where unresolved residual trends were considered to be large enough to possibly affect the magnitudes and significance levels of reported fitted trends, more complicated trend models were tested and in nearly all cases the more complicated models did not change the general findings and conclusions of this report. Therefore, the reported TSM results were judged to provide acceptable fits representative of linearity through nearly all of the range in FACs for a given site and constituent combination. Standard errors of estimates (SEEs) for the TSM analyses are presented in table 2-1. In this report, 
SEEs are expressed in percent and were converted from log units by using procedures described by Tasker (1978). For all trace elements, mean SEEs range from 20.9 to 64.5 percent. Mean SEEs for unfiltered-recoverable copper and arsenic concentrations are 47.0 and 28.8 percent, respectively. Mean SEE for suspended-sediment concentration (62.8) is substantially higher than for mean SEEs for trace elements. The SEEs indicate reasonably accurate definition of concentration and streamflow relations for the purpose of trend analysis.
However, higher mean SEE for suspended sediment than mean SEEs for trace elements indicates lower confidence in results. For each site and constituent combination, the fit of the TSM can be assessed by examination of the fitted trends in relation to the FACs that are shown in figures 4-1 through 4-3, 4-8 through 4-11, and 4-14 through 4-22. The distribution of the FACs about the fitted trend lines shows the extent to which the residuals might exhibit nonconstant variance or unresolved trends.

Table 2-1. Statistical summaries of standard errors of estimates (SEEs) for the time-series model (TSM) analyses ${ }^{1}$.

[NA, not applicable]

\begin{tabular}{|c|c|c|c|c|}
\hline \multirow[b]{2}{*}{ Constituent or property } & \multirow{2}{*}{$\begin{array}{l}\text { Number of sites for } \\
\text { which trend results } \\
\text { are reported }\end{array}$} & \multicolumn{3}{|c|}{ SEE, percent } \\
\hline & & Minimum & Mean & Maximum \\
\hline Specific conductance & 15 & 6.1 & 10.5 & 15.5 \\
\hline Cadmium, filtered & 2 & 54.0 & 64.5 & 74.9 \\
\hline Cadmium, unfiltered-recoverable & 2 & 52.1 & 56.5 & 61.0 \\
\hline Copper, filtered & 11 & 22.0 & 32.0 & 40.2 \\
\hline Copper, unfiltered-recoverable & 13 & 33.9 & 47.0 & 63.4 \\
\hline Iron, filtered & 7 & 29.9 & 44.4 & 54.0 \\
\hline Iron unfiltered-recoverable & 15 & 30.1 & 48.5 & 65.5 \\
\hline Lead, filtered & 0 & NA & NA & NA \\
\hline Lead, unfiltered-recoverable & 6 & 51.9 & 58.8 & 65.9 \\
\hline Manganese, filtered & 14 & 29.0 & 38.9 & 60.7 \\
\hline Manganese, unfiltered-recoverable & 14 & 33.7 & 42.8 & 51.2 \\
\hline Zinc, filtered & 2 & 56.4 & 62.0 & 67.6 \\
\hline Zinc, unfiltered-recoverable & 11 & 42.4 & 52.1 & 77.1 \\
\hline Arsenic, filtered & 13 & 12.8 & 20.9 & 28.2 \\
\hline Arsenic, unfiltered-recoverable & 13 & 18.0 & 28.8 & 45.1 \\
\hline Suspended sediment & 15 & 48.6 & 62.8 & 73.8 \\
\hline \multicolumn{5}{|c|}{$\begin{array}{l}{ }^{1} \text { The TSM was applied to the following } 15 \text { sites (fig. 1, table 1): Blacktail Creek (site 1), Silver Bow Creek } \\
\text { at Butte (site 2), Silver Bow Creek at Opportunity (site 3), Silver Bow Creek at Warm Springs (site 8), Warm } \\
\text { Springs Creek at Warm Springs (site 10), Clark Fork near Galen (site 11), Clark Fork at Deer Lodge (site 14), } \\
\text { Little Blackfoot River (site 15), Clark Fork at Goldcreek (site 16), Flint Creek (site 17), Clark Fork near Drum- } \\
\text { mond (site 18), Rock Creek (site 19), Clark Fork at Turah Bridge (site 20), Blackfoot River (site 21), and Clark } \\
\text { Fork above Missoula (site 22). For some of the site and constituent combinations, trend results are not reported } \\
\text { because greater than } 6 \text { percent of values were affected by recensoring at study reporting level, as discussed in } \\
\text { the section of this report "Time-Series Model." The statistical summaries present the mean and ranges of SEE } \\
\text { for the TSM analyses for each constituent or property for which trend results are reported. }\end{array}$} \\
\hline
\end{tabular}




\section{Appendix 3-Summary of Multiple Linear Regression of Water-Quality Constituents on Time, Streamflow, and Season, as Applied in this Study}

Multiple linear regression of water-quality constituents on time, streamflow, and season (MLR) was applied in this study following guidelines presented in Helsel and Hirsch (2002). The basic multiple linear regression model used is represented by the equation:

$$
\begin{gathered}
\log \left(C_{t}\right)=b_{0}+b_{1} T_{t}+b_{2} \log Q_{t}+b_{3} \sin \left(2 \pi T_{t}\right)+ \\
\mathrm{b}_{4} \cos \left(2 \pi T_{t}\right)+b_{5} \sin \left(4 \pi T_{t}\right)+b_{6} \cos \left(4 \pi T_{t}\right)+E_{t}
\end{gathered}
$$

where

$\log$ denotes the base-10 logarithm;

$C_{t} \quad$ is the value of the water-quality constituent or property, in indicated units of measurement, at time t;

$b_{0} \quad$ is the intercept;

$b_{1}$ through $b_{6}$ are the estimated slope coefficients associated with the various explanatory variables;

$T_{t} \quad$ is decimal time (day of year expressed in decimal form; for example, June 30, 2010, is expressed as 2010.5) at time $t$;

$Q_{t} \quad$ is instantaneous streamflow at the time of sampling, in cubic feet per second; $\sin \left(2 \pi T_{t}\right), \cos \left(2 \pi T_{t}\right), \sin \left(4 \pi T_{t}\right)$, and $\cos \left(4 \pi T_{t}\right)$ are periodic functions that describe seasonal variability; and

$E_{t} \quad$ is an approximately normally distributed random error.

The MLR used ordinary least squares if the concentration data contained no censored observations. If censored observations were present, the MLR used adjusted maximum-likelihood estimation (Cohn, 1988, 2005) with the same formulation of dependent and explanatory variables.

Use of MLR for trend analysis involves regression of constituent concentration $\left[\log \left(C_{t}\right)\right.$, equation 6] on streamflow ( $Q_{\mathrm{t}}$, equation 6$)$, which inherently provides for flow adjustment and quantifies concentration and streamflow relations. The residuals from the regression of concentration on streamflow represent flow-adjusted concentrations (FACs; Helsel and Hirsch, 2002). Including periodic functions that describe seasonal variability $\left[\sin \left(2 \pi T_{t}\right), \cos \left(2 \pi T_{t}\right), \sin \left(4 \pi T_{t}\right)\right.$, and $\cos \left(4 \pi T_{t}\right)$, equation 6] accounts for the effect of repetitive seasonal variability on concentration and streamflow relations. The residuals from the regression of concentration on streamflow and the periodic functions represent changes in concentration and streamflow relations through the trend-analysis period. Including decimal time ( $T_{t}$, equation 6$)$ in the model provides quantification of the change in concentration and streamflow relations through time and describes the temporal trend in $F A C$ s for the specified trend-analysis period. The slope coeffi- cient for decimal time ( $b_{1}$, equation 6$)$ is used to determine the significance and magnitude of the trend. The null hypothesis in the test for trend significance is that there is no trend (that is, $b_{1}=0$ ). If the two-tailed $p$-value for $b_{1}$ is less than the selected alpha level (0.01 in this report), the null hypothesis is rejected and the trend is determined to be significant. Determination of a nonsignificant trend (that is, a $p$-value greater than 0.01 ) does not imply that the null hypothesis is accepted (that is, that there is no trend). It indicates that within the statistical framework of the analysis, a significant trend was not detected. The magnitude of the trend is expressed as the percent difference between the geometric mean concentration at the end of the period and the geometric mean concentration at the start of the period and is determined by the equation:

$$
\% \triangle F A C=100\left(10^{\left(N b_{1}\right)}-1\right)
$$

where

$\% \triangle F A C$ is the percent change in the geometric mean of the flow-adjusted concentration; and

$N \quad$ is the number of years in the trend-analysis period.

Application of linear regression for flow-adjusted trend analysis assumes that the data are normally distributed and that relations between the response variable (a given waterquality constituent) and the combined explanatory variables (time, streamflow, and periodic functions that describe seasonal variability) can be represented appropriately by a linear fit. Further, the relation between the water-quality constituent and streamflow must be statistically significant to accurately determine significance level. Data for many water-quality constituents typically do not conform to a normal distribution because of positive skew (Helsel and Hirsch, 2002). To approximate normality, constituent concentrations and streamflow were transformed to logarithm (base 10) units.

In accounting for seasonal variability, $2 \pi$ and $4 \pi$ sine and cosine terms were included in the regression model for all site and constituent combinations. During exploratory analysis, different multiples of $\pi$ were added to the model and evaluated for significant effect. The $2 \pi$ and $4 \pi$ terms frequently, but not always, were significant. Inclusion of the periodic functions when they were not significant in the regression model for some site and constituent combinations probably had small effect on the trend analysis results.

Effects of serial correlation on MLR results were evaluated for each site and constituent combination. Significant serial correlation was determined if Spearman's correlation coefficient on the lag-one residuals produced a $p$-value less than 0.05 (Helsel and Hirsch, 2002). Significant serial correlation was infrequent, but for site and constituent combinations with significant serial correlation the significance level of the trend results was not reported. It is notable that the simple measure of serial correlation used in this report can be affected by many factors and also might not completely represent all serial correlation effects in a given MLR model. Serial correlation does not affect the unbiased estimate of the trend line, but can 
result in unrepresentatively deflated SEEs and $p$-values.

The regression model results for each site and constituent combination were evaluated by examining the SEEs, the significance of the concentration and streamflow relation, influence and leverage statistics, and homoscedasticity and normality of residuals. Statistical summaries of SEE for the regression models are presented in table 3-1. In this report, SEEs are expressed in percent and were converted from log units by using procedures described by Tasker (1978). For all trace elements, mean SEEs range from 29.7-58.6 percent. Mean SEEs for unfiltered-recoverable copper and arsenic concentrations are 41.2 and 29.7 percent, respectively. SEEs for trace-element MLR models are similar to SEEs for regressions of constituents on streamflow previously used to estimate trace-element loads in the Clark Fork Basin (Lambing, 1991; Hornberger and others, 1997; Lambing, 1998; Lambing and Sando, 2008, 2009; Sando and Lambing, 2011). Mean SEE for suspended-sediment concentration (70.9) is substantially higher than for mean SEEs for trace elements, but also generally is less than or similar to SEEs for regressions previously used to estimate suspended-sediment loads in the Clark Fork Basin (Lambing, 1991; Hornberger and others, 1997; Lambing, 1998; Lambing and Sando, 2008, 2009; Sando and Lambing, 2011). The SEEs indicate reasonably accurate definition of concentration and streamflow relations for the purpose of trend analysis. However, higher mean SEE for suspended sediment than mean SEEs for trace elements indicates lower confidence in results. For a given site and constituent combination, the significance level of the trend results was not reported if the concentration and streamflow relation was nonsignificant ( $p$-value greater than 0.05). No data values were determined to have significant high influence for any of the MLR models. Because of the application of a consistent regression model to the large number of site and constituent combinations, and practical considerations to keep the trend periods comparable among sites and constituents, some minor deviations of the residuals from model assumptions was tolerated. However, the reported regression model results were judged to provide acceptable fits representative of linearity through nearly all of the range in FACs for a given site and constituent combination. For each site and constituent combination, the fit of the regression model can be assessed by examination of the fitted trends in relation to the $F A C$ s that are shown in figures 4-4 through 4-7, 4-9, and 4-12 through 4-13. For plotting purposes, the $F A C \mathrm{~s}$ were determined by adding the residuals from the regression of concentration on streamflow to the geometric mean concentration based on data collected during water years 2001-2010. The distribution of the FACs about the fitted trend lines shows the extent to which the regression model results were affected by factors such as residual heteroscedasticity and curvature.
Table 3-1. Statistical summaries of standard errors of estimates (SEEs) for multiple linear regression models of waterquality constituents on time, streamflow, and season (MLR)'.

\begin{tabular}{lccc}
\hline \multirow{2}{*}{ Constituent or property } & \multicolumn{3}{c}{ SEE, percent } \\
\cline { 2 - 4 } & Minimum & Mean & Maximum \\
\hline Specific conductance & 4.7 & 9.4 & 17.5 \\
Cadmium, filtered & 21.4 & 34.9 & 43.9 \\
\hline $\begin{array}{l}\text { Cadmium, unfiltered-recov- } \\
\quad \text { erable }\end{array}$ & 34.0 & 42.4 & 50.1 \\
\hline Copper, filtered & & & \\
\hline Copper, unfiltered-recoverable & 27.9 & 30.5 & 35.6 \\
\hline Iron, filtered & 36.3 & 41.2 & 57.3 \\
\hline Iron unfiltered-recoverable & 34.0 & 43.1 & 63.9 \\
\hline Lead, filtered & 43.8 & 48.2 & 64.9 \\
\hline Lead, unfiltered-recoverable & 42.3 & 58.6 & 68.8 \\
\hline Manganese, filtered & 19.5 & 43.1 & 63.6 \\
\hline Manganese, unfiltered-recov- & 35.4 & 51.8 & 69.1 \\
\hline$\quad$ erable & & & \\
\hline Zinc, filtered & 24.2 & 35.9 & 51.9 \\
\hline Zinc, unfiltered-recoverable & 35.9 & 46.4 & 61.5 \\
\hline Arsenic, filtered & 17.4 & 30.1 & 38.4 \\
\hline Arsenic, unfiltered-recoverable & 20.3 & 29.7 & 36.3 \\
\hline Suspended sediment & 48.1 & 70.9 & 81.6 \\
\hline IMLR waplied to the follown & & & \\
\hline
\end{tabular}

${ }^{1}$ MLR was applied to the following seven sites (fig. 1, table 1): Mill Creek near Anaconda (site 4); Mill Creek at Opportunity (site 5); Willow Creek near Anaconda (site 6); Willow Creek at Opportunity (site 7); Warm Springs Creek near Anaconda (site 9); Lost Creek near Anaconda (site 12); and Lost Creek near Galen (site 13). The statistical summaries present the mean and ranges of SEE for the seven regression models for each constituent or property. 
Table 4-1. Flow-adjusted trend results determined by using the time-series model (TSM) for selected water-quality constituents and properties for selected sampling sites in the upper Clark Fork Basin, Montana, water years 1996-2010.

[Water year is the 12-month period from October 1 through September 30 and is designated by the year in which it ends. Values in parentheses indicate $p$-values for associated percent change or coefficient. Gray shading indicates statistical significance at $p$-value less than 0.01 . $p$-value, statistical probability level; $\mathrm{SEAS}_{\mathrm{C}}$, seasonal concentration anomaly coefficient; $\mathrm{ANN}_{\mathrm{C}}$, annual concentration anomaly coefficient; SEE, standard error of estimate in percent; NR, not reported; <, less than]

\begin{tabular}{|c|c|c|c|c|c|c|c|c|c|}
\hline Constituent or property & $\begin{array}{c}\text { Number } \\
\text { of } \\
\text { samples }\end{array}$ & $\begin{array}{l}\text { Total percent } \\
\text { change for } \\
\text { water years } \\
\text { 1996-2000 } \\
\text { (period 1) }\end{array}$ & $\begin{array}{l}\text { Total percent } \\
\text { change for } \\
\text { water years } \\
2001-05 \\
\text { (period 2) }\end{array}$ & $\begin{array}{l}\text { Total percent } \\
\text { change for } \\
\text { water years } \\
2006-2010 \\
\text { (period 3) }\end{array}$ & $\begin{array}{c}p \text {-value } \\
\text { for overall } \\
\text { trend } \\
\text { analysis' }\end{array}$ & SEAS $_{\mathrm{c}}$ & ANN $_{c}$ & SEE & $\begin{array}{l}\text { Percent of values affected } \\
\text { by recensoring at study } \\
\text { reporting level used in the } \\
\text { application of the time- } \\
\text { series model }{ }^{2}\end{array}$ \\
\hline \multicolumn{10}{|c|}{ Blacktail Creek (site 1, fig. 1, table 1) } \\
\hline Specific conductance & 131 & $7\left(\mathrm{NR}^{3}\right)$ & $-1\left(\mathrm{NR}^{3}\right)$ & $-2\left(\mathrm{NR}^{3}\right)$ & 1.000 & $-0.32(<0.001)$ & $-0.17(<0.001)$ & 8.7 & 0 \\
\hline Cadmium, filtered & 129 & $\mathrm{NR}^{4}$ & $\mathrm{NR}^{4}$ & $\mathrm{NR}^{4}$ & $\mathrm{NR}^{4}$ & $\mathrm{NR}^{4}$ & $\mathrm{NR}^{4}$ & $\mathrm{NR}^{4}$ & 64 \\
\hline Cadmium, unfiltered-recoverable & 131 & $\mathrm{NR}^{4}$ & $\mathrm{NR}^{4}$ & $\mathrm{NR}^{4}$ & $\mathrm{NR}^{4}$ & $\mathrm{NR}^{4}$ & $\mathrm{NR}^{4}$ & $\mathrm{NR}^{4}$ & 79 \\
\hline Copper, filtered & 130 & $-11\left(\mathrm{NR}^{3}\right)$ & $-2\left(\mathrm{NR}^{3}\right)$ & $-5\left(\mathrm{NR}^{3}\right)$ & 0.038 & $1.43(<0.001)$ & $-0.13(0.136)$ & 40.2 & 5 \\
\hline Copper, unfiltered-recoverable & 131 & $-17(0.060)$ & $0(0.974)$ & $-12(0.327)$ & 0.005 & $1.31(<0.001)$ & $-0.11(0.416)$ & 33.9 & 0 \\
\hline Iron, filtered & 131 & $-38(0.001)$ & $56(0.004)$ & $27(0.215)$ & $<0.001$ & $1.89(<0.001)$ & $1.61(<0.001)$ & 43.4 & 0 \\
\hline Iron unfiltered-recoverable & 131 & $-22\left(\mathrm{NR}^{3}\right)$ & $-14\left(\mathrm{NR}^{3}\right)$ & $48\left(\mathrm{NR}^{3}\right)$ & 0.030 & $1.17(<0.001)$ & $0.38(0.007)$ & 37.4 & 0 \\
\hline Lead, filtered & 129 & $\mathrm{NR}^{4}$ & $\mathrm{NR}^{4}$ & $\mathrm{NR}^{4}$ & $\mathrm{NR}^{4}$ & $\mathrm{NR}^{4}$ & $\mathrm{NR}^{4}$ & $\mathrm{NR}^{4}$ & 76 \\
\hline Lead, unfiltered-recoverable & 131 & $\mathrm{NR}^{4}$ & $\mathrm{NR}^{4}$ & $\mathrm{NR}^{4}$ & NR4 & $\mathrm{NR}^{4}$ & $\mathrm{NR}^{4}$ & $\mathrm{NR}^{4}$ & 36 \\
\hline Manganese, filtered & 131 & $1\left(\mathrm{NR}^{3}\right)$ & $-19\left(\mathrm{NR}^{3}\right)$ & $31\left(\mathrm{NR}^{3}\right)$ & 0.579 & $-0.40(0.006)$ & $-0.03(0.705)$ & 33.3 & 0 \\
\hline Manganese, unfiltered-recoverable & 131 & $-16(0.007)$ & $-17(0.010)$ & $45(<0.001)$ & 0.001 & $-0.42(0.004)$ & $-0.20(0.010)$ & 34.1 & 0 \\
\hline Zinc, filtered & 129 & $\mathrm{NR}^{4}$ & $\mathrm{NR}^{4}$ & $\mathrm{NR}^{4}$ & $\mathrm{NR}^{4}$ & $\mathrm{NR}^{4}$ & $\mathrm{NR}^{4}$ & $\mathrm{NR}^{4}$ & 64 \\
\hline Zinc, unfiltered-recoverable & 131 & $\mathrm{NR}^{4}$ & $\mathrm{NR}^{4}$ & $\mathrm{NR}^{4}$ & $\mathrm{NR}^{4}$ & $\mathrm{NR}^{4}$ & $\mathrm{NR}^{4}$ & $\mathrm{NR}^{4}$ & 24 \\
\hline Arsenic, filtered & 130 & $-27(<0.001)$ & $18(0.003)$ & $7(0.371)$ & $<0.001$ & $0.88(<0.001)$ & $0.31(<0.001)$ & 22.0 & 0 \\
\hline Arsenic, unfiltered-recoverable & 130 & $-26(<0.001)$ & $9(0.246)$ & $7(0.499)$ & 0.001 & $0.98(<0.001)$ & $0.51(<0.001)$ & 22.3 & 1 \\
\hline Suspended sediment & 131 & $7(0.648)$ & $-21(0.150)$ & $-10(0.599)$ & 0.089 & $1.09(<0.001)$ & $0.20(0.335)$ & 61.8 & 0 \\
\hline \multicolumn{10}{|c|}{ Silver Bow Creek at Butte (site 2, fig. 1, table 1) } \\
\hline Specific conductance & 139 & $-5\left(\mathrm{NR}^{3}\right)$ & $0\left(\mathrm{NR}^{3}\right)$ & $-3\left(\mathrm{NR}^{3}\right)$ & 0.010 & $-0.36(<0.001)$ & $-0.19(<0.001)$ & 9.7 & 0 \\
\hline Cadmium, filtered & 138 & $-69(<0.001)$ & $-66(<0.001)$ & $-68(<0.001)$ & $<0.001$ & $1.07(0.043)$ & $0.97(0.009)$ & 74.9 & 1 \\
\hline Cadmium, unfiltered-recoverable & 137 & $-58(<0.001)$ & $-64(<0.001)$ & $-73(<0.001)$ & $<0.001$ & $1.65(<0.001)$ & $0.47(0.103)$ & 61.0 & 1 \\
\hline Copper, filtered & 139 & $-79(<0.001)$ & $6(0.717)$ & $-56(<0.001)$ & $<0.001$ & $1.96(<0.001)$ & $0.96(<0.001)$ & 36.5 & 0 \\
\hline Copper, unfiltered-recoverable & 139 & $-76(<0.001)$ & $-29(<0.001)$ & $-55(<0.001)$ & $<0.001$ & $1.71(<0.001)$ & $0.89(<0.001)$ & 34.1 & 0 \\
\hline Iron, filtered & 139 & $-68(<0.001)$ & $67(<0.001)$ & $73(0.003)$ & $<0.001$ & $1.54(<0.001)$ & $0.74(0.005)$ & 46.2 & 0 \\
\hline Iron unfiltered-recoverable & 139 & $-55(<0.001)$ & $-17(0.080)$ & $28(0.072)$ & $<0.001$ & $2.07(<0.001)$ & $0.73(<0.001)$ & 47.6 & 0 \\
\hline Lead, filtered & 134 & $\mathrm{NR}^{4}$ & $\mathrm{NR}^{4}$ & $\mathrm{NR}^{4}$ & $\mathrm{NR}^{4}$ & $\mathrm{NR}^{4}$ & $\mathrm{NR}^{4}$ & $\mathrm{NR}^{4}$ & 79 \\
\hline Lead, unfiltered-recoverable & 138 & $-66(<0.001)$ & $-50(<0.001)$ & $-9(0.535)$ & $<0.001$ & $2.20(<0.001)$ & $0.73(0.004)$ & 65.5 & 1 \\
\hline
\end{tabular}


Table 4-1. Flow-adjusted trend results determined by using the time-series model (TSM) for selected water-quality constituents and properties for selected sampling sites in the upper Clark Fork Basin, Montana, water years 1996-2010.-Continued

[Water year is the 12-month period from October 1 through September 30 and is designated by the year in which it ends. Values in parentheses indicate $p$-values for associated percent change or coefficient. Gray shading indicates statistical significance at $p$-value less than $0.01 . p$-value, statistical probability level; $\mathrm{SEAS}_{\mathrm{C}}$, seasonal concentration anomaly coefficient; $\mathrm{ANN}_{\mathrm{C}}$, annual concentration anomaly coefficient; SEE, standard error of estimate in percent; NR, not reported; <, less than]

\begin{tabular}{|c|c|c|c|c|c|c|c|c|c|}
\hline Constituent or property & $\begin{array}{c}\text { Number } \\
\text { of } \\
\text { samples }\end{array}$ & $\begin{array}{c}\text { Total percent } \\
\text { change for } \\
\text { water years } \\
\text { 1996-2000 } \\
\text { (period 1) }\end{array}$ & $\begin{array}{c}\text { Total percent } \\
\text { change for } \\
\text { water years } \\
\text { 2001-05 } \\
\text { (period 2) }\end{array}$ & $\begin{array}{l}\text { Total percent } \\
\text { change for } \\
\text { water years } \\
\text { 2006-2010 } \\
\text { (period 3) }\end{array}$ & $\begin{array}{c}p \text {-value } \\
\text { for overall } \\
\text { trend } \\
\text { analysis }^{1}\end{array}$ & SEAS $_{\mathrm{c}}$ & ANN $_{c}$ & SEE & $\begin{array}{l}\text { Percent of values affected } \\
\text { by recensoring at study } \\
\text { reporting level used in the } \\
\text { application of the time- } \\
\text { series model }\end{array}$ \\
\hline \multicolumn{10}{|c|}{ Silver Bow Creek at Butte (site 2, fig. 1, table 1)-Continued } \\
\hline Manganese, filtered & 139 & $-56(<0.001)$ & $-7(0.234)$ & $-75(<0.001)$ & $<0.001$ & $1.32(<0.001)$ & $0.00(0.988)$ & 39.1 & 0 \\
\hline Manganese, unfiltered-recoverable & 139 & $-49(<0.001)$ & $-35(<0.001)$ & $-54(<0.001)$ & 0.003 & $1.24(<0.001)$ & $0.07(0.576)$ & 42.3 & 0 \\
\hline Zinc, filtered & 139 & $-69(<0.001)$ & $-73(<0.001)$ & $-59(<0.001)$ & $<0.001$ & $1.16(0.004)$ & $0.42(0.134)$ & 56.4 & 0 \\
\hline Zinc, unfiltered-recoverable & 139 & $-66(<0.001)$ & $-72(<0.001)$ & $-57(<0.001)$ & $<0.001$ & $1.40(<0.001)$ & $0.13(0.580)$ & 49.7 & 0 \\
\hline Arsenic, filtered & 139 & $4(0.525)$ & $-41(<0.001)$ & $7(0.420)$ & $<0.001$ & $0.21(0.150)$ & $-0.28(0.021)$ & 19.9 & 0 \\
\hline Arsenic, unfiltered-recoverable & 139 & $-26(<0.001)$ & $-44(<0.001)$ & $8(0.381)$ & $<0.001$ & $0.73(<0.001)$ & $-0.19(0.136)$ & 25.9 & 0 \\
\hline Suspended sediment & 138 & $-9(0.530)$ & $-46(<0.001)$ & $-2(0.939)$ & $<0.001$ & $1.19(0.001)$ & $0.00(0.990)$ & 68.5 & 0 \\
\hline \multicolumn{10}{|c|}{ Silver Bow Creek at Opportunity (site 3, fig. 1, table 1) } \\
\hline Specific conductance & 141 & $9(<0.001)$ & $1(0.187)$ & $-7(0.008)$ & $<0.001$ & $-0.31(<0.001)$ & $-0.25(<0.001)$ & 7.8 & 0 \\
\hline Cadmium, filtered & 139 & $-25(0.018)$ & $-36(<0.001)$ & $-45(<0.001)$ & $<0.001$ & $0.44(0.017)$ & $0.36(0.016)$ & 54.0 & 1 \\
\hline Cadmium, unfiltered-recoverable & 138 & $-6(0.581)$ & $-28(<0.001)$ & $-60(<0.001)$ & $<0.001$ & $0.51(<0.001)$ & $0.38(0.001)$ & 52.1 & 2 \\
\hline Copper, filtered & 139 & $-11(0.197)$ & $-33(<0.001)$ & $-40(<0.001)$ & $<0.001$ & $0.47(<0.001)$ & $0.22(0.034)$ & 34.6 & 0 \\
\hline Copper, unfiltered-recoverable & 141 & $-8(0.197)$ & $-23(<0.001)$ & $-53(<0.001)$ & $<0.001$ & $0.35(<0.001)$ & $0.40(<0.001)$ & 63.4 & 0 \\
\hline Iron, filtered & 139 & $-4\left(N^{3}\right)$ & $-8\left(\mathrm{NR}^{3}\right)$ & $19\left(\mathrm{NR}^{3}\right)$ & 0.267 & $0.88(<0.001)$ & $0.86(<0.001)$ & 54.0 & 2 \\
\hline Iron unfiltered-recoverable & 140 & $-4\left(\mathrm{NR}^{3}\right)$ & $6\left(\mathrm{NR}^{3}\right)$ & $-22\left(\mathrm{NR}^{3}\right)$ & 0.885 & $0.71(<0.001)$ & $0.73(<0.001)$ & 58.7 & 0 \\
\hline Lead, filtered & 137 & $\mathrm{NR}^{4}$ & $\mathrm{NR}^{4}$ & $\mathrm{NR}^{4}$ & $\mathrm{NR}^{4}$ & $\mathrm{NR}^{4}$ & $\mathrm{NR}^{4}$ & $\mathrm{NR}^{4}$ & 62 \\
\hline Lead, unfiltered-recoverable & 141 & $35(0.080)$ & $2(0.877)$ & $-65(<0.001)$ & $<0.001$ & $0.86(<0.001)$ & $0.81(<0.001)$ & 65.9 & 0 \\
\hline Manganese, filtered & 141 & $-20(<0.001)$ & $-36(<0.001)$ & $-49(<0.001)$ & $<0.001$ & $0.01(0.916)$ & $-0.19(0.051)$ & 55.2 & 0 \\
\hline Manganese, unfiltered-recoverable & 141 & $-10(0.276)$ & $-36(<0.001)$ & $-45(<0.001)$ & $<0.001$ & $0.14(0.303)$ & $0.00(0.977)$ & 48.4 & 0 \\
\hline Zinc, filtered & 140 & $-25(0.038)$ & $-39(<0.001)$ & $-60(<0.001)$ & $<0.001$ & $0.32(0.139)$ & $0.17(0.357)$ & 67.6 & 0 \\
\hline Zinc, unfiltered-recoverable & 141 & $-13(0.250)$ & $-42(<0.001)$ & $-52(<0.001)$ & $<0.001$ & $0.46(0.006)$ & $0.23(0.110)$ & 54.3 & 0 \\
\hline Arsenic, filtered & 141 & $19(0.005)$ & $14(0.005)$ & $-40(<0.001)$ & $<0.001$ & $-0.17(0.016)$ & $-0.16(0.014)$ & 28.2 & 0 \\
\hline Arsenic, unfiltered-recoverable & 141 & $7(0.121)$ & $6(0.036)$ & $-51(<0.001)$ & $<0.001$ & $0.02(0.730)$ & $0.15(0.008)$ & 45.1 & 0 \\
\hline Suspended sediment & 122 & $-26\left(\mathrm{NR}^{3}\right)$ & $20\left(\mathrm{NR}^{3}\right)$ & $-10\left(\mathrm{NR}^{3}\right)$ & 0.671 & $0.62(0.004)$ & $0.76(0.001)$ & 54.3 & 0 \\
\hline
\end{tabular}


Table 4-1. Flow-adjusted trend results determined by using the time-series model (TSM) for selected water-quality constituents and properties for selected sampling sites in the upper Clark Fork Basin, Montana, water years 1996-2010.-Continued

[Water year is the 12-month period from October 1 through September 30 and is designated by the year in which it ends. Values in parentheses indicate $p$-values for associated percent change or coefficient. Gray shading indicates statistical significance at $p$-value less than 0.01 . $p$-value, statistical probability level; $\mathrm{SEAS}_{\mathrm{C}}$, seasonal concentration anomaly coefficient; $\mathrm{ANN}_{\mathrm{C}}$, annual concentration anomaly coefficient; SEE, standard error of estimate in percent; NR, not reported; $<$, less than]

\begin{tabular}{|c|c|c|c|c|c|c|c|c|c|}
\hline Constituent or property & $\begin{array}{c}\text { Number } \\
\text { of } \\
\text { samples }\end{array}$ & $\begin{array}{l}\text { Total percent } \\
\text { change for } \\
\text { water years } \\
\text { 1996-2000 } \\
\text { (period 1) }\end{array}$ & $\begin{array}{l}\text { Total percent } \\
\text { change for } \\
\text { water years } \\
2001-05 \\
\text { (period 2) }\end{array}$ & $\begin{array}{l}\text { Total percent } \\
\text { change for } \\
\text { water years } \\
\text { 2006-2010 } \\
\text { (period 3) }\end{array}$ & $\begin{array}{c}p \text {-value } \\
\text { for overall } \\
\text { trend } \\
\text { analysis }\end{array}$ & SEAS $_{\mathrm{c}}$ & ANN $_{\mathrm{c}}$ & SEE & $\begin{array}{l}\text { Percent of values affected } \\
\text { by recensoring at study } \\
\text { reporting level used in the } \\
\text { application of the time- } \\
\text { series model }{ }^{2}\end{array}$ \\
\hline \multicolumn{10}{|c|}{ Silver Bow Creek at Warm Springs (site 8, fig. 1, table 1) } \\
\hline Specific conductance & 146 & $0(0.918)$ & $-4(0.063)$ & $5(0.114)$ & 0.002 & $-0.24(<0.001)$ & $-0.28(<0.001)$ & 10.4 & 0 \\
\hline Cadmium, filtered & 146 & $\mathrm{NR}^{4}$ & $\mathrm{NR}^{4}$ & $\mathrm{NR}^{4}$ & $\mathrm{NR}^{4}$ & $\mathrm{NR}^{4}$ & $\mathrm{NR}^{4}$ & $\mathrm{NR}^{4}$ & 68 \\
\hline Cadmium, unfiltered-recoverable & 146 & $\mathrm{NR}^{4}$ & $\mathrm{NR}^{4}$ & $\mathrm{NR}^{4}$ & $\mathrm{NR}^{4}$ & $\mathrm{NR}^{4}$ & $\mathrm{NR}^{4}$ & $\mathrm{NR}^{4}$ & 63 \\
\hline Copper, filtered & 146 & $-54(<0.001)$ & $-12(0.201)$ & $-5(0.683)$ & $<0.001$ & $0.31(0.020)$ & $0.24(0.034)$ & 31.9 & 0 \\
\hline Copper, unfiltered-recoverable & 146 & $-51(<0.001)$ & $-9(0.328)$ & $-13(0.234)$ & $<0.001$ & $0.49(<0.001)$ & $0.27(0.014)$ & 38.1 & 0 \\
\hline Iron, filtered & 146 & $\mathrm{NR}^{4}$ & $\mathrm{NR}^{4}$ & $\mathrm{NR}^{4}$ & $\mathrm{NR}^{4}$ & $\mathrm{NR}^{4}$ & $\mathrm{NR}^{4}$ & $\mathrm{NR}^{4}$ & 16 \\
\hline Iron unfiltered-recoverable & 146 & $-27(0.009)$ & $-10(0.336)$ & $-18(0.147)$ & $<0.001$ & $0.46(0.002)$ & $0.03(0.780)$ & 39.7 & 0 \\
\hline Lead, filtered & 145 & $\mathrm{NR}^{4}$ & $\mathrm{NR}^{4}$ & $\mathrm{NR}^{4}$ & $\mathrm{NR}^{4}$ & $\mathrm{NR}^{4}$ & $\mathrm{NR}^{4}$ & $\mathrm{NR}^{4}$ & 98 \\
\hline Lead, unfiltered-recoverable & 146 & $\mathrm{NR}^{4}$ & $\mathrm{NR}^{4}$ & $\mathrm{NR}^{4}$ & $\mathrm{NR}^{4}$ & $\mathrm{NR}^{4}$ & $\mathrm{NR}^{4}$ & $\mathrm{NR}^{4}$ & 20 \\
\hline Manganese, filtered & 146 & $-8\left(\mathrm{NR}^{3}\right)$ & $10\left(\mathrm{NR}^{3}\right)$ & $-38\left(\mathrm{NR}^{3}\right)$ & 1.000 & $0.38(0.099)$ & $0.10(0.647)$ & 60.7 & 0 \\
\hline Manganese, unfiltered-recoverable & 146 & $-16\left(\mathrm{NR}^{3}\right)$ & $2\left(\mathrm{NR}^{3}\right)$ & $-35\left(\mathrm{NR}^{3}\right)$ & 0.039 & $-0.01(0.955)$ & $-0.17(0.322)$ & 43.0 & 0 \\
\hline Zinc, filtered & 146 & $\mathrm{NR}^{4}$ & $\mathrm{NR}^{4}$ & $\mathrm{NR}^{4}$ & $\mathrm{NR}^{4}$ & $\mathrm{NR}^{4}$ & $\mathrm{NR}^{4}$ & $\mathrm{NR}^{4}$ & 58 \\
\hline Zinc, unfiltered-recoverable & 139 & $-64(<0.001)$ & $-47(<0.001)$ & $1(0.963)$ & $<0.001$ & $0.42(0.008)$ & $0.17(0.180)$ & 43.5 & 5 \\
\hline Arsenic, filtered & 146 & $11\left(\mathrm{NR}^{3}\right)$ & $0\left(\mathrm{NR}^{3}\right)$ & $4\left(\mathrm{NR}^{3}\right)$ & 0.562 & $0.26(0.001)$ & $0.00(0.996)$ & 25.9 & 0 \\
\hline Arsenic, unfiltered-recoverable & 146 & $12\left(\mathrm{NR}^{3}\right)$ & $-3\left(\mathrm{NR}^{3}\right)$ & $7\left(\mathrm{NR}^{3}\right)$ & 0.630 & $0.28(<0.001)$ & $0.01(0.930)$ & 26.3 & 0 \\
\hline Suspended sediment & 148 & $9(0.679)$ & $-30(0.026)$ & $-55(<0.001)$ & $<0.001$ & $0.29(0.147)$ & $0.16(0.403)$ & 64.7 & 0 \\
\hline \multicolumn{10}{|c|}{ Warm Springs Creek at Warm Springs (site 10, fig. 1, table 1) } \\
\hline Specific conductance & 108 & $-12(<0.001)$ & $0(0.853)$ & $-7(0.040)$ & $<0.001$ & $-0.26(<0.001)$ & $-0.17(<0.001)$ & 15.5 & 0 \\
\hline Cadmium, filtered & 108 & $\mathrm{NR}^{4}$ & $\mathrm{NR}^{4}$ & $\mathrm{NR}^{4}$ & $\mathrm{NR}^{4}$ & $\mathrm{NR}^{4}$ & $\mathrm{NR}^{4}$ & $\mathrm{NR}^{4}$ & 94 \\
\hline Cadmium, unfiltered-recoverable & 108 & $\mathrm{NR}^{4}$ & $\mathrm{NR}^{4}$ & $\mathrm{NR}^{4}$ & $\mathrm{NR}^{4}$ & $\mathrm{NR}^{4}$ & $\mathrm{NR}^{4}$ & $\mathrm{NR}^{4}$ & 88 \\
\hline Copper, filtered & 107 & $-2(0.837)$ & $-6(0.451)$ & $-34(<0.001)$ & $<0.001$ & $-0.15(0.029)$ & $-0.03(0.576)$ & 32.3 & 1 \\
\hline Copper, unfiltered-recoverable & 108 & $-26(<0.001)$ & $5(0.589)$ & $27(0.070)$ & $<0.001$ & $0.08(0.336)$ & $0.15(<0.001)$ & 60.9 & 0 \\
\hline Iron, filtered & 108 & $\mathrm{NR}^{4}$ & $\mathrm{NR}^{4}$ & $\mathrm{NR}^{4}$ & $\mathrm{NR}^{4}$ & $\mathrm{NR}^{4}$ & $\mathrm{NR}^{4}$ & $\mathrm{NR}^{4}$ & 11 \\
\hline Iron unfiltered-recoverable & 108 & $-32\left(\mathrm{NR}^{3}\right)$ & $11\left(\mathrm{NR}^{3}\right)$ & $58\left(\mathrm{NR}^{3}\right)$ & 0.044 & $0.34(<0.001)$ & $0.30(0.010)$ & 60.8 & 0 \\
\hline Lead, filtered & 108 & $\mathrm{NR}^{4}$ & $\mathrm{NR}^{4}$ & $\mathrm{NR}^{4}$ & $\mathrm{NR}^{4}$ & $\mathrm{NR}^{4}$ & $\mathrm{NR}^{4}$ & $\mathrm{NR}^{4}$ & 99 \\
\hline Lead, unfiltered-recoverable & 108 & $\mathrm{NR}^{4}$ & $\mathrm{NR}^{4}$ & $\mathrm{NR}^{4}$ & $\mathrm{NR}^{4}$ & $\mathrm{NR}^{4}$ & $\mathrm{NR}^{4}$ & $\mathrm{NR}^{4}$ & 47 \\
\hline
\end{tabular}


Table 4-1. Flow-adjusted trend results determined by using the time-series model (TSM) for selected water-quality constituents and properties for selected sampling sites in

the upper Clark Fork Basin, Montana, water years 1996-2010.-Continued

[Water year is the 12-month period from October 1 through September 30 and is designated by the year in which it ends. Values in parentheses indicate $p$-values for associated percent change or coefficient. Gray shading indicates statistical significance at $p$-value less than 0.01. $p$-value, statistical probability level; $\mathrm{SEAS}_{\mathrm{C}}$, seasonal concentration anomaly coefficient; $\mathrm{ANN}_{\mathrm{C}}$, annual concentration anomaly coefficient; SEE, standard error of estimate in percent; NR, not reported; $<$, less than]

\begin{tabular}{|c|c|c|c|c|c|c|c|c|c|}
\hline Constituent or property & $\begin{array}{c}\text { Number } \\
\text { of } \\
\text { samples }\end{array}$ & $\begin{array}{l}\text { Total percent } \\
\text { change for } \\
\text { water years } \\
\text { 1996-2000 } \\
\text { (period 1) }\end{array}$ & $\begin{array}{l}\text { Total percent } \\
\text { change for } \\
\text { water years } \\
2001-05 \\
\text { (period 2) }\end{array}$ & $\begin{array}{l}\text { Total percent } \\
\text { change for } \\
\text { water years } \\
2006-2010 \\
\text { (period 3) }\end{array}$ & $\begin{array}{c}p \text {-value } \\
\text { for overall } \\
\text { trend } \\
\text { analysis }\end{array}$ & SEAS $_{\mathrm{c}}$ & ANN $_{\mathrm{c}}$ & SEE & $\begin{array}{l}\text { Percent of values affected } \\
\text { by recensoring at study } \\
\text { reporting level used in the } \\
\text { application of the time- } \\
\text { series model }{ }^{2}\end{array}$ \\
\hline \multicolumn{10}{|c|}{ Warm Springs Creek at Warm Springs (site 10, fig. 1, table 1)—Continued } \\
\hline Manganese, filtered & 108 & $-40(<0.001)$ & $21(0.150)$ & $-52(<0.001)$ & $<0.001$ & $-0.30(0.047)$ & $-0.23(0.010)$ & 44.8 & 0 \\
\hline Manganese, unfiltered-recoverable & 108 & $-37\left(\mathrm{NR}^{3}\right)$ & $24\left(\mathrm{NR}^{3}\right)$ & $-34\left(\mathrm{NR}^{3}\right)$ & 0.081 & $-0.33(0.010)$ & $-0.29(0.001)$ & 46.9 & 0 \\
\hline Zinc, filtered & 108 & $\mathrm{NR}^{4}$ & $\mathrm{NR}^{4}$ & $\mathrm{NR}^{4}$ & $\mathrm{NR}^{4}$ & $\mathrm{NR}^{4}$ & $\mathrm{NR}^{4}$ & $\mathrm{NR}^{4}$ & 91 \\
\hline Zinc, unfiltered-recoverable & 108 & $\mathrm{NR}^{4}$ & $\mathrm{NR}^{4}$ & $\mathrm{NR}^{4}$ & $\mathrm{NR}^{4}$ & $\mathrm{NR}^{4}$ & $\mathrm{NR}^{4}$ & $\mathrm{NR}^{4}$ & 23 \\
\hline Arsenic, filtered & 108 & $13(<0.001)$ & $-1(0.685)$ & $-24(<0.001)$ & $<0.001$ & $-0.13(<0.001)$ & $-0.24(<0.001)$ & 24.4 & 0 \\
\hline Arsenic, unfiltered-recoverable & 108 & $-10\left(\mathrm{NR}^{3}\right)$ & $5\left(\mathrm{NR}^{3}\right)$ & $-12\left(\mathrm{NR}^{3}\right)$ & 0.353 & $-0.09(0.171)$ & $-0.17(<0.001)$ & 35.8 & 0 \\
\hline Suspended sediment & 109 & $-46(0.004)$ & $-33(0.051)$ & $144(<0.001)$ & $<0.001$ & $-0.19(0.226)$ & $0.26(0.072)$ & 68.3 & 0 \\
\hline \multicolumn{10}{|c|}{ Clark Fork near Galen (site 11, fig. 1, table 1) } \\
\hline Specific conductance & 147 & $-2\left(\mathrm{NR}^{3}\right)$ & $-2\left(\mathrm{NR}^{3}\right)$ & $-2\left(\mathrm{NR}^{3}\right)$ & 0.016 & $-0.23(<0.001)$ & $-0.27(<0.001)$ & 11.8 & 0 \\
\hline Cadmium, filtered & 145 & $\mathrm{NR}^{4}$ & $\mathrm{NR}^{4}$ & $\mathrm{NR}^{4}$ & $\mathrm{NR}^{4}$ & $\mathrm{NR}^{4}$ & $\mathrm{NR}^{4}$ & NR4 & 79 \\
\hline Cadmium, unfiltered-recoverable & 145 & $\mathrm{NR}^{4}$ & $\mathrm{NR}^{4}$ & $\mathrm{NR}^{4}$ & $\mathrm{NR}^{4}$ & $\mathrm{NR}^{4}$ & $\mathrm{NR}^{4}$ & NR4 & 65 \\
\hline Copper, filtered & 147 & $-49(<0.001)$ & $-6(0.409)$ & $-12(0.194)$ & $<0.001$ & $-0.17(0.015)$ & $-0.19(0.026)$ & 27.1 & 0 \\
\hline Copper, unfiltered-recoverable & 147 & $-38(<0.001)$ & $9(0.409)$ & $-10(0.437)$ & $<0.001$ & $0.12(0.211)$ & $0.13(0.226)$ & 46.5 & 0 \\
\hline Iron, filtered & 145 & $\mathrm{NR}^{4}$ & $\mathrm{NR}^{4}$ & $\mathrm{NR}^{4}$ & $\mathrm{NR}^{4}$ & $\mathrm{NR}^{4}$ & $\mathrm{NR}^{4}$ & $\mathrm{NR}^{4}$ & 15 \\
\hline Iron unfiltered-recoverable & 147 & $-36(<0.001)$ & $17(0.194)$ & $0(0.986)$ & 0.023 & $0.45(<0.001)$ & $0.32(0.003)$ & 44.9 & 0 \\
\hline Lead, filtered & 145 & $\mathrm{NR}^{4}$ & $\mathrm{NR}^{4}$ & $\mathrm{NR}^{4}$ & $\mathrm{NR}^{4}$ & $\mathrm{NR}^{4}$ & $\mathrm{NR}^{4}$ & $\mathrm{NR}^{4}$ & 95 \\
\hline Lead, unfiltered-recoverable & 145 & $\mathrm{NR}^{4}$ & $\mathrm{NR}^{4}$ & $\mathrm{NR}^{4}$ & $\mathrm{NR}^{4}$ & $\mathrm{NR}^{4}$ & $\mathrm{NR}^{4}$ & $\mathrm{NR}^{4}$ & 17 \\
\hline Manganese, filtered & 147 & $-16(0.114)$ & $20(0.114)$ & $-42(<0.001)$ & $<0.001$ & $-0.07(0.575)$ & $-0.09(0.391)$ & 34.3 & 0 \\
\hline Manganese, unfiltered-recoverable & 147 & $-23(0.007)$ & $7(0.491)$ & $-29(0.011)$ & $<0.001$ & $0.09(0.468)$ & $-0.24(0.008)$ & 33.7 & 0 \\
\hline Zinc, filtered & 145 & $\mathrm{NR}^{4}$ & $\mathrm{NR}^{4}$ & $\mathrm{NR}^{4}$ & $\mathrm{NR}^{4}$ & $\mathrm{NR}^{4}$ & $\mathrm{NR}^{4}$ & $\mathrm{NR}^{4}$ & 51 \\
\hline Zinc, unfiltered-recoverable & 140 & $-59(<0.001)$ & $-32(<0.001)$ & $9(0.576)$ & $<0.001$ & $0.32(0.029)$ & $0.23(0.043)$ & 42.4 & 6 \\
\hline Arsenic, filtered & 147 & $-4(0.667)$ & $9(0.276)$ & $-17(0.078)$ & 1.000 & $-0.13(0.091)$ & $0.17(0.032)$ & 25.6 & 0 \\
\hline Arsenic, unfiltered-recoverable & 147 & $-10(0.187)$ & $14(0.009)$ & $-25(<0.001)$ & $<0.001$ & $-0.07(0.180)$ & $0.10(0.174)$ & 26.4 & 0 \\
\hline Suspended sediment & 148 & $-3(0.859)$ & $-18(0.208)$ & $1(0.966)$ & 1.000 & $0.53(0.002)$ & $0.55(<0.001)$ & 57.5 & 0 \\
\hline
\end{tabular}


Table 4-1. Flow-adjusted trend results determined by using the time-series model (TSM) for selected water-quality constituents and properties for selected sampling sites in the upper Clark Fork Basin, Montana, water years 1996-2010.-Continued

[Water year is the 12-month period from October 1 through September 30 and is designated by the year in which it ends. Values in parentheses indicate $p$-values for associated percent change or coefficient. Gray shading indicates statistical significance at $p$-value less than 0.01 . $p$-value, statistical probability level; SEAS, seasonal concentration anomaly coefficient; ANN ${ }_{C}$, annual concentration anomaly coefficient; SEE, standard error of estimate in percent; NR, not reported; <, less than]

\begin{tabular}{|c|c|c|c|c|c|c|c|c|c|}
\hline Constituent or property & $\begin{array}{c}\text { Number } \\
\text { of } \\
\text { samples }\end{array}$ & $\begin{array}{l}\text { Total percent } \\
\text { change for } \\
\text { water years } \\
\text { 1996-2000 } \\
\text { (period 1) }\end{array}$ & $\begin{array}{l}\text { Total percent } \\
\text { change for } \\
\text { water years } \\
2001-05 \\
\text { (period 2) }\end{array}$ & $\begin{array}{l}\text { Total percent } \\
\text { change for } \\
\text { water years } \\
2006-2010 \\
\text { (period 3) }\end{array}$ & $\begin{array}{c}p \text {-value } \\
\text { for overall } \\
\text { trend } \\
\text { analysis' }\end{array}$ & SEAS $_{\mathrm{c}}$ & ANN $_{\mathrm{c}}$ & SEE & $\begin{array}{l}\text { Percent of values affected } \\
\text { by recensoring at study } \\
\text { reporting level used in the } \\
\text { application of the time- } \\
\text { series model }{ }^{2}\end{array}$ \\
\hline \multicolumn{10}{|c|}{ Clark Fork at Deer Lodge (site 14, fig. 1, table 1) } \\
\hline Specific conductance & 146 & $-2(0.355)$ & $-1(0.394)$ & $-7(0.002)$ & $<0.001$ & $-0.04(0.001)$ & $-0.20(<0.001)$ & 11.2 & 0 \\
\hline Cadmium, filtered & 146 & $\mathrm{NR}^{4}$ & $\mathrm{NR}^{4}$ & $\mathrm{NR}^{4}$ & $\mathrm{NR}^{4}$ & $\mathrm{NR}^{4}$ & $\mathrm{NR}^{4}$ & $\mathrm{NR}^{4}$ & 66 \\
\hline Cadmium, unfiltered-recoverable & 145 & $\mathrm{NR}^{4}$ & $\mathrm{NR}^{4}$ & $\mathrm{NR}^{4}$ & $\mathrm{NR}^{4}$ & $\mathrm{NR}^{4}$ & $\mathrm{NR}^{4}$ & $\mathrm{NR}^{4}$ & 51 \\
\hline Copper, filtered & 146 & $-18(0.002)$ & $3(0.691)$ & $-17(0.030)$ & 0.002 & $0.18(<0.001)$ & $0.16(0.023)$ & 22.0 & 0 \\
\hline Copper, unfiltered-recoverable & 145 & $-14\left(\mathrm{NR}^{3}\right)$ & $-2\left(\mathrm{NR}^{3}\right)$ & $2\left(\mathrm{NR}^{3}\right)$ & 0.753 & $0.23(0.034)$ & $0.28(0.030)$ & 45.0 & 0 \\
\hline Iron, filtered & 146 & $\mathrm{NR}^{4}$ & $\mathrm{NR}^{4}$ & $\mathrm{NR}^{4}$ & $\mathrm{NR}^{4}$ & $\mathrm{NR}^{4}$ & $\mathrm{NR}^{4}$ & $\mathrm{NR}^{4}$ & 25 \\
\hline Iron unfiltered-recoverable & 146 & $-25\left(\mathrm{NR}^{3}\right)$ & $9\left(\mathrm{NR}^{3}\right)$ & $18\left(\mathrm{NR}^{3}\right)$ & 0.059 & $0.30(0.042)$ & $0.43(0.002)$ & 51.8 & 0 \\
\hline Lead, filtered & 146 & $\mathrm{NR}^{4}$ & $\mathrm{NR}^{4}$ & $\mathrm{NR}^{4}$ & $\mathrm{NR}^{4}$ & $\mathrm{NR}^{4}$ & $\mathrm{NR}^{4}$ & $\mathrm{NR}^{4}$ & 91 \\
\hline Lead, unfiltered-recoverable & 143 & $-3\left(\mathrm{NR}^{3}\right)$ & $-11\left(\mathrm{NR}^{3}\right)$ & $33\left(\mathrm{NR}^{3}\right)$ & 0.666 & $0.26(0.101)$ & $0.35(0.039)$ & 59.5 & 6 \\
\hline Manganese, filtered & 146 & $-15\left(\mathrm{NR}^{3}\right)$ & $45\left(\mathrm{NR}^{3}\right)$ & $-31\left(\mathrm{NR}^{3}\right)$ & 0.013 & $-0.08(0.464)$ & $-0.08(0.443)$ & 42.8 & 1 \\
\hline Manganese, unfiltered-recoverable & 146 & $-29\left(\mathrm{NR}^{3}\right)$ & $13\left(\mathrm{NR}^{3}\right)$ & $-7\left(\mathrm{NR}^{3}\right)$ & 0.090 & $-0.16(0.258)$ & $-0.09(0.465)$ & 46.9 & 0 \\
\hline Zinc, filtered & 146 & $\mathrm{NR}^{4}$ & $\mathrm{NR}^{4}$ & $\mathrm{NR}^{4}$ & $\mathrm{NR}^{4}$ & $\mathrm{NR}^{4}$ & $\mathrm{NR}^{4}$ & $\mathrm{NR}^{4}$ & 25 \\
\hline Zinc, unfiltered-recoverable & 142 & $-36(<0.001)$ & $-8(0.490)$ & $-5(0.775)$ & $<0.001$ & $0.27(0.054)$ & $0.25(0.049)$ & 46.6 & 1 \\
\hline Arsenic, filtered & 146 & $-2(0.575)$ & $19(<0.001)$ & $-14(0.001)$ & 0.004 & $0.17(<0.001)$ & $0.21(<0.001)$ & 14.7 & 0 \\
\hline Arsenic, unfiltered-recoverable & 146 & $-3\left(\mathrm{NR}^{3}\right)$ & $5\left(\mathrm{NR}^{3}\right)$ & $-7\left(\mathrm{NR}^{3}\right)$ & 0.554 & $0.24(<0.001)$ & $0.24(<0.001)$ & 26.5 & 0 \\
\hline Suspended sediment & 147 & $-15(0.144)$ & $-11(0.380)$ & $3(0.870)$ & $<0.001$ & $-0.11(0.565)$ & $0.31(0.033)$ & 64.4 & 0 \\
\hline \multicolumn{10}{|c|}{ Little Blackfoot River (site 15, fig. 1, table 1) } \\
\hline Specific conductance & 65 & $3\left(\mathrm{NR}^{3}\right)$ & $1\left(\mathrm{NR}^{3}\right)$ & $\mathrm{NR}^{5}$ & 0.357 & $-0.10(<0.001)$ & $-0.06(<0.001)$ & 10.7 & 0 \\
\hline Cadmium, filtered & 64 & $\mathrm{NR}^{4}$ & $\mathrm{NR}^{4}$ & $\mathrm{NR}^{5}$ & $\mathrm{NR}^{4}$ & $\mathrm{NR}^{4}$ & $\mathrm{NR}^{4}$ & $\mathrm{NR}^{4}$ & 98 \\
\hline Cadmium, unfiltered-recoverable & 64 & $\mathrm{NR}^{4}$ & $\mathrm{NR}^{4}$ & $\mathrm{NR}^{5}$ & $\mathrm{NR}^{4}$ & $\mathrm{NR}^{4}$ & $\mathrm{NR}^{4}$ & $\mathrm{NR}^{4}$ & 94 \\
\hline Copper, filtered & 63 & $\mathrm{NR}^{4}$ & $\mathrm{NR}^{4}$ & $\mathrm{NR}^{5}$ & $\mathrm{NR}^{4}$ & $\mathrm{NR}^{4}$ & $\mathrm{NR}^{4}$ & $\mathrm{NR}^{4}$ & 27 \\
\hline Copper, unfiltered-recoverable & 65 & $-15\left(\mathrm{NR}^{3}\right)$ & $11\left(\mathrm{NR}^{3}\right)$ & $\mathrm{NR}^{5}$ & 0.705 & $-0.29(0.144)$ & $-0.09(0.643)$ & 47.4 & 10 \\
\hline Iron, filtered & 60 & $18\left(\mathrm{NR}^{3}\right)$ & $-49\left(\mathrm{NR}^{3}\right)$ & $\mathrm{NR}^{5}$ & 0.019 & $0.30(<0.001)$ & $0.50(<0.001)$ & 51.9 & 19 \\
\hline Iron unfiltered-recoverable & 65 & $-48(<0.001)$ & $33(0.027)$ & $\mathrm{NR}^{5}$ & $<0.001$ & $0.36(<0.001)$ & $-0.33(0.019)$ & 51.4 & 0 \\
\hline Lead, filtered & 65 & $\mathrm{NR}^{4}$ & $\mathrm{NR}^{4}$ & $\mathrm{NR}^{5}$ & $\mathrm{NR}^{4}$ & $\mathrm{NR}^{4}$ & $\mathrm{NR}^{4}$ & $\mathrm{NR}^{4}$ & 89 \\
\hline Lead, unfiltered-recoverable & 65 & $\mathrm{NR}^{4}$ & $\mathrm{NR}^{4}$ & $\mathrm{NR}^{5}$ & $\mathrm{NR}^{4}$ & $\mathrm{NR}^{4}$ & $\mathrm{NR}^{4}$ & $\mathrm{NR}^{4}$ & 61 \\
\hline
\end{tabular}


Table 4-1. Flow-adjusted trend results determined by using the time-series model (TSM) for selected water-quality constituents and properties for selected sampling sites in the upper Clark Fork Basin, Montana, water years 1996-2010.-Continued

[Water year is the 12-month period from October 1 through September 30 and is designated by the year in which it ends. Values in parentheses indicate $p$-values for associated percent change or coefficient. Gray shading indicates statistical significance at $p$-value less than $0.01 . p$-value, statistical probability level; $\mathrm{SEAS}_{\mathrm{C}}$, seasonal concentration anomaly coefficient; $\mathrm{ANN}_{\mathrm{C}}$, annual concentration anomaly coefficient; SEE, standard error of estimate in percent; NR, not reported; <, less than]

\begin{tabular}{|c|c|c|c|c|c|c|c|c|c|}
\hline Constituent or property & $\begin{array}{c}\text { Number } \\
\text { of } \\
\text { samples }\end{array}$ & $\begin{array}{l}\text { Total percent } \\
\text { change for } \\
\text { water years } \\
\text { 1996-2000 } \\
\text { (period 1) }\end{array}$ & $\begin{array}{l}\text { Total percent } \\
\text { change for } \\
\text { water years } \\
2001-05 \\
\text { (period 2) }\end{array}$ & $\begin{array}{l}\text { Total percent } \\
\text { change for } \\
\text { water years } \\
\text { 2006-2010 } \\
\text { (period 3) }\end{array}$ & $\begin{array}{l}p \text {-value } \\
\text { for overall } \\
\text { trend } \\
\text { analysis }\end{array}$ & SEAS $_{\mathrm{c}}$ & ANN $_{c}$ & SEE & $\begin{array}{l}\text { Percent of values affected } \\
\text { by recensoring at study } \\
\text { reporting level used in the } \\
\text { application of the time- } \\
\text { series model }{ }^{2}\end{array}$ \\
\hline \multicolumn{10}{|c|}{ Little Blackfoot River (site 15, fig. 1, table 1)—Continued } \\
\hline Manganese, filtered & 65 & $-12\left(\mathrm{NR}^{3}\right)$ & $-13\left(\mathrm{NR}^{3}\right)$ & $\mathrm{NR}^{5}$ & 1.000 & $-0.55(<0.001)$ & $-0.10(0.406)$ & 35.4 & 0 \\
\hline Manganese, unfiltered-recoverable & 62 & $-39(0.003)$ & $32(0.201)$ & $\mathrm{NR}^{5}$ & 0.002 & $0.03(0.860)$ & $-0.30(0.136)$ & 44.5 & 6 \\
\hline Zinc, filtered & 65 & $\mathrm{NR}^{4}$ & $\mathrm{NR}^{4}$ & $\mathrm{NR}^{5}$ & $\mathrm{NR}^{4}$ & $\mathrm{NR}^{4}$ & $\mathrm{NR}^{4}$ & $\mathrm{NR}^{4}$ & 88 \\
\hline Zinc, unfiltered-recoverable & 65 & $\mathrm{NR}^{4}$ & $\mathrm{NR}^{4}$ & $\mathrm{NR}^{5}$ & $\mathrm{NR}^{4}$ & $\mathrm{NR}^{4}$ & $\mathrm{NR}^{4}$ & $\mathrm{NR}^{4}$ & 56 \\
\hline Arsenic, filtered & 65 & $-4\left(\mathrm{NR}^{3}\right)$ & 12 (NR3) & $\mathrm{NR}^{5}$ & 0.077 & $0.00(0.976)$ & $0.03(0.501)$ & 12.8 & 0 \\
\hline Arsenic, unfiltered-recoverable & 65 & $-23(<0.001)$ & $-5(0.051)$ & NR5 & $<0.001$ & $0.15(<0.001)$ & $-0.21(<0.001)$ & 18.0 & 0 \\
\hline Suspended sediment & 66 & $-26(\mathrm{NR} 3)$ & $-25(\mathrm{NR} 3)$ & $\mathrm{NR}^{5}$ & 0.146 & $0.03(0.865)$ & $0.24(0.267)$ & 67.9 & 0 \\
\hline \multicolumn{10}{|c|}{ Clark Fork at Goldcreek (site 16, fig. 1, table 1) } \\
\hline Specific conductance & 146 & $0\left(\mathrm{NR}^{3}\right)$ & $-2\left(\mathrm{NR}^{3}\right)$ & $-5\left(\mathrm{NR}^{3}\right)$ & 0.197 & $-0.09(<0.001)$ & $-0.14(<0.001)$ & 10.0 & 0 \\
\hline Cadmium, filtered & 146 & $\mathrm{NR}^{4}$ & $\mathrm{NR}^{4}$ & $\mathrm{NR}^{4}$ & $\mathrm{NR}^{4}$ & $\mathrm{NR}^{4}$ & $\mathrm{NR}^{4}$ & $\mathrm{NR}^{4}$ & 85 \\
\hline Cadmium, unfiltered-recoverable & 146 & $\mathrm{NR}^{4}$ & $\mathrm{NR}^{4}$ & $\mathrm{NR}^{4}$ & $\mathrm{NR}^{4}$ & $\mathrm{NR}^{4}$ & $\mathrm{NR}^{4}$ & $\mathrm{NR}^{4}$ & 57 \\
\hline Copper, filtered & 145 & $-21\left(\mathrm{NR}^{3}\right)$ & $12\left(\mathrm{NR}^{3}\right)$ & $-6\left(\mathrm{NR}^{3}\right)$ & 0.019 & $0.01(0.856)$ & $0.35(<0.001)$ & 23.8 & 0 \\
\hline Copper, unfiltered-recoverable & 145 & $-14(0.168)$ & $-18(0.047)$ & $3(0.796)$ & 0.005 & $0.37(<0.001)$ & $0.62(<0.001)$ & 43.1 & 0 \\
\hline Iron, filtered & 145 & $\mathrm{NR}^{4}$ & $\mathrm{NR}^{4}$ & $\mathrm{NR}^{4}$ & $\mathrm{NR}^{4}$ & $\mathrm{NR}^{4}$ & $\mathrm{NR}^{4}$ & $\mathrm{NR}^{4}$ & 27 \\
\hline Iron unfiltered-recoverable & 146 & $-16(0.121)$ & $-28(0.005)$ & $45(0.028)$ & $<0.001$ & $0.49(0.001)$ & $0.68(<0.001)$ & 49.3 & 0 \\
\hline Lead, filtered & 146 & $\mathrm{NR}^{4}$ & $\mathrm{NR}^{4}$ & $\mathrm{NR}^{4}$ & $\mathrm{NR}^{4}$ & $\mathrm{NR}^{4}$ & $\mathrm{NR}^{4}$ & $\mathrm{NR}^{4}$ & 99 \\
\hline Lead, unfiltered-recoverable & 146 & $\mathrm{NR}^{4}$ & $\mathrm{NR}^{4}$ & $\mathrm{NR}^{4}$ & $\mathrm{NR}^{4}$ & $\mathrm{NR}^{4}$ & $\mathrm{NR}^{4}$ & $\mathrm{NR}^{4}$ & 11 \\
\hline Manganese, filtered & 146 & $-6\left(\mathrm{NR}^{3}\right)$ & $-8\left(\mathrm{NR}^{3}\right)$ & $3\left(\mathrm{NR}^{3}\right)$ & 0.341 & $0.05(0.648)$ & $-0.02(0.833)$ & 32.3 & 0 \\
\hline Manganese, unfiltered-recoverable & 146 & $-18(0.017)$ & $-20(0.016)$ & $22(0.139)$ & $<0.001$ & $0.06(0.631)$ & $0.13(0.208)$ & 38.8 & 0 \\
\hline Zinc, filtered & 146 & $\mathrm{NR}^{4}$ & $\mathrm{NR}^{4}$ & $\mathrm{NR}^{4}$ & $\mathrm{NR}^{4}$ & $\mathrm{NR}^{4}$ & $\mathrm{NR}^{4}$ & $\mathrm{NR}^{4}$ & 62 \\
\hline Zinc, unfiltered-recoverable & 144 & $-33(<0.001)$ & $-34(<0.001)$ & $36(0.046)$ & $<0.001$ & $0.34(0.010)$ & $0.46(<0.001)$ & 42.7 & 1 \\
\hline Arsenic, filtered & 146 & $-9\left(\mathrm{NR}^{3}\right)$ & $10\left(\mathrm{NR}^{3}\right)$ & $-2\left(\mathrm{NR}^{3}\right)$ & 0.811 & $-0.06(0.089)$ & $0.15(0.001)$ & 15.7 & 0 \\
\hline Arsenic, unfiltered-recoverable & 146 & $-13(0.003)$ & $6(0.056)$ & $5(0.162)$ & 0.003 & $0.06(0.066)$ & $0.23(<0.001)$ & 23.1 & 0 \\
\hline Suspended sediment & 147 & $18(0.263)$ & $-53(<0.001)$ & $69(0.011)$ & $<0.001$ & $0.48(0.006)$ & $0.50(0.003)$ & 58.9 & 0 \\
\hline
\end{tabular}


Table 4-1. Flow-adjusted trend results determined by using the time-series model (TSM) for selected water-quality constituents and properties for selected sampling sites in the upper Clark Fork Basin, Montana, water years 1996-2010.-Continued

[Water year is the 12-month period from October 1 through September 30 and is designated by the year in which it ends. Values in parentheses indicate $p$-values for associated percent change or coefficient. Gray shading indicates statistical significance at $p$-value less than 0.01 . $p$-value, statistical probability level; $\mathrm{SEAS}_{\mathrm{C}}$, seasonal concentration anomaly coefficient; $\mathrm{ANN}_{\mathrm{C}}$, annual concentration anomaly coefficient; SEE, standard error of estimate in percent; NR, not reported; <, less than]

\begin{tabular}{|c|c|c|c|c|c|c|c|c|c|}
\hline Constituent or property & $\begin{array}{c}\text { Number } \\
\text { of } \\
\text { samples }\end{array}$ & $\begin{array}{l}\text { Total percent } \\
\text { change for } \\
\text { water years } \\
\text { 1996-2000 } \\
\text { (period 1) }\end{array}$ & $\begin{array}{l}\text { Total percent } \\
\text { change for } \\
\text { water years } \\
2001-05 \\
\text { (period 2) }\end{array}$ & $\begin{array}{l}\text { Total percent } \\
\text { change for } \\
\text { water years } \\
\text { 2006-2010 } \\
\text { (period 3) }\end{array}$ & $\begin{array}{l}p \text {-value } \\
\text { for overall } \\
\text { trend } \\
\text { analysis }{ }^{1}\end{array}$ & SEAS $_{\mathrm{c}}$ & ANN $_{c}$ & SEE & $\begin{array}{l}\text { Percent of values affected } \\
\text { by recensoring at study } \\
\text { reporting level used in the } \\
\text { application of the time- } \\
\text { series model }{ }^{2}\end{array}$ \\
\hline \multicolumn{10}{|c|}{ Flint Creek (site 17, fig. 1, table 1) } \\
\hline Specific conductance & 89 & $7\left(\mathrm{NR}^{3}\right)$ & $10\left(\mathrm{NR}^{3}\right)$ & $\mathrm{NR}^{5}$ & 0.024 & $-0.12(<0.001)$ & $-0.12(<0.001)$ & 15.2 & 0 \\
\hline Cadmium, filtered & 85 & $\mathrm{NR}^{4}$ & $\mathrm{NR}^{4}$ & $\mathrm{NR}^{5}$ & $\mathrm{NR}^{4}$ & $\mathrm{NR}^{4}$ & $\mathrm{NR}^{4}$ & $\mathrm{NR}^{4}$ & 98 \\
\hline Cadmium, unfiltered-recoverable & 85 & $\mathrm{NR}^{4}$ & $\mathrm{NR}^{4}$ & $\mathrm{NR}^{5}$ & $\mathrm{NR}^{4}$ & $\mathrm{NR}^{4}$ & $\mathrm{NR}^{4}$ & $\mathrm{NR}^{4}$ & 91 \\
\hline Copper, filtered & 88 & $\mathrm{NR}^{4}$ & $\mathrm{NR}^{4}$ & $\mathrm{NR}^{5}$ & $\mathrm{NR}^{4}$ & $\mathrm{NR}^{4}$ & $\mathrm{NR}^{4}$ & $\mathrm{NR}^{4}$ & 20 \\
\hline Copper, unfiltered-recoverable & 89 & $-21\left(\mathrm{NR}^{3}\right)$ & $-16\left(\mathrm{NR}^{3}\right)$ & $\mathrm{NR}^{5}$ & 0.055 & $0.32(<0.001)$ & $0.23(0.011)$ & 37.9 & 1 \\
\hline Iron, filtered & 84 & $-2\left(\mathrm{NR}^{3}\right)$ & $0\left(\mathrm{NR}^{3}\right)$ & $\mathrm{NR}^{5}$ & 1.000 & $0.37(<0.001)$ & $0.35(<0.001)$ & 47.8 & 6 \\
\hline Iron unfiltered-recoverable & 89 & $-41\left(\mathrm{NR}^{3}\right)$ & $38\left(\mathrm{NR}^{3}\right)$ & $\mathrm{NR}^{5}$ & 1.000 & $0.65(<0.001)$ & $0.36(<0.001)$ & 37.0 & 0 \\
\hline Lead, filtered & 85 & $\mathrm{NR}^{4}$ & $\mathrm{NR}^{4}$ & $\mathrm{NR}^{5}$ & $\mathrm{NR}^{4}$ & $\mathrm{NR}^{4}$ & $\mathrm{NR}^{4}$ & $\mathrm{NR}^{4}$ & 73 \\
\hline Lead, unfiltered-recoverable & 84 & $-31(0.002)$ & $-9(0.481)$ & $\mathrm{NR}^{5}$ & $<0.001$ & $0.88(<0.001)$ & $0.52(<0.001)$ & 52.6 & 8 \\
\hline Manganese, filtered & 89 & $-4\left(\mathrm{NR}^{3}\right)$ & $32\left(\mathrm{NR}^{3}\right)$ & $\mathrm{NR}^{5}$ & 0.072 & $0.00(0.974)$ & $-0.45(<0.001)$ & 33.0 & 0 \\
\hline Manganese, unfiltered-recoverable & 89 & $-23(0.003)$ & $0(0.977)$ & $\mathrm{NR}^{5}$ & 0.003 & $0.09(0.095)$ & $-0.14(0.002)$ & 39.6 & 0 \\
\hline Zinc, filtered & 85 & $\mathrm{NR}^{4}$ & $\mathrm{NR}^{4}$ & $\mathrm{NR}^{5}$ & $\mathrm{NR}^{4}$ & $\mathrm{NR}^{4}$ & $\mathrm{NR}^{4}$ & $\mathrm{NR}^{4}$ & 70 \\
\hline Zinc, unfiltered-recoverable & 81 & $-33(0.017)$ & $-38(0.047)$ & $\mathrm{NR}^{5}$ & $<0.001$ & $0.60(<0.001)$ & $0.30(0.016)$ & 44.7 & 9 \\
\hline Arsenic, filtered & 89 & $-7\left(\mathrm{NR}^{3}\right)$ & $-4\left(\mathrm{NR}^{3}\right)$ & $\mathrm{NR}^{5}$ & 0.106 & $-0.08(0.009)$ & $-0.15(<0.001)$ & 20.1 & 0 \\
\hline Arsenic, unfiltered-recoverable & 89 & $-19(0.005)$ & $-3(0.687)$ & $\mathrm{NR}^{5}$ & 0.040 & $0.12(0.017)$ & $-0.05(0.327)$ & 29.6 & 0 \\
\hline Suspended sediment & 90 & $-9\left(\mathrm{NR}^{3}\right)$ & $-43\left(\mathrm{NR}^{3}\right)$ & $\mathrm{NR}^{5}$ & 1.000 & $0.62(<0.001)$ & $0.43(0.002)$ & 59.7 & 0 \\
\hline \multicolumn{10}{|c|}{ Clark Fork near Drummond (site 18, fig. 1, table 1) } \\
\hline Specific conductance & 146 & $-3(0.103)$ & $-3(0.026)$ & $-3(0.084)$ & 0.009 & $-0.19(<0.001)$ & $-0.22(<0.001)$ & 9.5 & 0 \\
\hline Cadmium, filtered & 146 & $\mathrm{NR}^{4}$ & $\mathrm{NR}^{4}$ & $\mathrm{NR}^{4}$ & $\mathrm{NR}^{4}$ & $\mathrm{NR}^{4}$ & $\mathrm{NR}^{4}$ & $\mathrm{NR}^{4}$ & 79 \\
\hline Cadmium, unfiltered-recoverable & 146 & $\mathrm{NR}^{4}$ & $\mathrm{NR}^{4}$ & $\mathrm{NR}^{4}$ & $\mathrm{NR}^{4}$ & $\mathrm{NR}^{4}$ & $\mathrm{NR}^{4}$ & $\mathrm{NR}^{4}$ & 55 \\
\hline Copper, filtered & 143 & $2(0.547)$ & $15(<0.001)$ & $-23(<0.001)$ & 0.002 & $0.15(0.029)$ & $0.68(<0.001)$ & 36.2 & 0 \\
\hline Copper, unfiltered-recoverable & 144 & $-23(0.014)$ & $-15(0.107)$ & $5(0.755)$ & $<0.001$ & $0.68(<0.001)$ & $0.47(<0.001)$ & 52.9 & 0 \\
\hline Iron, filtered & 143 & $\mathrm{NR}^{4}$ & $\mathrm{NR}^{4}$ & $\mathrm{NR}^{4}$ & $\mathrm{NR}^{4}$ & $\mathrm{NR}^{4}$ & $\mathrm{NR}^{4}$ & $\mathrm{NR}^{4}$ & 36 \\
\hline Iron unfiltered-recoverable & 145 & $-61(<0.001)$ & $7(0.194)$ & $44(0.013)$ & $<0.001$ & $0.95(<0.001)$ & $0.33(<0.001)$ & 65.5 & 0 \\
\hline Lead, filtered & 146 & $\mathrm{NR}^{4}$ & $\mathrm{NR}^{4}$ & $\mathrm{NR}^{4}$ & $\mathrm{NR}^{4}$ & $\mathrm{NR}^{4}$ & $\mathrm{NR}^{4}$ & $\mathrm{NR}^{4}$ & 95 \\
\hline Lead, unfiltered-recoverable & 145 & $\mathrm{NR}^{4}$ & $\mathrm{NR}^{4}$ & $\mathrm{NR}^{4}$ & $\mathrm{NR}^{4}$ & $\mathrm{NR}^{4}$ & $\mathrm{NR}^{4}$ & $\mathrm{NR}^{4}$ & 12 \\
\hline
\end{tabular}


Table 4-1. Flow-adjusted trend results determined by using the time-series model (TSM) for selected water-quality constituents and properties for selected sampling sites in

the upper Clark Fork Basin, Montana, water years 1996-2010.-Continued

[Water year is the 12-month period from October 1 through September 30 and is designated by the year in which it ends. Values in parentheses indicate $p$-values for associated percent change or coefficient. Gray shading indicates statistical significance at $p$-value less than 0.01 . $p$-value, statistical probability level; $\mathrm{SEAS}_{\mathrm{C}}$, seasonal concentration anomaly coefficient; $\mathrm{ANN}_{\mathrm{C}}$, annual concentration anomaly coefficient; SEE, standard error of estimate in percent; NR, not reported; <, less than]

\begin{tabular}{|c|c|c|c|c|c|c|c|c|c|}
\hline Constituent or property & $\begin{array}{c}\text { Number } \\
\text { of } \\
\text { samples }\end{array}$ & $\begin{array}{l}\text { Total percent } \\
\text { change for } \\
\text { water years } \\
\text { 1996-2000 } \\
\text { (period 1) }\end{array}$ & $\begin{array}{l}\text { Total percent } \\
\text { change for } \\
\text { water years } \\
\text { 2001-05 } \\
\text { (period 2) }\end{array}$ & $\begin{array}{l}\text { Total percent } \\
\text { change for } \\
\text { water years } \\
2006-2010 \\
\text { (period 3) }\end{array}$ & $\begin{array}{c}p \text {-value } \\
\text { for overall } \\
\text { trend } \\
\text { analysis }\end{array}$ & SEAS $_{\mathrm{c}}$ & ANN $_{\mathrm{c}}$ & SEE & $\begin{array}{l}\text { Percent of values affected } \\
\text { by recensoring at study } \\
\text { reporting level used in the } \\
\text { application of the time- } \\
\text { series model }{ }^{2}\end{array}$ \\
\hline \multicolumn{10}{|c|}{ Clark Fork near Drummond (site 18, fig. 1, table 1) —Continued } \\
\hline Manganese, filtered & 145 & $-8\left(\mathrm{NR}^{3}\right)$ & $1\left(\mathrm{NR}^{3}\right)$ & $-3\left(\mathrm{NR}^{3}\right)$ & 0.736 & $0.38(<0.001)$ & $0.15(0.162)$ & 34.6 & 0 \\
\hline Manganese, unfiltered-recoverable & 146 & $-35(<0.001)$ & $1(0.901)$ & $17(0.353)$ & 0.005 & $0.54(<0.001)$ & $0.32(0.038)$ & 46.6 & 0 \\
\hline Zinc, filtered & 145 & $\mathrm{NR}^{4}$ & $\mathrm{NR}^{4}$ & $\mathrm{NR}^{4}$ & $\mathrm{NR}^{4}$ & $\mathrm{NR}^{4}$ & $\mathrm{NR}^{4}$ & $\mathrm{NR}^{4}$ & 58 \\
\hline Zinc, unfiltered-recoverable & 143 & $-55(<0.001)$ & $-16(<0.001)$ & $10(0.448)$ & $<0.001$ & $0.78(<0.001)$ & $0.30(<0.001)$ & 56.2 & 2 \\
\hline Arsenic, filtered & 146 & $-8\left(\mathrm{NR}^{3}\right)$ & $8\left(\mathrm{NR}^{3}\right)$ & $-10\left(\mathrm{NR}^{3}\right)$ & 0.030 & $0.11(<0.001)$ & $0.06(0.153)$ & 15.8 & 0 \\
\hline Arsenic, unfiltered-recoverable & 146 & $-15\left(\mathrm{NR}^{3}\right)$ & $1\left(\mathrm{NR}^{3}\right)$ & $1\left(\mathrm{NR}^{3}\right)$ & 0.163 & $0.21(<0.001)$ & $0.10(0.121)$ & 24.7 & 0 \\
\hline Suspended sediment & 147 & $-39(<0.001)$ & $-11(0.084)$ & $8(0.686)$ & $<0.001$ & $0.40(0.009)$ & $0.52(<0.001)$ & 65.0 & 0 \\
\hline \multicolumn{10}{|c|}{ Rock Creek (site 19, fig. 1, table 1) } \\
\hline Specific conductance & 65 & $2\left(\mathrm{NR}^{3}\right)$ & $-8\left(\mathrm{NR}^{3}\right)$ & $\mathrm{NR}^{5}$ & 1.000 & $-0.27(<0.001)$ & $-0.23(<0.001)$ & 9.7 & 0 \\
\hline Cadmium, filtered & 64 & $\mathrm{NR}^{4}$ & $\mathrm{NR}^{4}$ & $\mathrm{NR}^{5}$ & $\mathrm{NR}^{4}$ & $\mathrm{NR}^{4}$ & $\mathrm{NR}^{4}$ & $\mathrm{NR}^{4}$ & 98 \\
\hline Cadmium, unfiltered-recoverable & 63 & $\mathrm{NR}^{4}$ & $\mathrm{NR}^{4}$ & $\mathrm{NR}^{5}$ & $\mathrm{NR}^{4}$ & $\mathrm{NR}^{4}$ & $\mathrm{NR}^{4}$ & $\mathrm{NR}^{4}$ & 95 \\
\hline Copper, filtered & 64 & $\mathrm{NR}^{4}$ & $\mathrm{NR}^{4}$ & $\mathrm{NR}^{5}$ & $\mathrm{NR}^{4}$ & $\mathrm{NR}^{4}$ & $\mathrm{NR}^{4}$ & $\mathrm{NR}^{4}$ & 65 \\
\hline Copper, unfiltered-recoverable & 64 & $\mathrm{NR}^{4}$ & $\mathrm{NR}^{4}$ & $\mathrm{NR}^{5}$ & $\mathrm{NR}^{4}$ & $\mathrm{NR}^{4}$ & $\mathrm{NR}^{4}$ & $\mathrm{NR}^{4}$ & 40 \\
\hline Iron, filtered & 64 & $-15\left(\mathrm{NR}^{3}\right)$ & $-29\left(\mathrm{NR}^{3}\right)$ & $\mathrm{NR}^{5}$ & 0.013 & $0.77(0.001)$ & $0.69(<0.001)$ & 29.9 & 4 \\
\hline Iron unfiltered-recoverable & 64 & $-26(<0.001)$ & $-27(0.044)$ & $\mathrm{NR}^{5}$ & $<0.001$ & $1.20(<0.001)$ & $0.60(<0.001)$ & 30.1 & 0 \\
\hline Lead, filtered & 64 & $\mathrm{NR}^{4}$ & $\mathrm{NR}^{4}$ & $\mathrm{NR}^{5}$ & $\mathrm{NR}^{4}$ & $\mathrm{NR}^{4}$ & $\mathrm{NR}^{4}$ & $\mathrm{NR}^{4}$ & 89 \\
\hline Lead, unfiltered-recoverable & 64 & $\mathrm{NR}^{4}$ & $\mathrm{NR}^{4}$ & $\mathrm{NR}^{5}$ & $\mathrm{NR}^{4}$ & $\mathrm{NR}^{4}$ & $\mathrm{NR}^{4}$ & $\mathrm{NR}^{4}$ & 69 \\
\hline Manganese, filtered & 63 & $\mathrm{NR}^{4}$ & $\mathrm{NR}^{4}$ & $\mathrm{NR}^{5}$ & $\mathrm{NR}^{4}$ & $\mathrm{NR}^{4}$ & $\mathrm{NR}^{4}$ & $\mathrm{NR}^{4}$ & 28 \\
\hline Manganese, unfiltered-recoverable & 63 & $\mathrm{NR}^{4}$ & $\mathrm{NR}^{4}$ & $\mathrm{NR}^{5}$ & $\mathrm{NR}^{4}$ & $\mathrm{NR}^{4}$ & $\mathrm{NR}^{4}$ & $\mathrm{NR}^{4}$ & 30 \\
\hline Zinc, filtered & 64 & $\mathrm{NR}^{4}$ & $\mathrm{NR}^{4}$ & $\mathrm{NR}^{5}$ & $\mathrm{NR}^{4}$ & $\mathrm{NR}^{4}$ & $\mathrm{NR}^{4}$ & $\mathrm{NR}^{4}$ & 90 \\
\hline Zinc, unfiltered-recoverable & 64 & $\mathrm{NR}^{4}$ & $\mathrm{NR}^{4}$ & $\mathrm{NR}^{5}$ & $\mathrm{NR}^{4}$ & $\mathrm{NR}^{4}$ & $\mathrm{NR}^{4}$ & $\mathrm{NR}^{4}$ & 77 \\
\hline Arsenic, filtered & 64 & $\mathrm{NR}^{4}$ & $\mathrm{NR}^{4}$ & $\mathrm{NR}^{5}$ & $\mathrm{NR}^{4}$ & $\mathrm{NR}^{4}$ & $\mathrm{NR}^{4}$ & $\mathrm{NR}^{4}$ & 92 \\
\hline Arsenic, unfiltered-recoverable & 64 & $\mathrm{NR}^{4}$ & $\mathrm{NR}^{4}$ & $\mathrm{NR}^{5}$ & $\mathrm{NR}^{4}$ & $\mathrm{NR}^{4}$ & $\mathrm{NR}^{4}$ & $\mathrm{NR}^{4}$ & 68 \\
\hline Suspended sediment & 66 & $52(<0.001)$ & $-56(<0.001)$ & $\mathrm{NR}^{5}$ & $<0.001$ & $3.04(<0.001)$ & $0.86(<0.001)$ & 54.5 & 0 \\
\hline
\end{tabular}


Table 4-1. Flow-adjusted trend results determined by using the time-series model (TSM) for selected water-quality constituents and properties for selected sampling sites in the upper Clark Fork Basin, Montana, water years 1996-2010.-Continued

[Water year is the 12-month period from October 1 through September 30 and is designated by the year in which it ends. Values in parentheses indicate $p$-values for associated percent change or coefficient. Gray shading indicates statistical significance at $p$-value less than 0.01 . $p$-value, statistical probability level; $\mathrm{SEAS}_{\mathrm{C}}$, seasonal concentration anomaly coefficient; $\mathrm{ANN}_{\mathrm{C}}$, annual concentration anomaly coefficient; SEE, standard error of estimate in percent; NR, not reported; <, less than]

\begin{tabular}{|c|c|c|c|c|c|c|c|c|c|}
\hline Constituent or property & $\begin{array}{c}\text { Number } \\
\text { of } \\
\text { samples }\end{array}$ & $\begin{array}{l}\text { Total percent } \\
\text { change for } \\
\text { water years } \\
\text { 1996-2000 } \\
\text { (period 1) }\end{array}$ & $\begin{array}{l}\text { Total percent } \\
\text { change for } \\
\text { water years } \\
2001-05 \\
\text { (period 2) }\end{array}$ & $\begin{array}{l}\text { Total percent } \\
\text { change for } \\
\text { water years } \\
2006-2010 \\
\text { (period 3) }\end{array}$ & $\begin{array}{c}p \text {-value } \\
\text { for overall } \\
\text { trend } \\
\text { analysis }{ }^{1}\end{array}$ & SEAS $_{c}$ & ANN $_{c}$ & SEE & $\begin{array}{l}\text { Percent of values affected } \\
\text { by recensoring at study } \\
\text { reporting level used in the } \\
\text { application of the time- } \\
\text { series model }{ }^{2}\end{array}$ \\
\hline \multicolumn{10}{|c|}{ Clark Fork at Turah Bridge (site 20 , fig. 1, table 1 ) } \\
\hline Specific conductance & 193 & $-5\left(\mathrm{NR}^{3}\right)$ & $-1\left(\mathrm{NR}^{3}\right)$ & $0\left(\mathrm{NR}^{3}\right)$ & 0.016 & $-0.12(<0.001)$ & $-0.20(<0.001)$ & 12.8 & 0 \\
\hline Cadmium, filtered & 170 & $\mathrm{NR}^{4}$ & $\mathrm{NR}^{4}$ & $\mathrm{NR}^{4}$ & $\mathrm{NR}^{4}$ & $\mathrm{NR}^{4}$ & $\mathrm{NR}^{4}$ & $\mathrm{NR}^{4}$ & 95 \\
\hline Cadmium, unfiltered-recoverable & 170 & $\mathrm{NR}^{4}$ & $\mathrm{NR}^{4}$ & $\mathrm{NR}^{4}$ & $\mathrm{NR}^{4}$ & $\mathrm{NR}^{4}$ & $\mathrm{NR}^{4}$ & $\mathrm{NR}^{4}$ & 68 \\
\hline Copper, filtered & 169 & $-20(N R 3)$ & 8 (NR3) & $-12(\mathrm{NR} 3)$ & 0.012 & $0.57(<0.001)$ & $0.51(<0.001)$ & 30.0 & 0 \\
\hline Copper, unfiltered-recoverable & 168 & $-6(N R 3)$ & $-16(\mathrm{NR} 3)$ & 27 (NR3) & 0.110 & $0.65(<0.001)$ & $0.58(<0.001)$ & 47.2 & 0 \\
\hline Iron, filtered & 150 & $\mathrm{NR}^{4}$ & $\mathrm{NR}^{4}$ & $\mathrm{NR}^{4}$ & $\mathrm{NR}^{4}$ & $\mathrm{NR}^{4}$ & $\mathrm{NR}^{4}$ & $\mathrm{NR}^{4}$ & 31 \\
\hline Iron unfiltered-recoverable & 170 & $-28(<0.001)$ & $-15(0.222)$ & $58(0.082)$ & $<0.001$ & $0.84(<0.001)$ & $0.44(<0.001)$ & 57.1 & 0 \\
\hline Lead, filtered & 170 & $\mathrm{NR}^{4}$ & $\mathrm{NR}^{4}$ & $\mathrm{NR}^{4}$ & $\mathrm{NR}^{4}$ & $\mathrm{NR}^{4}$ & $\mathrm{NR}^{4}$ & $\mathrm{NR}^{4}$ & 92 \\
\hline Lead, unfiltered-recoverable & 170 & $\mathrm{NR}^{4}$ & $\mathrm{NR}^{4}$ & $\mathrm{NR}^{4}$ & $\mathrm{NR}^{4}$ & $\mathrm{NR}^{4}$ & $\mathrm{NR}^{4}$ & $\mathrm{NR}^{4}$ & 18 \\
\hline Manganese, filtered & 170 & $1\left(\mathrm{NR}^{3}\right)$ & $-10\left(\mathrm{NR}^{3}\right)$ & $18\left(\mathrm{NR}^{3}\right)$ & 1.000 & $0.41(<0.001)$ & $0.27(<0.001)$ & 29.0 & 1 \\
\hline Manganese, unfiltered-recoverable & 170 & $-20(0.131)$ & $-16(0.147)$ & $45(0.025)$ & $<0.001$ & $0.67(<0.001)$ & $0.19(0.035)$ & 51.2 & 0 \\
\hline Zinc, filtered & 170 & $\mathrm{NR}^{4}$ & $\mathrm{NR}^{4}$ & $\mathrm{NR}^{4}$ & $\mathrm{NR}^{4}$ & $\mathrm{NR}^{4}$ & $\mathrm{NR}^{4}$ & $\mathrm{NR}^{4}$ & 56 \\
\hline Zinc, unfiltered-recoverable & 161 & $-33(0.317)$ & $-39(0.001)$ & $82(0.007)$ & $<0.001$ & $0.49(0.001)$ & $-0.10(0.483)$ & 56.3 & 5 \\
\hline Arsenic, filtered & 170 & $-4\left(\mathrm{NR}^{3}\right)$ & $7\left(\mathrm{NR}^{3}\right)$ & $2\left(\mathrm{NR}^{3}\right)$ & 0.022 & $0.23(<0.001)$ & $0.28(<0.001)$ & 19.7 & 0 \\
\hline Arsenic, unfiltered-recoverable & 170 & $-7\left(\mathrm{NR}^{3}\right)$ & $-6\left(\mathrm{NR}^{3}\right)$ & $21\left(\mathrm{NR}^{3}\right)$ & 0.173 & $0.35(<0.001)$ & $0.21(<0.001)$ & 31.2 & 0 \\
\hline Suspended sediment & 209 & $-7(0.895)$ & $-32(0.197)$ & $60(0.531)$ & 0.002 & $0.65(<0.001)$ & $0.18(<0.001)$ & 58.1 & 0 \\
\hline \multicolumn{10}{|c|}{ Blackfoot River (site 21, fig. 1, table 1) } \\
\hline Specific conductance & 102 & $0(0.796)$ & $-4(<0.001)$ & $6(<0.001)$ & $<0.001$ & $-0.14(<0.001)$ & $-0.05(0.009)$ & 6.1 & 0 \\
\hline Cadmium, filtered & 101 & $\mathrm{NR}^{4}$ & $\mathrm{NR}^{4}$ & $\mathrm{NR}^{4}$ & $\mathrm{NR}^{4}$ & $\mathrm{NR}^{4}$ & $\mathrm{NR}^{4}$ & $\mathrm{NR}^{4}$ & 99 \\
\hline Cadmium, unfiltered-recoverable & 100 & $\mathrm{NR}^{4}$ & $\mathrm{NR}^{4}$ & $\mathrm{NR}^{4}$ & $\mathrm{NR}^{4}$ & $\mathrm{NR}^{4}$ & $\mathrm{NR}^{4}$ & $\mathrm{NR}^{4}$ & 93 \\
\hline Copper, filtered & 102 & $\mathrm{NR}^{4}$ & $\mathrm{NR}^{4}$ & $\mathrm{NR}^{4}$ & $\mathrm{NR}^{4}$ & $\mathrm{NR}^{4}$ & $\mathrm{NR}^{4}$ & $\mathrm{NR}^{4}$ & 55 \\
\hline Copper, unfiltered-recoverable & 102 & $\mathrm{NR}^{4}$ & $\mathrm{NR}^{4}$ & $\mathrm{NR}^{4}$ & $\mathrm{NR}^{4}$ & $\mathrm{NR}^{4}$ & $\mathrm{NR}^{4}$ & $\mathrm{NR}^{4}$ & 25 \\
\hline Iron, filtered & 102 & $\mathrm{NR}^{4}$ & $\mathrm{NR}^{4}$ & $\mathrm{NR}^{4}$ & $\mathrm{NR}^{4}$ & $\mathrm{NR}^{4}$ & $\mathrm{NR}^{4}$ & $\mathrm{NR}^{4}$ & 32 \\
\hline Iron unfiltered-recoverable & 102 & $-37(<0.001)$ & $29(0.032)$ & $-28(0.021)$ & $<0.001$ & $1.13(<0.001)$ & $0.95(<0.001)$ & 43.6 & 2 \\
\hline Lead, filtered & 101 & $\mathrm{NR}^{4}$ & $\mathrm{NR}^{4}$ & $\mathrm{NR}^{4}$ & $\mathrm{NR}^{4}$ & $\mathrm{NR}^{4}$ & $\mathrm{NR}^{4}$ & $\mathrm{NR}^{4}$ & 93 \\
\hline Lead, unfiltered-recoverable & 102 & $\mathrm{NR}^{4}$ & $\mathrm{NR}^{4}$ & $\mathrm{NR}^{4}$ & $\mathrm{NR}^{4}$ & $\mathrm{NR}^{4}$ & $\mathrm{NR}^{4}$ & $\mathrm{NR}^{4}$ & 62 \\
\hline
\end{tabular}


Table 4-1. Flow-adjusted trend results determined by using the time-series model (TSM) for selected water-quality constituents and properties for selected sampling sites in

the upper Clark Fork Basin, Montana, water years 1996-2010.-Continued

[Water year is the 12-month period from October 1 through September 30 and is designated by the year in which it ends. Values in parentheses indicate $p$-values for associated percent change or coefficient. Gray shading indicates statistical significance at $p$-value less than 0.01. $p$-value, statistical probability level; $\mathrm{SEAS}_{\mathrm{C}}$, seasonal concentration anomaly coefficient; $\mathrm{ANN}_{\mathrm{C}}$, annual concentration anomaly coefficient; SEE, standard error of estimate in percent; NR, not reported; <, less than]

\begin{tabular}{|c|c|c|c|c|c|c|c|c|c|}
\hline Constituent or property & $\begin{array}{c}\text { Number } \\
\text { of } \\
\text { samples }\end{array}$ & $\begin{array}{c}\text { Total percent } \\
\text { change for } \\
\text { water years } \\
\text { 1996-2000 } \\
\text { (period 1) }\end{array}$ & $\begin{array}{l}\text { Total percent } \\
\text { change for } \\
\text { water years } \\
2001-05 \\
\text { (period 2) }\end{array}$ & $\begin{array}{c}\text { Total percent } \\
\text { change for } \\
\text { water years } \\
\text { 2006-2010 } \\
\text { (period 3) }\end{array}$ & $\begin{array}{c}p \text {-value } \\
\text { for overall } \\
\text { trend } \\
\text { analysis }\end{array}$ & SEAS $_{c}$ & ANN $_{c}$ & SEE & $\begin{array}{l}\text { Percent of values affected } \\
\text { by recensoring at study } \\
\text { reporting level used in the } \\
\text { application of the time- } \\
\text { series model }{ }^{2}\end{array}$ \\
\hline \multicolumn{10}{|c|}{ Blackfoot River (site 21, fig. 1, table 1)—Continued } \\
\hline Manganese, filtered & 99 & $\mathrm{NR}^{4}$ & $\mathrm{NR}^{4}$ & $\mathrm{NR}^{4}$ & $\mathrm{NR}^{4}$ & $\mathrm{NR}^{4}$ & $\mathrm{NR}^{4}$ & $\mathrm{NR}^{4}$ & 13 \\
\hline Manganese, unfiltered-recoverable & 100 & $\mathrm{NR}^{4}$ & $\mathrm{NR}^{4}$ & $\mathrm{NR}^{4}$ & $\mathrm{NR}^{4}$ & $\mathrm{NR}^{4}$ & $\mathrm{NR}^{4}$ & $\mathrm{NR}^{4}$ & 12 \\
\hline Zinc, filtered & 101 & $\mathrm{NR}^{4}$ & $\mathrm{NR}^{4}$ & $\mathrm{NR}^{4}$ & $\mathrm{NR}^{4}$ & $\mathrm{NR}^{4}$ & $\mathrm{NR}^{4}$ & $\mathrm{NR}^{4}$ & 88 \\
\hline Zinc, unfiltered-recoverable & 102 & $\mathrm{NR}^{4}$ & $\mathrm{NR}^{4}$ & $\mathrm{NR}^{4}$ & $\mathrm{NR}^{4}$ & $\mathrm{NR}^{4}$ & $\mathrm{NR}^{4}$ & $\mathrm{NR}^{4}$ & 65 \\
\hline Arsenic, filtered & 101 & $\mathrm{NR}^{4}$ & $\mathrm{NR}^{4}$ & $\mathrm{NR}^{4}$ & $\mathrm{NR}^{4}$ & $\mathrm{NR}^{4}$ & $\mathrm{NR}^{4}$ & $\mathrm{NR}^{4}$ & 51 \\
\hline Arsenic, unfiltered-recoverable & 101 & $\mathrm{NR}^{4}$ & $\mathrm{NR}^{4}$ & $\mathrm{NR}^{4}$ & $\mathrm{NR}^{4}$ & $\mathrm{NR}^{4}$ & $\mathrm{NR}^{4}$ & $\mathrm{NR}^{4}$ & 31 \\
\hline Suspended sediment & 103 & $-12\left(\mathrm{NR}^{3}\right)$ & $4\left(\mathrm{NR}^{3}\right)$ & $-24\left(\mathrm{NR}^{3}\right)$ & 0.403 & $1.21(<0.001)$ & $1.31(<0.001)$ & 48.6 & 0 \\
\hline
\end{tabular}

'Determination of and distinction between $p$-value for individual trend period and $p$-value for overall trend analysis are discussed in "Supplement 2: Summary of the Time-Series Model (TSM) as Applied in this Study."

${ }^{2}$ Procedures for determining and applying the study reporting level used in the application of the time-series model are discussed in the section of this report "Time-Series Model."

${ }^{3}$ Results not reported because of nonsignificant overall trend analysis ( $p$-value greater than 0.01 ).

${ }^{4}$ Results not reported because greater than 6 percent of values were affected by recensoring at study reporting level, as discussed in the section of this report "Time-Series Model."

${ }^{5}$ Results not reported because of no or insufficient data for application of the TSM during indicated trend-analysis period. 
Table 4-2. Flow-adjusted trend results determined by using the time-series model (TSM) for selected water-quality constituents and properties for Clark Fork above Missoula (site 22, fig. 1, table 1), water years 1996-2010.

[Water year is the 12-month period from October 1 through September 30 and is designated by the year in which it ends. Values in parentheses indicate $p$-values for associated percent change or coefficient. Gray shading indicates statistical significance at $p$-value less than 0.01 - $p$-value, statistical probability level; SEAS, seasonal concentration anomaly coefficient; ANN ${ }_{C}$, annual concentration anomaly coefficient; SEE, standard error of estimate in percent; NR, not reported; <, less than]

\begin{tabular}{|c|c|c|c|c|c|c|c|c|c|c|}
\hline Constituent or property & $\begin{array}{c}\text { Number } \\
\text { of } \\
\text { samples }\end{array}$ & $\begin{array}{l}\text { Total percent } \\
\text { change for } \\
\text { water years } \\
\text { 1996-2000 } \\
\text { (period 1) }\end{array}$ & $\begin{array}{l}\text { Total percent } \\
\text { change for } \\
\text { water years } \\
2001-05 \\
\text { (period 2) }\end{array}$ & $\begin{array}{l}\text { Total percent } \\
\text { change for } \\
\text { October 1, } \\
\text { 2005-March 27, } \\
2008 \text { (period 3A) }\end{array}$ & $\begin{array}{l}\text { Total percent } \\
\text { change for } \\
\text { March 28, 2008- } \\
\text { September 30, } \\
2010 \text { (period 3B) }\end{array}$ & $\begin{array}{c}p \text {-value } \\
\text { for overall } \\
\text { trend } \\
\text { analysis }{ }^{1}\end{array}$ & SEAS $_{\mathrm{c}}$ & $\mathrm{ANN}_{\mathrm{c}}$ & SEE & $\begin{array}{l}\text { Percent of values } \\
\text { affected by recensor- } \\
\text { ing at study reporting } \\
\text { level used in the } \\
\text { application of the } \\
\text { time-series model }{ }^{2}\end{array}$ \\
\hline \multicolumn{11}{|c|}{ Clark Fork above Missoula (site 22, fig. 1, table 1) } \\
\hline Specific conductance & 186 & $0\left(\mathrm{NR}^{3}\right)$ & $-2\left(\mathrm{NR}^{3}\right)$ & $0\left(\mathrm{NR}^{3}\right)$ & $5\left(\mathrm{NR}^{3}\right)$ & 0.031 & $-0.18(<0.001)$ & $-0.19(<0.001)$ & 8.5 & 0 \\
\hline Cadmium, filtered & 166 & $\mathrm{NR}^{4}$ & $\mathrm{NR}^{4}$ & $\mathrm{NR}^{4}$ & $\mathrm{NR}^{4}$ & $\mathrm{NR}^{4}$ & $\mathrm{NR}^{4}$ & $\mathrm{NR}^{4}$ & $\mathrm{NR}^{4}$ & 96 \\
\hline $\begin{array}{l}\text { Cadmium, unfiltered- } \\
\text { recoverable }\end{array}$ & 167 & $\mathrm{NR}^{4}$ & $\mathrm{NR}^{4}$ & $\mathrm{NR}^{4}$ & $\mathrm{NR}^{4}$ & $\mathrm{NR}^{4}$ & $\mathrm{NR}^{4}$ & $\mathrm{NR}^{4}$ & $\mathrm{NR}^{4}$ & 77 \\
\hline Copper, filtered & 166 & $-21\left(\mathrm{NR}^{3}\right)$ & $21\left(\mathrm{NR}^{3}\right)$ & $7\left(\mathrm{NR}^{3}\right)$ & $11\left(\mathrm{NR}^{3}\right)$ & 0.027 & $0.53(<0.001)$ & $0.37(0.007)$ & 37.6 & 1 \\
\hline $\begin{array}{l}\text { Copper, unfiltered- } \\
\text { recoverable }\end{array}$ & 165 & $-18(0.026)$ & $52(<0.001)$ & $104(<0.001)$ & $-59(0.002)$ & $<0.001$ & $0.55(<0.001)$ & $0.62(<0.001)$ & 60.1 & 0 \\
\hline Iron, filtered & 167 & $\mathrm{NR}^{4}$ & $\mathrm{NR}^{4}$ & $\mathrm{NR}^{4}$ & $\mathrm{NR}^{4}$ & $\mathrm{NR}^{4}$ & $\mathrm{NR}^{4}$ & $\mathrm{NR}^{4}$ & $\mathrm{NR}^{4}$ & 20 \\
\hline $\begin{array}{l}\text { Iron unfiltered-recov- } \\
\text { erable }\end{array}$ & 167 & $-30(<0.001)$ & $61(<0.001)$ & $79(<0.001)$ & $-58(0.001)$ & $<0.001$ & $0.77(<0.001)$ & $0.76(<0.001)$ & 52.5 & 0 \\
\hline Lead, filtered & 160 & $\mathrm{NR}^{4}$ & $\mathrm{NR}^{4}$ & $\mathrm{NR}^{4}$ & $\mathrm{NR}^{4}$ & $\mathrm{NR}^{4}$ & $\mathrm{NR}^{4}$ & $\mathrm{NR}^{4}$ & $\mathrm{NR}^{4}$ & 95 \\
\hline $\begin{array}{l}\text { Lead, unfiltered-recov- } \\
\text { erable }\end{array}$ & 162 & $\mathrm{NR}^{4}$ & $\mathrm{NR}^{4}$ & $\mathrm{NR}^{4}$ & $\mathrm{NR}^{4}$ & $\mathrm{NR}^{4}$ & $\mathrm{NR}^{4}$ & $\mathrm{NR}^{4}$ & $\mathrm{NR}^{4}$ & 25 \\
\hline Manganese, filtered & 167 & $-8(0.312)$ & $1(0.938)$ & $2(0.854)$ & $-44(0.001)$ & $<0.001$ & $-0.17(0.303)$ & $0.01(0.930)$ & 39.1 & 0 \\
\hline $\begin{array}{l}\text { Manganese, unfiltered- } \\
\text { recoverable }\end{array}$ & 167 & $-20(0.023)$ & $17(0.242)$ & $71(<0.001)$ & $-45(0.005)$ & $<0.001$ & $0.13(0.461)$ & $0.17(0.267)$ & 41.4 & 0 \\
\hline Zinc, filtered & 166 & $\mathrm{NR}^{4}$ & $\mathrm{NR}^{4}$ & $\mathrm{NR}^{4}$ & $\mathrm{NR}^{4}$ & $\mathrm{NR}^{4}$ & $\mathrm{NR}^{4}$ & $\mathrm{NR}^{4}$ & $\mathrm{NR}^{4}$ & 77 \\
\hline $\begin{array}{l}\text { Zinc, unfiltered-recov- } \\
\text { erable }\end{array}$ & 150 & $\mathrm{NR}^{4}$ & $\mathrm{NR}^{4}$ & $\mathrm{NR}^{4}$ & $\mathrm{NR}^{4}$ & $\mathrm{NR}^{4}$ & $\mathrm{NR}^{4}$ & $\mathrm{NR}^{4}$ & $\mathrm{NR}^{4}$ & 10 \\
\hline Arsenic, filtered & 167 & $-2(0.636)$ & $12(0.078)$ & $7(0.365)$ & $12(0.276)$ & 0.005 & $0.19(0.015)$ & $-0.02(0.765)$ & 26.8 & 0 \\
\hline $\begin{array}{l}\text { Arsenic, unfiltered- } \\
\text { recoverable }\end{array}$ & 167 & $-6(0.410)$ & $14(0.184)$ & $24(0.070)$ & $-2(0.921)$ & 0.008 & $0.49(<0.001)$ & $0.08(0.540)$ & 39.7 & 0 \\
\hline Suspended sediment & 209 & $-15(0.211)$ & $32(0.150)$ & $147(<0.001)$ & $-60(0.004)$ & $<0.001$ & $1.28(<0.001)$ & $0.72(<0.001)$ & 70.4 & 0 \\
\hline
\end{tabular}

'Determination of and distinction between $p$-value for individual trend period and $p$-value for overall trend analysis are discussed in "Supplement 2: Summary of the Time-Series Model (TSM) as Applied in this Study."

${ }^{2}$ Procedures for determining and applying the study reporting level used in the application of the time-series model are discussed in the section of this report "Time-Series Model."

${ }^{3}$ Results not reported because of nonsignificant overall trend analysis ( $p$-value greater than 0.01 ).

${ }^{4}$ Results not reported because greater than 6 percent of values were affected by recensoring at study reporting level, as discussed in the section of this report "Time-Series Model." 
Table 4-3. Flow-adjusted trend results determined by using multiple linear regression on time, streamflow, and season (MLR) for selected water-quality constituents and properties for selected sampling sites in the upper Clark Fork Basin, Montana, water years 2006-2010.

[Water year is the 12-month period from October 1 through September 30 and is designated by the year in which it ends. Values in parentheses indicate 95-percent confidence intervals. Gray shading indicates statistical significance at $p$-value less than 0.01. $p$-value, statistical probability level; SEE, standard error of estimate; NR, not reported; <, less than]

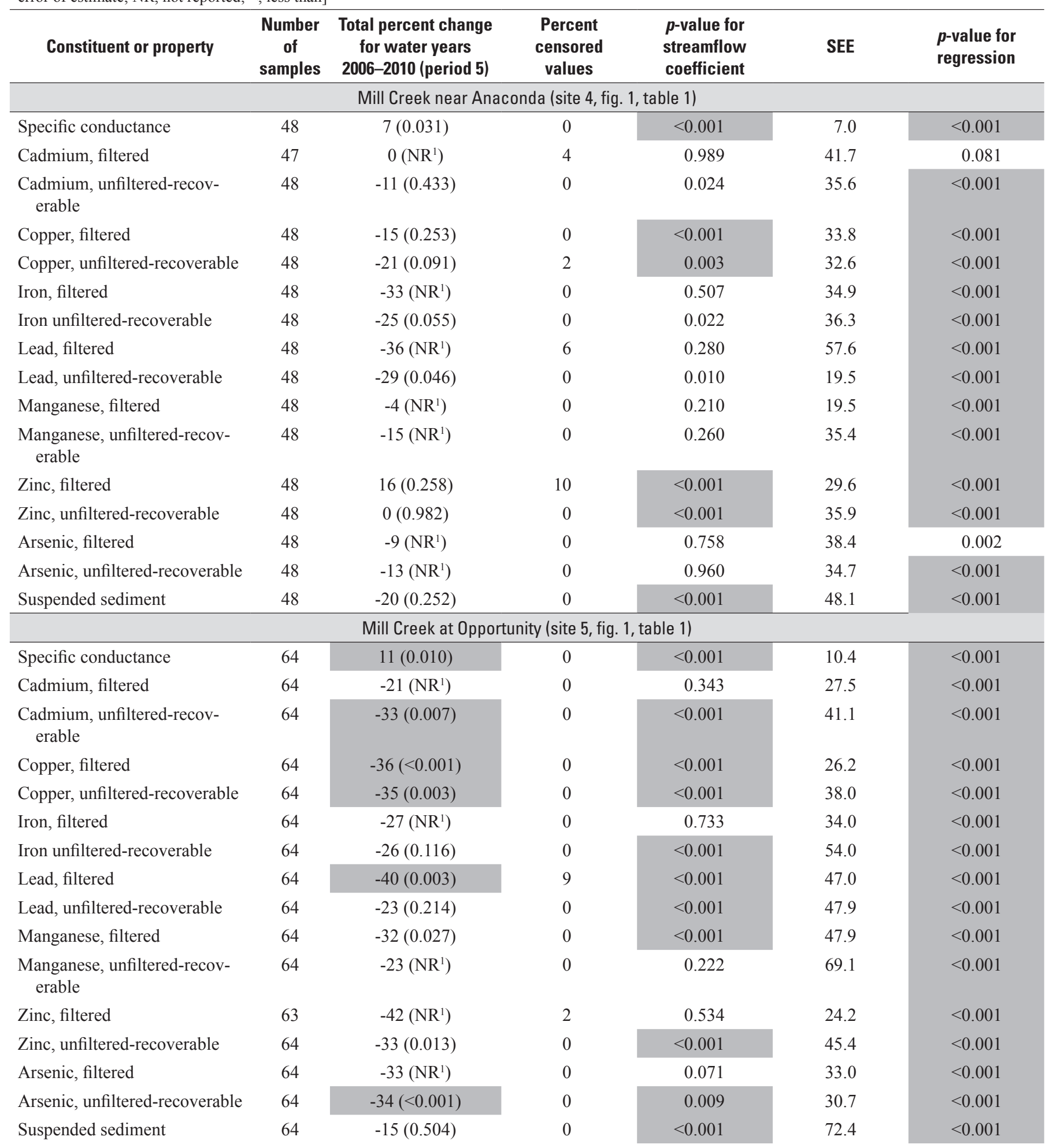


Table 4-3. Flow-adjusted trend results determined by using multiple linear regression on time, streamflow, and season (MLR) for selected water-quality constituents and properties for selected sampling sites in the upper Clark Fork Basin, Montana, water years 2006-2010.-Continued

[Water year is the 12-month period from October 1 through September 30 and is designated by the year in which it ends. Values in parentheses indicate 95-percent confidence intervals. Gray shading indicates statistical significance at $p$-value less than 0.01. $p$-value, statistical probability level; SEE, standard error of estimate; NR, not reported; <, less than]

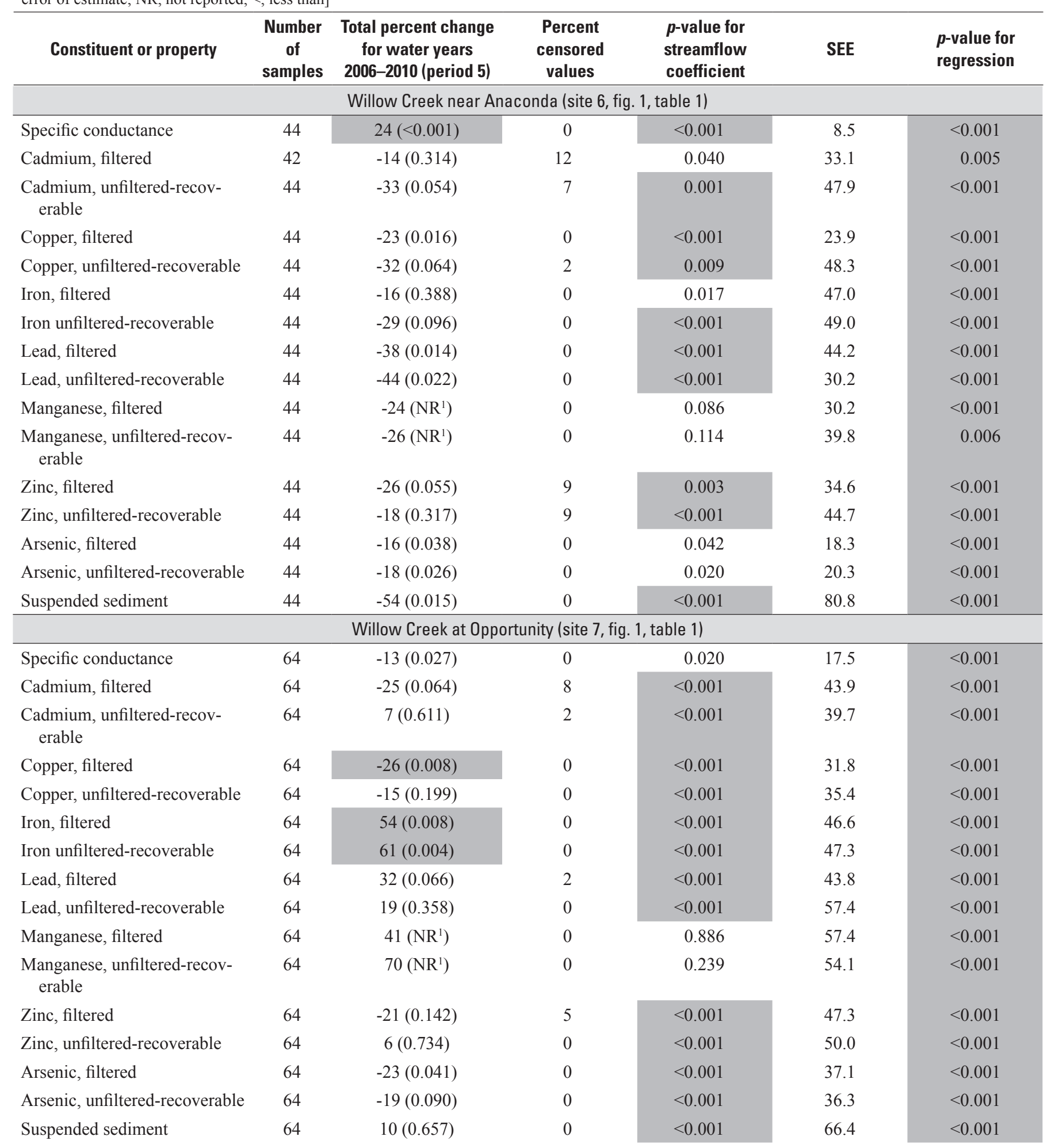


Table 4-3. Flow-adjusted trend results determined by using multiple linear regression on time, streamflow, and season (MLR) for selected water-quality constituents and properties for selected sampling sites in the upper Clark Fork Basin, Montana, water years 2006-2010.-Continued

[Water year is the 12-month period from October 1 through September 30 and is designated by the year in which it ends. Values in parentheses indicate 95 -percent confidence intervals. Gray shading indicates statistical significance at $p$-value less than 0.01. $p$-value, statistical probability level; SEE, standard error of estimate; NR, not reported; <, less than]

\begin{tabular}{|c|c|c|c|c|c|c|}
\hline Constituent or property & $\begin{array}{l}\text { Number } \\
\text { of } \\
\text { samples }\end{array}$ & $\begin{array}{l}\text { Total percent change } \\
\text { for water years } \\
2006-2010 \text { (period 5) }\end{array}$ & $\begin{array}{l}\text { Percent } \\
\text { censored } \\
\text { values }\end{array}$ & $\begin{array}{l}\text { p-value for } \\
\text { streamflow } \\
\text { coefficient }\end{array}$ & SEE & $\begin{array}{l}p \text {-value for } \\
\text { regression }\end{array}$ \\
\hline Specific conductance & 30 & $16(<0.001)$ & 0 & $<0.001$ & 4.7 & $<0.001$ \\
\hline Cadmium, filtered & 30 & $24\left(\mathrm{NR}^{1}\right)$ & 30 & 0.224 & 21.4 & $<0.001$ \\
\hline Copper, filtered & 30 & $-15\left(\mathrm{NR}^{1}\right)$ & 7 & 0.060 & 32.1 & $<0.001$ \\
\hline Copper, unfiltered-recoverable & 30 & $24\left(\mathrm{NR}^{1}\right)$ & 10 & 0.193 & 57.3 & $<0.001$ \\
\hline Iron, filtered & 30 & $-38\left(\mathrm{NR}^{1}\right)$ & 10 & 0.768 & 39.1 & $<0.001$ \\
\hline Iron unfiltered-recoverable & 30 & $-1(0.969)$ & 0 & 0.038 & 57.2 & $<0.001$ \\
\hline $\begin{array}{l}\text { Manganese, unfiltered-recov- } \\
\text { erable }\end{array}$ & 30 & $18(0.592)$ & 0 & 0.029 & 53.2 & $<0.001$ \\
\hline Zinc, filtered & 30 & $\mathrm{NR}^{2}$ & 47 & $\mathrm{NR}^{2}$ & $\mathrm{NR}^{2}$ & $\mathrm{NR}^{2}$ \\
\hline Zinc, unfiltered-recoverable & 30 & $22(0.564)$ & 13 & 0.005 & 61.5 & $<0.001$ \\
\hline Arsenic, filtered & 30 & $-9\left(\mathrm{NR}^{1}\right)$ & 0 & 0.130 & 17.4 & 0.010 \\
\hline Arsenic, unfiltered-recoverable & 30 & $18\left(\mathrm{NR}^{1}\right)$ & 0 & 0.058 & 20.3 & $<0.001$ \\
\hline Suspended sediment & 30 & $-24(0.498)$ & 0 & $<0.001$ & 72.3 & $<0.001$ \\
\hline \multicolumn{7}{|c|}{ Lost Creek near Anaconda (site 12, fig. 1, table 1) } \\
\hline Specific conductance & 47 & $-4(0.315)$ & 0 & $<0.001$ & 8.7 & $<0.001$ \\
\hline Iron unfiltered-recoverable & 47 & $-20(0.426)$ & 0 & 0.002 & 63.9 & $<0.001$ \\
\hline Lead, filtered & 47 & $\mathrm{NR}^{2}$ & 57 & $\mathrm{NR}^{2}$ & $\mathrm{NR}^{2}$ & $\mathrm{NR}^{2}$ \\
\hline Lead, unfiltered-recoverable & 47 & $-28(0.286)$ & 0 & 0.022 & 44.3 & $<0.001$ \\
\hline Manganese, filtered & 47 & $-16\left(\mathrm{NR}^{1}\right)$ & 2 & 0.429 & 44.3 & $<0.001$ \\
\hline $\begin{array}{l}\text { Manganese, unfiltered-recov- } \\
\text { erable }\end{array}$ & 47 & $-3\left(\mathrm{NR}^{1}\right)$ & 0 & 0.067 & 52.6 & $<0.001$ \\
\hline Zinc, filtered & 47 & $-32\left(\mathrm{NR}^{1}\right)$ & 30 & 0.245 & 28.1 & $<0.001$ \\
\hline Zinc, unfiltered-recoverable & 47 & $-43\left(\mathrm{NR}^{1}\right)$ & 4 & 0.081 & 47.4 & $<0.001$ \\
\hline Arsenic, filtered & 47 & $-51\left(\mathrm{NR}^{1}\right)$ & 0 & 0.161 & 32.3 & $<0.001$ \\
\hline Arsenic, unfiltered-recoverable & 47 & $-44\left(\mathrm{NR}^{1}\right)$ & 0 & 0.375 & 31.3 & $<0.001$ \\
\hline Suspended sediment & 47 & $-56(0.013)$ & 0 & $<0.001$ & 74.8 & $<0.001$ \\
\hline
\end{tabular}


Table 4-3. Flow-adjusted trend results determined by using multiple linear regression on time, streamflow, and season (MLR) for selected water-quality constituents and properties for selected sampling sites in the upper Clark Fork Basin, Montana, water years 2006-2010.-Continued

[Water year is the 12-month period from October 1 through September 30 and is designated by the year in which it ends. Values in parentheses indicate 95-percent confidence intervals. Gray shading indicates statistical significance at $p$-value less than 0.01. $p$-value, statistical probability level; SEE, standard error of estimate; NR, not reported; <, less than]

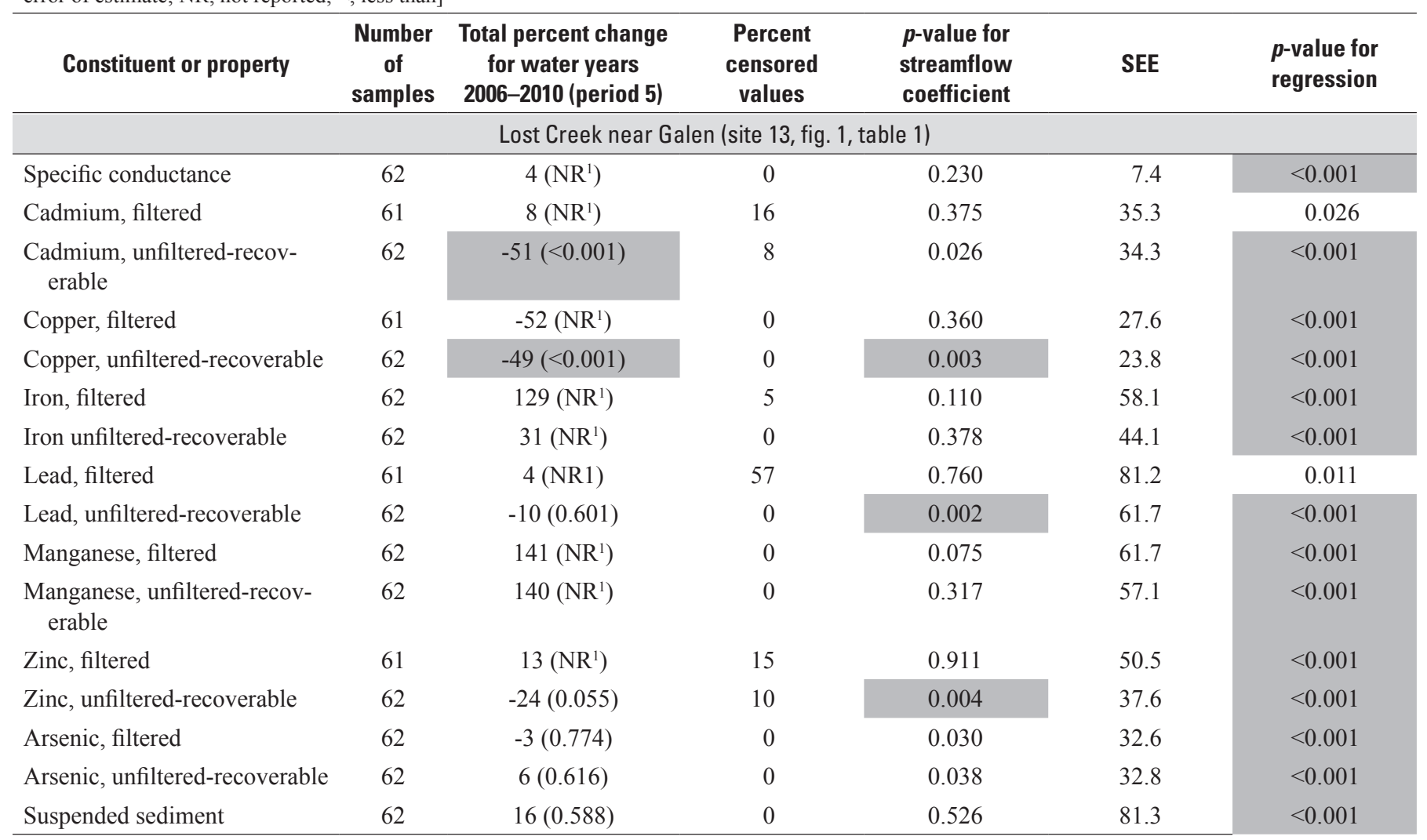

${ }^{1}$ Results not reported because of nonsignificant relation between streamflow and consituent concentration as indicated by $p$-value greater than 0.05 .

${ }^{2}$ Results not reported because greater than 45 percent of values were censored (that is, concentrations reported as less than the laboratory reporting level). 

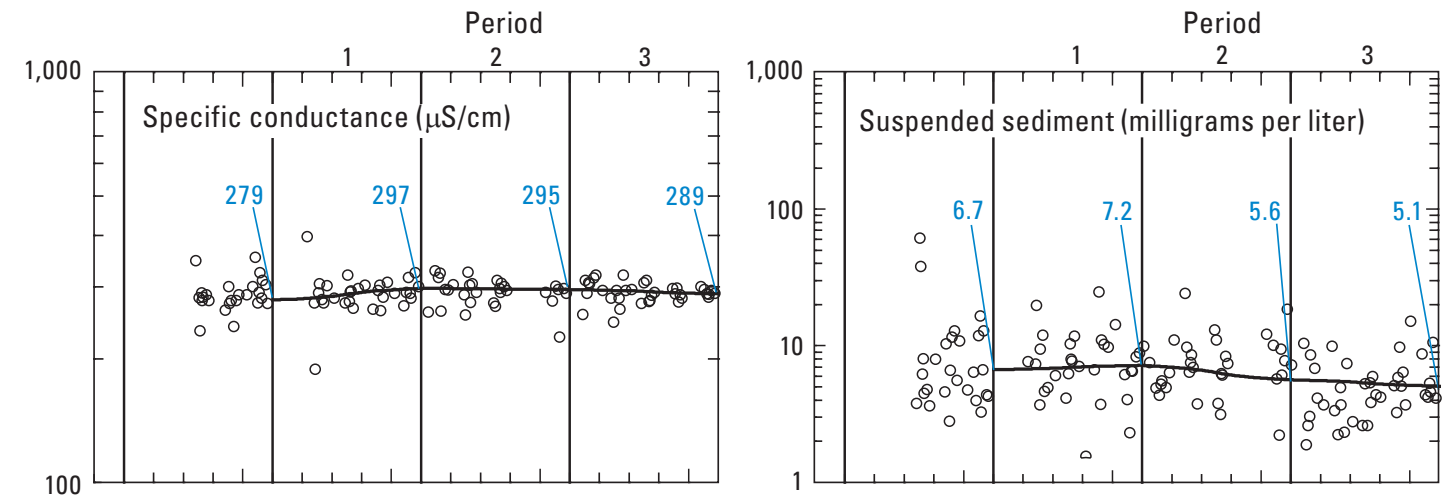

\section{EXPLANATION}

Water year is defined as the 12-month period from October 1 through Septembe 30 and is designated by the year in which it ends. $\mu \mathrm{S} / \mathrm{cm}$, microsiemens per centimeter at 25 degrees Celsius; $p$-value, statistical probability level]

- Flow-adjusted concentration (FAC) determined by using the time-series model
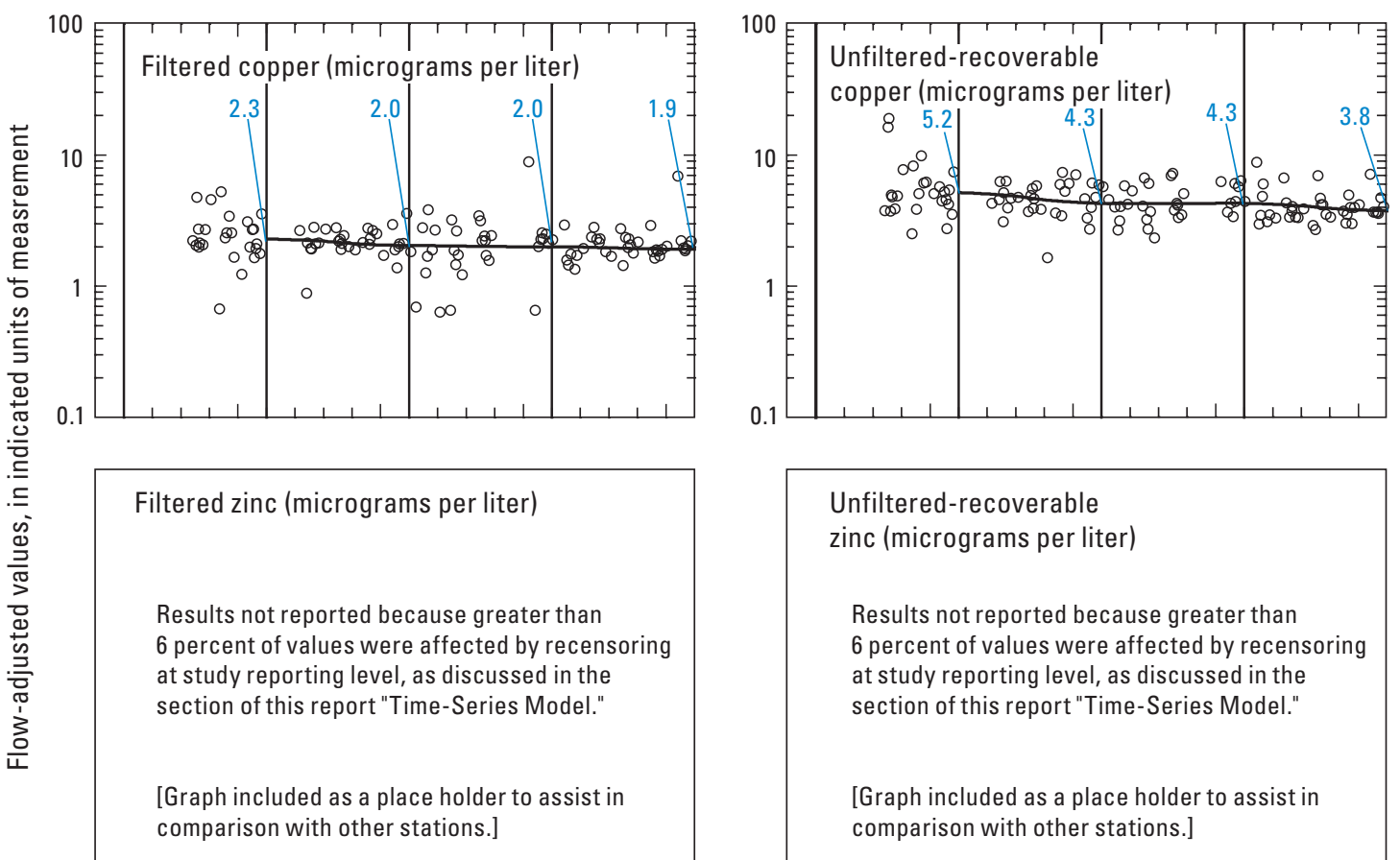

Flow-adjusted fitted trend determined by using the time-series model end of period

2.8 Bold values indicate statistical significance ( $p$-value less than $\mathbf{0 . 0 1}$ ) for period before value presented in bold

Unfiltered-recoverable

zinc (micrograms per liter)

Results not reported because greater than 6 percent of values were affected by recensoring at study reporting level, as discussed in the section of this report "Time-Series Model."

[Graph included as a place holder to assist in comparison with other stations.]
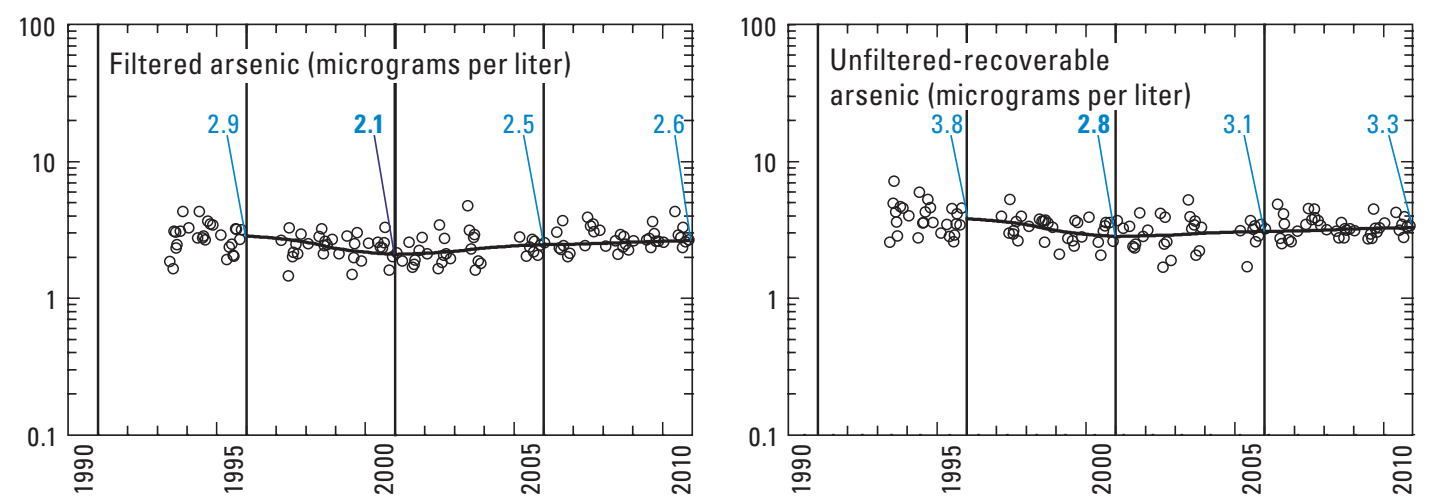

Water year (October-September)

Figure 4-1. Flow-adjusted fitted trends determined by using the time-series model (TSM) for selected water-quality constituents and properties for Blacktail Creek (site 1, fig. 1, table 1), water years 1996-2010. 


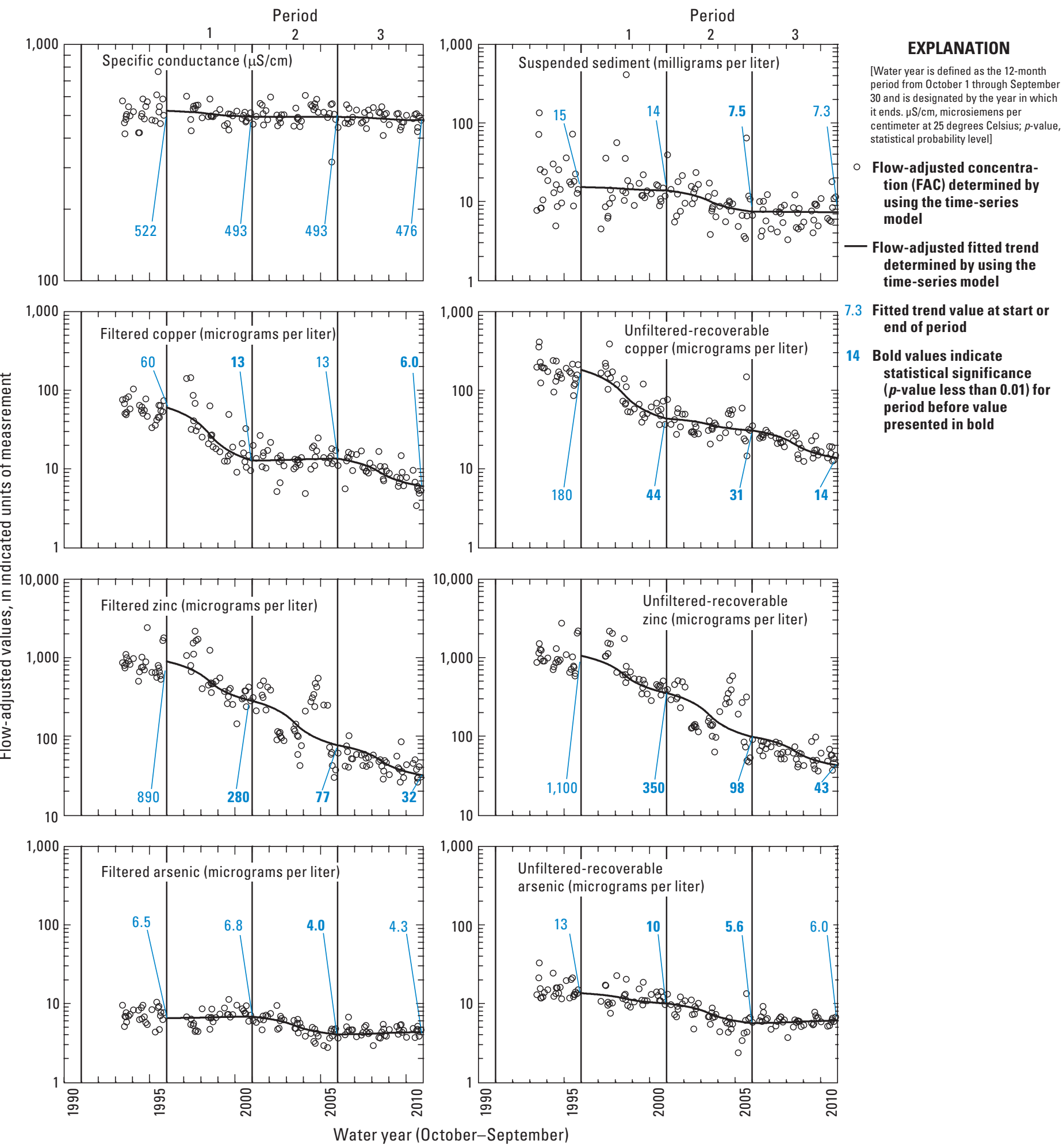

Figure 4-2. Flow-adjusted fitted trends determined by using the time-series model (TSM) for selected water-quality constituents and properties for Silver Bow Creek at Butte (site 2, fig. 1, table 1), water years 1996-2010. 

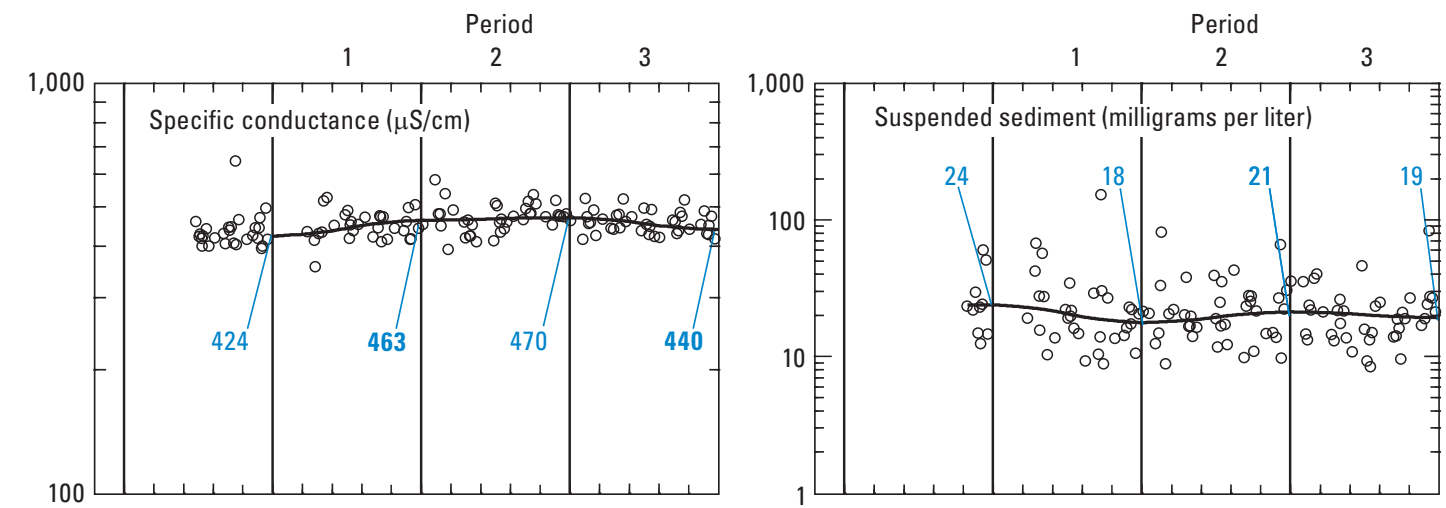

\section{EXPLANATION}

[Water year is defined as the 12 -month period from October 1 through September 30 and is designated by the year in which it ends. $\mu \mathrm{S} / \mathrm{cm}$, microsiemens per centimeter at 25 degrees Celsius; $p$-value, statistical probability level]

- Flow-adjusted concentration (FAC) determined by using the time-series model

- Flow-adjusted fitted trend determined by using the time-series model
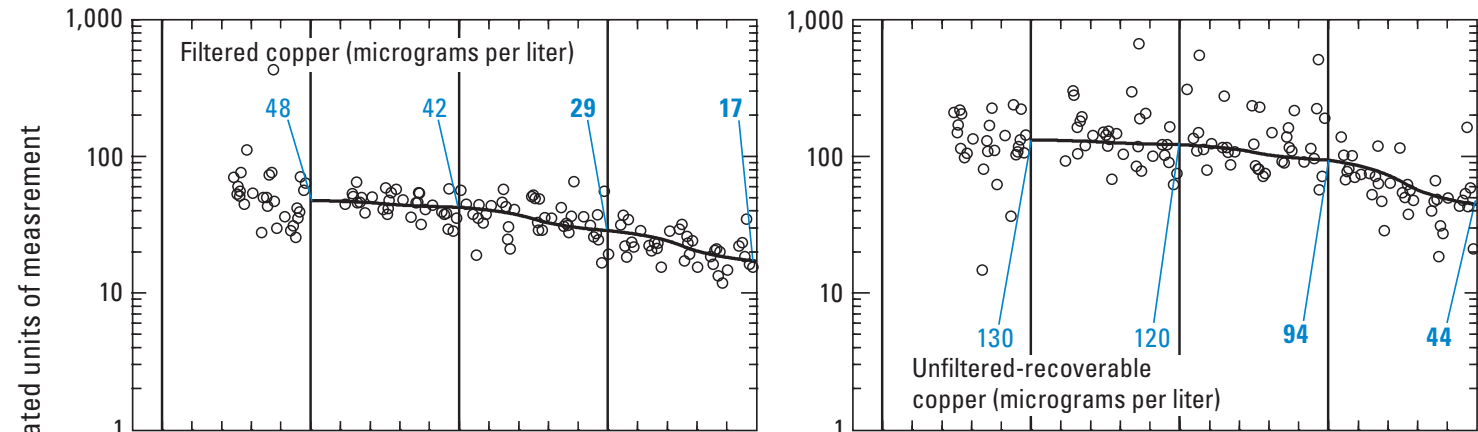

19 Fitted trend value at start or end of period

44 Bold values indicate statistical significance ( $p$-value less than 0.01) for period before value presented in bold
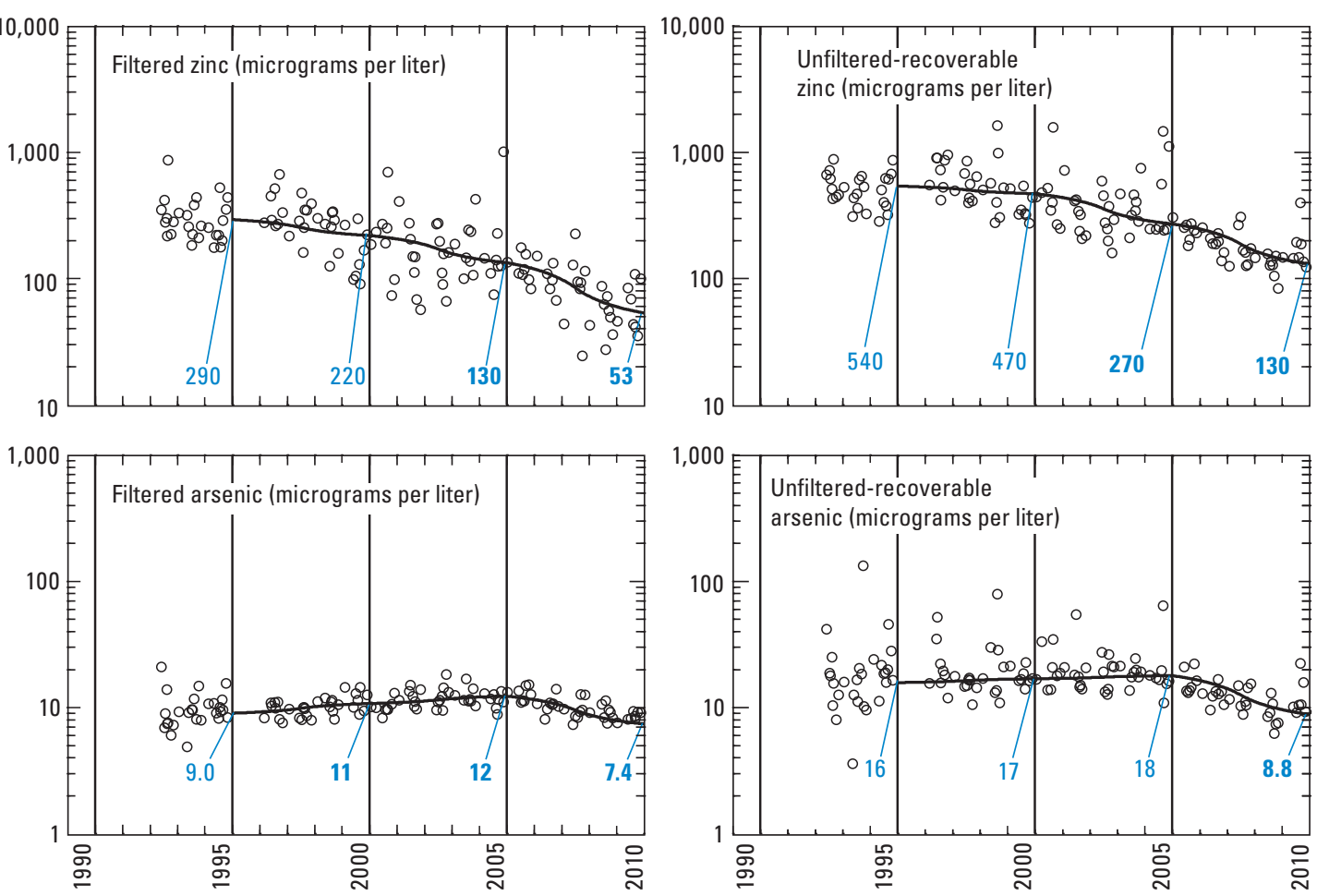

Water year (October-September)

Figure 4-3. Flow-adjusted fitted trends determined by using the time-series model (TSM) for selected water-quality constituents and properties for Silver Bow Creek at Opportunity (site 3, fig. 1, table 1), water years 1996-2010. 

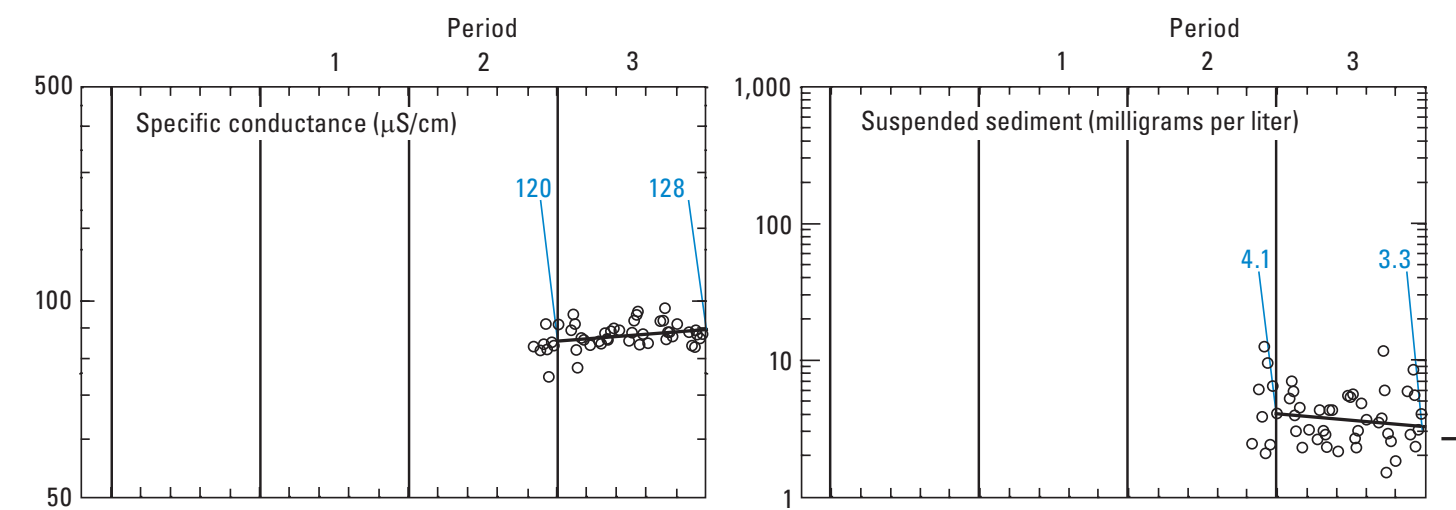

\section{EXPLANATION}

[Water year is defined as the 12-month period from 0ctober 1 through September 30 and is designated by the year in which it ends. $\mu \mathrm{S} / \mathrm{cm}$, microsiemens per

centimeter at 25 degrees Celsius; $p$-value, statistical probability leve

- Flow-adjusted concentration (FAC) determined by using multiple linear regression

- Flow-adjusted fitted trend determined by using multiple linear regression
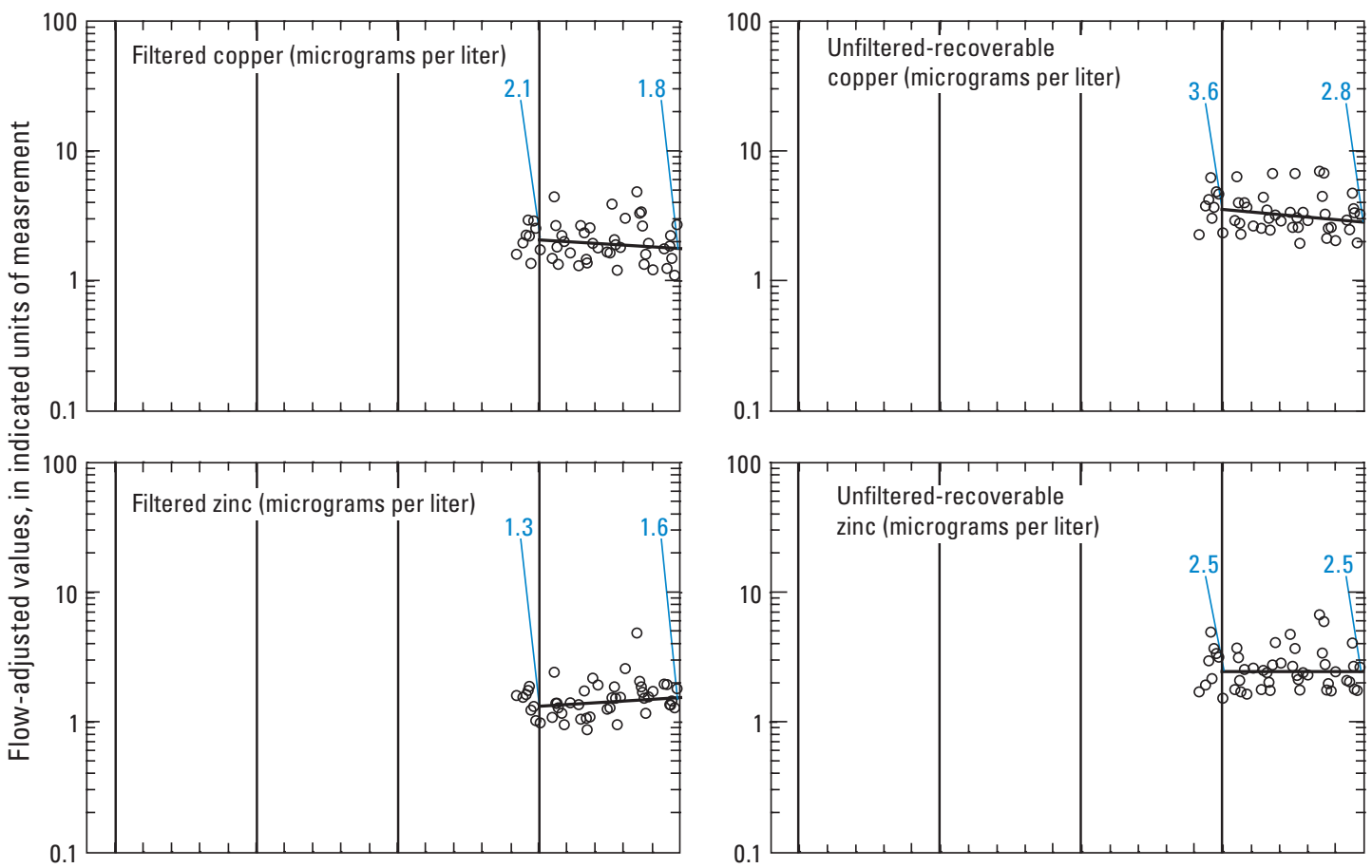

\subsection{Fitted trend value at start or} end of period
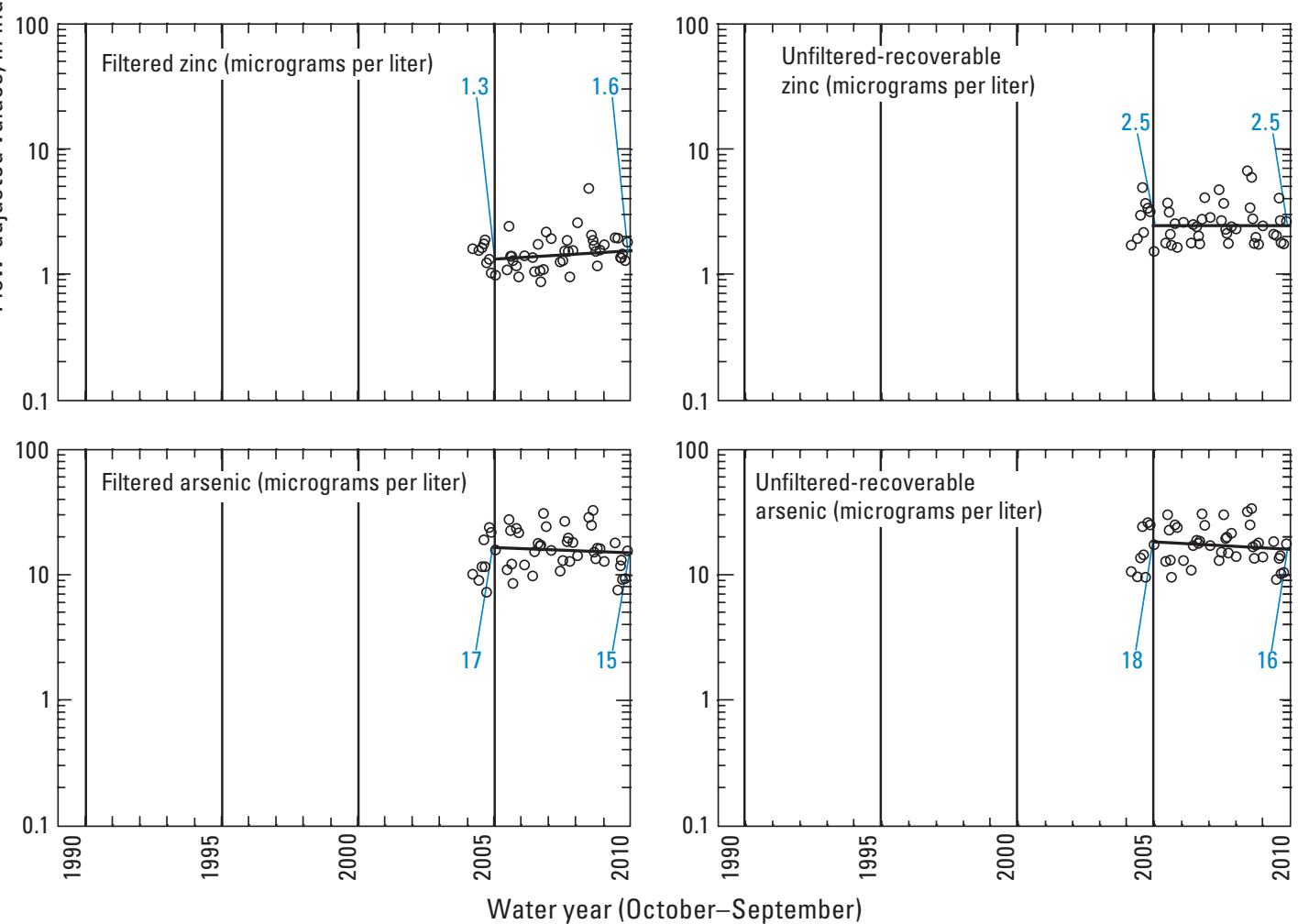

Figure 4-4. Flow-adjusted fitted trends determined by using multiple linear regression on time, discharge, and season (MLR) for selected water-quality constituents and properties for Mill Creek near Anaconda (site 4, fig. 1, table 1), water years 2006-2010. 

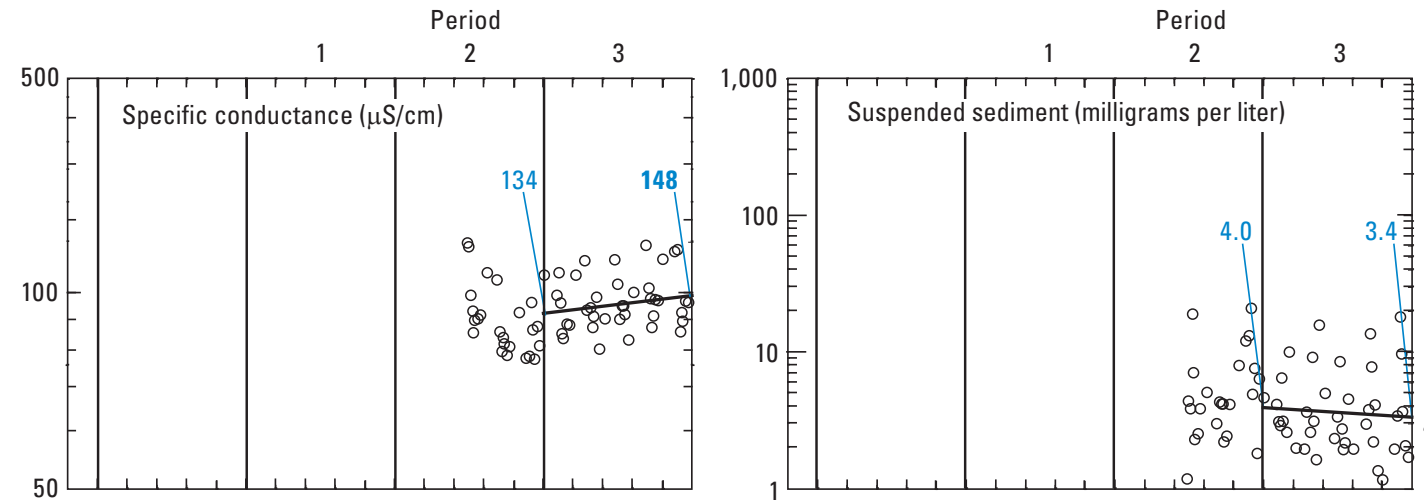

\section{EXPLANATION}

[Water year is defined as the 12-month period from October 1 through September 30 and is designated by the year in which it ends. $\mu \mathrm{S} / \mathrm{cm}$, microsiemens per centimeter at 25 degrees Celsius; $p$-value, statistical probability level]

- Flow-adjusted concentration (FAC) determined by using multiple linear regression
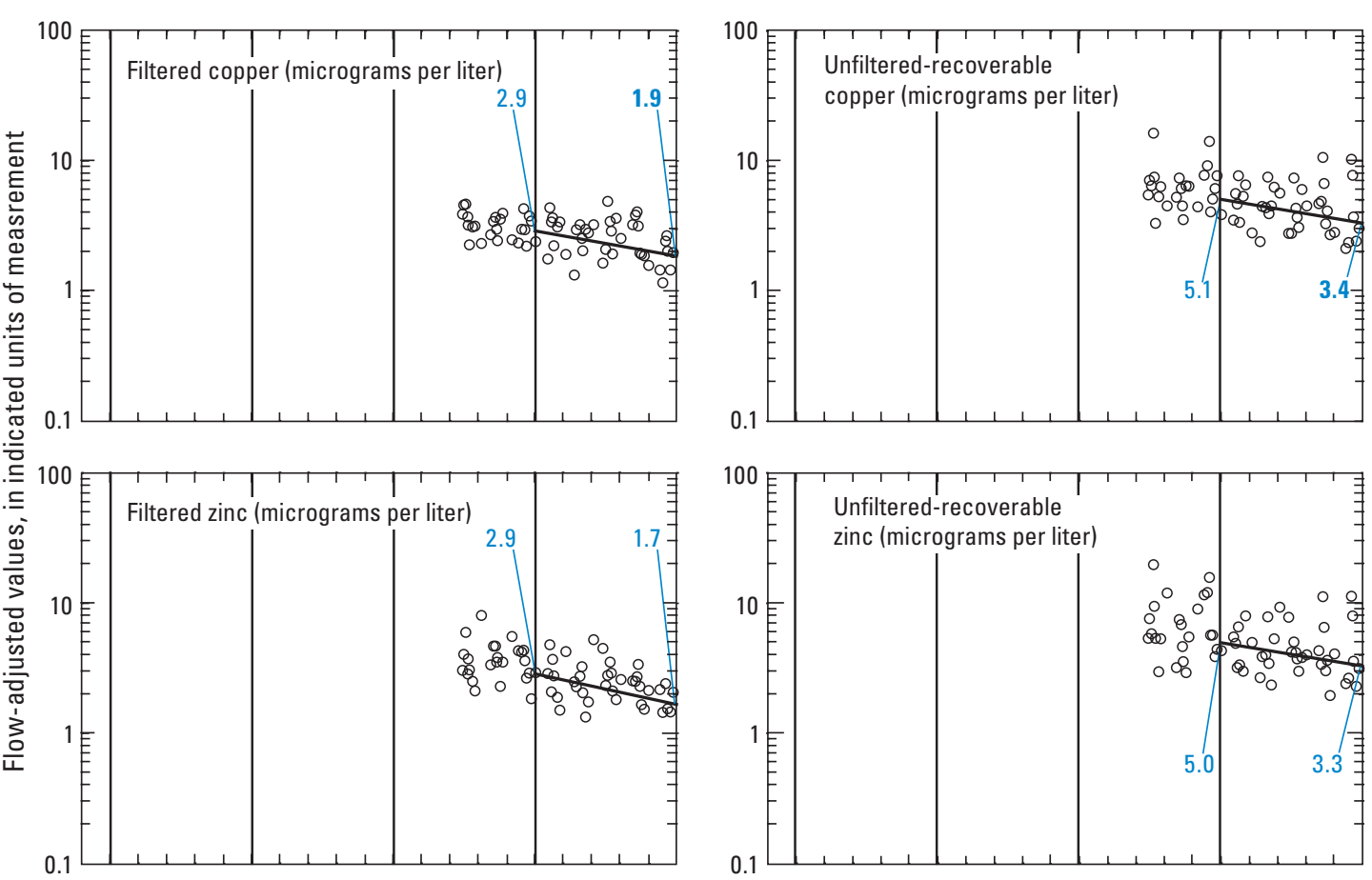

adjusted fitted trend determined by using multiple linear regression

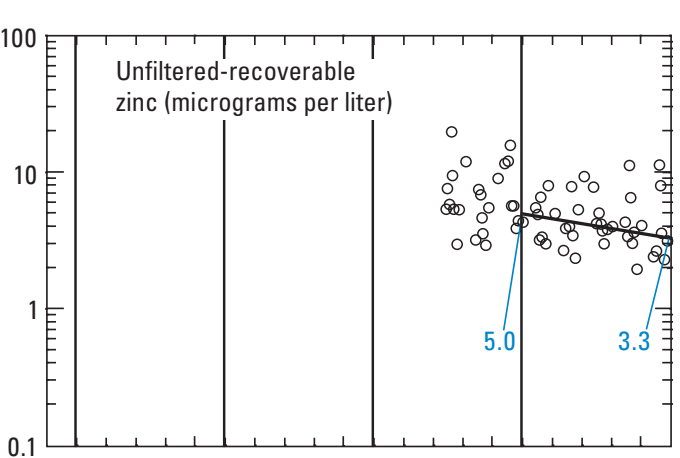

4.0 Fitted trend value at start or end of period

3.4 Bold values indicate statistical significance ( $p$-value less than 0.01 ) for period before value presented in bold
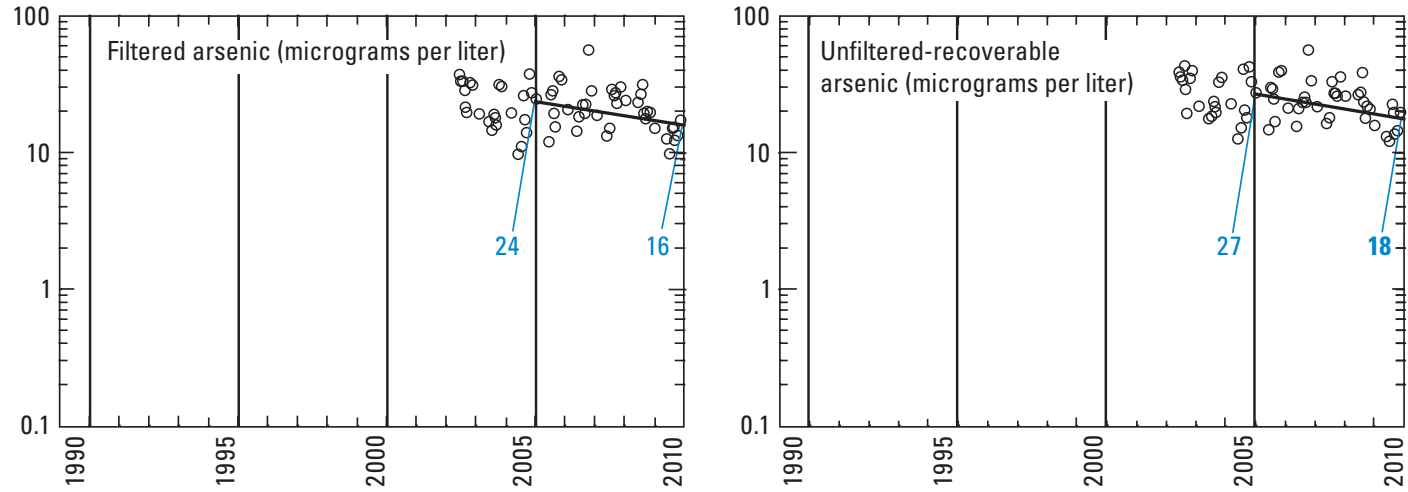

Water year (October-September)

Figure 4-5. Flow-adjusted fitted trends determined by using multiple linear regression on time, discharge, and season (MLR) for selected water-quality constituents and properties for Mill Creek at Opportunity (site 5, fig. 1, table 1), water years 2006-10. 

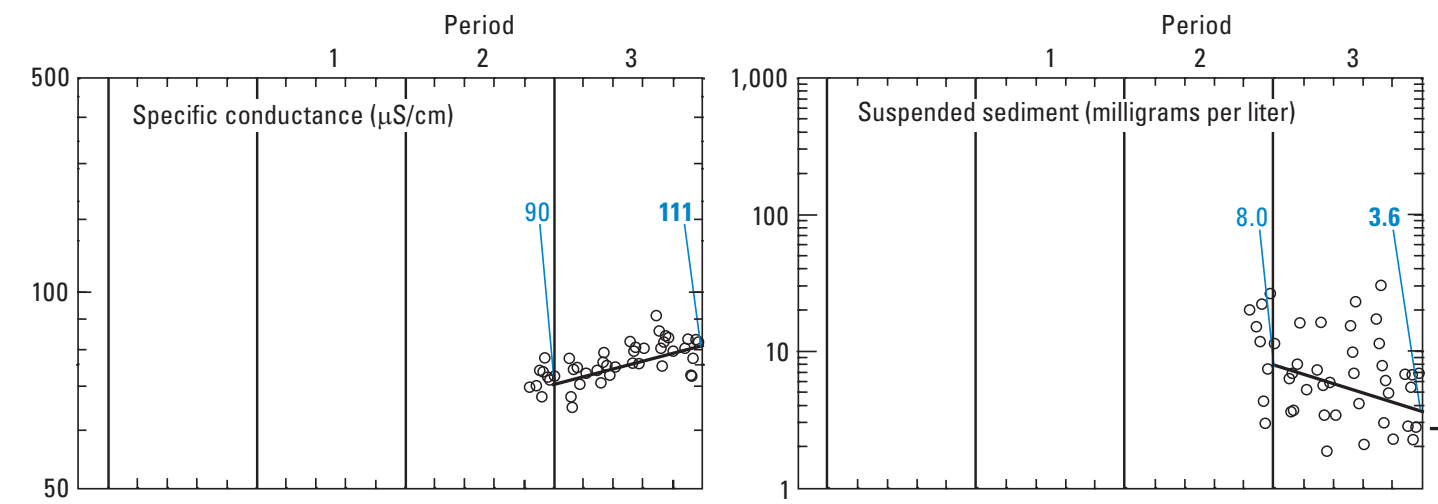

EXPLANATION

Water year is defined as the 12-month period from October 1 through September 30 and is designated by the year in which it ends. $\mu \mathrm{S} / \mathrm{cm}$, microsiemens per

centimeter at 25 degrees Celsius; $p$-value, statistical probability level]

- Flow-adjusted concentration (FAC) determined by using multiple linear regression

Flow-adjusted fitted trend determined by using multiple linear regression
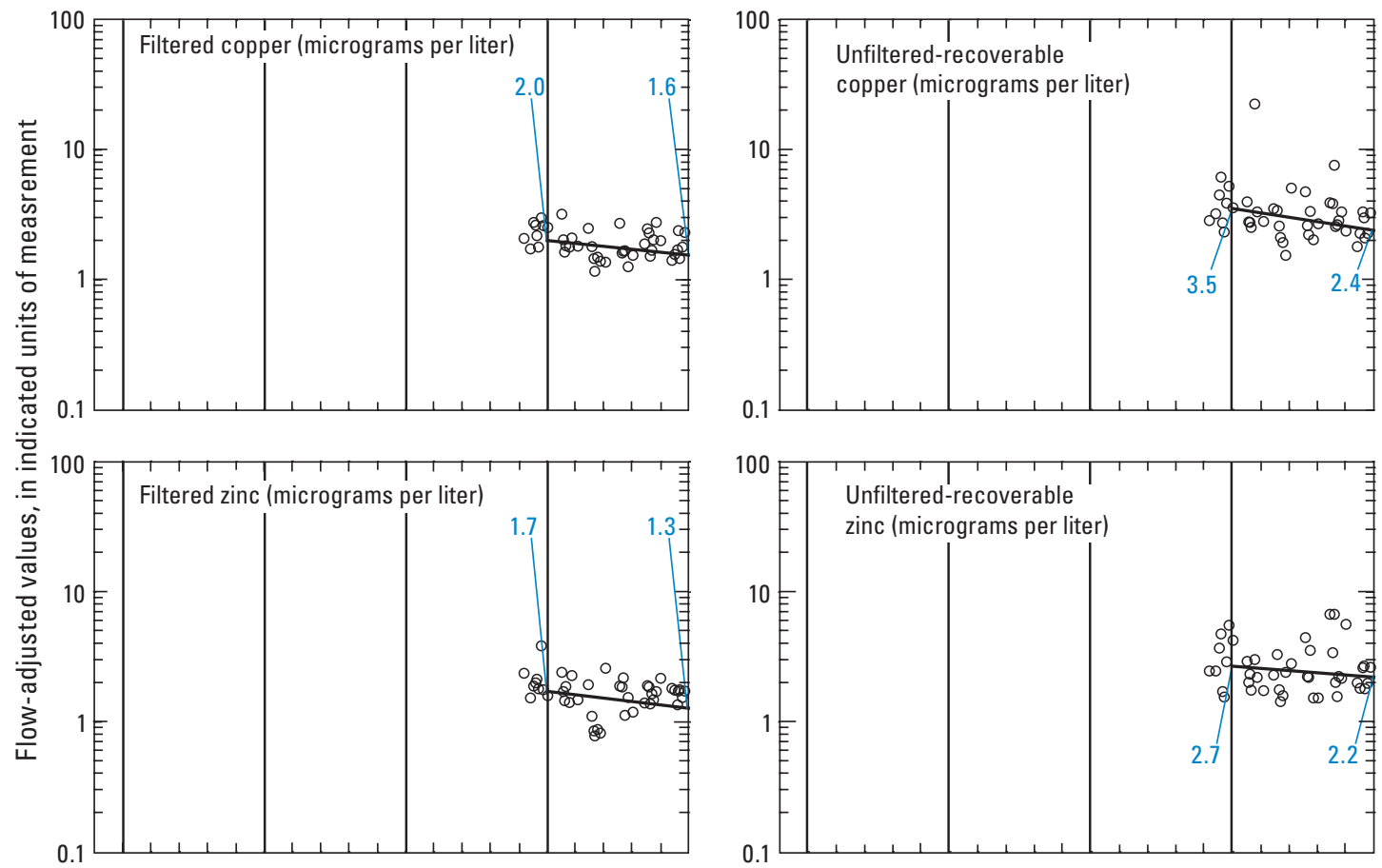

8.0 Fitted trend value at start or end of period

3.6 Bold values indicate statistical significance ( $p$-value less than 0.01 ) for period before value presented in bold
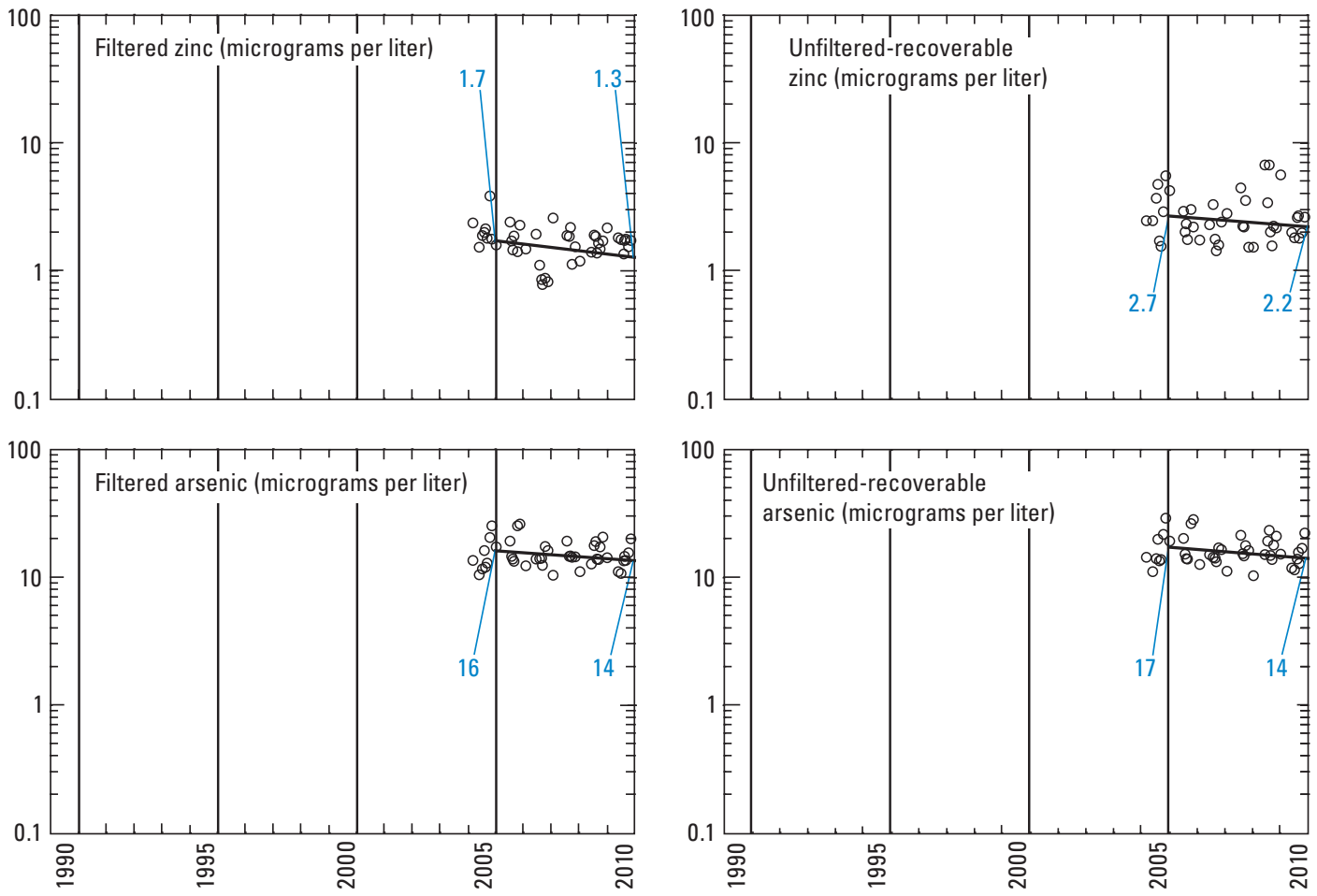

Water year (October-September)

Figure 4-6. Flow-adjusted fitted trends determined by using multiple linear regression on time, discharge, and season (MLR) for selected water-quality constituents and properties for Willow Creek near Anaconda (site 6, fig. 1, table 1), water years $2006-10$. 

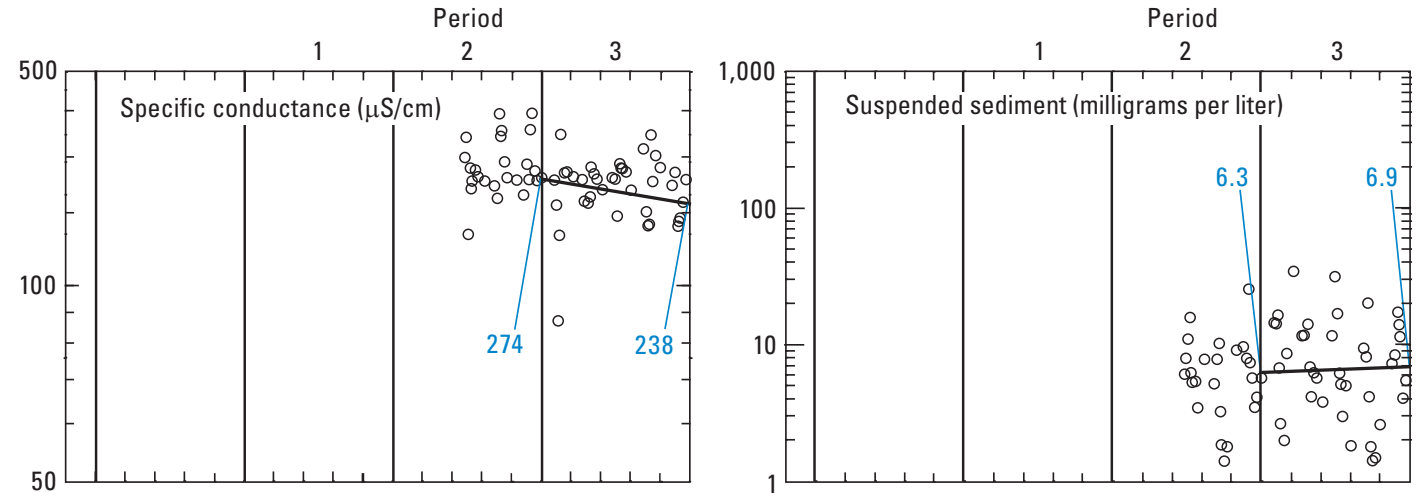

EXPLANATION

Wateryear is defined as the 12-month period from October 1 through September 30 and is designated by the year in which it ends. $\mu \mathrm{S} / \mathrm{cm}$, microsiemens per

centimeter at 25 degrees Celsius; $p$-value, statistical probability level]

- Flow-adjusted concentration (FAC) determined by using multiple linear regression
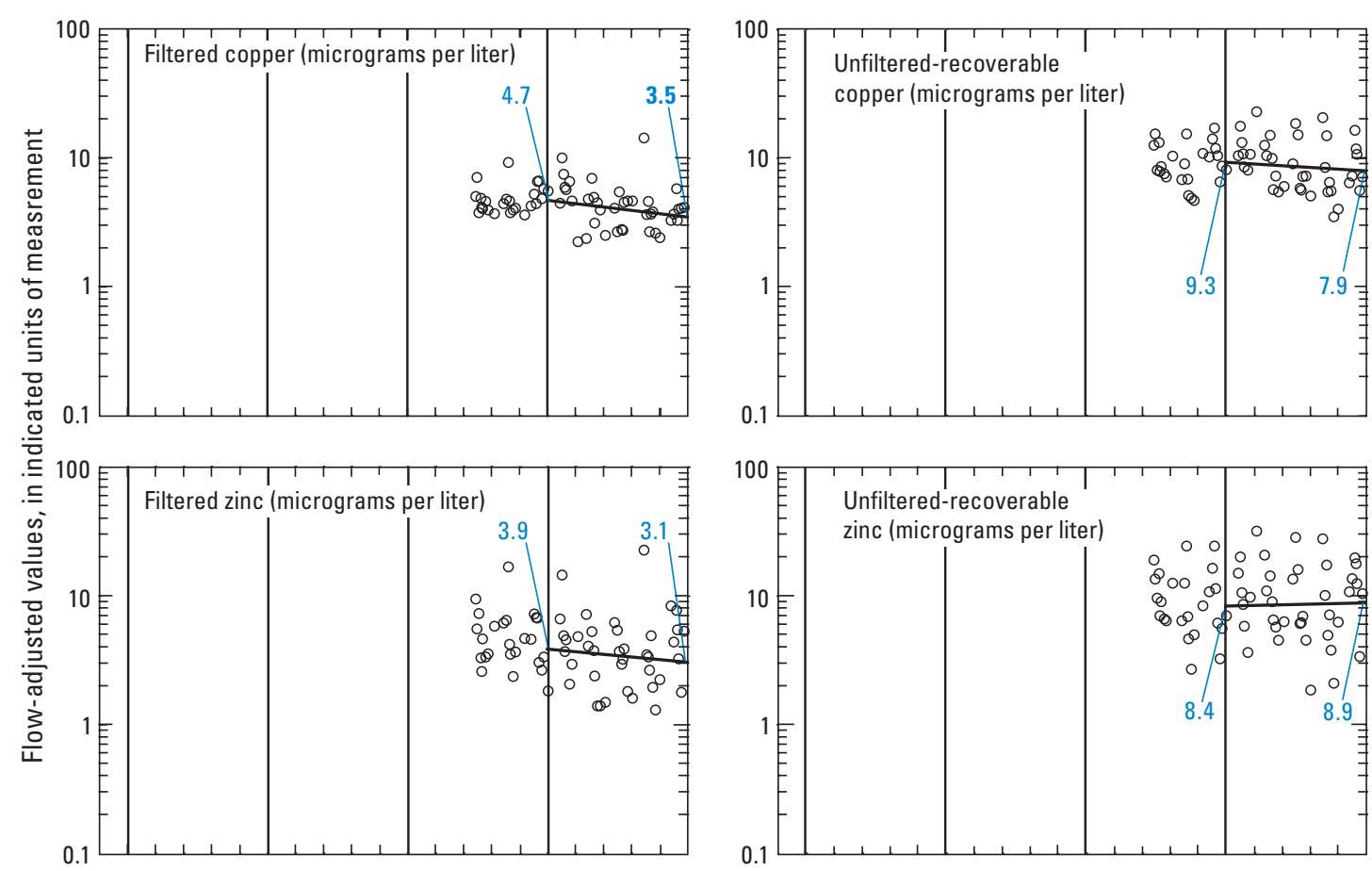

- Flow-adjusted fitted trend determined by using multiple linear regression

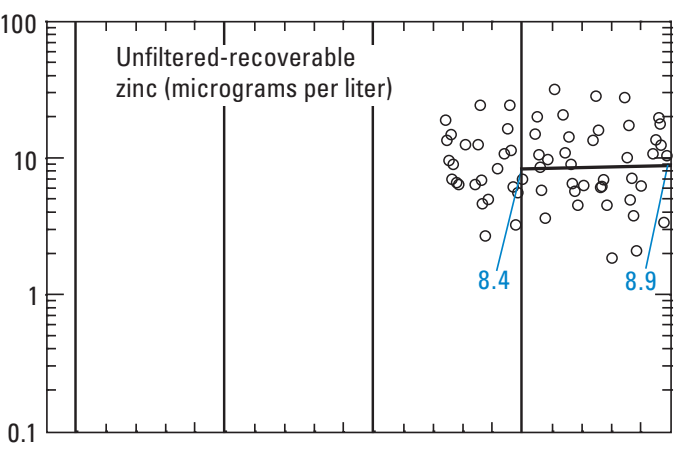

6.9 Fitted trend value at start or end of period

3.5 Bold values indicate statistical significance ( $p$-value less than $\mathbf{0 . 0 1}$ ) for period before value presented in bold
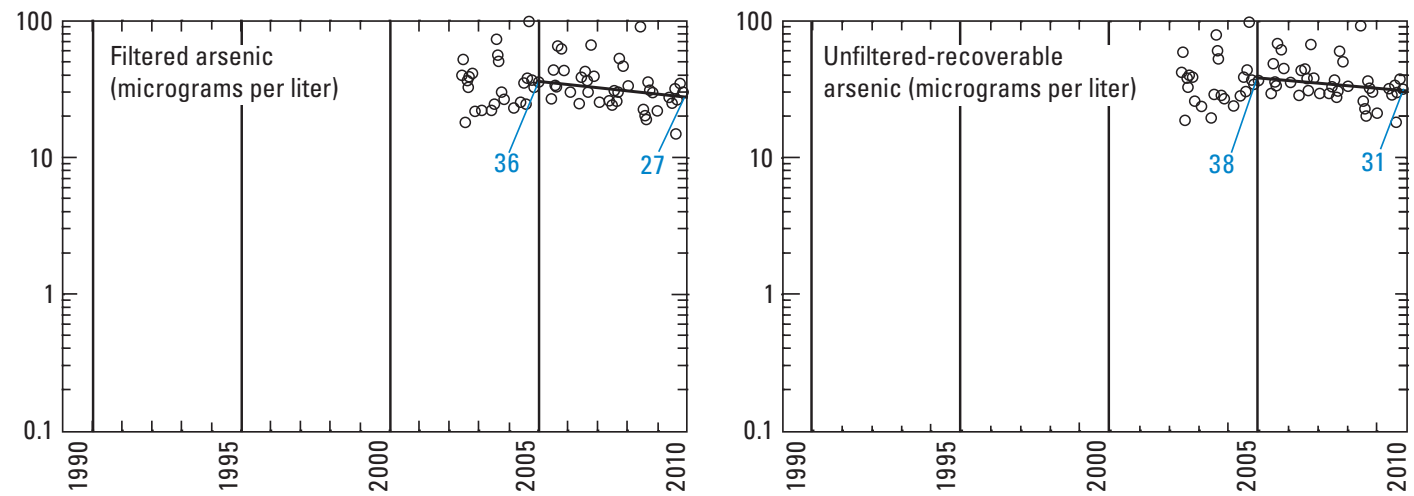

Water year (October-September)

Figure 4-7. Flow-adjusted fitted trends determined by using multiple linear regression on time, discharge, and season (MLR) for selected water-quality constituents and properties for Mill Creek at Opportunity (site 7, fig. 1, table 1), water years $2006-10$. 

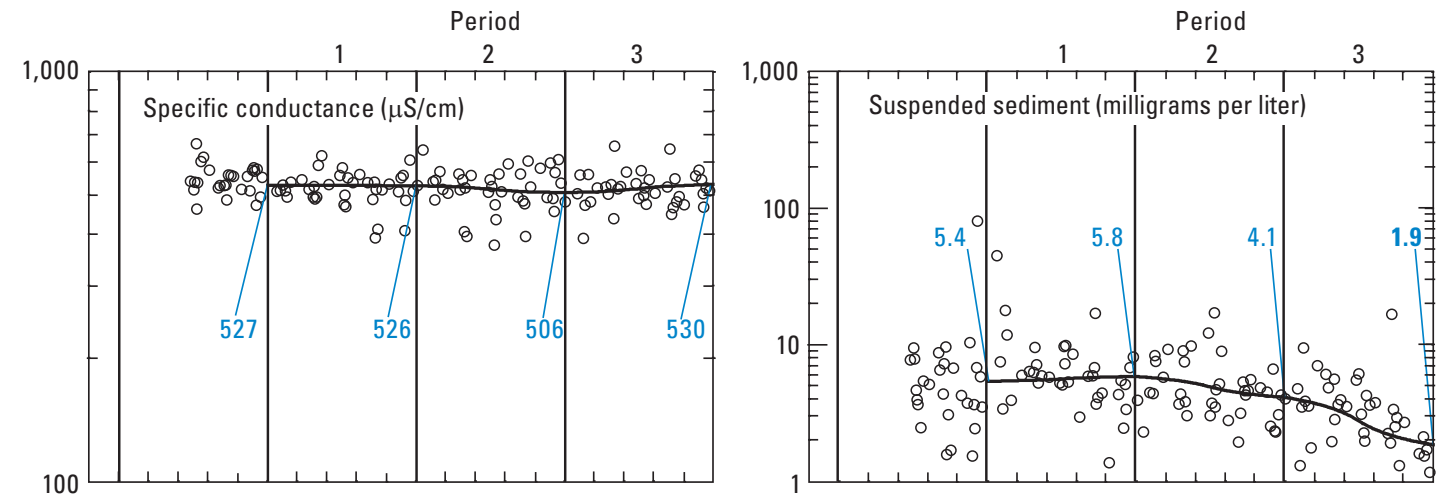

\section{EXPLANATION}

[Water year is defined as the 12-month period from October 1 through September 30 and is designated by the year in which it ends. $\mu \mathrm{S} / \mathrm{cm}$, microsiemens per

centimeter at 25 degrees Celsius; $p$-value,

statistical probability level]

- Flow-adjusted concentration (FAC) determined by using the time-series model

_Flow-adjusted fitted trend determined by using the time-series model
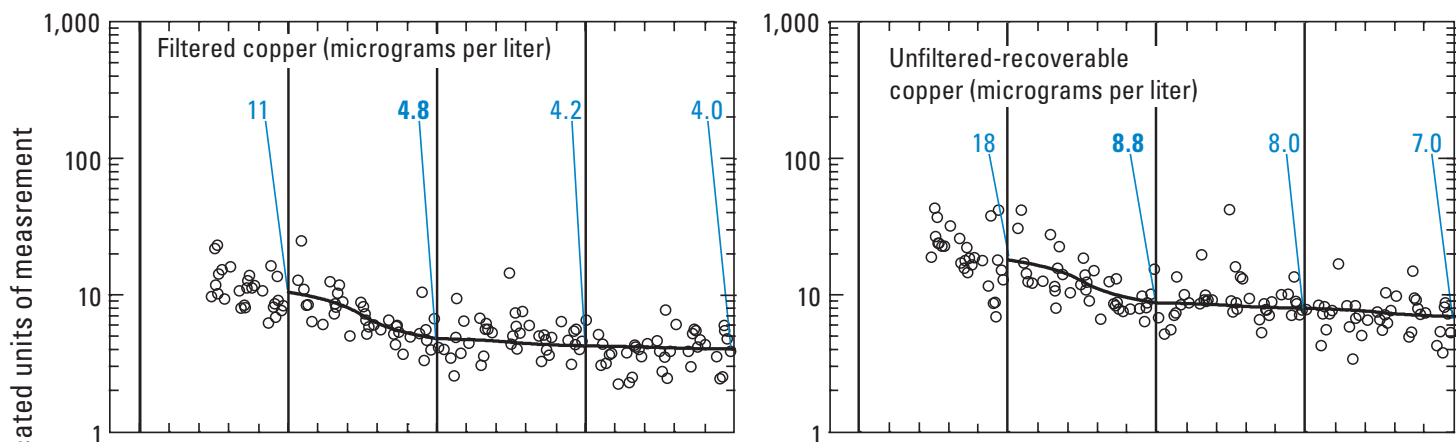

7.0 Fitted trend value at start or end of period

8.8 Bold values indicate statistical significance ( $p$-value less than $\mathbf{0 . 0 1}$ ) for period before value presented in bold
Filtered zinc (micrograms per liter)

Results not reported because greater than 6 percent of values were affected by recensoring at study reporting level, as discussed in the section of this report "Time-Series Model."

[Graph included as a place holder to assist in comparison with other stations.]

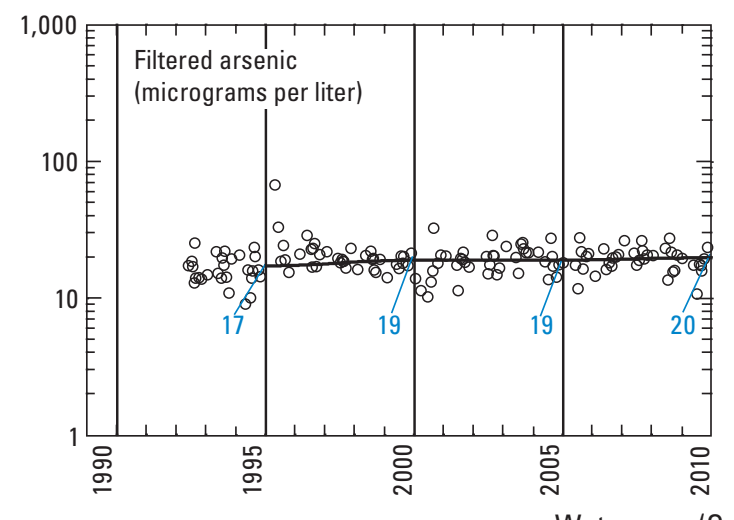

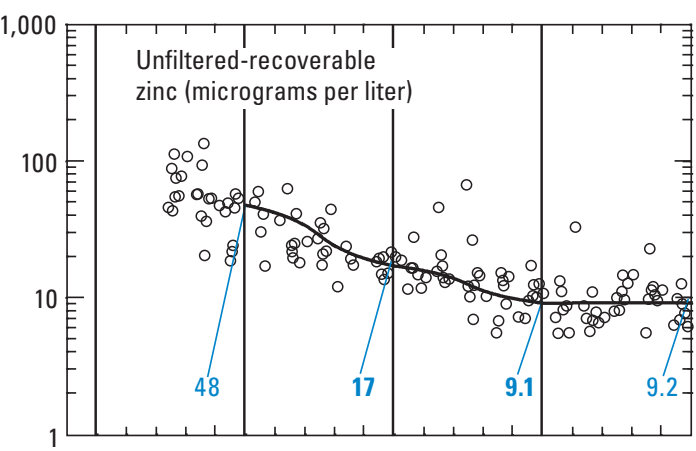

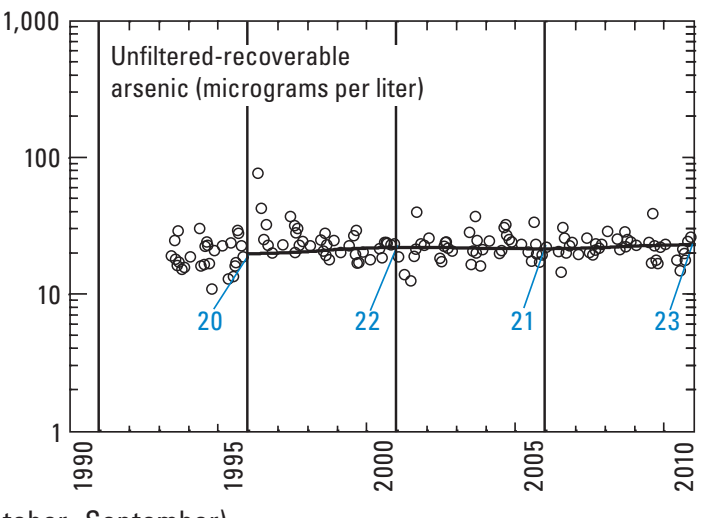

Figure 4-8. Flow-adjusted fitted trends determined by using the time-series model (TSM) for selected water-quality constituents and properties for Silver Bow Creek at Warm Springs (site 8, fig. 1, table 1), water years 1996-2010. 

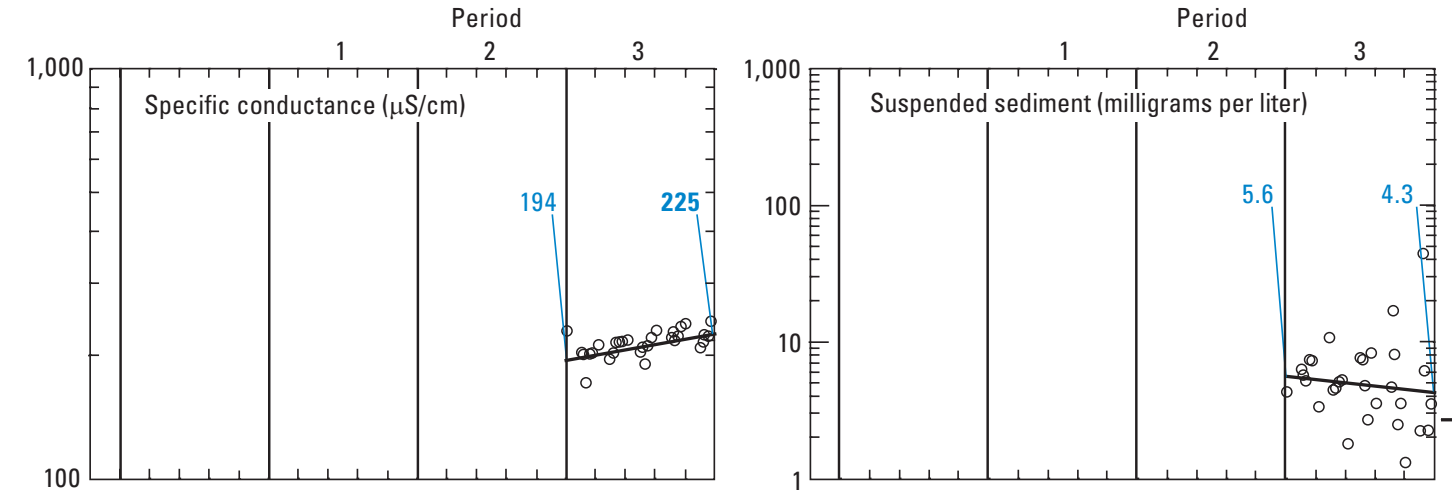

EXPLANATION

Water year is defined as the 12-month period from October 1 through September 30 and is designated by the year in which it ends. $\mu \mathrm{S} / \mathrm{cm}$, microsiemens per

centimeter at 25 degrees Celsius; $p$-value, statistical probability level]

- Flow-adjusted concentration (FAC) determined by using multiple linear regression

- Flow-adjusted fitted trend determined by using multiple linear regression
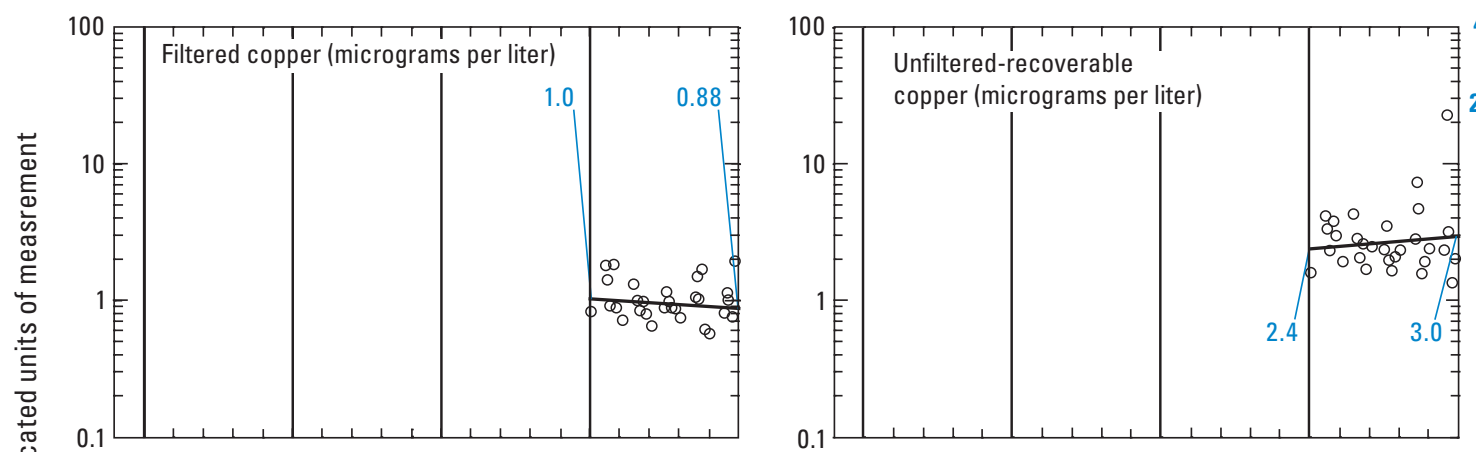

4.3 Fitted trend value at start or end of period

225 Bold values indicate statistical significance ( $p$-value less than 0.01 ) for period before value presented in bold

Filtered zinc (micrograms per liter) 45 percent of values were censored.

[Graph included as a place holder to assist in comparison with other stations.]
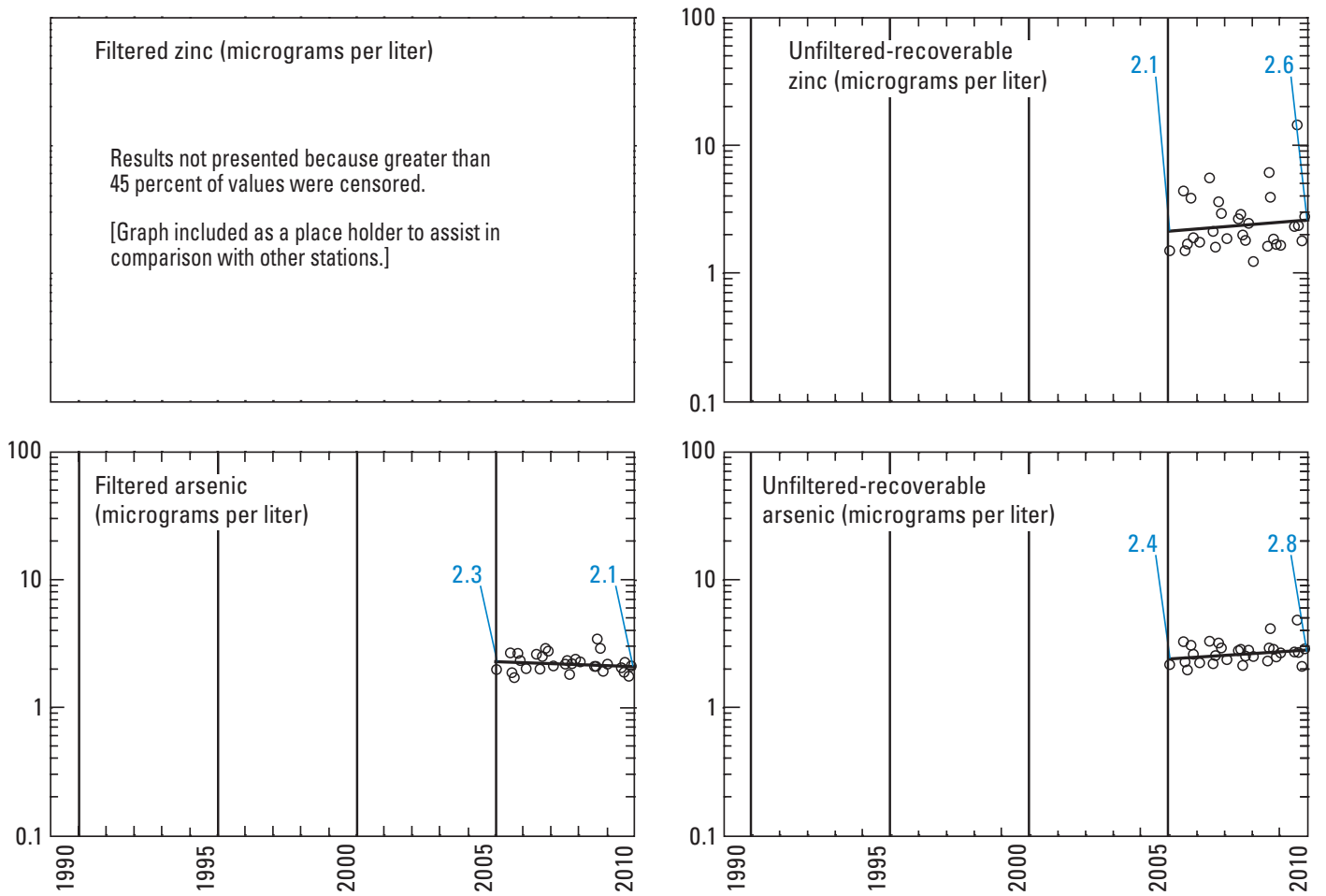

Water year (October-September)

Figure 4-9. Flow-adjusted fitted trends determined by using multiple linear regression on time, discharge, and season (MLR) for selected water-quality constituents and properties for Warm Springs Creek near Anaconda (site 9, fig. 1, table 1), water years 2006-10. 

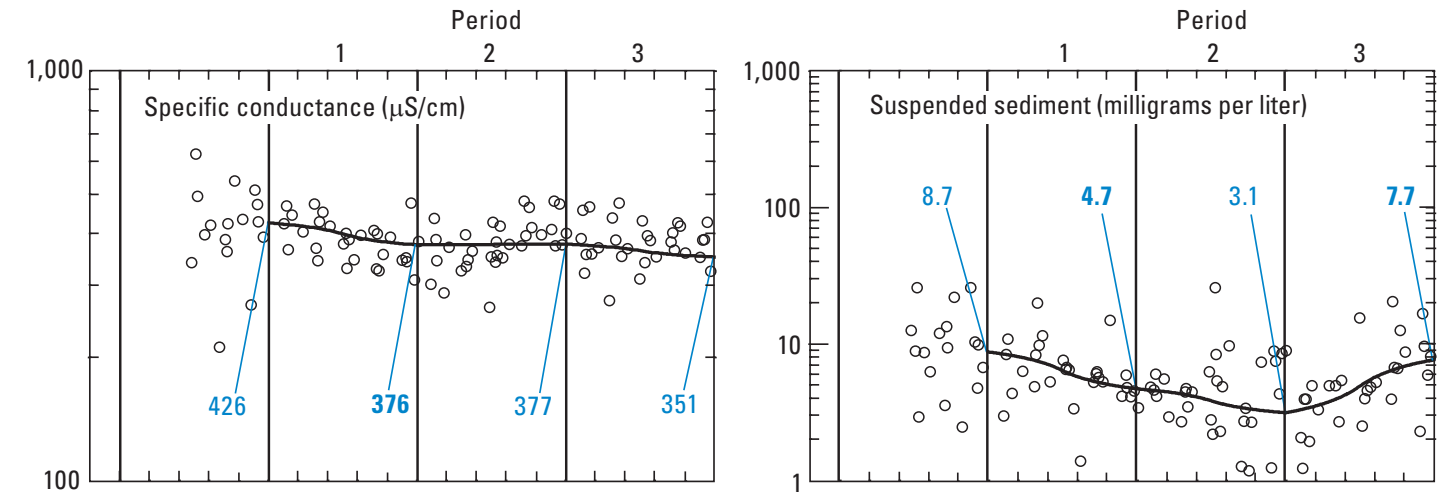

\section{EXPLANATION}

[Water year is defined as the 12-month period from October 1 through September 30 and is designated by the year in which it ends. $\mu \mathrm{S} / \mathrm{cm}$, microsiemens per centimeter at 25 degrees Celsius; $p$-value, statistical probability level]

- Flow-adjusted concentration (FAC) determined by using the time-series model
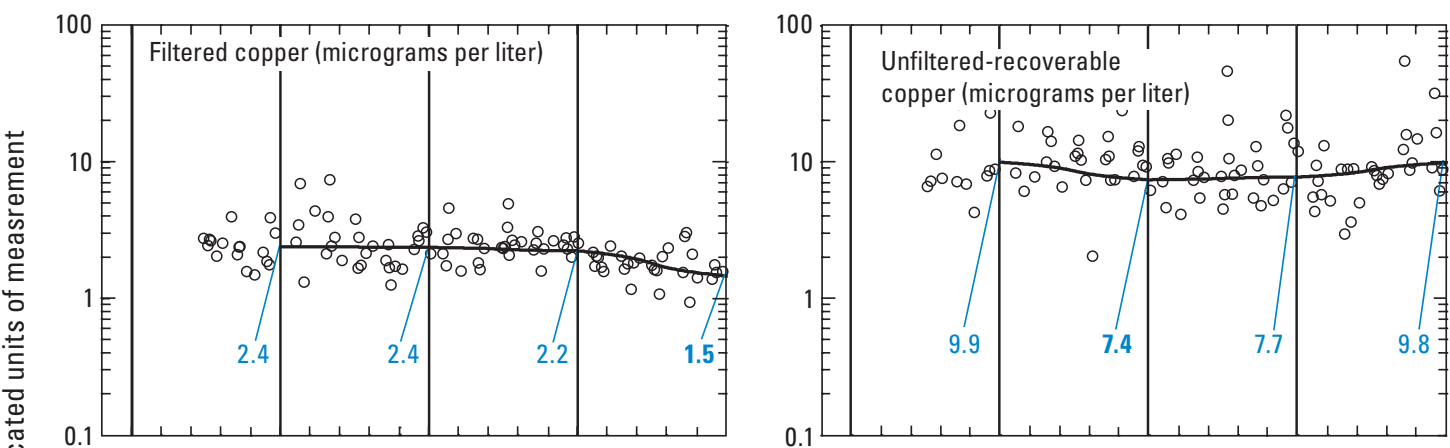

- Flow-adjusted fitted trend determined by using the time-series model

3.1 Fitted trend value at start or end of period

7.7 Bold values indicate statistical significance ( $p$-value less than $\mathbf{0 . 0 1 )}$ for period before value presented in bold

Unfiltered-recoverable zinc (micrograms per liter)

Results not reported because greater than 6 percent of values were affected by recensoring at study reporting level, as discussed in the section of this report "Time-Series Model."

[Graph included as a place holder to assist in comparison with other stations.]

[Graph included as a place holder to assist in comparison with other stations.]

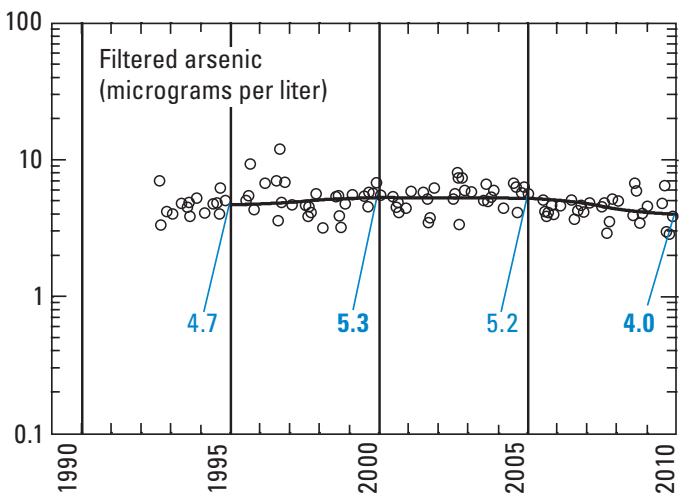

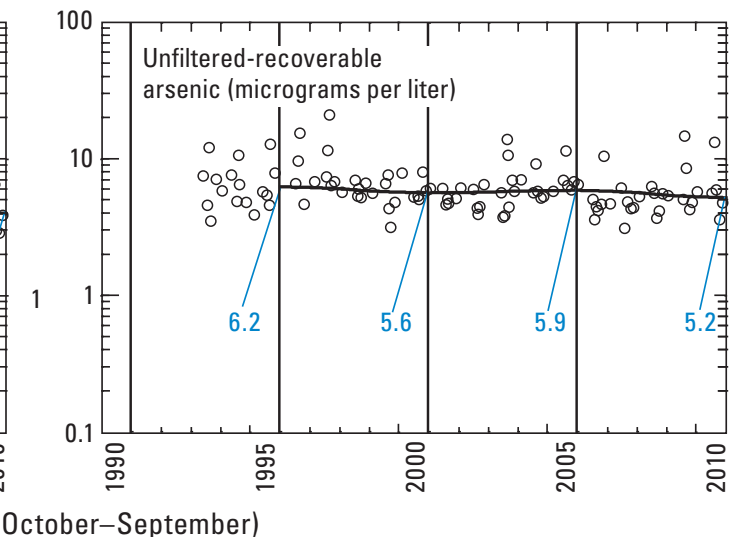

Figure 4-10. Flow-adjusted fitted trends determined by using the time-series model (TSM) for selected water-quality constituents and properties for Warm Springs Creek at Warm Springs (site 10, fig. 1, table 1), water years 1996-10. 

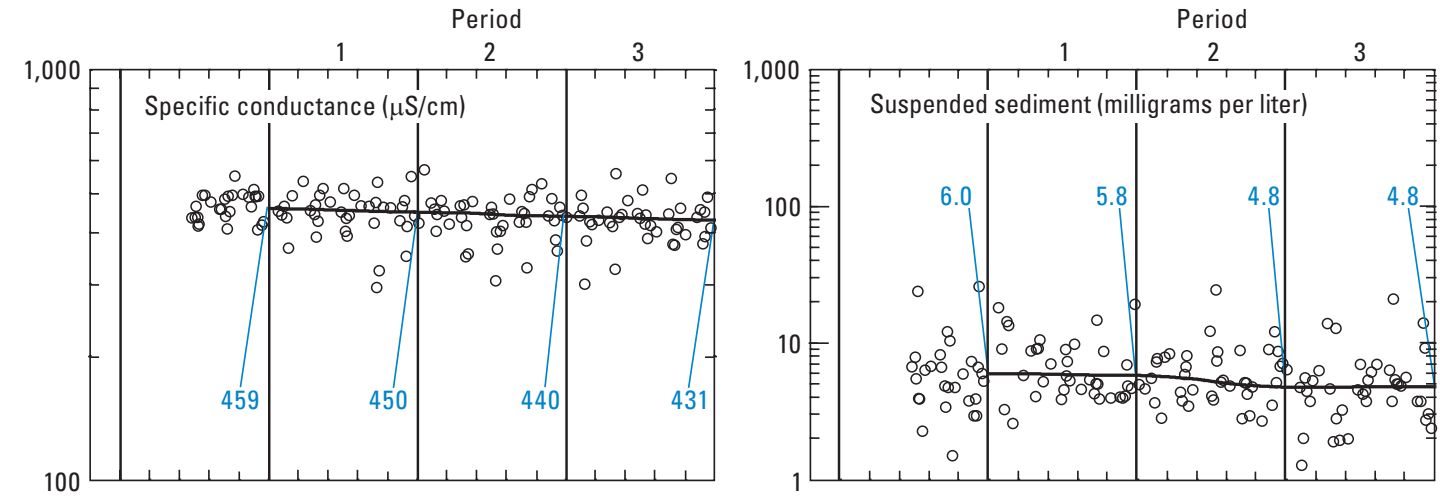

\section{EXPLANATION}

[Water year is defined as the 12-month period from October 1 through September 30 and is designated by the year in which it ends. $\mu \mathrm{S} / \mathrm{cm}$, microsiemens per centimeter at 25 degrees Celsius; $p$-value, statistical probability level]

- Flow-adjusted concentration (FAC) determined by using the time-series model

- Flow-adjusted fitted trend determined by using the time-series model
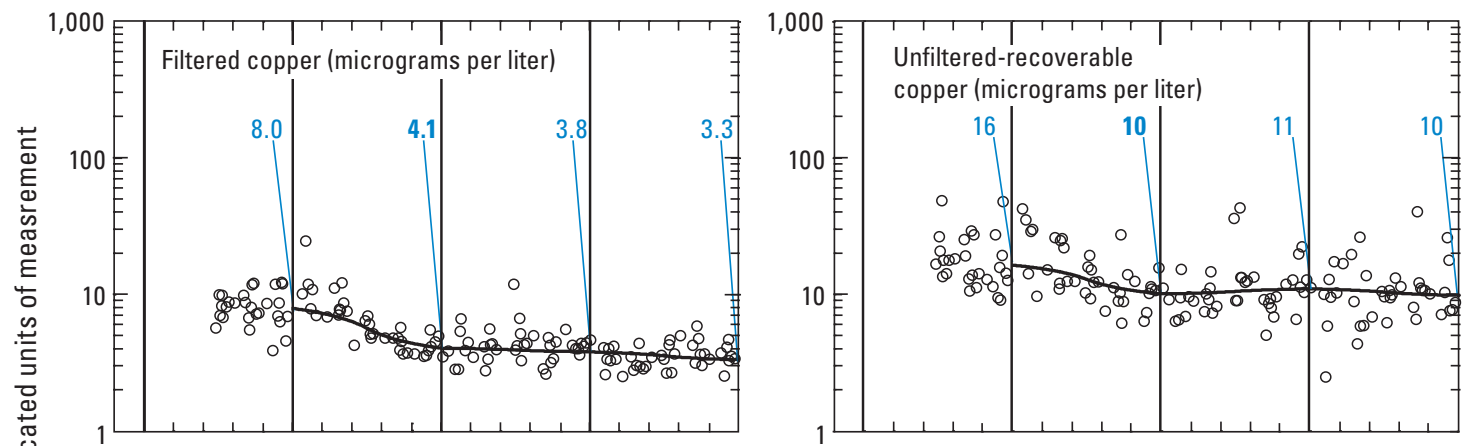

4.8 Fitted trend value at start or end of period

10 Bold values indicate statistical significance ( $p$-value less than $\mathbf{0 . 0 1 )}$ for period before value presented in bold

Filtered zinc (micrograms per liter)

Results not reported because greater than

6 percent of values were affected by recensoring at study reporting level, as discussed in the section of this report "Time-Series Model."

[Graph included as a place holder to assist in comparison with other stations.]
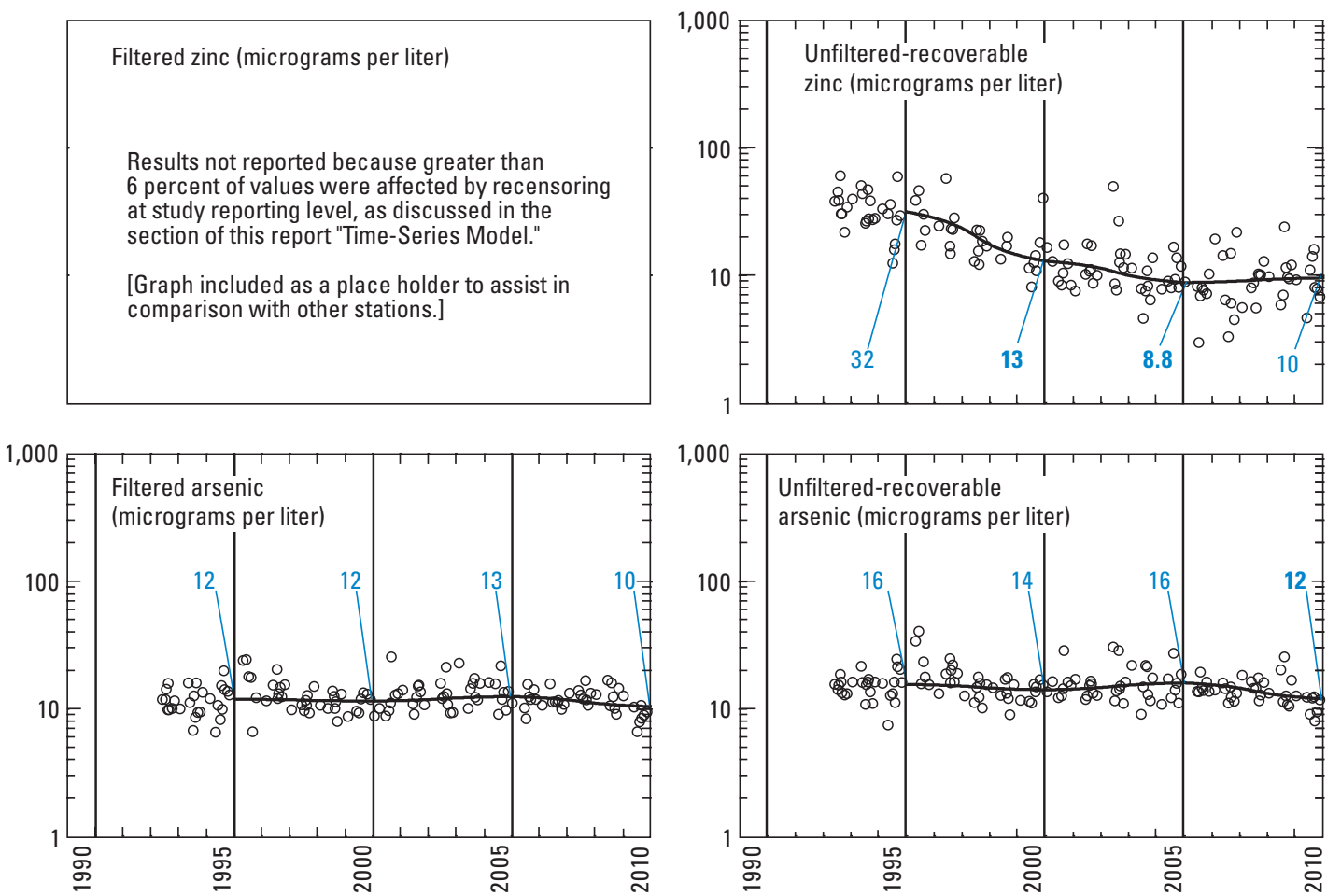

Water year (October-September)

Figure 4-11. Flow-adjusted fitted trends determined by using the time-series model (TSM) for selected water-quality constituents and properties for Clark Fork near Galen (site 11, fig. 1, table 1), water years 1996-2010. 

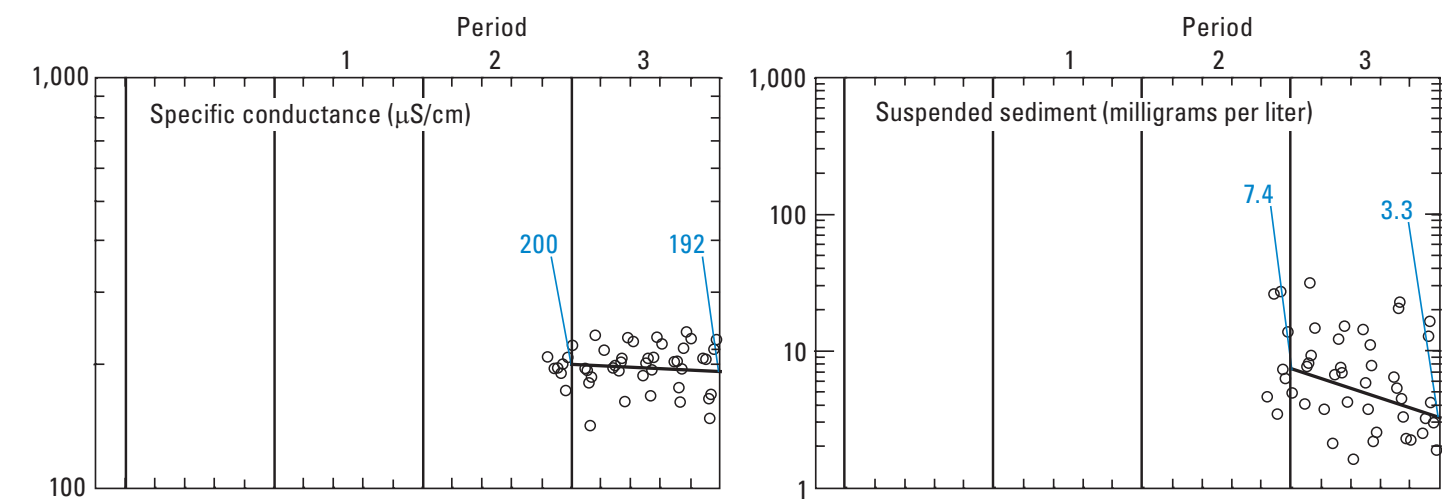

\section{EXPLANATION}

[Water year is defined as the 12-month period from October 1 through September 30 and is designated by the year in which it ends. $\mu \mathrm{S} / \mathrm{cm}$, microsiemens per

centimeter at 25 degrees Celsius; $p$-value, statistical probability level]

- Flow-adjusted concentration (FAC) determined by using multiple linear regression

Flow-adjusted fitted trend determined by using multiple linear regression
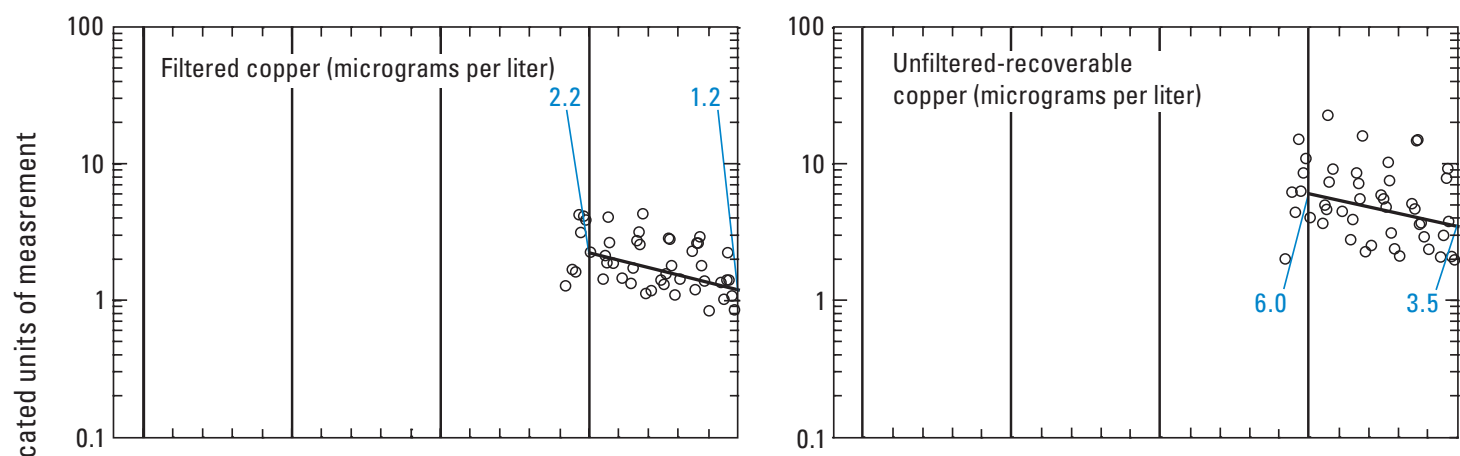

3.3 Fitted trend value at start or end of period
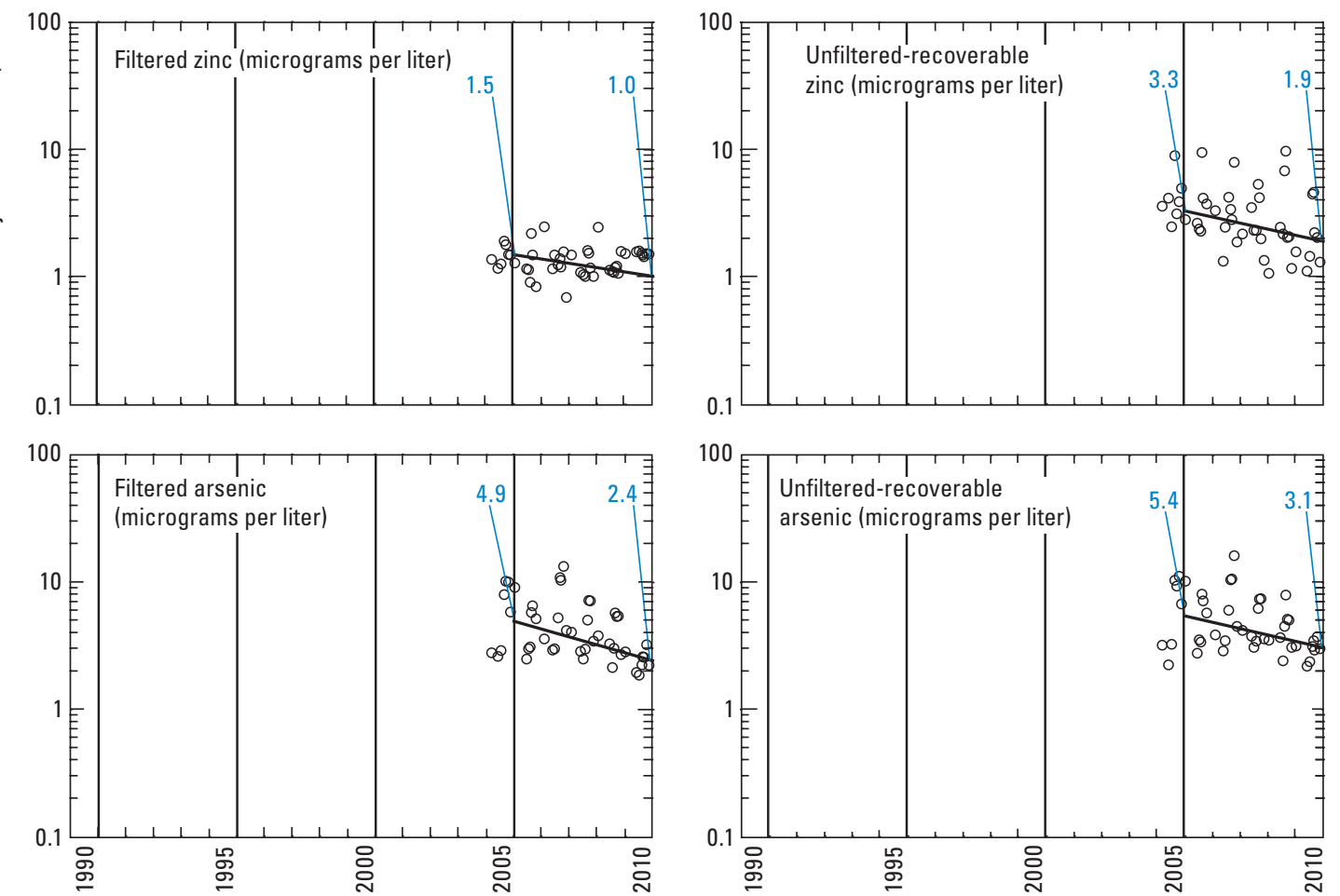

Water year (October-September)

Figure 4-12. Flow-adjusted fitted trends determined by using multiple linear regression on time, discharge, and season (MLR) for selected water-quality constituents and properties for Lost Creek near Anaconda (site 12, fig. 1, table 1), water years 2006-10. 

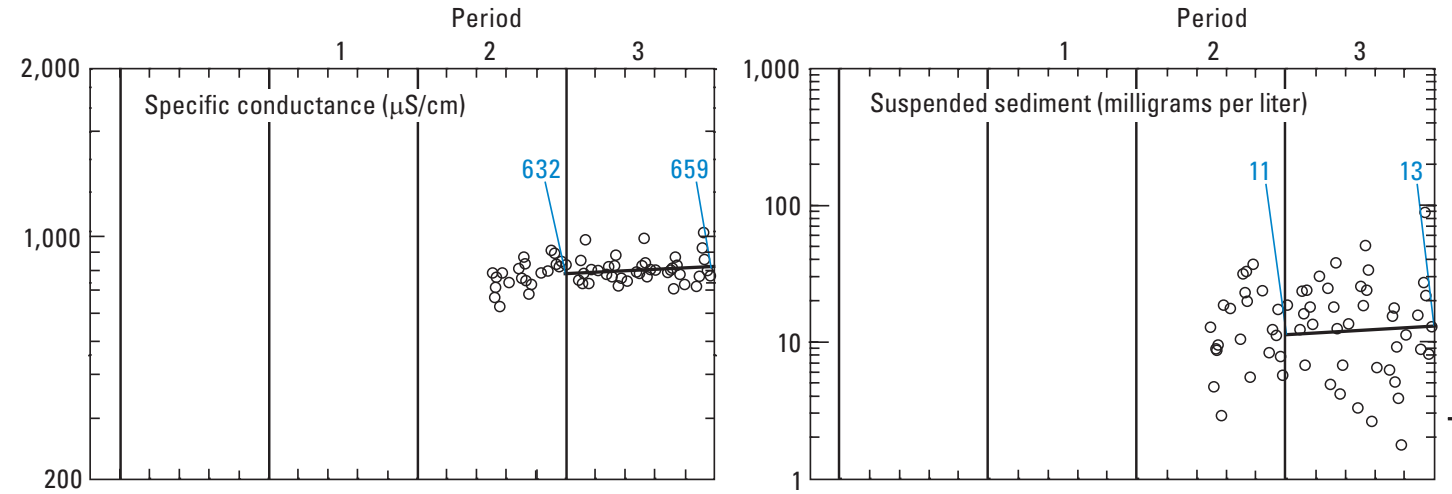

EXPLANATION

Water year is defined as the 12-month period from October 1 through September 30 and is designated by the year in which it ends. $\mu \mathrm{S} / \mathrm{cm}$, microsiemens per centimeter at 25 degrees Celsius; $p$-value, statistical probability level]

- Flow-adjusted concentration (FAC) determined by using multiple linear regression

- Flow-adjusted fitted trend determined by using the multiple linear regression
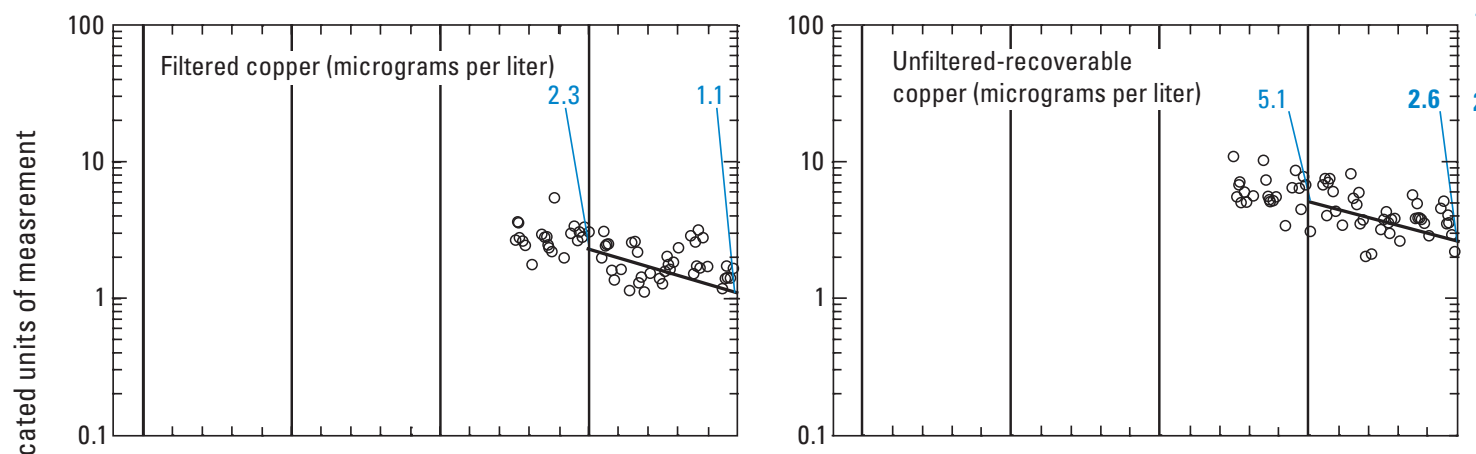

13 Fitted trend value at start or end of period

2.6 Bold values indicate statistical significance ( $p$-value less than $\mathbf{0 . 0 1 )}$ for period before value presented in bold
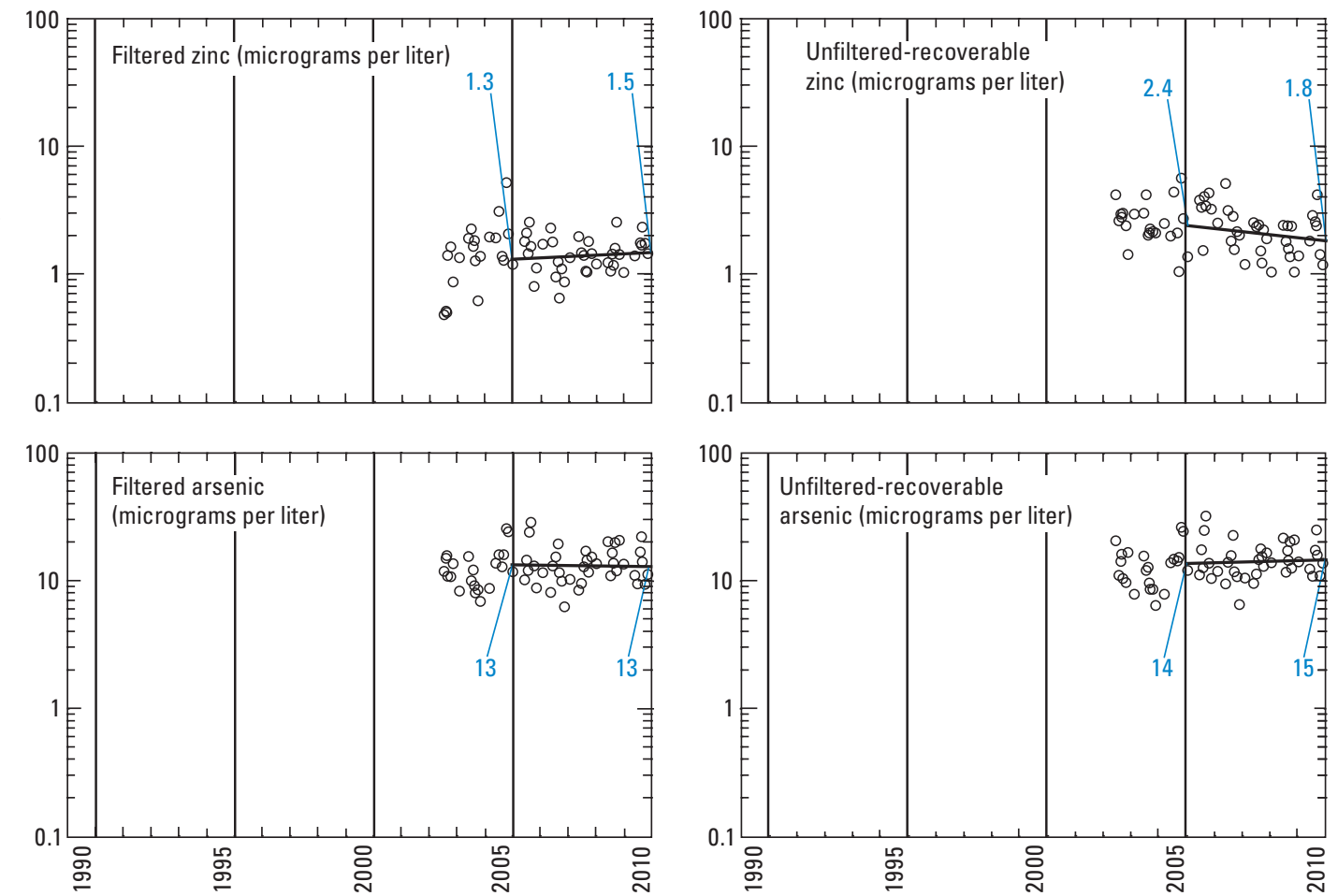

Water year (0ctober-September)

Figure 4-13. Flow-adjusted fitted trends determined by using multiple linear regression on time, discharge, and season (MLR) for selected water-quality constituents and properties for Lost Creek near Galen (site 13, fig. 1, table 1), water years 2006-10. 

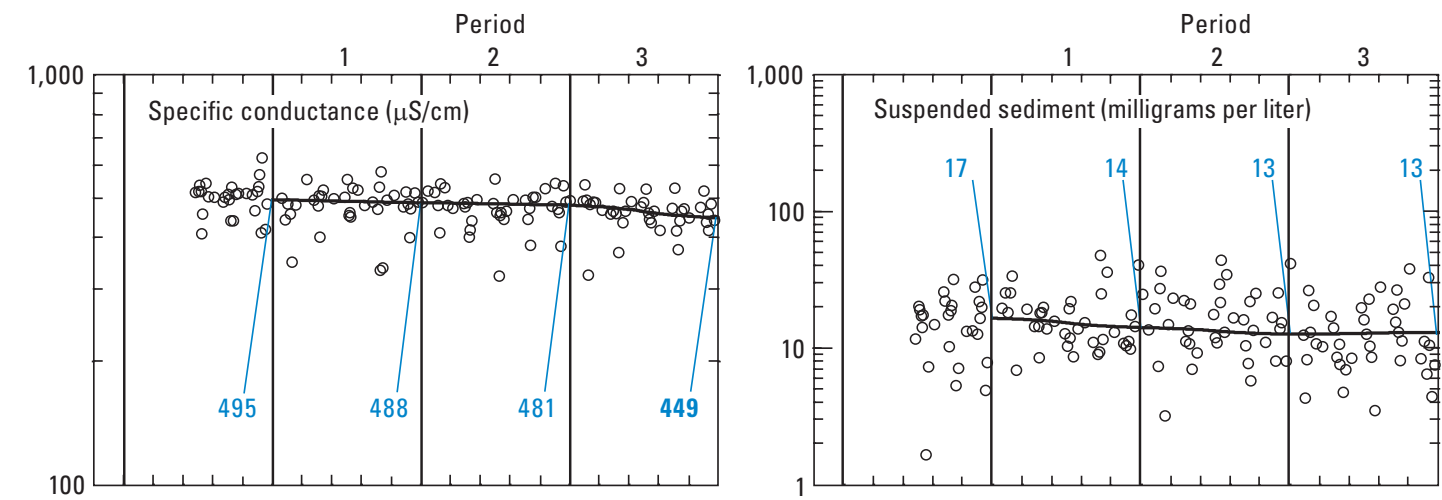

\section{EXPLANATION}

[Water year is defined as the 12-month period from October 1 through September 30 and is designated by the year in which it ends. $\mu \mathrm{S} / \mathrm{cm}$, microsiemens per

centimeter at 25 degrees Celsius; $p$-value, statistical probability level]

- Flow-adjusted concentration (FAC) determined by using the time-series model
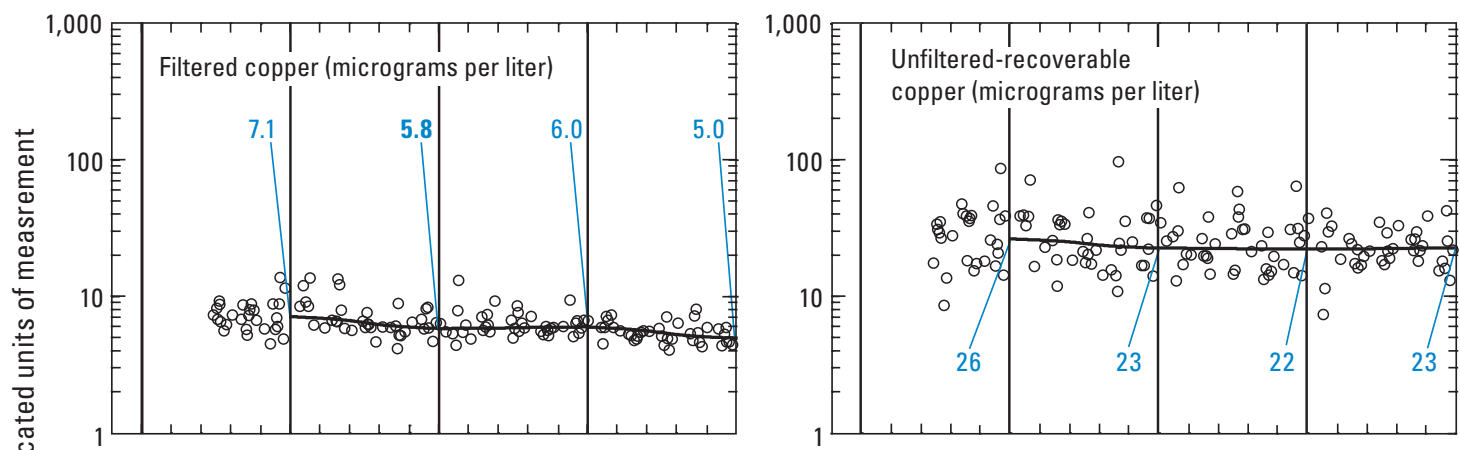

Flow-adjusted fitted trend determined by using the time-series model

13 Fitted trend value at start or end of period

23 Bold values indicate statistical significance ( $p$-value less than $\mathbf{0 . 0 1 )}$ for period before value presented in bold

Filtered zinc (micrograms per liter)

Results not reported because greater than 6 percent of values were affected by recensoring at study reporting level, as discussed in the section of this report "Time-Series Model."

[Graph included as a place holder to assist in comparison with other stations.]
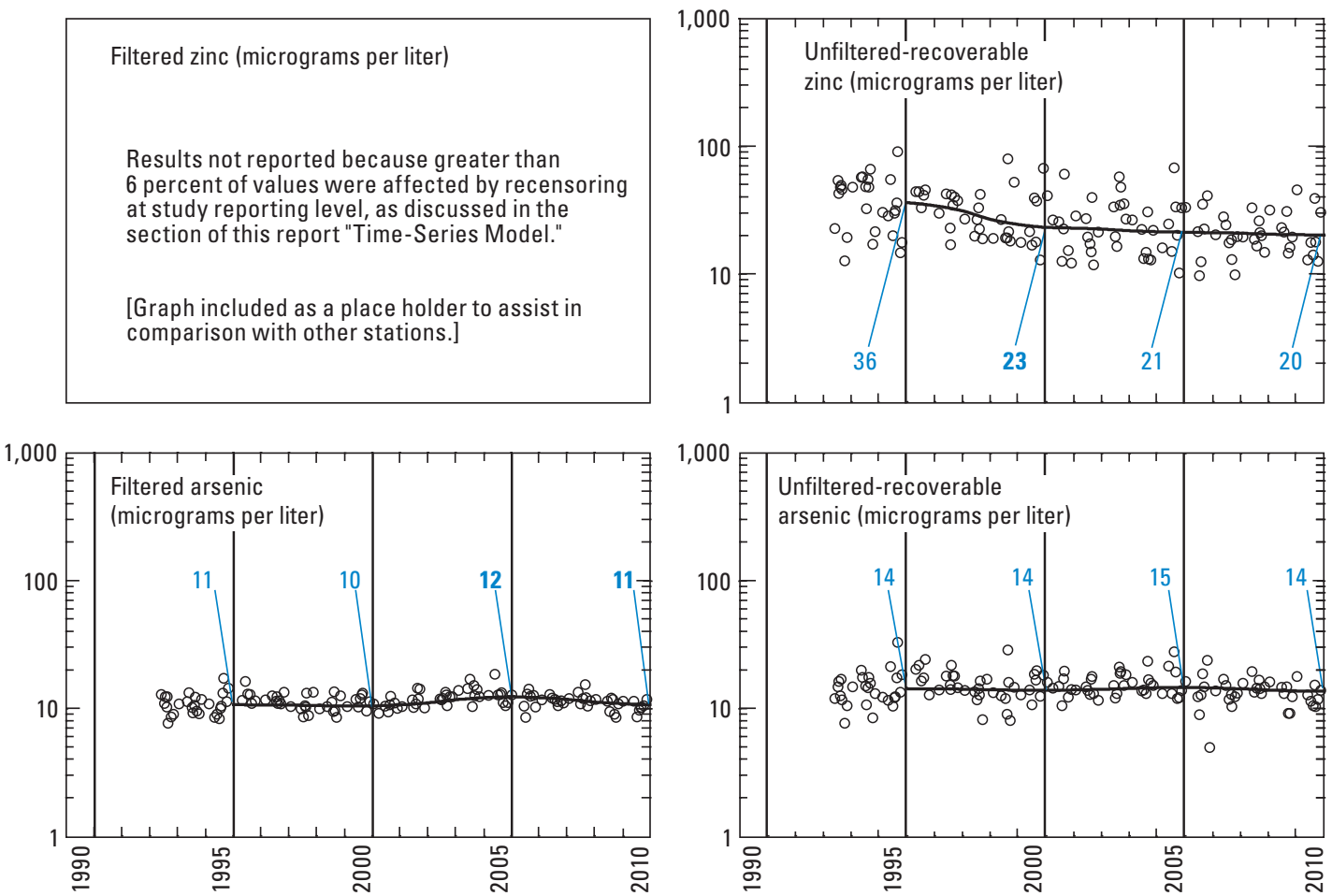

Water year (October-September)

Figure 4-14. Flow-adjusted fitted trends determined by using the time-series model (TSM) for selected water-quality constituents and properties for Clark Fork at Deer Lodge (site 14, fig. 1, table 1), water years 1996-2010. 

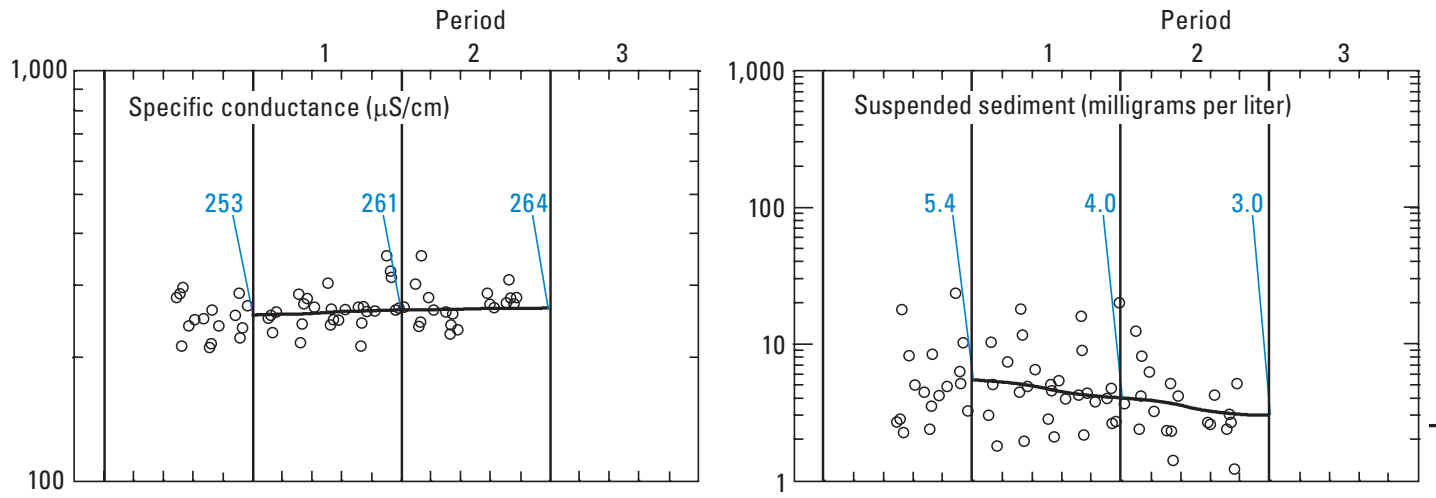

\section{EXPLANATION}

[Water year is defined as the 12-month period from October 1 through Septembe 30 and is designated by the year in which it ends. $\mu \mathrm{S} / \mathrm{cm}$, microsiemens per centimeter at 25 degrees Celsius; $p$-value, statistical probability level]

- Flow-adjusted concentration (FAC) determined by using the time-series model

- Flow-adjusted fitted trend determined by using the time-series model
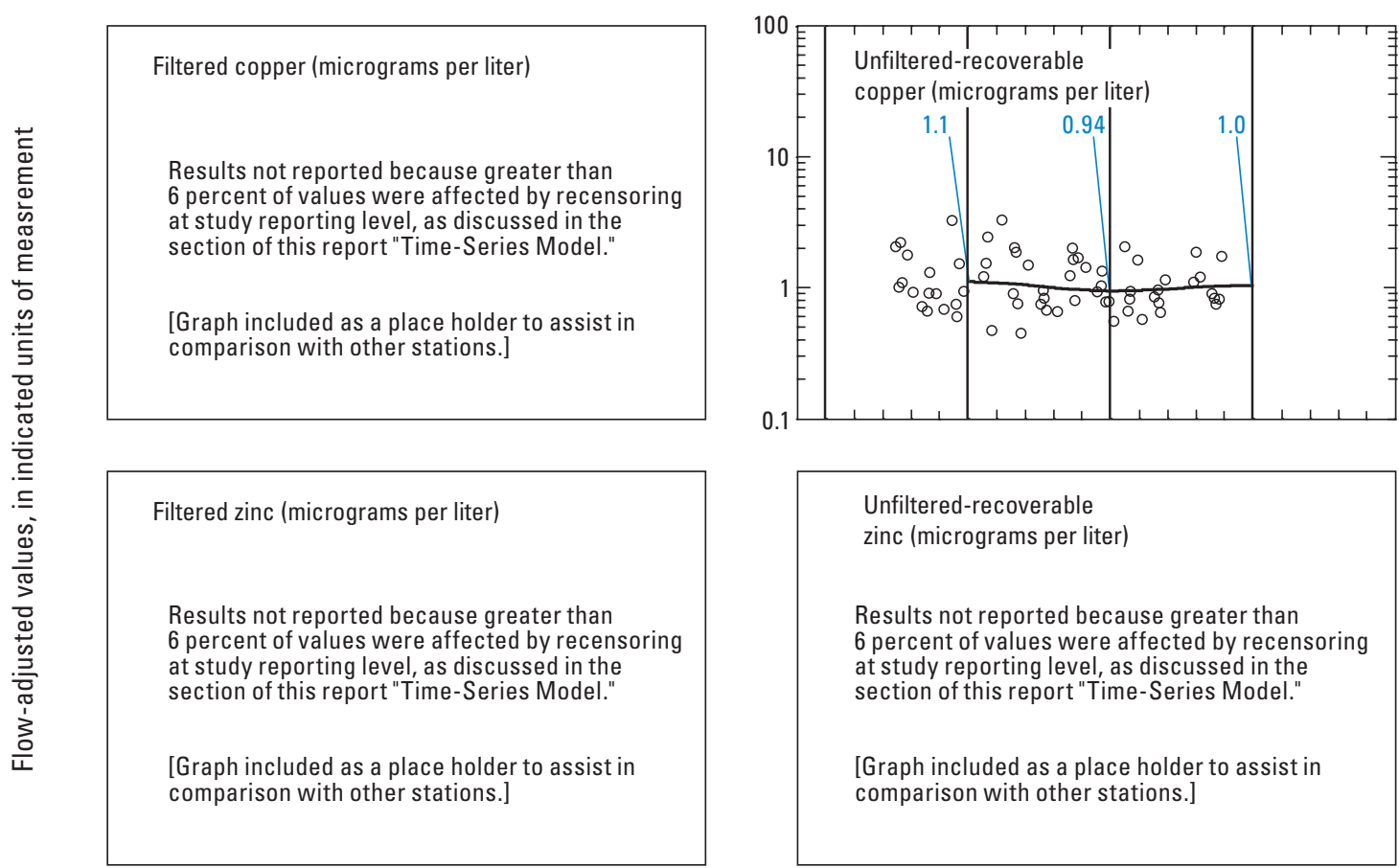

1.0 Fitted trend value at start or end of period

5.0 Bold values indicate statistical significance ( $p$-value less than 0.01 ) for period before value presented in bold

Unfiltered-recoverable zinc (micrograms per liter)

Results not reported because greater than 6 percent of values were affected by recensoring at study reporting level, as discussed in the section of this report "Time-Series Model."

[Graph included as a place holder to assist in comparison with other stations.]

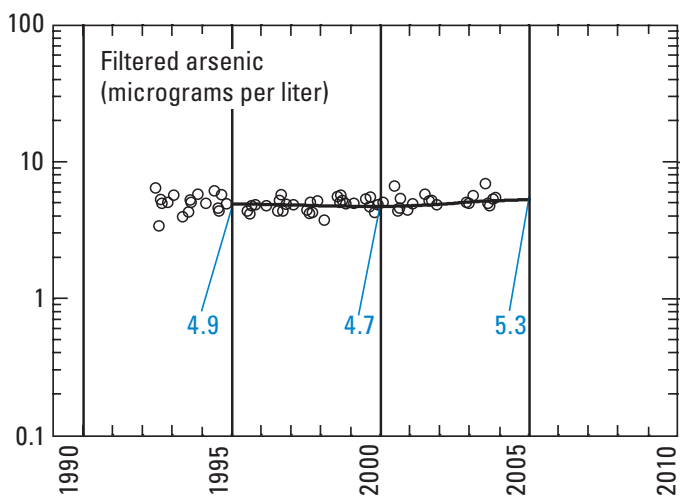

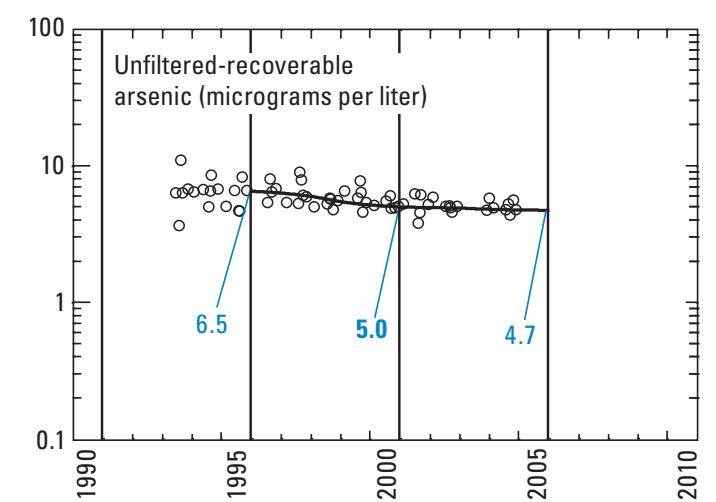

Water year (October-September)

Figure 4-15. Flow-adjusted fitted trends determined by using the time-series model (TSM) for selected water-quality constituents and properties for Little Blackfoot River (site 15, fig. 1, table 1), water years 1996-2005. 

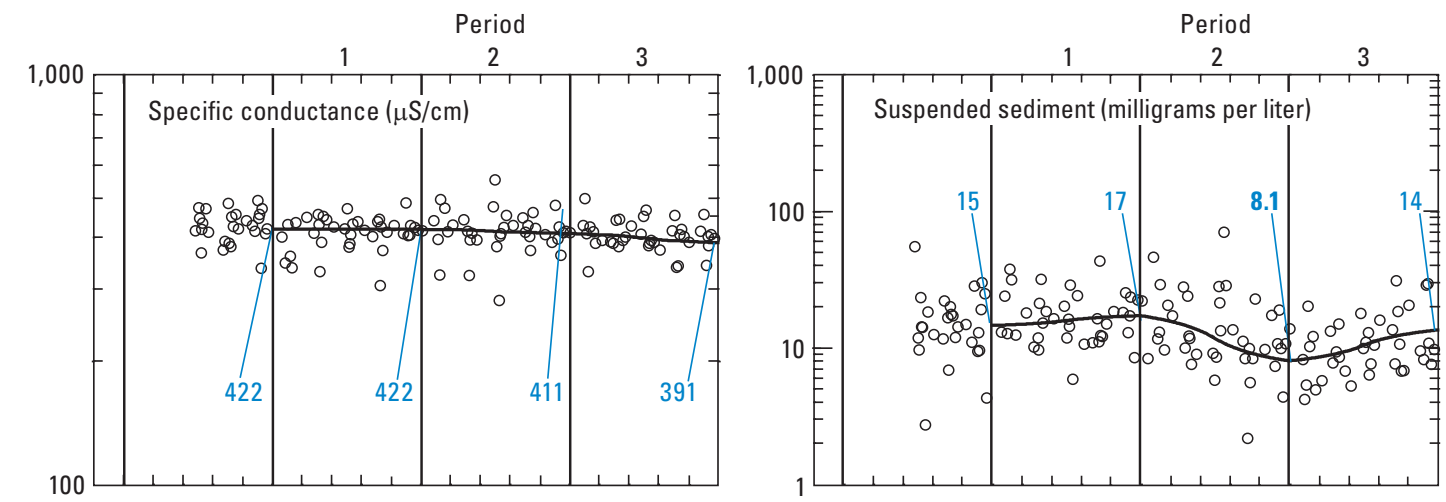

\section{EXPLANATION}

[Water year is defined as the 12-month period from October 1 through September 30 and is designated by the year in which it ends. $\mu \mathrm{S} / \mathrm{cm}$, microsiemens per

centimeter at 25 degrees Celsius; $p$-value, statistical probability level]

- Flow-adjusted concentration (FAC) determined by using the time-series model
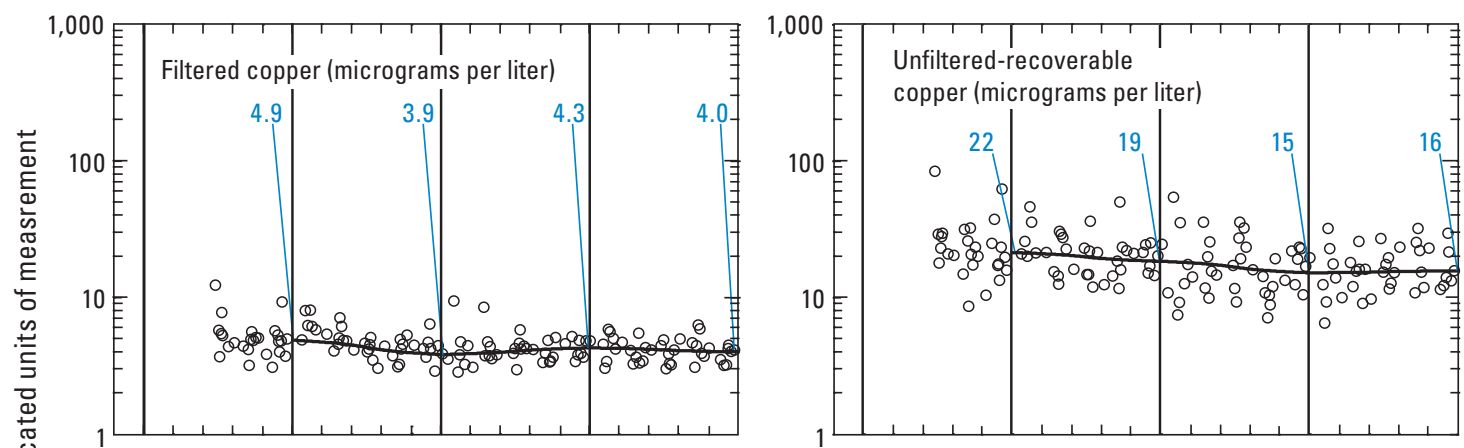

Flow-adjusted fitted trend determined by using the time-series model

16 Fitted trend value at start or end of period

8.1 Bold values indicate statistical significance ( $p$-value less than $\mathbf{0 . 0 1}$ ) for period before value presented in bold

Filtered zinc (micrograms per liter)

Results not reported because greater than
6 percent of values were affected by recensoring at study reporting level, as discussed in the section of this report "Time-Series Model."

[Graph included as a place holder to assist in comparison with other stations.]
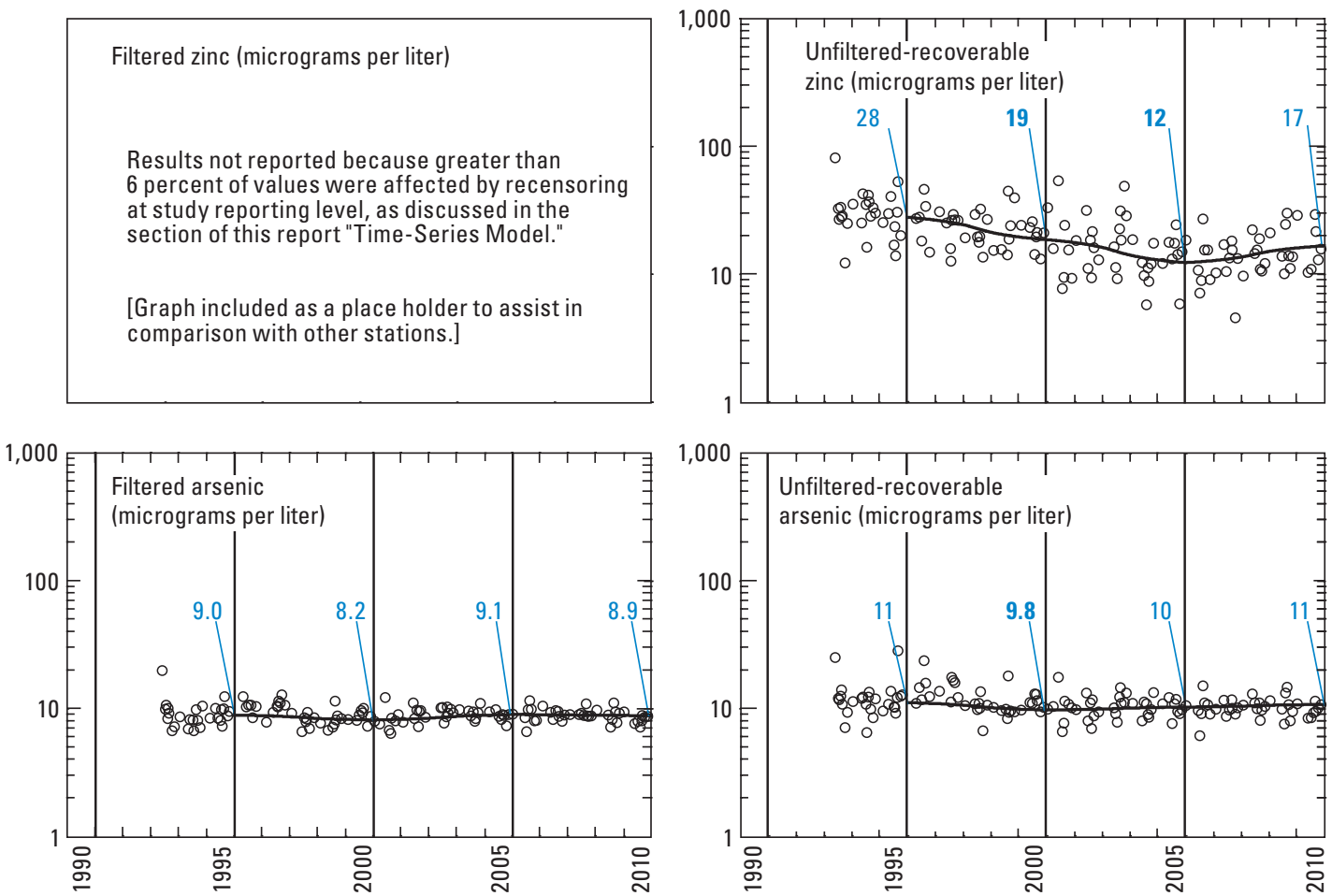

Water year (October-September)

Figure 4-16. Flow-adjusted fitted trends determined by using the time-series model (TSM) for selected water-quality constituents and properties for Clark Fork at Goldcreek (site 16, fig. 1, table 1), water years 1996-2010. 

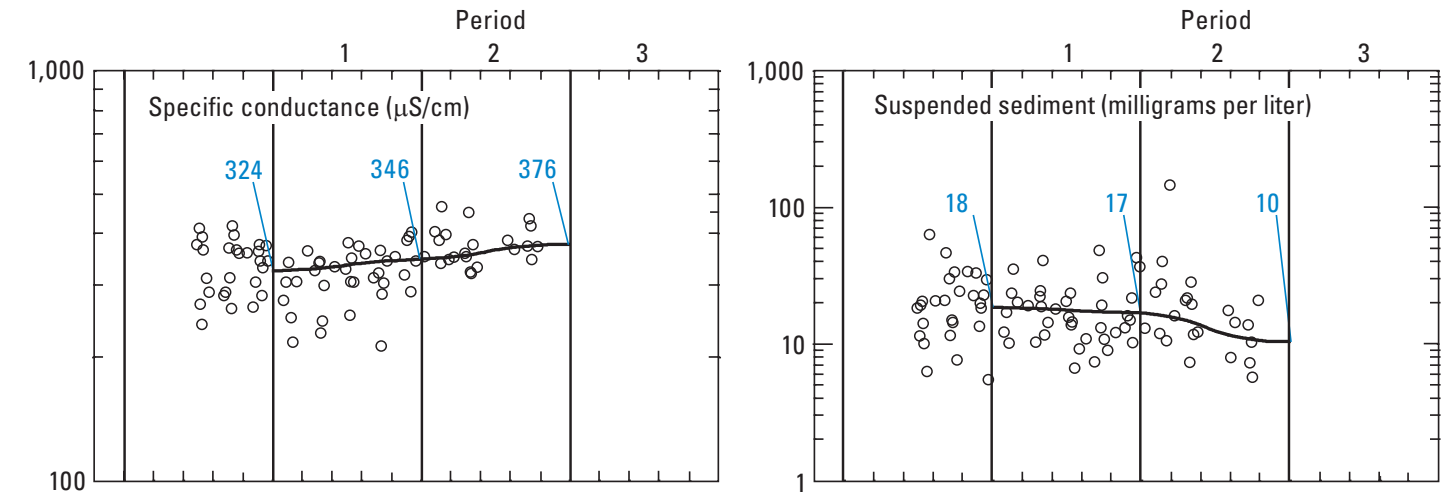

\section{EXPLANATION}

[Water year is defined as the 12-month period from October 1 through September 30 and is designated by the year in which it ends. $\mu \mathrm{S} / \mathrm{cm}$, microsiemens per centimeter at 25 degrees Celsius; $p$-value, statistical probability level]

- Flow-adjusted concentration (FAC) determined by using the time-series model

Filtered copper (micrograms per liter)

Results not reported because greater than 6 percent of values were affected by recensoring at study reporting level, as discussed in the section of this report "Time-Series Model."

[Graph included as a place holder to assist in comparison with other stations.]

Filtered zinc (micrograms per liter)

Results not reported because greater than 6 percent of values were affected by recensoring at study reporting level, as discussed in the section of this report "Time-Series Model."

[Graph included as a place holder to assist in comparison with other stations.]

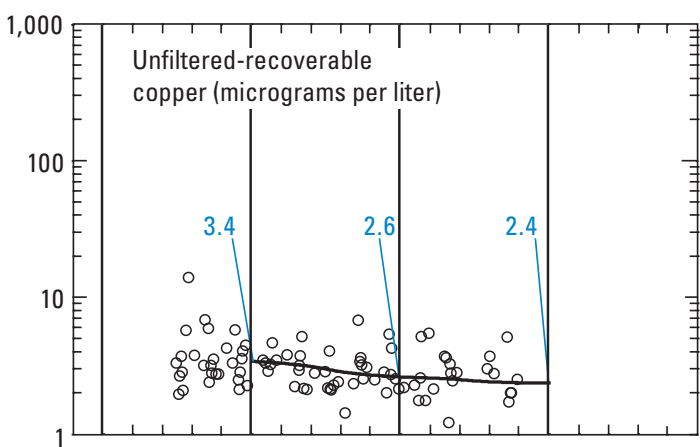

low-adjusted fitted trend determined by using the time-series model

2.4 Fitted trend value at start or end of period

11 Bold values indicate statistical significance ( $p$-value less than 0.01 ) for period before value presented in bold
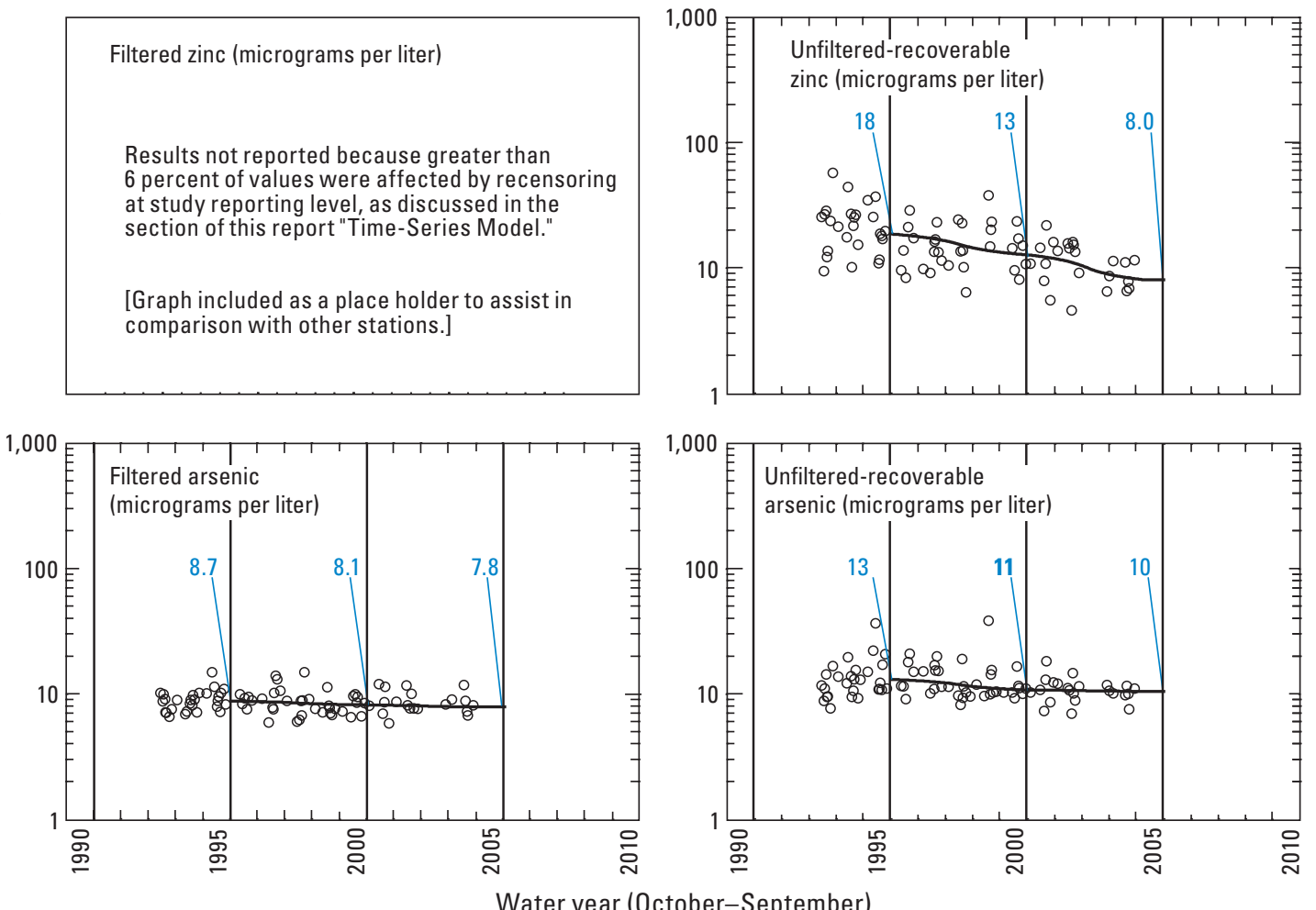

Figure 4-17. Flow-adjusted fitted trends determined by using the time-series model (TSM) for selected water-quality constituents and properties for Flint Creek (site 17, fig. 1, table 1), water years 1996-2005. 

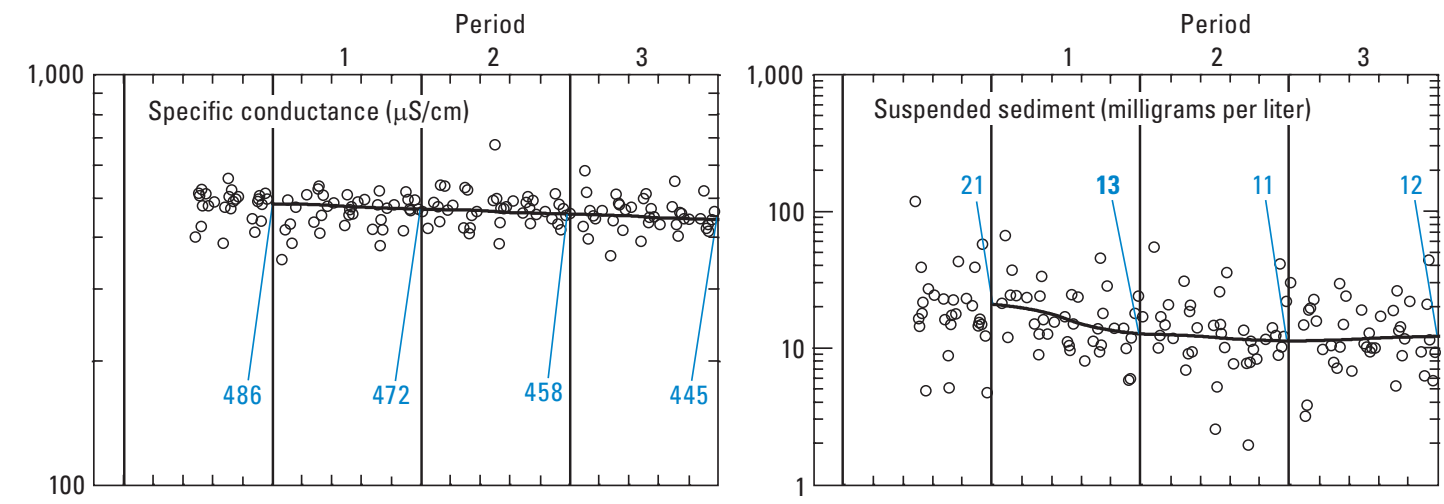

\section{EXPLANATION}

[Water year is defined as the 12-month period from October 1 through September 30 and is designated by the year in which it ends. $\mu \mathrm{S} / \mathrm{cm}$, microsiemens per centimeter at 25 degrees Celsius; $p$-value, statistical probability level]

Flow-adjusted concentration (FAC) determined by using the time-series model
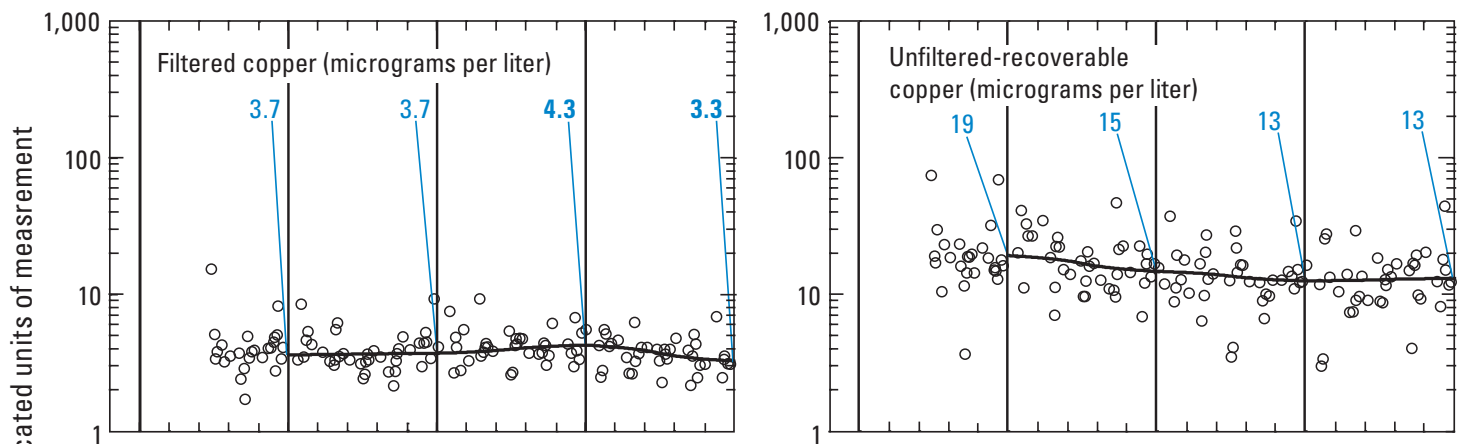

- Flow-adjusted fitted trend determined by using the time-series model

13 Fitted trend value at start or end of period

15 Bold values indicate statistical significance ( $p$-value less than $\mathbf{0 . 0 1}$ ) for period before value presented in bold

Filtered zinc (micrograms per liter)

Results not reported because greater than 6 percent of values were affected by recensoring at study reporting level, as discussed in the section of this report "Time-Series Model."

[Graph included as a place holder to assist in comparison with other stations.]
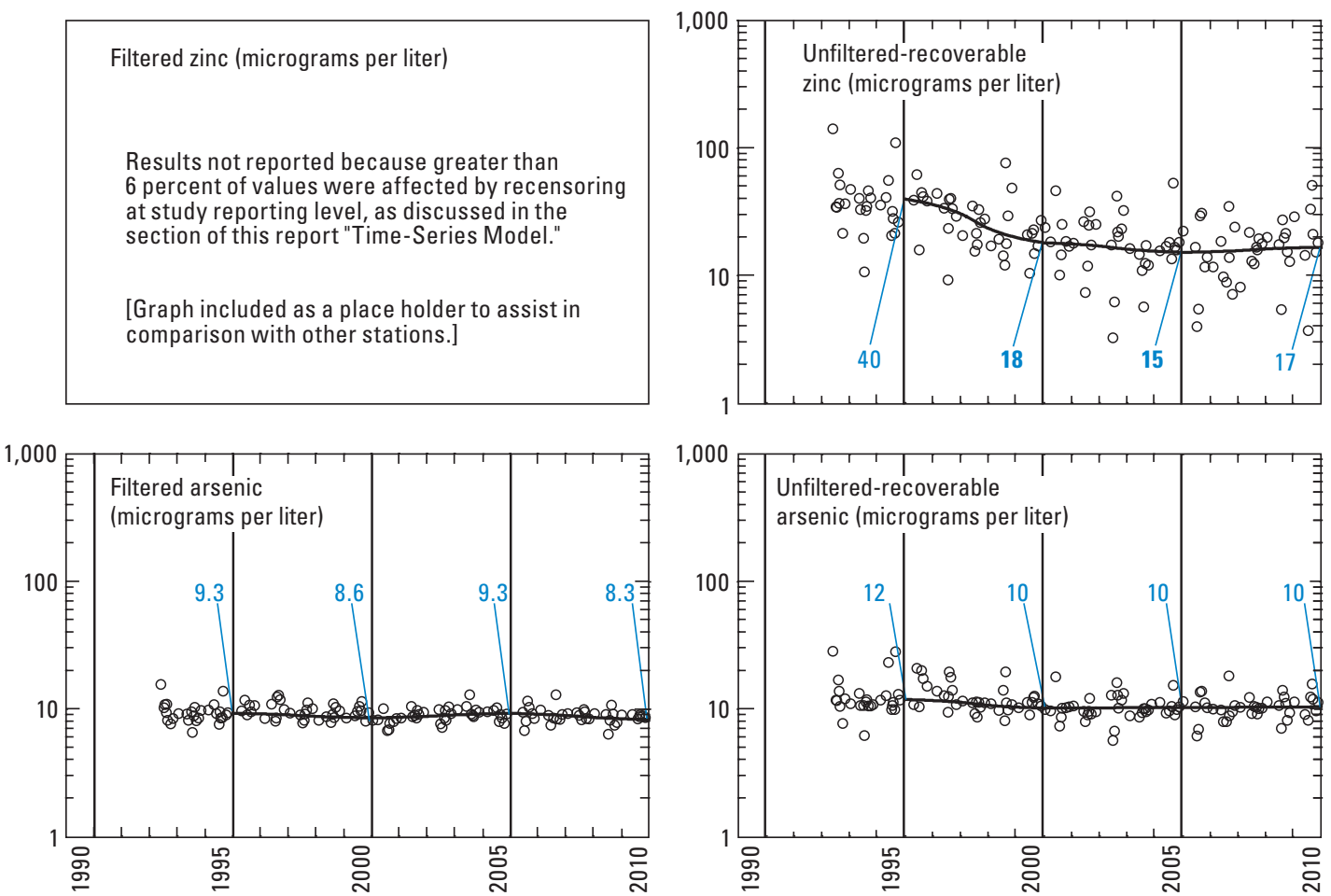

Water year (October-September)

Figure 4-18. Flow-adjusted fitted trends determined by using the time-series model (TSM) for selected water-quality constituents and properties for Clark Fork near Drummond (site 18, fig. 1, table 1), water years 1996-2010. 


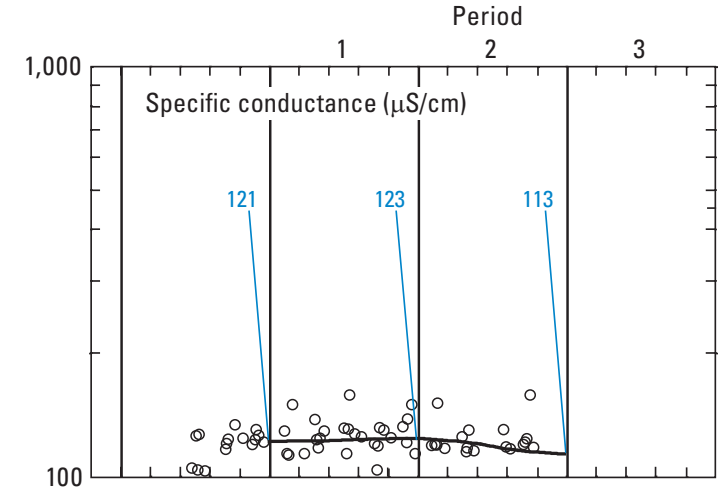

Filtered copper (micrograms per liter)

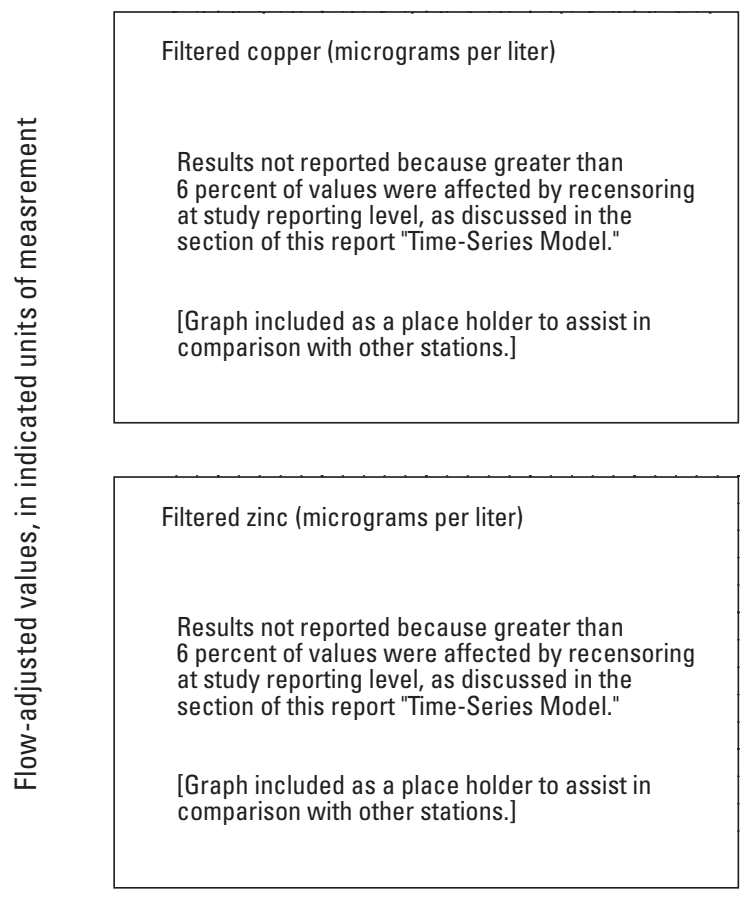

Filtered arsenic

(micrograms per liter)

Results not reported because greater than 6 percent of values were affected by recensoring at study reporting level, as discussed in the section of this report "Time-Series Model."

[Graph included as a place holder to assist in comparison with other stations.]

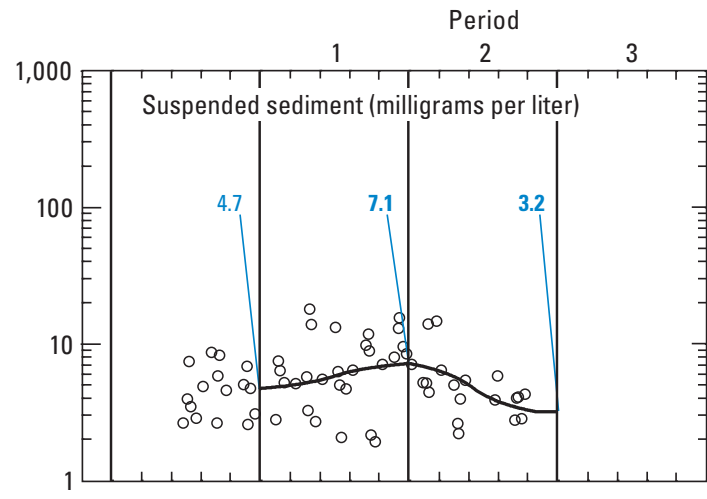

Unfiltered-recoverable

copper (micrograms per liter)

Results not reported because greater than 6 percent of values were affected by recensoring at study reporting level, as discussed in the section of this report "Time-Series Model."

[Graph included as a place holder to assist in comparison with other stations.]

Unfiltered-recoverable zinc (micrograms per liter)

Results not reported because greater than 6 percent of values were affected by recensoring at study reporting level, as discussed in the section of this report "Time-Series Model."

[Graph included as a place holder to assist in comparison with other stations.]

Unfiltered-recoverable zinc (micrograms per liter)

Results not reported because greater than 6 percent of values were affected by recensoring at study reporting level, as discussed in the section of this report "Time-Series Model."

[Graph included as a place holder to assist in comparison with other stations.]

\section{EXPLANATION}

[Water year is defined as the 12-month period from October 1 through September 30 and is designated by the year in which it ends. $\mu \mathrm{S} / \mathrm{cm}$, microsiemens per centimeter at 25 degrees Celsius; $p$-value, statistical probability level]

- Flow-adjusted concentration (FAC) determined by using the time-series model

- Flow-adjusted fitted trend determined by using the time-series model

4.7 Fitted trend value at start or end of period

7.1 Bold values indicate statistical significance ( $p$-value less than 0.01 ) for period before value presented in bold

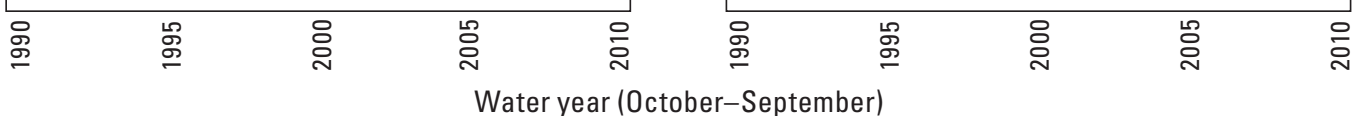

Figure 4-19. Flow-adjusted fitted trends determined by using the time-series model (TSM) for selected water-quality constituents and properties for Rock Creek (site19, fig. 1, table 1), water years 1996-2005. 

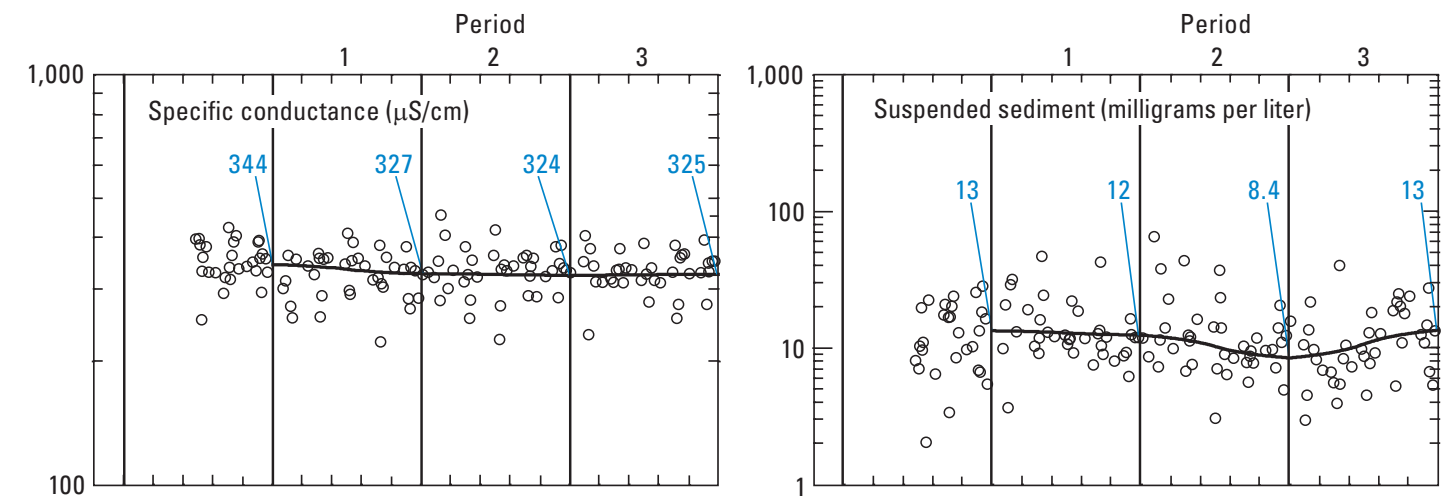

\section{EXPLANATION}

[Water year is defined as the 12-month period from October 1 through September 30 and is designated by the year in which it ends. $\mu \mathrm{S} / \mathrm{cm}$, microsiemens per centimeter at 25 degrees Celsius; $p$-value, statistical probability level]

- Flow-adjusted concentration (FAC) determined by using the time-series model

- Flow-adjusted fitted trend determined by using the time-series model
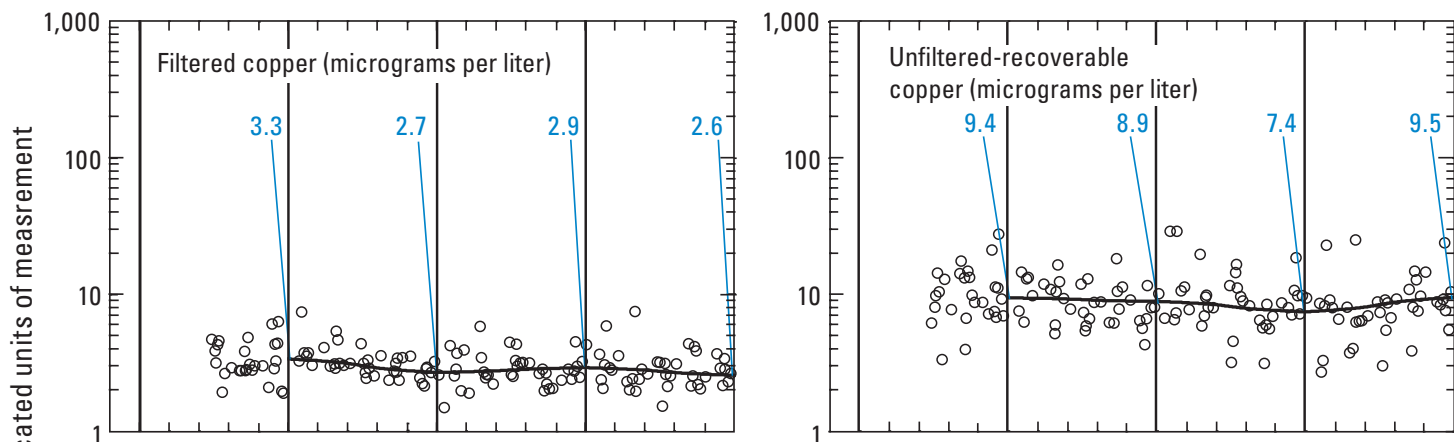

9.5 Fitted trend value at start or end of period

16 Bold values indicate statistical significance ( $p$-value less than $\mathbf{0 . 0 1}$ ) for period before value presented in bold
Results not reported because greater than 6 percent of values were affected by recensoring at study reporting level, as discussed in the section of this report "Time-Series Model."

[Graph included as a place holder to assist in comparison with other stations.]

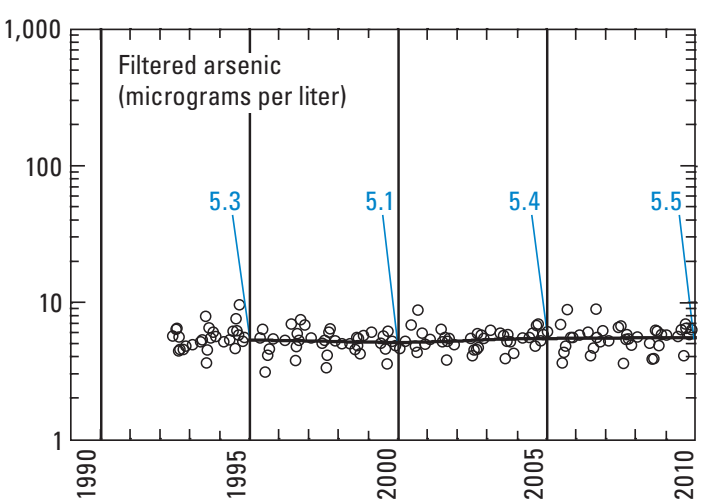

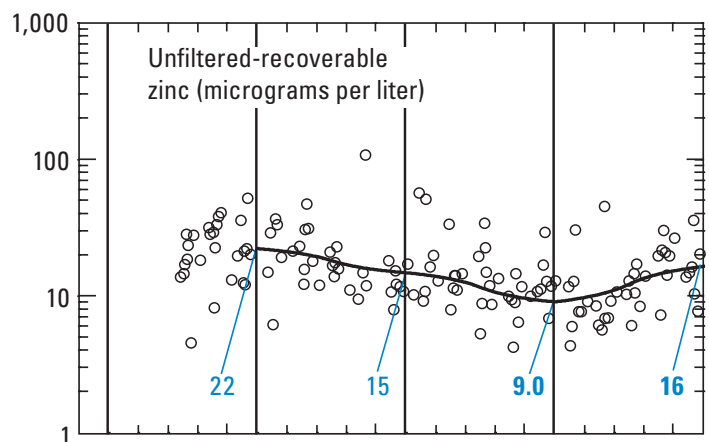

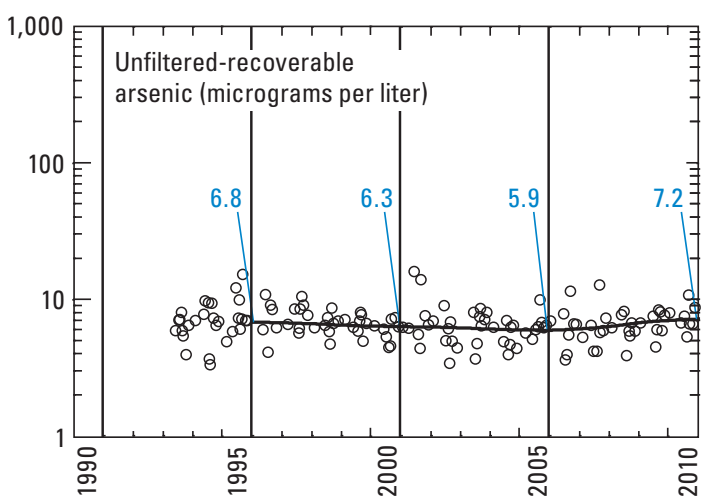

Water year (October-September)

Figure 4-20. Flow-adjusted fitted trends determined by using the time-series model (TSM) for selected water-quality constituents and properties for Clark For at Turah Bridge (site 20, fig. 1, table 1), water years 1996-2010. 


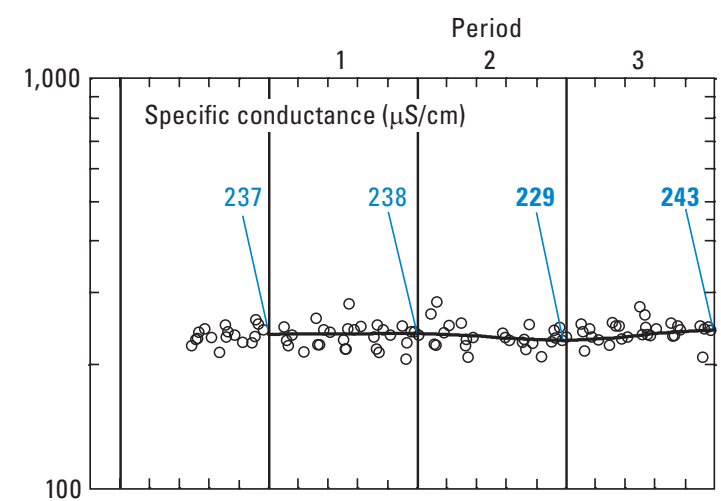

Filtered copper (micrograms per liter)

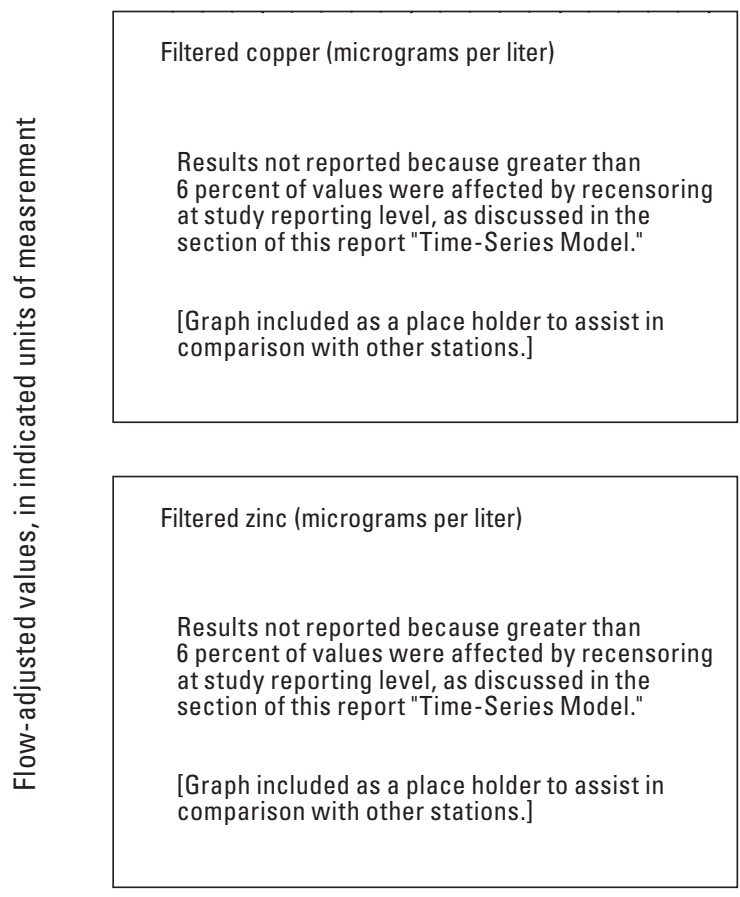

Filtered arsenic

(micrograms per liter)

Results not reported because greater than 6 percent of values were affected by recensoring at study reporting level, as discussed in the section of this report "Time-Series Model."

[Graph included as a place holder to assist in comparison with other stations.]

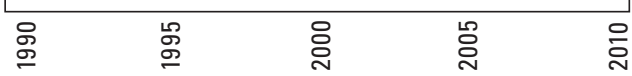

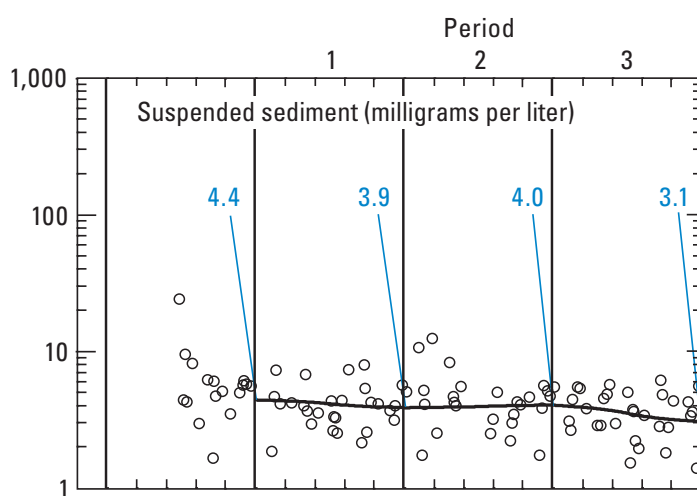

Unfiltered-recoverable copper (micrograms per liter)

Results not reported because greater than 6 percent of values were affected by recensoring at study reporting level, as discussed in the section of this report "Time-Series Model."

[Graph included as a place holder to assist in comparison with other stations.]

Unfiltered-recoverable zinc (micrograms per liter)

Results not reported because greater than 6 percent of values were affected by recensoring at study reporting level, as discussed in the section of this report "Time-Series Model."

[Graph included as a place holder to assist in comparison with other stations.]

Unfiltered-recoverable

arsenic (micrograms per liter)

Results not reported because greater than 6 percent of values were affected by recensoring at study reporting level, as discussed in the section of this report "Time-Series Model."

[Graph included as a place holder to assist in comparison with other stations.]

\begin{tabular}{|c|c|c|}
\hline & 용 욤 \\
\hline
\end{tabular}

\section{EXPLANATION}

[Water year is defined as the 12-month period from October 1 through September 30 and is designated by the year in which it ends. $\mu \mathrm{S} / \mathrm{cm}$, microsiemens per centimeter at 25 degrees Celsius; $p$-value, statistical probability level]

- Flow-adjusted concentration (FAC) determined by using the time-series model

-Flow-adjusted fitted trend determined by using the time-series model

3.1 Fitted trend value at start or end of period

243 Bold values indicate statistical significance ( $p$-value less than 0.01 ) for period before value presented in bold

Water year (October-September)

Figure 4-21. Flow-adjusted fitted trends determined by using the time-series model (TSM) for selected water-quality constituents and properties for Blackfoot River (site 21, fig. 1, table 1) water years 1996-2010. 


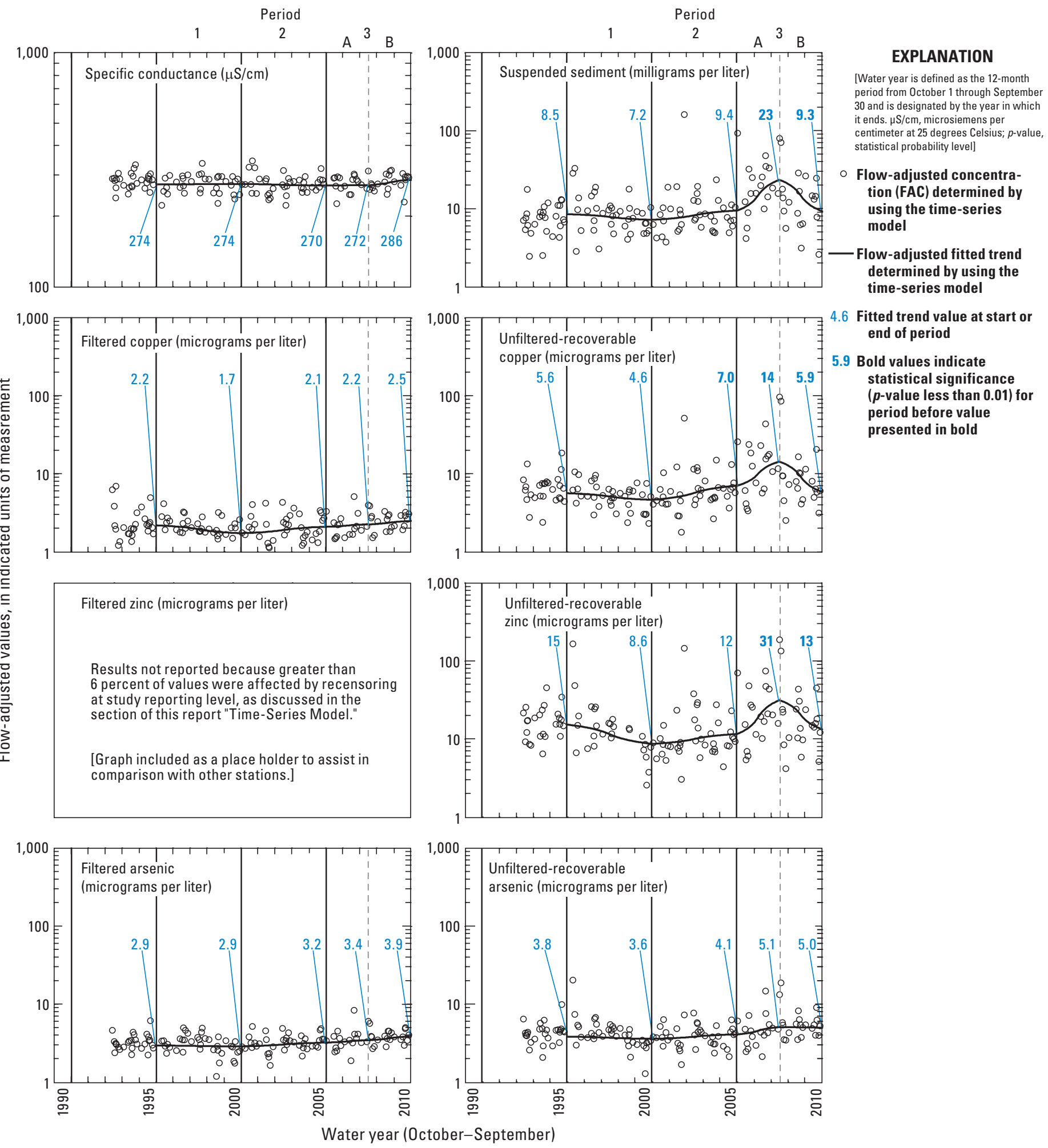

Figure 4-22. Flow-adjusted fitted trends determined by using the time-series model (TSM) for selected water-quality constituents and properties for Clark Fork above Missoula (site 22, fig. 1, table 1), water years 1996-2010. 
Table 5-1. Transport-analysis balance calculations for sites analyzed by using the time series model (TSM) in reach 1, extending from Blacktail Creek (site 1, fig. 1, table 1) to Silver Bow Creek at Butte (site 2, fig. 1, table 1) for selected periods, water years 1996-2010.

[Water year is the 12-month period from October 1 through September 30 and is designated by the year in which it ends]

\begin{tabular}{|c|c|c|c|}
\hline \multirow{2}{*}{ Site name and number or summation category } & \multicolumn{3}{|c|}{$\begin{array}{l}\text { Estimated normalized load' } \\
\text { (kilograms per day) }\end{array}$} \\
\hline & $\begin{array}{l}\text { Unfiltered-recover- } \\
\text { able copper }\end{array}$ & $\begin{array}{l}\text { Unfiltered-recover- } \\
\text { able arsenic }\end{array}$ & Suspended sediment \\
\hline \multicolumn{4}{|c|}{ Water years 1996-2000 (period 1) } \\
\hline Inflow Blacktail Creek (site 1) & 0.13 & 0.093 & 200 \\
\hline \multicolumn{4}{|c|}{ Water years 2001-05 (period 2) } \\
\hline Inflow Blacktail Creek (site 1) & 0.12 & 0.083 & 180 \\
\hline \multicolumn{4}{|c|}{ Water years 2006-10 (period 3) } \\
\hline Inflow Blacktail Creek (site 1) & 0.11 & 0.090 & 150 \\
\hline Outflow Silver Bow Creek at Butte (site 2) & 1.1 & 0.30 & 380 \\
\hline $\begin{array}{l}\text { Total within-reach change in load-outflow (site 2) minus } \\
\text { inflow (site 1) (positive values indicate net mobilization from } \\
\text { within-reach sources including groundwater inflow, unmoni- } \\
\text { tored tributaries, and the main-stem channel and floodplain) }\end{array}$ & 1.0 & 0.21 & 220 \\
\hline
\end{tabular}

${ }^{1}$ The estimated normalized load was computed by multiplying the mean annual fitted trend concentration (determined by using the time-series model) for the indicated period times the geometric mean streamflow for water years 1996-2010 and a units conversion factor according to equation 1 in the section of this report "Estimation of Normalized Constituent Loads." Loads are reported to two significant figures; however, before final rounding, calculations used three significant figures when necessary. As a result, some of the load values have minor rounding artifacts. 
Table 5-2. Transport-analysis balance calculations for sites analyzed by using the time series model (TSM) in reach 2, extending from Silver Bow Creek at Butte (site 2, fig. 1, table 1) to Silver Bow Creek at Opportunity (site 3, fig. 1, table 1) for selected periods, water years 1996-2010.

[Water year is the 12-month period from October 1 through September 30 and is designated by the year in which it ends]

\begin{tabular}{|c|c|c|c|}
\hline \multirow{2}{*}{ Site name and number or summation category } & \multicolumn{3}{|c|}{$\begin{array}{l}\text { Estimated normalized load' } \\
\text { (kilograms per day) }\end{array}$} \\
\hline & $\begin{array}{l}\text { Unfiltered-recover- } \\
\text { able copper }\end{array}$ & $\begin{array}{l}\text { Unfiltered-recover- } \\
\text { able arsenic }\end{array}$ & Suspended sediment \\
\hline \multicolumn{4}{|c|}{ Water years 1996-2000 (period 1) } \\
\hline Inflow Silver Bow Creek at Butte (site 2) & 5.0 & 0.59 & 740 \\
\hline \multicolumn{4}{|c|}{ Water years 2001-05 (period 2) } \\
\hline Inflow Silver Bow Creek at Butte (site 2) & 1.9 & 0.39 & 530 \\
\hline \multicolumn{4}{|c|}{ Water years 2006-10 (period 3) } \\
\hline Inflow Silver Bow Creek at Butte (site 2) & 1.1 & 0.29 & 380 \\
\hline Outflow Silver Bow Creek at Opportunity (site 3) & 6.5 & 1.3 & 2,000 \\
\hline $\begin{array}{l}\text { Total within-reach change in load-outflow (site 3) minus } \\
\text { inflow (site 2) (positive values indicate net mobilization from } \\
\text { within-reach sources including groundwater inflow, unmoni- } \\
\text { tored tributaries, and the main-stem channel and floodplain) }\end{array}$ & 5.4 & 1.0 & 1,600 \\
\hline
\end{tabular}

${ }^{1}$ The estimated normalized load was computed by multiplying the mean annual fitted trend concentration (determined by using the time-series model) for the indicated period times the geometric mean streamflow for water years 1996-2010 and a units conversion factor according to equation 1 in the section of this report "Estimation of Normalized Constituent Loads." Loads are reported to two significant figures; however, before final rounding, calculations used three significant figures when necessary. As a result, some of the load values have minor rounding artifacts. 
Table 5-3. Transport-analysis balance calculations for sites analyzed by using the time series model (TSM) in reach 31' extending from Silver Bow Creek at Opportunity (site 3, fig. 1, table 1) to Silver Bow Creek at Warm Springs (site 8, fig. 1, table 1) for selected periods, water years 1996-2010.

[Water year is the 12-month period from October 1 through September 30 and is designated by the year in which it ends]

\begin{tabular}{|c|c|c|c|}
\hline \multirow{2}{*}{ Site name and number or summation category } & \multicolumn{3}{|c|}{$\begin{array}{l}\text { Estimated normalized load² } \\
\text { (kilograms per day) }\end{array}$} \\
\hline & $\begin{array}{l}\text { Unfiltered-recover- } \\
\text { able copper }\end{array}$ & $\begin{array}{l}\text { Unfiltered-recover- } \\
\text { able arsenic }\end{array}$ & Suspended sediment \\
\hline \multicolumn{4}{|c|}{ Water years $1996-2000$ (period 1) } \\
\hline Inflow Silver Bow Creek at Opportunity (site 3) & 12 & 1.6 & 2,000 \\
\hline Outflow Silver Bow Creek at Warm Springs (site 8) & 1.3 & 3.3 & 740 \\
\hline $\begin{array}{l}\text { Total within-reach change in load-outflow (site 8) minus } \\
\text { inflow (site 3) (negative values indicate net accumulation in } \\
\text { Warm Springs Ponds; positive values indicate net mobilization } \\
\text { from within-reach sources including groundwater inflow, the } \\
\text { Mill-Willow bypass, the outflow from Warm Springs Ponds, } \\
\text { and the main-stem channel and floodplain downstream from } \\
\text { Warm Springs Ponds) }\end{array}$ & -9.2 & 1.6 & $-1,200$ \\
\hline \multicolumn{4}{|c|}{ Water years 2006-10 (period 3) } \\
\hline Inflow Silver Bow Creek at Opportunity (site 3) & 6.5 & 1.3 & 2,000 \\
\hline
\end{tabular}

${ }^{1}$ Data for Mill Creek at Opportunity (site 5) and Willow Creek at Opportunity (site 7) were not included as monitored tributary inflows because of factors that complicate directly combining the TSM results and multiple linear regression on time, streamflow, and season (MLR) results within a single analysis. The inability to distinguish the relative magnitudes of the within-reach contributions from the Mill-Willow bypass and Warm Springs Ponds to the reach outflow required simplifying assumptions. As a result, when net accumulation in the reach 3 channel is indicated for unfiltered-recoverable copper and suspended sediment, it is presumed that all of the reach inflow at site 3 is stored in Warm Springs Ponds.

${ }^{2}$ The estimated normalized load was computed by multiplying the mean annual fitted trend concentration (determined by using the time-series model) for the indicated period times the geometric mean streamflow for water years 1996-2010 and a units conversion factor according to equation 1 in the section of this report "Estimation of Normalized Constituent Loads." Loads are reported to two significant figures; however, before final rounding, calculations used three significant figures when necessary. As a result, some of the load values have minor rounding artifacts. 
Table 5-4. Transport-analysis balance calculations for sites analyzed by using the time series model (TSM) in reach 4, extending from Silver Bow Creek at Warm Springs (site 8, fig. 1, table 1) to Clark Fork near Galen (site 11, fig. 1, table 1) for selected periods, water years 1996-2010.

[Water year is the 12-month period from October 1 through September 30 and is designated by the year in which it ends]

\begin{tabular}{|c|c|c|c|}
\hline \multirow{2}{*}{ Site name and number or summation category } & \multicolumn{3}{|c|}{$\begin{array}{l}\text { Estimated normalized load } \\
\text { (kilograms per day) }\end{array}$} \\
\hline & $\begin{array}{l}\text { Unfiltered-recover- } \\
\text { able copper }\end{array}$ & $\begin{array}{l}\text { Unfiltered-recover- } \\
\text { able arsenic }\end{array}$ & Suspended sediment \\
\hline \multicolumn{4}{|c|}{ Water years 1996-2000 (period 1) } \\
\hline Inflow Silver Bow Creek at Warm Springs (site 8) & 2.0 & 3.1 & 850 \\
\hline $\begin{array}{l}\text { Monitored tributary inflow within reach Warm Springs } \\
\text { Creek at Warm Springs (site 10) }\end{array}$ & 1.0 & 0.70 & 780 \\
\hline Combined inflow (sum of sites 8 and 10) & 3.0 & 3.9 & 1,600 \\
\hline Outflow Clark Fork near Galen (site 11) & 3.6 & 4.1 & 1,600 \\
\hline $\begin{array}{l}\text { Total within-reach change in load-outflow (site 11) minus } \\
\text { inflow (site 8) (positive values indicate net mobilization from } \\
\text { all within-reach sources including groundwater inflow, the } \\
\text { monitored tributary, unmonitored tributaries, and the main-stem } \\
\text { channel and floodplain) }\end{array}$ & 1.7 & 1.0 & 790 \\
\hline \multicolumn{4}{|c|}{ Water years 2001-05 (period 2) } \\
\hline Inflow Silver Bow Creek at Warm Springs (site 8) & 1.3 & 3.3 & 740 \\
\hline $\begin{array}{l}\text { Monitored tributary inflow within reach } \\
\text { Warm Springs Creek at Warm Springs (site 10) }\end{array}$ & 0.89 & 0.68 & 460 \\
\hline Combined inflow (sum of sites 8 and 10) & 2.2 & 4.0 & 1,200 \\
\hline \multicolumn{4}{|c|}{ Water years 2006-10 (period 3) } \\
\hline Inflow Silver Bow Creek at Warm Springs (site 8) & 1.1 & 3.4 & 430 \\
\hline $\begin{array}{l}\text { Monitored tributary inflow within reach } \\
\text { Warm Springs Creek at Warm Springs (site 10) }\end{array}$ & 1.0 & 0.66 & 610 \\
\hline Combined inflow (sum of sites 8 and 10) & 2.1 & 4.0 & 1,040 \\
\hline Outflow Clark Fork near Galen (site 11) & 2.9 & 3.9 & 1,300 \\
\hline
\end{tabular}


Table 5-4. Transport-analysis balance calculations for sites analyzed by using the time series model (TSM) in reach 4, extending from Silver Bow Creek at Warm Springs (site 8, fig. 1, table 1) to Clark Fork near Galen (site 11, fig. 1, table 1) for selected periods, water years 1996-2010.-Continued

[Water year is the 12-month period from October 1 through September 30 and is designated by the year in which it ends]

\begin{tabular}{|c|c|c|c|}
\hline \multirow{2}{*}{ Site name and number or summation category } & \multicolumn{3}{|c|}{$\begin{array}{l}\text { Estimated normalized load' } \\
\text { (kilograms per day) }\end{array}$} \\
\hline & $\begin{array}{l}\text { Unfiltered-recover- } \\
\text { able copper }\end{array}$ & $\begin{array}{l}\text { Unfiltered-recover- } \\
\text { able arsenic }\end{array}$ & Suspended sediment \\
\hline \multicolumn{4}{|c|}{ Water years 2006-10 (period 3)-Continued } \\
\hline $\begin{array}{l}\text { Total within-reach change in load-outflow (site 11) minus } \\
\text { inflow (site 8) (positive values indicate net mobilization from } \\
\text { all within-reach sources including groundwater inflow, the } \\
\text { monitored tributary, unmonitored tributaries, and the main-stem } \\
\text { channel and floodplain) }\end{array}$ & 1.8 & 0.53 & 900 \\
\hline $\begin{array}{l}\text { Within-reach change in load after accounting for the moni- } \\
\text { tored tributary-outflow (site 11) minus combined inflow } \\
\text { (sum of sites } 8 \text { and 10) (positive values indicate net mobiliza- } \\
\text { tion from other within-reach sources including groundwater } \\
\text { inflow, unmonitored tributaries and the main-stem channel and } \\
\text { floodplain; negative values indicate net accumulation in reach } \\
\text { channel) }\end{array}$ & 0.74 & -0.12 & 290 \\
\hline
\end{tabular}

${ }^{1}$ The estimated normalized load was computed by multiplying the mean annual fitted trend concentration (determined by using the time-series model) for the indicated period times the geometric mean streamflow for water years 1996-2010 and a units conversion factor according to equation 1 in the section of this report "Estimation of Normalized Constituent Loads." Loads are reported to two significant figures; however, before final rounding, calculations used three significant figures when necessary. As a result, some of the load values have minor rounding artifacts. 
Table 5-5. Transport-analysis balance calculations for sites analyzed by using the time series model (TSM) in reach 51, extending from Clark Fork near Galen (site 11, fig. 1, table 1) to Clark Fork at Deer Lodge (site 14, fig. 1, table 1) for selected periods, water years 1996-2010.

[Water year is the 12-month period from October 1 through September 30 and is designated by the year in which it ends]

\begin{tabular}{|c|c|c|c|}
\hline \multirow{2}{*}{ Site name and number or summation category } & \multicolumn{3}{|c|}{$\begin{array}{l}\text { Estimated normalized load² } \\
\text { (kilograms per day) }\end{array}$} \\
\hline & $\begin{array}{l}\text { Unfiltered-recover- } \\
\text { able copper }\end{array}$ & $\begin{array}{l}\text { Unfiltered-recover- } \\
\text { able arsenic }\end{array}$ & Suspended sediment \\
\hline \multicolumn{4}{|c|}{ Water years $1996-2000$ (period 1) } \\
\hline Inflow Clark Fork near Galen (site 11) & 3.6 & 4.1 & 1,600 \\
\hline \multicolumn{4}{|c|}{ Water years 2001-05 (period 2) } \\
\hline Inflow Clark Fork near Galen (site 11) & 2.9 & 4.2 & 1,500 \\
\hline \multicolumn{4}{|c|}{ Water years 2006-10 (period 3) } \\
\hline Inflow Clark Fork near Galen (site 11) & 2.9 & 3.9 & 1,300 \\
\hline Outflow Clark Fork at Deer Lodge (site 14) & 11 & 7.0 & 6,300 \\
\hline $\begin{array}{l}\text { Total within-reach change in load-outflow (site 14) minus } \\
\text { inflow (site 11) (positive values indicate net mobilization from } \\
\text { within-reach sources including groundwater inflow, unmoni- } \\
\text { tored tributaries, and the main-stem channel and floodplain) }\end{array}$ & 8.1 & 3.1 & 5,000 \\
\hline
\end{tabular}

${ }^{1}$ Data for Lost Creek near Galen (site 13) were not included as monitored tributary inflows because of factors that complicate directly combining the TSM results and multiple linear regression on time, streamflow, and season (MLR) results within a single analysis.

${ }^{2}$ The estimated normalized load was computed by multiplying the mean annual fitted trend concentration (determined by using the time-series model) for the indicated period times the geometric mean streamflow for water years 1996-2010 and a units conversion factor according to equation 1 in the section of this report "Estimation of Normalized Constituent Loads." Loads are reported to two significant figures; however, before final rounding, calculations used three significant figures when necessary. As a result, some of the load values have minor rounding artifacts. 
Table 5-6. Transport-analysis balance calculations for sites analyzed by using the time series model (TSM) in reach 6, extending from Clark Fork at Deer Lodge (site 14, fig. 1, table 1) to Clark Fork at Goldcreek (site 16, fig. 1, table 1) for selected periods, water years 1996-2010.

[Water year is the 12-month period from October 1 through September 30 and is designated by the year in which it ends]

\begin{tabular}{|c|c|c|c|}
\hline \multirow{2}{*}{ Site name and number or summation category } & \multicolumn{3}{|c|}{$\begin{array}{l}\text { Estimated normalized load }{ }^{1} \\
\text { (kilograms per day) }\end{array}$} \\
\hline & $\begin{array}{l}\text { Unfiltered-recover- } \\
\text { able copper }\end{array}$ & $\begin{array}{l}\text { Unfiltered-recover- } \\
\text { able arsenic }\end{array}$ & Suspended sediment \\
\hline \multicolumn{4}{|c|}{ Water years 1996-2000 (period 1) } \\
\hline Inflow Clark Fork at Deer Lodge (site 14) & 12 & 6.9 & 7,500 \\
\hline $\begin{array}{l}\text { Monitored tributary inflow within reach } \\
\text { Little Blackfoot River (site 15) }\end{array}$ & 0.24 & 1.3 & 1,100 \\
\hline Combined inflow (sum of sites 14 and 15) & 12 & 8.3 & 8,600 \\
\hline Outflow Clark Fork at Goldcreek (site 16) & 19 & 10 & 16,000 \\
\hline $\begin{array}{l}\text { Total within-reach change in load-outflow (site 16) minus } \\
\text { inflow (site 14) (positive values indicate net mobilization from } \\
\text { all within-reach sources including groundwater inflow, the } \\
\text { monitored tributary, unmonitored tributaries, and the main-stem } \\
\text { channel and floodplain) }\end{array}$ & 7.3 & 3.2 & 8,000 \\
\hline \multicolumn{4}{|c|}{ Water years 2001-05 (period 2) } \\
\hline Inflow Clark Fork at Deer Lodge (site 14) & 11 & 7.0 & 6,600 \\
\hline $\begin{array}{l}\text { Monitored tributary inflow within reach } \\
\text { Little Blackfoot River (site 15) }\end{array}$ & 0.23 & 1.1 & 800 \\
\hline Combined inflow (sum of sites 14 and 15 ) & 11 & 8.1 & 7,400 \\
\hline Outflow Clark Fork at Goldcreek (site 16) & 16 & 9.7 & 12,000 \\
\hline
\end{tabular}
tored tributary-outflow (site 16) minus combined inflow (sum of sites 14 and 15) (positive values indicate net mobilization from other within-reach sources including groundwater inflow, unmonitored tributaries, and the mainstem channel and floodplain)

\begin{tabular}{lcr}
\hline \multicolumn{1}{c}{ Water years 2006-10 (period 32) } & 11 & 7.0 \\
\hline Inflow Clark Fork at Deer Lodge (site 14) & 15 & 10 \\
Outflow Clark Fork at Goldcreek (site 16) & 4.0 & 3.3 \\
Total within-reach change in load-outflow (site 16) minus & & 10,000 \\
$\quad$ inflow (site 14) (positive values indicate net mobilization from & & 4,000 \\
$\quad \begin{array}{l}\text { all within-reach sources including groundwater inflow, unmoni- } \\
\text { tored tributaries, and the main-stem channel and floodplain) }\end{array}$
\end{tabular}

${ }^{1}$ The estimated normalized load was computed by multiplying the mean annual fitted trend concentration (determined by using the time-series model) for the indicated period times the geometric mean streamflow for water years 1996-2010 and a units conversion factor according to equation 1 in the section of this report "Estimation of Normalized Constituent Loads." Loads are reported to two significant figures; however, before final rounding, calculations used three significant figures when necessary. As a result, some of the load values have minor rounding artifacts.

${ }^{2}$ No data available for site 15 for water years 2006-10 (period 3); thus loads from site 15 are not accounted for and contribute to the within-reach change in load for period 3. Further, for period 3, loads from site 15 are included in net mobilization from within-reach sources. 
Table 5-7. Transport-analysis balance calculations for sites analyzed by using the time series model (TSM) in reach 7, extending from Clark Fork at Goldcreek (site 16, fig. 1, table 1) to Clark Fork near Drummond (site 18, fig. 1, table 1) for selected periods, water years 1996-2010.

[Water year is the 12-month period from October 1 through September 30 and is designated by the year in which it ends]

\begin{tabular}{|c|c|c|c|}
\hline \multirow{2}{*}{ Site name and number or summation category } & \multicolumn{3}{|c|}{$\begin{array}{l}\text { Estimated normalized load }{ }^{1} \\
\text { (kilograms per day) }\end{array}$} \\
\hline & $\begin{array}{l}\text { Unfiltered-recover- } \\
\text { able copper }\end{array}$ & $\begin{array}{l}\text { Unfiltered-recover- } \\
\text { able arsenic }\end{array}$ & Suspended sediment \\
\hline \multicolumn{4}{|c|}{ Water years 1996-2000 (period 1) } \\
\hline Inflow Clark Fork at Goldcreek (site 16) & 19 & 10 & 16,000 \\
\hline $\begin{array}{l}\text { Monitored tributary inflow within reach } \\
\text { Flint Creek (site 17) }\end{array}$ & 0.69 & 2.7 & 4,100 \\
\hline Combined inflow (sum of sites 16 and 17) & 20 & 13 & 20,000 \\
\hline Outflow Clark Fork near Drummond (site 18) & 24 & 16 & 24,000 \\
\hline $\begin{array}{l}\text { Total within-reach change in load-outflow (site 18) minus } \\
\text { inflow (site 16) (positive values indicate net mobilization from } \\
\text { all within-reach sources including groundwater inflow, the } \\
\text { monitored tributary, unmonitored tributaries, and the main-stem } \\
\text { channel and floodplain) }\end{array}$ & 4.8 & 5.5 & 8,000 \\
\hline \multicolumn{4}{|c|}{ Water years $2001-05$ (period 2) } \\
\hline Inflow Clark Fork at Goldcreek (site 16) & 16 & 9.7 & 12,000 \\
\hline $\begin{array}{l}\text { Monitored tributary inflow within reach } \\
\text { Flint Creek (site 17) }\end{array}$ & 0.57 & 2.4 & 3,000 \\
\hline Combined inflow (sum of sites 16 and 17) & 17 & 12 & 15,000 \\
\hline Outflow Clark Fork near Drummond (site 18) & 19 & 15 & 17,000 \\
\hline \multicolumn{4}{|c|}{ Water years $2006-10\left(\right.$ period $\left.3^{2}\right)$} \\
\hline Inflow Clark Fork at Goldcreek (site 16) & 15 & 10 & 10,000 \\
\hline Outflow Clark Fork near Drummond (site 18) & 18 & 15 & 17,000 \\
\hline $\begin{array}{l}\text { Total within-reach change in load-outflow (site 18) minus } \\
\text { inflow (site 16) (positive values indicate net mobilization from } \\
\text { all within-reach sources including groundwater inflow, unmoni- } \\
\text { tored tributaries, and the main-stem channel and floodplain) }\end{array}$ & 3.3 & 4.5 & 6,300 \\
\hline
\end{tabular}

${ }^{1}$ The estimated normalized load was computed by multiplying the mean annual fitted trend concentration (determined by using the time-series model) for the indicated period times the geometric mean streamflow for water years 1996-2010 and a units conversion factor according to equation 1 in the section of this report "Estimation of Normalized Constituent Loads." Loads are reported to two significant figures; however, before final rounding, calculations used three significant figures when necessary. As a result, some of the load values have minor rounding artifacts.

${ }^{2}$ No data available for site 17 for water years 2006-10 (period 3); thus loads from site 17 are not accounted for and contribute to the total within-reach change in load for period 3. Further, for period 3, loads from site 17 are included in net mobilization from within-reach sources. 
Table 5-8. Transport-analysis balance calculations for sites analyzed by using the time series model (TSM) in reach 8, extending from Clark Fork near Drummond (site 18, fig. 1, table 1) to Clark Fork at Turah Bridge (site 20, fig. 1, table 1) for selected periods, water years 1996-2010.

[Water year is the 12-month period from October 1 through September 30 and is designated by the year in which it ends]

\section{Site name and number or summation category}

\begin{tabular}{ccc} 
& $\begin{array}{c}\text { Estimated normalized load } \\
\text { (kilograms per day) }\end{array}$ \\
\hline $\begin{array}{c}\text { Unfiltered-recover- } \\
\text { able copper }\end{array}$ & $\begin{array}{c}\text { Unfiltered-recover- } \\
\text { able arsenic }\end{array}$ & Suspended sediment \\
\hline
\end{tabular}

\begin{tabular}{|c|c|c|c|}
\hline \multicolumn{4}{|c|}{ Water years 1996-2000 (period 1) } \\
\hline InflowClark Fork near Drummond (site 18) & 24 & 16 & 24,000 \\
\hline $\begin{array}{l}\text { Monitored tributary inflow within reach } \\
\text { Rock Creek (site 19) }\end{array}$ & ND & $\mathrm{ND}$ & 4,900 \\
\hline Combined inflow (sum of sites 18 and 19) & ND & ND & 28,000 \\
\hline Outflow Clark Fork at Turah Bridge (site 20) & 23 & 17 & 32,000 \\
\hline $\begin{array}{l}\text { Total within-reach change in load-outflow (site 20) minus } \\
\text { inflow (site 18) (negative values indicate net accumulation in } \\
\text { reach channel; positive values indicate net mobilization from } \\
\text { all within-reach sources including groundwater inflow, the } \\
\text { monitored tributary, unmonitored tributaries, and the main-stem } \\
\text { channel and floodplain) }\end{array}$ & -1.0 & 0.89 & 8,900 \\
\hline Within-reach change in load after accounting for the moni- & ND & ND & 4,000 \\
\hline
\end{tabular}

tored tributary-outflow (site 20) minus combined inflow

(sum of sites 18 and 19) (positive values indicate net mobiliza-

tion from other within-reach sources including groundwater

inflow, unmonitored tributaries, and the main-stem channel and

floodplain)

\begin{tabular}{|c|c|c|c|}
\hline \multicolumn{4}{|c|}{ Water years $2001-05$ (period 2) } \\
\hline Inflow Clark Fork near Drummond (site 18) & 19 & 15 & 17,000 \\
\hline $\begin{array}{l}\text { Monitored tributary inflow within reach } \\
\text { Rock Creek (site 19) }\end{array}$ & ND & ND & 3,900 \\
\hline Combined inflow (sum of sites 18 and 19) & ND & ND & 21,000 \\
\hline Outflow Clark Fork at Turah Bridge (site 20) & 21 & 15 & 26,000 \\
\hline $\begin{array}{l}\text { Total within-reach change in load-outflow (site 20) minus } \\
\text { inflow (site 18) (negative values indicate net accumulation in } \\
\text { reach channel; positive values indicate net mobilization from } \\
\text { all within-reach sources including groundwater inflow, the } \\
\text { monitored tributary, unmonitored tributaries, and the main-stem } \\
\text { channel and floodplain) }\end{array}$ & 1.1 & 0.92 & 9,000 \\
\hline Within-reach change in load after accounting for the moni- & ND & ND & 5,100 \\
\hline
\end{tabular}

tored tributary-outflow (site 20) minus combined inflow

(sum of sites 18 and 19) (positive values indicate net mobiliza-

tion from other within-reach sources including groundwater

inflow, unmonitored tributaries, and the main-stem channel and

floodplain)

\begin{tabular}{|c|c|c|c|}
\hline \multicolumn{4}{|c|}{ Water years 2006-10 (period $3^{2}$ ) } \\
\hline Inflow Clark Fork near Drummond (site 18) & 18 & 15 & 17,000 \\
\hline Outflow Clark Fork at Turah Bridge (site 20) & 21 & 16 & 27,000 \\
\hline $\begin{array}{l}\text { Total within-reach change in load-outflow (site 20) minus } \\
\text { inflow (site 18) (positive values indicate net mobilization from } \\
\text { all within-reach sources including groundwater inflow, unmoni- } \\
\text { tored tributaries, and the main-stem channel and floodplain) }\end{array}$ & 3.0 & 1.8 & 10,000 \\
\hline
\end{tabular}

${ }^{1}$ The estimated normalized load was computed by multiplying the mean annual fitted trend concentration (determined by using the time-series model) for the indicated period times the geometric mean streamflow for water years 1996-2010 and a units conversion factor according to equation 1 in the section of this report "Estimation of Normalized Constituent Loads." Loads are reported to two significant figures; however, before final rounding, calculations used three significant figures when necessary. As a result, some of the load values have minor rounding artifacts.

${ }^{2}$ Load results for Rock Creek near Clinton (site 19) for copper and arsenic not reported because greater than 6 percent of data values were affected by recensoring at study reporting level, as discussed in the section of this report "Time-Series Model." No suspended-sediment data available for site 19 for period 3; thus loads from site 19 of copper and arsenic for all periods and suspended sediment for period 3 are not accounted for and contribute to the withinreach change in load. 
Table 5-9. Transport-analysis balance calculations for sites analyzed by using the time series model (TSM) in reach 9, extending from Clark Fork at Turah Bridge (site 20, fig. 1, table 1) to Clark Fork above Missoula (site 22, fig. 1, table 1) for selected periods, water years 1996-2010.

[Water year is the 12-month period from October 1 through September 30 and is designated by the year in which it ends. ND, not determined because of greater than 6 percent of values affected by recensoring at study reporting level, as discussed in the section of this report "Time-Series Model."]

\begin{tabular}{|c|c|c|c|}
\hline \multirow{2}{*}{ Site name and number or summation category } & \multicolumn{3}{|c|}{$\begin{array}{l}\text { Estimated normalized load' } \\
\text { (kilograms per day) }\end{array}$} \\
\hline & $\begin{array}{l}\text { Unfiltered-recover- } \\
\text { able copper }\end{array}$ & $\begin{array}{l}\text { Unfiltered-recover- } \\
\text { able arsenic }\end{array}$ & Suspended sediment \\
\hline \multicolumn{4}{|c|}{ Water years 1996-2000 (period 1) } \\
\hline Inflow Clark Fork at Turah Bridge (site 20) & 23 & 17 & 32,000 \\
\hline $\begin{array}{l}\text { Monitored tributary inflow within reach } \\
\text { Blackfoot River (site 21) }\end{array}$ & ND & ND & 9,900 \\
\hline Combined inflow (sum of sites 20 and 21) & ND & ND & 42,000 \\
\hline Outflow Clark Fork above Missoula (site 22) & 25 & 18 & 39,000 \\
\hline $\begin{array}{l}\text { Total within-reach change in load-outflow (site 22) minus } \\
\text { inflow (site 20) (positive values indicate net mobilization from } \\
\text { all within-reach sources including groundwater inflow, the } \\
\text { monitored tributary, unmonitored tributaries, and the main-stem } \\
\text { channel and floodplain) }\end{array}$ & 2.4 & 1.9 & 6,500 \\
\hline \multicolumn{4}{|c|}{ Water years 2001-05 (period 2) } \\
\hline Inflow Clark Fork at Turah Bridge (site 20) & 21 & 15 & 26,000 \\
\hline $\begin{array}{l}\text { Monitored tributary inflow within reach } \\
\text { Blackfoot River (site 21) }\end{array}$ & ND & ND & 9,400 \\
\hline Combined inflow (sum of sites 20 and 21) & 21 & 15 & 35,000 \\
\hline OutflowClark Fork above Missoula (site 22)" & 29 & 19 & 41,000 \\
\hline $\begin{array}{l}\text { Total within-reach change in load-outflow (site 22) minus } \\
\text { inflow (site 20) (positive values indicate net mobilization from } \\
\text { all within-reach sources including groundwater inflow, the } \\
\text { monitored tributary, unmonitored tributaries, and the main-stem } \\
\text { channel and floodplain) }\end{array}$ & 8.0 & 3.6 & 15,000 \\
\hline \multicolumn{4}{|c|}{ Water years 2006-10 (period 3) } \\
\hline Inflow Clark Fork at Turah Bridge (site 20) & 21 & 16 & 27,000 \\
\hline $\begin{array}{l}\text { Monitored tributary inflow within reach } \\
\text { Blackfoot River (site 21) }\end{array}$ & ND & ND & 8,400 \\
\hline Combined inflow (sum of sites 20 and 21 & 21 & 16 & 36,000 \\
\hline Outflow Clark Fork above Missoula (site 22) & 50 & 24 & 77,000 \\
\hline
\end{tabular}


Table 5-9. Transport-analysis balance calculations for sites analyzed by using the time series model (TSM) in reach 9, extending from Clark Fork at Turah Bridge (site 20, fig. 1, table 1) to Clark Fork above Missoula (site 22, fig. 1, table 1) for selected periods, water years 1996-2010.-Continued

[Water year is the 12-month period from October 1 through September 30 and is designated by the year in which it ends]

\begin{tabular}{|c|c|c|c|}
\hline \multirow{2}{*}{ Site name and number or summation category } & \multicolumn{3}{|c|}{$\begin{array}{l}\text { Estimated normalized load' } \\
\text { (kilograms per day) }\end{array}$} \\
\hline & $\begin{array}{l}\text { Unfiltered-recover- } \\
\text { able copper }\end{array}$ & $\begin{array}{l}\text { Unfiltered-recover- } \\
\text { able arsenic }\end{array}$ & Suspended sediment \\
\hline \multicolumn{4}{|c|}{ Water years 2006-10 (period 3)-Continued } \\
\hline $\begin{array}{l}\text { Total within-reach change in load-outflow (site 22) minus } \\
\text { inflow (site 20) (positive values indicate net mobilization from } \\
\text { all within-reach sources including groundwater inflow, the } \\
\text { monitored tributary, unmonitored tributaries, and the main-stem } \\
\text { channel and floodplain) }\end{array}$ & 28 & 7.4 & 50,000 \\
\hline $\begin{array}{l}\text { Within-reach change in load after accounting for the moni- } \\
\text { tored tributary-outflow (site 22) minus combined inflow } \\
\text { (sum of sites } 20 \text { and 21) (positive values indicate net mobiliza- } \\
\text { tion from other within-reach sources including groundwater } \\
\text { inflow, unmonitored tributaries, and the main-stem channel and } \\
\text { floodplain) }\end{array}$ & ND & ND & 42,000 \\
\hline
\end{tabular}

${ }^{1}$ The estimated normalized load was computed by multiplying the mean annual fitted trend concentration (determined by using the time-series model) for the indicated period times the geometric mean streamflow for water years 1996-2010 and a units conversion factor according to equation 1 in the section of this report "Estimation of Normalized Constituent Loads." Loads are reported to two significant figures; however, before final rounding, calculations used three significant figures when necessary. As a result, some of the load values have minor rounding artifacts.

${ }^{2}$ Loads results for Blackfoot River near Bonner (site 21) for copper and arsenic not reported because greater than 6 percent of data values were affected by recensoring at study reporting level, as discussed in the section of this report "Time-Series Model." Thus loads from site 21 of copper and arsenic for all periods are not accounted for and contribute to the within-reach change in load. 
Publishing support provided by:

Rolla Publishing Service Center

For more information concerning this publication, contact: Director, USGS Montana Water Science Center

3162 Bozeman Avenue

Helena, MT 59601

(406) 457-5900

Or visit the Montana Water Science Center Web site at: http://mt.water.usgs.gov/ 
ISBN ค78-1-4l13-3764-0 